\title{
Statystyki pozycyjne w procedurach estymacji i ich zastosowania w badaniach ekonomicznych
}


盗 


\section{Dorota Pekasiewicz}

\section{Statystyki pozycyjne}

w procedurach

estymacji i ich

zastosowania

w badaniach

ekonomicznych 
Dorota Pekasiewicz - Uniwersytet Łódzki, Wydział Ekonomiczno-Socjologiczny

Katedra Metod Statystycznych, 90-214 Łódź, ul. Rewolucji 1905 r. nr 41/43

\section{RECENZENT}

Wojciech Zieliński

\section{REDAKTOR WYDAWNICTWA UŁ \\ Iwona Gos}

\section{SKŁAD KOMPUTEROWY \\ Barbara Lebioda}

\section{PROJEKT OKŁADKI}

Stämpfli Polska Sp. z o.o.

Zdjęcie na okładce: (C) shutterstock.com

(C) Copyright by Uniwersytet Łódzki, Łódź 2015

Wydane przez Wydawnictwo Uniwersytetu Łódzkiego

Wydanie I. W.06340.13.0.H

ISBN 978-83-7969-519-5 (wersja papierowa)
978-83-7969-520-1 (wersja elektoniczna)

Wydawnictwo Uniwersytetu Łódzkiego

90-131 Łódź, ul. Lindleya 8

www.wydawnictwo.uni.lodz.pl

e-mail: ksiegarnia@uni.lodz.pl

tel. (42) 66558 63, faks (42) 6655862 


\section{SPIS TREŚCI}

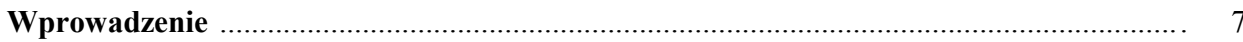

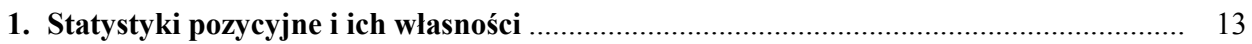

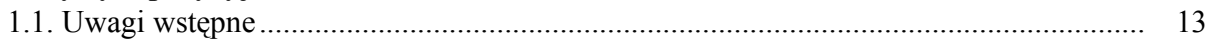

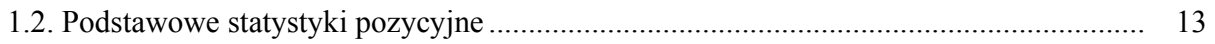

1.3. Charakterystyki liczbowe i funkcyjne statystyk pozycyjnych ..................................... 19

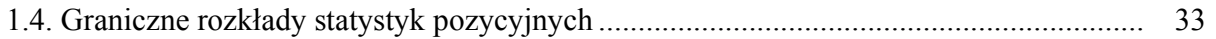

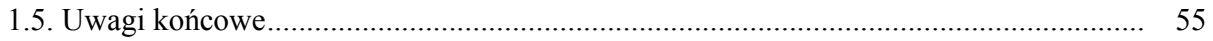

2. Metody estymacji oparte na statystykach pozycyjnych .......................................... 57

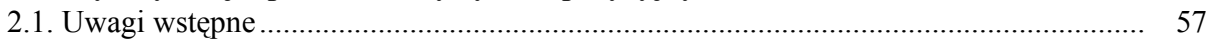

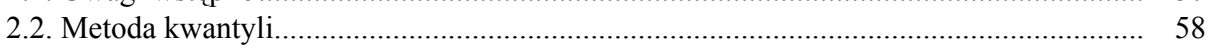

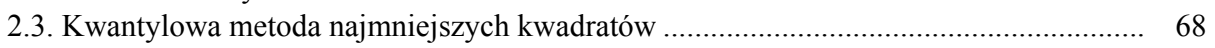

2.4. Modyfikacje kwantylowej metody najmniejszych kwadratów..................................... 69

2.4.1. Kwantylowa metoda najmniejszych kwadratów z uciętą liczbą kwantyli ............. $\quad 70$

2.4.2. Medianowo-kwantylowa metoda najmniejszych kwadratów .............................. 74

2.5. Metoda momentów ważonych prawdopodobieństwami.......................................... 75

2.6. Zmodyfikowana metoda momentów ważonych prawdopodobieństwami .......................... 84

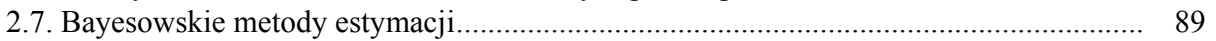

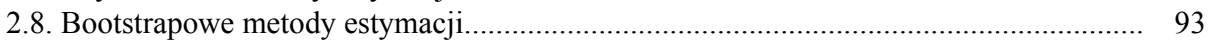

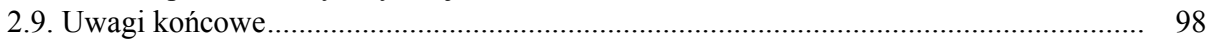

3. Analiza własności opartych na statystykach pozycyjnych estymatorów parametrów

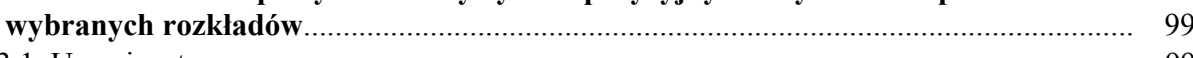

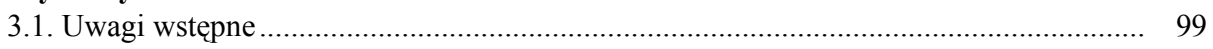

3.2. Badania własności estymatorów otrzymanych metodą kwantyli................................... 100

3.3. Symulacyjne badania własności estymatorów otrzymanych kwantylową metodą najmniejszych kwadratów z uciętą liczbą kwantyli ................................................................ 120

3.4. Symulacyjne badania własności estymatorów uzyskanych medianowo-kwantylową metodą najmniejszych kwadratów.................................................................................... 132

3.5. Symulacyjne badania własności estymatorów otrzymanych metodami momentów ważo-

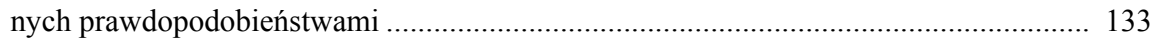

3.6. Analiza porównawcza własności wybranych estymatorów.......................................... 138

3.7. Zastosowanie procedur estymacji opartych na statystykach pozycyjnych w badaniach eko-

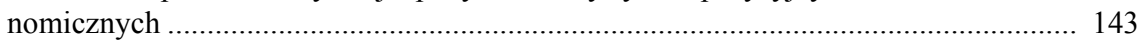

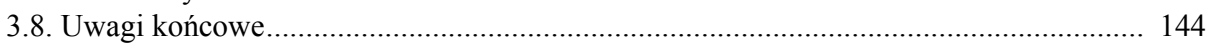


4. Procedury estymacji parametrów pozycyjnych zmiennej losowej i ich zastosowania.... 147

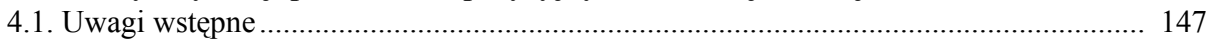

4.2. Estymatory kwantyli ................................................................................. 148

4.3. Klasyczne metody wyznaczania przedziałów ufności dla kwantyli ............................. 156

4.4. Bayesowska estymacja kwantyli ..................................................................... 163

4.5. Bootstrapowe procedury estymacji kwantyli............................................... 168

4.6. Estymacja dominanty ............................................................................... 173

4.7. Przykłady zastosowań estymatorów parametrów pozycyjnych................................. 178

4.7.1. Szacowanie miar ubóstwa i bogactwa w analizach dochodów ludności ............. 178

4.7.2. Estymacja miar ryzyka rynkowego ...................................................... 184

4.7.3. Konstrukcja kart kontrolnych z wykorzystaniem estymatorów mediany ............ 192

4.8. Uwagi końcowe........................................................................................... 195

5. Statystyki pozycyjne $w$ analizach zdarzeń ekstremalnych ....................................... 197

5.1. Uwagi wstępne ............................................................................................... 197

5.2. Estymacja parametrów uogólnionych rozkładów statystyk ekstremalnych.................. 198

5.3. Semiparametryczne metody szacowania indeksu ekstremalnego.............................. 201

5.4. Estymacja ogona rozkładu zmiennej losowej i jej zastosowanie................................. 207

5.5. Bootstrapowa estymacja kwantyli wykorzystująca oszacowanie ogona rozkładu zmiennej losowej.............................................................................................. 216

5.6. Zastosowanie statystyk ekstremalnych $\mathrm{w}$ wybranych procedurach estymacji................ 219

5.6.1. Szacowanie ryzyka ekstremalnego........................................................... 219

5.6.2. Konstrukcja kart kontrolnych w oparciu o statystyki ekstremalne............................. 223

5.7. Uwagi końcowe .......................................................................................... 226

6. Wybrane empiryczne zastosowania statystyk pozycyjnych w badaniach ekonomicznych ... 227

6.1. Uwagi wstępne ............................................................................................. 227

6.2. Zastosowanie statystyk pozycyjnych $w$ analizach dochodów i wydatków ludności............. 228

6.3. Zastosowanie kwantyli z próby do estymacji miar ryzyka na rynku finansowym.......... 234

6.4. Zastosowanie metod estymacji opartych na statystykach pozycyjnych na rynku ubezpie-

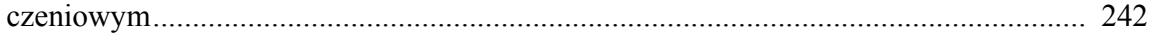

6.5. Wykorzystanie statystyk pozycyjnych w ocenie działalności przedsiębiorstw .............. 248

6.6. Uwagi końcowe.................................................................................... 251

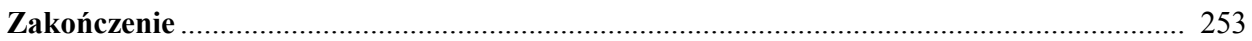

Order statistics in estimation procedures and their applications in economic research

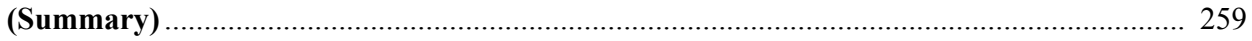

Aneks. Charakterystyki funkcyjne i liczbowe wybranych rozkładów .......................... 263

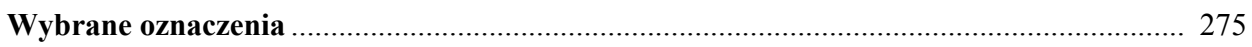

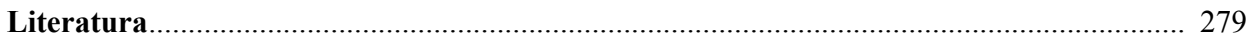

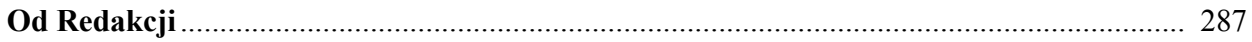




\section{WPROWADZENIE}

We współczesnych badaniach ekonomicznych, będących podstawą podejmowania decyzji na różnych poziomach - przedsiębiorstwa, regionu czy też kraju - zauważa się wzrost zapotrzebowania na metody statystyczne. Odgrywają one rolę $w$ procesach zbierania informacji, ich analizowania $i$ interpretowania, a także udostępniania otrzymanych wyników. Ze względu na złożoność i różnorodność gromadzonych obserwacji metody statystyczne oparte na klasycznych parametrach i ich estymatorach, wykorzystywane do analizy zjawisk ekonomicznych, nie zawsze pozwalają na przeprowadzenie pogłębionych analiz i sformułowanie prawidłowych wniosków. Brak momentów zwykłych i centralnych odpowiednich rzędów analizowanych zmiennych losowych, z którymi utożsamiane są badane cechy statystyczne, jak również występowanie obserwacji nietypowych utrudnia wnioskowanie statystyczne klasycznymi metodami. W takich przypadkach mogą być przydatne procedury oparte na statystykach pozycyjnych.

Statystyki pozycyjne stanowią grupę statystyk wyznaczanych na podstawie uporządkowanych prób losowych. Znajdują one zastosowanie w konstrukcji estymatorów parametrów zmiennych losowych wykorzystywanych w procedurach parametrycznej i nieparametrycznej estymacji oraz przy weryfikacji hipotez statystycznych.

Do podstawowych statystyk pozycyjnych zalicza się kwantyle z próby, w tym medianę, statystyki ekstremalne, tj. maksimum i minimum, oraz dominantę z próby. Medianę z próby stosuje się do szacowania wartości średniej, gdy rozkład populacji jest asymetryczny bądź charakteryzuje się tzw. grubymi ogonami. Jest ona znacznie stabilniejsza niż średnia arytmetyczna, która jest bardzo wrażliwa na wartości ekstremalne. Kwantyle rozkładu empirycznego używa się do pomiarów ryzyka rynkowego, finansowego i operacyjnego. Miary oparte na statystykach pozycyjnych stosowane są także w analizach dochodów oraz analizach zjawisk bardzo rzadko występujących, których pojawienie się powoduje duże straty finansowe. Oszacowanie wielkości tych strat możliwe jest przy użyciu statystyk ekstremalnych, ich rozkładów dokładnych lub granicznych. Statystyki pozycyjne i ich funkcje wykorzystywane są również w statystycznej kontroli jakości do tworzenia kart kontrolnych stosowanych w monitorowaniu 
i regulacji procesu produkcyjnego oraz w wielu innych analizach dotyczących różnorodnych problemów ekonomicznych.

Głównym celem rozprawy jest przedstawienie metod estymacji parametrów rozkładu populacji wykorzystujących statystyki pozycyjne oraz propozycji ich modyfikacji wraz z zaprezentowaniem wyników przeprowadzonych analiz własności estymatorów stanowiących wskazówki w praktycznych zastosowaniach. $\mathrm{W}$ rozważaniach uwzględnione jest klasyczne ujęcie procedur estymacji oraz podejście nieklasyczne - bayesowskie i bootstrapowe, zarówno parametryczne, jak i nieparametryczne.

Aby zrealizować tak sformułowany cel główny, określono cele szczegółowe, do których należą:

- analiza własności statystyk pozycyjnych, w szczególności ich rozkładów dla wybranych klas rozkładów zmiennych losowych;

- prezentacja metod opartych na statystykach pozycyjnych wykorzystywanych do szacowania parametrów rozkładów zmiennych losowych oraz analiza ich własności;

- propozycje modyfikacji procedur szacowania parametrów rozkładu zmiennej losowej, prowadzące do otrzymania estymatorów o mniejszych obciążeniach i mniejszych błędach średniokwadratowych;

- porównanie rozważanych metod dla wybranych klas rozkładów zmiennych losowych oraz sformułowanie wniosków dotyczących ich efektywności;

- prezentacja parametrycznych i nieparametrycznych metod estymacji kwantyli, w tym mediany;

- analiza wybranych metod estymacji stosowanych w badaniach zjawisk ekstremalnych, w szczególności metod wykorzystujących oszacowania ogonów rozkładów rozważanych zmiennych;

- wskazanie obszarów zastosowań rozważanych procedur statystycznych opartych na kwantylach w badaniach ekonomicznych.

Weryfikacji poddano następujące hipotezy badawcze:

- zastosowanie metody kwantyli z odpowiednio dobranymi rangami stosowanych statystyk pozycyjnych umożliwia uzyskanie estymatorów nieobciążonych lub asymptotycznie nieobciążonych o małych błędach średniokwadratowych;

- modyfikacje kwantylowej metody najmniejszych kwadratów prowadzą do otrzymania estymatorów parametrów rozkładów populacji o mniejszych obciążeniach i błędach średniokwadratowych niż estymatory uzyskane kwantylową metodą najmniejszych kwadratów oraz metodą kwantyli;

- modyfikacja metody momentów ważonych prawdopodobieństwami, polegająca na zastosowaniu dystrybuanty empirycznej typu level crossing, pozwala otrzymać estymatory o lepszych własnościach w stosunku do estymatorów 
uzyskanych metodą momentów ważonych prawdopodobieństwami z klasyczną dystrybuantą empiryczną;

- procedury nieparametrycznej estymacji bootstrapowej umożliwiają uzyskanie przedziałów ufności pokrywających wartość szacowanego parametru $\mathrm{z}$ prawdopodobieństwem $\mathrm{w}$ przybliżeniu równym ustalonemu współczynnikowi ufności o dokładności większej niż nieparametryczne metody klasyczne.

Praca składa się z sześciu rozdziałów, w których omówiono zagadnienia metodologiczne związane z procedurami estymacji opartymi na kwantylach z próby oraz podano przykłady ich zastosowań.

W rozdziale pierwszym przedstawiono statystyki pozycyjne $\mathrm{i}$ ich matematyczne funkcje. Zaprezentowano, znane z literatury przedmiotu, podstawowe twierdzenia dotyczace ich charakterystyk liczbowych, funkcyjnych, w tym rozkładów granicznych, uzupełniając je twierdzeniami dotyczącymi własności statystyk pozycyjnych wyznaczanych w oparciu o ciagi zmiennych losowych o wybranych rozkładach. Są one niezbędne do konstrukcji estymatorów przedstawionych w dalszej części pracy.

W rozdziale drugim omówiono metody estymacji punktowej parametrów rozkładu zmiennej losowej, wykorzystujące statystyki pozycyjne. Prezentowane w literaturze metody: kwantyli (por. J. Bartoszewicz [1996]), kwantylowa metoda najmniejszych kwadratów (por. E. Castillo i in. [2004]), metoda momentów ważonych prawdopodobieństwami (por. J. A. Greenwood i in. [1979]), bootstrapowa (por. B. Efron, R. J. M. Tibshirani [1993]), uzupełnione są autorskimi propozycjami ich modyfikacji pozwalającymi uzyskać estymatory o mniejszym obciążeniu i mniejszej wariancji. Dwie proponowane metody stanowią modyfikacje kwantylowej metody najmniejszych kwadratów, a trzecia - metody momentów ważonych prawdopodobieństwami. Pierwsza z nich polega na pominięciu w estymacji kwantylową metodą najmniejszych kwadratów ustalonej liczby $k$ skrajnych kwantyli z próby, natomiast druga na wyznaczeniu estymatorów kwantylową metodą najmniejszych kwadratów z pominięciem różnej liczby skrajnych kwantyli, a następnie wyznaczeniu mediany z otrzymanych oszacowań. Inna propozycja modyfikacji dotyczy wykorzystania dystrybuanty empirycznej level crossing w metodzie momentów ważonych prawdopodobieństwami. Ponadto $\mathrm{w}$ rozdziale tym prezentowane są metody estymacji bayesowskiej konstruowane przy ustalonym rozkładzie a priori szacowanego parametru i ustalonej funkcji straty. Liniowa funkcja straty sprawia, że estymatorami szacowanych parametrów są kwantyle rozkładu a posteriori, czyli pewne funkcje statystyk pozycyjnych. W metodach bootstrapowych, omówionych $\mathrm{w}$ jednym z podrozdziałów, istotne znaczenie mają kwantyle rozkładów bootstrapowych stosowane do konstrukcji przedziałów ufności.

W rozdziale trzecim przedstawiono wyniki badań własnych dotyczących własności metod estymacji opartych na statystykach pozycyjnych, ze szczególnym 
uwzględnieniem autorskich propozycji. W przypadku rozważanych metod nie zawsze możliwe jest analityczne zbadanie obciążeń i błędów średniokwadratowych otrzymanych estymatorów, dlatego stosowano metody Monte Carlo. Dzięki dostępnemu oprogramowaniu komputerowemu, szybkim procesorom istnieje możliwość wykonania tak dużej liczby powtórzeń analizowanych procedur, że wyniki badań symulacyjnych są praktycznie identyczne $\mathrm{z}$ wynikami obliczeń analitycznych. Przeprowadzone badania pozwalają ocenić własności rozpatrywanych metod dla wybranych klas rozkładów populacji, porównać je oraz sformułować wnioski dotyczące ich efektywności i praktycznego zastosowania.

W kolejnym rozdziale pracy zaprezentowano wykorzystanie statystyk pozycyjnych w estymacji parametrów pozycyjnych rozkładu zmiennej losowej, czyli kwantyli i dominanty. Problematyce estymacji punktowej i przedziałowej, parametrycznej oraz nieparametrycznej kwantyli rozkładu badanej zmiennej, w szczególności parametru położenia - mediany, poświęconych jest wiele prac R. Zielińskiego (m.in. [2001], [2003], [2005a]) oraz W. Zielińskiego (np. [2008], [2009]). Oprócz klasycznych metod estymacji, w rozdziale tym przeanalizowano również wybrane bayesowskie i bootstrapowe metody szacowania parametrów pozycyjnych. Rozważano także metody szacowania dominanty, wykorzystujące statystyki pozycyjne (por. np. D. R. Bickel [2002], A. Sokołowski [2013], J. Wywiał [2000b]). W ostatnich podrozdziałach przedstawiono zastosowanie rozważanych estymatorów kwantyli, w tym własnych propozycji do konstrukcji estymatorów miar stosowanych w badaniach ekonomicznych.

W rozdziale piątym omówiono metody estymacji wykorzystywane w analizach zjawisk ekstremalnych, rzadko występujących, których źródłem są załamania na rynkach finansowych, katastrofy czy też nietypowe warunki pogodowe. Podobnie jak w przypadku estymacji kwantyli, do estymacji parametrów rozkładu statystyk ekstremalnych mogą być stosowane parametryczne i nieparametryczne metody prezentowane w literaturze (por. m.in. R. A. Davis, S. T. Resnick [1984], A. L. M. Dekkers i in. [1989], B. M. Hill [1975], J. R. M. Hosting i in. [1985], J. Pickands [1975]) oraz proponowane w rozdziale drugim zmodyfikowane metody estymacji. Istotnym zagadnieniem jest szacowanie indeksu ekstremalnego - parametru określającego kształt rozkładu statystyk ekstremalnych. Jego wartość związana jest z klasą rozkładu populacji. Gdy rozkład populacji charakteryzuje się grubymi (ciężkimi) ogonami, to jego wartość jest dodatnia, gdy cienkimi (lekkimi) ogonami - indeks wynosi zero, natomiast dla rozkładów o krótkich ogonach (ograniczonym przedziale wartości) przyjmuje on wartość ujemną. Ma to znaczenie przy wykrywaniu wartości nietypowych, rzadko występujących, przy obliczaniu prawdopodobieństw zajścia zdarzeń ekstremalnych oraz szacowaniu wielkości pojawiających się katastrof, przy ustalonym prawdopodobieństwie ich wystapienia. Ponadto podano przykłady wykorzystania statystyk 
ekstremalnych i ich funkcji do określania miar stosowanych w analizach ekonomicznych, w tym finansowych.

W rozdziale szóstym zaprezentowano empiryczne przykłady zastosowań metod estymacji opartych na statystykach pozycyjnych rozważanych w pracy. Ograniczono się do wspomnianych już wcześniej trzech obszarów badań ekonomicznych: analizy dochodów, bogactwa i ubóstwa, statystycznej kontroli jakości oraz zarządzania ryzykiem, tzw. zwykłym i ekstremalnym, a także wskazano możliwość ich wykorzystania $\mathrm{w}$ ubezpieczeniach majątkowych. Na podstawie rzeczywistych danych statystycznych pochodzących z Głównego Urzędu Statystycznego, jednostki kontrolującej jakość w przedsiębiorstwie produkującym urządzenia gospodarstwa domowego, publikowanych indeksów polskiej i amerykańskiej giełdy papierów wartościowych oraz danych dotyczących ubezpieczeń komunikacyjnych pochodzących z pewnego zakładu ubezpieczeń zaprezentowano zastosowanie wybranych metod.

W zamieszczonym aneksie przedstawiono podstawowe charakterystyki funkcyjne i liczbowe rozkładów zmiennych losowych rozważanych w pracy.

$\mathrm{W}$ niniejszej monografii zaprezentowano zarówno znane $\mathrm{z}$ literatury procedury estymacji, jak i własne propozycje. W poszczególnych rozdziałach monografii przedstawiano rezultaty analitycznych rozważań oraz badań symulacyjnych przeprowadzonych $\mathrm{w}$ oparciu o samodzielnie przygotowane programy napisane w środowisku Gauss i Mathematica.

Pragnę serdecznie podziękować Recenzentowi - Panu Profesorowi zw. dr. hab. Wojciechowi Zielińskiemu - za cenne uwagi i sugestie, które wpłynęły na poprawę jakości publikacji. 



\section{STATYSTYKI POZYCYJNE I ICH WLASNOŚCI}

\subsection{Uwagi wstępne}

Statystyki pozycyjne, zwane również porządkowymi, definiuje się na podstawie prób losowych uporządkowanych w sposób niemalejący lub nierosnący.

W rozdziale przedstawiono pojęcia i własności podstawowych statystyk pozycyjnych, do których należą kwantyle z próby, w szczególności mediana, kwartyle, decyle i percentyle z próby, statystyki ekstremalne oraz dominanta z próby. Ponadto rozważano statystyki będące funkcjami statystyk porządkowych, wykorzystywane w estymacji parametrów położenia i zróżnicowania.

Dla wybranych klas rozkładów sformułowano twierdzenia określające funkcje gęstości, dystrybuanty oraz charakterystyki liczbowe statystyk pozycyjnych. Analizowano również rozkłady graniczne statystyk ekstremalnych, wykorzystywanych $\mathrm{w}$ badaniach zjawisk nietypowych. Wyboru rozpatrywanych rozkładów dokonano na podstawie analizy rozkładów mających praktyczne zastosowanie w badaniach społeczno-ekonomicznych. W szczególności rozważano rozkłady zmiennych losowych, które nie mają momentów centralnych pierwszego i drugiego rzędu. Wykorzystanie zatem we wnioskowaniu statystycznym takich estymatorów, jak średnia arytmetyczna czy wariancja jest niemożliwe.

Przedstawione statystyki pozycyjne oraz ich funkcje stosowane są w estymacji parametrów rozkładów zmiennych losowych występujących w badaniach ekonomicznych oraz do szacowania różnego rodzaju miar definiowanych w oparciu o kwantyle rozkładów.

\subsection{Podstawowe statystyki pozycyjne}

Niech $X_{1}, X_{2}, \ldots, X_{n}$ będzie ciagiem niezależnych zmiennych losowych o rozkładzie określonym za pomocą dystrybuanty $F, x_{1}, x_{2}, \ldots, x_{n}$ - ciagiem ich wartości, natomiast $x_{(1)}^{(n)}, x_{(2)}^{(n)}, \ldots, x_{(n)}^{(n)}$ - uporządkowanym niemalejąco ciągiem tych wartości. 
Statystyka pozycyjna jest funkcją wektora losowego $\left(X_{1}, X_{2}, \ldots, X_{n}\right)$ zdefiniowaną w następujący sposób (por. np. M. Fisz [1967, s. 389-390], C. Domański i in. [1998, s. 176]).

Definicja 1.2.1. Statystyką pozycyjną $X_{(k)}^{(n)}$, gdzie $k=1,2, \ldots, n$, nazywamy zmienną losową, której wartościami są $k$-te co do wielkości wartości realizacji, uporządkowanego w sposób niemalejący, wektora losowego $\left(X_{1}, X_{2}, \ldots, X_{n}\right)$, stanowiącego próbę losową, czyli wartości $x_{(k)}^{(n)}$.

Liczbę $k$ nazywamy rangą statystyki pozycyjnej $X_{(k)}^{(n)}$, natomiast wielkość $\frac{k}{n}$ określamy jako rangę względną tej statystyki.

Statystyki pozycyjne zwane są również statystykami porządkowymi (por. J. Bartoszewicz [1996, s. 68]).

We wnioskowaniu statystycznym wykorzystuje się statystyki wyznaczane w oparciu o $n$-elementową próbę prostą, którą stanowi ciąg niezależnych zmiennych losowych $X_{1}, X_{2}, \ldots, X_{n}$, czyli wektor losowy $\left(X_{1}, X_{2}, \ldots, X_{n}\right)$. Za pomoca statystyk pozycyjnych definiuje się kwantyle z próby, w szczególności medianę, kwartyle, decyle i percentyle z próby.

Definicja 1.2.2. Kwantylem rzędu $p$, gdzie $p \in(0,1), \mathrm{z} n$-elementowej próby prostej $X_{1}, X_{2}, \ldots, X_{n}$ nazywamy statystykę postaci:

$$
X_{p ; n}= \begin{cases}X_{(n p)}^{(n)}, & \text { gdy } n p \in N, \\ X_{([n p]+1)}^{(n)}, & \text { gdy } n p \notin N,\end{cases}
$$

gdzie $[n p]$ oznacza część całkowitą liczby $n p$, natomiast $N$ jest zbiorem liczb naturalnych.

Kwantyl rzędu $p=0,5 \mathrm{z}$ próby losowej $X_{1}, X_{2}, \ldots, X_{n}$ nazywany jest medianą. Ze względu na symetrię często definiuje się medianę w poniższy sposób (por. R. Zieliński [2011, s. 33]).

Definicja 1.2.3. Medianą $M e \mathrm{z} n$-elementowej próby prostej $X_{1}, X_{2}, \ldots, X_{n}$ nazywamy statystykę określoną wzorem: 


$$
M e= \begin{cases}\frac{1}{2}\left(X_{\left(\frac{n}{2}\right)}^{(n)}+X_{\left(\frac{n}{2}+1\right)}^{(n)}\right), & \text { gdy } n \text { jest parzyste } \\ X_{\left(\frac{n+1}{2}\right)}^{(n)}, & \text { gdy } n \text { jest nieparzyste. }\end{cases}
$$

Oprócz mediany szczególnymi przypadkami kwantyli są kwartyle, kwintyle, decyle i percentyle.

Kwartylem rzędu $s$ z $n$-elementowej próby prostej $X_{1}, X_{2}, \ldots, X_{n}$ nazywamy kwantyl z próby rzędu $p=\frac{s}{4}$, gdzie $s=1,2,3$. Jeśli $s=1$, to kwantyl nazywamy kwartylem rzędu pierwszego, jeśli $s=3$, wówczas jest on kwartylem rzędu trzeciego, natomiast dla $s=2$ otrzymujemy medianę.

Kwintylem z próby rzędu $s$ nazywamy kwantyl z próby rzędu $p=\frac{s}{5}$, gdzie $s=1,2,3,4$, i podobnie jak $\mathrm{w}$ przypadku kwartyla mówimy odpowiednio o kwintylu pierwszym, drugim, trzecim i czwartym.

Decylem z próby rzędu $s$ nazywamy kwantyl z próby rzędu $p=\frac{s}{10}$, gdzie $s=1, \ldots, 9$.

Jako percentyl rzędu $s$ z próby prostej $X_{1}, X_{2}, \ldots, X_{n}$ określamy kwantyl z próby rzędu $p=\frac{s}{100}$, gdzie $s=1, \ldots, 99$.

W badaniach społecznych, ekonomicznych i przyrodniczych do analiz zdarzeń ekstremalnych wykorzystywane są statystyki ekstremalne, nazywane również statystykami skrajnymi. Należą do nich minimum i maksimum z próby.

Definicja 1.2.4. Statystykę, której wartością jest najmniejszy element próby prostej $X_{1}, X_{2}, \ldots, X_{n}$, nazywamy minimum z próby lub statystyką minimalną i oznaczamy $X_{(1)}^{(n)}=\min \left\{X_{1}, \ldots, X_{n}\right\}$.

Definicja 1.2.5. Statystykę, której wartością jest największy element próby prostej $X_{1}, X_{2}, \ldots, X_{n}$, nazywamy maksimum z próby lub statystyką maksymalną i oznaczamy $X_{(n)}^{(n)}=\max \left\{X_{1}, \ldots, X_{n}\right\}$. 
W analizach statystycznych wykorzystuje się dominantę zwaną również modą. Ze względu na sposób wyznaczania dominanty z próby, można zaliczyć ją także do statystyk pozycyjnych.

Definicja 1.2.6. Dominantą $D_{0} \quad \mathrm{z} \quad n$-elementowej próby prostej $X_{1}, X_{2}, \ldots, X_{n}$ nazywamy statystykę, której wartość najczęściej występuje wśród wartości $x_{1}, x_{2}, \ldots, x_{n}$ tej próby.

Nie zawsze można określić w sposób jednoznaczny dominantę. Czasami jest kilka wartości występujących tyle samo razy. $Z$ takimi sytuacjami możemy mieć do czynienia m.in. w przypadku rozważań dotyczących ciagu zmiennych losowych o pewnych rozkładach skokowych lub o rozkładach będących mieszaninami co najmniej dwóch rozkładów.

Mediana Me określona wzorem (1.2.2) jest liniową funkcją statystyk pozycyjnych. Do innych funkcji statystyk pozycyjnych, które można zapisać w postaci $\sum_{i=1}^{n} c_{i} X_{(i)}^{(n)}$, gdzie $c_{1}, c_{2}, \ldots, c_{n}$ są pewnymi stałymi, należą rozstęp z próby i studentyzowany rozstęp z próby, zdefiniowane za pomocą statystyk ekstremalnych oraz odchylenie ćwiartkowe określone za pomocą kwartyli rzędu pierwszego i trzeciego (por. R.J. Serfling [1991, s. 137]). Znajdują one zastosowanie w procedurach oceny rozproszenia zmiennej losowej oraz wykrywania obserwacji odstających w próbie. Rozkład studentyzowanego rozstępu wykorzystuje się przy konstrukcji testów statystycznych stosowanych w analizie wariancji.

Definicja 1.2.7. Rozstępem $R \mathrm{z} n$-elementowej próby prostej $X_{1}, X_{2}, \ldots, X_{n}$ nazywamy statystykę postaci:

$$
R=X_{(n)}^{(n)}-X_{(1)}^{(n)},
$$

gdzie $X_{(1)}^{(n)}, X_{(n)}^{(n)}$ są odpowiednio minimum i maksimum z próby.

Definicja 1.2.8. Rozstępem studentyzowanym $R_{s} \quad \mathrm{z}$ próby prostej $X_{1}, X_{2}, \ldots, X_{n}$ nazywamy statystykę postaci:

$$
R_{s}=\frac{X_{(n)}^{(n)}-X_{(1)}^{(n)}}{S_{n}},
$$

gdzie $\quad X_{(1)}^{(n)}, X_{(n)}^{(n)} \quad$ są $\quad$ statystykami ekstremalnymi, natomiast $S_{n}=\sqrt{\frac{1}{n-1} \sum_{i=1}^{n}\left(X_{i}-\bar{X}\right)^{2}}$ oraz $\bar{X}=\frac{1}{n} \sum_{i=1}^{n} X_{i}$. 
Definicja 1.2.9. Odchyleniem ćwiartkowym $Q \quad \mathrm{z}$ próby prostej $X_{1}, X_{2}, \ldots, X_{n}$ nazywamy statystykę postaci:

$$
Q=\frac{1}{2}\left(X_{0,75 ; n}-X_{0,25 ; n}\right),
$$

gdzie $X_{0,25 ; n}, \quad X_{0,75 ; n}$ są odpowiednio pierwszym i trzecim kwartylem $\mathrm{z} n$-elementowej próby.

Analogicznie definiuje się odchylenie kwintylowe, decylowe i percentylowe z próby wykorzystywane do oceny zróżnicowania wartości zmiennej losowej, które w praktyce znajdują zastosowanie np. do szacowania ryzyka (por. K. Jajuga [2007, s. 42]). Odchylenie kwintylowe z próby jest statystyką definiowaną jako połowa różnicy między kwintylem czwartym i pierwszym, odchylenie decylowe jest określane jako połowa różnicy między decylem dziewiątym i pierwszym, zaś odchylenie percentylowe jako połowa różnicy między percentylem 99-tym i pierwszym.

Statystyki ekstremalne i kwartyle służą do określania średnich midrange (midextreme), midhinge, trimean, będących estymatorami parametrów położenia (por. W. G. Gilchrist [2000, s. 195], S. Kotz i in. [2006, s. 4768, 8762]).

Definicja 1.2.10. Statystyką midrange nazywamy zmienną losową postaci:

$$
M_{r}=\frac{1}{2}\left(X_{(1)}^{(n)}+X_{(n)}^{(n)}\right)
$$

gdzie $X_{(1)}^{(n)}, X_{(n)}^{(n)}$ są odpowiednio minimum i maksimum z próby prostej $X_{1}, X_{2}, \ldots, X_{n}$.

Definicja 1.2.11. Statystyką midhinge nazywamy zmienną losową wyrażoną wzorem:

$$
M_{h}=\frac{1}{2}\left(X_{0,25 ; n}+X_{0,75 ; n}\right)
$$

gdzie $X_{0,25 ; n}, \quad X_{0,75 ; n}$ są odpowiednio pierwszym i trzecim kwartylem $\mathrm{z} n$-elementowej próby.

Definicja 1.2.12. Statystyką trimean nazywamy następującą zmienną losową:

$$
T_{m}=\frac{1}{2}\left(M e+\frac{X_{0,25 ; n}+X_{0,75 ; n}}{2}\right),
$$


gdzie Me jest medianą z próby, natomiast $X_{0,25 ; n}, X_{0,75 ; n}$ są pierwszym i trzecim kwartylem z próby.

Innymi estymatorami parametrów położenia określonymi na podstawie statystyk pozycyjnych są $\alpha$-obcięta średnia oraz $\alpha$-winsorowska średnia (R. J. Serfling [1991, s.137, 258]).

Definicja 1.2.13. Statystykę wyznaczoną $\mathrm{w}$ oparciu o próbę prostą $X_{1}, X_{2}, \ldots, X_{n}$ postaci:

$$
T_{\alpha}=\frac{1}{n-2[n \alpha]} \sum_{i=[n \alpha]+1}^{n-[n \alpha]} X_{(i)}^{(n)}, \quad \text { gdzie } \alpha \in\left(0, \frac{1}{2}\right)
$$

nazywamy $\alpha$-obciętą średnią.

Definicja 1.2.14. Statystykę wyrażoną wzorem:

$$
T_{w}=\frac{1}{n}\left([n \alpha] X_{([n \alpha]+1)}^{(n)}+\sum_{i=[n \alpha]+1}^{n-[n \alpha]} X_{(i)}^{(n)}+[n \alpha] X_{(n-[n \alpha])}^{(n)}\right),
$$

gdzie $\alpha \in\left(0, \frac{1}{2}\right)$ oraz $X_{(i)}^{(n)}$, dla $i=[n \alpha]+1, \ldots, n-[n \alpha]$, są statystykami pozycyjnymi wyznaczonymi na podstawie próby $X_{1}, X_{2}, \ldots, X_{n}$, nazywamy $\alpha$-winsorowską średnią.

Mediana z próby, $\alpha$-obcięta średnia oraz $\alpha$-winsorowska średnia są statystykami wykorzystywanymi w odpornych metodach estymacji parametrów populacji, gdyż pomijają one istniejące obserwacje nietypowe (odstające).

Funkcją statystyk pozycyjnych jest również statystyka nazywana spacja, zdefiniowana w następujący sposób.

Definicja 1.2.15. Spacją $D_{i}^{(n)}$, dla $2 \leq i \leq n$, nazywamy różnicę między kolejnymi statystykami pozycyjnymi $X_{(i)}^{(n)}$ oraz $X_{(i-1)}^{(n)}$ wyznaczonymi na podstawie próby losowej $X_{1}, X_{2}, \ldots, X_{n}$, czyli

$$
D_{i}^{(n)}=X_{(i)}^{(n)}-X_{(i-1)}^{(n)} .
$$

Wektor spacji $\mathbf{D}^{(n)}=\left[D_{2}^{(n)}, \ldots, D_{n}^{(n)}\right]$ wykorzystywany jest w konstrukcji statystyk nieparametrycznych testów zgodności oraz w badaniu własności dystrybuanty. 
Dla $p$-wielowymiarowych zmiennych losowych $\mathbf{X}=\left(X_{1}, X_{2}, \ldots, X_{p}\right)$ określa się $p$-wymiarowe statystyki pozycyjne m.in. statystyki ekstremalne (por. S. Kotz, S. Nadarajah [2000 s. 95]).

Definicja 1.2.16. Niech $\mathbf{X}_{1}, \ldots, \mathbf{X}_{n}$ będzie próbą prostą pochodzącą z populacji $\mathbf{X}$. Wielowymiarową statystyką minimum $\mathbf{X}_{(1)}^{(n)}$ nazywamy $p$-wymiarowy wektor złożony ze statystyk minimalnych wyznaczonych w oparciu o ciagi wartości $\left(X_{i, 1}, X_{i, 2}, \ldots, X_{i, n}\right)$ dla $i=1, \ldots, p$, czyli

$$
\mathbf{X}_{(1)}^{(n)}=\left(X_{(1), 1}^{(n)}, X_{(1), 2}^{(n)}, \ldots, X_{(1), p}^{(n)}\right),
$$

gdzie $X_{(1, i}^{(n)}=\min \left\{X_{i, 1}, \ldots, X_{i, n}\right\}$.

Definicja 1.2.17. Niech $\mathbf{X}_{1}, \ldots, \mathbf{X}_{n}$ będzie próbą prostą pochodzącą z populacji X. Wielowymiarową statystyką maksimum $\mathbf{X}_{(n)}^{(n)}$ nazywamy $p$-wymiarowy wektor złożony ze statystyk maksymalnych wyznaczonych $\mathrm{w}$ oparciu o ciagi wartości $\left(X_{i, 1}, X_{i, 2}, \ldots, X_{i, n}\right)$ dla $i=1, \ldots, p$, czyli

$$
\mathbf{X}_{(n)}^{(n)}=\left(X_{(n), 1}^{(n)}, X_{(n), 2}^{(n)}, \ldots, X_{(n), p}^{(n)}\right),
$$

gdzie $X_{(n), i}^{(n)}=\max \left\{X_{i, 1}, \ldots, X_{i, n}\right\}$.

\subsection{Charakterystyki liczbowe i funkcyjne statystyk pozycyjnych}

Każdą statystykę pozycyjną określa funkcja gęstości lub funkcja rozkładu prawdopodobieństwa, dystrybuanta oraz charakterystyki liczbowe, takie jak wartość oczekiwana i wariancja. Twierdzenia o rozkładach statystyk pozycyjnych przedstawione są m.in. w pracach J. Bartoszewicza [1996, s. 68-76], H. A. Davida, H. N. Nagaraja [2003, s. 9-22], C. Domańskiego, K. Pruskiej [2000, s. 100-104], M. Fisza [1967, s. 395-408], M. Krzyśko [1996, s. 46-52], J. Wywiała [2004, s. 60-62]).

Sformułowane poniżej twierdzenia określają rozkłady statystyk pozycyjnych wyznaczanych na podstawie ciagu $X_{1}, X_{2}, \ldots, X_{n}$ niezależnych zmiennych losowych stanowiących próbę prostą wylosowaną z populacji, która utożsamiana jest ze zmienną $X$. 
Łączny rozkład wektora statystyk porządkowych $X_{(1)}^{(n)}, X_{(2)}^{(n)}, \ldots, X_{(n)}^{(n)}$ ciagłej zmiennej losowej $X$ przedstawia następujące twierdzenie.

Twierdzenie 1.3.1. Jeżeli $X_{1}, X_{2}, \ldots, X_{n}$ jest próbą prostą wylosowaną z populacji $X$ o rozkładzie ciagłym, określonym za pomocą funkcji gęstości $f$, to gęstość łącznego rozkładu statystyk pozycyjnych $X_{(1)}^{(n)}, X_{(2)}^{(n)}, \ldots, X_{(n)}^{(n)}$ ma postać:

$$
g\left(x_{(1)}, x_{(2)}, \ldots, x_{(n)}\right)=n ! \prod_{k=1}^{n} f\left(x_{(k)}\right) \quad \text { dla } \quad-\infty<x_{(1)}<x_{(2)}<\ldots<x_{(n)}<\infty .
$$

Kolejne twierdzenia dotyczą postaci rozkładu statystyk pozycyjnych $X_{(k)}^{(n)}$ dla $k=1,2, \ldots, n$.

Twierdzenie 1.3.2. Niech $X_{1}, X_{2}, \ldots, X_{n}$ będzie próbą prostą wylosowaną z populacji $X$ o rozkładzie określonym za pomocą dystrybuanty $F$. Statystyka pozycyjna $X_{(k)}^{(n)}$, dla $k=1,2, \ldots, n$, ma rozkład o dystrybuancie wyrażonej wzorem:

$$
F_{k: n}(x)=\sum_{i=k}^{n}\left(\begin{array}{l}
n \\
i
\end{array}\right)(F(x))^{i}(1-F(x))^{n-i}
$$

W szczególności maksimum z próby $X_{(n)}^{(n)}$ ma rozkład określony za pomocą dystrybuanty:

$$
F_{n: n}(x)=(F(x))^{n}
$$

natomiast minimum z próby $X_{(1)}^{(n)}$ ma rozkład o dystrybuancie postaci:

$$
F_{1: n}(x)=\sum_{l=1}^{n}\left(\begin{array}{l}
n \\
l
\end{array}\right)(F(x))^{l}(1-F(x))^{n-l}=1-(1-F(x))^{n} .
$$

Twierdzenie 1.3.2 jest prawdziwe dla statystyk pozycyjnych wyznaczonych w oparciu o próbę prostą wylosowaną z populacji zarówno o rozkładzie skokowym, jak i ciągłym.

W przypadku populacji badanej ze względu na skokową zmienną losową $X$ o rozkładzie określonym za pomocą funkcji prawdopodobieństwa $p\left(x_{(i)}\right)=p_{i}$ dla $i=1,2, \ldots$, gdzie $x_{(1)}, x_{(2)}, \ldots$ są wartościami rosnąco uporządkowanymi tej zmiennej, statystyka pozycyjna $X_{(k)}^{(n)}$, gdzie $1 \leq k \leq n$, wyznaczona 
na podstawie $n$-elementowej próby prostej ma rozkład prawdopodobieństwa postaci:

$$
P\left(X_{(k)}^{(n)}=x_{(i)}\right)=\sum_{l=k}^{n}\left(\begin{array}{l}
n \\
l
\end{array}\right)\left[P_{i}^{l}\left(1-P_{i}\right)^{n-l}-P_{i-1}^{l}\left(1-P_{i-1}\right)^{n-l}\right] \quad \text { dla } i=1,2, \ldots,
$$

zaś dystrybuanta $F_{k: n} k$-tej statystyki pozycyjnej:

$$
F_{k: n}(x)=\sum_{l=k}^{n}\left(\begin{array}{l}
n \\
l
\end{array}\right) P_{i}^{l}\left(1-P_{i}\right)^{n-l}, \quad \text { gdzie } i=\max \left\{j: x_{j} \leq x\right\}
$$

gdzie $P_{0}=0, P_{1}=p_{1}, P_{2}=p_{1}+p_{2}, \ldots, P_{i}=p_{1}+p_{2}+\ldots+p_{i}, \ldots$

Dla populacji badanych ze względu na ciagłą zmienną losową postaci rozkładów statystyk pozycyjnych wyznaczonych na podstawie $n$-elementowej próby prostej formułują twierdzenia będące wnioskami z twierdzenia 1.3.2.

Twierdzenie 1.3.3. Jeżeli $X_{1}, X_{2}, \ldots, X_{n}$ jest próbą prostą wylosowaną z populacji $X$ o ciagłym rozkładzie określonym za pomocą dystrybuanty $F$, to statystyka pozycyjna $X_{(k)}^{(n)}$, dla $k=1,2, \ldots, n$, ma rozkład o dystrybuancie wyrażonej wzorem:

$$
F_{k: n}(x)=\frac{n !}{(k-1) !(n-k) !} \int_{0}^{F(x)} t^{k-1}(1-t)^{n-k} d t
$$

Dystrybuanta $F_{k: n}$ jest więc superpozycją dystrybuanty rozkładu beta $\beta(k, n-k+1)$ i dystrybuanty $F$.

Twierdzenie 1.3.4. Jeżeli $X_{1}, X_{2}, \ldots, X_{n}$ jest próbą prostą wylosowaną z populacji $X$ o ciagłym rozkładzie określonym za pomocą dystrybuanty $F$, to funkcja gęstości $k$-tej statystyki pozycyjnej $X_{(k)}^{(n)}$, dla $k=1,2, \ldots, n$, ma postać:

$$
g_{k: n}(x)=\frac{n !}{(k-1) !(n-k) !}[F(x)]^{k-1}[1-F(x)]^{n-k} f(x),
$$

gdzie $f$ jest funkcją gęstości zmiennej losowej $X_{i}$ dla $i=1,2, \ldots, n$.

Funkcje gęstości statystyk pozycyjnych $\mathrm{z} n$-elementowej próby prostej $X_{1}, X_{2}, \ldots, X_{n}$ mogą mieć różnorodne postaci w zależności od typu rozkładu 
prawdopodobieństwa populacji $X$ (por. M. M. Desu [1971], C. Dimaki, E. Xekalaki [1993]). W tablicy 1.3.1 przedstawione są funkcje gęstości statystyk pozycyjnych $X_{(k)}^{(n)}$, gdzie $k=1,2, \ldots, n$, wyznaczone dla wybranych ciagłych rozkładów populacji, natomiast $\mathrm{w}$ tablicach 1.3.2 i 1.3.3 funkcje gęstości ich szczególnych przypadków - statystyk ekstremalnych. Do rozważań wybrano rozkłady znajdujące zastosowanie w badaniach społeczno-ekonomicznych (m.in. rozkład wykładniczy, Pareto, Burra, Cauchy’ego, logistyczny), wykorzystywane w analizach dochodów ludności, analizach przeżycia, w teorii niezawodności, teorii masowej obsługi, w modelowaniu procesów na rynkach finansowych i ubezpieczeniowych. Postaci charakterystyk funkcyjnych i liczbowych rozważanych rozkładów podano $\mathrm{w}$ aneksie.

Z twierdzenia 1.3.4 wynika, że funkcje gęstości statystyk pozycyjnych można formalnie zapisać za pomocą odpowiednich wzorów, ale zwykle nie mają postaci znanego, zdefiniowanego rozkładu. Spośród rozważanych rozkładów statystyki pozycyjne wyznaczone na podstawie ciagu zmiennych losowych o rozkładzie jednostajnym $U(a, b)$ mają rozkłady beta (por. np. C. Domański [1996, s. 15-16]). W szczególności, statystyka $X_{(1)}^{(n)}$ ma rozkład $\beta(1, n)$, zaś $X_{(n)}^{(n)}-\operatorname{rozkład} \beta(n, 1)$. Ponadto statystyka minimum $X_{(1)}^{(n)}$ wyznaczona w oparciu o ciag zmiennych losowych o rozkładzie wykładniczym $\operatorname{Exp}(\lambda)$ ma rozkład wykładniczy o wartości oczekiwanej $\frac{\lambda}{n}$, natomiast dla zmiennych o rozkładzie Pareto $P a(\theta, a)$ statystyka $X_{(1)}^{(n)}$ ma rozkład Pareto $P a(\theta, n a)$, a dla zmiennych o rozkładzie Burra $\operatorname{Br}(a, c)$ statystyka minimum ma rozkład $\operatorname{Br}(n a, c)$. Dla rozkładu potegowego $P o(\lambda)$ statystyka maksimum $X_{(n)}^{(n)}$ ma rozkład potęgowy $\operatorname{Po}(n \lambda)$.

Kwantyl $X_{p ; n}$ rzędu $p$ charakteryzuje rozkład o funkcji gęstości postaci:

$$
g_{p ; n}(x)=\frac{n p !}{(n p-1) !(n-n p) !}[F(x)]^{n p-1}[1-F(x)]^{n-n p} f(x), \text { gdy } n p \in N
$$

lub

$$
g_{p ; n}(x)=\frac{[n p] !}{([n p]) !(n-[n p]-1) !}[F(x)]^{[n p]}[1-F(x)]^{n-[n p]-1} f(x) \text {, gdy } n p \notin N .
$$


Tablica 1.3.1. Funkcje gęstości statystyk pozycyjnych rangi $k$ dla wybranych rozkładów ciagłych

\begin{tabular}{|c|c|}
\hline Rozkład populacji & Funkcja gęstości statystyki $X_{(k)}^{(n)}$ \\
\hline $\begin{array}{l}\operatorname{Br}(a, c) \\
\text { (Burra) }\end{array}$ & $g_{k: n}(x)= \begin{cases}\frac{n !}{(k-1) !(n-k) !}\left(1-\frac{1}{\left(1+x^{c}\right)^{a}}\right)^{k-1} \frac{a c x^{c-1}}{\left(1+x^{c}\right)^{a(n-k+1)+1}} & \text { dla } x \geq 0 \\
0 & \text { dla } x<0\end{cases}$ \\
\hline $\begin{array}{c}C a(m, \lambda) \\
\text { (Cauchy'ego) }\end{array}$ & $\begin{aligned} g_{k: n}(x) & =\frac{n !}{(k-1) !(n-k) !}\left[\frac{1}{2}+\frac{1}{\pi} \operatorname{arctg}\left(\frac{x-m}{\lambda}\right)\right]^{k-1} . \\
& \cdot\left[\frac{1}{2}-\frac{1}{\pi} \operatorname{arctg}\left(\frac{x-m}{\lambda}\right)\right]^{n-k} \frac{\lambda}{\pi\left(\lambda^{2}+(x-m)^{2}\right)}\end{aligned}$ \\
\hline $\begin{array}{c}\operatorname{Exp}(\lambda) \\
\text { (wykładniczy) }\end{array}$ & $g_{k: n}(x)= \begin{cases}\frac{n !}{(k-1) !(n-k) ! \lambda}\left(1-\exp \left(-\frac{x}{\lambda}\right)\right)^{k-1}\left(\exp \left(-\frac{x}{\lambda}\right)\right)^{n-k+1} & \text { dla } x \geq 0 \\
0 & \text { dla } x<0\end{cases}$ \\
\hline $\begin{array}{c}\text { Logist }(\mu, s) \\
\text { (logistyczny) }\end{array}$ & $g_{k: n}(x)=\frac{n !}{(k-1) !(n-k) !} \cdot \frac{\exp \left(-\frac{x-\mu}{s}(n-k+1)\right)}{s\left(1+\exp \left(-\frac{x-\mu}{s}\right)\right)^{n+1}}$ \\
\hline $\begin{array}{l}P a(\theta, a) \\
\text { (Pareto) }\end{array}$ & $g_{k: n}(x)=\left\{\begin{array}{l}\frac{n !}{(k-1) !(n-k) !}\left[1-\left(\frac{\theta}{x}\right)^{a}\right]^{k-1} \frac{a \theta^{\alpha(n-k+1)}}{x^{a(n-k+1)+1}} \\
0\end{array}\right.$ \\
\hline $\begin{array}{c}P o(\lambda) \\
\text { (potęgowy) }\end{array}$ & $g_{k: n}(x)=\left\{\begin{array}{l}\frac{n !}{(k-1) !(n-k) !} \lambda x^{\lambda k-1}\left(1-x^{\lambda}\right)^{n-k} \\
0\end{array}\right.$ \\
\hline $\begin{array}{l}U(a, b) \\
\text { (jednostajny na } \\
\text { przedziale }[a, b] \text { ) }\end{array}$ & $g_{k: n}(x)=\left\{\begin{array}{l}\frac{n !(x-a)^{k-1}(b-x)^{n-k}}{(k-1) !(n-k) !(b-a)^{n}} \\
0\end{array}\right.$ \\
\hline
\end{tabular}

Źródło: opracowanie własne. 
Tablica 1.3.2. Funkcje gęstości statystyk minimalnych dla wybranych ciągłych rozkładów populacji

\begin{tabular}{|c|c|}
\hline Rozkład populacji & Funkcja gęstości statystyki minimum \\
\hline $\begin{array}{l}\operatorname{Br}(a, c) \\
\text { (Burra) }\end{array}$ & $g_{1: n}(x)= \begin{cases}n \frac{a c x^{c-1}}{\left(1+x^{c}\right)^{a n+1}} & \text { dla } \quad x \geq 0 \\
0 & \text { dla } x<0\end{cases}$ \\
\hline $\begin{array}{c}C a(m, \lambda) \\
\text { (Cauchy'ego) }\end{array}$ & $g_{1: n}(x)=n\left[\frac{1}{2}-\frac{1}{\pi} \operatorname{arctg}\left(\frac{x-m}{\lambda}\right)\right]^{n-1} \frac{\lambda}{\pi\left(\lambda^{2}+(x-m)^{2}\right)}, x \in R$ \\
\hline $\begin{array}{c}\operatorname{Exp}(\lambda) \\
\text { (wykładniczy) }\end{array}$ & $g_{1: n}(x)= \begin{cases}\frac{n}{\lambda} \exp \left(-\frac{n}{\lambda} x\right) & \text { dla } x \geq 0 \\
0 & \text { dla } x<0\end{cases}$ \\
\hline $\begin{array}{l}\operatorname{Logist}(\mu, s) \\
\text { (logistyczny) }\end{array}$ & $g_{1: n}(x)=\frac{n}{s} \exp \left(-\frac{x-\mu}{s} n\right)\left(1+\exp \left(-\frac{x-\mu}{s}\right)\right)^{-n-1}, x \in R$ \\
\hline $\begin{array}{l}P a(\theta, a) \\
\text { (Pareto) }\end{array}$ & $g_{1: n}(x)= \begin{cases}n \frac{a \theta^{a n}}{x^{a n+1}} & \text { dla } x \geq \theta \\
0 & \text { dla } x<\theta\end{cases}$ \\
\hline $\begin{array}{c}\operatorname{Po}(\lambda) \\
\text { (potęgowy) }\end{array}$ & $g_{1: n}(x)= \begin{cases}n \lambda x^{\lambda-1}\left(1-x^{\lambda}\right)^{n-1} & \text { dla } 0 \leq x \leq 1 \\
0 & \text { dla } x<0 \quad \vee \quad x>1\end{cases}$ \\
\hline $\begin{array}{l}U(a, b) \\
\text { (jednostajny na prze- } \\
\text { dziale }[a, b])\end{array}$ & $g_{1: n}(x)=\left\{\begin{array}{l}n \frac{(b-x)^{n-1}}{(b-a)^{n}} \\
0\end{array}\right.$ \\
\hline
\end{tabular}

Źródło: opracowanie własne.

Dla rozkładu $U(a, b)$ kwantyl $X_{p ; n}$ ma rozkład $\beta(n p, n-n p+1)$ lub $\beta([n p]+1, n-[n p])$, odpowiednio gdy $n p \in N$ lub $n p \notin N$.

Wykresy funkcji gęstości statystyk ekstremalnych i kwantyla rzędu 0,5 wyznaczone na podstawie dla 30-elementowego wektora zmiennych losowych o rozkładzie jednostajnym i wykładniczym przedstawione są na rysunkach 1.3.1 i 1.3.2. 
Tablica 1.3.3. Funkcje gęstości statystyk maksymalnych dla wybranych ciągłych rozkładów populacji

\begin{tabular}{|c|c|}
\hline Rozkład populacji & Funkcja gęstości statystyki maksimum \\
\hline $\begin{array}{l}\operatorname{Br}(a, c) \\
\text { (Burra) }\end{array}$ & $g_{n: n}(x)= \begin{cases}n\left(\left(1+x^{c}\right)^{a}-1\right)^{n-1} \frac{a c x^{c-1}}{\left(1+x^{c}\right)^{a n+1}} & \text { dla } x \geq 0 \\
0 & \text { dla } x<0\end{cases}$ \\
\hline $\begin{array}{c}C a(m, \lambda) \\
\text { (Cauchy'ego) }\end{array}$ & $g_{n: n}(x)=n\left[\frac{1}{2}+\frac{1}{\pi} \operatorname{arctg}\left(\frac{x-m}{\lambda}\right)\right]^{n-1} \frac{\lambda}{\pi\left(\lambda^{2}+(x-m)^{2}\right)}, x \in R$ \\
\hline $\begin{array}{c}\quad \operatorname{Exp}(\lambda) \\
\text { (wykładniczy) }\end{array}$ & $g_{n: n}(x)= \begin{cases}\frac{n}{\lambda}\left(1-\exp \left(-\frac{x}{\lambda}\right)\right)^{n-1} \exp \left(-\frac{x}{\lambda}\right) & \text { dla } x \geq 0 \\
0 & \text { dla } x<0\end{cases}$ \\
\hline $\begin{array}{l}\operatorname{Logist}(\mu, s) \\
\text { (logistyczny) }\end{array}$ & $g_{n: n}(x)=\frac{n}{s} \exp \left(-\frac{x-\mu}{s}\right) s\left(1+\exp \left(-\frac{x-\mu}{s}\right)\right)^{-n-1}, x \in R$ \\
\hline $\begin{array}{l}P a(\theta, a) \\
\text { (Pareto) }\end{array}$ & $g_{n: n}(x)=\left\{\begin{array}{l}{\left[1-\left(\frac{\theta}{x}\right)^{a}\right]^{n-1} \frac{n a \theta^{\alpha n}}{x^{a n+1}}} \\
0\end{array}\right.$ \\
\hline $\begin{array}{c}\operatorname{Po}(\lambda) \\
\text { (potęgowy) }\end{array}$ & $g_{n: n}(x)=\left\{\begin{array}{lll}n \lambda x^{n \lambda-1} & \text { dla } & 0 \leq x \leq 1 \\
0 & \text { dla } & x<0 \quad \vee \quad x>1\end{array}\right.$ \\
\hline $\begin{array}{l}U(a, b) \\
\text { (jednostajny na prze- } \\
\text { dziale }[a, b])\end{array}$ & $g_{n: n}(x)= \begin{cases}n \frac{(x-a)^{n-1}}{(b-a)^{n}} & \text { dla } x \in[a, b] \\
0 & \text { dla } x \notin[a, b]\end{cases}$ \\
\hline
\end{tabular}

Źródło: opracowanie własne.

Dla innych liczebności wektorów losowych kształty wykresów funkcji gęstości poszczególnych statystyk pozycyjnych są zbliżone.

Na rysunkach 1.3.3 - 1.3.5 przedstawiono wykresy funkcji gęstości minimum, maksimum i mediany z próby - dla prób o liczebnościach $n=10,30,60$ pochodzących z populacji o rozkładzie wykładniczym $\operatorname{Exp}(1)$. 


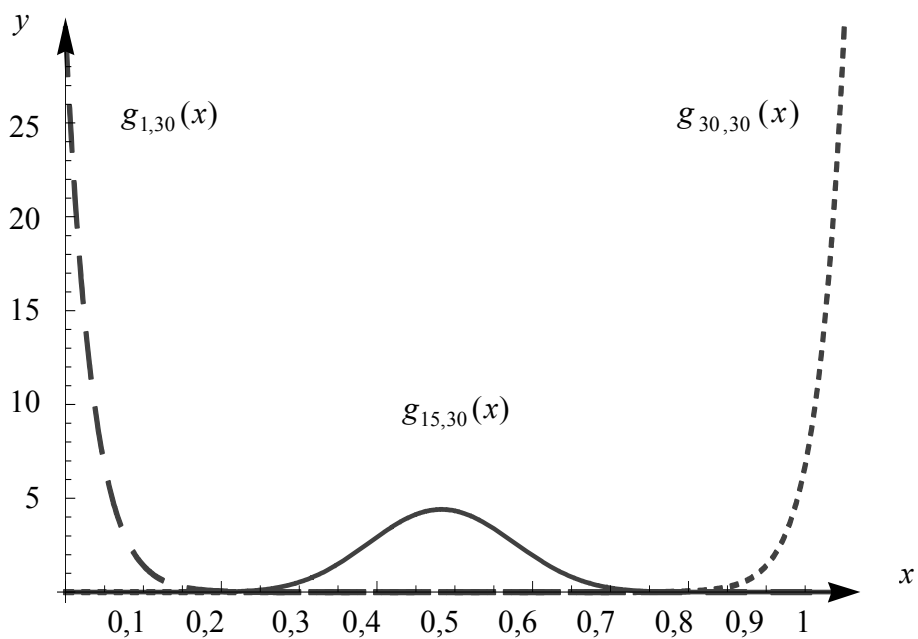

Rysunek 1.3.1. Funkcje gęstości statystyk pozycyjnych wyznaczonych w oparciu o próbę 30-elementową wylosowaną z populacji o rozkładzie jednostajnym $U(0,1)$ Źródło: opracowanie własne

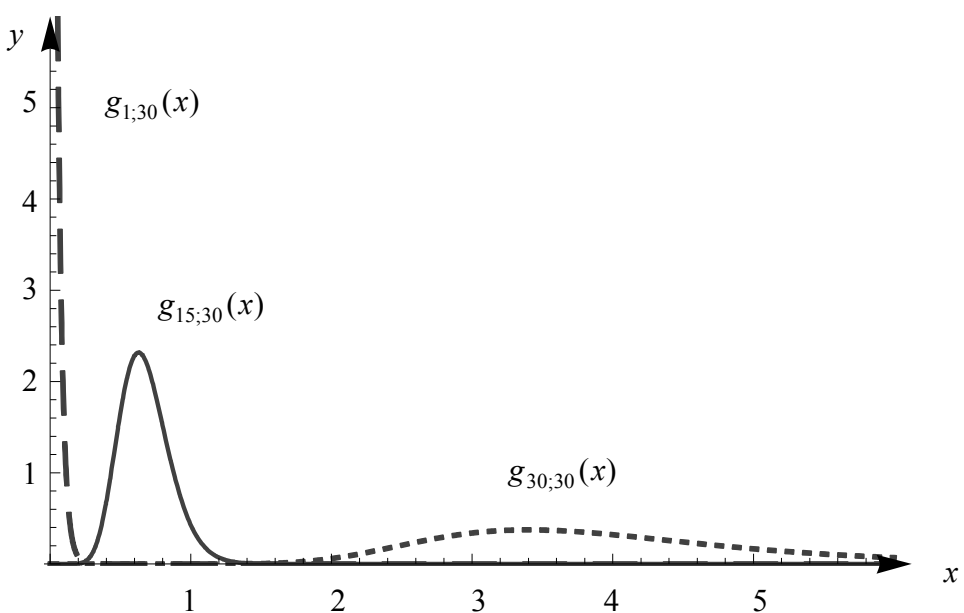

Rysunek 1.3.2. Funkcje gęstości statystyk pozycyjnych wyznaczonych w oparciu o próbę 30-elementową wylosowaną z populacji o rozkładzie wykładniczym $\operatorname{Exp}(1)$

Źródło: opracowanie własne 


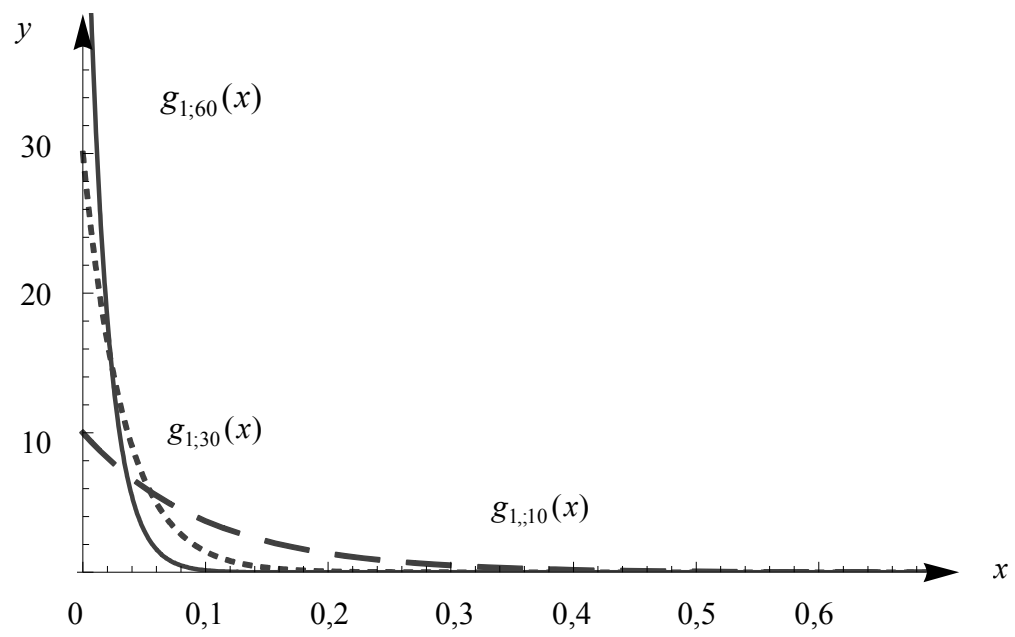

Rysunek 1.3.3. Funkcje gęstości minimum z próby wylosowanej z populacji o rozkładzie $\operatorname{Exp}(1)$ i wybranych liczebności prób

Źródło: opracowanie własne

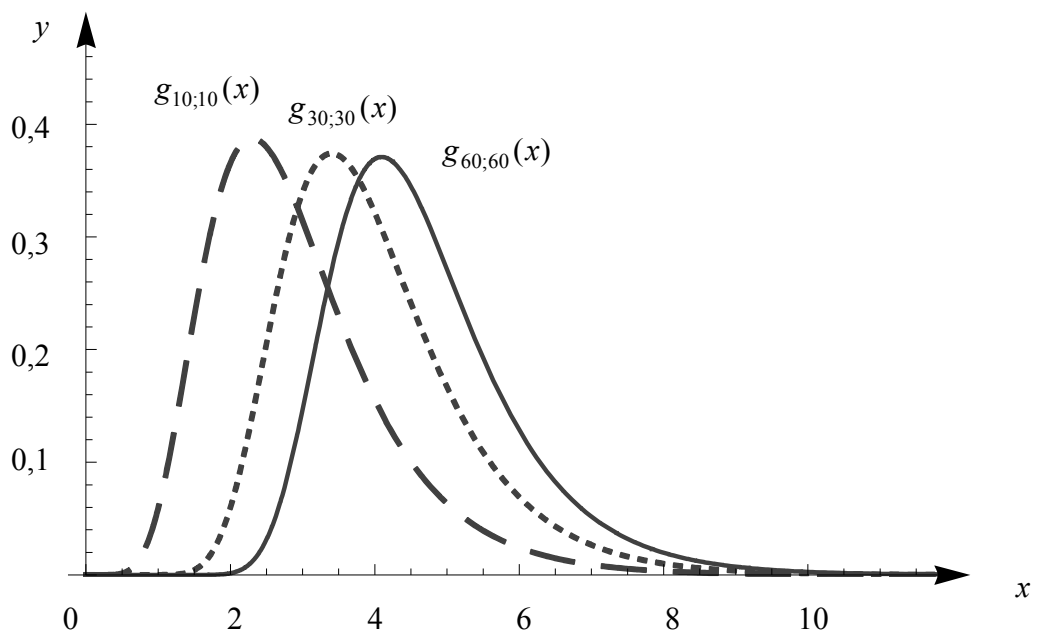

Rysunek 1.3.4. Funkcje gęstości maksimum z próby wylosowanej z populacji o rozkładzie $\operatorname{Exp}(1)$ i wybranych liczebności prób

Źródło: opracowanie własne 


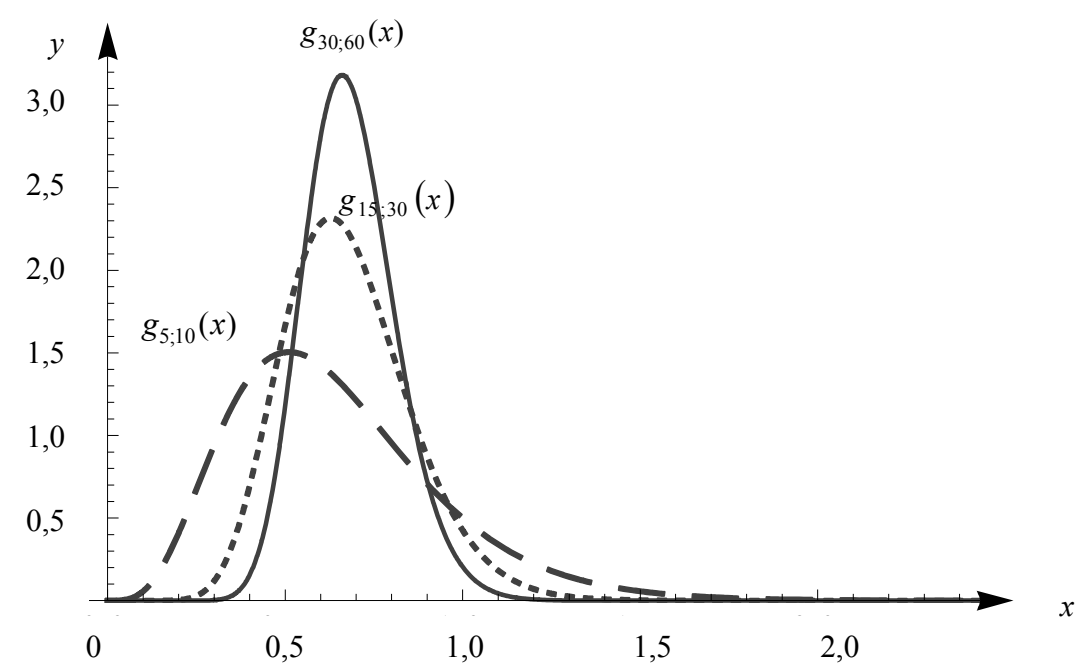

Rysunek 1.3.5. Funkcje gęstości mediany z próby wylosowanej z populacji o rozkładzie $\operatorname{Exp}(1)$ i wybranych liczebności prób Źródło: opracowanie własne

Klasy rozkładów zmiennych losowych, dla których rozważano rozkłady statystyk pozycyjnych, nie wyczerpują wszystkich rozkładów mających zastosowanie w różnego rodzaju badaniach statystycznych. Dystrybuanty i funkcje gęstości statystyk pozycyjnych dla innych klas ciagłych rozkładów wyznacza się, w sposób analogiczny, na podstawie twierdzeń 1.3.3 i 1.3.4.

Funkcje prawdopodobieństwa i funkcje gęstości statystyk pozycyjnych pozwalają określić ich charakterystyki liczbowe, m.in. wartość oczekiwaną i wariancję.

Twierdzenie 1.3.5. Wartość oczekiwana (o ile istnieje) statystyki pozycyjnej $X_{(k)}^{(n)}$, dla $k=1, \ldots, n$, określonej na podstawie ciagu niezależnych zmiennych losowych $X_{1}, X_{2}, \ldots, X_{n}$ o rozkładzie skokowym o wartościach rosnąco uporządkowanych $x_{(1)}, x_{(2)}, \ldots$, i funkcji prawdopodobieństwa $p\left(x_{(i)}\right)=p_{i}$ dla $i=1,2, \ldots$ wyraża się wzorem:

$$
E\left(X_{(k)}^{(n)}\right)=\sum_{i} x_{(i)} \cdot P\left(X_{(k)}^{(n)}=x_{(i)}\right)=\sum_{i}\left[x_{(i)} \cdot \sum_{l=k}^{n}\left(\begin{array}{l}
n \\
l
\end{array}\right)\left[P_{i}^{l}\left(1-P_{i}\right)^{n-l}-P_{i-1}^{l}\left(1-P_{i-1}\right)^{n-l}\right]\right],
$$

natomiast dla ciagu niezależnych zmiennych losowych $X_{1}, X_{2}, \ldots, X_{n}$ o rozkładzie ciągłym o dystrybuancie $F$ i funkcji gęstości $f$ ma postać: 


$$
E\left(X_{(k)}^{(n)}\right)=\int_{-\infty}^{\infty} x g_{k ; n}(x) d x=\frac{n !}{(k-1) !(n-k) !} \int_{-\infty}^{\infty} x[F(x)]^{k-1}[1-F(x)]^{n-k} f(x) d x
$$

W zagadnieniach teoretycznych i praktycznych często wykorzystuje się fakt, że dla ciągłej zmiennej losowej $X$ o funkcji gęstości $f$ i dystrybuancie $F$ zmienna losowa $Y=F(X)$ ma rozkład jednostajny na przedziale $[0,1]$.

W szczególności, dla statystyk pozycyjnych $X_{(1)}^{(n)}, X_{(2)}^{(n)}, \ldots, X_{(n)}^{(n)}$ o ciagłych rozkładach, zmienne losowe $F\left(X_{(1)}^{(n)}\right), F\left(X_{(2)}^{(n)}\right), \ldots, F\left(X_{(n)}^{(n)}\right)$ mają rozkład jednostajny na przedziale $[0,1]$, a ich funkcje gęstości określa następujące twierdzenie (por. C. Domański, K. Pruska [2000, s. 102]).

Twierdzenie 1.3.6. Jeżeli $X_{1}, X_{2}, \ldots, X_{n}$ jest ciagiem niezależnych zmiennych losowych o rozkładzie ciagłym oraz $X_{(k)}^{(n)}$ jest $k$-tą statystyką pozycyjną wyznaczoną na podstawie ciagu $X_{1}, X_{2}, \ldots, X_{n}$, to brzegowy rozkład zmiennej $Y_{(k)}=F\left(X_{(k)}^{(n)}\right)$ w łącznym rozkładzie statystyk $X_{(1)}^{(n)}, X_{(2)}^{(n)}, \ldots, X_{(n)}^{(n)}$ jest rozkładem beta z parametrami $q=k, p=n-k+1$ i funkcją gęstości postaci:

$$
g_{k: n}(y)=\frac{n !}{(k-1) !(n-k) !} y^{k-1}(1-y)^{n-k} \quad \text { dla } \quad 0 \leq y \leq 1 .
$$

Zatem wartość oczekiwana i wariancja zmiennej $Y_{(k)}=F\left(X_{(k)}^{(n)}\right)$ wyrażają się wzorami:

$$
E\left(Y_{(k)}\right)=\frac{k}{n+1} \quad \text { oraz } \quad D^{2}\left(Y_{(k)}\right)=\frac{k(n-k+1)}{(n+1)^{2}(n+2)} .
$$

Do określenia własności rozstępu z próby czy też odchylenia ćwiartkowego z próby wykorzystuje się twierdzenie o postaci funkcji gęstości łącznego rozkładu dwóch statystyk pozycyjnych (por. H. A. David, H. N. Nagaraja [2003, s. 12]).

Twierdzenie 1.3.7. Jeżeli $X_{1}, X_{2}, \ldots, X_{n}$ jest ciagiem niezależnych zmiennych losowych o rozkładzie ciagłym, określonym za pomocą funkcji gęstości $f$, to gęstość łącznego rozkładu statystyk pozycyjnych $\left(X_{(r)}^{(n)}, X_{(s)}^{(n)}\right)$ dla $1 \leq r<s \leq n$ ma postać: 


$$
g(x, y)= \begin{cases}\frac{n ![F(x)]^{r-1} f(x)[F(y)-F(x)]^{s-r-1} f(y)[1-F(y)]^{n-s}}{(r-1) !(s-r-1) !(n-s) !} & \text { dla } x<y, \\ 0 & \text { dla } x \geq y .\end{cases}
$$

Z twierdzenia 1.3.7 wynika, że funkcja gęstości zmiennej losowej $\left(X_{(1)}^{(n)}, X_{(n)}^{(n)}\right)$ wyraża się wzorem:

$$
g(x, y)=\left\{\begin{array}{lrc}
n(n-1)[F(y)-F(x)]^{n-2} f(x) f(y) & \text { dla } & x<y, \\
0 & \text { dla } & x \geq y .
\end{array}\right.
$$

Na podstawie wzoru (1.3.15) i twierdzenia o rozkładzie różnicy zmiennych losowych można wyznaczyć funkcję gęstości $g_{n}(r)$ rozstępu $R$ z $n$-elementowej próby prostej:

$$
g_{n}(r)=\int_{-\infty}^{+\infty} g(x, x+r) d x
$$

Twierdzenie 1.3.8. Niech $X_{1}, X_{2}, \ldots, X_{n}$ będzie próbą prostą pochodzącą z populacji o rozkładzie ciagłym określonym za pomocą funkcji gęstości $f$ i dystrybuanty $F$. Rozstęp z próby $R=X_{(n)}^{(n)}-X_{(1)}^{(n)}$ ma rozkład o funkcji gęstości określonej wzorem:

$$
g_{n}(r)=\int_{-\infty}^{+\infty} n(n-1)[F(x+r)-F(x)]^{n-2} f(x) f(x+r) d x .
$$

Nie dla wszystkich rozkładów można w sposób analityczny zapisać wzór na funkcję gęstości rozstępu z próby.

Dla rozkładów wykładniczego i jednostajnego postaci funkcji gęstości rozstępu sformułowano $\mathrm{w}$ twierdzeniach 1.3 .9 i 1.3.10, natomiast na rysunkach 1.3.6 i 1.3.7 przedstawiono ich wykresy dla wybranych liczebności prób.

Twierdzenie 1.3.9. Niech $X_{1}, X_{2}, \ldots, X_{n}$ będzie próbą prostą wylosowaną z populacji o rozkładzie wykładniczym $\operatorname{Exp}(\lambda)$. Rozstęp $R$ z próby ma rozkład o funkcji gęstości określonej wzorem:

$$
g_{n}(r)=(n-1) \frac{1}{\lambda} e^{-\frac{r}{\lambda}}\left(1-e^{-\frac{r}{\lambda}}\right)^{n-2} \quad \text { dla } \quad r>0 .
$$


Wzór (1.3.18) wynika z własności funkcji gęstości i następujących przekształceń:

$$
\begin{aligned}
& g_{n}(r)=n(n-1) \frac{1}{\lambda^{2}} \int_{0}^{+\infty}\left[e^{-\frac{x}{\lambda}}-e^{-\frac{x+r}{\lambda}}\right]^{n-2} e^{-\frac{x}{\lambda}} e^{-\frac{x+r}{\lambda}} d x= \\
& =n(n-1) \frac{1}{\lambda^{2}} e^{-\frac{r}{\lambda}}\left(1-e^{-\frac{r}{\lambda}}\right)^{n-2} \int_{0}^{+\infty} e^{-\frac{n x}{\lambda}} d x= \\
& =(n-1) \frac{1}{\lambda} e^{-\frac{r}{\lambda}}\left(1-e^{-\frac{r}{\lambda}}\right)^{n-2} \frac{n}{\lambda} \int_{0}^{+\infty} e^{-\frac{n x}{\lambda}} d x=(n-1) \frac{1}{\lambda} e^{-\frac{r}{\lambda}}\left(1-e^{-\frac{r}{\lambda}}\right)^{n-2} .
\end{aligned}
$$

Twierdzenie 1.3.10. Niech $X_{1}, X_{2}, \ldots, X_{n}$ będzie próbą prostą wylosowaną z populacji o rozkładzie jednostajnym $U(a, b)$. Funkcja gęstości rozstępu $R$ z próby ma postać:

$$
g_{n}(r)= \begin{cases}\frac{n(n-1) r^{n-2}(b-a-r)}{(b-a)^{n}} & \text { dla } 0 \leq r \leq b-a, \\ 0 & \text { dla } r<0 \quad \vee \quad r>b-a .\end{cases}
$$

Dla innych rozważanych rozkładów teoretycznych istnieje możliwość, na podstawie próby losowej, numerycznego oszacowania wartości funkcji gęstości rozstępu.

Twierdzenie 1.3.7 wykorzystuje się również do wyznaczania rozkładów innych statystyk będących funkcjami dwóch statystyk pozycyjnych, m.in. odchylenia ćwiartkowego. Funkcja gęstości zmiennej losowej $\left(X_{0,25 ; n}, X_{0,75 ; n}\right)$, gdy $0,25 n \in N$ wyraża się wzorem:

$$
g(x, y)= \begin{cases}\frac{n ![F(x)]^{0,25 n-1} f(x)[F(y)-F(x)]^{0,5 n-1} f(y)[1-F(y)]^{0,25 n}}{(0,25 n-1) !(0,5 n-1) !(0,25 n) !} & \text { dla } x<y, \\ 0 & \text { dla } x \geq y,\end{cases}
$$

natomiast odchylenie ćwiartkowe $Q$ z $n$-elementowej próby ma funkcję gęstości postaci:

$$
g_{n}(z)=\int_{-\infty}^{+\infty} g(x, x+z) d x .
$$




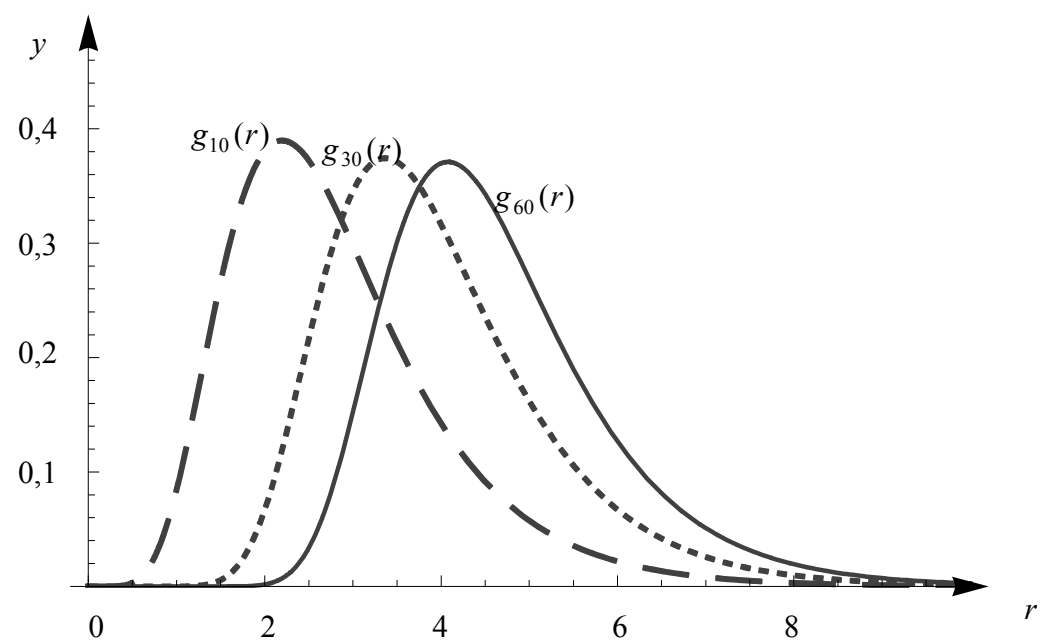

Rysunek 1.3.6. Funkcje gęstości rozstępu $R$ z próby wylosowanej z populacji o rozkładzie wykładniczym $\operatorname{Exp}(1)$ i wybranych liczebności prób

Źródło: opracowanie własne

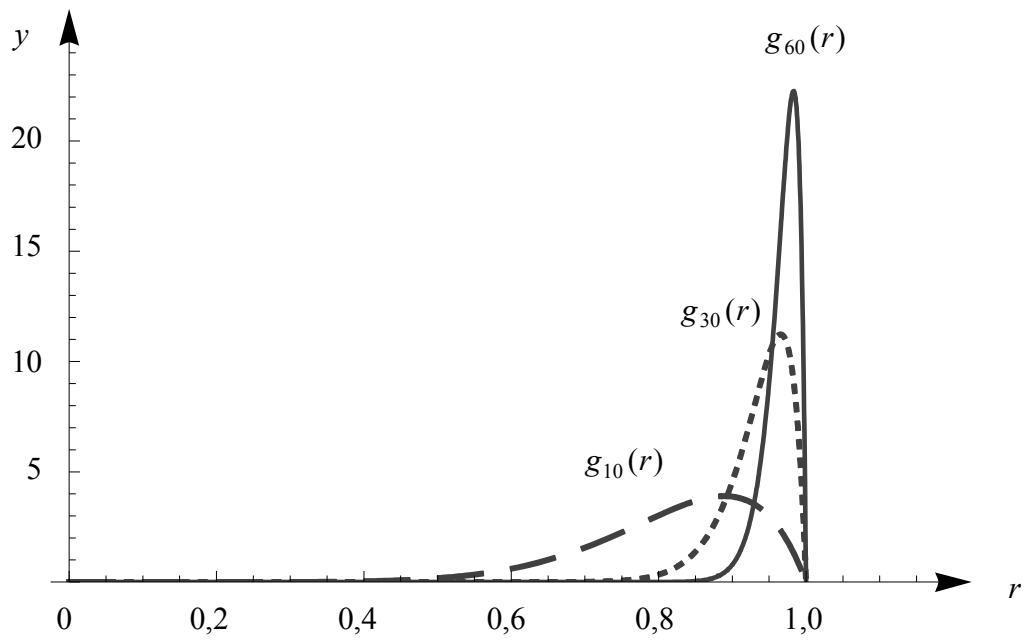

Rysunek 1.3.7. Funkcje gęstości rozstępu $R$ z próby wylosowanej z populacji o rozkładzie jednostajnym $U(0,1)$ i wybranych liczebności prób

Źródło: opracowanie własne 
Dla populacji o rozkładzie $U(a, b)$ postać funkcji gęstości odchylenia ćwiartkowego $\mathrm{z}$ próby przedstawiona jest $\mathrm{w}$ twierdzeniu 1.3.11. Niestety, dla większości rozkładów nie da się wyznaczyć analitycznej postaci funkcji gęstości odchylenia ćwiartkowego z próby.

Twierdzenie 1.3.11. Niech $X_{1}, X_{2}, \ldots, X_{n}$ będzie próbą prostą wylosowaną z populacji o rozkładzie jednostajnym $U(a, b)$. Funkcja gęstości odchylenia ćwiartkowego $Q$ z $n$-elementowej próby, gdy $n$ jest liczbą naturalną podzielną przez 4, ma postać:

$$
g_{n}(z)= \begin{cases}\frac{n !(b-a-z)^{0,5 n} z^{0,5 n-1}}{2(0,5 n) !(0,5 n-1) !(b-a)^{n}}, & \text { gdy } 0 \leq z \leq b-a, \\ 0, & \text { gdy } z<0 \quad \vee \quad z>b-a .\end{cases}
$$

W analogiczny sposób można wyznaczyć rozkład odchylenia ćwiartkowego, gdy $0,25 n \notin N$. W tym przypadku $\left(X_{0,25 ; n}, X_{0,75 ; n}\right)=\left(X_{([0,25 n]+1)}^{(n)}, X_{([0,75 n]+1)}^{(n)}\right)$.

\subsection{Graniczne rozkłady statystyk pozycyjnych}

Wśród ciagów statystyk pozycyjnych $\left\{X_{(k)}^{(n)}\right\}_{n \in N}$ wyróżnia się dwa typy (por. M. Fisz [1967, s. 390]):

- ciagi statystyk centralnych,

- ciagi statystyk skrajnych.

Definicja 1.4.1. Ciag statystyk pozycyjnych $\left\{X_{(k)}^{(n)}\right\}_{n \in N}$ nazywamy ciagiem statystyk centralnych, gdy $\lim _{n \rightarrow \infty} \frac{k}{n}=\lambda$ oraz $0<\lambda<1$.

Definicja 1.4.2. Ciagg statystyk pozycyjnych $\left\{X_{(k)}^{(n)}\right\}_{n \in N}$ jest ciagiem statystyk skrajnych, gdy $\lim _{n \rightarrow \infty} \frac{k}{n}=0$ lub $\lim _{n \rightarrow \infty} \frac{k}{n}=1$.

Liczbę $\lambda \in(0,1)$ nazywamy rangą graniczną ciagu statystyk centralnych. Ranga graniczna ciagu statystyk skrajnych jest równa 0 lub 1 . 
Ciagi statystyk centralnych otrzymujemy, gdy $k$ jest funkcją $n$, np. $k=[n p]+1$, gdzie $p \in(0,1)$. Gdy za $k$ przyjmiemy ustaloną liczbę naturalną ze zbioru $\{1,2, \ldots, n\}$, to uzyskamy ciag statystyk skrajnych.

Ciagi kwantyli $X_{p ; n}$, gdzie $p \in(0,1)$, są ciaggami statystyk centralnych, zaś ciaggi statystyk ekstremalnych $X_{(1)}^{(n)}, X_{(n)}^{(n)}$ to ciagi statystyk skrajnych.

Rozkłady graniczne statystyk centralnych i skrajnych charakteryzują się różnymi własnościami. Rozkłady statystyk centralnych są asymptotycznie normalne, natomiast rozkłady graniczne unormowanych statystyk ekstremalnych należą do rodziny tzw. uogólnionych rozkładów statystyk ekstremalnych (por. E. Castillo i in. [2004, s. 212], P. Embrechts i in. [1997, s. 152-155]). Wyróżniamy klasę uogólnionych rozkładów statystyk maksimum $\left(G E V D_{M}\right)$ oraz klasę uogólnionych rozkładów statystyk minimum $\left(G E V D_{m}\right)$.

Definicja 1.4.3. Uogólnionym rozkładem statystyki maksimum ( $\left.G E V D_{M}\right)$ nazywamy rozkład określony za pomocą dystrybuanty:

$$
F_{\mu, \sigma, \xi}^{M}(x)= \begin{cases}\exp \left(-\left(1+\xi \frac{x-\mu}{\sigma}\right)^{-\frac{1}{\xi}}\right) & \text { dla } \xi \neq 0, \quad 1+\xi \frac{x-\mu}{\sigma}>0, \\ \exp \left(-\exp \left(-\frac{x-\mu}{\sigma}\right)\right) & \text { dla } \xi=0, \quad x \in R,\end{cases}
$$

gdzie $\mu$ jest parametrem położenia, $\sigma$ - skali, natomiast $\frac{1}{\xi}-$ parametrem kształtu.

Szczególnymi przypadkami rozkładu (1.4.1) są trzy następujące rodziny rozkładów (por. J. Beirlant i in. [2004, s. 45-72], S. Kotz, S. Nadarajah [2000, s. 6-8]:

- typu Gumbela $G l(\lambda, \delta), \lambda, \delta \in R$, o dystrybuancie określonej wzorem:

$$
H_{1, \lambda, \delta}(x)=\exp \left(-\exp \left(-\frac{x-\lambda}{\delta}\right)\right) \text { dla } x \in R .
$$

- typu Frécheta $\operatorname{Fr}(\lambda, \delta, \gamma), \lambda, \delta \in R, \gamma>0$, o dystrybuancie postaci:

$$
H_{2, \lambda, \delta, \gamma}(x)= \begin{cases}0 & \text { dla } x \leq \lambda, \\ \exp \left(-\left(\frac{x-\lambda}{\delta}\right)^{-\gamma}\right) & \text { dla } x>\lambda,\end{cases}
$$


- typu Weibulla $I W(\lambda, \delta, \gamma), \lambda, \delta \in R, \gamma>0$, o dystrybuancie:

$$
H_{3, \lambda, \delta, \gamma}(x)= \begin{cases}\exp \left(-\left(-\frac{x-\lambda}{\delta}\right)^{\gamma}\right) & \text { dla } x \leq \lambda, \\ 1 & \text { dla } x>\lambda .\end{cases}
$$

Rodziny rozkładów (1.4.2-1.4.4) nazywane są również typu I, typu II oraz typu III. Rozkład statystyki maksymalnej typu III zwany jest rozkładem odwróconym Weibulla.

Postać dystrybuanty rozkładu Frécheta otrzymujemy z rozkładu $G E V D_{M}$, gdy $\xi=\frac{1}{\gamma}, \mu=\lambda+\delta$ i $\sigma=\frac{\delta}{\gamma}$, rozkład odwrócony Weibulla, gdy $\xi=-\frac{1}{\gamma}$, $\mu=\lambda+\delta$ oraz $\sigma=\frac{\delta}{\gamma}$, zaś rozkład Gumbela mamy, gdy $\mu=\lambda$ i $\sigma=\delta$.

Funkcje gęstości rozkładów Gumbela, Frécheta i odwróconego Weibulla o dystrybuantach (1.4.2)-(1.4.4) są odpowiednio postaci:

$$
\begin{gathered}
f_{1, \lambda, \delta}(x)=\frac{1}{\delta} \exp \left(-\frac{x-\lambda}{\delta}-\exp \left(-\frac{x-\lambda}{\delta}\right)\right) \\
f_{2, \lambda, \delta, \gamma}(x)=\left\{\begin{array}{lr}
0 & \text { dla } x \in R . \\
\frac{\gamma}{\delta}\left(\frac{x-\lambda}{\delta}\right)^{-\gamma-1} \exp \left(-\left(\frac{x-\lambda}{\delta}\right)^{-\gamma}\right) & \text { dla } x>\lambda,
\end{array}\right. \\
f_{3, \lambda, \delta, \gamma}(x)=\left\{\begin{array}{lr}
\frac{\gamma}{\delta}\left(-\frac{x-\lambda}{\delta}\right)^{\gamma-1} \exp \left(-\left(-\frac{x-\lambda}{\delta}\right)^{\gamma}\right) & \text { dla } x \leq \lambda, \\
0 & \text { dla } x>\lambda,
\end{array}\right.
\end{gathered}
$$

gdzie $\lambda, \delta \in R, \gamma>0$.

Wprowadzając zmienną $Z=\frac{X_{(n)}^{(n)}-\lambda}{\delta}$, otrzymujemy unormowane zmienne losowe o rozkładach Gumbela, Frécheta oraz odwróconym Weibulla. Dystrybuanty tych rozkładów oznaczane są odpowiednio $H_{1,0}, H_{2, \gamma}, H_{3, \gamma}$, a funkcje gęstości $f_{1,0}, f_{2, \gamma}$ oraz $f_{3, \gamma}$. 
Wykresy wybranych dystrybuant unormowanych rozkładów typu I, II i III oraz ich funkcje gęstości przedstawione są na rysunkach 1.4.1 i 1.4.2.

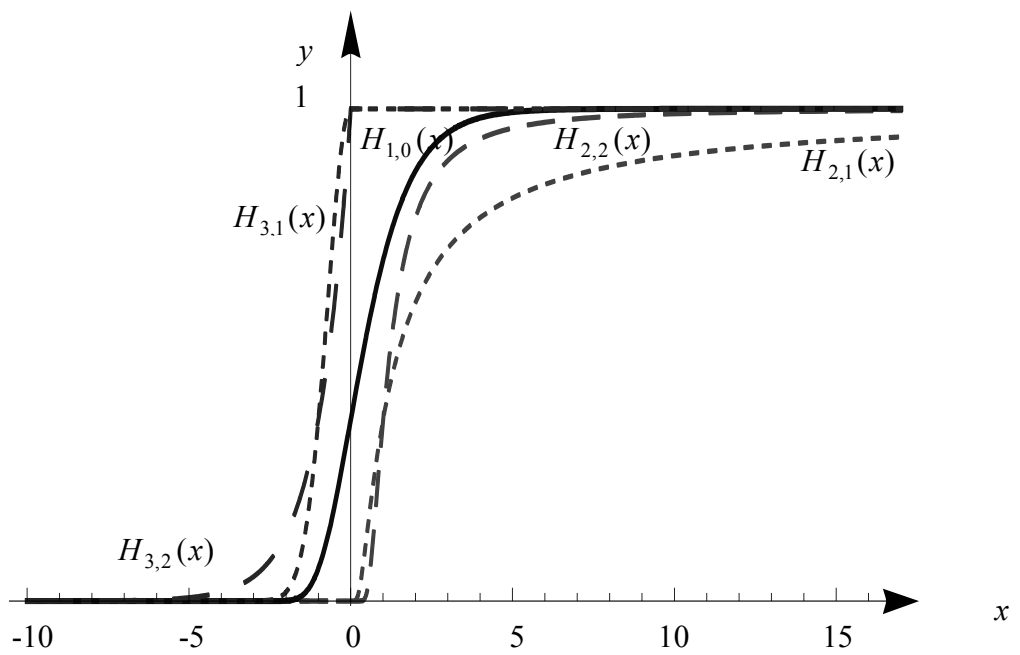

Rysunek 1.4.1. Dystrybuanty $H_{2, \gamma}, H_{3, \gamma}(\gamma=1,2)$ oraz $H_{1,0}$

Źródło: opracowanie własne

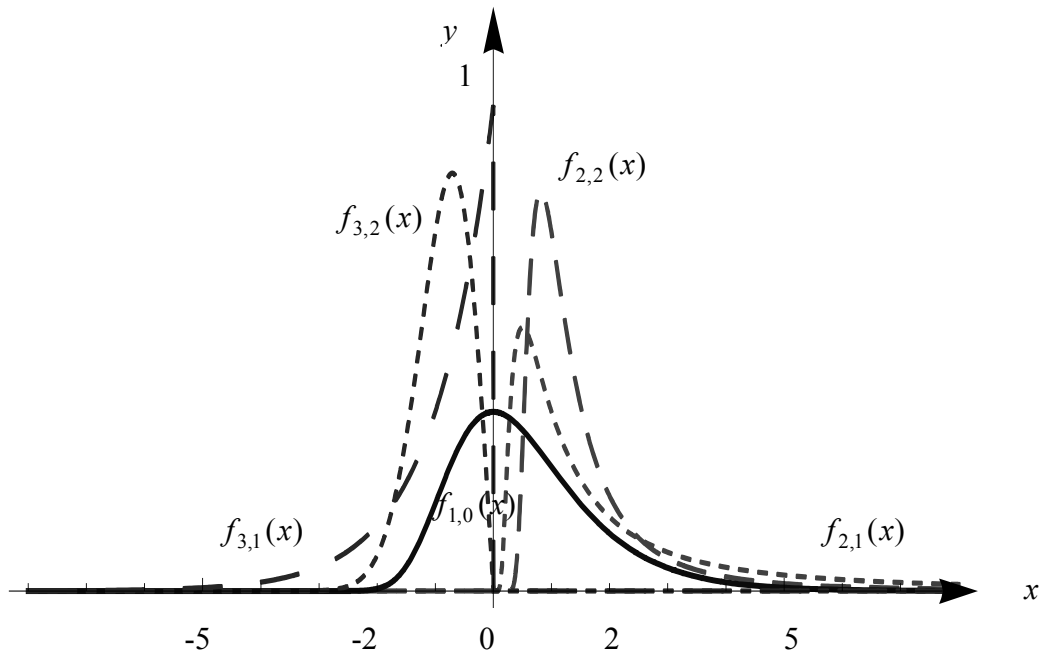

Rysunek 1.4.2. Funkcje gęstości rozkładów typu II, III ( $\gamma=1,2)$ oraz typu I

Źródło: opracowanie własne 
Wykres funkcji $H_{1,0}$ dzieli ćwiartki I i II układu współrzędnych na dwa obszary. Po jego prawej stronie znajdują się wykresy dystrybuant $H_{2, \gamma}$ i jest tzw. obszar przyciagania dystrybuanty granicznej typu Frécheta, zaś po lewej stronie znajdują się wykresy dystrybuant $H_{3, \gamma}$ i jest to obszar przyciagania dystrybuanty typu Weibulla. Podstawowe charakterystyki liczbowe uogólnionych rozkładów maksimum przedstawione są $\mathrm{w}$ tablicy 1.4.1.

Tablica 1.4.1. Parametry rozkładów maksimum

\begin{tabular}{|c|c|c|c|}
\hline $\begin{array}{c}\text { Parametr } \\
\text { rozkładu }\end{array}$ & $\begin{array}{c}\text { Rozkład } \\
\text { Frécheta }\end{array}$ & $\begin{array}{c}\text { Rozkład odwrócony } \\
\text { Weibulla }\end{array}$ & $\begin{array}{c}\text { Rozkład } \\
\text { Gumbela }\end{array}$ \\
\hline $\begin{array}{c}\text { Wartość } \\
\text { oczekiwana }\end{array}$ & $\lambda+\delta \Gamma\left(1-\frac{1}{\gamma}\right), \gamma>1$ & $\lambda-\delta \Gamma\left(1+\frac{1}{\gamma}\right)$ & $\lambda+0,57772 \delta$ \\
\hline Mediana & $\lambda+\delta 0,693^{-\frac{1}{\gamma}}$ & $\lambda-\delta 0,693^{\frac{1}{\gamma}}$ & $\lambda+0,3665 \delta$ \\
\hline Dominanta & $\left(1+\frac{1}{\gamma}\right)^{-\frac{1}{\gamma}\left[\lambda\left(1+\frac{1}{\gamma}\right)^{\frac{1}{\gamma}}+\delta\right]}$ & $\lambda-\delta\left(\frac{\gamma-1}{\gamma}\right)^{\frac{1}{\gamma}}, \operatorname{gdy} \gamma>1$ & $\lambda$ \\
\hline Wariancja & $\delta^{2}\left[\Gamma\left(1-\frac{2}{\gamma}\right)-\Gamma^{2}\left(1-\frac{1}{\gamma}\right)\right]$ & $\delta^{2}\left[\Gamma\left(1+\frac{2}{\gamma}\right)-\Gamma^{2}\left(1+\frac{1}{\gamma}\right)\right]$ & $\frac{\pi^{2} \delta^{2}}{6}$ \\
\hline Kwantyl $Q_{p}$ & $\lambda+\delta(-\ln p)^{-\frac{1}{\gamma}}$ & $\lambda-\delta(-\ln p)^{\frac{1}{\gamma}}$ & $\lambda-\delta \ln (-\ln p)$ \\
\hline
\end{tabular}

Źródło: opracowanie na podstawie E. Castillo i in. [2004, s. 201-202].

Związek między statystykami ekstremalnymi:

$$
X_{(1)}^{(n)}=\min \left\{X_{1}, X_{2}, \ldots, X_{n}\right\}=-\max \left\{-X_{1},-X_{2}, \ldots,-X_{n}\right\}=-(-X)_{(n)}^{(n)}
$$

umożliwia wyznaczenie dystrybuanty granicznej $F_{\mu, \sigma, \xi}^{m}$ statystyki minimum $X_{(1)}^{(n)}$.

Dystrybuantę graniczną minimum $X_{(1)}^{(n)}$ wyznaczamy, korzystając z zależności:

$$
F_{\mu, \delta, \xi}^{m}(x)=1-F_{\mu, \sigma, \xi}^{M}(-x),
$$

gdzie $F_{\mu, \sigma, \xi}^{M}$ jest dystrybuantą graniczną zmiennej $X_{(n)}^{(n)}$. 
Rozkłady graniczne minimum należą do rodziny uogólnionych rozkładów statystyk minimalnych.

Definicja 1.4.4. Uogólnionym rozkładem statystyki minimum $\left(G E V D_{m}\right)$ nazywamy rozkład określony za pomocą dystrybuanty:

$$
F_{\mu, \delta, \xi}^{m}(x)= \begin{cases}1-\exp \left(-\left(1-\xi \frac{x-\mu}{\sigma}\right)^{-\frac{1}{\xi}}\right) & \text { dla } \xi \neq 0, \quad 1-\xi \frac{x-\mu}{\sigma}>0, \\ 1-\exp \left(-\exp \left(\frac{x-\mu}{\sigma}\right)\right) & \text { dla } \xi=0, \quad x \in R .\end{cases}
$$

Zmienną losową $X_{(1)}^{(n)}$, analogicznie jak zmienną $X_{(n)}^{(n)}$, może charakteryzować jeden z trzech rozkładów granicznych:

- odwrócony Gumbela $I G l(\lambda, \delta), \lambda, \delta \in R$, o dystrybuancie:

$$
L_{1, \lambda, \delta}(x)=1-\exp \left(-\exp \left(\frac{x-\lambda}{\delta}\right)\right), \quad x \in R .
$$

- odwrócony Frécheta $\operatorname{IFr}(\lambda, \delta, \gamma), \lambda, \delta \in R, \gamma>0$, o dystrybuancie:

$$
L_{2, \lambda, \delta, \gamma}(x)= \begin{cases}1-\exp \left(-\left(-\frac{x-\lambda}{\delta}\right)^{-\gamma}\right) & \text { dla } x<\lambda, \\ 1 & \text { dla } x \geq \lambda,\end{cases}
$$

- Weibulla $W(\lambda, \delta, \gamma), \lambda, \delta \in R, \gamma>0$, o dystrybuancie:

$$
L_{3, \lambda, \delta, \gamma}(x)= \begin{cases}0 & \text { dla } \quad x<\lambda, \\ 1-\exp \left(-\left(\frac{x-\lambda}{\delta}\right)^{\gamma}\right) & \text { dla } x \geq \lambda .\end{cases}
$$

Charakterystyki liczbowe statystyk minimum przedstawione są w tablicy 1.4.2. Podobnie jak w przypadku maksimum, zmienną $X_{(1)}^{(n)}$ można standaryzować, otrzymując rozkłady o parametrach $\lambda=0$ i $\delta=1$ oznaczane odpowiednio $L_{2, \gamma}, L_{3, \gamma}$ oraz $L_{1,0}$. 
Tablica 1.4.2. Parametry rozkładów minimum

\begin{tabular}{|l|c|c|c|}
\hline \multicolumn{1}{|c|}{$\begin{array}{c}\text { Parametr } \\
\text { rozkładu }\end{array}$} & $\begin{array}{c}\text { Rozkład odwrócony } \\
\text { Frécheta }\end{array}$ & $\begin{array}{c}\text { Rozkład } \\
\text { Weibulla }\end{array}$ & $\begin{array}{c}\text { Rozkład odwrócony } \\
\text { Gumbela }\end{array}$ \\
\hline $\begin{array}{l}\text { Wartość } \\
\text { oczekiwana }\end{array}$ & $\lambda-\delta \Gamma\left(1-\frac{1}{\gamma}\right), \gamma>1$ & $\lambda+\delta \Gamma\left(1+\frac{1}{\gamma}\right)$ & $\lambda-0,57772 \delta$ \\
\hline Mediana & $\lambda-\delta 0,693^{-\frac{1}{\gamma}}$ & $\lambda+\delta 0,693^{\frac{1}{\gamma}}$ & $\lambda-0,3665 \delta$ \\
\hline Dominanta & $\left(1+\frac{1}{\gamma}\right)^{-\frac{1}{\gamma}[}\left[\left(1+\frac{1}{\gamma}\right)^{\frac{1}{\gamma}}-\delta\right.$ & $\begin{array}{c}\lambda+\delta\left(\frac{\gamma-1}{\gamma}\right)^{\frac{1}{\gamma}} \\
\operatorname{gdy} \gamma>1, \\
\lambda, \operatorname{gdy} \gamma \leq 1\end{array}$ & $\lambda$ \\
\hline Wariancja & $\delta^{2}\left[\Gamma\left(1-\frac{2}{\gamma}\right)-\Gamma^{2}\left(1-\frac{1}{\gamma}\right)\right]$ & $\begin{array}{r}\delta^{2}\left[\Gamma\left(1+\frac{2}{\gamma}\right)-\Gamma^{2}\left(1+\frac{1}{\gamma}\right)\right. \\
\operatorname{gdy} \gamma>2\end{array}$ & $\frac{\pi^{2} \delta^{2}}{6}$ \\
\hline Kwantyl $Q_{p}$ & $\lambda-\delta(-\ln (1-p))^{-\frac{1}{\gamma}}$ & $\lambda+\delta(-\ln (1-p))^{\frac{1}{\gamma}}$ & $\lambda+\delta \ln (-\ln (1-p) p)$ \\
\hline
\end{tabular}

Źródło: opracowanie na podstawie E. Castillo i in. [2004, s. 201-202].

Wykresy dystrybuant i funkcji gęstości standaryzowanej zmiennej $X_{(1)}^{(n)}$ dla wybranych wartości parametru $\gamma$ przedstawione są na rysunkach 1.4.3 i 1.4.4.

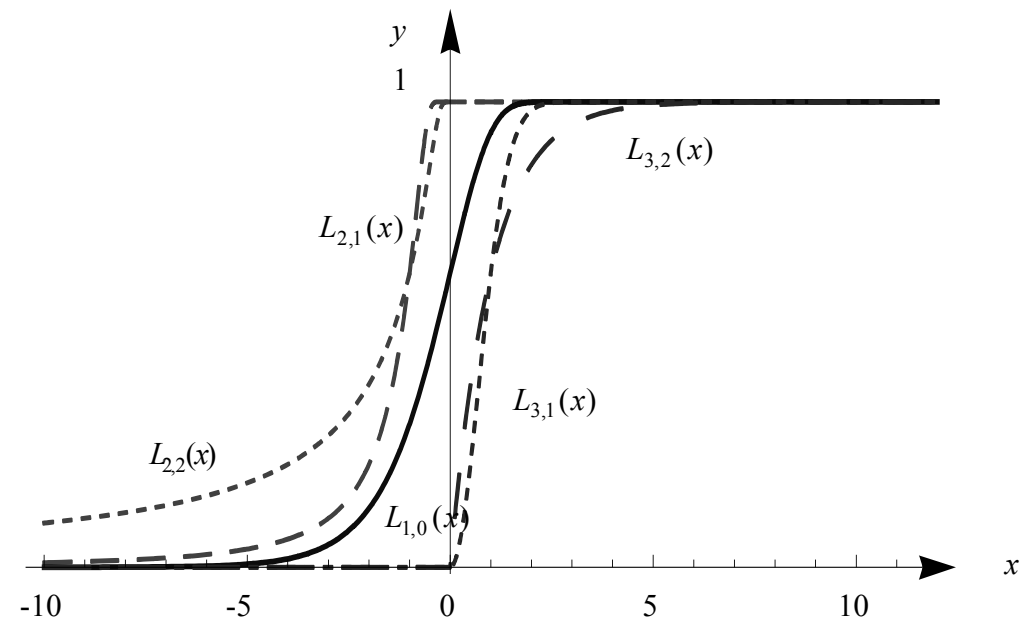

Rysunek 1.4.3. Dystrybuanty $L_{2, \gamma}, L_{3, \gamma}(\gamma=1,2)$ oraz $L_{1,0}$ Źródło: opracowanie własne 


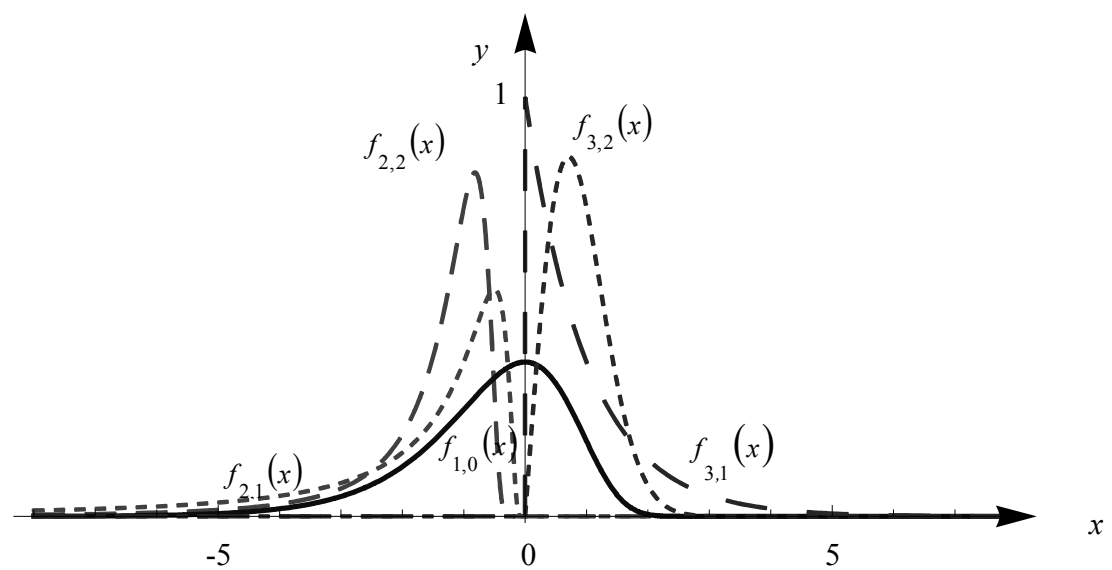

Rysunek 1.4.4. Funkcje gęstości rozkładów typu odwróconego Frécheta i Weibulla $(\gamma=1,2)$ oraz odwróconego Gumbela Źródło: opracowanie własne

Warunki dostateczne, określające istnienie i postać dystrybuant granicznych rozkładów ekstremalnych, czyli przynależność dystrybuanty $F$ do obszaru przyciagania dystrybuanty granicznej odpowiedniego typu, precyzuja twierdzenia 1.4.1 i 1.4.2 (por. E. Castillo i in. [2004, s. 203-204]).

Twierdzenie 1.4.1. Jeżeli zmienna losowa $X$ ma rozkład o dystrybuancie $F$ oraz

$$
\lim _{\varepsilon \rightarrow 0} \frac{F^{-1}(1-\varepsilon)-F^{-1}(1-2 \varepsilon)}{F^{-1}(1-2 \varepsilon)-F^{-1}(1-4 \varepsilon)}=2^{\xi},
$$

to rozkładem granicznym unormowanej statystyki maksimum $X_{(n)}^{(n)}$ jest uogólniony rozkład statystyki maksimum o dystrybuancie określonej wzorem (1.4.1) o wartości parametru kształtu $\xi$.

Gdy $\xi<0$, to maksimum ma rozkład odwrócony Weibulla, jeśli $\xi=0$, to rozkład Gumbela, natomiast gdy $\xi>0$ - rozkład Frécheta.

Twierdzenie 1.4.2. Jeżeli zmienna losowa $X$ ma rozkład o dystrybuancie $F$ oraz

$$
\lim _{\varepsilon \rightarrow 0} \frac{F^{-1}(\varepsilon)-F^{-1}(2 \varepsilon)}{F^{-1}(2 \varepsilon)-F^{-1}(4 \varepsilon)}=2^{\xi},
$$


to rozkładem granicznym unormowanej statystyki minimum $X_{(1)}^{(n)}$ jest uogólniony rozkład statystyki minimum o dystrybuancie postaci (1.4.9) z parametrem kształtu $\xi$.

Dla statystyki $X_{(n)}^{(n)}$ wyznaczonej w oparciu o ciąg niezależnych zmiennych losowych $X_{1}, X_{2}, \ldots, X_{n}$, stanowiących próbę wylosowaną z populacji o dystrybuancie $F$, możemy określić warunek dostateczny przynależności dystrybuanty statystyki $X_{(n)}^{(n)}$ do określonego typu dystrybuant, korzystając z twierdzenia 1.4.3 (Fishera-Tippetta) oraz twierdzeń 1.4.4-1.4.6 (por. M. Czekała [2001, s. 20-31]).

Twierdzenie 1.4.3. Niech $X_{1}, X_{2}, \ldots, X_{n}$ będzie ciagiem niezależnych zmiennych losowych o jednakowym rozkładzie o dystrybuancie $F$. Jeżeli ciąg zmiennych losowych $\left(Y_{n}\right)_{n \in N}$, gdzie $Y_{n}=\frac{X_{(n)}^{(n)}-a_{n}}{b_{n}}$ oraz $\left(a_{n}\right)_{n \in N}, \quad\left(b_{n}\right)_{n \in N}$ sa ciagami liczb rzeczywistych, jest zbieżny według rozkładu do zmiennej $Y$ o niezdegenerowanym rozkładzie określonym przez dystrybuantę $H$, to dystrybuanta $H$ jest dystrybuantą rozkładu typu Gumbela, Frécheta lub odwróconego Weibulla.

Postaci ciągów $\left(a_{n}\right)_{n \in N},\left(b_{n}\right)_{n \in N}$ normujących statystyki maksimum $X_{(n)}^{(n)}$ dla poszczególnych typów dystrybuant $H$ określają następujące warunki dostateczne.

Twierdzenie 1.4.4. Jeżeli dla ciągu niezależnych zmiennych losowych $X_{1}, X_{2}, \ldots, X_{n}$ o ciagłej dystrybuancie $F$ spełnione są warunki:

a) funkcja gęstości $f(x)$ ma ujemną pochodną $f^{\prime}(x)$ dla $x \in\left(x_{0}, x_{F}\right)$, gdzie $x_{F} \leq \infty$ oraz $f(x)=0$ dla $x \geq x_{F}$,

b) $\lim _{t \rightarrow x_{F}} \frac{f^{\prime}(t)(1-F(t))}{f^{2}(t)}=-1$,

to

$$
\lim _{n \rightarrow \infty} P\left\{\frac{\max \left\{X_{1}, X_{2}, \ldots, X_{n}\right\}-a_{n}}{b_{n}}<x\right\}=H_{1,0}(x),
$$

gdzie

$$
a_{n}=F^{-1}\left(1-\frac{1}{n}\right) \quad \text { oraz } \quad b_{n}=F^{-1}\left(1-\frac{1}{n e}\right)-a_{n} .
$$


Twierdzenie 1.4.5. Jeżeli dla ciągu niezależnych zmiennych losowych $X_{1}, X_{2}, \ldots, X_{n}$ o ciagłej dystrybuancie $F$ spełnione są warunki:

a) $\sup \{x: F(x)<1\}=+\infty$,

b) istnieje taka stała $\gamma>0$, że dla każdej wartości $x>0$ mamy:

$$
\lim _{t \rightarrow \infty} \frac{1-F(t x)}{1-F(t)}=x^{-\gamma}
$$

to

$$
\lim _{n \rightarrow \infty} P\left\{\frac{\max \left\{X_{1}, X_{2}, \ldots, X_{n}\right\}}{b_{n}}<x\right\}=H_{2, \gamma}(x),
$$

gdzie

$$
b_{n}=F^{-1}\left(1-\frac{1}{n}\right)
$$

Twierdzenie 1.4.6. Jeżeli dla ciagu niezależnych zmiennych losowych $X_{1}, X_{2}, \ldots, X_{n}$ o ciagłej dystrybuancie $F$ spełnione są warunki:

a) funkcja gęstości $f(x)>0$ dla $x \in\left(x_{0}, x_{F}\right)$ oraz $f(x)=0$ dla $x>x_{F}$,

b) $\lim _{t \rightarrow x_{F}} \frac{\left(x_{F}-t\right) f(t)}{1-F(t)}=\gamma$ dla pewnej stałej $\gamma>0$,

to

$$
\lim _{n \rightarrow \infty} P\left\{\frac{\max \left\{X_{1}, X_{2}, \ldots, X_{n}\right\}-a_{n}}{b_{n}}<x\right\}=H_{3, \gamma}(x),
$$

gdzie

$$
a_{n}=a=\sup \{x: F(x)<1\} \quad \text { oraz } \quad b_{n}=a-F^{-1}\left(1-\frac{1}{n}\right) .
$$

Rozkład Frécheta charakteryzuje rozkład graniczny statystyk maksymalnych zmiennych losowych o tzw. grubych (ciężkich) ogonach, czyli zmiennych, dla których prawdopodobieństwo wystąpienia wartości nietypowych jest wyższe niż w przypadku rozkładu normalnego. Rozkład odwrócony Weibulla jest granicznym rozkładem statystyk maksymalnych zmiennych losowych przyjmujących wartości z ograniczonego przedziału, nazywanych również zmiennymi o krótkich ogonach, natomiast Gumbela - maksimum zmiennych losowych o cienkich ogonach.

Dla statystyki minimalnej można sformułować następujące twierdzenie. 
Twierdzenie 1.4.7. Niech $X_{1}, X_{2}, \ldots, X_{n}$ będzie ciagiem niezależnych zmiennych losowych o jednakowym rozkładzie o dystrybuancie $F$. Jeżeli ciąg zmiennych losowych $\left(Y_{n}\right)_{n \in N}$, gdzie $Y_{n}=\frac{X_{1}^{(n)}-c_{n}}{d_{n}}$ oraz $\left(c_{n}\right)_{n \in N},\left(d_{n}\right)_{n \in N}$ są ciągami liczb rzeczywistych, jest zbieżny według rozkładu do zmiennej $Y$ o niezdegenerowanym rozkładzie określonym przez dystrybuantę $L$, to $L$ jest dystrybuantą rozkładu odwróconego Gumbela, odwróconego Frécheta lub Weibulla.

Postaci wyrazów ogólnych ciagów $\left(c_{n}\right)_{n \in N},\left(d_{n}\right)_{n \in N}$ normujących statystyki minimalne $X_{(1)}^{(n)}$ są następujące:

- dla rozkładu odwróconego Gumbela:

$$
c_{n}=F^{-1}\left(\frac{1}{n}\right) \quad \text { oraz } \quad d_{n}=c_{n}-F^{-1}\left(\frac{1}{n e}\right),
$$

- dla rozkładu odwróconego Frécheta:

$$
c_{n}=0 \quad \text { oraz } \quad d_{n}=\left|F^{-1}\left(\frac{1}{n}\right)\right|,
$$

- dla rozkładu Weibulla:

$$
c_{n}=\inf \{x: F(x)>0\} \quad \text { oraz } \quad d_{n}=F^{-1}\left(\frac{1}{n}\right)-c_{n} .
$$

Dla wybranych rozkładów zmiennych losowych $X_{1}, X_{2}, \ldots, X_{n}$ wyznaczone zostały postaci rozkładów granicznych maksimum $X_{(n)}^{(n)}$ i minimum $X_{(1)}^{(n)}$. Przedstawiają je twierdzenia 1.4.8 - 1.4.15.

Twierdzenie 1.4.8. Jeżeli $X_{1}, X_{2}, \ldots, X_{n}$ jest ciagiem niezależnych zmiennych losowych o rozkładzie Cauchy'ego $C a(m, \lambda)$, to unormowane maksimum $X_{(n)}^{(n)}$ oraz minimum $X_{(1)}^{(n)}$ mają rozkłady graniczne typu Frécheta.

Dla rozkładu Cauchy'ego o dystrybuancie $F(x)=\frac{1}{\pi} \operatorname{arctg}\left(\frac{x-m}{\lambda}\right)+\frac{1}{2}$ otrzymujemy $F^{-1}(p)=\lambda \operatorname{tg}\left(p-\frac{1}{2}\right) \pi+m$ dla $p \in[0,1]$. 
Ponieważ spełniony jest warunek:

$$
\begin{aligned}
& \lim _{\varepsilon \rightarrow 0} \frac{\lambda \operatorname{tg}\left(\frac{1}{2}-\varepsilon\right) \pi-\lambda \operatorname{tg}\left(\frac{1}{2}-2 \varepsilon\right) \pi}{\lambda \operatorname{tg}\left(\frac{1}{2}-2 \varepsilon\right) \pi-\lambda \operatorname{tg}\left(\frac{1}{2}-4 \varepsilon\right) \pi}=\lim _{\varepsilon \rightarrow 0} \frac{\operatorname{ctg}(\varepsilon \pi)-\operatorname{ctg}(2 \varepsilon \pi)}{\operatorname{ctg}(2 \varepsilon \pi)-\operatorname{ctg}(4 \varepsilon \pi)}= \\
& =\lim _{\varepsilon \rightarrow 0} \frac{\sin (4 \varepsilon \pi)}{\sin (2 \varepsilon \pi)}=\lim _{\varepsilon \rightarrow 0} \frac{4 \pi \cos (4 \varepsilon \pi)}{2 \pi \cos (2 \varepsilon \pi)}=2,
\end{aligned}
$$

zatem jak wynika $\mathrm{z}$ twierdzenia 1.4.1, rozkładem granicznym unormowanej statystyki $X_{(n)}^{(n)}$ jest rozkład Frécheta, gdzie $\gamma=\frac{1}{\xi}=1$ oraz $b_{n}=F^{-1}\left(1-\frac{1}{n}\right)=$ $=\lambda \operatorname{tg}\left(1-\frac{1}{n}-\frac{1}{2}\right) \pi+m=\lambda \operatorname{ctg}\left(\frac{\pi}{n}\right)+m$.

Stąd mamy:

$$
\lim _{n \rightarrow \infty} P\left\{\frac{X_{(n)}^{(n)}}{\lambda \operatorname{ctg}\left(\frac{\pi}{n}\right)+m}<x\right\}=H_{2,1}(x)
$$

Dla statystyki minimum $X_{(1)}^{(n)}$ otrzymujemy:

$$
\lim _{\varepsilon \rightarrow 0} \frac{\lambda \operatorname{tg}\left(\varepsilon-\frac{1}{2}\right) \pi-\lambda \operatorname{tg}\left(2 \varepsilon-\frac{1}{2}\right) \pi}{\lambda \operatorname{tg}\left(2 \varepsilon-\frac{1}{2}\right) \pi-\lambda \operatorname{tg}\left(4 \varepsilon-\frac{1}{2}\right) \pi}=\lim _{\varepsilon \rightarrow 0} \frac{\operatorname{ctg}(2 \varepsilon \pi)-\operatorname{ctg}(\varepsilon \pi)}{\operatorname{ctg}(4 \varepsilon \pi)-\operatorname{ctg}(2 \varepsilon \pi)}=2
$$

czyli zgodnie z twierdzeniem 1.4.2, granicznym rozkładem unormowanej statystyki $X_{(1)}^{(n)}$ jest rozkład odwrócony Frécheta, gdzie $\gamma=1$ oraz $d_{n}=\left|F^{-1}\left(\frac{1}{n}\right)\right|=\left|-\lambda \operatorname{ctg}\left(\frac{\pi}{n}\right) \pi+m\right|$. 
Zatem

$$
\lim _{n \rightarrow \infty} P\left\{\frac{X_{(1)}^{(n)}}{\left|m-\lambda \operatorname{ctg}\left(\frac{\pi}{n}\right)\right|}<x\right\}=L_{2,1}(x)
$$

Twierdzenie 1.4.9. Jeżeli $X_{1}, X_{2}, \ldots, X_{n}$ jest ciągiem niezależnych zmiennych losowych o rozkładzie Pareto $P a(\theta, a)$, to unormowane maksimum $X_{(n)}^{(n)}$ ciagu tych zmiennych losowych ma rozkład graniczny typu Frécheta, zaś unormowane minimum $X_{(1)}^{(n)}$ ciagu tych zmiennych losowych ma rozkład graniczny typu Weibulla.

Dla zmiennej losowej o rozkładzie Pareto funkcja odwrotna do dystrybuanty ma postać:

$$
F^{-1}(p)=\frac{\theta}{(1-p)^{1 / a}} \quad \text { dla } \quad p \in[0,1]
$$

Korzystając z twierdzenia 1.4.1, otrzymujemy:

$$
\lim _{\varepsilon \rightarrow 0} \frac{F^{-1}(1-\varepsilon)-F^{-1}(1-2 \varepsilon)}{F^{-1}(1-2 \varepsilon)-F^{-1}(1-4 \varepsilon)}=\lim _{\varepsilon \rightarrow 0} \frac{\frac{\theta}{\varepsilon^{1 / a}}-\frac{\theta}{(2 \varepsilon)^{1 / a}}}{\frac{\theta}{(2 \varepsilon)^{1 / a}}-\frac{\theta}{(4 \varepsilon)^{1 / a}}}=2^{\frac{1}{a}},
$$

więc statystyka maksimum charakteryzuje się granicznym rozkładem Frécheta, gdzie $\gamma=\frac{1}{\xi}=a$ oraz $b_{n}=F^{-1}\left(1-\frac{1}{n}\right)=n^{\frac{1}{a}} \theta$.

Zatem

$$
\lim _{n \rightarrow \infty} P\left\{\frac{X_{(n)}^{(n)}}{b_{n}}<x\right\}=\lim _{n \rightarrow \infty} P\left\{\frac{X_{(n)}^{(n)}}{\theta \sqrt[a]{n}}<x\right\}=H_{2, a}(x) .
$$

Ponieważ $\lim _{\varepsilon \rightarrow 0} \frac{F^{-1}(\varepsilon)-F^{-1}(2 \varepsilon)}{F^{-1}(2 \varepsilon)-F^{-1}(4 \varepsilon)}=\lim _{\varepsilon \rightarrow 0} \frac{(1-2 \varepsilon)^{1 / a}-(1-\varepsilon)^{1 / a}}{(1-4 \varepsilon)^{1 / a}-(1-2 \varepsilon)^{1 / a}}=2^{-1}, \quad \mathrm{z}$ twierdzenia 1.4.2 wynika, że graniczny rozkład unormowanej statystyki minimum 
$X_{(1)}^{(n)}$ jest rozkładem Weibulla o dystrybuancie $L_{3,1}(x)\left(\gamma=-\frac{1}{\xi}=1\right)$. Stałe normujące są postaci: $c_{n}=\inf \{x: F(x)>0\}=\theta$ oraz $d_{n}=\frac{\theta}{\sqrt[a]{1-1 / n}}-\theta$.

Stąd otrzymujemy:

$$
\lim _{n \rightarrow \infty} P\left\{\frac{X_{(1)}^{(n)}-\theta}{\theta(1-\sqrt[a]{1-1 / n})} \sqrt[a]{1-1 / n}<x\right\}=L_{3,1}(x) .
$$

Twierdzenie 1.4.10. Jeżeli $X_{1}, X_{2}, \ldots, X_{n}$ jest ciagiem niezależnych zmiennych losowych o rozkładzie Burra $\operatorname{Br}(a, c)$, o dystrybuancie postaci $F(x)=1-\left(1+x^{c}\right)^{-a}$, gdzie $a>0, c>0$ oraz $x>0$, to unormowane maksimum $X_{(n)}^{(n)}$ ma rozkład graniczny typu Frécheta, natomiast unormowane minimum $X_{(1)}^{(n)}$ ma rozkład graniczny typu Weibulla.

$\mathrm{Z}$ równości:

$$
\lim _{\varepsilon \rightarrow 0} \frac{F^{-1}(1-\varepsilon)-F^{-1}(1-2 \varepsilon)}{F^{-1}(1-2 \varepsilon)-F^{-1}(1-4 \varepsilon)}=\lim _{\varepsilon \rightarrow 0} \frac{\sqrt[c]{\varepsilon^{-1 / a}-1}-\sqrt[c]{(2 \varepsilon)^{-1 / a}-1}}{\sqrt[c]{(2 \varepsilon)^{-1 / a}-1}-\sqrt[c]{(4 \varepsilon)^{-1 / a}-1}}=2^{\frac{1}{c a}}
$$

oraz

$$
\lim _{\varepsilon \rightarrow 0} \frac{F^{-1}(\varepsilon)-F^{-1}(2 \varepsilon)}{F^{-1}(2 \varepsilon)-F^{-1}(4 \varepsilon)}=\lim _{\varepsilon \rightarrow 0} \frac{\sqrt[c]{(1-\varepsilon)^{-1 / a}-1}-\sqrt[c]{(1-2 \varepsilon)^{-1 / a}-1}}{\sqrt[c]{(1-2 \varepsilon)^{-1 / a}-1}-\sqrt[c]{(1-4 \varepsilon)^{-1 / a}-1}}=2^{-c}
$$

wynika, że rozkładem granicznym maksimum jest rozkład Frécheta o dystrybuancie $H_{2, c a}$, natomiast rozkładem granicznym minimum jest rozkład Weibulla o dystrybuancie $L_{3, \frac{1}{c}}$.

Dla statystyki $X_{(n)}^{(n)}$ mamy $b_{n}=\sqrt[c]{\sqrt[a]{n}-1}$, natomiast dla minimum stałe normujące są postaci: $c_{n}=\inf \{x: \quad F(x)>0\}=0$ oraz $d_{n}=\sqrt[c]{\left(1-\frac{1}{n}\right)^{-\frac{1}{a}}-1}$. 
Zatem

$$
\lim _{n \rightarrow \infty} P\left\{\frac{X_{(n)}^{(n)}}{\sqrt[c]{\sqrt[a]{n}-1}}<x\right\}=H_{2, c a}(x)
$$

oraz

$$
\lim _{n \rightarrow \infty} P\left\{\frac{X_{(1)}^{(n)}}{\sqrt[c]{\left(1-\frac{1}{n}\right)^{-\frac{1}{a}}-1}}<x\right\}=L_{3, \frac{1}{c}}(x) .
$$

Do innych rozkładów zmiennych losowych, dla których ciagi statystyk maksymalnych mają rozkład Frécheta, należą również rozkłady: $t$-Studenta, loggamma oraz rozkłady $\alpha$-stabilne dla $\alpha<2$.

Dla zmiennych losowych o rozkładach pozbawionych ogona (o krótkich ogonach), np. o rozkładzie jednostajnym, potęgowym, beta, odwróconym Pareto czy też odwróconym Burra, maksimum i minimum z próby mają rozkłady typu Weibulla.

Twierdzenie 1.4.11. Jeżeli $X_{1}, X_{2}, \ldots, X_{n}$ jest ciagiem niezależnych zmiennych losowych o rozkładzie jednostajnym na przedziale [0,1], to unormowane statystyki ekstremalne $X_{(n)}^{(n)}$ oraz $X_{(1)}^{(n)}$ mają rozkłady graniczne typu Weibulla.

Ponieważ

$$
\begin{gathered}
\lim _{\varepsilon \rightarrow 0} \frac{F^{-1}(1-\varepsilon)-F^{-1}(1-2 \varepsilon)}{F^{-1}(1-2 \varepsilon)-F^{-1}(1-4 \varepsilon)}=\lim _{\varepsilon \rightarrow 0} \frac{1-\varepsilon-1+2 \varepsilon}{1-2 \varepsilon-1+4 \varepsilon}=2^{-1}, \\
\lim _{\varepsilon \rightarrow 0} \frac{F^{-1}(\varepsilon)-F^{-1}(2 \varepsilon)}{F^{-1}(2 \varepsilon)-F^{-1}(4 \varepsilon)}=2^{-1},
\end{gathered}
$$

zatem unormowane statystyki ekstremalne $X_{(n)}^{(n)}$ oraz $X_{(1)}^{(n)}$ charakteryzują rozkłady graniczne Weibulla oraz $\gamma=1$.

Ponadto ciagi stałych normujących dla statystyki maksimum mają wyrazy ogólne postaci: $a_{n}=\sup \{x: F(x)<1\}=1$ oraz $b_{n}=1-F^{-1}\left(1-\frac{1}{n}\right)=\frac{1}{n}$, natomiast dla statystyki minimum: $c_{n}=\inf \{x: F(x)>0\}=0$ oraz $d_{n}=F^{-1}\left(\frac{1}{n}\right)=\frac{1}{n}$. 
Stąd

$$
\lim _{n \rightarrow \infty} P\left\{\frac{X_{(n)}^{(n)}-1}{1 / n}<x\right\}=\lim _{n \rightarrow \infty} P\left\{n\left(X_{(n)}^{(n)}-1\right)<x\right\}=H_{3,1}(x)
$$

oraz

$$
\lim _{n \rightarrow \infty} P\left\{\frac{X_{(1)}^{(n)}}{1 / n}<x\right\}=\lim _{n \rightarrow \infty} P\left\{n X_{(1)}^{(n)}<x\right\}=L_{3,1}(x) .
$$

Twierdzenie 1.4.12. Jeżeli $X_{1}, X_{2}, \ldots, X_{n}$ jest ciagiem niezależnych zmiennych losowych o rozkładzie potęgowym $P o(\lambda)$, to unormowane statystyki ekstremalne $X_{(n)}^{(n)}$ i $X_{(1)}^{(n)}$ mają rozkłady graniczne typu Weibulla.

Dla rozkładu $P o(\lambda)$ otrzymamy:

$$
\lim _{\varepsilon \rightarrow 0} \frac{F^{-1}(1-\varepsilon)-F^{-1}(1-2 \varepsilon)}{F^{-1}(1-2 \varepsilon)-F^{-1}(1-4 \varepsilon)}=\lim _{\varepsilon \rightarrow 0} \frac{(1-\varepsilon)^{1 / \lambda}-(1-2 \varepsilon)^{1 / \lambda}}{(1-2 \varepsilon)^{1 / \lambda}-(1-4 \varepsilon)^{1 / \lambda}}=2^{-1}
$$

oraz

$$
\lim _{\varepsilon \rightarrow 0} \frac{F^{-1}(\varepsilon)-F^{-1}(2 \varepsilon)}{F^{-1}(2 \varepsilon)-F^{-1}(4 \varepsilon)}=\lim _{\varepsilon \rightarrow 0} \frac{\varepsilon^{1 / \lambda}-(2 \varepsilon)^{1 / \lambda}}{(2 \varepsilon)^{1 / \lambda}-(4 \varepsilon)^{1 / \lambda}}=\lim _{\varepsilon \rightarrow 0} \frac{1-2^{1 / \lambda}}{2^{1 / \lambda}-4^{1 / \lambda}}=2^{-1 / \lambda}
$$

czyli statystyka $X_{(n)}^{(n)}$ ma rozkład graniczny typu Weibulla o dystrybuancie $H_{3,1}$ i wyrazy ogólne ciągów stałych normujących są postaci: $a_{n}=\sup \{x: F(x)<1\}=1, \quad b_{n}=1-\left(1-\frac{1}{n}\right)^{\frac{1}{\lambda}}$.

Unormowaną statystykę $X_{(1)}^{(n)}$ charakteryzuje rozkład graniczny Weibulla $L_{3, \lambda}, \operatorname{przy} \operatorname{czym} c_{n}=\inf \{x: F(x)>0\}=0, \quad d_{n}=\left(\frac{1}{n}\right)^{\frac{1}{\lambda}}$.

Wynika stąd, że

$$
\lim _{n \rightarrow \infty} P\left\{\frac{X_{(n)}^{(n)}-1}{1-\left(1-\frac{1}{n}\right)^{\frac{1}{\lambda}}}<x\right\}=H_{3,1}(x)
$$


oraz

$$
\lim _{n \rightarrow \infty} P\left\{\sqrt[\lambda]{n} X_{(1)}^{(n)}<x\right\}=L_{3, \frac{1}{\lambda}}(x)
$$

Do grupy rozkładów typu Gumbela (Gumbela, odwróconego Gumbela) należą m.in. rozkłady graniczne unormowanych maksimów i minimów zmiennych losowych o rozkładzie normalnym, log-normalnym, logistycznym oraz unormowane statystyki maksimum zmiennych losowych o rozkładzie gamma, w tym wykładniczym.

Twierdzenia 1.4.13-1.4.15 określają postaci rozkładów granicznych statystyk ekstremalnych, w przypadku gdy $X_{1}, X_{2}, \ldots, X_{n}$ jest ciągiem niezależnych zmiennych losowych o rozkładzie wykładniczym, logistycznym oraz normalnym.

Twierdzenie 1.4.13. Jeżeli $X_{1}, X_{2}, \ldots, X_{n}$ jest ciągiem niezależnych zmiennych losowych o rozkładzie wykładniczym $\operatorname{Exp}(\lambda)$, to unormowane maksimum $X_{(n)}^{(n)}$ ma rozkład graniczny Gumbela, natomiast unormowane minimum $X_{(1)}^{(n)}$ ma rozkład graniczny Weibulla.

Dla rozkładu wykładniczego funkcja odwrotna do dystrybuanty jest postaci: $F^{-1}(x)=-\lambda \ln (1-x)$, czyli korzystając $z$ twierdzeń 1.4 .1 i 1.4.2, otrzymujemy:

$$
\lim _{\varepsilon \rightarrow 0} \frac{F^{-1}(1-\varepsilon)-F^{-1}(1-2 \varepsilon)}{F^{-1}(1-2 \varepsilon)-F^{-1}(1-4 \varepsilon)}=\lim _{\varepsilon \rightarrow 0} \frac{-\lambda \ln \varepsilon+\lambda \ln (2 \varepsilon)}{-\lambda \ln (2 \varepsilon)+\lambda \ln (4 \varepsilon)}=1
$$

oraz

$$
\lim _{\varepsilon \rightarrow 0} \frac{F^{-1}(\varepsilon)-F^{-1}(2 \varepsilon)}{F^{-1}(2 \varepsilon)-F^{-1}(4 \varepsilon)}=\lim _{\varepsilon \rightarrow 0} \frac{-\lambda \ln (1-\varepsilon)+\lambda \ln (1-2 \varepsilon)}{-\lambda \ln (1-2 \varepsilon)+\lambda \ln (1-4 \varepsilon)}=2^{-1} .
$$

Zatem statystyka maksimum $X_{(n)}^{(n)}$ ma rozkład graniczny Gumbela $H_{1,0}$, zaś unormowana statystyka minimum $X_{(1)}^{(n)}-\operatorname{rozkład~Weibulla~} L_{3,1}(x)$.

Wyrazy ogólne ciąów stałych normujących statystykę maksimum wyrażają się wzorami postaci: $a_{n}=F^{-1}\left(1-\frac{1}{n}\right)=\lambda \ln n$ oraz $b_{n}=F^{-1}\left(1-\frac{1}{n e}\right)-a_{n}=$ $=-\lambda \ln \left(1-\left(1-\frac{1}{n e}\right)\right)-\lambda \ln n=\lambda$, natomiast statystykę minimum: $c_{n}=0$ oraz $d_{n}=F^{-1}\left(\frac{1}{n}\right)-c_{n}=\lambda \ln \frac{n}{n-1}$. 
Otrzymujemy zatem

$$
\lim _{n \rightarrow \infty} P\left\{\frac{X_{(n)}^{(n)}-\lambda \ln n}{\lambda}<x\right\}=H_{1,0}
$$

oraz

$$
\lim _{n \rightarrow \infty} P\left\{\frac{X_{(1)}^{(n)}}{\lambda(\ln n-\ln (n-1))}<x\right\}=L_{3,1}(x) .
$$

Twierdzenie 1.4.14. Jeżeli $X_{1}, X_{2}, \ldots, X_{n}$ jest ciągiem niezależnych zmiennych losowych o rozkładzie logistycznym $\operatorname{Logist}(\mu, s)$, to unormowane maksimum $X_{(n)}^{(n)}$ i minimum $X_{(1)}^{(n)}$ mają rozkłady graniczne typu Gumbela.

Ponieważ funkcja odwrotna do dystrybuanty rozkładu logistycznego ma postać: $F^{-1}(x)=\mu-s \ln \left(\frac{1}{x}-1\right)$, zatem

$$
\lim _{\varepsilon \rightarrow 0} \frac{F^{-1}(1-\varepsilon)-F^{-1}(1-2 \varepsilon)}{F^{-1}(1-2 \varepsilon)-F^{-1}(1-4 \varepsilon)}=\lim _{\varepsilon \rightarrow 0} \frac{\ln \frac{2 \varepsilon}{1-2 \varepsilon}-\ln \frac{\varepsilon}{1-\varepsilon}}{\ln \frac{4 \varepsilon}{1-4 \varepsilon}-\ln \frac{2 \varepsilon}{1-2 \varepsilon}}=1
$$

oraz

$$
\lim _{\varepsilon \rightarrow 0} \frac{F^{-1}(\varepsilon)-F^{-1}(2 \varepsilon)}{F^{-1}(2 \varepsilon)-F^{-1}(4 \varepsilon)}=\lim _{\varepsilon \rightarrow 0} \frac{\ln \left(\frac{1}{2 \varepsilon}-1\right)-\ln \left(\frac{1}{\varepsilon}-1\right)}{\ln \left(\frac{1}{4 \varepsilon}-1\right)-\ln \left(\frac{1}{2 \varepsilon}-1\right)}=1 .
$$

W tym przypadku wyrazy ogólne ciagów stałych normujących statystykę maksimum wyrażone są wzorami: $a_{n}=\mu+s \ln (n-1), b_{n}=s \ln \frac{n e-1}{n-1}$, natomiast statystykę minimum: $c_{n}=\mu-s \ln (n-1)$ oraz $d_{n}=s \ln \frac{n e-1}{n-1}$.

Stąd

$$
\lim _{n \rightarrow \infty} P\left\{\frac{X_{(n)}^{(n)}-\mu-s \ln (n-1)}{s(\ln (n e-1)-\ln (n-1))}<x\right\}=H_{1,0}
$$


oraz

$$
\lim _{n \rightarrow \infty} P\left\{\frac{X_{(1)}^{(n)}-\mu+s \ln (n-1)}{s(\ln (n e-1)-\ln (n-1))}<x\right\}=L_{1,0}(x)
$$

Twierdzenie 1.4.15. Jeżeli $X_{1}, X_{2}, \ldots, X_{n}$ jest ciagiem niezależnych zmiennych losowych o standaryzowanym rozkładzie normalnym $N(0,1)$, to unormowane maksimum $X_{(n)}^{(n)}$ i minimum $X_{(1)}^{(n)}$ mają rozkłady graniczne typu Gumbela o dystrybuantach, odpowiednio, $H_{1,0}$ i $L_{1,0}$. Przy czym stałe normujące dla statystyki maksimum sa postaci: $a_{n}=(2 \ln n)^{1 / 2}-\frac{\ln \ln n+\ln 4 \pi}{2(2 \ln n)^{1 / 2}}$ oraz $b_{n}=(2 \ln n)^{-1 / 2}$, natomiast dla statystyki minimum: $c_{n}=-a_{n}, d_{n}=b_{n}$.

Dla wybranych populacji $X$ typy granicznych rozkładów statystyk maksymalnych i minimalnych wyznaczanych na podstawie prób prostych $X_{1}, X_{2}, \ldots, X_{n}$ przedstawione są w tablicy 1.4.3.

Tablica 1.4.3. Typy rozkładów statystyk ekstremalnych dla wybranych populacji

\begin{tabular}{|l|c|c|}
\hline Rozkład $X$ & Rozkład $X_{(n)}^{(n)}$ & Rozkład $X_{(1)}^{(n)}$ \\
\hline Beta & Weibulla & Weibulla \\
\hline Burra & Frécheta & Weibulla \\
\hline Cauchy'ego & Frécheta & Weibulla \\
\hline Gamma & Gumbela & Gumbela \\
\hline Gumbela & Gumbela & Weibulla \\
\hline Jednostajny & Weibulla & Gumbela \\
\hline Logistyczny & Gumbela & Gumbela \\
\hline Log-normalny & Gumbela & Gumbela \\
\hline Normalny & Gumbela & Weibulla \\
\hline Pareto & Frécheta & Weibulla \\
\hline Potęgowy & Weibulla & Weibulla \\
\hline Rayleigha & Gumbela & Frécheta \\
\hline$t$-Studenta & Frécheta & Weibulla \\
\hline Wykładniczy & Gumbela & \\
\hline
\end{tabular}

Źródło: opracowanie własne. 
Nie dla wszystkich rozkładów istnieje dystrybuanta graniczna. Przykładami rozkładów, dla których nie da się określić granicznego rozkładu statystyk ekstremalnych, są rozkłady Poissona i geometryczny. Dla tych rozkładów, przy dowolnym wyborze stałych $a_{n}$ i $b_{n}$, prawdopodobieństwo zdarzenia $X_{(n)}^{(n)}<a_{n}+b_{n} x$ wynosi 0 lub 1 (por. R. Korzonek [2009]).

W praktycznych zastosowaniach wykorzystywane są nie tylko rozkłady graniczne statystyk $\min \left\{X_{1}, X_{2}, \ldots, X_{n}\right\}$ i $\max \left\{X_{1}, X_{2}, \ldots, X_{n}\right\}$, ale również rozkłady graniczne innych statystyk pozycyjnych (por. M. Czekała [2001, s. 30-31]).

Postaci rozkładów $k$-tych statystyk pozycyjnych, gdzie $1<k<n$, zależą od rozkładu granicznego statystyk ekstremalnych. Twierdzenia 1.4.16 i 1.4.17 określają graniczne rozkłady statystyk pozycyjnych rangi $n-k+1$ oraz $k$.

Twierdzenie 1.4.16. Niech $X_{(n-k+1)}^{(n)}$, dla $k>1$, będzie $(n-k+1)$-szą statystyką pozycyjną będącą funkcją próby prostej $X_{1}, X_{2}, \ldots, X_{n}$. Jeżeli dla pewnych ciagów $\left(a_{n}\right)_{n \in N}, \quad\left(b_{n}\right)_{n \in N} \quad \mathrm{o}$ wyrazach dodatnich zachodzi równość $\lim _{n \rightarrow \infty} P\left\{\frac{\max \left\{X_{1}, \ldots, X_{n}\right\}-a_{n}}{b_{n}}<x\right\}=H(x)$, gdzie $H$ jest jedną $\mathrm{z}$ dystrybuant $H_{1,0}, H_{2, \gamma}, H_{3, \gamma}$, to

$$
\lim _{n \rightarrow \infty} P\left\{\frac{X_{(n-k+1)}^{(n)}-a_{n}}{b_{n}}<x\right\}=H^{(k)}(x), \quad \text { dla } k>1,
$$

gdzie

$$
H^{(k)}(x)=H(x) \cdot \sum_{t=0}^{k-1} \frac{1}{t !}(-\ln H(x))^{t} .
$$

Twierdzenie 1.4.17. Niech $X_{(k)}^{(n)}$ będzie $k$-tą statystyką pozycyjną będącą funkcją próby prostej $X_{1}, X_{2}, \ldots, X_{n}$. Jeżeli dla pewnych ciagów $\left(c_{n}\right)_{n \in N}$, $\left(d_{n}\right)_{n \in N}$ o wyrazach dodatnich $\lim _{n \rightarrow \infty} P\left\{\frac{\min \left\{X_{1}, \ldots, X_{n}\right\}-c_{n}}{d_{n}}<x\right\}=L(x)$, gdzie $L$ jest jedną z dystrybuant $L_{1,0}, L_{2, \gamma}, L_{3, \gamma}$, to

$$
\lim _{n \rightarrow \infty} P\left\{\frac{X_{(k)}^{(n)}-c_{n}}{d_{n}}<x\right\}=L^{(k)}(x), \text { dla } k>1,
$$


gdzie

$$
L^{(k)}(x)=1-(1-L(x)) \cdot \sum_{t=0}^{k-1} \frac{1}{t !}(-\ln (1-L(x)))^{t} .
$$

Twierdzenia odwrotne są również prawdziwe. Przynależność dystrybuanty $k$-tej statystyki pozycyjnej do danego obszaru przyciągania determinuje postać rozkładu statystyki minimum, natomiast przynależność dystrybuanty $(n-k+1)$-szej statystyki pozycyjnej określa typ rozkładu statystyki maksimum.

Ciagi kwantyli $\left\{X_{p ; n}\right\}_{n \in N} \mathrm{z} n$-elementowej próby są ciagami statystyk centralnych i ich rozkłady graniczne są rozkładami normalnymi o parametrach określonych w twierdzeniu 1.4.18 (por. C. Domański, K. Pruska [2000, s.103]).

Twierdzenie 1.4.18. Jeżeli $X_{1}, X_{2}, \ldots, X_{n}$ jest ciągiem niezależnych zmiennych losowych stanowiących próbę wylosowana z populacji o ciagłym rozkładzie z funkcję gęstości $f$, zaś $Q_{p}$ jest kwantylem rozkładu rzędu $p$ spełniającym warunek $f\left(Q_{p}\right)>0$, to kwantyl z próby $X_{p ; n}$ ma rozkład asymptotycznie normalny $N\left(Q_{p}, \frac{1}{f\left(Q_{p}\right)} \sqrt{\frac{p(1-p)}{n}}\right)$.

Z twierdzenia 1.4.18 otrzymujemy graniczny rozkład mediany.

Twierdzenie 1.4.19. Jeżeli $X_{1}, X_{2}, \ldots, X_{n}$ jest ciągiem niezależnych zmiennych losowych o ciągłym rozkładzie z funkcję gęstości $f$, natomiast $M_{0,5}$ jest medianą rozkładu, to mediana $\mathrm{z}$ próby $M e$ ma rozkład asymptotycznie normalny $N\left(M_{0,5}, \frac{1}{2 \sqrt{n} f\left(M_{0,5}\right)}\right)$.

W szczególności dla zmiennych losowych $X_{1}, X_{2}, \ldots, X_{n}$ o rozkładzie normalnym $N(\mu, \sigma)$ mediana $\mathrm{z}$ próby $M e$ ma rozkład asymptotycznie normalny $N\left(\mu, \frac{\sigma}{\sqrt{n}} \sqrt{\frac{\pi}{2}}\right)$.

Badania symulacyjne, których wyniki zaprezentowane są $\mathrm{W}$ pracy R. R. Wilcoxa [2001], wskazują, że zbieżność rozkładu mediany z próby do 
rozkładu normalnego o wartości oczekiwanej $\mu=M_{0,5}$ zachodzi już dla median wyznaczonych w oparciu o próby 20 -elementowe.

Dla $p$-wymiarowej zmiennej losowej $\mathbf{X}=\left(X_{1}, X_{2}, \ldots, X_{p}\right)$ o dystrybuancie $F$ graniczne rozkłady odpowiednio unormowanych statystyk ekstremalnych $\mathbf{X}_{(n)}^{(n)}$ oraz $\mathbf{X}_{(1)}^{(n)}$ wyznacza się następująco (S. Kotz, S. Nadarajah [2000, s. 95-129], J. Beirlant i in. [2004, s. 254-286]):

$$
\begin{aligned}
H\left(x_{1}, \ldots, x_{p}\right) & =\lim _{n \rightarrow \infty} P\left(\frac{X_{(n), 1}^{(n)}-a_{1, n}}{b_{1, n}} \leq x_{1}, \ldots, \frac{X_{(n), p}^{(n)}-a_{p, n}}{b_{p, n}} \leq x_{p}\right)= \\
& =\lim _{n \rightarrow \infty} F^{n}\left(a_{1, n}+b_{1, n} x_{1}, \ldots, a_{p, n}+b_{p, n} x_{p}\right),
\end{aligned}
$$

oraz

$$
L\left(x_{1}, \ldots, x_{p}\right)=\lim _{n \rightarrow \infty} P\left(\frac{X_{(1), 1}^{(n)}-c_{1, n}}{d_{1, n}} \leq x_{1}, \ldots, \frac{X_{(1), p}^{(n)}-c_{p, n}}{d_{p, n}} \leq x_{p}\right),
$$

gdzie $\left(a_{i, n}\right)_{n \in N},\left(b_{i, n}\right)_{n \in N}$, dla $i=1, \ldots, p$, są ciaggami stałych normujących dla statystyki maksimum określonymi wzorami (1.4.16), (1.4.19), (1.4.21), zaś $\left(c_{i, n}\right)_{n \in N},\left(d_{i, n}\right)_{n \in N}$ - ciaggami stałych normujących dla statystyki minimum danymi wzorami (1.4.22)-(1.4.24).

Rozkład odpowiednio unormowanej $p$-wymiarowej statystyki maksymalnej $\mathbf{X}_{(n)}^{(n)}=\left(X_{(n), 1}^{(n)}, X_{(n), 2}^{(n)}, \ldots, X_{(n), p}^{(n)}\right)$ jest zbieżny do $p$-wymiarowego rozkładu o dystrybuancie $H$, przy czym dystrybuanta ta jest $p$-wymiarową kopulą (funkcją połączenia):

$$
H\left(x_{1}, x_{2}, \ldots, x_{p}\right)=C\left(H_{1}\left(x_{1}\right), H_{2}\left(x_{2}\right), \ldots, H_{p}\left(x_{p}\right)\right),
$$

gdzie $H_{1}, H_{2}, \ldots, H_{p}$ są dystrybuantami brzegowymi statystyk $X_{(n), 1}^{(n)}, X_{(n), 2}^{(n)}, \ldots, X_{(n), p}^{(n)}$, czyli dystrybuantami jednowymiarowych rozkładów typu Gumbela, Frécheta lub Weibulla.

W przypadku dwuwymiarowej zmiennej losowej $\mathbf{X}=\left(X_{1}, X_{2}\right)$ statystykę maksimum $\mathbf{X}_{(n)}^{(n)}=\left(X_{(n), 1}^{(n)}, X_{(n), 2}^{(n)}\right)$ charakteryzuje dystrybuanta $H$ często będąca kopulą postaci (por. K. Jajuga, D. Papla [2005, s. 57-60]): 
- kopuli Gumbela:

$$
C\left(u_{1}, u_{2}\right)=\exp \left[-\left\{\left(\ln u_{1}\right)^{\theta}+\left(\ln u_{21}\right)^{\theta}\right\}^{\frac{1}{\theta}}\right], \quad \theta \in\langle 1, \infty),
$$

- kopuli Gumbela II:

$$
C\left(u_{1}, u_{2}\right)=u_{1} u_{2} \exp \left[\frac{\theta \ln u_{1} \ln u_{2}}{\ln u_{1}+\ln u_{2}}\right], \quad \theta \in\langle 0,1\rangle,
$$

- kopuli Galambosa:

$$
C\left(u_{1}, u_{2}\right)=1-\exp \left[\left\{\left(\ln u_{1}\right)^{-\theta}+\left(\ln u_{2}\right)^{-\theta}\right\}^{-\frac{1}{\theta}}\right], \quad \theta \in\langle 0, \infty) .
$$

W analizach finansowych wielowymiarowe statystyki maksimum wykorzystuje się w estymacji maksymalnych strat każdego ze składników portfela, utożsamianego ze zmienną losową wielowymiarową.

\subsection{Uwagi końcowe}

Rozdział ten poświęcony został statystykom pozycyjnym i ich własnościom.

$\mathrm{Na}$ podstawie literatury przedmiotu zaprezentowano definicje najważniejszych statystyk pozycyjnych i ich funkcji, a w postaci twierdzeń przestawiono własności. Dla wybranych rozkładów populacji podano funkcje gęstości statystyk pozycyjnych, w szczególności statystyk minimum i maksimum.

Ponadto analizowano graniczne rozkłady statystyk ekstremalnych. Rezultatem przeprowadzonych rozważań jest sformułowanie twierdzeń określających klasy i parametry rozkładów granicznych statystyk maksimum i minimum dla populacji o wybranych rozkładach teoretycznych. Dla populacji o innych rozkładach w sposób analogiczny można sformułować twierdzenia dotyczące rozkładów kwantyli z próby i statystyk ekstremalnych.

Przedstawione twierdzenia są wykorzystywane w teoretycznych i praktycznych zagadnieniach związanych $\mathrm{z}$ wnioskowaniem statystycznym, $\mathrm{w}$ tym $\mathrm{z}$ procedurami estymacji stosowanymi w badaniach społeczno-ekonomicznych, których przykłady przedstawione zostaną w kolejnych rozdziałach pracy. 



\section{METODY ESTYMACJI OPARTE NA STATYSTYKACH POZYCYJNYCH}

\subsection{Uwagi wstępne}

Do wyznaczania estymatorów parametrów rozkładu zmiennej losowej służą szeroko stosowane metody największej wiarygodności, momentów i najmniejszych kwadratów. Istniejące ograniczenia w wykorzystywaniu tych metod, np. ze względu na brak możliwości wyznaczenia maksimum funkcji wiarygodności lub brak momentów centralnych odpowiednich rzędów, stwarzają potrzebę poszukiwania procedur bardziej uniwersalnych, do których zalicza się metody estymacji oparte na statystykach pozycyjnych. Do tej grupy należą: metoda kwantyli, kwantylowa metoda najmniejszych kwadratów, metoda momentów ważonych prawdopodobieństwami, metody bootstrapowe oraz proponowane modyfikacje tych metod, prowadzące do otrzymania estymatorów charakteryzujących się mniejszymi obciążeniami i błędami średniokwadratowymi.

Pierwsza proponowana metoda polega na pominięciu, przy szacowaniu parametrów rozkładu populacji kwantylową metodą najmniejszych kwadratów, $k$ ustalonych skrajnych statystyk pozycyjnych. W zależności od klasy rozkładu nie uwzględnia się $\frac{1}{2} k$ najmniejszych i $\frac{1}{2} k$ największych statystyk pozycyjnych lub tylko $k$ najmniejszych bądź tylko $k$ największych statystyk pozycyjnych. Za niedogodność w stosowaniu tej metody można uznać konieczność ustalenia liczby pomijanych statystyk pozycyjnych, aczkolwiek dostępność do oprogramowania komputerowego i możliwość wstępnych analiz symulacyjnych pozwala ten problem rozwiązać.

Kolejna propozycja modyfikacji kwantylowej metody najmniejszych kwadratów polega na wyznaczeniu estymatorów kwantylową metodą najmniejszych kwadratów z pominięciem $k$ statystyk pozycyjnych przy wszystkich możliwych wartościach $k$, a następnie wyznaczeniu mediany uzyskanych oszacowań.

Do estymacji parametrów rozkładu zmiennej losowej stosuje się metodę momentów ważonych prawdopodobieństwami, która wykorzystuje funkcje kwantyli z próby jako estymatory odpowiednio zdefiniowanych momentów 
rozkładu ważonych prawdopodobieństwami. Zastosowanie różnych estymatorów dystrybuanty rozkładu zmiennej losowej do szacowania prawdopodobieństw nieprzekroczenia wartości statystyk pozycyjnych prowadzi do różnych postaci estymatorów parametrów uzyskanych metodą momentów ważonych prawdopodobieństwami. Autorską propozycję stanowi zastosowanie zmodyfikowanej dystrybuanty empirycznej, zwanej w literaturze angielskojęzycznej level crossing empirical distribution function.

$\mathrm{W}$ rozdziale tym rozważano również bayesowskie i bootstrapowe metody estymacji. W przypadku metod bayesowskich wykorzystujących informacje a priori o rozkładzie szacowanego parametru zmiennej losowej i liniowe funkcje straty estymatorami parametrów są kwantyle rozkładów a posteriori, które można traktować jako pewne funkcje statystyk pozycyjnych. Estymacja bootstrapowa może być stosowana, gdy istnieje konieczność uzyskania oszacowania parametru na podstawie małej próby lub przy braku informacji o klasie rozkładu analizowanej zmiennej.

Wszystkie rozważane procedury, oprócz bootstrapowych, są metodami parametrycznymi, dlatego ich zastosowanie związane jest z wyprowadzeniem wzorów na estymatory parametrów poszczególnych rozkładów. Spośród rozkładów wykorzystywanych w badaniach ekonomicznych do prezentacji wybrano klasy rozkładów charakteryzujące się odmiennymi własnościami, m.in. różną asymetrią i różną grubością ogonów.

\subsection{Metoda kwantyli}

Metoda kwantyli $(m K)$ ma dość prostą konstrukcję i może być stosowana przy szacowaniu parametrów każdego rozkładu opisanego za pomocą dystrybuanty (por. J. Bartoszewicz [1996, s. 230-231], J. Wywiał [2004, s. 84-85]).

Oznaczmy przez $X$ ciągłą zmienną losową o rozkładzie określonym przez dystrybuantę $F\left(\cdot, \theta_{1}, \theta_{2}, \ldots, \theta_{s}\right)$, gdzie $\theta_{1}, \theta_{2}, \ldots, \theta_{s}$ są parametrami rozkładu tej zmiennej.

Niech $Q_{p}$ będzie kwantylem rzędu $p$ rozkładu o dystrybuancie $F\left(\cdot, \theta_{1}, \theta_{2}, \ldots, \theta_{s}\right)$, gdzie $p \in(0,1)$.

Rozważmy problem estymacji parametrów $\theta_{1}, \theta_{2}, \ldots, \theta_{s}$ metodą kwantyli w oparciu o $n$-elementową próbę prostą $X_{1}, X_{2}, \ldots, X_{n}$. Przy wyznaczaniu estymatorów nieznanych parametrów rozkładu zmiennej losowej $X$ wykorzystuje się definicję kwantyla rozkładu i wartości kwantyli z próby wybranych rzędów.

$\mathrm{Z}$ definicji kwantyla rozkładu $Q_{p}$ wynika, że $F\left(Q_{p}, \theta_{1}, \theta_{2}, \ldots, \theta_{s}\right)=p$, czyli w celu wyznaczenia estymatorów $s$ parametrów tworzymy układ $s$-równań postaci: 


$$
\left\{\begin{array}{l}
F\left(Q_{p_{1}}, \theta_{1}, \theta_{2}, \ldots, \theta_{s}\right)=p_{1}, \\
F\left(Q_{p_{2}}, \theta_{1}, \theta_{2}, \ldots, \theta_{s}\right)=p_{2} \\
\cdots \\
F\left(Q_{p_{s}}, \theta_{1}, \theta_{2}, \ldots, \theta_{s}\right)=p_{s}
\end{array}\right.
$$

gdzie $p_{i} \in(0,1), \quad p_{i} \neq p_{j}$ dla $i \neq j$ oraz $i, j \in\{1,2, \ldots, s\}$.

Podstawienie do układu równań w miejsce kwantyli rozkładu rzędu $p_{i}$ wartości kwantyli z próby $X_{p_{i}, n}$ i rozwiązanie tego układu prowadzi do otrzymania estymatorów parametrów $\theta_{1}, \theta_{2}, \ldots, \theta_{s}$ określonych w definicji 2.2.1.

Definicja 2.2.1. Estymatorami parametrów $\theta_{1}, \theta_{2}, \ldots, \theta_{s}$ ciągłej zmiennej losowej $X$ o dystrybuancie $F\left(\cdot, \theta_{1}, \theta_{2}, \ldots, \theta_{s}\right)$ otrzymanymi metodą kwantyli nazywamy statystyki $\hat{\theta}_{1}^{m K}, \hat{\theta}_{2}^{m K}, \ldots, \hat{\theta}_{s}^{m K}$, będące funkcjami $n$-elementowej próby prostej $X_{1}, X_{2}, \ldots, X_{n}$ i spełniające układ równań:

$$
\left\{\begin{array}{l}
X_{p_{1} ; n}=F^{-1}\left(p_{1}, \hat{\theta}_{1}^{m K}, \hat{\theta}_{2}^{m K}, \ldots, \hat{\theta}_{s}^{m K}\right), \\
X_{p_{2} ; n}=F^{-1}\left(p_{2}, \hat{\theta}_{1}^{m K}, \hat{\theta}_{2}^{m K}, \ldots, \hat{\theta}_{s}^{m K}\right), \\
\cdots \ldots \\
X_{p_{s} ; n}=F^{-1}\left(p_{s}, \hat{\theta}_{1}^{m K}, \hat{\theta}_{2}^{m K}, \ldots, \hat{\theta}_{s}^{m K}\right),
\end{array}\right.
$$

gdzie $F^{-1}$ jest funkcją odwrotną do dystrybuanty $F$, natomiast $X_{p_{i} ; n}$ są kwantylami ustalonych rzędów $p_{i}$, dla $i=1, \ldots, s$, wyznaczonymi na podstawie wylosowanej próby.

Dla poszczególnych klas rozkładów można sformułować twierdzenia podające postaci estymatorów ich parametrów. Wzory na estymatory parametrów rozkładu logarytmiczno-normalnego oraz wyniki badań symulacyjnych dotyczące analizy zależności własności estymatorów od wyboru statystyk pozycyjnych podane są w pracy J. Aitchison, J. A. C. Brown [1975]. Poniżej przedstawiono wykorzystanie metody kwantyli do szacowania parametrów następujących rozkładów Cauchy’ego, Pareto, Weibulla (dwuparametrowego), logistycznego 
i Gumbela. Wybrane klasy rozkładów charakteryzują się odmiennymi własnościami. Rozkład Cauchy’ego jest rozkładem z dwoma grubymi ogonami, Pareto ma tylko prawy gruby ogon, natomiast rozkład logistyczny i Gumbela mają cienkie ogony, a Weibulla ma tylko jeden cienki ogon. Rozkłady te opisane są przez dystrybuanty z dwoma parametrami, zatem w metodzie kwantyli wykorzystuje się dwa kwantyle z próby. Wartości $p_{i}$ dla $i=1,2$ mogą być różnymi liczbami z przedziału $(0,1)$, ale $\mathrm{w}$ praktycznych zastosowaniach do estymacji parametrów tych rozkładów wygodnie jest stosować kwantyle rzędu $p$ oraz $1-p$.

Niech $X$ będzie zmienną losową o rozkładzie Cauchy'ego $C a(m, \lambda)$.

W celu oszacowania nieznanych wartości parametrów $m$ i $\lambda$ tworzymy układ równań:

$$
\left\{\begin{array}{l}
F\left(X_{p ; n}\right)=p, \\
F\left(X_{(1-p) ; n}\right)=1-p,
\end{array}\right.
$$

gdzie $p \in(0,0,5)$ oraz $F(x)=\frac{1}{\pi} \operatorname{arctg}\left(\frac{x-m}{\lambda}\right)+\frac{1}{2}$.

Korzystając z definicji dystrybuanty, otrzymujemy układ równań:

$$
\left\{\begin{array}{l}
X_{p ; n}=m+\lambda \operatorname{tg}(\pi(p-0,5)), \\
X_{(1-p) ; n}=m+\lambda \operatorname{tg}(\pi(0,5-p)),
\end{array}\right.
$$

który po wykorzystaniu własności funkcji trygonometrycznych przyjmuje postać:

$$
\left\{\begin{array}{l}
X_{p ; n}=m-\lambda \operatorname{ctg}(\pi p), \\
X_{(1-p) ; n}=m+\lambda \operatorname{ctg}(\pi p) .
\end{array}\right.
$$

Rozwiązanie układu równań (2.2.5) prowadzi do estymatorów parametrów $m$ i $\lambda$ o wzorach przedstawionych w twierdzeniu 2.2.1.

Twierdzenie 2.2.1. Jeżeli $X_{1}, X_{2}, \ldots, X_{n}$ jest próbą prostą wylosowaną z populacji o rozkładzie Cauchy'ego $\mathrm{Ca}(m, \lambda)$ oraz $p \in(0,0,5)$, to estymatory parametrów $m$ i $\lambda$ wyznaczone metodą kwantyli mają postaci: 


$$
\begin{aligned}
& \hat{m}^{m K}=\frac{X_{p ; n}+X_{(1-p) ; n}}{2}, \\
& \hat{\lambda}^{m K}=\frac{X_{(1-p) ; n}-X_{p ; n}}{2 \operatorname{ctg}(\pi p)},
\end{aligned}
$$

gdzie $X_{p ; n}, X_{(1-p) ; n}$ są kwantylami z próby losowej rzędów, odpowiednio, p i $1-p$.

W celu oszacowania nieznanych wartości parametrów zmiennej losowej $X$ o rozkładzie Pareto $P a(\theta, a)$ tworzymy układ równań:

$$
\left\{\begin{array}{l}
p=1-\left(\frac{\theta}{X_{p ; n}}\right)^{a}, \\
p=\left(\frac{\theta}{X_{(1-p) ; n}}\right)^{a},
\end{array}\right.
$$

przyjmujący po przekształceniach postać:

$$
\left\{\begin{array}{l}
\ln (1-p)=a\left(\ln \theta-\ln X_{p ; n}\right), \\
\ln p=a\left(\ln \theta-\ln X_{(1-p) ; n}\right),
\end{array}\right.
$$

a jego rozwiązaniem są estymatory $\hat{\theta}^{m K}, \hat{a}^{m K}$ parametrów $\theta$ oraz a określone w twierdzeniu 2.2.2.

Twierdzenie 2.2.2. Jeżeli $X_{1}, X_{2}, \ldots, X_{n}$ jest próbą prostą wylosowaną z populacji $X$ o rozkładzie Pareto $P a(\theta, a)$ oraz $p \in(0,0,5)$, to estymatory parametrów $\theta$ i $a$ wyznaczone metodą kwantyli wyrażone są wzorami:

$$
\begin{gathered}
\hat{\theta}^{m K}=X_{(1-p) ; n} \cdot p^{\frac{\ln X_{(1-p) ; n}-\ln X_{p ; n}}{\ln (1-p)-\ln p}}, \\
\hat{a}^{m K}=\frac{\ln (1-p)-\ln p}{\ln X_{(1-p) ; n}-\ln X_{p ; n}},
\end{gathered}
$$

gdzie $X_{p ; n}, X_{(1-p) ; n}$, to kwantyle z próby rzędu $p$ i $1-p$. 
Kolejne twierdzenie określa wzory na estymatory parametrów rozkładu logistycznego.

Twierdzenie 2.2.3. Jeżeli $X_{1}, X_{2}, \ldots, X_{n}$. jest próbą prostą wylosowaną z populacji o rozkładzie logistycznym $\operatorname{Logist}(\mu, s)$ oraz $X_{p ; n}, X_{(1-p) ; n}$ są kwantylami z próby rzędu $p$ i $1-p$, dla $p \in(0,0,5)$, to estymatory parametrów $\mu$ oraz $s$ wyznaczone metodą kwantyli są postaci:

$$
\begin{gathered}
\hat{\mu}^{m K}=\frac{X_{p ; n}+X_{(1-p) ; n}}{2}, \\
\hat{s}^{m K}=\frac{X_{p ; n}-X_{(1-p) ; n}}{2 \ln p-2 \ln (1-p)} .
\end{gathered}
$$

Postaci estymatorów wynikają ze wzoru na kwantyl $Q_{p}$ rozkładu logistycznego: $Q_{p}=\mu-s \ln \left(\frac{1}{p}-1\right)$.

Rozkładem, którego parametry można estymować metodą kwantyli, jest również dwuparametrowy rozkład Weibulla.

Twierdzenie 2.2.4. Jeżeli $X_{1}, X_{2}, \ldots, X_{n}$ jest ciagiem niezależnych zmiennych losowych stanowiących próbę wylosowaną z populacji o rozkładzie Weibulla o dystrybuancie $F(x)=1-e^{-\left(\frac{x}{\delta}\right)^{\gamma}}$, gdzie $\delta>0, \quad \gamma>0$, oraz $X_{p ; n}$, $X_{(1-p) ; n}$ są kwantylami z próby rzędu $p$ i $1-p$, dla $p \in(0,0,5)$, to estymatory parametrów $\gamma$ i $\delta$ wyznaczone metodą kwantyli wyrażone są wzorami:

$$
\begin{gathered}
\hat{\gamma}^{m K}=\frac{\ln (-\ln (1-p))-\ln (-\ln p)}{\ln X_{p ; n}-\ln X_{(1-p) ; n}}, \\
\hat{\delta}^{m K}=X_{p ; n}(-\ln (1-p)) \frac{\ln X_{p ; n}-\ln X_{(1-;) ; n}}{\ln (-\ln (1-p))-\ln (-\ln p)} .
\end{gathered}
$$

Metodę kwantyli można stosować do szacowania parametrów uogólnionych rozkładów statystyk ekstremalnych $\operatorname{GEVD}_{M}(\mu, \sigma, \xi)$ oraz $G E V D_{m}(\mu, \sigma, \xi)$ 
wykorzystywanych w analizach zjawisk ekstremalnych. Dla rozkładów tych zastosowanie metody największej wiarygodności nie pozwala wyznaczyć wzorów na estymatory parametrów, a zastosowanie oprogramowania komputerowego w celu numerycznego wyznaczenia wartości estymatorów też nie zawsze przynosi pożąadane rezultaty. Metoda momentów również posiada ograniczenia, w przypadku rozkładu Frécheta nie zawsze istnieją momenty zwykłe i centralne rozkładu (dla $\xi \geq 1$ brak jest wartości oczekiwanej i wariancji, dla $\frac{1}{2} \leq \xi<1$ istnieje tylko wartość oczekiwana).

Rozważmy problem szacowania parametrów rozkładu Gumbela $G l(\lambda, \delta)$ o dystrybuancie określonej wzorem (1.4.2) oraz odwróconego rozkładu Gumbela $\operatorname{IGl}(\lambda, \delta)$ o dystrybuancie (1.4.10).

Ponieważ kwantyl rzędu $p$ zmiennej losowej $X$ o rozkładzie $G l(\lambda, \delta)$ wyrażony jest wzorem:

$$
Q_{p}=\lambda-\ln (-\ln p)
$$

otrzymujemy następujący układ równań:

$$
\left\{\begin{array}{l}
X_{p ; n}=\lambda-\delta \ln (-\ln p) \\
X_{(1-p) ; n}=\lambda-\delta \ln (-\ln (1-p)),
\end{array}\right.
$$

gdzie $X_{p ; n}$ oraz $X_{(1-p) ; n}$ są kwantylami rzędu $p$ i $1-p$ wyznaczonymi na podstawie próby losowej $X_{1}, X_{2}, \ldots, X_{n}$.

W wyniku rozwiązania układu równań (2.2.17) otrzymujemy estymatory parametrów rozkładu Gumbela o wzorach określonych w twierdzeniu 2.2.5.

Twierdzenie 2.2.5. Jeżeli $X_{1}, X_{2}, \ldots, X_{n}$ jest próbą prostą pochodzącą z populacji o rozkładzie Gumbela $G l(\lambda, \delta)$ oraz $X_{p ; n}, X_{(1-p) ; n}$ są kwantylami z próby rzędów $p$ i $1-p$, dla $p \in(0,0,5)$, to estymatory parametrów $\lambda$ oraz $\delta$ wyznaczone metodą kwantyli są następującej postaci:

$$
\hat{\lambda}^{m K}=X_{p ; n}+\frac{X_{p ; n}-X_{(1-p) ; n}}{\ln (-\ln (1-p))-\ln (-\ln p)} \ln (-\ln p),
$$




$$
\hat{\delta}^{m K}=\frac{X_{p ; n}-X_{(1-p) ; n}}{\ln (-\ln (1-p))-\ln (-\ln p)} .
$$

Analogiczne twierdzenie można sformułować dla estymatorów parametrów odwróconego rozkładu Gumbela $I G l(\lambda, \delta)$, który jest asymptotycznym rozkładem minimum z próby dla populacji charakteryzujących się cienkim lewym ogonem (por. tablica 1.4.3).

Twierdzenie 2.2.6. Jeżeli $X_{1}, X_{2}, \ldots, X_{n}$ jest próbą prostą pochodząca z populacji o odwróconym rozkładzie Gumbela $I G l(\lambda, \delta)$ oraz $X_{p ; n}, X_{(1-p) ; n}$ są kwantylami z próby rzędów $p$ i $1-p$, dla $p \in(0,0,5)$, to estymatory parametrów $\mu$ oraz $\sigma$ wyznaczone metodą kwantyli są postaci:

$$
\begin{gathered}
\hat{\lambda}^{m K}=X_{p ; n}+\frac{X_{p ; n}-X_{(1-p) ; n}}{\ln (-\ln (1-p))-\ln (-\ln p)} \ln (-\ln (1-p)), \\
\hat{\delta}^{m K}=\frac{X_{p ; n}-X_{(1-p) ; n}}{\ln (-\ln (1-p))-\ln (-\ln p)} .
\end{gathered}
$$

W przypadku gdy graniczne rozkłady statystyk ekstremalnych są typu Frécheta lub typu Weibulla, to w celu oszacowania parametrów metodą kwantyli korzystamy z definicji kwantyla rzędu $p$ postaci:

$$
Q_{p}=\mu+\sigma\left((-\ln p)^{-\xi}-1\right) / \xi .
$$

Estymacja parametrów uogólnionego rozkładu statystyki maksymalnej związana jest zatem $\mathrm{z}$ rozwiązaniem układu równań składającego się z trzech równań wyznaczonych w oparciu o $n$-elementową próbę $X_{1}, X_{2}, \ldots, X_{n}$.

Wykorzystując trzy kwantyle z próby wybranych rzędów, otrzymujemy:

$$
\left\{\begin{array}{l}
X_{(i)}^{(n)}=\mu+\sigma\left(\left(-\ln p_{i}\right)^{-\xi}-1\right) / \xi \\
X_{(j)}^{(n)}=\mu+\sigma\left(\left(-\ln p_{j}\right)^{-\xi}-1\right) / \xi, \\
X_{(l)}^{(n)}=\mu+\sigma\left(\left(-\ln p_{l}\right)^{-\xi}-1\right) / \xi
\end{array}\right.
$$


gdzie $X_{(i)}^{(n)}, \quad X_{(j)}^{(n)}, \quad X_{(l)}^{(n)}$ są różnymi statystykami pozycyjnymi o rangach $i, j, l \in\{1,2, \ldots, n-1\}$ oraz $p_{s}=\frac{s}{n}$ dla $s=i, j, l$.

Niestety, przy estymacji parametrów uogólnionego rozkładu statystyki maksymalnej nie da się określić wzorów na postaci estymatorów parametrów $\xi, \mu$ oraz $\sigma$.

Estymatorem parametru $\xi$ jest statystyka $\hat{\xi}^{m K}$ spełniająca równanie:

$$
\frac{\left(-\ln p_{i}\right)^{-\xi}-\left(-\ln p_{l}\right)^{-\xi}}{\left(-\ln p_{j}\right)^{-\xi}-\left(-\ln p_{l}\right)^{-\xi}}-\frac{X_{(i)}^{(n)}-X_{(l)}^{(n)}}{X_{(j)}^{(n)}-X_{(l)}^{(n)}}=0
$$

natomiast estymatory parametrów $\mu$ i $\sigma$ wyrażone są wzorami:

$$
\begin{gathered}
\hat{\mu}^{m K}=X_{(i)}^{(n)}-\frac{\left(X_{(i)}^{(n)}-X_{(l)}^{(n)}\right)\left(\left(-\ln p_{i}\right)^{-\xi^{m K}}-1\right)}{\left(-\ln p_{i}\right)^{-\xi^{m K}}-\left(-\ln p_{l}\right)^{-\xi^{m K}}}, \\
\hat{\sigma}^{m K}=\frac{\hat{\xi}^{m K}\left(X_{(i)}^{(n)}-X_{(l)}^{(n)}\right)}{\left(-\ln p_{i}\right)^{-\hat{\xi}^{m K}}-\left(-\ln p_{l}\right)^{-\hat{\xi}^{m K}}} .
\end{gathered}
$$

Rozwiązanie równania (2.2.24) wyznacza się numerycznie.

Funkcja

$$
f(\xi)=\frac{\left(-\ln p_{i}\right)^{-\xi}-\left(-\ln p_{l}\right)^{-\xi}}{\left(-\ln p_{j}\right)^{-\xi}-\left(-\ln p_{l}\right)^{-\xi}}-\frac{X_{(i)}^{(n)}-X_{(l)}^{(n)}}{X_{(j)}^{(n)}-X_{(l)}^{(n)}}
$$

zawsze posiada miejsce zerowe.

Dla zmiennej losowej $X$ o rozkładzie $G E V D_{M}(-1,1,1)$ przykładowy wykres funkcji $f_{0}(\xi)=\frac{(-\ln 0,1)^{-\xi}-(-\ln 0,9)^{-\xi}}{(-\ln 0,3)^{-\xi}-(-\ln 0,9)^{-\xi}}-\frac{X_{(10)}^{(100)}-X_{(90)}^{(100)}}{X_{(30)}^{(100)}-X_{(90)}^{(100)}}$ przedstawiony jest na rysunku 2.2.1.

Wartości estymatorów $\hat{\xi}^{m K}, \hat{\mu}^{m K}, \hat{\sigma}^{m K}$ powinny spełniać nierówność $X_{(n)}^{(n)}>\hat{\mu}^{m K}-\frac{\hat{\sigma}^{m K}}{\hat{\xi}^{m K}}$, gdy $\hat{\xi}^{m K}>0$ lub $X_{(n)}^{(n)}<\hat{\mu}^{m K}-\frac{\hat{\sigma}^{m K}}{\hat{\xi}^{m K}}$, gdy $\hat{\xi}^{m K}<0$. 
Ze względu na wiele możliwości wyboru rang statystyk pozycyjnych do estymacji parametrów uogólnionego rozkładu maksimum praktycznym podejściem jest wybranie kilku czy nawet kilkunastu trójek kwantyli wykorzystywanych do estymacji, a następnie „uśrednienie" wyników poprzez zastosowanie mediany czy też $\alpha$-obciętej średniej (por. E. Castillo i. in. [2004, s. 274-275]).

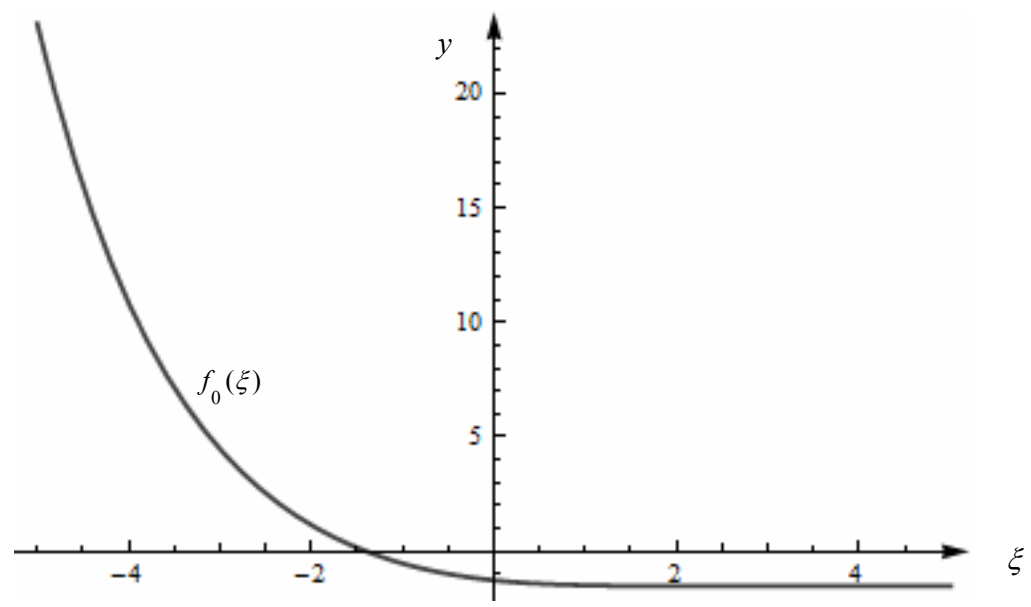

Rysunek 2.2.1. Wykres funkcji $f_{0}(\xi)$

Źródło: opracowanie własne

Powtórzenie procedury estymacji $N$ razy dla statystyk pozycyjnych o określonych wielkościach rang prowadzi do otrzymania po $N$ wartości $\hat{\xi}_{1}^{m K}, \ldots, \hat{\xi}_{N}^{m K}$, $\hat{\mu}_{1}^{m K}, \ldots, \hat{\mu}_{N}^{m K}, \hat{\sigma}_{1}^{m K}, \ldots, \hat{\sigma}_{N}^{m K}$, będących oszacowaniami parametrów odpowiednio $\xi, \mu, \sigma$. Wyznaczenie na podstawie otrzymanych wyników mediany lub $\alpha$-obciętej średniej (definicje 1.2 .3 i 1.2.13) prowadzi do otrzymania estymatorów postaci:

$$
M e_{\xi}=M e\left(\hat{\xi}_{1}^{m K}, \ldots, \hat{\xi}_{N}^{m K}\right), M e_{\mu}=\operatorname{Me}\left(\hat{\mu}_{1}^{m K}, \ldots, \hat{\mu}_{N}^{m K}\right), M e_{\sigma}=\operatorname{Me}\left(\hat{\sigma}_{1}^{m K}, \ldots, \hat{\sigma}_{N}^{m K}\right)
$$

lub

$$
T_{\alpha, \xi}=T_{\alpha}\left(\hat{\xi}_{1}^{m K}, \ldots, \hat{\xi}_{N}^{m K}\right), T_{\alpha, \mu}=T_{\alpha}\left(\hat{\mu}_{1}^{m K}, \ldots, \hat{\mu}_{N}^{m K}\right), T_{\alpha, \sigma}=T_{\alpha}\left(\hat{\sigma}_{1}^{m K}, \ldots, \hat{\sigma}_{N}^{m K}\right),
$$


gdzie $T_{\alpha}$ jest $\alpha$-obciętą średnią o wzorze (1.2.9) dla $\alpha \in\left(0, \frac{1}{2}\right)$.

Przy zastosowaniu $\alpha$-obciętej średniej pojawia się dodatkowy problem wyboru wielkości $\alpha$, od której zależą własności uzyskanych estymatorów.

Do innych rozkładów, dla których nie można wyznaczyć wzorów na estymatory ich parametrów, należą rozkład Burra $\operatorname{Br}(a, c)$ i uogólniony rozkład Pareto $G P D(\beta, \xi)$ z parametrami $\xi \neq 0, \beta>0$.

Dla rozkładu Burra o dystrybuancie:

$$
F(x)= \begin{cases}0 & \text { dla } x \leq 0 \\ 1-\left(1+x^{c}\right)^{-a} & \text { dla } x>0\end{cases}
$$

kwantyl rzędu $p$ jest postaci $Q_{p}=\left((1-p)^{-\frac{1}{a}}-1\right)^{\frac{1}{c}}$, zatem otrzymujemy następujący układ równań:

$$
\left\{\begin{array}{l}
c \ln X_{p ; n}=\ln \left[(1-p)^{-\frac{1}{a}}-1\right] \\
c \ln X_{(1-p) ; n}=\ln \left[p^{-\frac{1}{a}}-1\right]
\end{array}\right.
$$

Dla uogólnionego rozkładu Pareto charakteryzującego się dystrybuantą wyrażoną wzorem:

$$
F_{\beta, \xi}(x)=1-\left(1+\xi \frac{x}{\beta}\right)^{-\frac{1}{\xi}} \text { dla } \xi x>-\beta \wedge x>0
$$

mamy $Q_{p}=\frac{\beta}{\xi}\left(1-(1-p)^{-\xi}\right)$ oraz

$$
\left\{\begin{array}{l}
\xi X_{p ; n}=\beta\left[1-(1-p)^{-\xi}\right] \\
\xi X_{(1-p) ; n}=\beta\left(1-p^{-\xi}\right) .
\end{array}\right.
$$

Zarówno układ równań (2.2.29), jak i (2.2.30) można rozwiązać tylko numerycznie. 
Rezultaty badań obciążeń i błędów średniokwadratowych estymatorów parametrów wybranych klas rozkładów zmiennych losowych w zależności od rzędów wykorzystywanych kwantyli przedstawione zostaną w trzecim rozdziale pracy.

W literaturze metoda kwantyli zwana jest również metodą percentyli (por. E. Castillo i in. [2004, s. 119-120]).

\subsection{Kwantylowa metoda najmniejszych kwadratów}

Estymacja parametrów rozkładu zmiennej losowej kwantylową metodą najmniejszych kwadratów (quantile least squares method) polega na minimalizacji sumy kwadratów odchyleń kwantyli z próby i kwantyli rozkładu badanej zmiennej losowej (por. W. G. Gilchrist [2000, s. 198-207]).

Definicja 2.3.1. Estymatorami parametrów $\theta_{1}, \theta_{2}, \ldots, \theta_{s}$ rozkładu zmiennej losowej $X$ o dystrybuancie $F\left(\cdot, \theta_{1}, \theta_{2}, \ldots, \theta_{s}\right)$ otrzymanymi kwantylową metodą najmniejszych kwadratów nazywamy statystyki $\hat{\theta}_{1}^{\text {Knnk }}, \hat{\theta}_{2}^{K m n k}, \ldots, \hat{\theta}_{s}^{K m n k}$ będące funkcjami elementów próby losowej $X_{1}, X_{2}, \ldots, X_{n}$, dla których osiaga minimum globalne wyrażenie postaci:

$$
G\left(\theta_{1}, \theta_{2}, \ldots, \theta_{s}\right)=\sum_{i=1}^{n}\left(X_{p_{i} ; n}-Q_{p_{i}}\right)^{2},
$$

gdzie statystyki $X_{p_{i} ; n}$ są kwantylami z próby rzędu $p_{i}=\frac{i}{n}$, natomiast $Q_{p_{i}}$ to kwantyle rozkładu rzędu $p_{i}$, dla $i=1, \ldots, n$.

Zastosowanie kwantylowej metody najmniejszych kwadratów (Kmnk) przedstawione jest w pracy A. Lakhany, H. Mausser [2000] do szacowania parametrów uogólnionego rozkładu lambda, za pomocą którego można przybliżać większość rozkładów.

Uogólniony rozkład lambda określa funkcja kwantylowa postaci (por. A. Öztürk, R. Dale [1985]):

$$
Q(p)=\lambda_{1}+\left(\frac{p^{\lambda_{3}}-(1-p)^{\lambda_{4}}}{\lambda_{2}}\right),
$$


gdzie $\lambda_{1}, \lambda_{2}, \lambda_{3}, \lambda_{4}$ są parametrami, odpowiednio, położenia, skali, skośności i kurtozy, ewentualnie funkcja kwantylowa określona wzorem (por. M. Freimer $i$ in. [1988]):

$$
Q(p)=\lambda_{1}+\frac{1}{\lambda_{2}}\left(\frac{p^{\lambda_{1}}-1}{\lambda_{3}}-\frac{(1-p)^{\lambda_{4}}-1}{\lambda_{4}}\right) .
$$

Stosując metodę Kmnk, nie zawsze można wykorzystać wszystkie kwantyle z próby. Ograniczenie wiąże się z postacią funkcji kwantylowej, która nie jest określona dla każdej wartości $p$. Przykładem może być rozważany w poprzednim podrozdziale rozkład Cauchy'ego $C a(m, \lambda)$, dla którego funkcja kwantylowa postaci:

$$
Q(p)=m-\lambda \operatorname{ctg}(\pi p)
$$

jest nieokreślona dla $p=1$.

W tym przypadku wyznaczenie postaci estymatorów parametrów $m$ oraz $\lambda$ za pomocą kwantylowej metody najmniejszych kwadratów związane jest $\mathrm{z}$ obliczeniem minimum globalnego funkcji wyrażonej wzorem:

$$
G(m, \lambda)=\sum_{i=1}^{n-1}\left(X_{p_{i} ; n}-m+\lambda \operatorname{ctg}\left(\pi p_{i}\right)\right)^{2} .
$$

Estymatory parametrów rozkładu Cauchy'ego otrzymane metodą Kmnk ze względu na nieskończoną wariancję statystyki pozycyjnej $X_{(1)}^{(n)}$ charakteryzują się dużymi obciążeniami i wariancjami. Wydaje się zatem uzasadnione pominięcie w kwantylowej metodzie najmniejszych kwadratów wartości statystyki minimalnej, a nawet statystyk pozycyjnych innych rang bliskich rangom statystyk ekstremalnych. Stąd powstała idea autorskich propozycji modyfikacji metody Kmnk.

\subsection{Modyfikacje kwantylowej metody najmniejszych kwadratów}

Rezultatem poszukiwań metod kwantylowych pozwalających uzyskać estymatory parametrów rozkładu charakteryzujące się małym obciążeniem i małą wariancją są dwie propozycje modyfikacji kwantylowej metody najmniejszych kwadratów. Ze względu na sposób konstrukcji estymatorów pierwszą $\mathrm{z}$ nich nazwano kwantylową metodą najmniejszych kwadratów z uciętą liczbą kwantyli, czasem określaną jako uciętą kwantylową metodę najmniejszych kwadratów, a drugą - medianowo-kwantylową metodą najmniejszych kwadratów. 


\subsubsection{Kwantylowa metoda najmniejszych kwadratów z uciętą liczbą kwantyli}

Istotą pierwszej modyfikacji kwantylowej metody najmniejszych kwadratów jest pominięcie, w konstrukcji estymatorów parametrów rozkładu, ustalonej liczby $k$ skrajnych statystyk pozycyjnych, czyli wykorzystanie $n-k$ kwantyli. Metoda ta nazywana została w pracy kwantylową metodą najmniejszych kwadratów z uciętą liczbą kwantyli ( $u K m n k)$.

Definicja 2.4.1. Estymatorami parametrów $\theta_{1}, \theta_{2}, \ldots, \theta_{s}$ rozkładu zmiennej losowej $X$ o dystrybuancie $F\left(\cdot, \theta_{1}, \theta_{2}, \ldots, \theta_{s}\right)$ otrzymanymi kwantylową metodą najmniejszych kwadratów z uciętą liczbą kwantyli nazywamy statystyki $\hat{\theta}_{1}^{u K n n k}, \hat{\theta}_{2}^{u K m n k}, \ldots, \hat{\theta}_{s}^{u K m n k}$ będące funkcjami elementów próby prostej $X_{1}, X_{2}, \ldots, X_{n}$, dla których osiaga minimum globalne wyrażenie postaci:

$$
G\left(\theta_{1}, \theta_{2}, \ldots, \theta_{s}\right)=\sum_{i \in I_{k}}\left(X_{p_{i} ; n}-Q_{p_{i}}\right)^{2},
$$

gdzie $k$ jest ustaloną liczbą naturalną, natomiast $X_{p_{i} ; n}, Q_{p_{i}}$ są odpowiednio kwantylami z próby i kwantylami rozkładu rzędu $p_{i}=\frac{i}{n}$, zaś $I_{k}$ jest pewnym $(n-k)$ elementowym podzbiorem zbioru $\{1,2, \ldots, n\}$.

Dla różnych rozkładów zbiór $I_{k}$ może być różny. W przypadku rozkładów symetrycznych lub zbliżonych do rozkładów symetrycznych sensowne jest pominięcie parzystej liczby $k$ kwantyli: $\frac{k}{2}$ kwantyli najmniejszych $\mathrm{i} \frac{k}{2}$ największych, a następnie poszukiwanie minimum globalnego funkcji postaci:

$$
G\left(\theta_{1}, \theta_{2}, \ldots, \theta_{s}\right)=\sum_{i=1+k / 2}^{n-k / 2}\left(X_{p_{i} ; n}-Q_{p_{i}}\right)^{2} .
$$

Gdy liczebność próby $n$ jest liczbą parzystą, to $k$ może być liczbą ze zbioru $\{2,4, \ldots, n-2\}$, natomiast gdy $n$ jest liczbą nieparzysta, to $k \in\{2,4, \ldots, n-3\}$.

Dla rozkładów asymetrycznych charakteryzujących się tylko grubym prawym lub tylko grubym lewym ogonem pomijamy $k$ kwantyli z ogona rozkładu, odpowiednio, prawego bądź lewego i wyznaczamy minimum globalne funkcji wyrażonej wzorem:

$$
G\left(\theta_{1}, \theta_{2}, \ldots, \theta_{s}\right)=\sum_{i=1}^{n-k}\left(X_{p_{i} ; n}-Q_{p_{i}}\right)^{2}
$$


lub

$$
G\left(\theta_{1}, \theta_{2}, \ldots, \theta_{s}\right)=\sum_{i=k+1}^{n}\left(X_{p_{i} ; n}-Q_{p_{i}}\right)^{2} .
$$

Poniżej przedstawione zostaną wzory określające estymatory parametrów wybranych symetrycznych rozkładów zmiennej losowej.

Dla rozkładu Cauchy'ego $\mathrm{Ca}(m, \lambda)$ wyznaczenie estymatorów parametrów $m$ oraz $\lambda$ za pomocą kwantylowej metody najmniejszych kwadratów z uciętą liczbą kwantyli związane jest z obliczeniem minimum funkcji wyrażonej wzorem:

$$
G(m, \lambda)=\sum_{i=1+k / 2}^{n-k / 2}\left(X_{p_{i} ; n}-m+\lambda \operatorname{ctg}\left(\pi p_{i}\right)\right)^{2} .
$$

$\mathrm{Z}$ warunku koniecznego istnienia minimum lokalnego funkcji wielu zmiennych postaci: $\operatorname{grad} G(m, \lambda)=\mathbf{0}$, gdzie $\operatorname{grad} G$ jest wektorem złożonym z pochodnych cząstkowych pierwszego rzędu funkcji $G$ liczonych po zmiennych $m$ i $\lambda$, otrzymujemy następujący układ równań:

$$
\left\{\begin{array}{l}
\sum_{i=1+k / 2}^{n-k / 2}\left(X_{p_{i} ; n}-m+\lambda \operatorname{ctg}\left(\pi p_{i}\right)\right)=0 \\
\sum_{i=1+k / 2}^{n-k / 2}\left(X_{p_{i} ; n}-m+\lambda \operatorname{ctg}\left(\pi p_{i}\right)\right) \operatorname{ctg}\left(\pi p_{i}\right)=0
\end{array}\right.
$$

a po przekształceniach:

$$
\left\{\begin{array}{l}
\sum_{i=1+k / 2}^{n-k / 2} X_{p_{i} ; n}-(n-k) m+\lambda \sum_{i=1+k / 2}^{n-k / 2} \operatorname{ctg}\left(\pi p_{i}\right)=0, \\
\sum_{i=1+k / 2}^{n-k / 2} X_{p_{i} ; n} \operatorname{ctg}\left(\pi p_{i}\right)-m \sum_{i=1+k / 2}^{n-k / 2} \operatorname{ctg}\left(\pi p_{i}\right)+\lambda \sum_{i=1+k / 2}^{n-k / 2} \operatorname{ctg}^{2}\left(\pi p_{i}\right)=0 .
\end{array}\right.
$$

Rozwiązanie układu równań (2.4.7), dla którego hesjan funkcji $G$ (macierz złożona z pochodnych cząstkowych rzędu drugiego funkcji $G$ ) jest dodatnio określony, prowadzi do uzyskania wzorów na estymatory parametrów $m$ i $\lambda$, które podane zostały w twierdzeniu 2.4.1. 
Twierdzenie 2.4.1. Jeśli $X$ jest zmienną losową o rozkładzie Cauchy’ego $C a(m, \lambda)$, to estymatory parametrów $m$ i $\lambda$ otrzymane kwantylową metodą najmniejszych kwadratów z uciętą liczbą kwantyli, będące funkcjami próby prostej $X_{1}, X_{2}, \ldots, X_{n}$, mają postać:

$$
\begin{gathered}
\hat{m}^{u K m n k}=\frac{\sum_{i=1+k / 2}^{n-k / 2} X_{p_{i} ; n}}{n-k}-\frac{\sum_{i=1+k / 2}^{n-k / 2} X_{p_{i} ; n} \sum_{i=1+k / 2}^{n-k / 2} \operatorname{ctg}\left(\pi p_{i}\right)-(n-k) \sum_{i=1+k / 2}^{n-k / 2} X_{p_{i} ; n} \operatorname{ctg}\left(\pi p_{i}\right)}{(n-k)\left(\sum_{i=1+k / 2}^{n-k / 2} \operatorname{ctg}\left(\pi p_{i}\right)\right)^{2}-(n-k)^{2} \sum_{i=1+k / 2}^{n-k / 2} \operatorname{ctg}\left(\pi p_{i}\right)} \sum_{i=1+k / 2} \operatorname{ctg}\left(\pi p_{i}\right), \\
\hat{\lambda}^{n K m n k}=\frac{\sum_{i=1+k / 2}^{n-k / 2} X_{p_{i} ; n} \sum_{i=1+k / 2}^{n-k / 2} \operatorname{ctg}\left(\pi p_{i}\right)-(n-k) \sum_{i=1+k / 2}^{n-k / 2} X_{p_{i} ; n} \operatorname{ctg}\left(\pi p_{i}\right)}{(n-k) \sum_{i=1+k / 2}^{n-k / 2} \operatorname{ctg}^{2}\left(\pi p_{i}\right)-\left(\sum_{i=1+k / 2}^{n-k / 2} \operatorname{ctg}\left(\pi p_{i}\right)\right)^{2}},
\end{gathered}
$$

gdzie $k$ jest ustaloną liczbą parzystą, natomiast $X_{p_{i} ; n}$ są kwantylami z próby rzędu $p_{i}=\frac{i}{n}$ oraz $i=1+\frac{k}{2}, \ldots, n-\frac{k}{2}$.

Innym rozważanym rozkładem, którego parametry można oszacować metodą $u K m n k$, jest rozkład logistyczny Logist $(\mu, s)$.

Wzory na estymatory parametrów $s$ i $\mu$ podane są w twierdzeniu 2.4.2.

Twierdzenie 2.4.2. Jeśli $X$ jest zmienną losową o rozkładzie logistycznym $\operatorname{Logist}(\mu, s)$, to estymatory parametrów $s i \mu$ otrzymane kwantylową metodą najmniejszych kwadratów z uciętą liczbą kwantyli, będące funkcjami próby prostej $X_{1}, X_{2}, \ldots, X_{n}$, wyrażają się wzorami:

$$
\begin{gathered}
\hat{s}^{u K m n k}=\frac{(n-k) \sum_{i=1+k / 2}^{n-k / 2} X_{p_{i} ; n} \ln \left(\frac{p_{i}}{1-p_{i}}\right)-\sum_{i=1+k / 2}^{n-k / 2} X_{p_{i} ; n} \sum_{i=1+k / 2}^{n-k / 2} \ln \left(\frac{p_{i}}{1-p_{i}}\right)}{(n-k) \sum_{i=1+k / 2}^{n-k / 2}\left(\ln \left(\frac{p_{i}}{1-p_{i}}\right)\right)^{2}-\left(\sum_{i=1+k / 2}^{n-k / 2} \ln \left(\frac{p_{i}}{1-p_{i}}\right)\right)^{2}}, \\
\hat{\mu}^{u K m n k}=\frac{\sum_{i=1+k / 2}^{n-k / 2} X_{p_{i} ; n}-\hat{s}^{u K m n k} \sum_{i=1+k / 2}^{n-k / 2} \ln \left(\frac{p_{i}}{1-p_{i}}\right)}{(n-k)},
\end{gathered}
$$


gdzie $k$ jest ustaloną liczbą parzystą, natomiast $X_{p_{i} ; n}$ to kwantyl próby rzędu $p_{i}=\frac{i}{n}$ oraz $i=1+\frac{k}{2}, \ldots, n-\frac{k}{2}$.

Proponowaną kwantylową metodę najmniejszych kwadratów z uciętą liczbą kwantyli można stosować w estymacji parametrów rozkładu Gumbela. W tym celu określa się funkcję kwantylową postaci:

$$
G(\lambda, \delta)=\sum_{i=1+k / 2}^{n-k / 2}\left(X_{p_{i} ; n}-\lambda+\delta \ln \left(-\ln p_{i}\right)\right)^{2}
$$

gdzie $X_{p_{i} ; n}$ są kwantylami z próby $X_{1}, X_{2}, \ldots, X_{n}$ rzędu $p_{i}=\frac{i}{n} \quad$ dla $i=1+\frac{k}{2}, \ldots, n-\frac{k}{2}$ oraz $k$ jest ustaloną parzystą liczbą naturalną.

Wzory na estymatory parametrów $\lambda$ i $\delta$ podane są w twierdzeniu 2.4.3.

Twierdzenie 2.4.3. Jeśli $X$ jest zmienną losową o rozkładzie Gumbela $G l(\lambda, \delta)$, to estymatory parametrów $\lambda$ i $\delta$ otrzymane kwantylową metodą najmniejszych kwadratów z uciętą liczba kwantyli, będące funkcjami próby losowej $X_{1}, X_{2}, \ldots, X_{n}$, wyrażają się wzorami:

$$
\begin{gathered}
\hat{\lambda}^{u K m n k}=\frac{\sum_{i=1+k / 2}^{n-k / 2} X_{p_{i} ; m} \sum_{i=1+k / 2}^{n-k / 2}\left(\ln \left(-\ln p_{i}\right)\right)^{2}-\sum_{i=1+k / 2}^{n-k / 2} X_{p_{i} ; n} \ln \left(-\ln p_{i}\right) \sum_{i=1+k / 2}^{n-k / 2} \ln \left(-\ln p_{i}\right)}{(n-k) \sum_{i=1+k / 2}^{n-k / 2}\left(\ln \left(-\ln p_{i}\right)\right)^{2}-\left(\sum_{i=1+k / 2}^{n-k / 2} \ln \left(-\ln p_{i}\right)\right)^{2}}, \\
\hat{\delta}^{u K m n k}=\frac{\sum_{i=1+k / 2}^{n-k / 2} X_{p_{i} ; m} \sum_{i=1+1 k / 2}^{n-k / 2} \ln \left(-\ln p_{i}\right)-(n-k) \sum_{i=1+k / 2}^{n-k / 2} X_{p_{i} ; m} \ln \left(-\ln p_{i}\right)}{(n-k) \sum_{i=1+k / 2}^{n-k / 2}\left(\ln \left(-\ln p_{i}\right)\right)^{2}-\left(\sum_{i=1+k / 2}^{n-k / 2} \ln \left(-\ln p_{i}\right)\right)^{2}} .
\end{gathered}
$$

Zastosowanie kwantylowej metody najmniejszych kwadratów z uciętą liczbą kwantyli do szacowania parametrów uogólnionego rozkładu maksimum typu Frécheta i Weibulla jest możliwe, jeśli posiadamy informację o przybliżonym jego kształcie, tzn. wiadomo jest, czy rozkład można uznać za symetryczny czy też nie.

Podobnie jak w przypadku metody kwantyli, nie dla wszystkich rozkładów można analitycznie wyznaczyć postaci estymatorów ich parametrów. Do takich rozkładów należy m.in. wcześniej rozważany rozkład Pareto, którego parametry szacować należy tą metodą w sposób numeryczny. 
Rozkład Pareto jest rozkładem asymetrycznym i ponadto charakteryzuje się prawym grubym ogonem, zatem poszukiwanie oszacowań jego parametrów metodą $u K m n k$ związane jest z pominięciem $k$ kwantyli z prawego ogona, czyli $\mathrm{z}$ wyznaczeniem minimum globalnego funkcji:

$$
G(\theta, a)=\sum_{i=1}^{n-k}\left(X_{p_{i} ; n}-\frac{\theta}{\left(1-p_{i}\right)^{1 / a}}\right)^{2},
$$

gdzie $X_{p_{i} ; n}$ są kwantylami z próby rzędu $p_{i}=\frac{i}{n}$ wyznaczonymi na podstawie $n$-elementowej próby losowej.

W badaniach finansowych modeluje się rozkłady ogonów zmiennej losowej, wykorzystując uogólniony rozkład Pareto, którego parametry można szacować uKmnk, poszukując minimum globalnego funkcji kwantylowej wyrażonej wzorem:

$$
G(\beta, \xi)=\sum_{i=1}^{n-k}\left(X_{p_{i} ; n}-\frac{\beta}{\xi}\left(1-\left(1-p_{i}\right)^{-\xi}\right)\right)^{2} .
$$

W przypadku zastosowania proponowanej metody do szacowania parametrów określonej klasy rozkładów problemem może być ustalenie liczby $k$ pomijanych kwantyli. Dzięki istniejącemu oprogramowaniu komputerowemu problem ten można rozwiązać symulacyjnie, wyznaczając wielkości obciążeń i błędów średniokwadratowych dla różnych wartości $k$ i formułując wnioski dotyczące najbardziej optymalnej liczby pomijanych kwantyli $\mathrm{w}$ procedurze estymacji parametrów danej klasy rozkładów.

\subsubsection{Medianowo-kwantylowa metoda najmniejszych kwadratów}

Kolejną autorską propozycją modyfikacji kwantylowej metody najmniejszych kwadratów jest medianowo-kwantylowa metoda najmniejszych kwadratów (MKmnk). Polega ona na wyznaczeniu najpierw oszacowań parametru $\theta$ przy zastosowaniu kwantylowej metodę najmniejszych kwadratów z uciętą liczbą kwantyli dla różnych wielkości $k$, a następnie ich mediany. Zatem po otrzymaniu estymatorów: $\hat{\theta}_{k=2}^{u K m n k}, \hat{\theta}_{k=4}^{u K m n k}, \ldots, \hat{\theta}_{k=r}^{u K m n k}$, gdzie $r=n-2$, gdy $n$ jest liczbą parzysta, lub $r=n-3$, gdy $n$ jest liczbą nieparzystą, wyznacza się $\hat{\theta}^{M K}=\operatorname{Me}\left(\hat{\theta}_{k=2}^{u K m n k}, \hat{\theta}_{k=4}^{u K m n k}, \ldots, \hat{\theta}_{k=r}^{u K m n k}\right)$. 
Definicja 2.4.2. Estymatorami parametrów $\theta_{1}, \theta_{2}, \ldots, \theta_{s}$ rozkładu zmiennej losowej $X$ o dystrybuancie $F\left(\cdot, \theta_{1}, \theta_{2}, \ldots, \theta_{s}\right)$ otrzymanymi medianowokwantylową metodą najmniejszych kwadratów nazywamy statystyki $\hat{\theta}_{1}^{M K}, \hat{\theta}_{2}^{M K}, \ldots, \hat{\theta}_{s}^{M K}$ postaci:

$$
\hat{\theta}_{i}^{M K}=\operatorname{Me}\left(\hat{\theta}_{i ; k=2}^{u K m n k}, \hat{\theta}_{i ; k=4}^{u k m n k}, \ldots, \hat{\theta}_{i ; k=r}^{u K m n k}\right) \quad \text { dla } i=1, \ldots, s,
$$

gdzie $\hat{\theta}_{i ; k=2}^{u K m n k}, \hat{\theta}_{i ; k=4}^{u K m n k}, \ldots, \hat{\theta}_{i ; k=r}^{u K m n k}$ są estymatorami parametru $\theta_{i}$ uzyskanymi kwantylową metodą najmniejszych kwadratów z uciętą liczbą kwantyli na podstawie próby losowej $X_{1}, X_{2}, \ldots, X_{n}$, zaś $r=n-2$, gdy $n$ jest liczbą parzystą, oraz $r=n-3$, gdy $n$ jest liczbą nieparzystą.

Podobnie jak w przypadku poprzedniej proponowanej metody, stosowanie medianowo-kwantylowej metody najmniejszych kwadratów związane jest z podjęciem decyzji dotyczącej obustronnego czy jednostronnego pomijania kwantyli, ale metoda MKmnk nie wymaga ustaleń związanych z liczbą pomijanych kwantyli, co stanowi jej zaletę w praktycznych zastosowaniach.

\subsection{Metoda momentów ważonych prawdopodobieństwami}

Metoda momentów ważonych prawdopodobieństwami (probability weighted moments method) jest kolejną procedurą estymacji parametrów wykorzystującą statystyki pozycyjne (por. m.in. R. Furrer, P. Naveau [2007], M. T. Rasool $i$ in. [2002]).

Rozważmy zmienną losową $X$ o rozkładzie określonym za pomocą dystrybuanty $F\left(\cdot, \theta_{1}, \theta_{2}, \ldots, \theta_{s}\right)$. Niech $X_{1}, X_{2}, \ldots, X_{n}$ oznacza wylosowaną próbę prostą, na podstawie której metodą momentów ważonych prawdopodobieństwami $(m M W P)$ szacowane są nieznane parametry rozkładu $\theta_{1}, \ldots, \theta_{s}$.

Pojęcia momentów rozkładu ważonych prawdopodobieństwami oraz momentów $\mathrm{z}$ próby ważonych prawdopodobieństwami określają definicje 2.5.1 i 2.5.2 (por. P. F. Rasmussen [2001]).

Definicja 2.5.1. Momentami rozkładu zmiennej losowej $X$ o dystrybuancie $F$ ważonymi prawdopodobieństwami (o ile istnieją) nazywamy wyrażenia postaci:

$$
M_{1, j, 0}=E\left(X F^{j}\left(x, \theta_{1}, \ldots, \theta_{s}\right)\right),
$$




$$
M_{1,0, k}=E\left(X\left(1-F\left(x, \theta_{1}, \ldots, \theta_{s}\right)\right)^{k}\right),
$$

dla $j, k=0,1, \ldots$

Definicja 2.5.2. Momentami z próby $X_{1}, X_{2}, \ldots, X_{n}$ ważonymi prawdopodobieństwami nazywamy następujące statystyki:

$$
\begin{gathered}
m_{1, j, 0}=\frac{1}{n} \sum_{i=1}^{n} X_{(i)}^{(n)}\left[F_{n}\left(x_{(i)}^{(n)}, \theta_{1}, \ldots, \theta_{s}\right)\right]^{j}, \\
m_{1,0, k}=\frac{1}{n} \sum_{i=1}^{n} X_{(i)}^{(n)}\left[1-F_{n}\left(x_{(i)}^{(n)}, \theta_{1}, \ldots, \theta_{s}\right)\right]^{k},
\end{gathered}
$$

gdzie $X_{(i)}^{(n)}$ są statystykami pozycyjnymi wyznaczonymi na podstawie $n$-elementowej próby losowej, natomiast $F_{n}\left(x_{(i)}^{(n)}, \theta_{1}, \ldots, \theta_{s}\right)$ to wartości dystrybuanty empirycznej dla $i$-tych statystyk pozycyjnych, określające prawdopodobieństwa nieprzekroczenia wartości $x_{(i)}^{(n)}$, dla $i=1,2, \ldots, n$.

Stosując metodę $m M W P$, wyznaczamy estymatory parametrów rozkładu zmiennej $X \mathrm{z}$ układu równań powstałego poprzez porównanie momentów rozkładu ważonych prawdopodobieństwami $\mathrm{z}$ ich estymatorami, czyli momentami z próby ważonymi prawdopodobieństwami, co określa definicja 2.5.3.

Definicja 2.5.3. Estymatorami parametrów $\theta_{1}, \theta_{2}, \ldots, \theta_{s}$ rozkładu zmiennej losowej $X$ o dystrybuancie $F\left(\cdot, \theta_{1}, \theta_{2}, \ldots, \theta_{s}\right)$ otrzymanymi metodą momentów ważonych prawdopodobieństwami nazywamy statystyki będące rozwiązaniem układu $s$ równań postaci $m_{1, j, 0}=M_{1, j, 0}$ lub $m_{1,0, k}=M_{1,0, k}$, dla wybranych $j, k$, gdzie $m_{1, j, 0}, m_{1,0, k}$ oraz $M_{1, j, 0}, M_{1,0, k}$ są istniejącymi momentami ważonymi prawdopodobieństwami, odpowiednio, z wylosowanej próby oraz rozkładu zmiennej $X$.

Metoda $m M W P$, podobnie jak metoda momentów $(m M)$, ma ograniczenia w zastosowaniu. Można ją wykorzystywać do estymacji parametrów rozkładów mających momenty wyrażone wzorami (2.5.1) i (2.5.2).

Postaci estymatorów $m_{1, j, 0}$ i $m_{1,0, k}$ momentów $M_{1, j, 0}$ i $M_{1,0, k}$ zależą od przyjętej dystrybuanty empirycznej $F_{n}$. W literaturze rozważane są różne dystrybuanty (por. J. R. M Hosking, J. R. Wallis [1987], J. M. Landwehr i in. [1979], N. Seckin i in. [2010]), m.in.: 


$$
\begin{gathered}
F_{n}(x)=\frac{1}{n-1} \sum_{i=1}^{n}\left(I_{(-\infty, x\rangle}\left(x_{(i)}^{(n)}\right)-1\right), \\
F_{n}(x)=\frac{1}{n} \sum_{i=1}^{n}\left(I_{(-\infty, x\rangle}\left(x_{(i)}^{(n)}\right)-0,35\right), \\
F_{n}(x)=\frac{1}{n} \sum_{i=1}^{n} I_{(-\infty, x\rangle}\left(x_{(i)}^{(n)}\right),
\end{gathered}
$$

gdzie $I$ jest indykatorem przyjmującym wartość 1 , gdy $x_{(i)}^{(n)} \leq x$, oraz $0 \mathrm{w}$ przeciwnym przypadku.

Dla dystrybuanty empirycznej określonej wzorem (2.5.5) nieobciążonymi estymatorami momentów rozkładu $M_{1,0, k}$ i $M_{1, j, 0}$ są statystyki:

$$
\begin{gathered}
m_{1,0,0}=\bar{X}=\frac{1}{n} \sum_{i=1}^{n} X_{(i)}^{(n)}, \\
m_{1, j, 0}=\frac{1}{n} \sum_{i=1}^{n} \frac{(i-1)(i-2) \ldots(i-j)}{(n-1)(n-2) \ldots(n-j)} X_{(i)}^{(n)} \quad \text { dla } j=1,2, \ldots, \\
m_{1,0, k}=\frac{1}{n} \sum_{i=1}^{n} \frac{(n-i)(n-i-1) \ldots(n-i-k+1)}{(n-1)(n-2) \ldots(n-k)} X_{(i)}^{(n)} \quad \text { dla } k=1,2, \ldots
\end{gathered}
$$

Rozważmy problem szacowania parametrów rozkładu ciąłej zmiennej losowej $X$ o funkcji gęstości $f\left(\cdot, \theta_{1}, \theta_{2}\right)$, która ma wartość oczekiwaną, a nie ma wariancji.

Istnienie momentów:

$$
\begin{gathered}
M_{1,0,0}=E X=\int_{-\infty}^{+\infty} x f\left(x, \theta_{1}, \theta_{2}\right) d x, \\
M_{1,0,1}=\int_{-\infty}^{+\infty} x\left[1-F\left(x, \theta_{1}, \theta_{2}\right)\right] f\left(x, \theta_{1}, \theta_{2}\right) d x, \\
M_{1,1,0}=\int_{-\infty}^{+\infty} x F\left(x, \theta_{1}, \theta_{2}\right) f\left(x, \theta_{1}, \theta_{2}\right) d x
\end{gathered}
$$


oraz wykorzystanie średniej arytmetycznej i estymatora określonego wzorem (2.5.9) lub (2.5.10), dla $j=1$ lub $k=1$, prowadzi do układu równań:

$$
\left\{\begin{array}{l}
E X=\bar{X} \\
M_{1,1.0}=\frac{1}{n} \sum_{i=1}^{n} \frac{i-1}{n-1} X_{(i)}^{(n)}
\end{array}\right.
$$

lub

$$
\left\{\begin{array}{l}
E X=\bar{X}, \\
M_{1,0,1}=\frac{1}{n} \sum_{i=1}^{n} \frac{n-i}{n-1} X_{(i)}^{(n)} .
\end{array}\right.
$$

Rozwiązaniem jednego $\mathrm{z}$ powyższych układów równań są estymatory $\hat{\theta}_{1}$ i $\hat{\theta}_{2}$ parametrów, odpowiednio, $\theta_{1}$ i $\theta_{2}$.

Wybór między $M_{1,0,1}$ i $M_{1,1,0}$ ma znaczenie wyłącznie rachunkowe, gdyż momenty te łączy zależność: $M_{1,0,1}=M_{1,0,0}-M_{1,1,0}$.

Przy szacowaniu parametrów rozkładów niemających wartości oczekiwanej należy wykorzystać istniejące momenty ważone prawdopodobieństwami postaci $M_{1,0, k}$ lub $M_{1, k, 0}$ dla $k=1,2, \ldots$, czyli np. w przypadku szacowania dwóch parametrów rozkładu tworzymy układ równań:

$$
\left\{\begin{array} { l } 
{ M _ { 1 , 0 , k } = m _ { 1 , 0 , k } } \\
{ M _ { 1 , 0 , l } = m _ { 1 , 0 , l } }
\end{array} \quad \text { lub } \quad \left\{\begin{array}{l}
M_{1, k, 0}=m_{1, k, 0} \\
M_{1, l, 0}=m_{1, l, 0}
\end{array} \quad \text { dla } l \neq k .\right.\right.
$$

Istnienie momentów rzędu $k$ lub $l$ nie zawsze jest łatwe do ustalenia dla pewnych klas rozkładów.

Metoda $m M W P$ zostanie zaprezentowana na przykładzie estymacji parametrów uogólnionego rozkładu Pareto, którego szczególnym przypadkiem jest rozkład Pareto. Dla obydwu tych rozkładów istnienie momentów jest ściśle związane z wartością jednego z parametrów.

Rozważmy najpierw problem szacowania parametrów rozkładu Pareto $\operatorname{Pa}(\theta, a)$. Dla $a>2$ rozkład ten ma zarówno wartość oczekiwana, jak i wariancję, czyli do wyznaczania estymatorów można stosować metodę momentów. Dla $a \leq 2$ nie istnieje wariancja, zatem uzasadnione jest zastosowanie metody momentów ważonych prawdopodobieństwami. Gdy $1<a \leq 2$ rozkład ma tylko 
wartość oczekiwana, więc przy zastosowaniu dystrybuanty empirycznej określonej wzorem (2.5.5) parametry $\theta$ oraz $a$ wyznaczane są w oparciu o rozwiązanie układu równań (2.5.15).

Ponieważ

$$
E X=\frac{a \theta}{a-1} \quad \text { dla } a>1
$$

oraz

$$
M_{1,0,1}=\int_{\theta}^{+\infty} x\left(\frac{\theta}{x}\right)^{a} \frac{\alpha \theta}{x^{2}}\left(\frac{\theta}{x}\right)^{a-1} d x=\int_{\theta}^{+\infty} \frac{a \theta^{2 a}}{x^{2 a}} d x=\frac{a \theta}{2 a-1} \quad \text { dla } a>\frac{1}{2}
$$

zatem mamy układ równań postaci:

$$
\left\{\begin{array}{l}
\frac{\theta a}{a-1}=\bar{X}, \\
\frac{a \theta}{2 a-1}=\frac{1}{n} \sum_{i=1}^{n} \frac{n-i}{n-1} X_{(i)}^{(n)} .
\end{array}\right.
$$

Rozwiązując układ równań (2.5.16), otrzymujemy postaci estymatorów parametrów rozkładu Pareto $P a(\theta, a)$, gdzie $a>1$, określone w twierdzeniu 2.5.1.

Twierdzenie 2.5.1. Jeśli $X$ jest populacją o rozkładzie Pareto $P a(\theta, a)$, gdzie $a>1$, to estymatory parametrów $a$ i $\theta$ otrzymane na podstawie próby prostej $X_{1}, X_{2}, \ldots, X_{n}$ metodą momentów ważonych prawdopodobieństwami z dystrybuantą empiryczną $F_{n}(x)=\frac{1}{n-1} \sum_{i=1}^{n}\left(I_{(-\infty, x)}\left(x_{(i)}^{(n)}\right)-1\right)$ wyrażają się wzorami:

$$
\begin{gathered}
\hat{a}^{m M W P}=\frac{n \bar{X}-\sum_{i=1}^{n} \frac{n-i}{n-1} X_{(i)}^{(n)}}{n \bar{X}-2 \sum_{i=1}^{n} \frac{n-i}{n-1} X_{(i)}^{(n)}}, \\
\hat{\theta}^{m M W P}=\frac{\bar{X} \sum_{i=1}^{n} \frac{n-i}{n-1} X_{(i)}^{(n)}}{n \bar{X}-\sum_{i=1}^{n} \frac{n-i}{n-1} X_{(i)}^{(n)}},
\end{gathered}
$$


gdzie $X_{(i)}^{(n)}$ są statystykami pozycyjnymi wyznaczonymi na podstawie próby losowej.

Rozważmy problem szacowania parametrów rozkładu Pareto, gdy $a \leq 1$, czyli parametrów rozkładu, dla którego nie istnieje ani wartość oczekiwana, ani wariancja. Dla wybranych momentów $M_{1,0, k}$ i $M_{1,0, l}$ dla $l>k$ oraz dystrybuanty empirycznej określonej wzorem (2.5.5) otrzymujemy układ równań:

$$
\left\{\begin{array}{l}
\frac{a \theta}{(k+1) a-1}==m_{1,0, k}, \\
\frac{a \theta}{(l+1) a-1}=m_{1,0, l} .
\end{array}\right.
$$

Wzory estymatorów parametrów rozkładu $P a(\theta, a)$ podane są w twierdzeniu 2.5.2.

Twierdzenie 2.5.2. Niech $X$ będzie populacją o rozkładzie Pareto $P a(\theta, a)$, gdzie $a \leq 1$. Jeżeli istnieją momenty ważone prawdopodobieństwami rzędów $k$ i $l$, to estymatory parametrów $a$ i $\theta$ otrzymane na podstawie próby losowej $X_{1}, X_{2}, \ldots, X_{n}$ metodą momentów ważonych prawdopodobieństwami z dystrybuantą empiryczną $F_{n}(x)=\frac{1}{n-1} \sum_{i=1}^{n}\left(I_{(-\infty, x)}\left(x_{(i)}^{(n)}\right)-1\right)$ są postaci:

$$
\begin{gathered}
\hat{a}^{m M W P}=\frac{m_{1,0, k}-m_{1,0, l}}{(k+1) m_{1,0, k}-(l+1) m_{1,0, l}}, \\
\hat{\theta}^{m M W P}=\frac{(l-k) m_{1,0, k} m_{1,0, l}}{m_{1,0, k}-m_{1,0, l}},
\end{gathered}
$$

gdzie $m_{1,0, r}=\frac{1}{n} \sum_{i=1}^{n} \frac{(n-i)(n-i-1) \ldots(n-i-r+1)}{(n-1)(n-2) \ldots(n-r)} X_{(i)}^{(n)}$, dla $r=k$, $l$, oraz $X_{(i)}^{(n)}$, dla $i=1,2, \ldots, n$, są statystykami pozycyjnymi wyznaczonymi na podstawie próby losowej.

Liczba $k$ musi być tak dobrana, aby była pewność, że $k>\frac{1}{a}-1$, natomiast $l$ może być równe $k+1$, gdyż istnienie momentu $M_{1,0, k}$ sprawia, że istnieją momenty $M_{1,0, l}$ dla $l>k$. W szczególności dla $l=k+1$ otrzymujemy: 


$$
\hat{a}^{m M W P}=\frac{m_{1,0, k}-m_{1,0, k+1}}{(k+1) m_{1,0, k}-(k+2) m_{1,0, k+1}}, \quad \hat{\theta}^{m M W P}=\frac{m_{1,0, k} m_{1,0, k+1}}{m_{1,0, k}-m_{1,0, k+1}} .
$$

Dla innych dystrybuant empirycznych proponowanych w literaturze, m.in. dystrybuant określonych wzorami (2.5.6) i (2.5.7), w analogiczny sposób można wyznaczyć estymatory parametrów rozkładu zmiennej losowej $X$.

Rozważmy zmienną losową $X$ o uogólnionym rozkładzie Pareto $\operatorname{GPD}(\beta, \xi)$, w szczególności gdy $\xi=0$, to mamy rozkład wykładniczy zmiennej losowej $X$ o wartości oczekiwanej $\beta$, gdy $\xi=-1$ - rozkład jednostajny na przedziale $[0, \beta]$, natomiast dla $\xi>0$-rozkład Pareto.

Dla uogólnionego rozkładu Pareto, gdy $\xi=0$, estymatorem parametru $\beta$ otrzymanym metodą największej wiarygodności jest średnia arytmetyczna wartości elementów wylosowanej próby.

Metoda największej wiarygodności znajduje zastosowanie w przypadku gdy $\xi>-1$, ale poza przypadkiem $\xi=0$ tylko numerycznie można wyznaczyć wartości estymatorów obydwu parametrów. Dla $\xi \leq-1$ funkcja wiarygodności nie ma maksimum.

Dla zmiennej losowej $X$ o uogólnionym rozkładzie Pareto z parametrem $\xi$ spełniającym nierówność $\xi<0,5$ istnieją: $E X=\frac{\beta}{1-\xi}, E X^{2}=\frac{2 \beta^{2}}{(1-\xi)(1-2 \xi)}$ oraz $D^{2} X=\frac{\beta^{2}}{(1-\xi)^{2}(1-2 \xi)}$, zatem w estymacji można stosować metodę momentów (por. J. Zhang [2007]).

Dla $\xi \geq 0,5$ nie istnieje wariancja i przy estymacji parametrów $\xi$ i $\beta$ wykorzystuje się metodę momentów ważonych prawdopodobieństwami. Postaci estymatorów tych parametrów w przypadku zastosowania dystrybuanty empirycznej (2.5.5) przedstawia twierdzenie 2.5.3.

Twierdzenie 2.5.3. Jeśli $X$ jest zmienną losową o uogólnionym rozkładzie Pareto $\operatorname{GPD}(\beta, \xi)$, gdzie $0,5 \leq \xi<1$, to estymatory parametrów $\xi$ i $\beta$ otrzymane na podstawie próby prostej $X_{1}, X_{2}, \ldots, X_{n}$ metodą momentów ważonych prawdopodobieństwami z dystrybuantą $F_{n}(x)=\frac{1}{n-1} \sum_{i=1}^{n}\left(I_{(-\infty, x)}\left(x_{(i)}^{(n)}\right)-1\right)$ wyrażają się wzorami:

$$
\hat{\xi}^{m M W P}=2-\frac{n \bar{X}}{n \bar{X}-2 \sum_{i=1}^{n} \frac{n-i}{n-1} X_{(i)}^{(n)}},
$$




$$
\hat{\beta}^{m M W P}=\frac{2 \sum_{i=1}^{n} \frac{n-i}{n-1} X_{(i)}^{(n)} \bar{X}}{n \bar{X}-2 \sum_{i=1}^{n} \frac{n-i}{n-1} X_{(i)}^{(n)}},
$$

gdzie $X_{(i)}^{(n)}$ są statystykami pozycyjnymi wyznaczonymi na podstawie próby losowej.

Zastosowanie metody momentów ważonych prawdopodobieństwami do estymacji parametrów uogólnionego rozkładu Pareto, gdy $\xi \geq 1$, związane jest z wyznaczeniem momentów $M_{1,0, k}$ postaci:

$$
M_{1,0, k}=\frac{\beta}{(k+1)(k+1-\xi)}, \quad \text { gdy } \quad \xi<k+1
$$

i porównaniem z odpowiednimi momentami z próby, co pozwala sformułować twierdzenie podające wzory na estymatory parametrów tego rozkładu.

Twierdzenie 2.5.4. Jeśli $X$ jest zmienną losową o uogólnionym rozkładzie Pareto $\operatorname{GPD}(\beta, \xi)$, gdzie $\xi \geq 1$, to estymatory parametrów $\xi$ i $\beta$ otrzymane na podstawie próby prostej $X_{1}, X_{2}, \ldots, X_{n}$ metodą momentów ważonych prawdopodobieństwami z dystrybuantą empiryczną $F_{n}(x)=\frac{1}{n-1} \sum_{i=1}^{n}\left(I_{(-\infty, x)}\left(x_{(i)}^{(n)}\right)-1\right)$ są postaci:

$$
\begin{gathered}
\hat{\xi}^{m M W P}=\frac{(k+2)^{2} m_{1,0, k+1}-(k+1)^{2} m_{1,0, k}}{(k+2) m_{1,0, k+1}-(k+1) m_{1,0, k}}, \\
\hat{\beta}^{m M W P}=\frac{(k+2)(k+1) m_{1,0, k} m_{1,0, k+1}}{(k+1) m_{1,0, k}-(k+2) m_{1,0, k+1}},
\end{gathered}
$$

gdzie $m_{1,0, r}=\frac{1}{n} \sum_{i=1}^{n} \frac{(n-i)(n-i-1) \ldots(n-i-r+1)}{(n-1)(n-2) \ldots(n-r)} X_{(i)}^{(n)}$, dla $r=k, k+1$ i $k>\xi-1$ oraz $X_{(i)}^{(n)}$ są statystykami pozycyjnymi wyznaczonymi na podstawie próby losowej. 
Szacowanie parametrów uogólnionego rozkładu Pareto jest istotne ze względu na zastosowanie tego rozkładu do estymacji ogona rozkładu zmiennych losowych o grubych ogonach.

Metodę momentów ważonych prawdopodobieństwami można wykorzystywać również do szacowania parametrów uogólnionych rozkładów maksimum i minimum dla $\xi \geq \frac{1}{2}$, gdyż ze względu na brak wariancji nie można zastosować metody momentów (por. tablice 1.4.1, 1.4.2).

Jeśli istnieją momenty ważone prawdopodobieństwami rozkładu $G E V D_{M}$ zmiennej losowej $X$, to są one postaci (por. J. R. M. Hoskings i in.[1985]):

$$
M_{1, j, 0}=(j+1)^{-1}\left(\mu+\sigma\left[(j+1)^{\xi} \Gamma(1-\xi)-1\right] / \xi\right) \text { dla } j \geq 1,
$$

a ich estymatorami są statystyki wyrażone wzorem:

$$
m_{1, j, 0}=n \sum_{i=1}^{n} \frac{(i-1)(i-2) \ldots(i-j)}{(n-1)(n-2) \ldots(n-j)} X_{(i)}^{(n)} .
$$

Parametry uogólnionego rozkładu maksimum dla $\xi \geq \frac{1}{2}$ można zatem wyznaczyć z następującego układu równań:

$$
\left\{\begin{array}{l}
E X=\mu-\sigma(1-\Gamma(1-\xi)) / \xi, \\
2 M_{1,1,0}-E X=\sigma \Gamma(1-\xi)\left(2^{\xi}-1\right) / \xi, \\
\left(3 M_{1,2,0}-E X\right)\left(2 M_{1,1,0}-E X\right)=\left(1-3^{\xi}\right) /\left(1-2^{\xi}\right),
\end{array}\right.
$$

który po podstawieniu estymatorów wartości oczekiwanej i momentów ważonych prawdopodobieństwami przyjmuje postać:

$$
\left\{\begin{array}{l}
\bar{X}=\mu-\sigma(1-\Gamma(1-\xi)) / \xi \\
2 \frac{1}{n} \sum_{i=1}^{n} \frac{i-1}{n-1} X_{(i)}^{(n)}-\bar{X}=\sigma \Gamma(1-\xi)\left(2^{\xi}-1\right) / \xi \\
\left(3 \frac{1}{n} \sum_{i=1}^{m} \frac{(i-1)(i-2)}{(n-1)(n-2)} X_{(i)}^{(n)}-\bar{X}\right)\left(2 \frac{1}{n} \sum_{i=1}^{n} \frac{i-1}{n-1} X_{(i)}^{(n)}-\bar{X}\right)=\left(1-3^{\xi}\right) /\left(1-2^{\xi}\right) .
\end{array}\right.
$$


Rozwiązując ten układ równań, otrzymujemy postaci estymatorów określone w twierdzeniu 2.5.5.

Twierdzenie 2.5.5. Jeśli $X$ jest zmienną losową o uogólnionym rozkładzie $\operatorname{GEVD}_{M}(\xi, \mu, \sigma)$, gdzie $\xi \geq \frac{1}{2}$, to estymatory parametrów $\xi, \mu$ i $\sigma$ otrzymane na podstawie próby prostej $X_{1}, X_{2}, \ldots, X_{n}$ metodą momentów ważonych prawdopodobieństwami z dystrybuantą empiryczną $F_{n}(x)=\frac{1}{n-1} \sum_{i=1}^{n}\left(I_{(-\infty, x)}\left(x_{(i)}^{(n)}\right)-1\right)$ są postaci:

$$
\hat{\xi}^{m M W P}=7,859 c+2,9554 c^{2},
$$$$
\hat{\sigma}^{m M W P}=\frac{\hat{\xi}^{m M W P}\left(2 \frac{1}{n} \sum_{i=1}^{n} \frac{i-1}{n-1} X_{(i)}^{(n)}-\bar{X}\right)}{\Gamma\left(1-\hat{\xi}^{m M W P}\right)\left(2^{\xi^{m M W P}}-1\right)},
$$$$
\hat{\mu}^{m M W P}=\bar{X}-\hat{\sigma}^{m M W P} \frac{\Gamma\left(\left(1-\hat{\xi}^{m M W P}\right)-1\right)}{\hat{\xi}^{m M W P}},
$$

gdzie $c=\frac{2 \frac{1}{n} \sum_{i=1}^{n} \frac{i-1}{n-1} X_{(i)}^{(n)}-\bar{X}}{3 \frac{1}{n} \sum_{i=1}^{n} \frac{(i-1)(i-2)}{(n-1)(n-2)} X_{(i)}^{(n)}-\bar{X}}-\frac{\ln 2}{\ln 3}$.

Własności powyższych estymatorów przedstawione są w pracy J. R. M. Hoskinga $i$ in. [1985].

W analogiczny sposób można sformułować twierdzenie dotyczące postaci estymatorów parametrów uogólnionego rozkładu $\operatorname{GEVD}_{m}(\mu, \sigma, \xi)$.

\subsection{Zmodyfikowana metoda momentów ważonych prawdopodobieństwami}

Autorską propozycję stanowi wykorzystanie przy szacowaniu parametrów rozkładu zmiennej losowej $X$ metodą momentów ważonych prawdopodobieństwami zmodyfikowanej dystrybuanty empirycznej - level crossing empirical distribution function - określonej wzorem (por. M. L. Huang, P. H. Brill [1999]): 


$$
F_{n}(x)=\sum_{i=1}^{n} w_{n, i} I_{(-\infty, x)}\left(x_{(i)}^{(n)}\right)
$$

gdzie

$$
w_{n, i}=\left\{\begin{array}{l}
\frac{1}{2}\left[1-\frac{n-2}{\sqrt{n(n-1)}}\right] \quad \text { dla } i=1, n, \\
\frac{1}{\sqrt{n(n-1)}} \quad \text { dla } i=2,3, \ldots, n-1 .
\end{array}\right.
$$

Dystrybuantę tę zapisać można w postaci:

$$
F_{n}(x)=\left\{\begin{array}{lc}
0 & \text { dla } x<x_{(1)}^{(n)}, \\
\frac{1}{2}\left[1-\frac{n-2}{\sqrt{n(n-1)}}\right] & \text { dla } x_{(1)}^{(n)} \leq x<x_{(2)}^{(n)}, \\
\frac{1}{2}\left[1-\frac{n-2 i}{\sqrt{n(n-1)}}\right] & \text { dla } x_{(i)}^{(n)} \leq x<x_{(i+1)}^{(n)}, i=2,3, \ldots, n-1, \\
1 & \text { dla } x \geq x_{(n)}^{(n)} .
\end{array}\right.
$$

Rozważmy problem szacowania parametrów rozkładu ciagłej zmiennej losowej $X$, która ma wartość oczekiwana, nie ma wariancji i jest określona za pomocą funkcji gęstości $f\left(\cdot, \theta_{1}, \theta_{2}\right)$. Wykorzystanie proponowanej dystrybuanty empirycznej prowadzi do następujących wzorów na momenty z próby ważone prawdopodobieństwami:

$$
m_{1,1,0}=\frac{1}{n}\left(\frac{1}{2}-\frac{n-2}{2 \sqrt{n(n-1)}}\right) X_{(1)}^{(n)}+\frac{1}{n} \sum_{i=2}^{n-1}\left(\frac{1}{2}-\frac{n-2 i}{2 \sqrt{n(n-1)}}\right) X_{(i)}^{(n)}+\frac{1}{n} X_{(n)}^{(n)}
$$

oraz

$$
m_{1,0,1}=\frac{1}{n}\left(\frac{1}{2}+\frac{n-2}{2 \sqrt{n(n-1)}}\right) X_{(1)}^{(n)}+\frac{1}{n} \sum_{i=2}^{n-1}\left(\frac{1}{2}+\frac{n-2 i}{2 \sqrt{n(n-1)}}\right) X_{(i)}^{(n)} .
$$

Stosując średnią arytmetyczną jako estymator wartości oczekiwanej i jeden z momentów ważonych prawdopodobieństwami (2.6.4) lub (2.6.5) jako estymator, odpowiednio, $M_{1,0,1}$ lub $M_{1,1,0}$, otrzymujemy układ równań: 


$$
\left\{\begin{array}{l}
E X=\bar{X} \\
M_{1,1,0}=\frac{1}{n}\left(\frac{1}{2}-\frac{n-2}{2 \sqrt{n(n-1)}}\right) X_{(1)}^{(n)}+\frac{1}{n} \sum_{i=2}^{n-1}\left(\frac{1}{2}-\frac{n-2 i}{2 \sqrt{n(n-1)}}\right) X_{(i)}^{(n)}+\frac{1}{n} X_{(n)}^{(n)}
\end{array}\right.
$$

lub

$$
\left\{\begin{array}{l}
E X=\bar{X} \\
M_{1,0,1}=\frac{1}{n}\left(\frac{1}{2}+\frac{n-2}{2 \sqrt{n(n-1)}}\right) X_{(1)}^{(n)}+\frac{1}{n} \sum_{i=2}^{n-1}\left(\frac{1}{2}+\frac{n-2 i}{2 \sqrt{n(n-1)}}\right) X_{(i)}^{(n)},
\end{array}\right.
$$

którego rozwiązaniem są estymatory parametrów $\theta_{1}$ i $\theta_{2}$.

Zastosowanie metody momentów ważonych prawdopodobieństwami i proponowanej dystrybuanty przedstawione zostanie na przykładach estymacji parametrów rozkładu Pareto i uogólnionego rozkładu Pareto. Dla rozkładu $P a(\theta, a)$, gdzie $a>1$, i zmodyfikowanej dystrybuanty level crossing $\mathrm{w}$ celu oszacowania parametrów $\theta$ i $a$ należy rozwiązać układ równań:

$$
\left\{\begin{array}{l}
\frac{\theta a}{a-1}=\bar{X}, \\
\frac{a \theta}{2 a-1}=\frac{1}{n}\left(\frac{1}{2}+\frac{n-2}{2 \sqrt{n(n-1)}}\right) X_{(1)}^{(n)}+\frac{1}{n} \sum_{i=2}^{n-1}\left(\frac{1}{2}+\frac{n-2 i}{2 \sqrt{n(n-1)}}\right) X_{(i)}^{(n)},
\end{array}\right.
$$

otrzymując postaci estymatorów określone w twierdzeniu 2.6.1.

Twierdzenie 2.6.1. Jeśli $X$ jest zmienną losową o rozkładzie Pareto $P a(\theta, a)$, gdzie $a>1$, to estymatory parametrów $a$ i $\theta$ otrzymane na podstawie próby losowej $X_{1}, X_{2}, \ldots, X_{n}$ metodą momentów ważonych prawdopodobieństwami z dystrybuantą empiryczną level crossing mają postać:

$$
\hat{a}^{z m M W P}=\frac{2 n \bar{X}-\left(1+\frac{n-2}{\sqrt{n(n-1)}}\right) X_{(1)}^{(n)}-\sum_{i=2}^{n-1}\left(1+\frac{n-2 i}{\sqrt{n(n-1)}}\right) X_{(i)}^{(n)}}{2 n \bar{X}-2\left(1+\frac{n-2}{\sqrt{n(n-1)}}\right) X_{(1)}^{(n)}-2 \sum_{i=2}^{n-1}\left(1+\frac{n-2 i}{\sqrt{n(n-1)}}\right) X_{(i)}^{(n)}},
$$




$$
\hat{\theta}^{z m M W P}=\bar{X}\left(1-\frac{1}{\hat{a}^{z m M W P}}\right)=\frac{\bar{X}\left(\left[1+\frac{n-2}{\sqrt{n(n-1)}}\right] X_{(1)}^{(n)}+\sum_{i=2}^{n-1}\left[1+\frac{n-2 i}{\sqrt{n(n-1)}}\right] X_{(i)}^{(n)}\right)}{2\left[1+\frac{n-2}{\sqrt{n(n-1)}}\right] X_{(1)}^{(n)}+2 \sum_{i=2}^{n-1}\left[1+\frac{n-2 i}{\sqrt{n(n-1)}}\right] X_{(i)}^{(n)}-2 n \bar{X}} .
$$

Zastosowanie metody momentów ważonych prawdopodobieństwami ze zmodyfikowaną dystrybuantą empiryczną określoną wzorem (2.6.3) do estymacji parametrów rozkładu zmiennej losowej $X$ nieposiadającej wartości oczekiwanej związane jest z wyznaczeniem momentów z próby ważonych prawdopodobieństwami rzędu $k$ oraz $j$ :

$$
\begin{gathered}
m_{1, j, 0}=\left(\frac{1}{2}-\frac{n-2}{2 \sqrt{n(n-1)}}\right)^{j} \frac{X_{(1)}^{(n)}}{n}+\sum_{i=2}^{n-1} \frac{X_{(i)}^{(n)}}{n}\left(\frac{1}{2}-\frac{n-2 i}{2 \sqrt{n(n-1)}}\right)^{j}+\frac{1}{n} X_{(i)}^{(n)}, \\
m_{1,0, k}=\left(\frac{1}{2}+\frac{n-2}{2 \sqrt{n(n-1)}}\right)^{k} \frac{X_{(1)}^{(n)}}{n}+\sum_{i=2}^{n-1} \frac{X_{(i)}^{(n)}}{n}\left(\frac{1}{2}+\frac{n-2 i}{2 \sqrt{n(n-1)}}\right)^{k}
\end{gathered}
$$

Dla rozkładu Pareto $P a(\theta, a)$, gdzie $a \leq 1$, otrzymujemy wzory na estymatory parametrów $\theta$ i $a$ poprzez rozwiązanie układu równań:

$$
\left\{\begin{array}{l}
\frac{a \theta}{(k+1) a-1}=m_{1,0, k} \\
\frac{a \theta}{(l+1) a-1}=m_{1,0, l}
\end{array}\right.
$$

przy założeniu, że istnieją momenty $M_{1,0, k}$ oraz $M_{1,0, l}$.

Twierdzenie 2.6.2. Jeśli $X$ jest zmienną losową o rozkładzie Pareto $\operatorname{Pa}(\theta, a)$, gdzie $a \leq 1$, to estymatory parametrów $a$ i $\theta$ otrzymane na podstawie próby prostej $X_{1}, X_{2}, \ldots, X_{n}$ metodą momentów ważonych prawdopodobieństwami z dystrybuantą empiryczną level crossing wyrażają się wzorami:

$$
\hat{a}^{z m M W P}=\frac{m_{1,0, k}-m_{1,0, l}}{(k+1) m_{1,0, k}-(l+1) m_{1,0, l}},
$$




$$
\hat{\theta}^{\text {zmMWP}}=\frac{m_{1,0, k} m_{1,0, l}(l-k)}{m_{1,0, k}-m_{1,0, l}}
$$

gdzie $m_{1,0, r}=\left(\frac{1}{2}+\frac{n-2}{2 \sqrt{n(n-1)}}\right)^{r} \frac{X_{(1)}^{(n)}}{n}+\sum_{i=2}^{n-1} \frac{X_{(i)}^{(n)}}{n}\left(\frac{1}{2}+\frac{n-2 i}{2 \sqrt{n(n-1)}}\right)^{r}$ dla $r=k, l$.

Zastosowanie zmodyfikowanej metody momentów ważonych prawdopodobieństwami, podobnie jak metody $m M W P \mathrm{z}$ dystrybuantami empirycznymi zaprezentowanymi $\mathrm{w}$ podrozdziale 2.5 , wymaga wiedzy o istnieniu określonych momentów, co nie zawsze jest oczywiste.

W estymacji parametrów uogólnionego rozkładu Pareto $\operatorname{GPD}(\beta, \xi)$ metodą momentów ważonych prawdopodobieństwami $\mathrm{z}$ proponowaną dystrybuantą rozwiązujemy układ równań:

$$
\left\{\begin{array}{l}
\frac{\beta}{1-\xi}=\bar{X} \\
\frac{\beta}{2(2-\xi)}=\frac{1}{n}\left(\frac{1}{2}+\frac{n-2}{2 \sqrt{n(n-1)}}\right) X_{(1)}^{(n)}+\frac{1}{n} \sum_{i=2}^{n-1}\left(\frac{1}{2}+\frac{n-2 i}{2 \sqrt{n(n-1)}}\right) X_{(i)}^{(n)},
\end{array}\right.
$$

Rozwiązanie prowadzi do otrzymania estymatorów o postaciach określonych w twierdzeniu 2.6.3.

Twierdzenie 2.6.3. Jeśli $X$ jest zmienną losową o uogólnionym rozkładzie Pareto $\operatorname{GPD}(\beta, \xi)$, gdzie $0,5 \leq \xi<1$, to estymatory parametrów $\xi$ i $\beta$ otrzymane na podstawie próby prostej $X_{1}, X_{2}, \ldots, X_{n}$ metodą momentów ważonych prawdopodobieństwami z dystrybuantą empiryczną level crossing mają postać:

$$
\begin{gathered}
\hat{\xi}^{z m M W P}=2-\frac{\bar{X}}{\bar{X}-2 \gamma}, \\
\hat{\beta}^{z m M W P}=\frac{2 \gamma \bar{X}}{\bar{X}-2 \gamma},
\end{gathered}
$$

gdzie

$$
\gamma=m_{1,0,1}=\frac{1}{n}\left(\frac{1}{2}+\frac{n-2}{2 \sqrt{n(n-1)}}\right) X_{(1)}^{(n)}+\frac{1}{n} \sum_{i=2}^{n-1}\left(\frac{1}{2}+\frac{n-2 i}{2 \sqrt{n(n-1)}}\right) X_{(i)}^{(n)} .
$$


Wzory na estymatory parametrów rozkładu $G P D(\beta, \xi)$, gdy $\xi \geq 1$, są zawarte w twierdzeniu 2.6.4.

Twierdzenie 2.6.4. Jeśli $X$ jest zmienną losową o uogólnionym rozkładzie Pareto $\operatorname{GPD}(\beta, \xi)$, gdzie $\xi \geq 1$, to estymatory parametrów $\xi$ i $\beta$ otrzymane na podstawie próby losowej $X_{1}, X_{2}, \ldots, X_{n}$ metodą momentów ważonych prawdopodobieństwami z level crossing empirical distribution function mają postać:

$$
\begin{gathered}
\hat{\xi}^{z m M W P}=\frac{(k+1)^{2} m_{1,0, k}-(k+2)^{2} m_{1,0, k+1}}{(k+1) m_{1,0, k}-(k+2) m_{1,0, k+1}}, \\
\hat{\beta}^{z m M W P}=\frac{(k+2)(k+1) m_{1,0, k} m_{1,0, k+1}}{(k+1) m_{1,0, k}-(k+2) m_{1,0, k+1}},
\end{gathered}
$$

gdzie

$$
m_{1,0, r}=\left(\frac{1}{2}+\frac{n-2}{2 \sqrt{n(n-1)}}\right)^{r} \frac{X_{(1)}^{(n)}}{n}+\sum_{i=2}^{n-1} \frac{X_{(i)}^{(n)}}{n}\left(\frac{1}{2}+\frac{n-2 i}{2 \sqrt{n(n-1)}}\right)^{r} \text { dla } r=k, k+1 .
$$

Estymacja parametrów innych rozkładów, dla których istnieją momenty ważone prawdopodobieństwami odpowiednich rzędów, przebiega w sposób analogiczny.

\subsection{Bayesowskie metody estymacji}

Bayesowskie metody szacowania parametru $\theta$ zmiennej losowej $X$ należą do metod nieklasycznych. Problematyce estymacji bayesowskiej i jej zastosowania poświęconych jest wiele prac, m.in. F. J. Anscombe [1961], J. O. Berger [1985], B. P. Carlin, T.A. Louis [2000], J. Osiewalski [1991], M. Szreder [1989], [1994], A. Zellner [1971], [1986].

W metodach bayesowskich zakłada się, że parametr $\theta$ jest zmienną losową i wykorzystuje się, oprócz informacji zawartych w próbie losowej, wiedzę a priori o rozkładzie szacowanego parametru.

W podejściu bayesowskim decyzje statystyka są decyzjami podejmowanymi w grze z natura, przy czym za grę statystyczną uznaje się trójkę $\langle\Theta, D, L\rangle$, gdzie $\Theta$ jest zbiorem wszystkich wartości parametru rozkładu $\theta, D$ to zbiór 
decyzji $d$ dotyczących parametru $\theta$, będących zmienną losową i funkcją elementów próby $X_{1}, X_{2}, \ldots, X_{n}$, zaś $L(\theta, d)$ to funkcja straty, określająca wielkość straty, jaką statystyk ponosi na skutek podjęcia określonej decyzji $d \in D$. W oparciu o przyjętą funkcję straty definiuje się funkcję ryzyka jako wartość oczekiwaną funkcji straty (por. M. Krzyśko [1998, s. 40-60]).

$\mathrm{Z}$ twierdzenie Bayesa wyznaczamy warunkowy rozkład zmiennej losowej $\theta$, czyli tzw. rozkład a posteriori, stosując wzory:

$$
g\left(\theta_{k} \mid \mathbf{x}\right)=\frac{f\left(\mathbf{x} \mid \theta_{k}\right) \cdot g\left(\theta_{k}\right)}{\sum_{k} f\left(\mathbf{x} \mid \theta_{k}\right) \cdot g\left(\theta_{k}\right)},
$$

gdy $\theta$ ma rozkład skokowy o wartościach $\theta_{k}, k=1,2, \ldots$

lub

$$
g(\theta \mid \mathbf{x})=\frac{f(\mathbf{x} \mid \theta) \cdot g(\theta)}{\int_{\Theta} f(\mathbf{x} \mid \theta) \cdot g(\theta) d \theta},
$$

gdy $\theta$ ma rozkład ciagły.

Funkcja $g(\theta)$ jest funkcją gęstości lub funkcją prawdopodobieństwa rozkładu a priori parametru $\theta$, zaś $f(\mathbf{x} \mid \theta)$ jest funkcją gęstości rozkładu próby losowej $X_{1}, X_{2}, \ldots, X_{n}$.

W oparciu o wyznaczony rozkład a posteriori i przyjętą funkcję straty wyznaczamy funkcję ryzyka a posteriori, a następnie minimalizujemy to ryzyko, otrzymując estymator bayesowski szacowanego parametru o najmniejszym ryzyku.

Gdy parametr $\theta$ ma rozkład skokowy, funkcja ryzyka a posteriori przyjmuje postać:

$$
r_{p}(d, \mathbf{x})=\sum_{k} L\left(\theta_{k}, d(\mathbf{x})\right) \cdot g\left(\theta_{k} \mid \mathbf{x}\right)
$$

natomiast gdy $\theta$ ma rozkład ciagły, funkcja ryzyka a posteriori wyraża się wzorem:

$$
r_{p}(d, \mathbf{x})=\int_{\Theta} L(\theta, d(\mathbf{x})) \cdot g(\theta \mid \mathbf{x}) d \theta .
$$

Wartość szacowanego parametru zależy od jego rozkładu a priori oraz od przyjętej funkcji straty. 
W zależności od ilości posiadanych informacji wstępnych o parametrze $\theta$ wyróżniamy dwa podstawowe typy rozkładów a priori (por. M. Szreder [1994, s. 31-40]):

- nieinformacyjne (niewłaściwe, rozproszone),

- informacyjne (właściwe).

Rozkłady nieinformacyjne pełnią dwie różne role. Służą one albo do wyrażenia zupełnego braku wiedzy o szacowanym parametrze, albo wykorzystywane są jako wzorcowe do analizy efektów wprowadzenia do estymacji wiedzy spoza próby.

Rozkłady informacyjne a priori mogą być subiektywnymi rozkładami prawdopodobieństwa, jeśli skonstruowano je na podstawie subiektywnych ocen badacza, albo rozkładami empirycznymi, jeżeli podstawą ich konstrukcji są poprzednie oszacowania empiryczne parametrów na bazie wcześniejszych informacji statystycznych lub innej próby losowej. Wśród informacyjnych rozkładów a priori wyróżniamy rozkłady sprzężone z rozkładem próby charakteryzujące się tym, że rozkłady a priori i a posteriori należą do tej samej rodziny rozkładów prawdopodobieństwa.

Często wykorzystywana $\mathrm{w}$ estymacji bayesowskiej funkcja straty ma postać:

$$
L_{K}(\theta, d)=\left\{\begin{array}{ll}
a(\theta-d)^{2}, & \text { gdy } \theta \geq d, \\
b(\theta-d)^{2}, & \text { gdy } \theta<d,
\end{array} \quad \text { gdzie } a, b>0,\right.
$$

której szczególnym przypadkiem jest kwadratowa funkcja straty $L_{K}(\theta, d)=a(\theta-d)^{2}$, gdy $b=a$.

Inną funkcją straty jest funkcja wyrażona wzorem:

$$
L_{L}(\theta, d)=\left\{\begin{array}{lll}
a(\theta-d), & \text { gdy } & \theta \geq d, \\
b(d-\theta), & \text { gdy } & d>\theta,
\end{array} \quad \text { gdzie } a, b>0,\right.
$$

nazywana w literaturze liniową funkcją straty.

Obydwie funkcje straty dla $a \neq b$ są funkcjami asymetrycznymi, zaś dla $a=b$ symetrycznymi. Liniową, symetryczną funkcję straty nazywa się również modułową funkcją straty postaci:

$$
L_{M}(\theta, d)=a|\theta-d|, \quad \text { gdzie } a>0 .
$$


Dla symetrycznych funkcji straty: liniowej i kwadratowej, strata wynikająca $\mathrm{z}$ niedoszacowania i przeszacowania parametru $\theta$ jest jednakowa, przy czym dla kwadratowej funkcji straty większym błędom przyporządkowuje się stratę większą niż proporcjonalna. Dla asymetrycznych funkcji straty poprzez ustalenie wartości $a$ i $b$ określamy, która strata ma być większa - przy niedoszacowaniu czy przeszacowaniu parametru $\theta$.

Do innych funkcji straty prezentowanych w literaturze należy zaliczyć m.in. liniowo-wykładniczą i uogólnioną entropijną funkcję straty (por. A. Zellner [1986]).

Liniowo-wykładnicza funkcja straty (LINEX) określona jest wzorem:

$$
L_{\text {Linex }}(\theta, d)=b[\exp (a(\theta-d))-a(\theta-d)-1], \quad \text { gdzie } a \neq 0, b>0 \text {. }
$$

Parametr $b$ jest parametrem skali i najczęściej zakłada się $b=1$. Parametr $a$ jest parametrem kształtu. Jeśli $a<0$, to strata związana $\mathrm{z}$ przeszacowaniem wartości parametru $\theta$ jest liniowa, natomiast wykładnicza - przy niedoszacowaniu. Jeżeli natomiast $a>0$, sytuacja jest przeciwna.

Uogólniona entropijna funkcja straty ma postać (por. S. K. Singh i in. [2011]):

$$
L_{E}(\theta, d) \propto\left(\frac{\theta}{d}\right)^{q}-q \ln \left(\frac{\theta}{d}\right)-1, \quad \text { gdzie } \quad q>0 .
$$

Funkcja ta przypisuje większe straty błędom związanym z niedoszacowaniem wartości parametru $\theta$.

Dla każdej z wymienionych funkcji straty estymator bayesowski ma inną postać.

Dla symetrycznej kwadratowej funkcji straty optymalnym bayesowskim estymatorem punktowym parametru $\theta$ jest wartość oczekiwana rozkładu $a$ posteriori.

W przypadku symetrycznej liniowej funkcji straty (modułowej) optymalnym bayesowskim estymatorem parametru $\theta$ jest mediana rozkładu a posteriori. Optymalnym bayesowskim estymatorem parametru $\theta$ odpowiadającym liniowej niesymetrycznej funkcji straty jest kwantyl rzędu $\frac{a}{a+b}$ rozkładu a posteriori. Dobierając odpowiednie wartości $a, b$, otrzymujemy kwantyle odpowiednich rzędów, w tym medianę, kwartyle czy też percentyle, rozkładu a posteriori.

Dla liniowo-wykładniczej funkcji straty estymatorem bayesowskim parametru $\theta$ jest statystyka: 


$$
\left.\hat{\theta}=-\frac{1}{a} \ln E_{g(\theta \mid \mathbf{x})}(\exp (-a \theta))\right)
$$

gdzie $E_{g(\theta \mid \mathbf{x})}$ oznacza wartość oczekiwaną rozkładu a posteriori zmiennej $Y=\exp (-a \theta)$.

Zastosowanie uogólnionej entropijnej funkcji straty sprawia, że otrzymujemy estymator bayesowski postaci:

$$
\hat{\theta}=\left(E_{g(\theta \mid \mathbf{x})}\left(\theta^{-q}\right)\right)^{-\frac{1}{q}}
$$

W przypadku zastosowania liniowej funkcji straty bayesowskie metody estymacji, wykorzystują medianę i inne kwantyle rozkładu a posteriori wyznaczonego na podstawie próby losowej. Zatem estymatory bayesowskie można również uznać za funkcje statystyk pozycyjnych.

\subsection{Bootstrapowe metody estymacji}

Metody bootstrapowe, podobnie jak bayesowskie, należą do grupy metod nieklasycznych. Są to metody symulacyjne wymagające oprogramowania komputerowego. Pojawiły się w latach osiemdziesiątych ubiegłego stulecia. Początki ich zastosowania związane były z szacowaniem wariancji estymatorów, przy punktowej estymacji parametrów, w sytuacji wykorzystywania skomplikowanych postaci estymatorów, złożonych schematów losowania prób i problemów $\mathrm{z}$ analityczną postacią estymatora wariancji. Rozwój metod bootstrapowych umożliwiają coraz szybsze procesory komputerowe i powstające oprogramowania komputerowe.

Bootstrapowe metody estymacji można stosować, oprócz szacowania wariancji estymatorów, do aproksymacji rozkładów estymatorów oraz do punktowego i przedziałowego szacowania wartości parametrów rozkładu zmiennej losowej. Wykorzystuje się je w przypadkach, gdy klasycznych metod nie można zastosować ze względu na nieznany rozkład badanej zmiennej bądź zbyt małą liczebność próby uniemożliwiającą użycie twierdzeń granicznych o rozkładach estymatorów (por. A. C. Davison, D. V. Hinkley [1997], B. Efron [1979], B. Efron, R. J. Tibshirani [1993], T. DiCiccio, B. Efron [1996]). W zależności od posiadanych informacji wykorzystuje się parametryczne lub nieparametryczne metody bootstrapowe. Bardziej popularne jest stosowanie nieparametrycznych metod szacowania parametrów zmiennej losowej, które nie wymagają żadnych założeń o jej rozkładzie i liczebności próby. 
W konstrukcji bootstrapowych przedziałów ufności dla parametrów rozkładu zmiennej losowej wykorzystuje się statystyki pozycyjne rozkładów bootstrapowych.

Niech $X$ będzie zmienną losową o rozkładzie określonym za pomocą nieznanej dystrybuanty $F$, z którą utożsamiamy badaną populację oraz niech $X_{1}, X_{2}, \ldots, X_{n}$ będzie próbą prostą wylosowaną z tej populacji. Na podstawie próby losowej generujemy próby bootstrapowe według rozkładu bootstrapowego. Definicje próby i rozkładu bootstrapowego zostały sformułowane poniżej (por. C. Domański, K. Pruska [2000, s. 260-261]).

Definicja 2.8.1. Rozkładem bootstrapowym z próby prostej $X_{1}, X_{2}, \ldots, X_{n}$ nazywamy rozkład prawdopodobieństwa postaci:

$$
P\left(X^{B}=x_{i}\right)=\frac{1}{n} \quad \text { dla } i=1, \ldots, n,
$$

gdzie ciąg wartości $x_{1}, x_{2}, \ldots, x_{n}$ stanowi realizację próby prostej $X_{1}, X_{2}, \ldots, X_{n}$.

\section{Rozkład bootstrapowy oznaczamy przez $\hat{F}$.}

Definicja 2.8.2. Próbą bootstrapową liczebności $k$ nazywamy ciąg niezależnych zmiennych losowych $X_{1}^{B}, X_{2}^{B}, \ldots, X_{k}^{B}$ o rozkładzie bootstrapowym, gdzie $k$ jest ustaloną liczbą naturalną.

Często przyjmuje się, że liczebność próby bootstrapowej jest równa liczebności próby prostej wylosowanej z badanej populacji, czyli $k=n$.

Do estymacji parametrów rozkładu zmiennej losowej niezbędna jest pewna statystyka $R$ określona na przestrzeni prób. W metodach bootstrapowych rozkład tej statystyki aproksymuje się rozkładem bootstrapowym.

Definicja 2.8.3. Rozkładem bootstrapowym statystyki $R$ nazywamy rozkład zmiennej losowej $R^{B}=R\left(\boldsymbol{X}^{B}, \hat{F}\right)$, gdzie $\boldsymbol{X}^{B}=\left(X_{1}^{B}, X_{2}^{B}, \ldots, X_{k}^{B}\right)$.

Rozkład zmiennej losowej $R^{B}$ wyznaczamy najczęściej poprzez aproksymację Monte Carlo, generując $N(N \geq 1000)$ prób bootstrapowych według rozkładu bootstrapowego i wyznaczając histogram rozkładu statystyki $R^{B}$.

Rozważmy najpierw problem estymacji przedziałowej parametru $\theta$ zmiennej losowej $X$ o nieznanej klasie rozkładu. 
Niech $1-\alpha$ będzie ustalonym współczynnikiem ufności, natomiast $X_{1}, X_{2}, \ldots, X_{n}$ to $n$-elementowa próba losowa pochodząca z rozpatrywanej populacji generalnej.

Konstrukcje bootstrapowych przedziałów ufności dla parametrów rozkładu populacji wykorzystują kwantyle odpowiednich rzędów rozkładu empirycznego rozważanego parametru, które wyznacza się w oparciu o wygenerowane próby bootstrapowe. Do takich metod należy zaliczyć (por. C. Domański, K. Pruska [2000, s. 262-264], B. Efron, R. J. Tibshirani [1993, s. 321-331]) m.in.:

- metodę percentyli,

- metodę $t$-bootstrapowa,

- dwustopniową metodę $t$-bootstrapową.

Metoda percentyli szacowania parametru $\theta$ sprowadza się do wygenerowania $N$ prób bootstrapowych $X_{1 j}^{B}, X_{2 j}^{B}, \ldots, X_{n j}^{B}$ i wyznaczenia na podstawie każdej $\mathrm{z}$ nich wartości estymatora parametru $\theta$ oznaczanego przez $\hat{\theta}_{j}^{B}$, gdzie $j=1,2, \ldots, N$. Otrzymujemy $\mathrm{w}$ ten sposób ciag uporządkowanych wartości $\hat{\theta}_{1}^{B}, \ldots, \hat{\theta}_{N}^{B}$. Za ich pomoca aproksymujemy rozkład estymatora $\hat{\theta}$ i wyznaczamy kwantyle rzędu $\frac{\alpha}{2}$ oraz $1-\frac{\alpha}{2}$, czyli statystyki $\hat{\theta}_{\frac{N \alpha}{2}}^{B}$ i $\hat{\theta}_{N-\frac{N \alpha}{2}}^{B}$. Posłużą one do budowy przedziału ufności $\hat{\theta}_{\frac{N \alpha}{2}}^{B}<\theta<\hat{\theta}_{N-\frac{N \alpha}{2}}^{B}$ dla parametru $\theta$ na przybliżonym poziomie ufności $1-\alpha$, tzn.

$$
P\left(\hat{\theta}_{\frac{N \alpha}{2}}^{B}<\theta<\hat{\theta}_{N-\frac{N \alpha}{2}}^{B}\right) \approx 1-\alpha .
$$

Liczbę powtórzeń $N$ najwygodniej dobrać jest tak, aby wielkość $\frac{N \alpha}{2}$ była liczbą całkowitą. W przeciwnym przypadku należy wykorzystać statystyki pozycyjne o rangach $\left[\frac{N \alpha}{2}\right]+1$ oraz $N-\left[\frac{N \alpha}{2}\right]$.

Rozpatrywanym parametrem $\theta$ może być w szczególności wartość oczekiwana lub mediana, zaś estymatorem $\hat{\theta}$, odpowiednio, średnia arytmetyczna i mediana $z$ próby.

Druga $\mathrm{z}$ metod, $t$-bootstrapowa, polega na wyznaczeniu na podstawie $j$-tej próby bootstrapowej wartości: 


$$
t_{j}^{B}=\frac{\hat{\theta}_{j}^{B}-\hat{\theta}}{\hat{D}\left(\hat{\theta}_{j}^{B}\right)} \text { dla } j=1, \ldots, N,
$$

gdzie $\hat{\theta}$ jest oszacowaniem parametru $\theta$ na podstawie wylosowanej próby $X_{1}, X_{2}, \ldots, X_{n}$, natomiast $\hat{\theta}_{j}^{B}$ to oszacowanie parametru $\theta$ na podstawie próby bootstrapowej $X_{1 j}^{B}, X_{2 j}^{B}, \ldots, X_{n j}^{B}$, z kolei $\hat{D}\left(\hat{\theta}_{j}^{B}\right)$ jest estymatorem odchylenia standardowego zmiennej $\hat{\theta}_{j}^{B}$.

W ten sposób otrzymujemy ciąg wartości $\left(t_{j}^{B}\right)_{j=1, \ldots N}$ i wyznaczamy kwantyle $t_{\frac{\alpha}{2} ; N}^{B}, t_{1-\frac{\alpha}{2} ; N}^{B}$ rzędu odpowiednio $\frac{\alpha}{2}$ i $1-\frac{\alpha}{2}$, które wykorzystujemy do budowy metodą $t$-bootstrapową przedziału ufności dla parametru $\theta$, na przybliżonym poziomie ufności $1-\alpha$, postaci:

$$
P\left(\hat{\theta}-t_{1-\frac{\alpha}{2} ; N}^{B} \hat{D}(\hat{\theta})<\theta<\hat{\theta}-t_{\frac{\alpha}{2} ; N}^{B} \hat{D}(\hat{\theta})\right) \approx 1-\alpha,
$$

gdzie $\hat{D}(\hat{\theta})$ jest oszacowanym odchyleniem standardowym estymatora $\hat{\theta}$.

Dwustopniowa metoda $t$-bootstrapowa jest modyfikacją metody $t$-bootstrapowej. Pierwszy etap tej procedury estymacji polega na losowaniu $N_{1}$ prób bootstrapowych zawierających po $n$ elementów, wyznaczeniu na podstawie każdej z tych prób wartości estymatora $\hat{\theta}_{i}^{B}$ dla $i=1,2, \ldots, N_{1}$ i obliczeniu $\bar{\theta}^{B}=\frac{1}{N_{1}} \sum_{i=1}^{N_{1}} \hat{\theta}_{i}^{B}$ oraz $\hat{D}\left(\theta^{B}\right)=\sqrt{\frac{1}{N_{1}} \sum_{i=1}^{N_{1}}\left(\hat{\theta}_{i}^{B}-\bar{\theta}^{B}\right)^{2}}$. Następnie, spośród wartości $\hat{\theta}_{1}^{B}, \ldots, \hat{\theta}_{N_{1}}^{B}$ losujemy niezależnie jedną wartość i oznaczamy ją $\hat{\theta}_{0}^{B}$. Powtarzamy procedurę $N_{2}$ razy, otrzymując wartości $\hat{\theta}_{0 j}^{B}$ dla $j=1,2, \ldots, N_{2}$.

W kolejnym etapie obliczamy wartości $t_{j}^{B}$ dla $j=1,2, \ldots, N_{2}$ ze wzoru:

$$
t_{0 j}^{B}=\frac{\hat{\theta}_{0 j}^{B}-\hat{\theta}}{\hat{D}\left(\theta^{B}\right)} .
$$

Na podstawie otrzymanego ciągu wartości $\left(t_{0 j}^{B}\right)_{j=1, \ldots N_{2}}$ wyznaczamy kwantyle $t_{\frac{\alpha}{2} ; N_{2}}^{B}, t_{1-\frac{\alpha}{2} ; N_{2}}^{B}$ rzędu odpowiednio $\frac{\alpha}{2}$ i $1-\frac{\alpha}{2}$. 
Przedział ufności $\hat{\theta}-t_{1-\frac{\alpha}{2} ; N_{2}}^{B} \hat{D}(\hat{\theta})<\theta<\hat{\theta}-t_{\frac{\alpha}{2} ; N_{2}}^{B} \hat{D}(\hat{\theta})$ otrzymany dwustopniową metodą $t$-bootstrapową pokrywa szacowaną wartość parametru $\theta$ na przybliżonym poziomie ufności $1-\alpha$, tzn.

$$
P\left(\hat{\theta}-t_{1-\frac{\alpha}{2} ; N_{2}}^{B} \hat{D}(\hat{\theta})<\theta<\hat{\theta}-t_{\frac{\alpha}{2} ; N_{2}}^{B} \hat{D}(\hat{\theta})\right) \approx 1-\alpha .
$$

Jeśli $\theta$ jest parametrem zmiennej losowej $X$ szacowanym na podstawie próby prostej $X_{1}, X_{2}, \ldots, X_{n}$, to wariancję estymatora $\hat{\theta}$ możemy oszacować na podstawie prób bootstrapowych, korzystając ze wzoru:

$$
\hat{D}(\hat{\theta})=\frac{1}{N-1} \sum_{j=1}^{N}\left(\hat{\theta}_{j}^{B}-\bar{\theta}^{B}\right)^{2},
$$

gdzie $\hat{\theta}_{j}^{B}$ jest estymatorem parametru $\theta$ wyznaczonym na podstawie $j$-tej próby bootstrapowej, natomiast $\bar{\theta}^{B}=\frac{1}{N} \sum_{j=1}^{N} \hat{\theta}_{j}^{B}$.

Informacja o klasie rozkładu zmiennej losowej $X$ może być wykorzystana do budowy parametrycznego, bootstrapowego przedziału ufności dla parametru tego rozkładu. W tym przypadku próby bootstrapowe generuje się, wykorzystując typ rozkładu zmiennej $X$ i wartości próby bootstrapowej $x_{1}^{B}, x_{2}^{B}, \ldots, x_{k}^{B}$ wyznacza się w następujący sposób:

$$
x_{i}^{B}=\hat{F}^{-1}(u), \quad \text { dla } i=1,2, \ldots, k,
$$

gdzie $u$ jest wartością wygenerowaną z rozkładu jednostajnego na przedziale $[0,1]$, zaś $\hat{F}$ jest oszacowaną dystrybuantą zmiennej $X$.

Pozostałe etapy estymacji parametrów, takich jak wartość oczekiwana czy kwantyle, lub etapy szacowania wariancji estymatorów, są identyczne jak w prezentowanym podejściu nieparametrycznym.

W praktyce stosuje się również podejście semiparametryczne, charakteryzujące się tym, że niektóre elementy próby bootstrapowej generuje się z rozkładu bootstrapowego (wzór (2.8.1)), natomiast inne z konkretnego rozkładu teoretycznego. Tego typu podejście wykorzystywane jest $\mathrm{w}$ przypadku estymacji parametrów rozkładów zmiennych losowych o grubych ogonach. 
Gdy rozkład charakteryzuje się prawym grubym ogonem, wartości próby bootstrapowej poniżej ustalonego progu $u$ generuje się z empirycznego rozkładu, natomiast wartości powyżej progu z rozkładu uwzględniającego asymptotyczne własności rozkładu ogona (por. M. D. Pandey i in. [2003]). Zatem dystrybuantę rozkładu bootstrapowego można zapisać w następujący sposób:

$$
F^{B}(x \mid u)= \begin{cases}\left(1-F_{n}(u)\right) F_{P}(x)+F_{n}(u), & \text { gdy } x>u, \\ F_{n}(x), & \text { gdy } x \leq u,\end{cases}
$$

gdzie $F_{n}$ oznacza dystrybuantę rozkładu bootstrapowego, zaś $F_{P}$ to dystrybuanta uogólnionego rozkładu Pareto z parametrami rozkładu oszacowanymi na podstawie próby.

Semiparametryczna estymacja bootstrapowa analizowana będzie dokładniej w piątym rozdziale pracy.

\subsection{Uwagi końcowe}

W rozdziale tym przedstawione zostały metody estymacji punktowej i przedziałowej parametrów rozkładów zmiennych losowych, które wykorzystują statystyki pozycyjne wyznaczone na podstawie $n$-elementowej próby prostej. Oprócz metod znanych z literatury przedmiotu zaprezentowano własne propozycje, będące modyfikacjami kwantylowej metody najmniejszych kwadratów i metody momentów ważonych prawdopodobieństwami. Zaletą większości metod estymacji opartych na statystykach pozycyjnych jest ich uniwersalność. Spośród omówionych metod tylko metody momentów ważonych prawdopodobieństwami wymagają informacji o istnieniu odpowiednich momentów, a metody bayesowskie informacji o rozkładzie a priori rozważanego parametru.

W celu prezentacji zastosowania rozważanych procedur metod wybrane zostały pewne klasy rozkładów i dla nich wyznaczono wzory na estymatory ich parametrów oraz sformułowano odpowiednie twierdzenia. Uwzględniono rozkłady o grubych (Cauchy'ego, Pareto) i cienkich ogonach (logistyczny), symetryczne $\mathrm{i}$ asymetryczne oraz rozkłady wykorzystywane w analizie zdarzeń ekstremalnych (Gumbela, uogólniony Pareto), którym poświęcony będzie rozdział piąty. Stosując metody estymacji oparte na kwantylach, podobnie jak w przypadku metody największej wiarygodności, nie dla wszystkich typów rozkładów można analitycznie wyprowadzić wzory na postaci estymatorów. W tych sytuacjach oprogramowania komputerowe pozwalają numerycznie obliczać ich wartości na podstawie wartości prób losowych. 


\section{ANALIZA WLASNOŚCI OPARTYCH NA STATYSTYKACH POZYCYJNYCH ESTYMATORÓW PARAMETRÓW WYBRANYCH ROZKŁADÓW}

\subsection{Uwagi wstępne}

Rozważania teoretyczne dotyczące metod estymacji parametrów rozkładu zmiennej losowej wykorzystujących statystyki pozycyjne wymagają uzupełnień poprzez analizy związane $\mathrm{z}$ własnościami otrzymywanych estymatorów. Na obciążenia i błędy średniokwadratowe estymatorów wpływają rzędy wybieranych kwantyli w metodzie kwantyli oraz rzędy pomijanych kwantyli w kwantylowej metodzie najmniejszych kwadratów z uciętą liczbą kwantyli. Na własności estymatorów uzyskanych metodą momentów ważonych prawdopodobieństwami istotny wpływ ma wybór rzędów momentów oraz postać dystrybuanty empirycznej.

W rozdziale tym przedstawiono wyniki analiz własności estymatorów otrzymanych metodą kwantyli i wpływu rzędów stosowanych kwantyli na własności estymatorów parametrów wybranych klas rozkładów, m.in. rozkładu Cauchy'ego, logistycznego i uogólnionego Pareto oraz uogólnionych rozkładów statystyk ekstremalnych. Ze względu na skomplikowane postacie estymatorów, badania obciążoności i błędów średniokwadratowych nie zawsze można przeprowadzić metodami analitycznymi, dlatego w większości przypadków zaprezentowano wyniki analiz symulacyjnych. Wykonane obliczenia i uzyskane wyniki badań symulacyjnych pozwalają sformułować wnioski dotyczące właściwego wyboru tych wielkości w praktycznym wykorzystaniu procedur estymacji parametrów opartych na statystykach pozycyjnych.

Szczególnie istotne są wyniki badań, które odnoszą się do własności estymatorów uzyskanych przy zastosowaniu autorskich metod estymacji, tj. kwantylowej metody najmniejszych kwadratów z uciętą liczbą kwantyli, medianowokwantylowej metody najmniejszych kwadratów i metody momentów ważonych prawdopodobieństwami ze zmodyfikowaną dystrybuantą empiryczną (level 
crossing empirical distribution function). W rozdziale tym przedstawiono wyniki analiz porównawczych obciążeń i błędów średniokwadratowych estymatorów parametrów wybranych klas rozkładów otrzymanych metodami proponowanymi oraz prezentowanymi w literaturze przedmiotu.

\subsection{Badania własności estymatorów otrzymanych metodą kwantyli}

Zastosowanie metody kwantyli do estymacji parametrów rozkładu zmiennej losowej wymaga ustalenia rzędów wykorzystywanych kwantyli, których liczba uzależniona jest od ilości parametrów rozkładu. Od wyboru wielkości rzędów kwantyli zależą własności otrzymanych estymatorów: ich obciążenia i błędy średniokwadratowe. W pracy J. Aitchisona, J. A. C. Browna [1975] określone zostały wielkości rzędów kwantyli, które należy stosować w estymacji parametrów rozkładu logarytmiczno-normalnego. Analiza własności estymatorów parametrów innych klas rozkładów: Cauchy’ego, Pareto, logistycznego i Gumbela, przedstawiona jest poniżej.

Dla rozkładu Cauchy'ego $C a(m \lambda)$ w oparciu o definicję kwantyla, twierdzenie 1.3.7 oraz własności wartości oczekiwanej można obliczyć obciążenia estymatorów parametrów $m$ oraz $\lambda$ dla wybranych rzędów kwantyli. Obciążenia estymatorów tych parametrów, przy założeniu, że $n p \in N$, wyznacza się z następujących wzorów:

$$
\begin{gathered}
E\left(\hat{m}^{m K}\right)-m=\frac{1}{2}\left(E\left(X_{p ; n}\right)+E\left(X_{(1-p) ; n}\right)\right)-m= \\
=\frac{\lambda n !}{2(n p-1) !(n-n p) !} \int_{0}^{1} t^{n p-1}(1-t)^{n-n p} \operatorname{tg} \pi(t-0,5) d t+ \\
+\frac{\lambda n !}{2(n p) !(n-n p-1) !} \int_{0}^{1} t^{n-n p-1}(1-t)^{n p} \operatorname{tg} \pi(t-0,5) d t
\end{gathered}
$$

oraz

$$
\begin{aligned}
& E\left(\hat{\lambda}^{m K}\right)-\lambda=\frac{\operatorname{tg}(\pi p)}{2}\left(E\left(X_{(1-p) ; n}\right)-E\left(X_{p ; n}\right)\right)-\lambda= \\
= & \frac{\lambda \operatorname{tg}(\pi p) n !}{2(n p) !(n-n p-1) !} \int_{0}^{1} t^{n-n p-1}(1-t)^{n p} \operatorname{tg} \pi(t-0,5) d t+
\end{aligned}
$$




$$
-\frac{\lambda \operatorname{tg}(\pi p) n !}{2(n p-1) !(n-n p) !} \int_{0}^{1} t^{n p-1}(1-t)^{n-n p} \operatorname{tg} \pi(t-0,5) d t-\lambda .
$$

Obliczone, przy użyciu pakietu Mathematica, wielkości obciążeń $B\left(\hat{m}^{m K}\right)=E\left(\hat{m}^{m K}\right)-m$ oraz $B\left(\hat{\lambda}^{m K}\right)=E\left(\hat{\lambda}^{m K}\right)-\lambda \quad$ estymatorów parametrów $m$ i $\lambda$ dla dwóch wybranych rozkładów Cauchy'ego i liczebności próby równej 40, 60 i 100 przedstawione są w tablicy 3.2.1.

Tablica 3.2.1. Obciążenia estymatorów $m K$ parametrów rozkładu Cauchy'ego dla wybranych rzędów kwantyli

\begin{tabular}{|c|c|c|c|c|c|c|c|}
\hline \multirow{3}{*}{ Rozkład } & $p$ & \multicolumn{2}{|c|}{$n=40$} & \multicolumn{2}{c|}{$n=60$} & \multicolumn{2}{c|}{$n=100$} \\
\cline { 3 - 8 } & & $B\left(\hat{m}^{m K}\right)$ & $B\left(\hat{\lambda}^{m K}\right)$ & $B\left(\hat{m}^{m K}\right)$ & $B\left(\hat{\lambda}^{m K}\right)$ & $B\left(\hat{m}^{m K}\right)$ & $B\left(\hat{\lambda}^{m K}\right)$ \\
\hline \multirow{5}{*}{$C a(1,2)$} & 0,05 & $-6,3673$ & 1,0006 & $-3,2004$ & 0,5016 & $-1,6020$ & 0,2506 \\
\cline { 2 - 8 } & 0,10 & $-1,0875$ & 0,3375 & $-0,6543$ & 0,2020 & $-0,3643$ & 0,1120 \\
\cline { 2 - 8 } & 0,20 & $-0,2557$ & 0,1499 & $-0,1636$ & 0,0950 & $-0,0953$ & 0,0548 \\
\cline { 2 - 8 } & 0,30 & $-0,1283$ & 0,1026 & $-0,0836$ & 0,0660 & $-0,0493$ & 0,0385 \\
\cline { 2 - 8 } & 0,40 & $-0,0908$ & 0,0849 & $-0,0596$ & 0,0549 & $-0,0353$ & 0,0321 \\
\cline { 2 - 8 } & 0,45 & $-0,0838$ & 0,0812 & $-0,0551$ & 0,0525 & $-0,0327$ & 0,0308 \\
\hline \multirow{5}{*}{$C a(2,1)$} & 0,05 & $-3,1836$ & 0,5003 & $-1,6002$ & 0,2508 & $-0,8010$ & 0,1253 \\
\cline { 2 - 8 } & 0,10 & $-0,5437$ & 0,1688 & $-0,3271$ & 0,1010 & $-0,1821$ & 0,0560 \\
\cline { 2 - 8 } & 0,20 & $-0,1279$ & 0,0750 & $-0,0818$ & 0,0475 & $-0,0475$ & 0,0274 \\
\cline { 2 - 8 } & 0,30 & $-0,0641$ & 0,0513 & $-0,0418$ & 0,0330 & $-0,0246$ & 0,0192 \\
\cline { 2 - 8 } & 0,40 & $-0,0454$ & 0,0424 & $-0,0298$ & 0,0274 & $-0,0178$ & 0,0161 \\
\cline { 2 - 8 } & 0,45 & $-0,0419$ & 0,0406 & $-0,0275$ & 0,0263 & $-0,0164$ & 0,0154 \\
\hline
\end{tabular}

Źródło: opracowanie własne.

Analiza otrzymanych wyników pozwala stwierdzić, że estymator $\hat{\lambda}^{m K}$ przeszacowuje wartości parametru $\lambda$, zaś estymator $\hat{m}^{m K}$ niedoszacowuje wartości $m$. Wielkości obciążeń zależą od wybranych rzędów kwantyli. Dla kwantyli bliskich medianie obciążenia estymatorów są małe, dużo mniejsze niż dla rzędów kwantyli $p$ bliskich 0,05 . Spośród wyników prezentowanych w tablicy 3.2.1 najmniejsze obciążenia uzyskano przy zastosowaniu kwantyli rzędów $p=0,45$ i $1-p=0,55$. W przypadku rozkładu Cauchy'ego o innych parametrach wyniki są analogiczne (por. D. Pekasiewicz [2012]).

Obliczone wielkości obciążeń i wyznaczone wariancje kwantyli z próby $X_{p ; n}$ i $X_{(1-p) ; n}$, a następnie wariancje estymatorów $\hat{m}^{m K}$ i $\hat{\lambda}^{m k}$ prowadzą do 
obliczenia wielkości błędów średniokwadratowych estymatorów parametrów rozkładu Cauchy'ego.

Wariancje estymatorów parametrów $m$ i $\lambda$, gdy $n p \in N$, są następujące:

$$
\begin{gathered}
D^{2}\left(\hat{m}^{m K}\right)=\frac{D^{2}\left(X_{p ; n}\right)}{4}+\frac{D^{2}\left(X_{(1-p) ; n}\right)}{4}+\frac{1}{2} \operatorname{cov}\left(X_{p ; n}, X_{(1-p) ; n}\right), \\
D^{2}\left(\hat{\lambda}^{m K}\right)=\frac{D^{2}\left(X_{(1-p) ; n}\right)}{4 \operatorname{ctg}^{2}(\pi p)}+\frac{D^{2}\left(X_{p ; n}\right)}{4 \operatorname{ctg}^{2}(\pi p)}-\frac{1}{2 \operatorname{ctg}^{2}(\pi p)} \operatorname{cov}\left(X_{p ; n}, X_{(1-p) ; n}\right),
\end{gathered}
$$

gdzie

$$
\begin{gathered}
D^{2}\left(X_{p ; n}\right)=\int_{-\infty}^{+\infty}\left(x-E\left(X_{p ; n}\right)\right)^{2} g_{n p ; n}(x) d x, \\
D^{2}\left(X_{(1-p) ; n}\right)=\int_{-\infty}^{+\infty}\left(x-E\left(X_{(1-p) ; n}\right)\right)^{2} g_{n-n p ; n}(x) d x
\end{gathered}
$$

oraz

$$
\operatorname{cov}\left(X_{p ; n}, X_{(1-p) ; n}\right)=\int_{-\infty-\infty}^{+\infty} \int_{-\infty}^{y}\left(x-E\left(X_{p ; n}\right)\right)\left(y-E\left(X_{(1-p) ; n}\right)\right) \cdot g(x, y) d x d y .
$$

Funkcje gęstości $g_{n p ; n}(x), \quad g_{n-n p ; n}(x)$ statystyk, odpowiednio, $X_{p ; n}$ oraz $X_{(1-p) ; n}$ określone są w twierdzeniu 1.3.4, natomiast postać łącznej funkcji gęstości $g(x, y)$ tych statystyk podana jest w twierdzeniu 1.3.7. Obliczone, przy użyciu pakietu Mathematica, wielkości błędów średniokwadratowych estymatorów, gdy $n=40,60,100$, zamieszczone są w tablicy 3.2.2.

Różnice między wielkościami błędów średniokwadratowych estymatorów $m K$ wyznaczanych dla różnych $p$ są bardzo duże. Najmniejsze błędy średniokwadratowe estymatora parametru $m$ są dla kwantyli rzędów bliskich 0,45 , natomiast dla parametru $\lambda$ dla wartości $p$ z przedziału $\langle 0,25,0,3\rangle$. Wybór zbyt małej wartości rzędu kwantyla $p$ przy estymacji parametrów rozkładu Cauchy'ego skutkuje otrzymaniem estymatora o wielokrotnie większym błędzie średniokwadratowym $\mathrm{w}$ porównaniu z błędem średniokwadratowym estymatora wyznaczonego w oparciu o kwantyle bliższe medianie, czyli rzędów bliskich 0,5.

W przypadku gdy $n p \notin N$, obliczenia dotyczące obciążeń i błędów średniokwadratowych przeprowadza się w sposób analogiczny, przy czym $X_{p ; n}=X_{([n p]+1)}^{(n)}$. 
Tablica 3.2.2. Błędy średniokwadratowe estymatorów parametrów rozkładu Cauchy’ego dla wybranych rzędów kwantyli

\begin{tabular}{|c|c|c|c|c|c|c|c|}
\hline \multirow[b]{2}{*}{ Rozkład } & \multirow[b]{2}{*}{$p$} & \multicolumn{2}{|c|}{$n=40$} & \multicolumn{2}{|c|}{$n=60$} & \multicolumn{2}{|c|}{$n=100$} \\
\hline & & $\operatorname{MSE}\left(\hat{m}^{m K}\right)$ & $\operatorname{MSE}\left(\hat{\lambda}^{m K}\right)$ & $\operatorname{MSE}\left(\hat{m}^{m K}\right)$ & $\operatorname{MSE}\left(\hat{\lambda}^{m K}\right)$ & $\operatorname{MSE}\left(\hat{m}^{m K}\right)$ & $\operatorname{MSE}\left(\hat{\lambda}^{m K}\right)$ \\
\hline \multirow{6}{*}{$C a(1,2)$} & 0,05 & 921,942 & 14,8465 & 119,7136 & 2,8944 & 33,7743 & 0,7758 \\
\hline & 0,10 & 12,8465 & 1,1625 & 6,2560 & 0,5646 & 2,9405 & 0,2581 \\
\hline & 0,20 & 1,1000 & 0,3807 & 0,6857 & 0,2297 & 0,3754 & 0,1228 \\
\hline & 0,30 & 0,3993 & 0,3241 & 0,2597 & 0,2042 & 0,1508 & 0,1071 \\
\hline & 0,40 & 0,2648 & 0,5188 & 0,1744 & 0,3328 & 0,1012 & 0,1928 \\
\hline & 0,45 & 0,2535 & 1,0202 & 0,1672 & 0,6604 & 0,0974 & 0,3869 \\
\hline \multirow{6}{*}{$\mathrm{Ca}(2,1)$} & 0,05 & 233,386 & 3,6389 & 29,9237 & 0,7237 & 8,4424 & 0,1985 \\
\hline & 0,10 & 3,1134 & 0,2906 & 1,5640 & 0,1412 & 0,7352 & 0,0645 \\
\hline & 0,20 & 0,5432 & 0,3675 & 0,1712 & 0,0575 & 0,0938 & 0,0307 \\
\hline & 0,30 & 0,2750 & 0,0952 & 0,0650 & 0,0511 & 0,0370 & 0,0290 \\
\hline & 0,40 & 0,0662 & 0,1297 & 0,0436 & 0,0838 & 0,0253 & 0,0411 \\
\hline & 0,45 & 0,0639 & 0,2560 & 0,0418 & 0,1694 & 0,0244 & 0,0959 \\
\hline
\end{tabular}

Źródło: opracowanie własne.

Symulacyjna analiza własności estymatorów polegająca na powtórzeniu 20000 razy procedury estymacji parametrów rozkładu Cauchy'ego metodą kwantyli pozwala w sposób graficzny przedstawić zależności wielkości obciążeń estymatorów i błędów średniokwadratowych od ustalonego rzędu $p$ kwantyla z próby. Rezultaty przeprowadzonych badań dla wygenerowanej populacji i losowanych 100-elementowych prób prostych zaprezentowane są na rysunkach 3.2.1-3.2.4. Sa one zgodne $\mathrm{z}$ wynikami obliczeniowymi przedstawionymi w tablicach 3.2.1 i 3.2.2.

Rozważmy zmienną losową $X$ o rozkładzie Pareto $P a(\theta, a)$. Własności parametrów rozkładu Pareto, tj. obciążenia i błędy średniokwadratowe analizowano metodą Monte Carlo. W tablicach 3.2.3-3.2.4 przedstawiono oszacowane obciążenia i błędy średniokwadratowe estymatorów parametrów $\theta$ oraz $a$ dla trzech wybranych rozkładów Pareto i ustalonych liczebności prób $n=40,60$, 100 , otrzymane w wyniku powtórzenia procedury estymacji 20000 razy. 
obciqżenie

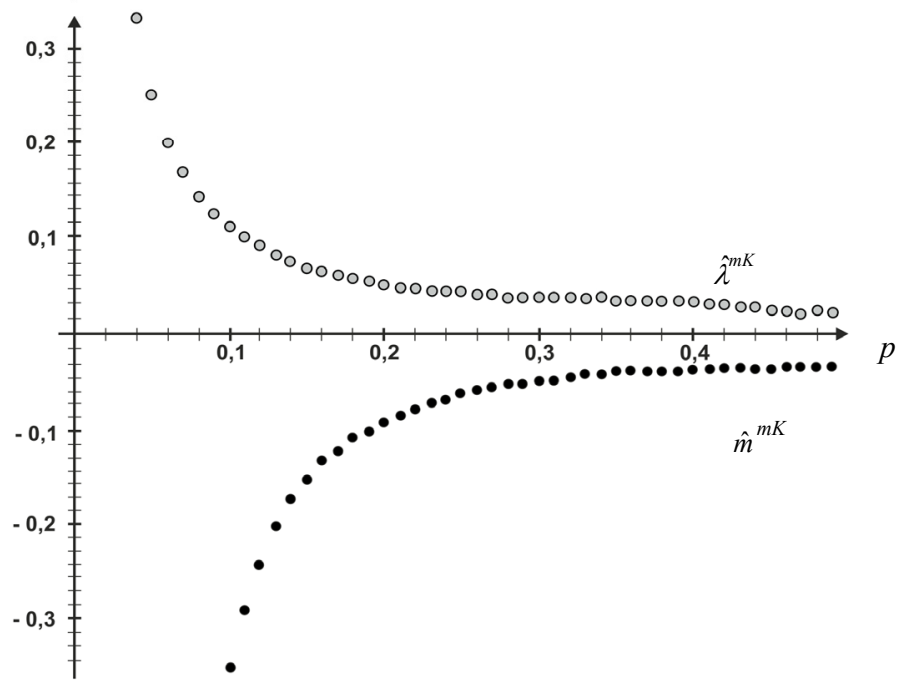

Rysunek 3.2.1. Zależność obciążeń estymatorów parametrów rozkładu Cauchy'ego $C a(1,2)$ od rzędów kwantyli w metodzie kwantyli

Źródło: opracowanie własne

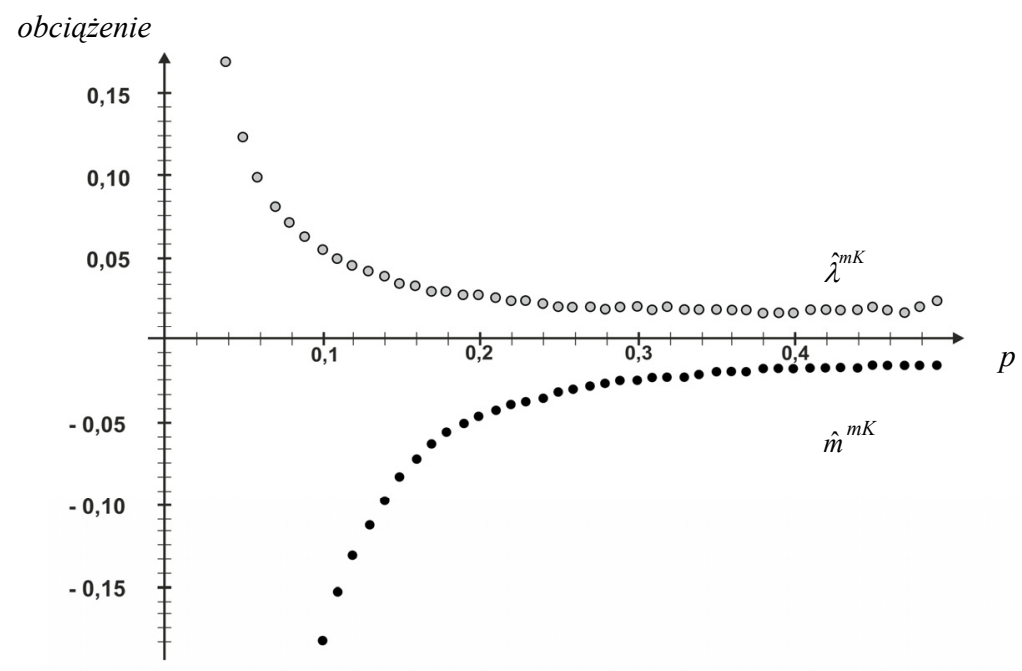

Rysunek 3.2.2. Zależność obciążeń estymatorów parametrów rozkładu Cauchy'ego $C a(2,1)$ od rzędów kwantyli w metodzie kwantyli

Źródło: opracowanie własne 


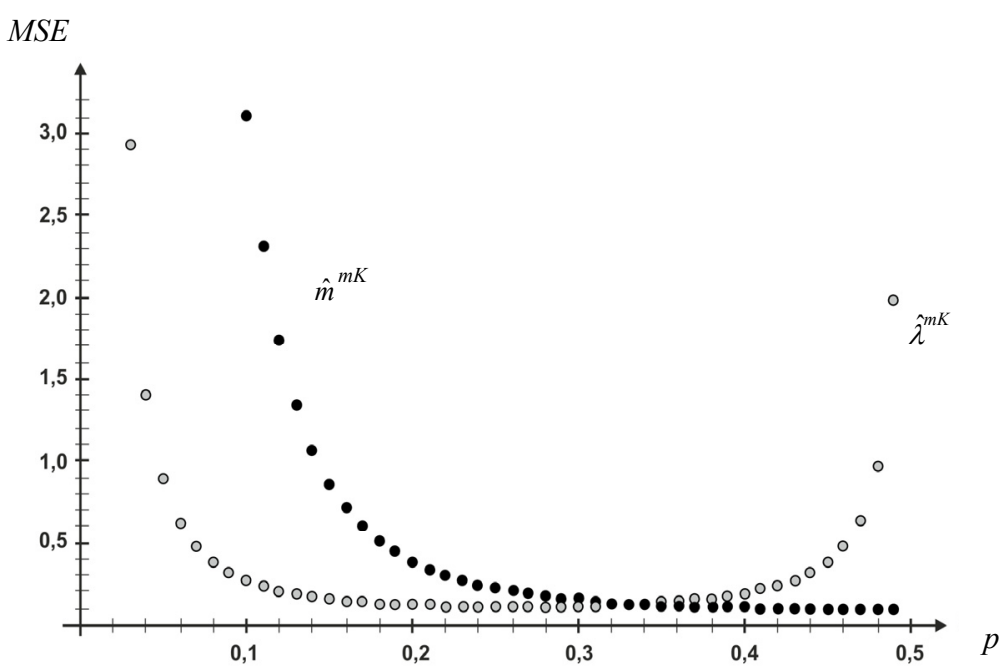

Rysunek 3.2.3. Zależność błędów średniokwadratowych estymatorów parametrów rozkładu Cauchy'ego $C a(1,2)$ od rzędów kwantyli w metodzie kwantyli

Źródło: opracowanie własne

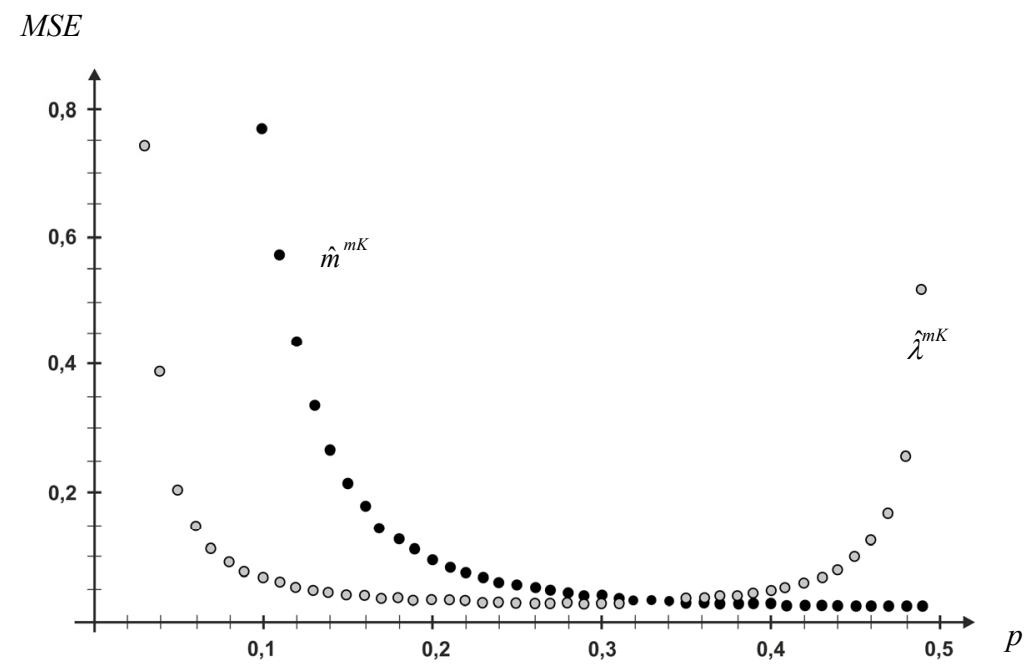

Rysunek 3.2.4. Zależność błędów średniokwadratowych estymatorów parametrów rozkładu Cauchy'ego $\mathrm{Ca}(2,1)$ od rzędów kwantyli w metodzie kwantyli

Źródło: opracowanie własne 
Tablica 3.2.3. Wartości oszacowanych obciążeń estymatorów parametrów rozkładu Pareto dla wybranych rzędów kwantyli

\begin{tabular}{|c|c|c|c|c|c|c|c|}
\hline \multirow{3}{*}{ Rozkład } & \multirow{2}{*}{$p$} & \multicolumn{2}{|c|}{$n=40$} & \multicolumn{2}{c|}{$n=60$} & \multicolumn{2}{c|}{$n=100$} \\
\cline { 3 - 8 } & & $\overline{\hat{\theta}}^{m K}-\theta$ & $\overline{\hat{a}}^{m K}-a$ & $\overline{\hat{\theta}}^{m K}-\theta$ & $\overline{\hat{a}}^{m K}-a$ & $\overline{\hat{\theta}}^{m K}-\theta$ & $\overline{\hat{a}}^{m K}-a$ \\
\hline \multirow{5}{*}{$\operatorname{Pa}(3,3)$} & 0,05 & 0,0032 & 0,4064 & 0,0023 & 0,2690 & 0,0015 & 0,1595 \\
\cline { 2 - 8 } & 0,10 & 0,0042 & 0,2983 & 0,0034 & 0,1930 & 0,0017 & 0,1138 \\
\cline { 2 - 8 } & 0,20 & 0,0056 & 0,2627 & 0,0044 & 0,1670 & 0,0020 & 0,0986 \\
\cline { 2 - 8 } & 0,30 & 0,0069 & 0,3018 & 0,0055 & 0,1979 & 0,0028 & 0,1146 \\
\cline { 2 - 8 } & 0,40 & 0,0126 & 0,5325 & 0,0102 & 0,3363 & 0,0049 & 0,1915 \\
\cline { 2 - 8 } & 0,45 & 0,0224 & 1,1193 & 0,0168 & 0,6737 & 0,0089 & 0,3662 \\
\hline \multirow{5}{*}{$P a(3,1,5)$} & 0,05 & 0,0070 & 0,1968 & 0,0052 & 0,1360 & 0,0035 & 0,0802 \\
\cline { 2 - 8 } & 0,10 & 0,0094 & 0,1433 & 0,0081 & 0,0978 & 0,0046 & 0,0592 \\
\cline { 2 - 8 } & 0,20 & 0,0141 & 0,1239 & 0,0107 & 0,0844 & 0,0081 & 0,0516 \\
\cline { 2 - 8 } & 0,30 & 0,0217 & 0,1490 & 0,0164 & 0,1005 & 0,0128 & 0,0625 \\
\cline { 2 - 8 } & 0,40 & 0,0394 & 0,2582 & 0,0277 & 0,1663 & 0,0206 & 0,1008 \\
\cline { 2 - 8 } & 0,45 & 0,7630 & 0,5500 & 0,0507 & 0,3340 & 0,0354 & 0,1890 \\
\hline \multirow{5}{*}{$\operatorname{Pa}(3,0,5)$} & 0,05 & 0,0276 & 0,0656 & 0,0184 & 0,0451 & 0,0120 & 0,0275 \\
\cline { 2 - 8 } & 0,10 & 0,0433 & 0,0482 & 0,0255 & 0,0325 & 0,0164 & 0,0193 \\
\cline { 2 - 8 } & 0,20 & 0,0860 & 0,0417 & 0,0519 & 0,0279 & 0,0269 & 0,0157 \\
\cline { 2 - 8 } & 0,30 & 0,1459 & 0,0487 & 0,0965 & 0,0327 & 0,0517 & 0,0183 \\
\cline { 2 - 7 } & 0,40 & 0,3254 & 0,0854 & 0,2178 & 0,0561 & 0,1229 & 0,0311 \\
\hline & 0,45 & 0,6472 & 0,1824 & 0,4346 & 0,1102 & 0,2543 & 0,0587 \\
\hline
\end{tabular}

Źródło: opracowanie własne.

Tablica 3.2.4. Wartości oszacowanych błędów średniokwadratowych estymatorów parametrów rozkładu Pareto dla wybranych rzędów kwantyli

\begin{tabular}{|c|c|c|c|c|c|c|c|}
\hline \multirow{3}{*}{ Rozkład } & \multirow{2}{*}{$p$} & \multicolumn{2}{|c|}{$n=40$} & \multicolumn{2}{c|}{$n=60$} & \multicolumn{2}{c|}{$n=100$} \\
\cline { 3 - 8 } & & $M \hat{S} E\left(\hat{\theta}^{m K}\right)$ & $M \hat{S} E\left(\hat{a}^{m K}\right)$ & $M \hat{S} E\left(\hat{\theta}^{m K}\right)$ & $M \hat{S} E\left(\hat{a}^{m K}\right)$ & $M \hat{S} E\left(\hat{\theta}^{m K}\right)$ & $M \hat{S} E\left(\hat{a}^{m K}\right)$ \\
\hline 1 & 2 & 3 & 4 & 5 & 6 & 7 & 8 \\
\hline \multirow{5}{*}{$\operatorname{Pa}(3,3)$} & 0,05 & 0,0014 & 0,9143 & 0,0010 & 0,5144 & 0,0006 & 0,2593 \\
\cline { 2 - 8 } & 0,10 & 0,0032 & 0,6768 & 0,0022 & 0,3868 & 0,0013 & 0,2033 \\
\cline { 2 - 8 } & 0,20 & 0,0084 & 0,6962 & 0,0057 & 0,3979 & 0,0034 & 0,2097 \\
\cline { 2 - 8 } & 0,30 & 0,0186 & 1,0189 & 0,0126 & 0,5687 & 0,0076 & 0,2971 \\
\cline { 2 - 8 } & 0,40 & 0,0476 & 2,5717 & 0,0320 & 1,3478 & 0,0193 & 0,6435 \\
\cline { 2 - 8 } & 0,45 & 0,1015 & 11,4877 & 0,0692 & 4,3676 & 0,0419 & 1,6716 \\
\hline
\end{tabular}


Tablica 3.2.4 (cd.)

\begin{tabular}{|c|c|c|c|c|c|c|c|}
\hline 1 & 2 & 3 & 4 & 5 & 6 & 7 & 8 \\
\hline \multirow{5}{*}{$P a(3,1,5)$} & 0,05 & 0,0058 & 0,2203 & 0,0039 & 0,1284 & 0,0024 & 0,0657 \\
\cline { 2 - 8 } & 0,10 & 0,0133 & 0,1652 & 0,0090 & 0,0965 & 0,0054 & 0,0521 \\
\cline { 2 - 8 } & 0,20 & 0,0356 & 0,1698 & 0,0236 & 0,0995 & 0,0140 & 0,0531 \\
\cline { 2 - 8 } & 0,30 & 0,0758 & 0,2508 & 0,0514 & 0,1419 & 0,0305 & 0,0751 \\
\cline { 2 - 8 } & 0,40 & 0,1929 & 0,6561 & 0,1293 & 0,3361 & 0,0787 & 0,1677 \\
\cline { 2 - 8 } & 0,45 & 0,4030 & 2,7572 & 0,2777 & 1,1112 & 0,1698 & 0,4361 \\
\hline \multirow{5}{*}{$P a(3,0,5)$} & 0,05 & 0,0593 & 0,0244 & 0,0376 & 0,0142 & 0,0217 & 0,0073 \\
\cline { 2 - 8 } & 0,10 & 0,1366 & 0,0183 & 0,0840 & 0,0107 & 0,0494 & 0,0056 \\
\cline { 2 - 8 } & 0,20 & 0,3730 & 0,0184 & 0,2308 & 0,0110 & 0,1320 & 0,0058 \\
\cline { 2 - 8 } & 0,30 & 0,8363 & 0,0272 & 0,5259 & 0,0157 & 0,2893 & 0,0082 \\
\cline { 2 - 8 } & 0,40 & 2,2909 & 0,0710 & 1,4272 & 0,0380 & 0,7943 & 0,0180 \\
\cline { 2 - 8 } & 0,45 & 5,5077 & 0,2919 & 3,2632 & 0,1164 & 1,8099 & 0,0454 \\
\hline
\end{tabular}

Źródło: opracowanie własne.

Parametry prezentowanych rozkładów Pareto zostały ustalone tak, aby rozkłady różniły się liczbą istniejących momentów. Pierwszy z rozkładów $P a(3,3)$ należy do grupy rozkładów Pareto posiadających wartość oczekiwaną $(E X=4,5)$ i wariancję $\left(D^{2} X=6,75\right)$, drugi $P a(3,1,5)$ reprezentuje grupę rozkładów Pareto mających tylko wartość oczekiwaną $(E X=2,25)$, natomiast trzeci $P a(3,0,5)$ nie ma ani wartości oczekiwanej, ani wariancji.

Zależności obciążeń i błędów średniokwadratowych estymatorów parametrów rozkładów Pareto $P a(3,1,5)$ i $P a(3,0,5)$ od wybranych w estymacji rzędów kwantyli, dla 100-elementowej próby, w sposób graficzny przedstawione są na rysunkach 3.2.5-3.2.8.

Na podstawie uzyskanych wyników można wnioskować, że dla wybranych populacji o rozkładzie Pareto estymatory parametru $\theta$ dla małych wartości $p$ są praktycznie nieobciążone. Oszacowane błędy średniokwadratowe estymatorów dla tych wartości $p$ też okazały się małe dla małych wartości $p$.

Przy estymacji parametru $a$ najmniejsze obciążenia uzyskano dla wartości $p$ bliskich 0,2. Oszacowane błędy średniokwadratowe otrzymano najmniejsze dla rzędów kwantyli $p \in\langle 0,1,0,2\rangle$. 
obciqżenie

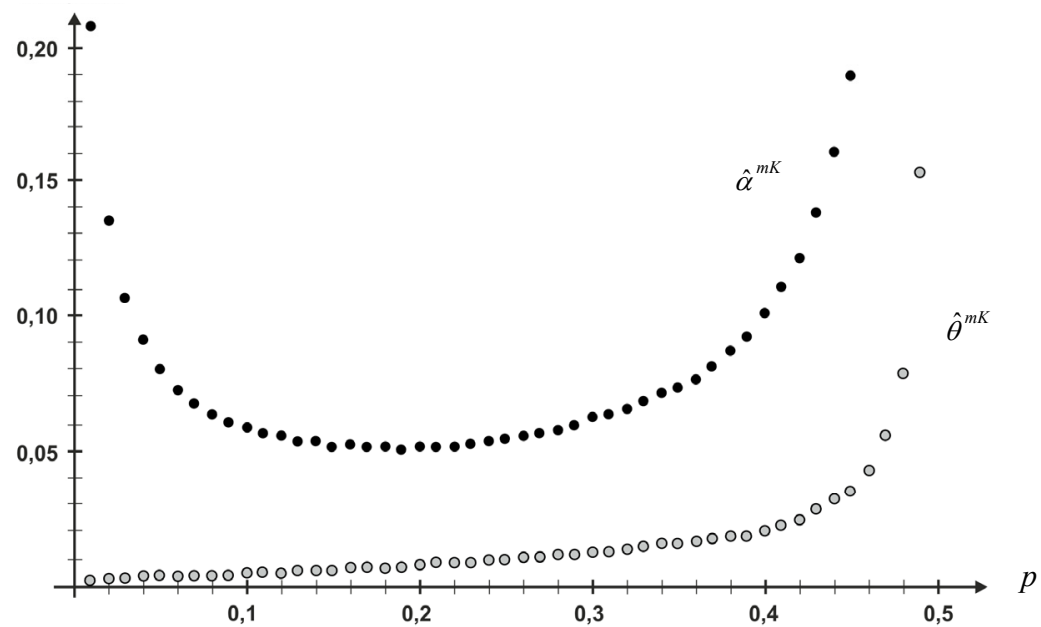

Rysunek 3.2.5. Zależność obciążeń estymatorów parametrów rozkładu Pareto $P a(3,1,5)$ od rzędów kwantyli w metodzie kwantyli Źródło: opracowanie własne

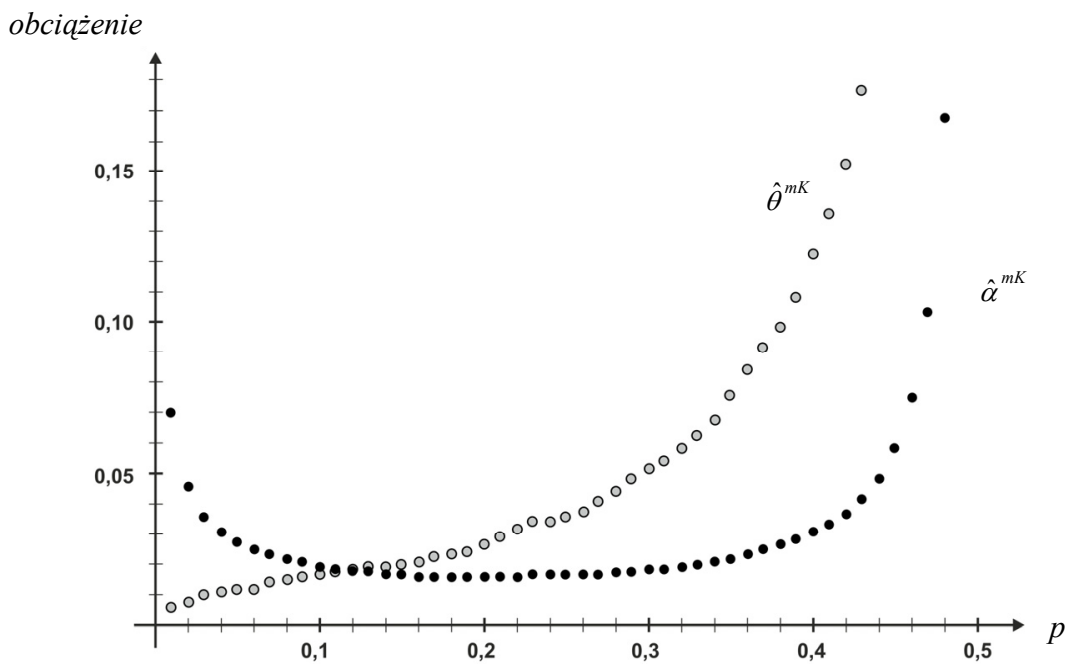

Rysunek 3.2.6. Zależność obciążeń estymatorów parametrów rozkładu Pareto $P a(3,0,5)$ od rzędów kwantyli w metodzie kwantyli Źródło: opracowanie własne 


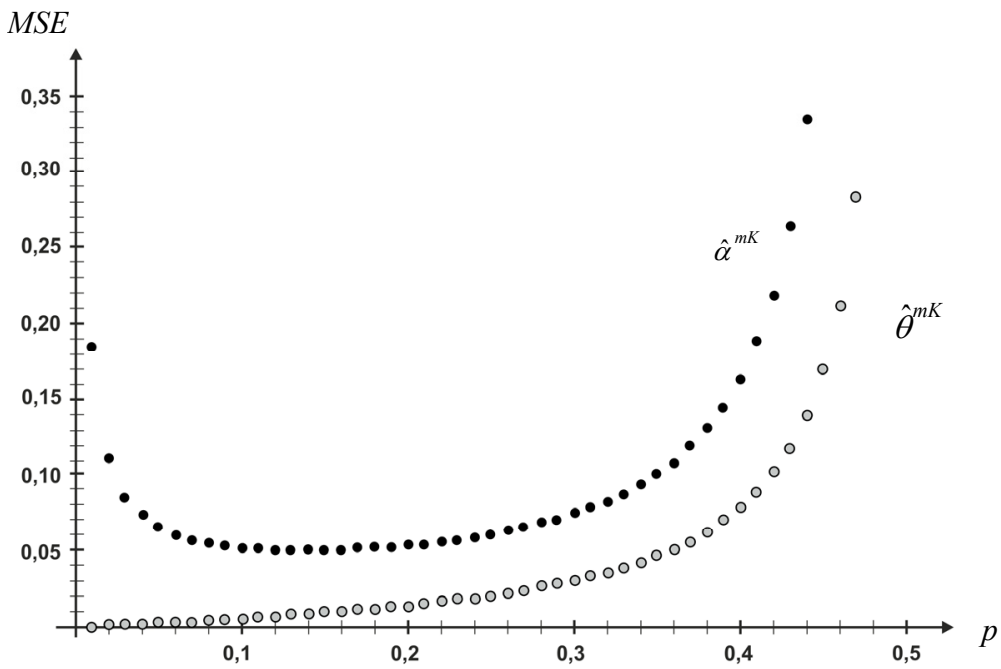

Rysunek 3.2.7. Zależność błędów średniokwadratowych estymatorów parametrów rozkładu Pareto $P a(3,1,5)$ od rzędów kwantyli w metodzie kwantyli

Źródło: opracowanie własne

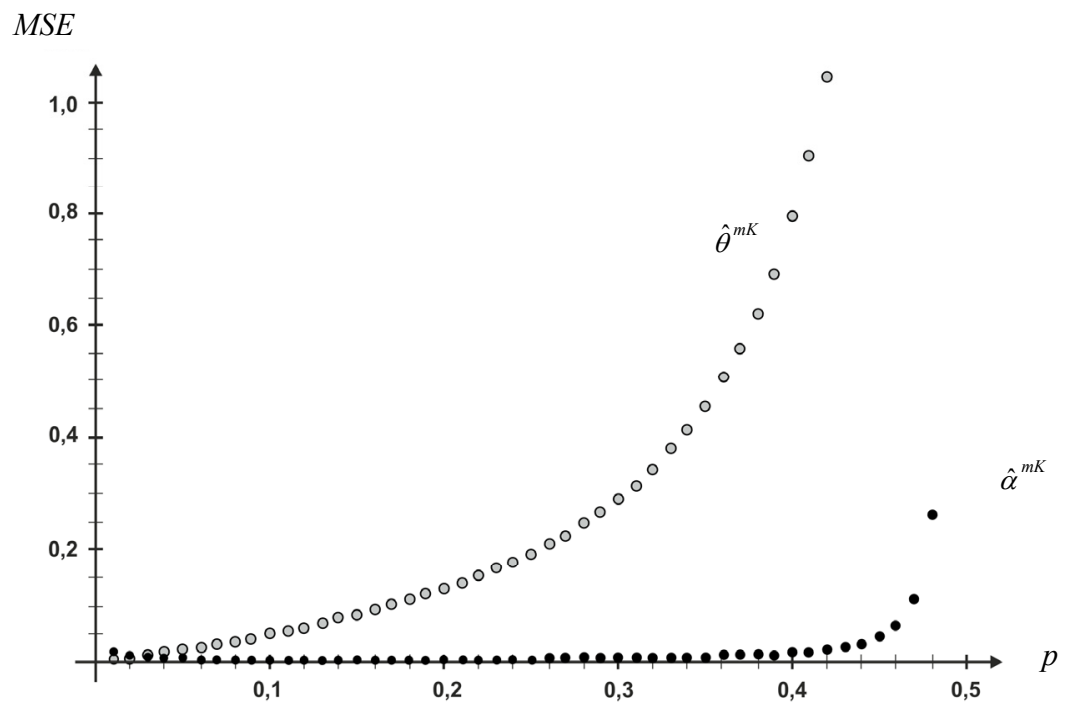

Rysunek 3.2.8. Zależność błędów średniokwadratowych estymatorów parametrów rozkładu Pareto $P a(3,0,5)$ od rzędów kwantyli w metodzie kwantyli

Źródło: opracowanie własne 
Rozkłady Cauchy'ego i Pareto należą do grupy rozkładów gruboogonowych, przy czym rozkład Cauchy'ego reprezentuje grupę rozkładów symetrycznych, a Pareto - rozkładów o asymetrii dodatniej. Dla porównania rozpatrywano również inne typy rozkładów, m.in. rozkład logistyczny, charakteryzujący się cienkimi ogonami. W tablicach 3.2.5 i 3.2.6 zamieszczone są wartości oszacowanych obciążeń i błędów średniokwadratowych estymatorów parametrów tego rozkładu otrzymanych metodami symulacyjnymi dla wybranych rzędów kwantyli i wybranych liczebności prób. Na rysunkach 3.2.9-3.2.12 graficznie zaprezentowane są wyniki przeprowadzonych analiz w przypadku estymacji parametrów w oparciu o 100-elementowe próby.

Na podstawie uzyskanych wyników można stwierdzić, że w przypadku szacowania parametrów rozkładu logistycznego nie ma tak znaczących różnic między obciążeniami i błędami średniokwadratowymi estymatorów dla poszczególnych kwantyli jak w przypadku rozkładu Cauchy'ego. Jednak daje się zauważyć, że stosowanie kwantyli rzędów $p$ i $1-p$ dla małych wartości $p$ prowadzi do oszacowań parametrów bardziej obciążonych i obarczonych większymi błędami średniokwadratowymi.

Tablica 3.2.5. Oszacowania obciążeń estymatorów parametrów rozkładu logistycznego dla wybranych rzędów kwantyli

\begin{tabular}{|c|c|c|c|c|c|c|c|}
\hline \multirow{4}{*}{ Rozkład } & \multirow{2}{*}{$p$} & \multicolumn{2}{|c|}{$n=40$} & \multicolumn{2}{c|}{$n=60$} & \multicolumn{2}{c|}{$n=100$} \\
\cline { 3 - 8 } & & $\overline{\hat{\mu}}^{m K}-\mu$ & $\overline{\hat{s}}^{m K}-s$ & $\overline{\hat{\mu}}^{m K}-\mu$ & $\overline{\hat{s}}^{m K}-s$ & $\overline{\hat{\mu}}^{m K}-\mu$ & $\overline{\hat{s}}^{m K}-s$ \\
\hline \multirow{5}{*}{ Logist $(1,3)$} & 0,05 & $-0,7868$ & 0,0266 & $-0,5251$ & 0,0052 & $-0,3025$ & 0,0027 \\
\cline { 2 - 8 } & 0,10 & $-0,4162$ & 0,0121 & $-0,2885$ & 0,0014 & $-0,1586$ & 0,0018 \\
\cline { 2 - 8 } & 0,20 & $-0,2382$ & 0,0041 & $-0,1624$ & 0,0065 & $-0,0892$ & 0,0003 \\
\cline { 2 - 8 } & 0,30 & $-0,1825$ & 0,0021 & $-0,1224$ & 0,0032 & $-0,0704$ & 0,0024 \\
\cline { 2 - 8 } & 0,40 & $-0,1589$ & 0,0102 & $-0,1105$ & 0,0060 & $-0,0611$ & 0,0070 \\
\cline { 2 - 8 } & 0,45 & $-0,1499$ & 0,0168 & $-0,1069$ & 0,0074 & $-0,0602$ & 0,0025 \\
\hline \multirow{5}{*}{ Logist(3,1) } & 0,05 & $-0,2752$ & 0,0088 & $-0,1723$ & 0,0038 & $-0,1050$ & 0,0010 \\
\cline { 2 - 8 } & 0,10 & $-0,1413$ & 0,0028 & $-0,0908$ & 0,0022 & $-0,0551$ & 0,0006 \\
\cline { 2 - 8 } & 0,20 & $-0,0817$ & 0,0016 & $-0,0512$ & 0,0014 & $-0,0312$ & 0,0005 \\
\cline { 2 - 8 } & 0,30 & $-0,0634$ & 0,0014 & $-0,0388$ & 0,0020 & $-0,0237$ & $-0,0019$ \\
\cline { 2 - 8 } & 0,40 & $-0,0545$ & $-0,0029$ & $-0,0345$ & 0,0031 & $-0,0205$ & $-0,0014$ \\
\cline { 2 - 8 } & 0,45 & $-0,0536$ & $-0,0067$ & $-0,0339$ & 0,0030 & $-0,0207$ & $-0,0007$ \\
\hline
\end{tabular}

Źródło: opracowanie własne. 
Tablica 3.2.6. Oszacowania błędów średniokwadratowych estymatorów parametrów rozkładu logistycznego dla wybranych rzędów kwantyli

\begin{tabular}{|c|c|c|c|c|c|c|c|}
\hline \multirow{3}{*}{ Rozkład } & \multirow{2}{*}{$p$} & \multicolumn{2}{|c|}{$n=40$} & \multicolumn{2}{c|}{$n=60$} & \multicolumn{2}{c|}{$n=100$} \\
\cline { 3 - 8 } & & $M \hat{S} E\left(\hat{\mu}^{m K}\right)$ & $M \hat{S} E\left(\hat{s}^{m K}\right)$ & $M \hat{S} E\left(\hat{\mu}^{m K}\right)$ & $M \hat{S} E\left(\hat{s}^{m K}\right)$ & $M \hat{S} E\left(\hat{\mu}^{m K}\right)$ & $M \hat{S} E\left(\hat{s}^{m K}\right)$ \\
\hline \multirow{4}{*}{ Logist $(1,3)$} & 0,05 & 3,8440 & 0,2681 & 2,2500 & 0,1748 & 1,1804 & 0,1034 \\
\cline { 2 - 8 } & 0,10 & 1,7453 & 0,2303 & 1,0870 & 0,1518 & 0,6083 & 0,0917 \\
\cline { 2 - 9 } & 0,20 & 0,9717 & 0,2714 & 0,6406 & 0,1793 & 0,3717 & 0,1093 \\
\cline { 2 - 9 } & 0,30 & 0,8237 & 0,4288 & 0,5533 & 0,2808 & 0,3151 & 0,1718 \\
\cline { 2 - 8 } & 0,40 & 0,8126 & 0,9417 & 0,5587 & 0,6365 & 0,3194 & 0,3895 \\
\cline { 2 - 8 } & 0,45 & 0,8590 & 2,0367 & 0,5835 & 1,3606 & 0,3359 & 0,8153 \\
\hline \multirow{5}{*}{ Logist (3, 1) } & 0,05 & 0,4449 & 0,0304 & 0,2471 & 0,0195 & 0,1327 & 0,0116 \\
\cline { 2 - 8 } & 0,10 & 0,1946 & 0,0259 & 0,1195 & 0,0172 & 0,0679 & 0,0102 \\
\cline { 2 - 8 } & 0,20 & 0,1109 & 0,0304 & 0,0703 & 0,0205 & 0,0409 & 0,0123 \\
\cline { 2 - 8 } & 0,40 & 0,0937 & 0,0473 & 0,0591 & 0,0318 & 0,0347 & 0,0192 \\
\cline { 2 - 8 } & 0,45 & 0,0922 & 0,1057 & 0,0597 & 0,0703 & 0,0351 & 0,0418 \\
\hline
\end{tabular}

Źródło: opracowanie własne.

obciqżenie

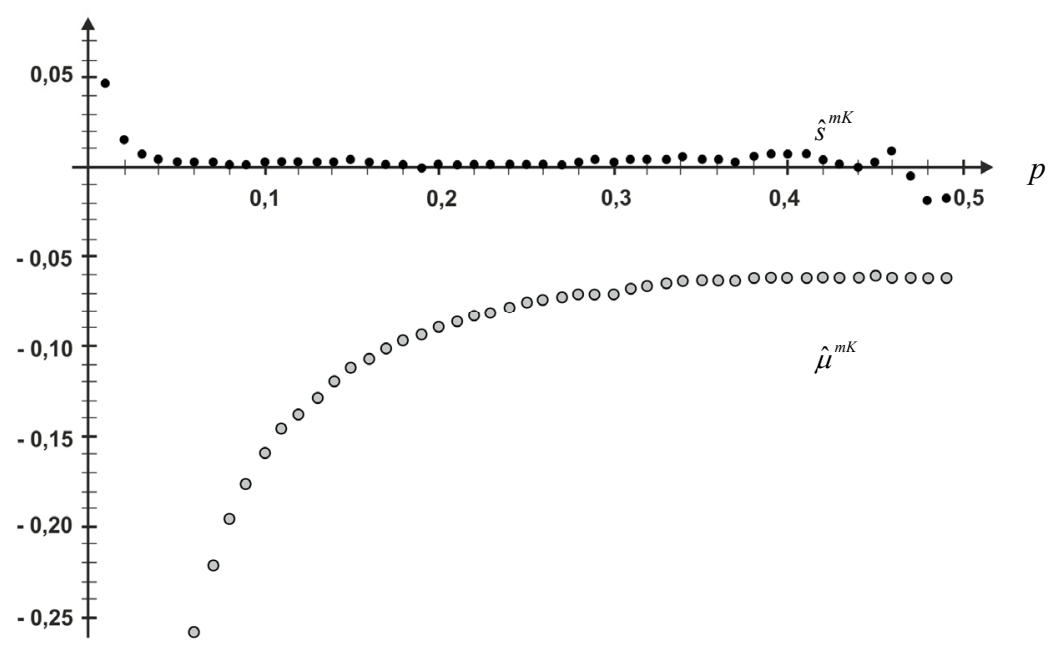

Rysunek 3.2.9. Zależność obciążeń estymatorów parametrów rozkładu logistycznego Logist $(1,3)$ od rzędów kwantyli w metodzie kwantyli

Źródło: opracowanie własne 


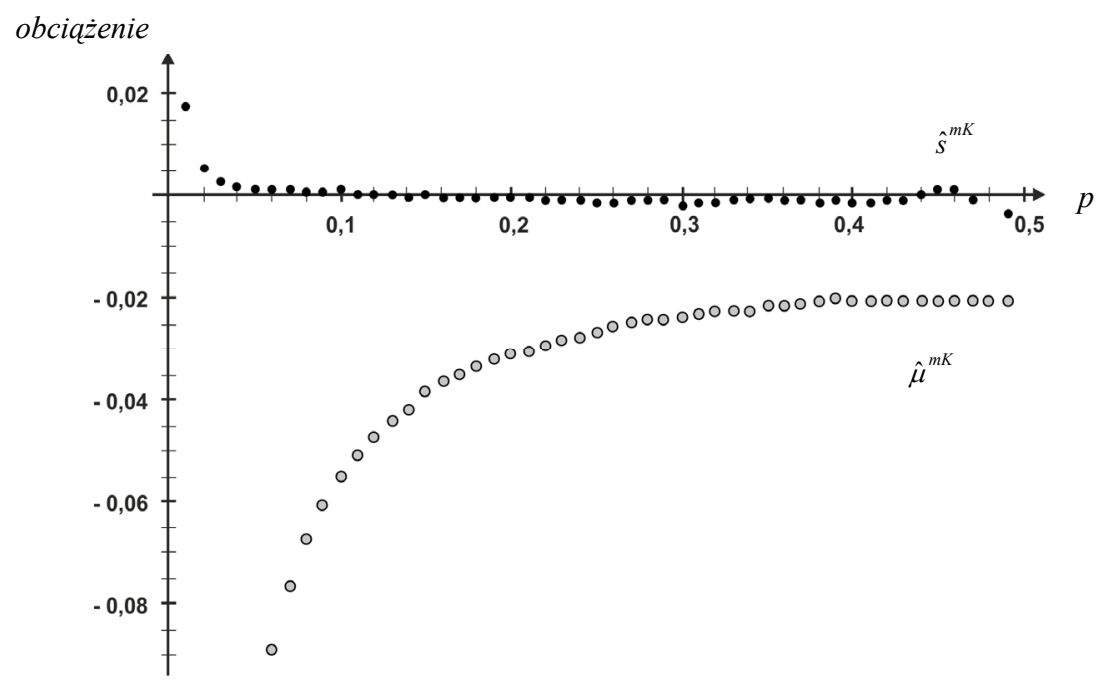

Rysunek 3.2.10. Zależność obciążeń estymatorów parametrów rozkładu logistycznego Logist $(3,1)$ od rzędów kwantyli w metodzie kwantyli

Źródło: opracowanie własne

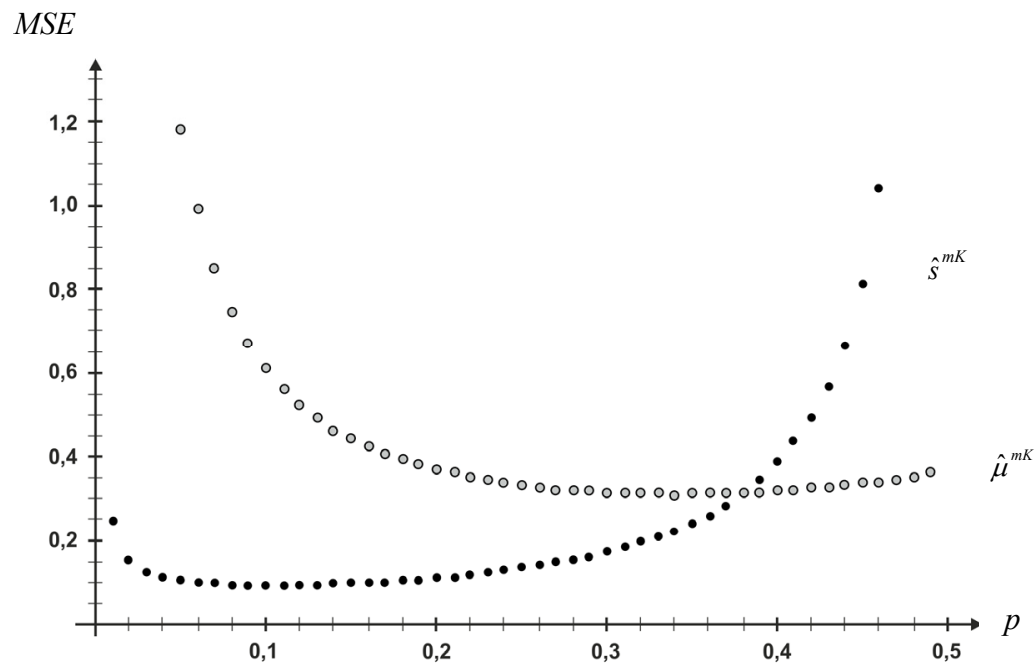

Rysunek 3.2.11. Zależność błędów średniokwadratowych estymatorów parametrów rozkładu logistycznego Logist $(1,3)$ od rzędów kwantyli w metodzie kwantyli

Źródło: opracowanie własne 


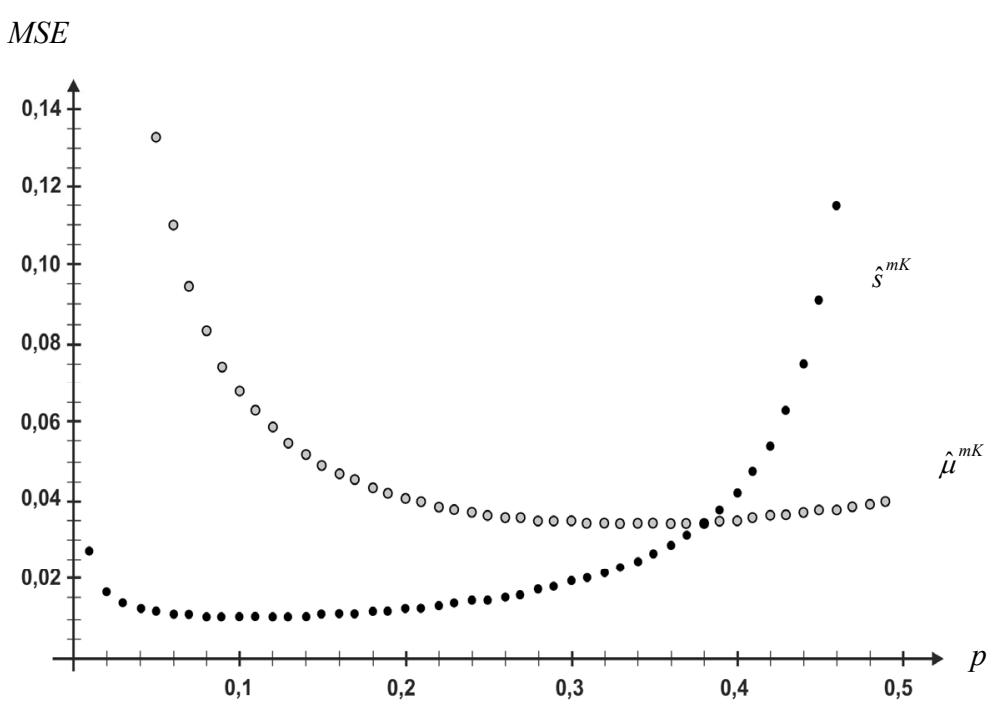

Rysunek 3.2.12. Zależność błędów średniokwadratowych estymatorów parametrów rozkładu logistycznego $\operatorname{Logist}(3,1)$ od rzędów kwantyli w metodzie kwantyli

Źródło: opracowanie własne

Estymatory parametru $s$ rozkładu logistycznego są asymptotycznie nieobciążone, zaś obciążenie estymatorów parametru $\mu$ jest dość duże dla małych liczebności prób i małych wartości $p$. Najmniejszymi błędami średniokwadratowymi charakteryzują się estymatory parametru $\mu$ dla $p \in\langle 0,3,0,4\rangle$, natomiast dla parametru $s$ dla $p \approx 0,1$.

Metodę kwantyli stosowano również do estymacji parametrów rozkładu Gumbela, powtarzając ją dla wygenerowanej populacji o rozkładzie z ustalonymi wartościami parametrów 20000 razy. Tak jak w poprzednich przypadkach szacowano obciążenia i błędy średniokwadratowe $m K$ estymatorów. Otrzymane rezultaty zaprezentowane są $w$ tablicach $3.2 .7-3.2 .8$ oraz graficznie na rysunkach 3.2.13-3.2.16 dla liczebności próby $n=100$.

W tym przypadku również dają się zauważyć pewne prawidłowości: obciążenia parametru $\lambda$ i $\delta$ maleją wraz ze wzrostem $p$, przy czym dla obydwu parametrów dość dobre wyniki są dla $p \approx 0,4$. Najmniejsze błędy średniokwadratowe estymatora parametru $\lambda$ otrzymano dla $p \in\langle 0,2,0,3\rangle$, natomiast estymatora parametru $\delta$ dla $p$ bliskich 0,1 
Tablica 3.2.7. Oszacowania obciążeń estymatorów parametrów rozkładu Gumbela dla wybranych rzędów kwantyli

\begin{tabular}{|c|c|c|c|c|c|c|c|}
\hline \multirow{4}{*}{ Rozkład } & $p$ & \multicolumn{2}{|c|}{$n=40$} & \multicolumn{2}{c|}{$n=60$} & \multicolumn{2}{c|}{$n=100$} \\
\cline { 3 - 8 } & & $\overline{\hat{\lambda}}^{m K}-\lambda$ & $\overline{\hat{\delta}}^{m K}-\delta$ & $\overline{\hat{\lambda}}^{m K}-\lambda$ & $\overline{\hat{\delta}}^{m K}-\delta$ & $\overline{\hat{\lambda}}^{m K}-\lambda$ & $\overline{\hat{\delta}}^{m K}-\delta$ \\
\hline \multirow{5}{*}{$G l(1,1)$} & 0,05 & $-0,1065$ & $-0,0415$ & $-0,0727$ & $-0,0302$ & $-0,0434$ & $-0,0181$ \\
\cline { 2 - 9 } & 0,10 & $-0,0601$ & $-0,0262$ & $-0,0401$ & $-0,0191$ & $-0,0230$ & $-0,0107$ \\
\cline { 2 - 8 } & 0,20 & $-0,0354$ & $-0,0173$ & $-0,0235$ & $-0,0130$ & $-0,0131$ & $-0,0076$ \\
\cline { 2 - 9 } & 0,30 & $-0,0283$ & $-0,0143$ & $-0,0177$ & $-0,0105$ & $-0,0097$ & $-0,0067$ \\
\cline { 2 - 8 } & 0,40 & $-0,0230$ & $-0,0150$ & $-0,0147$ & $-0,0093$ & $-0,0080$ & $-0,0052$ \\
\cline { 2 - 8 } & 0,45 & $-0,0207$ & $-0,0161$ & $-0,0141$ & $-0,0107$ & $-0,0075$ & $-0,0047$ \\
\hline \multirow{5}{*}{$G l(0,2)$} & 0,05 & $-0,2161$ & $-0,0782$ & $-0,1474$ & $-0,00583$ & $-0,0919$ & $-0,0341$ \\
\cline { 2 - 8 } & 0,10 & $-0,1234$ & $-0,0502$ & $-0,0824$ & $-0,0374$ & $-0,0516$ & $-0,0212$ \\
\cline { 2 - 8 } & 0,20 & $-0,0736$ & $-0,0315$ & $-0,0496$ & $-0,0215$ & $-0,0312$ & $-0,0120$ \\
\cline { 2 - 8 } & 0,30 & $-0,0588$ & $-0,0232$ & $-0,0398$ & $-0,0178$ & $-0,0235$ & $-0,0111$ \\
\cline { 2 - 8 } & 0,40 & $-0,0470$ & $-0,0274$ & $-0,0346$ & $-0,0187$ & $-0,0229$ & $-0,0055$ \\
\cline { 2 - 8 } & 0,45 & $-0,0463$ & $-0,0273$ & $-0,0313$ & $-0,0227$ & $-0,0235$ & $-0,0045$ \\
\hline
\end{tabular}

Źródło: opracowanie własne.

Tablica 3.2.8. Oszacowania błędów średniokwadratowych estymatorów parametrów rozkładu Gumbela dla wybranych rzędów kwantyli

\begin{tabular}{|c|c|c|c|c|c|c|c|}
\hline \multirow{3}{*}{ Rozkład } & \multirow{2}{*}{$p$} & \multicolumn{2}{|c|}{$n=40$} & \multicolumn{2}{c|}{$n=60$} & \multicolumn{2}{c|}{$n=100$} \\
\cline { 3 - 8 } & & $M \hat{S} E\left(\hat{\lambda}^{m K}\right)$ & $M \hat{S} E\left(\hat{\delta}^{m K}\right)$ & $M \hat{S} E\left(\hat{\lambda}^{m K}\right)$ & $M \hat{S} E\left(\hat{\delta}^{m K}\right)$ & $M \hat{S} E\left(\hat{\lambda}^{m K}\right)$ & $M \hat{S} E\left(\hat{\delta}^{m K}\right)$ \\
\hline \multirow{5}{*}{$G l(1,1)$} & 0,05 & 0,0840 & 0,0300 & 0,0530 & 0,0205 & 0,0298 & 0,0126 \\
\cline { 2 - 8 } & 0,10 & 0,0508 & 0,0268 & 0,0329 & 0,0185 & 0,0189 & 0,0111 \\
\cline { 2 - 8 } & 0,20 & 0,0374 & 0,0318 & 0,0245 & 0,0216 & 0,0148 & 0,0129 \\
\cline { 2 - 8 } & 0,30 & 0,0380 & 0,0481 & 0,0252 & 0,0332 & 0,0152 & 0,0198 \\
\cline { 2 - 8 } & 0,40 & 0,0480 & 0,1050 & 0,0327 & 0,0725 & 0,0193 & 0,0432 \\
\cline { 2 - 8 } & 0,45 & 0,0665 & 0,2209 & 0,0458 & 0,1534 & 0,0268 & 0,0903 \\
\hline \multirow{6}{*}{$G l(0,2)$} & 0,05 & 0,3402 & 0,1183 & 0,2124 & 0,0819 & 0,1218 & 0,0495 \\
\cline { 2 - 8 } & 0,10 & 0,2046 & 0,1067 & 0,1299 & 0,0728 & 0,0772 & 0,0440 \\
\cline { 2 - 8 } & 0,20 & 0,1513 & 0,1267 & 0,1004 & 0,0855 & 0,0591 & 0,0520 \\
\cline { 2 - 8 } & 0,30 & 0,1531 & 0,1931 & 0,1019 & 0,1321 & 0,0612 & 0,0804 \\
\cline { 2 - 8 } & 0,40 & 0,1926 & 0,4265 & 0,1307 & 0,2840 & 0,0788 & 0,1743 \\
\cline { 2 - 8 } & 0,45 & 0,2662 & 0,8960 & 0,1809 & 0,5965 & 0,1095 & 0,3674 \\
\hline
\end{tabular}

Źródło: opracowanie własne. 
obciqżenie

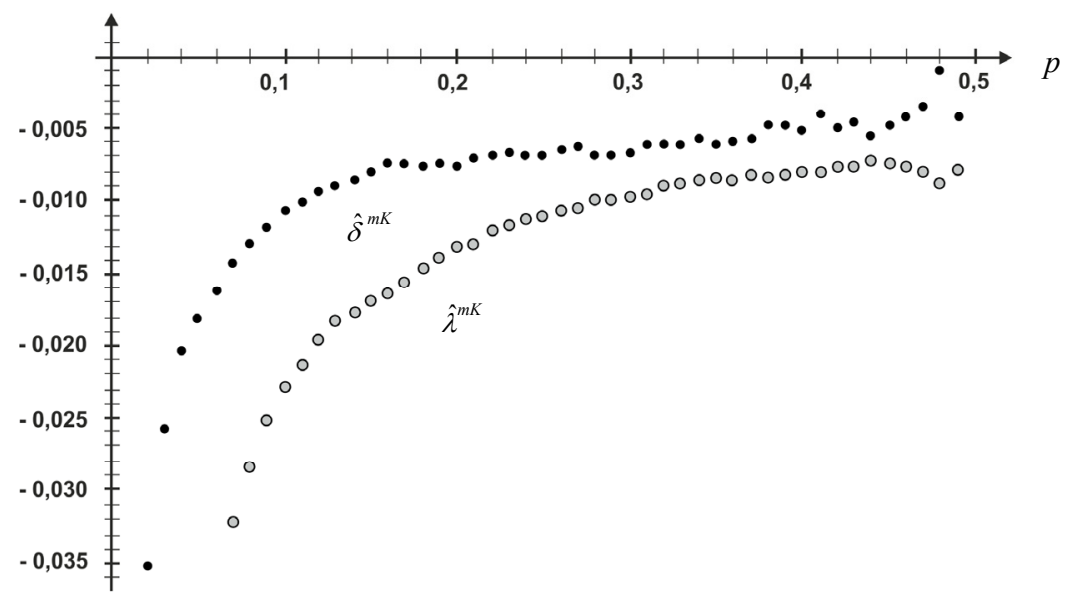

Rysunek 3.2.13. Zależność obciążeń estymatorów parametrów rozkładu Gumbela $G l(1,1)$ od rzędów kwantyli w metodzie kwantyli Źródło: opracowanie własne

obciqżenie

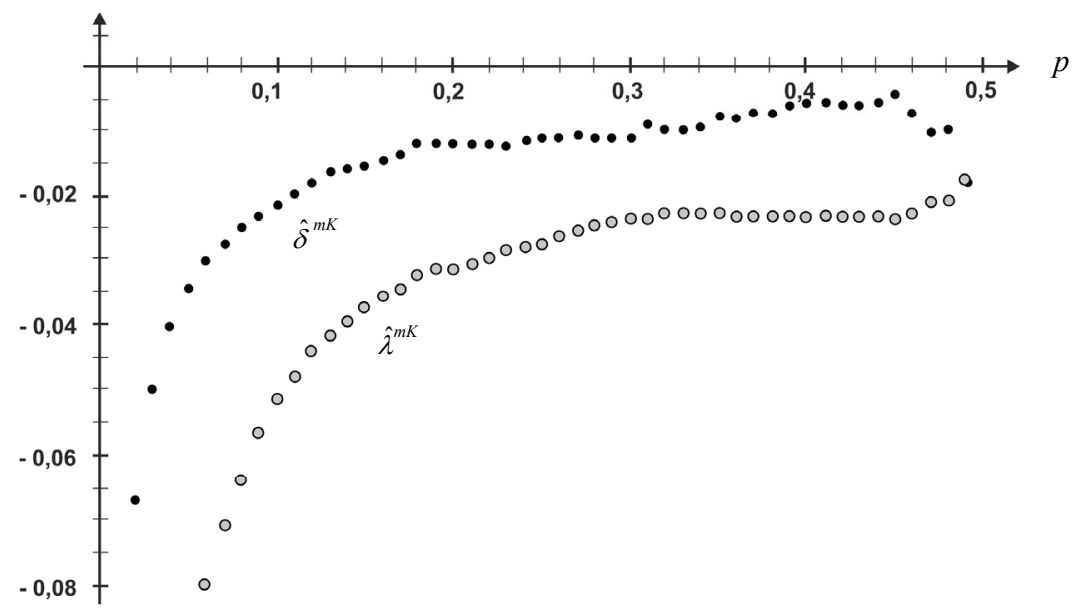

Rysunek 3.2.14. Zależność obciążeń estymatorów parametrów rozkładu Gumbela $G l(0,2)$ od rzędów kwantyli w metodzie kwantyli Źródło: opracowanie własne 


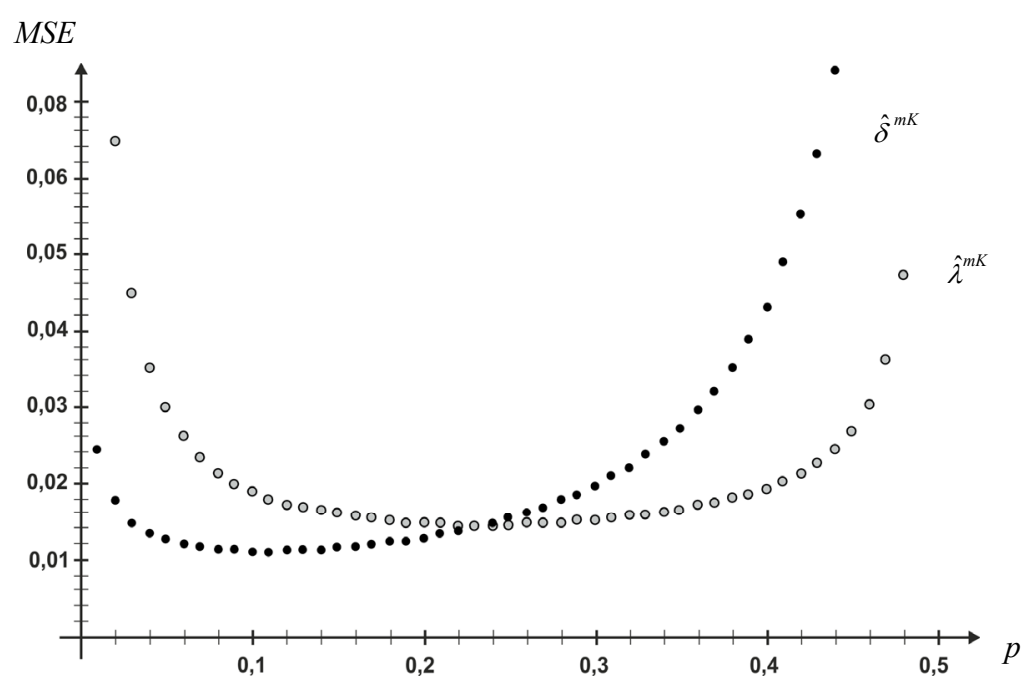

Rysunek 3.2.15. Zależność błędów średniokwadratowych estymatorów parametrów rozkładu Gumbela $G l(1,1)$ od rzędów kwantyli w metodzie kwantyli

Źródło: opracowanie własne

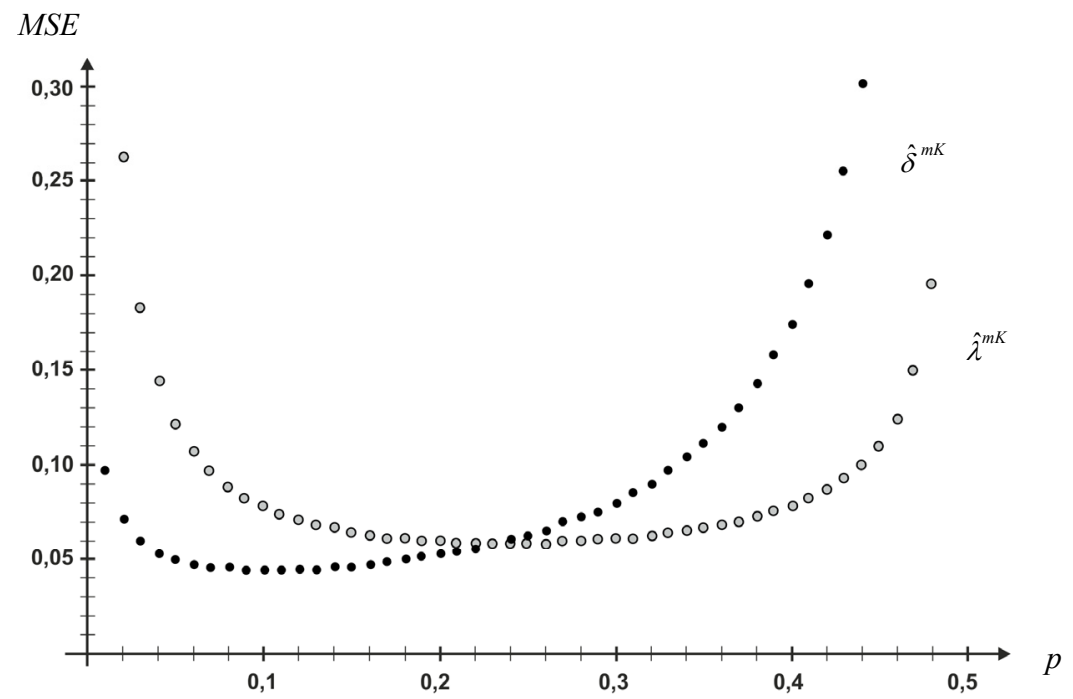

Rysunek 3.2.16. Zależność błędów średniokwadratowych estymatorów parametrów rozkładu Gumbela $G l(0,2)$ od rzędów kwantyli w metodzie kwantyli

Źródło: opracowanie własne 
W celu określenia rzędów kwantyli dających oszacowania parametrów uogólnionego rozkładu maksimum dla $\xi \neq 0$ charakteryzujące się niewielkimi obciążeniami i małymi błędami średniokwadratowymi numerycznie wyznaczano wartość estymatora parametru $\xi$, a następnie szacowano wartości parametrów $\mu$ i $\sigma$ (wzory (2.2.23), (2.2.24)). Rzędy stosowanych trzech kwantyli wybrano tak, aby spełniały warunki: $p_{1}<p_{3}<p_{2}$ oraz $p_{2}=1-p_{1}$. Własności estymatorów parametrów rozkładu otrzymanych na podstawie prób losowych o ustalonych liczebnościach, dla różnych wartości $p_{1} \in(0,01,0,49)$ oraz $p_{3}=0,5$, dla wybranych uogólnionych rozkładów maksimum przedstawiają rysunki 3.2.173.2.20. Pierwszy $\mathrm{z}$ prezentowanych rozkładów to rozkład typu Weibulla $(\xi=-0,5)$, a drugi Frécheta $(\xi=0,5)$.

Na podstawie otrzymanych rezultatów można wnioskować, że estymatory parametrów $\xi$ i $\sigma$ mają najmniejsze obciążenia dla kwantyla $p_{1} \in\langle 0,1,0,2\rangle$, natomiast estymator parametru $\mu$ dla kwantyla rzędu bliskiego $p_{1}=0,35$. Podobnie kształtowały się wielkości błędów średniokwadratowych.

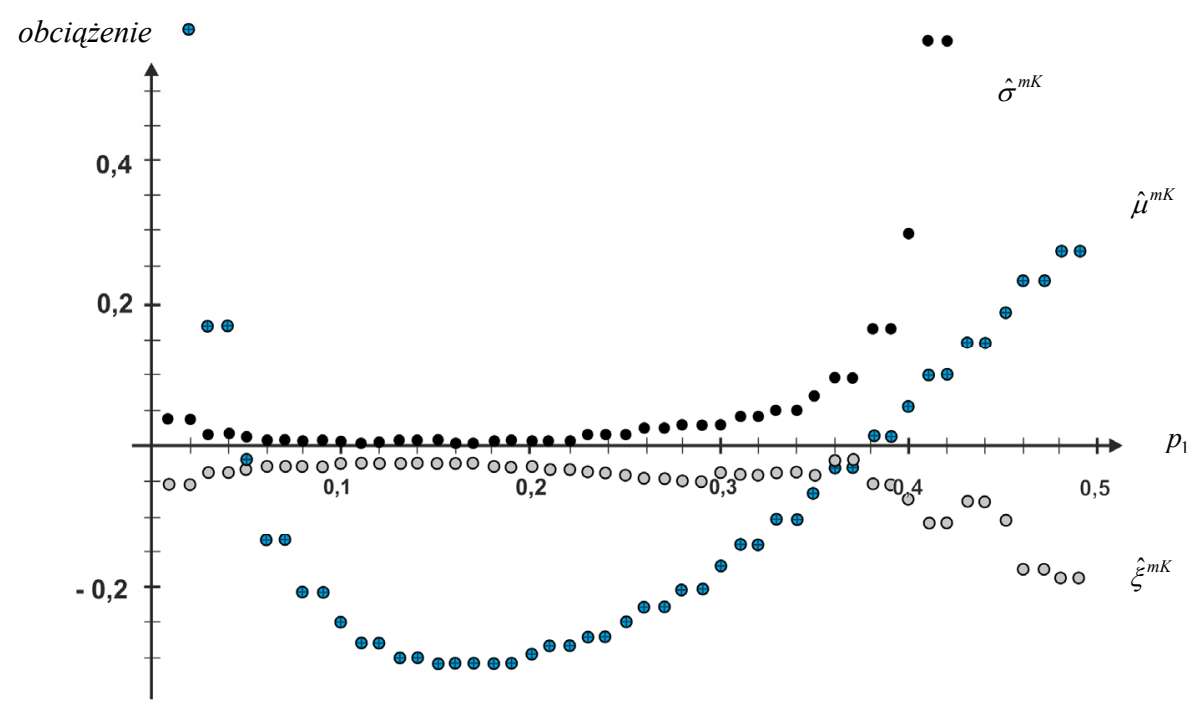

Rysunek 3.2.17. Zależność obciążeń estymatorów parametrów rozkładu $G E V D_{M}(0,1,-0,5)$ od rzędu $p_{1}$ w metodzie kwantyli

Źródło: opracowanie własne 


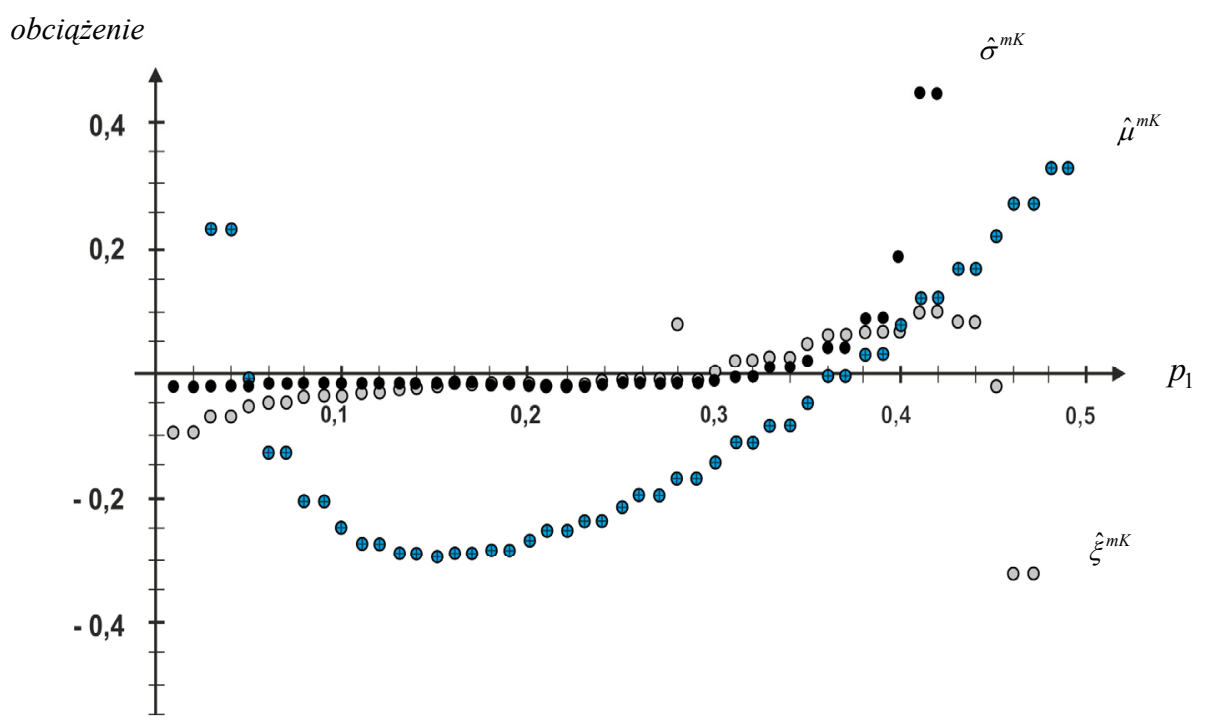

Rysunek 3.2.18. Zależność obciążeń estymatorów parametrów rozkładu $G E V D_{M}(0,1,0,5)$ od rzędu $p_{1}$ w metodzie kwantyli

Źródło: opracowanie własne

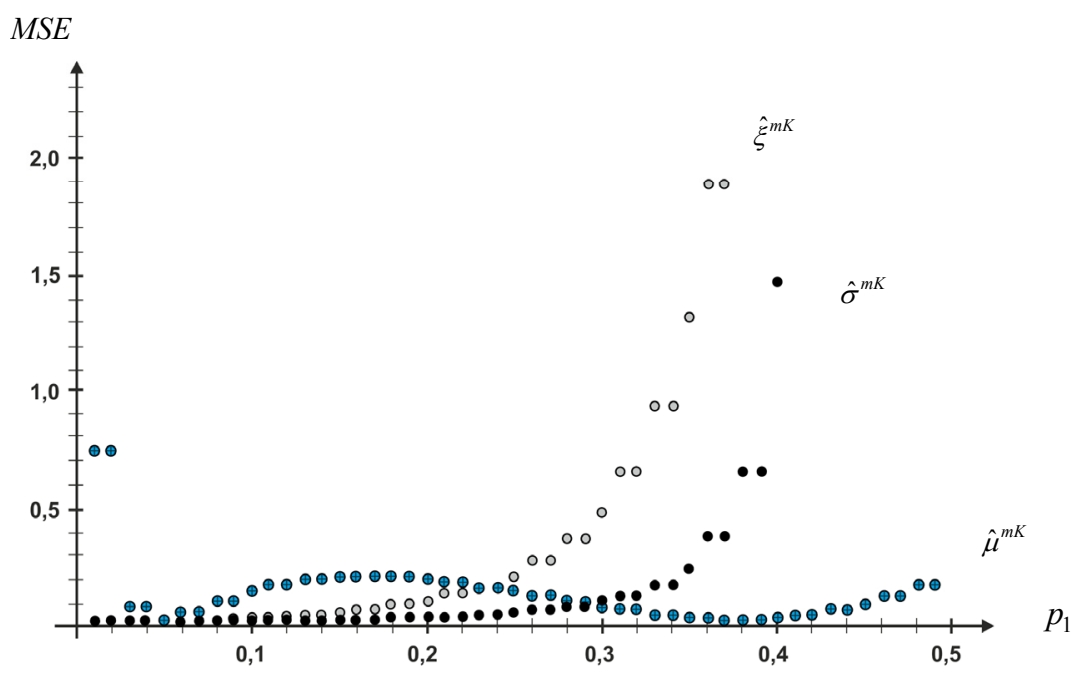

Rysunek 3.2.19. Zależność błędów średniokwadratowych estymatorów parametrów rozkładu $G E V D_{M}(0,1,-0,5)$ od rzędu $p_{1}$ w metodzie kwantyli

Źródło: opracowanie własne 


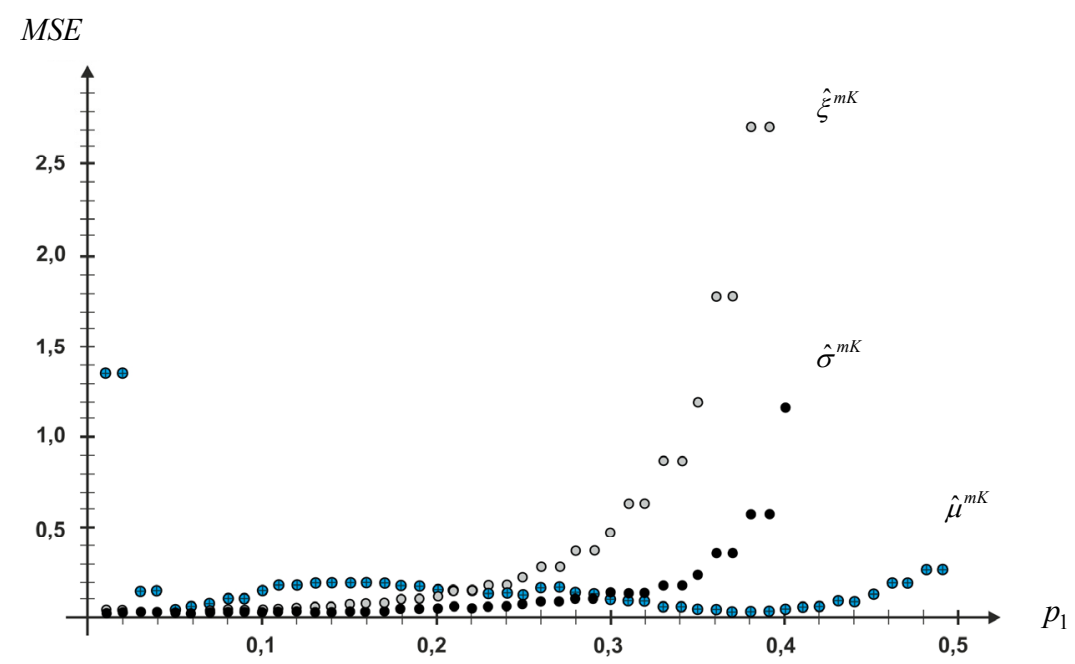

Rysunek 3.2.20. Zależność błędów średniokwadratowych estymatorów parametrów rozkładu $G E V D_{M}(0,1,0,5)$ od rzędu $p_{1}$ w metodzie kwantyli

Źródło: opracowanie własne

Wyznaczenie mediany z wartości obciążeń i błędów średniokwadratowych (wzór (2.2.25)) prowadzi do otrzymania następujących oszacowań obciążeń i błędów średniokwadratowych:

- dla $\operatorname{GEVD}_{M}(0,1,-0,5)$ :

$$
\begin{array}{ccc}
E\left(M e_{\mu}\right)-\mu=-0,128, & E\left(M e_{\xi}\right)-\xi=-0,021, & E\left(M e_{\sigma}\right)-\sigma=-0,002, \\
M S E\left(M e_{\mu}\right)=0,223, & M S E\left(M e_{\xi}\right)=0,391, & M S E\left(M e_{\sigma}\right)=0,197, \\
- \text { dla } G E V D_{M}(0,1,0,5): & \\
E\left(M e_{\mu}\right)-\mu=-0,124, & E\left(M e_{\xi}\right)-\xi=0,031, & E\left(M e_{\sigma}\right)-\sigma=0,005, \\
\operatorname{MSE}\left(M e_{\mu}\right)=0,211, & \operatorname{MSE}\left(M e_{\xi}\right)=0,390, & \operatorname{MSE}\left(M e_{\sigma}\right)=0,238 .
\end{array}
$$

Z przeprowadzonych badań wynika, że dla każdej z rozważanych klas rozkładów dało się ustalić, w sposób analityczny albo symulacyjny, rangi statystyk pozycyjnych dających „dobre” oszacowania parametrów tych rozkładów, przy 
zastosowaniu metody kwantyli. Okazuje się, że rzędy kwantyli pozwalających uzyskać małe obciążenia i małe błędy średniokwadratowe są zwykle różne dla każdego z parametrów rozkładu.

Dla innych klas rozkładów analogicznie można przeprowadzić badania dotyczące zależności własności estymatorów od rzędów stosowanych kwantyli i dokonać ich wyboru tak, aby otrzymać estymatory o małym obciążeniu, a nawet asymptotycznie nieobciążone i charakteryzujące się małym błędem średniokwadratowym.

Idea metody kwantyli nie jest skomplikowana i nawet bez oprogramowania komputerowego można oszacować parametry rozkładów zmiennych losowych. Jest szczególnie przydatna przy szacowaniu parametrów rozkładów, w przypadku gdy inne metody okazują się zawodne.

\subsection{Symulacyjne badania własności estymatorów otrzymanych kwantylową metodą najmniejszych kwadratów z uciętą liczbą kwantyli}

Analiza własności estymatorów parametrów rozkładu zmiennej losowej otrzymanych w wyniku zastosowania autorskiej propozycji - kwantylowej metody najmniejszych kwadratów z uciętą liczbą kwantyli - związana była z badaniem zależności obciążeń i błędów średniokwadratowych estymatorów od $k$-liczby pomijanych kwantyli oraz sposobu ich wyboru.

Dla rozkładów symetrycznych w estymacji nie brano pod uwagę $s=0,5 k$ kwantyli o najmniejszych wartościach i $s=0,5 k$ o wartościach największych.

Badania własności estymatorów parametrów rozkładów symetrycznych typu Cauchy'ego, logistycznego i Gumbela otrzymanych proponowaną metodą przeprowadzone zostały symulacyjnie. Rozpatrywano wykorzystanie $n-k$ statystyk pozycyjnych, gdzie $k$ jest ustaloną liczbą ze zbioru $\{2,4, \ldots, n-2\}$.

Procedurę estymacji parametrów populacji o rozkładzie $C a(m, \lambda)$ powtórzono 20000 razy. Oszacowane obciążenia i błędy średniokwadratowe estymatorów, uzyskane rozważaną metodą dla wybranych wartości $k$ oraz ustalonych liczebności prób $n$, zawarte są w tablicy 3.3.1, natomiast na rysunkach 3.3.13.3.4 przedstawione są zależności tych wielkości dla wszystkich możliwych wartości $s$ i liczebności próby $n$.

Ze względu na nieskończoną wariancję statystyk ekstremalnych nieuwzględnienie ich w estymacji prowadzi do otrzymania estymatorów o lepszych własno- 
ściach, o mniejszym obciążeniu i znacznie mniejszych błędach średniokwadratowych. $\mathrm{Z}$ otrzymanych rezultatów wynika, że wraz ze wzrostem $k$ maleje wartość bezwzględna obciążenia estymatorów parametrów rozkładu Cauchy'ego. Również błędy średniokwadratowe maleją, ale dla estymatora parametru $\lambda$ od pewnej wartości $k$ zauważa się wzrost błędu średniokwadratowego. Przy zastosowaniu uciętej kwantylowej metody najmniejszych kwadratów, podobnie jak w przypadku metody kwantyli, istotne znaczenie ma ustalenie rzędów wykorzystywanych kwantyli.

Tablica 3.3.1. Oszacowane obciążenia i błędy średniokwadratowe estymatorów parametrów wybranych rozkładów $\mathrm{Ca}(m, \lambda)$ otrzymanych $u K m n k$

\begin{tabular}{|c|c|c|c|c|c|c|}
\hline Rozkład & $n$ & $k$ & $\overline{\hat{m}}^{u K m n k}-m$ & $M \hat{S} E\left(\hat{m}^{u K m n k}\right)$ & $\overline{\hat{\lambda}}^{u K m n k}-\lambda$ & $M \hat{S} E\left(\hat{\lambda}^{u K m n k}\right)$ \\
\hline 1 & 2 & 3 & 4 & 5 & 6 & 7 \\
\hline \multirow{18}{*}{$\mathrm{Ca}(1,2)$} & \multirow{6}{*}{40} & 2 & $-0,8079$ & 8,2269 & 0,3638 & 5,7062 \\
\hline & & 8 & $-0,2086$ & 0,6889 & 0,1598 & 0,4507 \\
\hline & & 14 & $-0,1310$ & 0,3897 & 0,1097 & 0,2995 \\
\hline & & 20 & $-0,1025$ & 0,3000 & 0,0884 & 0,2918 \\
\hline & & 28 & $-0,0862$ & 0,2608 & 0,0745 & 0,4222 \\
\hline & & 34 & $-0,0810$ & 0,5996 & 0,0667 & 0,8660 \\
\hline & \multirow{6}{*}{60} & 2 & $-0,7803$ & 7,2382 & 0,3419 & 5,0034 \\
\hline & & 10 & $-0,1656$ & 0,4986 & 0,1244 & 0,3043 \\
\hline & & 20 & $-0,0951$ & 0,2552 & 0,0782 & 0,1867 \\
\hline & & 30 & $-0,0719$ & 0,1924 & 0,0629 & 0,1871 \\
\hline & & 40 & $-0,0618$ & 0,1706 & 0,0577 & 0,2494 \\
\hline & & 50 & $-0,0571$ & 0,1678 & 0,0560 & 0,4929 \\
\hline & \multirow{6}{*}{100} & 2 & $-0,7473$ & 6,3993 & 0,3187 & 6,7075 \\
\hline & & 10 & $-0,1453$ & 0,4568 & 0,1110 & 0,2535 \\
\hline & & 30 & $-0,0556$ & 0,1523 & 0,0483 & 0,1022 \\
\hline & & 50 & $-0,0388$ & 0,1074 & 0,0359 & 0,1012 \\
\hline & & 70 & $-0,0324$ & 0,0957 & 0,0311 & 0,1518 \\
\hline & & 90 & $-0,0292$ & 0,0975 & 0,0285 & 0,4696 \\
\hline \multirow{6}{*}{$\mathrm{Ca}(2,1)$} & \multirow{6}{*}{40} & 2 & $-0,3963$ & 2,1285 & 0,1985 & 2,5736 \\
\hline & & 8 & $-0,1037$ & 0,1736 & 0,0845 & 0,1172 \\
\hline & & 14 & $-0,0661$ & 0,0992 & 0,0597 & 0,0775 \\
\hline & & 20 & $-0,0522$ & 0,0764 & 0,0487 & 0,0753 \\
\hline & & 28 & $-0,0442$ & 0,0667 & 0,0407 & 0,1067 \\
\hline & & 34 & $-0,0413$ & 0,0665 & 0,0361 & 0,2136 \\
\hline
\end{tabular}


Tablica 3.3.1 (cd.)

\begin{tabular}{|c|c|c|c|c|c|c|}
\hline 1 & 2 & 3 & 4 & 5 & 6 & 7 \\
\hline \multirow{5}{*}{6} & 2 & $-0,3819$ & 1,6574 & 0,1724 & 1,9712 \\
\cline { 3 - 7 } & \multirow{4}{*}{60} & 10 & $-0,0775$ & 0,1245 & 0,0638 & 0,0759 \\
\cline { 3 - 7 } & & 20 & $-0,0429$ & 0,0636 & 0,0404 & 0,0466 \\
\cline { 3 - 7 } & & 30 & $-0,0323$ & 0,0480 & 0,0326 & 0,0455 \\
\cline { 3 - 7 } & & 40 & $-0,0276$ & 0,0425 & 0,0290 & 0,0597 \\
\cline { 3 - 7 } & & 50 & $-0,0275$ & 0,0421 & 0,0296 & 0,1209 \\
\cline { 3 - 7 } & \multirow{4}{*}{100} & 2 & $-0,3764$ & 1,4838 & 0,1564 & 1,0038 \\
\cline { 3 - 7 } & & 10 & $-0,0728$ & 0,1146 & 0,0575 & 0,0639 \\
\cline { 3 - 7 } & & 30 & $-0,0287$ & 0,0391 & 0,0264 & 0,0261 \\
\cline { 3 - 7 } & & 50 & $-0,0209$ & 0,0280 & 0,0192 & 0,0256 \\
\cline { 3 - 7 } & & 70 & $-0,0184$ & 0,0248 & 0,0170 & 0,0382 \\
\cline { 3 - 7 } & 90 & $-0,0170$ & 0,0252 & 0,0167 & 0,1207 \\
\hline
\end{tabular}

Źródło: opracowanie własne.

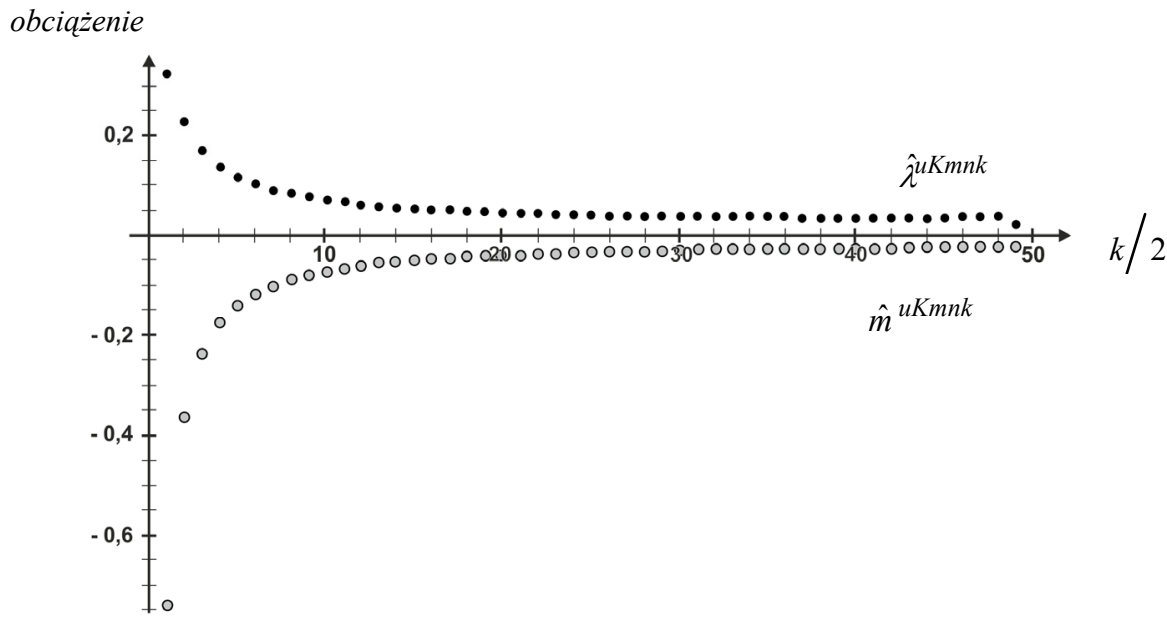

Rysunek 3.3.1. Zależność obciążeń estymatorów parametrów rozkładu $C a(1,3)$ od liczby pomijanych kwantyli w metodzie $u K m n k$ 


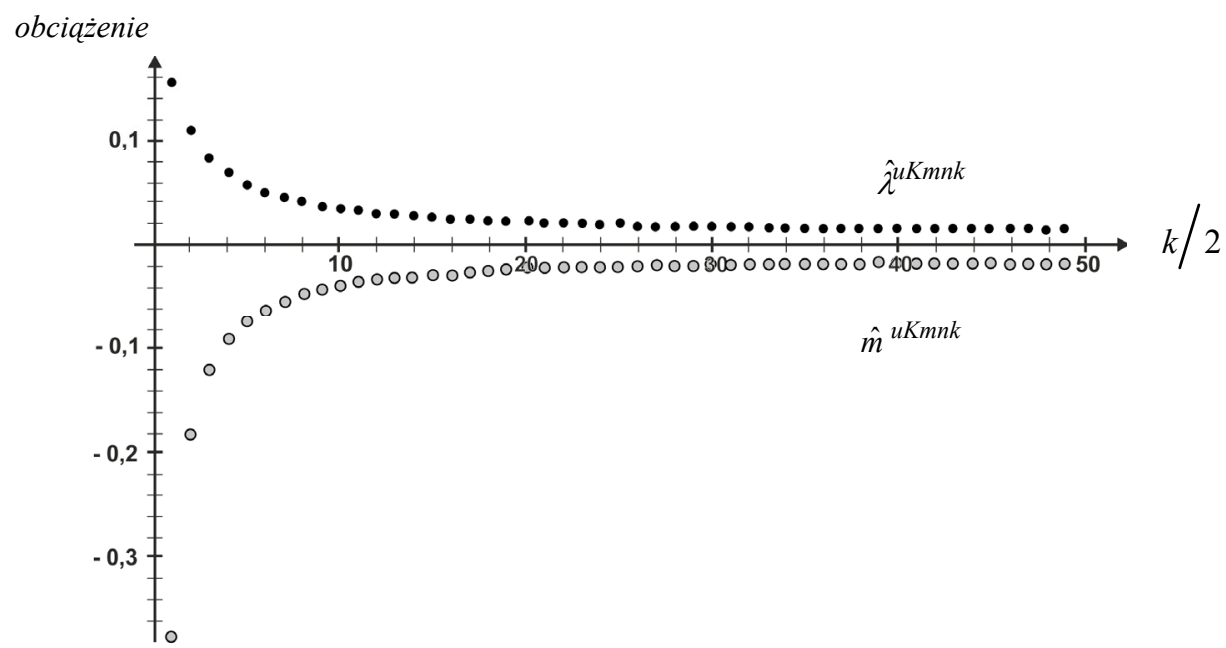

Rysunek 3.3.2. Zależność obciążeń estymatorów parametrów rozkładu $C a(3,1)$ od liczby pomijanych kwantyli Źródło: opracowanie własne

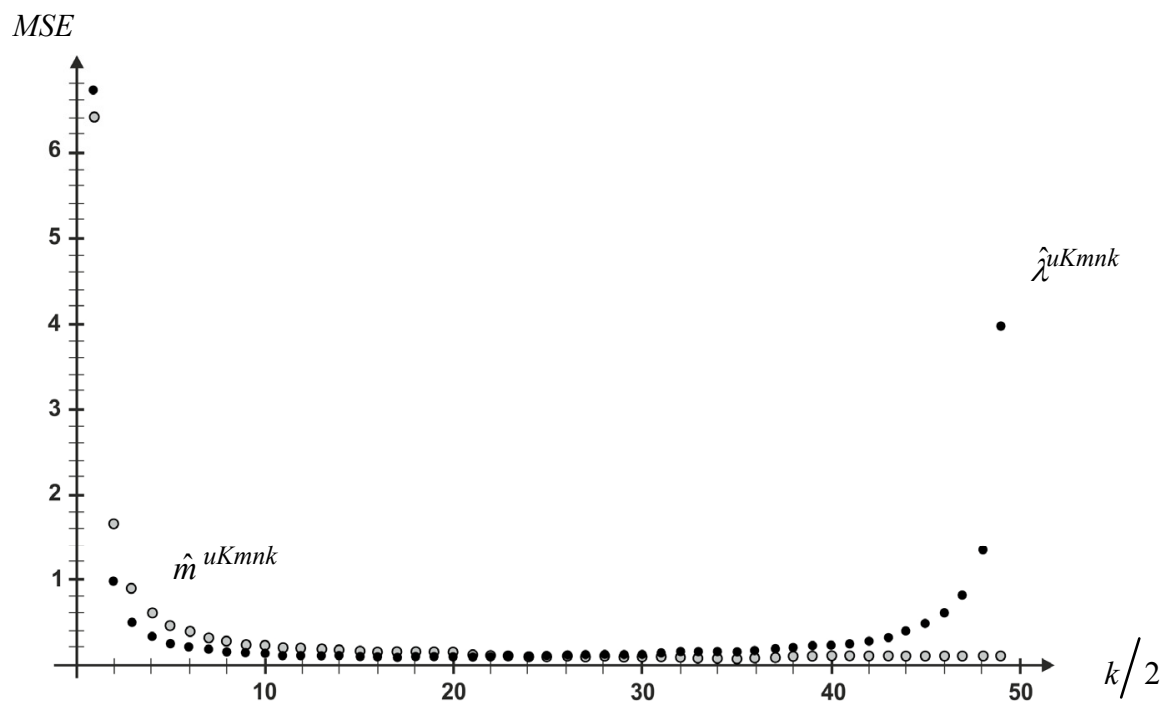

Rysunek 3.3.3. Zależność błędów średniokwadratowych estymatorów parametrów rozkładu $C a(1,3)$ od liczby pomijanych kwantyli w metodzie $u K m n k$

Źródło: opracowanie własne 


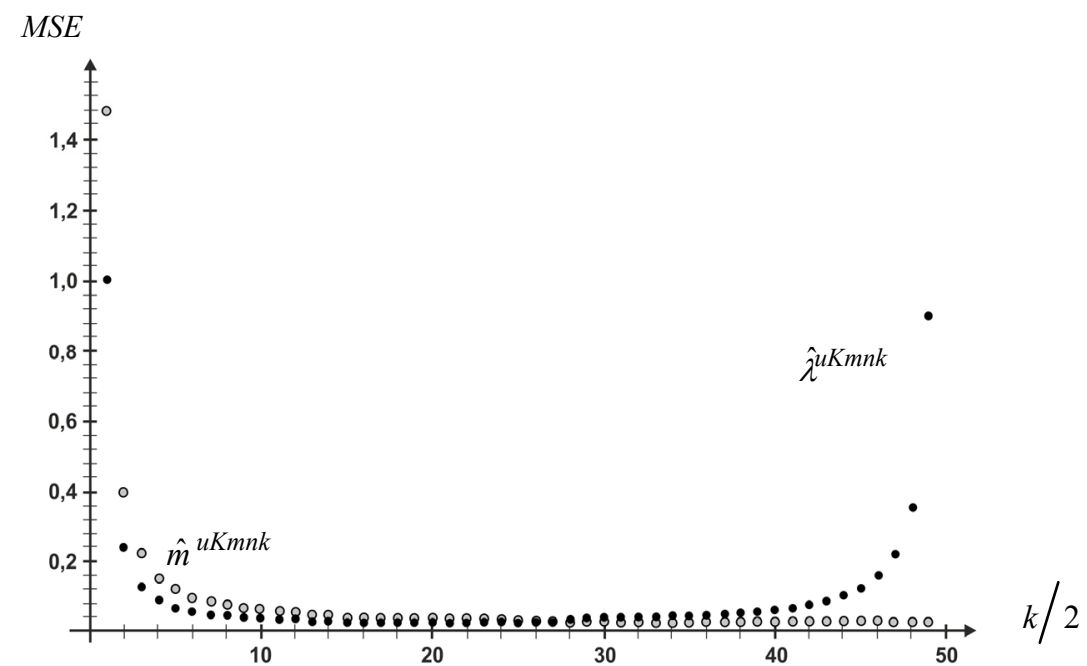

Rysunek 3.3.4. Zależność błędów średniokwadratowych estymatorów parametrów rozkładu $C a(3,1)$ od liczby pomijanych kwantyli w metodzie $u K m n k$

Źródło: opracowanie własne

Innym rozważanym rozkładem, którego parametry szacowane były kwantylową metodą najmniejszych kwadratów z uciętą liczbą kwantyli, był rozkład logistyczny $\operatorname{Logist}(\mu, s)$. Wyniki analiz własności estymatorów parametrów tego rozkładu o wybranych parametrach dla ustalonych liczebności prób i wielkości $k$ są zawarte w tablicy 3.3.2 oraz zaprezentowane na rysunkach 3.3.5-3.3.8.

W przypadku szacowania parametrów rozkładu logistycznego własności estymatorów zależą od ustalonej wielkości $k$ w sposób mniej istotny niż przy szacowaniu parametrów rozkładu Cauchy'ego. Estymator parametru $s$ rozkładu logistycznego charakteryzuje się bardzo małym obciążeniem, a dla pewnych wartości $k$ można uznać, że jest nieobciążony (dla bliskich $0,5 n$ ). Estymator parametru $\mu$ jest ujemnie obciążony i wartość bezwzględna jego obciążenia maleje wraz ze wzrostem $k$. Błąd średniokwadratowy parametru $s$ jest najmniejszy dla małych wartości $k$, zaś dla parametru $\mu$ jest w przybliżeniu jednakowy dla każdej wartości $k$. 
Tablica 3.3.2. Oszacowane obciążenia i błędy średniokwadratowe estymatorów parametrów wybranych rozkładów logistycznych otrzymanych $u K m n k$

\begin{tabular}{|c|c|c|c|c|c|c|}
\hline Rozkład & $n$ & $k$ & $\overline{\hat{\mu}}^{u K m n k}-\mu$ & $M \hat{S} E\left(\hat{\mu}^{u K m n k}\right)$ & $\overline{\hat{s}}^{u K m n k}-S$ & $M \hat{S} E\left(\hat{s}^{u K m n k}\right)$ \\
\hline \multirow{6}{*}{ Logist $(1,3)$} & \multirow{6}{*}{40} & 2 & $-0,2926$ & 0,8774 & $-0,0341$ & 0,1666 \\
\hline & & 8 & $-0,2106$ & 0,7719 & $-0,0043$ & 0,2052 \\
\hline & & 14 & $-0,1848$ & 0,7602 & $-0,0002$ & 0,2732 \\
\hline & & 20 & $-0,1714$ & 0,7761 & 0,0006 & 0,3852 \\
\hline & & 28 & $-0,1616$ & 0,8244 & $-0,0002$ & 0,7215 \\
\hline & & 34 & $-0,1579$ & 0,8843 & 0,0033 & 1,6726 \\
\hline \multirow{12}{*}{ Logist $(1,3)$} & \multirow{6}{*}{60} & 2 & $-0,2113$ & 0,5684 & $-0,0264$ & 0,1088 \\
\hline & & 10 & $-0,1462$ & 0,5030 & $-0,0055$ & 0,1274 \\
\hline & & 20 & $-0,1232$ & 0,4963 & $-0,0032$ & 0,1713 \\
\hline & & 30 & $-0,1119$ & 0,5086 & $-0,0022$ & 0,2518 \\
\hline & & 40 & $-0,1055$ & 0,5337 & $-0,0034$ & 0,4189 \\
\hline & & 50 & $-0,1016$ & 0,5716 & $-0,0115$ & 0,9467 \\
\hline & \multirow{6}{*}{100} & 2 & $-0,1402$ & 0,3245 & $-0,0140$ & 0,0662 \\
\hline & & 10 & $-0,0986$ & 0,2944 & $-0,0008$ & 0,0705 \\
\hline & & 30 & $-0,0748$ & 0,2843 & 0,0012 & 0,0976 \\
\hline & & 50 & $-0,0663$ & 0,2933 & 0,0023 & 0,1509 \\
\hline & & 70 & $-0,0621$ & 0,3129 & 0,0062 & 0,2838 \\
\hline & & 90 & $-0,0594$ & 0,3456 & 0,0070 & 0,9999 \\
\hline \multirow{18}{*}{$\operatorname{Logist}(3,1)$} & \multirow{6}{*}{40} & 2 & $-0,0925$ & 0,0967 & $-0,0122$ & 0,0183 \\
\hline & & 8 & $-0,0657$ & 0,0855 & $-0,0028$ & 0,0224 \\
\hline & & 14 & $-0,0567$ & 0,0842 & $-0,0009$ & 0,0297 \\
\hline & & 20 & $-0,0516$ & 0,0858 & 0,0008 & 0,0420 \\
\hline & & 28 & $-0,0477$ & 0,0911 & 0,0011 & 0,0813 \\
\hline & & 34 & $-0,0459$ & 0,0976 & 0,0003 & 0,1904 \\
\hline & \multirow{6}{*}{60} & 2 & $-0,0720$ & 0,0620 & $-0,0077$ & 0,0123 \\
\hline & & 10 & $-0,0497$ & 0,0545 & $-0,0011$ & 0,0144 \\
\hline & & 20 & $-0,0419$ & 0,0535 & $-0,0001$ & 0,0195 \\
\hline & & 30 & $-0,0383$ & 0,0547 & 0,0002 & 0,0283 \\
\hline & & 40 & $-0,0363$ & 0,0573 & 0,0003 & 0,0473 \\
\hline & & 50 & $-0,0353$ & 0,0617 & $-0,0015$ & 0,1082 \\
\hline & \multirow{6}{*}{100} & 2 & $-0,0489$ & 0,0369 & $-0,0048$ & 0,0073 \\
\hline & & 10 & $-0,0350$ & 0,0333 & $-0,0006$ & 0,0078 \\
\hline & & 30 & $-0,0269$ & 0,0318 & 0,0006 & 0,0107 \\
\hline & & 50 & $-0,0241$ & 0,0328 & 0,0008 & 0,0169 \\
\hline & & 70 & $-0,0227$ & 0,0350 & 0,0019 & 0,0321 \\
\hline & & 90 & $-0,0215$ & 0,0386 & 0,0037 & 0,1161 \\
\hline
\end{tabular}

Źródło: opracowanie własne. 
obciqżenie

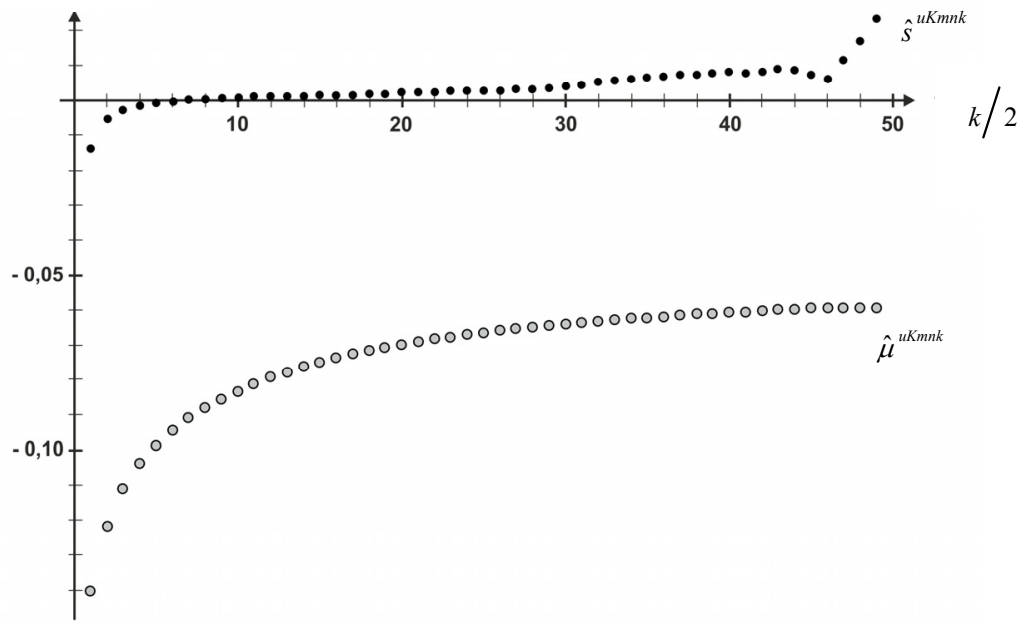

Rysunek 3.3.5. Zależność obciążeń estymatorów parametrów rozkładu Logist $(1,3)$ od liczby pomijanych kwantyli w metodzie $u K m n k$

Źródło: opracowanie własne

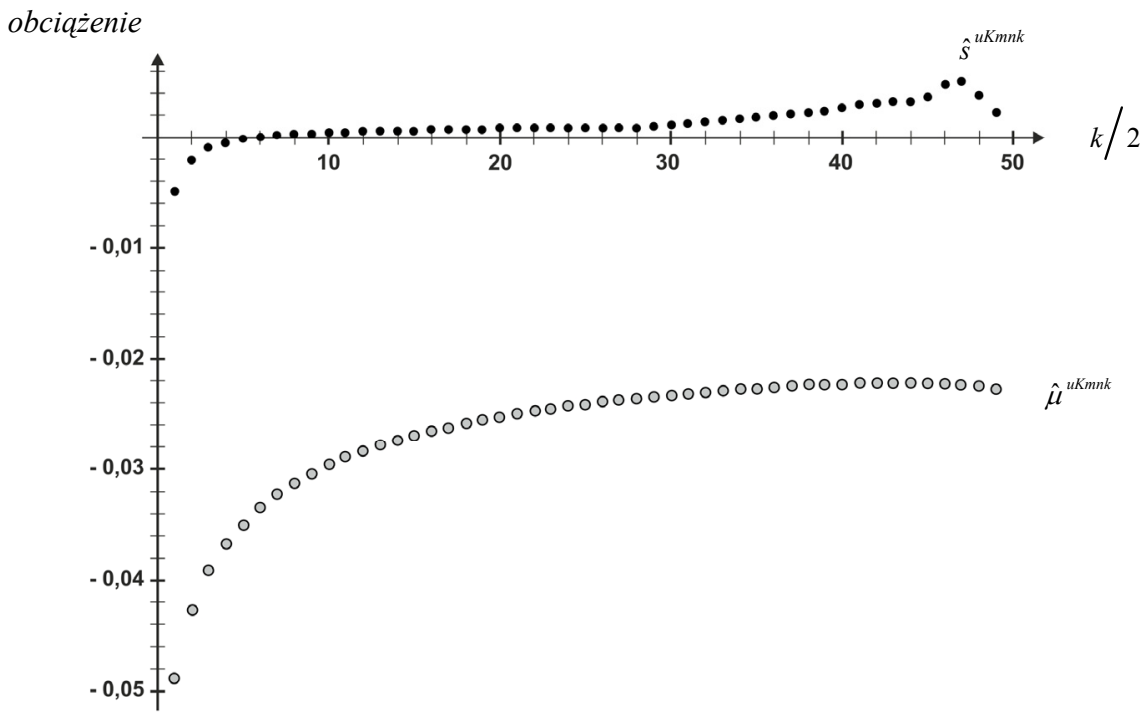

Rysunek 3.3.6. Zależność obciążeń estymatorów parametrów rozkładu Logist $(3,1)$ od liczby pomijanych kwantyli w metodzie $u K m n k$

Źródło: opracowanie własne 


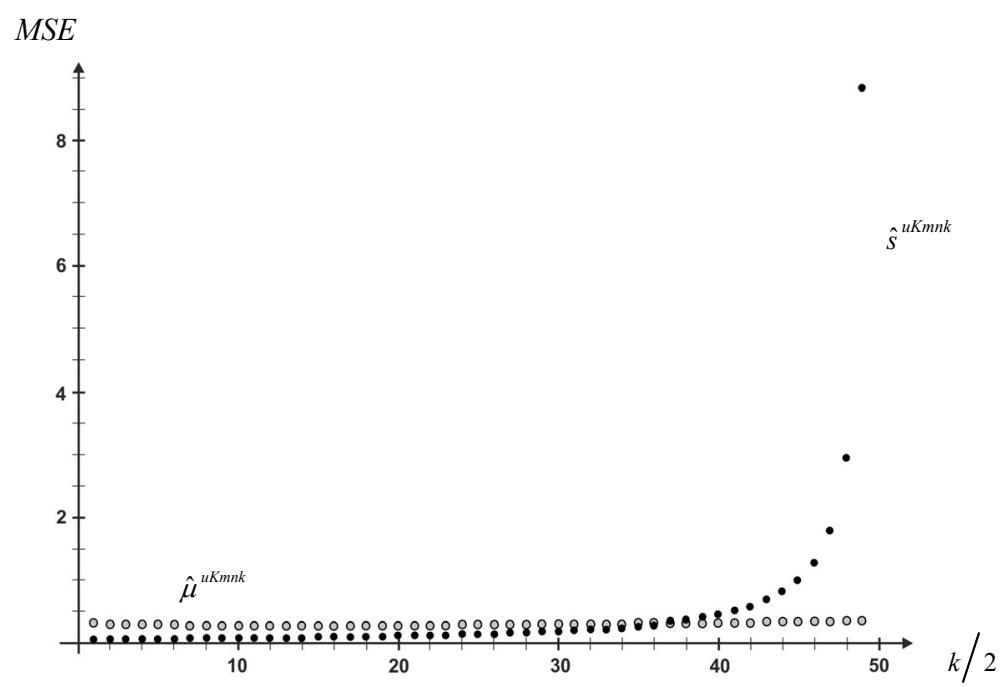

Rysunek 3.3.7. Zależność błędów średniokwadratowych estymatorów parametrów rozkładu Logist $(1,3)$ od liczby pomijanych kwantyli w metodzie $u K m n k$ Źródło: opracowanie własne

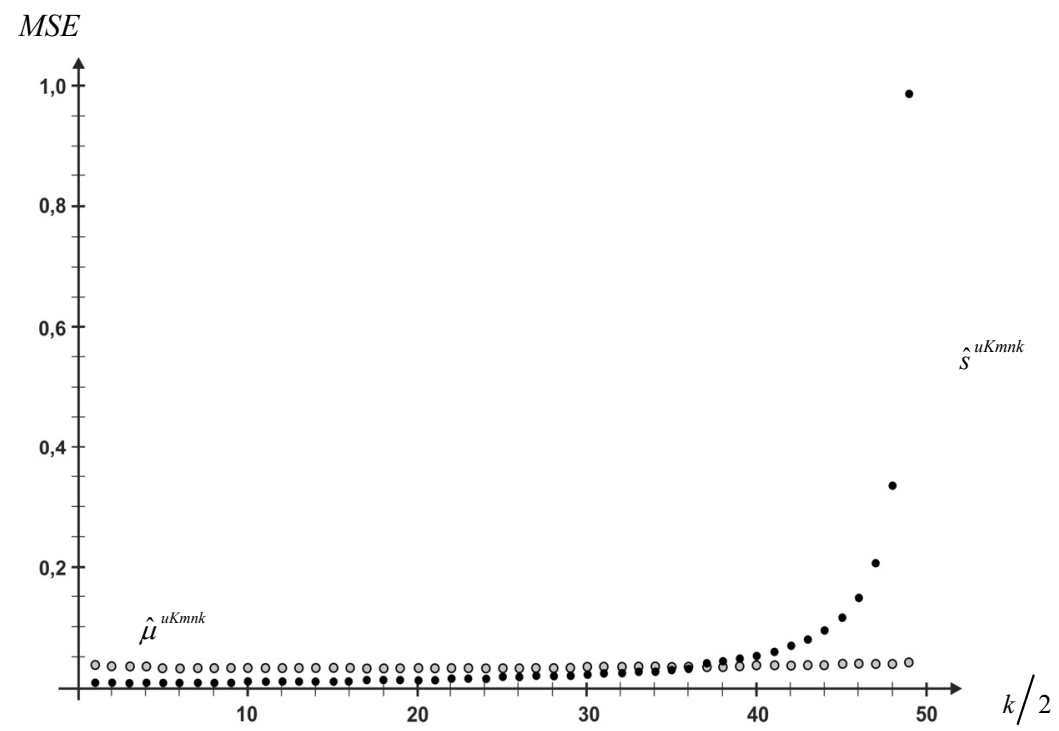

Rysunek 3.3.8. Zależność błędów średniokwadratowych estymatorów parametrów rozkładu Logist (3,1) od liczby pomijanych kwantyli w metodzie $u K m n k$

Źródło: opracowanie własne 
Wyniki analiz symulacyjnych dotyczących badania zależności własności estymatorów parametrów rozkładu Gumbela otrzymanych metodą $u K m n k$ od liczby pomijanych kwantyli przedstawione są w tablicy 3.3.3, a na rysunkach 3.3.9-3.3.12 zaprezentowano wykresy obrazujące te zależności dla estymatorów wyznaczonych w oparciu o próby 100-elementowe.

Tablica 3.3.3. Oszacowane obciążenia i błędy średniokwadratowe estymatorów parametrów wybranych rozkładów Gumbela otrzymanych $u K m n k$

\begin{tabular}{|c|c|c|c|c|c|c|}
\hline Rozkład & $n$ & $k$ & $\overline{\hat{\lambda}}^{u K m n k}-\lambda$ & $M \hat{S} E\left(\hat{\lambda}^{u K m n k}\right)$ & $\overline{\hat{\delta}}^{u K m n k}-\delta$ & $M \hat{S} E\left(\hat{\delta}^{u K m n k}\right)$ \\
\hline 1 & 2 & 3 & 4 & 5 & 6 & 7 \\
\hline \multirow{18}{*}{$G l(1,1)$} & \multirow{6}{*}{40} & 2 & $-0,0287$ & 0,0308 & $-0,0483$ & 0,0260 \\
\hline & & 8 & $-0,0269$ & 0,0324 & $-0,0227$ & 0,0265 \\
\hline & & 14 & $-0,0246$ & 0,0350 & $-0,0174$ & 0,0332 \\
\hline & & 20 & $-0,0235$ & 0,0389 & $-0,0146$ & 0,0454 \\
\hline & & 28 & $-0,0229$ & 0,0479 & $-0,0126$ & 0,0826 \\
\hline & & 34 & $-0,0223$ & 0,0672 & $-0,0125$ & 0,1859 \\
\hline & \multirow{6}{*}{60} & 2 & $-0,0189$ & 0,0199 & $-0,0375$ & 0,0175 \\
\hline & & 10 & $-0,0181$ & 0,0208 & $-0,0161$ & 0,0171 \\
\hline & & 20 & $-0,0162$ & 0,0225 & $-0,0118$ & 0,0216 \\
\hline & & 30 & $-0,0152$ & 0,0253 & $-0,0096$ & 0,0304 \\
\hline & & 40 & $-0,0143$ & 0,0299 & $-0,0091$ & 0,0493 \\
\hline & & 50 & $-0,0144$ & 0,0415 & $-0,0071$ & 0,1103 \\
\hline & \multirow{6}{*}{100} & 2 & $-0,0127$ & 0,0117 & $-0,0281$ & 0,0106 \\
\hline & & 10 & $-0,0132$ & 0,0120 & $-0,0126$ & 0,0094 \\
\hline & & 30 & $-0,0115$ & 0,0130 & $-0,0074$ & 0,0121 \\
\hline & & 50 & $-0,0105$ & 0,0148 & $-0,0063$ & 0,0181 \\
\hline & & 70 & $-0,0099$ & 0,0181 & $-0,0061$ & 0,0329 \\
\hline & & 90 & $-0,0097$ & 0,0310 & $-0,0053$ & 0,1121 \\
\hline \multirow{6}{*}{$G l(0,2)$} & \multirow{6}{*}{40} & 2 & $-0,0549$ & 0,1213 & $-0,0930$ & 0,1031 \\
\hline & & 8 & $-0,0513$ & 0,1275 & $-0,0423$ & 0,1040 \\
\hline & & 14 & $-0,0465$ & 0,1373 & $-0,0328$ & 0,1313 \\
\hline & & 20 & $-0,0437$ & 0,1517 & $-0,0279$ & 0,1804 \\
\hline & & 28 & $-0,0414$ & 0,1874 & $-0,0260$ & 0,3350 \\
\hline & & 34 & $-0,0398$ & 0,2691 & $-0,0264$ & 0,7698 \\
\hline
\end{tabular}


Tablica 3.3.3 (cd.)

\begin{tabular}{|c|c|c|c|c|c|c|}
\hline 1 & 2 & 3 & 4 & 5 & 6 & 7 \\
\hline & \multirow{6}{*}{60} & 2 & $-0,0402$ & 0,0809 & $-0,0761$ & 0,0700 \\
\hline & & 10 & $-0,0383$ & 0,0845 & $-0,0339$ & 0,0664 \\
\hline & & 20 & $-0,0345$ & 0,0917 & $-0,0255$ & 0,0853 \\
\hline & & 30 & $-0,0323$ & 0,1024 & $-0,0225$ & 0,1201 \\
\hline & & 40 & $-0,0304$ & 0,1207 & $-0,0227$ & 0,1930 \\
\hline & & 50 & $-0,0299$ & 0,1657 & $-0,0208$ & 0,4252 \\
\hline & \multirow{6}{*}{100} & 2 & $-0,0134$ & 0,0118 & $-0,0288$ & 0,0108 \\
\hline & & 10 & $-0,0140$ & 0,0120 & $-0,0132$ & 0,0096 \\
\hline & & 30 & $-0,0122$ & 0,0131 & $-0,0081$ & 0,0122 \\
\hline & & 50 & $-0,0112$ & 0,0149 & $-0,0066$ & 0,0182 \\
\hline & & 70 & $-0,0104$ & 0,0183 & $-0,0070$ & 0,0332 \\
\hline & & 90 & $-0,0105$ & 0,0140 & $-0,0060$ & 0,1127 \\
\hline
\end{tabular}

Źródło: opracowanie własne.

obciqżenie

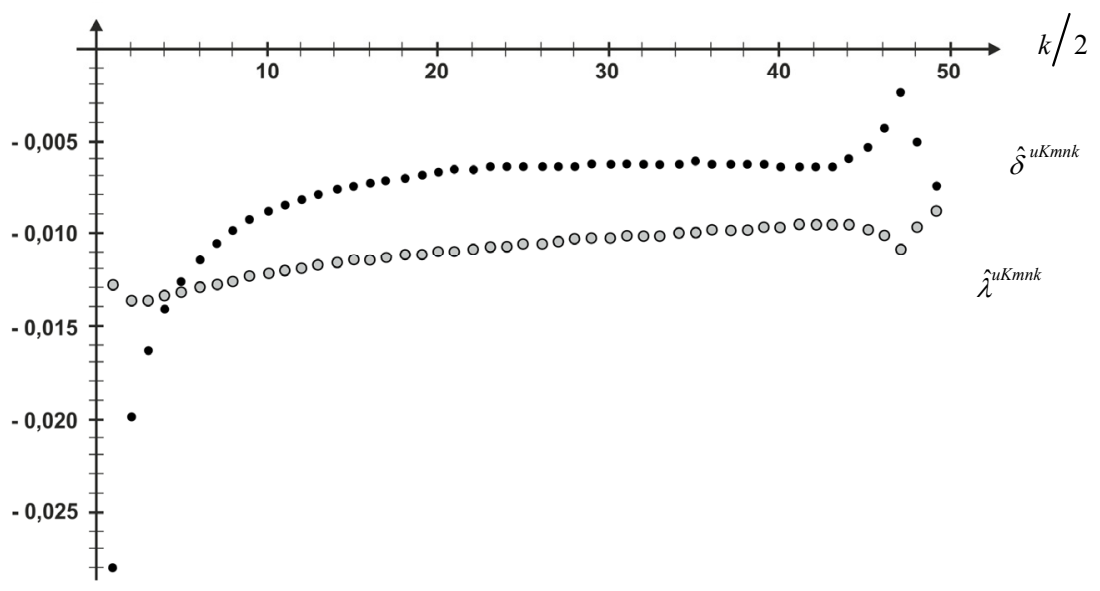

Rysunek 3.3.9. Zależność obciążeń estymatorów parametrów rozkładu $G l(1,1)$ od liczby pomijanych kwantyli w metodzie $u K m n k$

Źródło: opracowanie własne 
obciqżenie

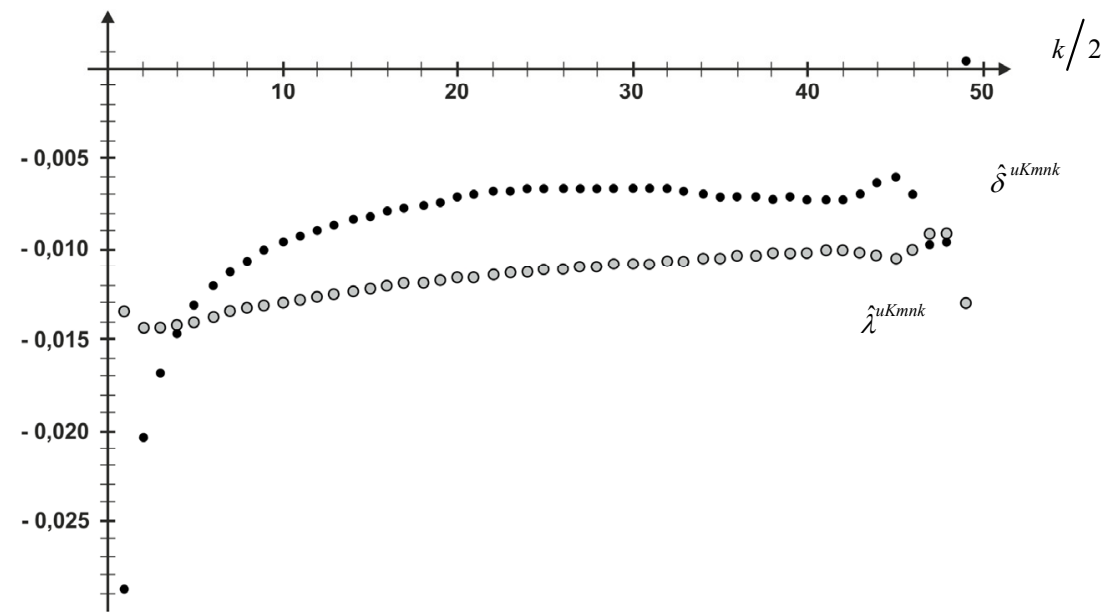

Rysunek 3.3.10. Zależność obciążeń estymatorów parametrów rozkładu $G l(0,2)$ od liczby pomijanych kwantyli w metodzie $u K m n k$

Źródło: opracowanie własne

MSE

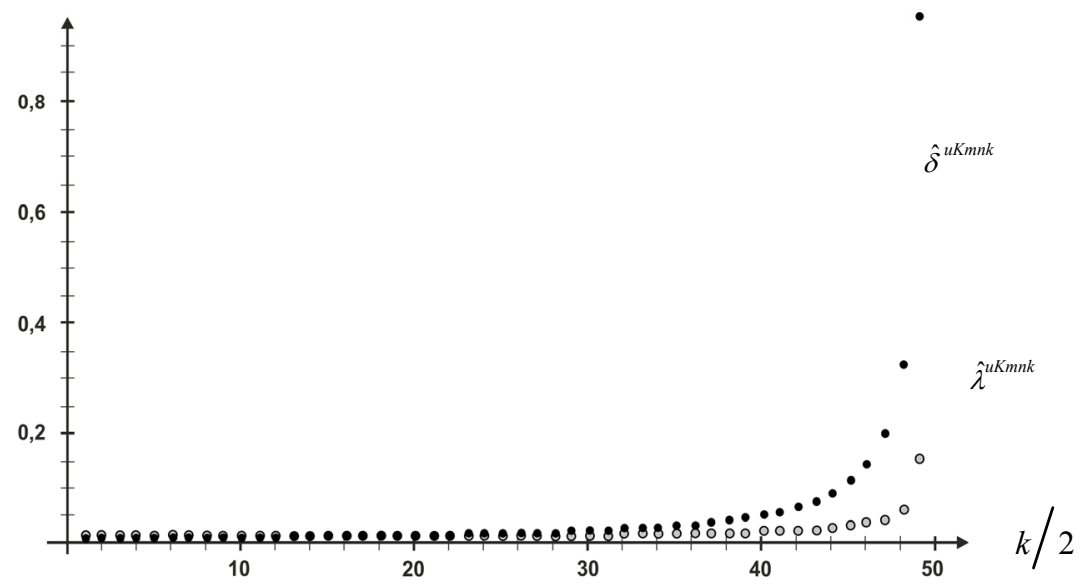

Rysunek 3.3.11. Zależność błędów średniokwadratowych estymatorów parametrów rozkładu $G l(1,1)$ od liczby pomijanych kwantyli w metodzie $u K m n k$

Źródło: opracowanie własne 


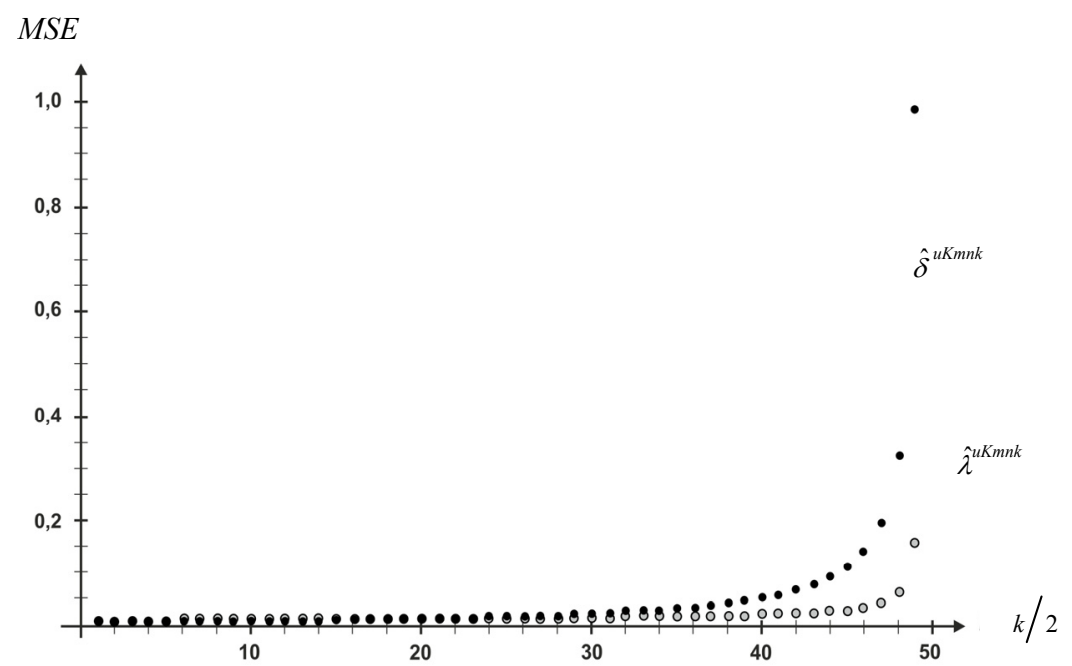

Rysunek 3.3.12. Zależność błędów średniokwadratowych estymatorów parametrów rozkładu $G l(0,2)$ od liczby pomijanych kwantyli w metodzie $u K m n k$

Źródło: opracowanie własne

W przypadku rozkładu Gumbela również widoczna jest zależność wielkości obciążeń i błędów średniokwadratowych od ustalonej liczby pomijanych kwantyli. Obciążenia estymatorów są niewielkie i nieznacznie maleją wraz ze wzrostem $k$, natomiast wielkości błędów średniokwadratowych dla większych wartości $k$ rosną, nawet kilkukrotnie w stosunku do wartości najmniejszych.

Analizy symulacyjne własności estymatorów uzyskanych kwantylową metodą najmniejszych kwadratów z uciętą liczbą kwantyli dotyczyły grupy rozkładów symetrycznych lub zbliżonych do symetrycznych. Estymatory parametrów niektórych rozkładów okazały się bardzo wrażliwe na liczbę pomijanych kwantyli, zaś dla innych różnice między obciążeniami i błędami średniokwadratowymi nie były tak istotne dla różnej liczby pomijanych kwantyli.

Kwantylową metodę najmniejszych kwadratów z uciętą liczbą kwantyli można stosować do estymacji parametrów różnych rozkładów, ale nie zawsze istnieje możliwość analitycznego przedstawienia wzorów na postaci ich estymatorów (np. rozkłady Pareto i Burra). W tych przypadkach, wykorzystując oprogramowanie komputerowe, numerycznie wyznacza się wartości estymatorów. 


\subsection{Symulacyjne badania własności estymatorów uzyskanych medianowo-kwantylową metodą najmniejszych kwadratów}

Medianowo-kwantylową metodę najmniejszych kwadratów zastosowano do szacowania parametrów rozważanych wcześniej rozkładów Cauchy’ego, logistycznego i Gumbela. Podobnie jak w przypadku poprzednich metod badano własności otrzymanych estymatorów. Rezultaty analiz zawarto w tablicach 3.4.1-3.4.3.

Tablica 3.4.1. Oszacowania obciążeń i błędów średniokwadratowych estymatorów parametrów wybranych rozkładów Cauchy'ego otrzymanych MKmnk

\begin{tabular}{|c|c|c|c|c|c|}
\hline \multirow{2}{*}{ Rozkład } & $n$ & $\overline{\hat{m}}^{M K}-m$ & $M \hat{S} E\left(\hat{m}^{M K}\right)$ & $\overline{\hat{\lambda}}^{M K}-\lambda$ & $M \hat{S} E\left(\hat{\lambda}^{M K}\right)$ \\
\hline \multirow{3}{*}{$C a(1,2)$} & 40 & $-0,1122$ & 0,3147 & 0,0773 & 0,2773 \\
\cline { 2 - 6 } & 60 & $-0,0737$ & 0,1958 & 0,0537 & 0,1715 \\
\cline { 2 - 6 } & 100 & $-0,0404$ & 0,1122 & 0,0378 & 0,0975 \\
\hline \multirow{3}{*}{$C a(2,1)$} & 40 & $-0,0563$ & 0,0780 & 0,0368 & 0,0679 \\
\cline { 2 - 6 } & 60 & $-0,0342$ & 0,0488 & 0,0296 & 0,0425 \\
\cline { 2 - 6 } & 100 & $-0,0249$ & 0,0284 & 0,0190 & 0,0248 \\
\hline
\end{tabular}

Źródło: opracowanie własne.

Tablica 3.4.2. Oszacowania obciążeń i błędów średniokwadratowych estymatorów parametrów wybranych rozkładów logistycznych otrzymanych MKmnk

\begin{tabular}{|c|c|c|c|c|c|}
\hline \multirow{2}{*}{ Rozkład } & $n$ & $\overline{\hat{\mu}}^{M K}-\mu$ & $M \hat{S} E\left(\hat{\mu}^{M K}\right)$ & $\overline{\hat{S}}^{M K}-s$ & $M \hat{S} E\left(\hat{S}^{M K}\right)$ \\
\hline \multirow{3}{*}{$\operatorname{Logist}(1,3)$} & 40 & $-0,1732$ & 0,7664 & $-0,0195$ & 0,3121 \\
\cline { 2 - 6 } & 60 & $-0,1159$ & 0,4978 & $-0,0121$ & 0,2071 \\
\cline { 2 - 6 } & 100 & $-0,0702$ & 0,2928 & $-0,0102$ & 0,1232 \\
\hline \multirow{3}{*}{$\operatorname{Logist}(3,1)$} & 40 & $-0,0587$ & 0,0865 & $-0,0072$ & 0,0343 \\
\cline { 2 - 6 } & 60 & $-0,0381$ & 0,0562 & $-0,0039$ & 0,0230 \\
\cline { 2 - 6 } & 100 & $-0,0232$ & 0,0323 & $-0,0027$ & 0,0136 \\
\hline
\end{tabular}

Źródło: opracowanie własne. 
Tablica 3.4.3. Oszacowania obciążeń i błędów średniokwadratowych estymatorów parametrów wybranych rozkładów Gumbela otrzymanych MKmnk

\begin{tabular}{|c|c|c|c|c|c|}
\hline \multirow{2}{*}{ Rozkład } & $n$ & $\overline{\hat{\lambda}}^{M K}-\lambda$ & $M \hat{S} E\left(\hat{\lambda}^{M K}\right)$ & $\overline{\hat{\delta}}^{M K}-\delta$ & $M \hat{S} E\left(\hat{\delta}^{M K}\right)$ \\
\hline \multirow{2}{*}{$G l(1,1)$} & 40 & $-0,0264$ & 0,0368 & $-0,0233$ & 0,0379 \\
\cline { 2 - 6 } & 60 & $-0,0182$ & 0,0238 & $-0,0167$ & 0,0253 \\
\cline { 2 - 6 } & 100 & $-0,0092$ & 0,0141 & $-0,0082$ & 0,0150 \\
\hline \multirow{2}{*}{$G l(0,2)$} & 40 & $-0,0460$ & 0,1447 & $-0,0484$ & 0,1496 \\
\cline { 2 - 6 } & 60 & $-0,0299$ & 0,0959 & $-0,0353$ & 0,1001 \\
\cline { 2 - 6 } & 100 & $-0,0172$ & 0,0566 & $-0,0219$ & 0,0596 \\
\hline
\end{tabular}

Źródło: opracowanie własne.

W wyniku zastosowania medianowo-kwantylowej metody najmniejszych kwadratów otrzymano estymatory parametrów charakteryzujące się mniejszymi obciążeniami i błędami średniokwadratowymi niż przy stosowaniu kwantylowej metody najmniejszych kwadratów wykorzystującej wszystkie możliwe kwantyle lub kwantyle $\mathrm{z}$ pominięciem pierwszego i ostatniego, ale nieznacznie gorsze $\mathrm{w}$ stosunku do estymatorów otrzymanych $u K m n k \mathrm{z}$ odpowiednio dobraną liczbą pomijanych kwantyli. Jednak przy braku pewności co do liczby stosowanych kwantyli bezpieczniej jest wykorzystywać medianowo-kwantylową metodę najmniejszych kwadratów niż inne metody oparte na kwantylach. Dokładniejsze wyniki stanowiące rezultaty porównań metod estymacji opartych na statystykach pozycyjnych przedstawione zostaną w jednym z kolejnych podrozdziałów.

\subsection{Symulacyjne badania własności estymatorów otrzymanych metodami momentów ważonych prawdopodobieństwami}

Metodę momentów ważonych prawdopodobieństwami wykorzystuje się m.in. do wyznaczania estymatorów parametrów rozkładu Pareto i uogólnionego rozkładu Pareto, dla których nie da się zmodyfikowanymi kwantylowymi metodami najmniejszych kwadratów wyznaczyć wzorów na postaci estymatorów. Badania własności estymatorów parametrów tych klas rozkładów otrzymanych metodą $m M W P \mathrm{z}$ dystrybuantą określoną wzorem (2.5.5) oraz metodą $z m M W P$ z proponowaną dystrybuantą (2.6.3) przeprowadzone zostały metodą Monte Carlo. Parametry rozpatrywanych rozkładów szacowano 20000 razy. Otrzymane wyniki zawarte są w tablicach 3.5.1 i 3.5.2. 
Tablica 3.5.1. Oszacowane obciążenia i błędy średniokwadratowe estymatorów parametrów wybranych rozkładów $\mathrm{Pa}(\theta, a)$, gdy $1<a \leq 2$, otrzymanych metodami momentów ważonych prawdopodobieństwami

\begin{tabular}{|c|c|c|c|c|c|c|}
\hline Rozkład & Metoda & $n$ & $\overline{\hat{\theta}}-\theta$ & $M \hat{S} E(\hat{\theta})$ & $\overline{\hat{a}}-a$ & $M \hat{S} E(\hat{a})$ \\
\hline \multirow{6}{*}{$P a(3,2)$} & \multirow{3}{*}{$m M W P$} & 40 & 0,0548 & 0,0475 & 0,2159 & 0,2900 \\
\hline & & 60 & 0,0408 & 0,0344 & 0,1588 & 0,1887 \\
\hline & & 100 & 0,0282 & 0,0237 & 0,1052 & 0,1113 \\
\hline & \multirow{3}{*}{$z m M W P$} & 40 & $-0,0784$ & 0,0490 & 0,0962 & 0,1603 \\
\hline & & 60 & $-0,0488$ & 0,0334 & 0,0834 & 0,1262 \\
\hline & & 100 & $-0,0260$ & 0,0224 & 0,0627 & 0,0869 \\
\hline \multirow{6}{*}{$P a(3,1,5)$} & \multirow{3}{*}{$m M W P$} & 40 & 0,1530 & 0,1298 & 0,2364 & 0,2203 \\
\hline & & 60 & 0,1249 & 0,0926 & 0,1898 & 0,1511 \\
\hline & & 100 & 0,0943 & 0,0631 & 0,1401 & 0,0921 \\
\hline & \multirow{3}{*}{$z m M W P$} & 40 & 0,0165 & 0,0746 & 0,1782 & 0,1493 \\
\hline & & 60 & 0,0331 & 0,0591 & 0,1539 & 0,1155 \\
\hline & & 100 & 0,0388 & 0,0462 & 0,1205 & 0,0776 \\
\hline \multirow{6}{*}{$\operatorname{Pa}(3,1,2)$} & \multirow{3}{*}{$m M W P$} & 40 & 0,3400 & 0,3801 & 0,2732 & 0,2150 \\
\hline & & 60 & 0,2969 & 0,2812 & 0,2305 & 0,1527 \\
\hline & & 100 & 0,2542 & 0,2006 & 0,1874 & 0,1007 \\
\hline & \multirow{3}{*}{$z m M W P$} & 40 & 0,1921 & 0,2051 & 0,2406 & 0,1702 \\
\hline & & 60 & 0,1968 & 0,1744 & 0,2110 & 0,1303 \\
\hline & & 100 & 0,1929 & 0,1428 & 0,1769 & 0,0911 \\
\hline
\end{tabular}

Źródło: opracowanie własne.

Dla analizowanych rozkładów Pareto proponowana metoda zmMWP pozwoliła uzyskać estymatory parametrów $a$ i $\theta$ charakteryzujące się zwykle mniejszymi obciążeniami i mniejszymi błędami średniokwadratowymi niż $m M W P$ z klasyczną dystrybuantą empiryczną. Tylko dla mniejszych liczebności prób, przy szacowaniu parametru $\theta$ zdarzało się, że zastosowanie zmodyfikowanej dystrybuanty prowadziło do uzyskania estymatorów o większym obciążeniu (spośród prezentowanych rozkładów dla parametru $\theta$ rozkładu $P a(3,2)$ dla $n=40$ i $n=60$ ), ale w tych przypadkach błędy średniokwadratowe były zbliżone.

Przy szacowaniu parametrów rozkładów niemających wartości oczekiwanej należy wykorzystać (istniejące) momenty ważone prawdopodobieństwami $M_{1,0, k}$ i $M_{1, j, 0}$ dla $j, k=1,2, \ldots$ 
W przypadku rozkładu Pareto liczba $k$ musi być tak dobrana, aby była pewność, że $k>\frac{1}{a}-1$, natomiast rząd drugiego z momentów może być równy $k+1$, gdyż istnienie momentu $M_{1,0, k}$ sprawia, że istnieją momenty $M_{1,0, l}$ dla $l>k$ (podobnie przy stosowaniu momentów $M_{1, j, 0}$ ).

Znajomość klasy rozkładu nie jest równoznaczna $\mathrm{z}$ wiedzą o istnieniu momentów ważonych prawdopodobieństwami. Dlatego przy nieznanych parametrach rozkładu trudno jest ocenić, które momenty $M_{1,0, k}$ wykorzystać $\mathrm{w}$ estymacji. Kolejne analizy dotyczyły wpływu wyboru wielkości $k$ i $l$ na własności estymatorów parametrów rozkładu Pareto dla $a \leq 1$. W tablicy 3.5.2 przedstawiono obciążenia i błędy średniokwadratowe estymatorów parametrów dwóch wybranych rozkładów Pareto. Można wykazać, że dla rozkładu $P a(3,1)$ istnieją momenty $M_{1,0, k}$ gdy $k \geq 1$, zaś dla $P a\left(3, \frac{1}{2}\right)$ - momenty $M_{1,0, k}$ gdy $k \geq 2$, dlatego wybierano pary momentów ważonych prawdopodobieństwami rzędów spełniających te nierówności.

Tablica 3.5.2. Oszacowane obciążenia i błędy średniokwadratowe estymatorów parametrów wybranych rozkładów $P a(\theta, a)$, gdy $a \leq 1$, otrzymanych metodami momentów ważonych prawdopodobieństwami

\begin{tabular}{|c|c|c|c|c|c|c|c|c|}
\hline Rozkład & Metoda & $k$ & $l$ & $n$ & $\overline{\hat{\theta}}-\theta$ & $M \hat{S E} E(\hat{\theta})$ & $\overline{\hat{a}}-a$ & $M \hat{S} E(\hat{a})$ \\
\hline 1 & 2 & 3 & 4 & 5 & 6 & 7 & 8 & 9 \\
\hline \multirow{9}{*}{$P a(3,1)$} & \multirow{9}{*}{$m M W P$} & \multirow{3}{*}{1} & \multirow{3}{*}{2} & 40 & 0,0457 & 0,0720 & 0,0737 & 0,0446 \\
\hline & & & & 60 & 0,0325 & 0,0489 & 0,0484 & 0,0267 \\
\hline & & & & 100 & 0,0222 & 0,0301 & 0,0289 & 0,0144 \\
\hline & & \multirow{3}{*}{2} & \multirow{3}{*}{3} & 40 & 0,0154 & 0,0335 & 0,0564 & 0,0421 \\
\hline & & & & 60 & 0,0102 & 0,0219 & 0,0360 & 0,0248 \\
\hline & & & & 100 & 0,0072 & 0,0129 & 0,0201 & 0,0140 \\
\hline & & \multirow{3}{*}{3} & \multirow{3}{*}{4} & 40 & 0,0093 & 0,0226 & 0,0585 & 0,0497 \\
\hline & & & & 60 & 0,0586 & 0,0146 & 0,0367 & 0,0287 \\
\hline & & & & 100 & 0,0042 & 0,0084 & 0,0199 & 0,0154 \\
\hline \multirow{6}{*}{$P a(3,1)$} & \multirow{6}{*}{$z m M W P$} & \multirow{3}{*}{1} & \multirow{3}{*}{2} & 40 & 0,0111 & 0,0618 & 0,1027 & 0,0542 \\
\hline & & & & 60 & 0,0135 & 0,0426 & 0,0709 & 0,0319 \\
\hline & & & & 100 & 0,0149 & 0,0274 & 0,0446 & 0,0166 \\
\hline & & \multirow{3}{*}{2} & \multirow{3}{*}{3} & 40 & $-0,0910$ & 0,0473 & 0,0293 & 0,0311 \\
\hline & & & & 60 & $-0,0601$ & 0,0279 & 0,0200 & 0,0205 \\
\hline & & & & 100 & $-0,0346$ & 0,0148 & 0,0113 & 0,0120 \\
\hline
\end{tabular}


Tablica 3.5.2 (cd.)

\begin{tabular}{|c|c|c|c|c|c|c|c|c|}
\hline 1 & 2 & 3 & 4 & 5 & 6 & 7 & 8 & 9 \\
\hline & & \multirow{3}{*}{3} & \multirow{3}{*}{4} & 40 & $-0,1388$ & 0,0591 & $-0,0159$ & 0,0284 \\
\hline & & & & 60 & $-0,0925$ & 0,0309 & $-0,0100$ & 0,0200 \\
\hline & & & & 100 & $-0,0547$ & 0,0141 & $-0,0067$ & 0,0126 \\
\hline \multirow{18}{*}{$P a(3,0,5)$} & \multirow{9}{*}{$m M W P$} & \multirow{3}{*}{2} & \multirow{3}{*}{3} & 40 & 0,1593 & 0,3104 & 0,0490 & 0,0126 \\
\hline & & & & 60 & 0,1133 & 0,1923 & 0,0350 & 0,0074 \\
\hline & & & & 100 & 0,0725 & 0,1158 & 0,0219 & 0,0040 \\
\hline & & & & 40 & 0,0592 & 0,1429 & 0,0379 & 0,0120 \\
\hline & & 3 & 4 & 60 & 0,0391 & 0,0872 & 0,0261 & 0,0071 \\
\hline & & & & 100 & 0,0210 & 0,0508 & 0,0151 & 0,0037 \\
\hline & & & & 40 & 0,0348 & 0,0942 & 0,0372 & 0,0138 \\
\hline & & 4 & 5 & 60 & 0,0226 & 0,0575 & 0,0254 & 0,0081 \\
\hline & & & & 100 & 0,0114 & 0,0330 & 0,0146 & 0,0042 \\
\hline & & & & 40 & 0,1076 & 0,3019 & 0,0400 & 0,0110 \\
\hline & & 2 & 3 & 60 & 0,0684 & 0,1887 & 0,0277 & 0,0067 \\
\hline & & & & 100 & 0,0381 & 0,1240 & 0,0163 & 0,0038 \\
\hline & & & & 40 & $-0,0481$ & 0,1458 & 0,0183 & 0,0086 \\
\hline & $z m M W P$ & 3 & 4 & 60 & $-0,0339$ & 0,0891 & 0,0132 & 0,0056 \\
\hline & & & & 100 & $-0,0240$ & 0,0528 & 0,0074 & 0,0033 \\
\hline & & & & 40 & $-0,1035$ & 0,1119 & 0,0073 & 0,0082 \\
\hline & & 4 & 5 & 60 & $-0,0695$ & 0,0655 & 0,0066 & 0,0057 \\
\hline & & & & 100 & $-0,0439$ & 0,0365 & 0,0038 & 0,0035 \\
\hline
\end{tabular}

Źródło: opracowanie własne.

Rezultaty analiz symulacyjnych wskazują, że przy zastosowaniu metody momentów ważonych prawdopodobieństwami z klasyczną dystrybuantą empiryczną, wykorzystanie momentów o nieco wyższych rzędach nie pogarsza własności estymatorów. Zastosowanie zmodyfikowanej metody momentów ważonych prawdopodobieństwami zwykle prowadzi do otrzymania estymatorów o lepszych własnościach, ale zbyt wysokie rzędy stosowanych momentów mogą znacznie zwiększyć obciążenie i błąd średniokwadratowy estymatora parametru $\theta$.

$\mathrm{W}$ poprzednim rozdziale podane zostały również wzory na estymatory parametrów uogólnionego rozkładu Pareto. Rozkład ten został wyszczególniony ze względu na jego wykorzystanie do szacowania ogona rozkładów gruboogonowych, a następnie do szacowania np. ekstremalnego ryzyka inwestycyjnego. Własności estymatorów dla wybranych rozkładów o parametrze $\xi<1$, otrzymanych przy zastosowaniu metod momentów ważonych prawdopodobieństwami, zawarte są w tablicy 3.5.3. 
W tym przypadku również zastosowanie zmodyfikowanej metody momentów ważonych prawdopodobieństwami zmniejszyło obciążenia i błędy średniokwadratowe estymatorów parametrów uogólnionego rozkładu Pareto w stosunku do estymatorów otrzymanych metodą momentów ważonych prawdopodobienstwami z klasyczną dystrybuantą.

Tablica 3.5.3. Oszacowane obciążenia i wariancje estymatorów parametrów wybranych uogólnionych rozkładów $\operatorname{GPD}(\beta, \xi)$ otrzymanych metodami momentów ważonych prawdopodobieństwami wykorzystującymi estymator wartości oczekiwanej

\begin{tabular}{|c|c|c|c|c|c|c|}
\hline Rozkład & Metoda & $n$ & $\overline{\hat{\beta}}-\beta$ & $\operatorname{MSE}(\hat{\beta})$ & $\overline{\hat{\xi}}-\xi$ & $\operatorname{MSE}(\hat{\xi})$ \\
\hline \multirow{6}{*}{$G P D(3,0,5)$} & \multirow{3}{*}{$m M W P$} & 40 & 0,1613 & 0,7392 & $-0,0828$ & 0,0511 \\
\hline & & 60 & 0,1260 & 0,4867 & $-0,0638$ & 0,0351 \\
\hline & & 100 & 0,0897 & 0,2940 & $-0,0448$ & 0,02246 \\
\hline & \multirow{3}{*}{$z m M W P$} & 40 & $-0,0386$ & 0,5993 & $-0,0457$ & 0,0364 \\
\hline & & 60 & $-0,0096$ & 0,4139 & $-0,0391$ & 0,0276 \\
\hline & & 100 & 0,0897 & 0,2624 & $-0,0301$ & 0,0192 \\
\hline \multirow{6}{*}{$G P D(3,0,7)$} & \multirow{3}{*}{$m M W P$} & 40 & 0,3305 & 1,0786 & $-0,1476$ & 0,0802 \\
\hline & & 60 & 0,2725 & 0,7000 & $-0,1222$ & 0,0568 \\
\hline & & 100 & 0,2220 & 0,4305 & $-0,0970$ & 0,0380 \\
\hline & \multirow{3}{*}{$z m M W P$} & 40 & 0,1209 & 0,7772 & $-0,1193$ & 0,0604 \\
\hline & & 60 & 0,1299 & 0,5359 & $-0,1038$ & 0,0461 \\
\hline & & 100 & 0,1342 & 0,3495 & $-0,086$ & 0,0330 \\
\hline \multirow{6}{*}{$G P D(3,0,9)$} & \multirow{3}{*}{$m M W P$} & 40 & 0,6249 & 1,9565 & $-0,2409$ & 0,1476 \\
\hline & & 60 & 0,5606 & 1,3788 & $-0,2131$ & 0,1149 \\
\hline & & 100 & 0,4742 & 0,8809 & $-0,1820$ & 0,0831 \\
\hline & \multirow{3}{*}{$z m M W P$} & 40 & 0,3901 & 1,3148 & $-0,2191$ & 0,1237 \\
\hline & & 60 & 0,3982 & 0,9929 & $-0,1991$ & 0,1014 \\
\hline & & 100 & 0,3731 & 0,6834 & $-0,1740$ & 0,0765 \\
\hline
\end{tabular}

Źródło: obliczenia własne. 


\subsection{Analiza porównawcza własności wybranych estymatorów}

Analiza wyników badań własności estymatorów otrzymanych metodami opartymi na statystykach pozycyjnych, które zaprezentowane zostały $\mathrm{w}$ poprzednich punktach rozdziału, pozwoliła sformułować wnioski dotyczące efektywności rozważanych procedur szacowania parametrów rozkładów zmiennych losowych. Wydaje się zatem wskazane porównanie tych metod i wyciagnięcie konkluzji. Porównań własności estymatorów dokonano w obrębie metody kwantyli i zmodyfikowanych kwantylowych metod najmniejszych kwadratów. Dla rozkładów mających momenty centralne lub momenty ważone prawdopodobieństwami stosowano również metody wykorzystujące te charakterystyki liczbowe.

W tablicach 3.6.1 i 3.6.2 zestawiono wyniki oszacowanych obciążeń i błędów średniokwadratowych estymatorów parametrów rozkładu Cauchy'ego otrzymanych metodami kwantylowymi, przy czym jako Kmnk oznaczono kwantylową metodę najmniejszych kwadratów nieuwzględniającą statystyk ekstremalnych. W nawiasach podano rzędy kwantyli w metodzie kwantylowej oraz liczbę $k$ pomijanych kwantyli w kwantylowej metodzie najmniejszych kwadratów z uciętą liczbą kwantyli, które prowadzą do otrzymania estymatorów o najlepszych własnościach.

Tablica 3.6.1. Oszacowania obciążeń estymatorów parametrów wybranych rozkładów $C a(\mu, \lambda)$

$$
\text { dla } n=100
$$

\begin{tabular}{|c|c|c|c|c|c|}
\hline \multirow{2}{*}{ Rozkład } & \multirow{2}{*}{ Estymatory } & \multicolumn{4}{|c|}{ Metoda } \\
\cline { 3 - 6 } & & $m K$ & Kmnk & $u$ Kmnk & MKmnk \\
\hline \multirow{2}{*}{$C a(1,2)$} & $\hat{m}$ & $\begin{array}{c}0,0305 \\
(p=0,49)\end{array}$ & $-0,7473$ & $\begin{array}{c}-0,0286 \\
(k=98)\end{array}$ & $-0,0404$ \\
& & 0,0331 & 0,3187 & 0,0174 & 0,0378 \\
& $\hat{\lambda}$ & $(p=0,38)$ & & $(k=98)$ & \\
\hline \multirow{2}{*}{$C a(2,1)$} & $\hat{m}$ & 0,0165 & $-0,3764$ & $-0,0147$ & 0,0249 \\
& & $(p=0,49)$ & & $(k=98)$ & \\
& $\hat{\lambda}$ & 0,0143 & 0,1564 & 0,0161 & 0,0190 \\
& & $(p=0,37)$ & & $(k=98)$ & \\
\hline
\end{tabular}

Źródło: opracowanie własne. 
Tablica 3.6.2. Oszacowania błędów średniokwadratowych estymatorów parametrów wybranych rozkładów $C a(\mu, \lambda)$ dla $n=100$

\begin{tabular}{|c|c|c|c|c|c|}
\hline \multirow{2}{*}{ Rozkład } & \multirow{2}{*}{ Estymatory } & \multicolumn{4}{|c|}{ Metoda } \\
\hline & & $m K$ & Kmnk & $u K m n k$ & MKmnk \\
\hline \multirow{4}{*}{$\mathrm{Ca}(1,2)$} & $\hat{m}$ & 0,0974 & 6,3993 & 0,0951 & 0,1112 \\
\hline & & $(p=0,45)$ & & $(k=78)$ & \\
\hline & $\hat{\lambda}$ & 0,1052 & 6,7076 & 0,0963 & 0,0975 \\
\hline & $\lambda$ & $(p=0,27)$ & & $(k=40)$ & \\
\hline \multirow{4}{*}{$C a(2,1)$} & $\hat{m}$ & 0,0234 & 1,4838 & 0,0241 & 0,0284 \\
\hline & & $(p=0,44)$ & & $(k=76)$ & \\
\hline & $\hat{\lambda}$ & 0,0275 & 1,1038 & 0,0240 & 0,0248 \\
\hline & & $(p=0,28)$ & & $(k=40)$ & \\
\hline
\end{tabular}

Źródło: opracowanie własne.

W tablicach 3.6.3 i 3.6.4 zaprezentowano własności estymatorów parametrów rozkładów logistycznego i Gumbela uzyskanych metodami kwantylowymi oraz metodą momentów, gdyż dla tych rozkładów istnieje zarówno wartość oczekiwana, jak i wariancja.

Estymatory parametrów otrzymane metodą momentów $(m M)$ są postaci:

- dla parametrów rozkładu logistycznego:

$$
\begin{gathered}
\hat{\mu}^{m M}=\bar{X}, \\
\hat{s}^{m M}=\frac{\hat{\sigma} \sqrt{3}}{\pi},
\end{gathered}
$$

- dla parametrów rozkładu Gumbela:

$$
\begin{gathered}
\hat{\lambda}^{m M}=\bar{X}-0,57772 \frac{\hat{\sigma} \sqrt{6}}{\pi}, \\
\hat{\delta}^{m M}=\frac{\hat{\sigma} \sqrt{6}}{\pi},
\end{gathered}
$$

gdzie $\bar{X}, \hat{\sigma}$ są odpowiednio średnią arytmetyczna i odchyleniem standardowym obliczanym na podstawie próby losowej. 
Tablica 3.6.3. Oszacowania obciążeń estymatorów parametrów wybranych rozkładów $\operatorname{Logis}(\mu, s)$ i $G l(\lambda, \delta)$ dla $n=100$

\begin{tabular}{|c|c|c|c|c|c|c|}
\hline \multirow{2}{*}{ Rozkład } & \multirow{2}{*}{ Estymatory } & \multicolumn{5}{|c|}{ Metoda } \\
\hline & & $m K$ & Kmnk & uKmnk & MKmnk & $m M$ \\
\hline \multirow[b]{2}{*}{$\operatorname{Logist}(1,3)$} & $\hat{\mu}$ & $\begin{array}{c}-0,0602 \\
(p=0,45)\end{array}$ & $-0,1403$ & $\begin{array}{l}-0,0592 \\
(k=98)\end{array}$ & $-0,0702$ & $-0,0050$ \\
\hline & $\hat{s}$ & $\begin{array}{c}-0,0000 \\
(p=0,22)\end{array}$ & $-0,0154$ & $\begin{array}{l}0,0002 \\
(k=16)\end{array}$ & $-0,0102$ & $-0,0115$ \\
\hline \multirow[b]{2}{*}{$\operatorname{Logist}(3,1)$} & $\hat{\mu}$ & $\begin{array}{c}0,0182 \\
(p=0,44)\end{array}$ & $-0,0489$ & $\begin{array}{l}-0,0221 \\
(k=90)\end{array}$ & $-0,0232$ & $-0,0020$ \\
\hline & $\hat{s}$ & $\begin{array}{c}0,0005 \\
(p=0,20)\end{array}$ & $-0,0048$ & $\begin{array}{c}0,0000 \\
(k=12)\end{array}$ & $-0,0027$ & $-0,0030$ \\
\hline \multirow{2}{*}{$G l(1,1)$} & $\hat{\lambda}$ & $\begin{array}{c}-0,0073 \\
(p=0,46)\end{array}$ & $-0,0117$ & $\begin{array}{c}-0,0023 \\
(k=94\end{array}$ & $-0,0702$ & 0,0030 \\
\hline & $\hat{\delta}$ & $\begin{array}{c}-0,0009 \\
(p=0,48)\end{array}$ & $-0,0106$ & $\begin{array}{c}0,0095 \\
(k=82)\end{array}$ & $-0,0102$ & $-0,0052$ \\
\hline \multirow[b]{2}{*}{$G l(0,2)$} & $\hat{\lambda}$ & $\begin{array}{c}-0,0222 \\
(p=0,49)\end{array}$ & $-0,0106$ & $\begin{array}{l}-0,0091 \\
(k=94)\end{array}$ & & 0,0060 \\
\hline & $\hat{\delta}$ & $\begin{array}{c}-0,0045 \\
(p=0,45)\end{array}$ & $-0,0288$ & $\begin{array}{c}-0,0006 \\
(k=90)\end{array}$ & $-0,0219$ & $-0,0123$ \\
\hline
\end{tabular}

Źródło: opracowanie własne.

Tablica 3.6.4. Oszacowania błędów średniokwadratowych estymatorów parametrów wybranych rozkładów $\operatorname{Logist}(\mu, s)$ i $G l(\lambda, \delta)$ dla $n=100$

\begin{tabular}{|c|c|c|c|c|c|c|}
\hline \multirow{2}{*}{ Rozkład } & \multirow{2}{*}{ Estymatory } & \multicolumn{5}{|c|}{ Metoda } \\
\hline & & $m K$ & Kmnk & uKmnk & MKmnk & $m M$ \\
\hline 1 & 2 & 3 & 4 & 5 & 6 & 7 \\
\hline \multirow[b]{2}{*}{$\operatorname{Logist}(1,3)$} & $\hat{\mu}$ & $\begin{array}{c}0,3148 \\
(p=0,35)\end{array}$ & 0,3245 & $\begin{array}{c}0,2842 \\
(k=28)\end{array}$ & 0,2928 & 0,2944 \\
\hline & $\hat{s}$ & $\begin{array}{r}0,0917 \\
(p=0,10)\end{array}$ & 0,0662 & $\begin{array}{l}0,0662 \\
(k=2)\end{array}$ & 0,1232 & 0,0712 \\
\hline \multirow[b]{2}{*}{$\operatorname{Logist}(3,1)$} & $\hat{\mu}$ & $\begin{array}{c}0,0344 \\
(p=0,38)\end{array}$ & 0,0369 & $\begin{array}{c}0,0318 \\
(k=30)\end{array}$ & 0,0323 & 0,0323 \\
\hline & $\hat{s}$ & $\begin{array}{c}0,0102 \\
(p=0,10)\end{array}$ & 0,0073 & $\begin{array}{l}0,0073 \\
(k=2)\end{array}$ & 0,0136 & 0,0080 \\
\hline \multirow{2}{*}{$G l(1,1)$} & $\hat{\lambda}$ & $\begin{array}{c}0,0145 \\
(p=0,24)\end{array}$ & 0,0117 & $\begin{array}{l}0,0117 \\
(k=2)\end{array}$ & 0,0141 & 0,00118 \\
\hline & $\hat{\delta}$ & $\begin{array}{r}0,0111 \\
(p=0,10)\end{array}$ & 0,0106 & $\begin{array}{l}0,0093 \\
(k=8)\end{array}$ & 0,0150 & 0,0108 \\
\hline
\end{tabular}


Tablica 3.6.4 (cd.)

\begin{tabular}{|c|c|c|c|c|c|c|}
\hline 1 & 2 & 3 & 4 & 5 & 6 & 7 \\
\hline \multirow{3}{*}{$G l(0,2)$} & $\hat{\lambda}$ & 0,0584 & 0,0118 & $\begin{array}{c}0,0118 \\
(k=2)\end{array}$ & 0,0566 & 0,0460 \\
& $\hat{\delta}$ & $\begin{array}{c}0,0439 \\
(p=0,24)\end{array}$ & 0,0108 & $\begin{array}{c}0,0096 \\
(k=10)\end{array}$ & 0,0596 & 0,0436 \\
\hline
\end{tabular}

Źródło: opracowanie własne.

Z przedstawionych rezultatów wynika, że najmniejsze obciążenia i błędy średniokwadratowe charakteryzowały estymatory uzyskane proponowaną kwantylową metodą najmniejszych kwadratów z uciętą liczbą kwantyli, przy czym istotny jest właściwy wybór rzędów kwantyli wykorzystywanych w tej metodzie. Pominięcie niewłaściwej liczby kwantyli może powodować otrzymanie oszacowań znacznie różniących się od wartości rzeczywistych, ze względu na duże obciążenia i błędy średniokwadratowe estymatorów. Jak wynika z wartości zamieszczonych w tablicach, szczególnie istotna jest liczba pomijanych kwantyli przy szacowaniu parametrów rozkładu Cauchy’ego.

Zastosowanie metody kwantyli prowadzić może do zadowalających rezultatów, jeśli właściwie wybrane zostaną rzędy par kwantyli. W innych przypadkach wyniki będą dużo gorsze (por. rysunki 3.2.1-3.2.6).

Estymatory parametrów Cauchy'ego otrzymane medianowo-kwantylową metodą najmniejszych kwadratów mają nieznacznie większe obciążenia i błędy średniokwadratowe.

W przypadku rozkładu Pareto porównać można własności estymatorów otrzymanych metodą kwantyli $(m K)$ oraz metodami momentów ważonych prawdopodobieństwami: z klasyczną dystrybuantą ( $m M W P)$ i z proponowaną level crossing empirical distribution (zmMWP). Zestawienia obciążeń i błędów średniokwadratowych estymatorów wyznaczonych w oparciu o próby 100-elementowe przedstawiają tablice 3.6.5 oraz 3.6.6.

Tablica 3.6.5. Oszacowania obciążeń estymatorów parametrów wybranych rozkładów Pareto

\begin{tabular}{|c|c|c|c|c|}
\hline \multirow{2}{*}{ Rozkład } & \multirow{2}{*}{ Estymatory } & \multicolumn{3}{|c|}{ Metoda estymacji } \\
\cline { 2 - 5 } & & $m K$ & $m M W P$ & $z m M W P$ \\
\hline 1 & 2 & 3 & 4 & 5 \\
\hline \multirow{3}{*}{$\operatorname{Pa}(3,2)$} & $\hat{\theta}$ & $0,0014(p=0,01)$ & 0,0282 & $-0,0260$ \\
\cline { 2 - 3 } & $\hat{a}$ & $0,0693(p=0,19)$ & 0,1052 & $-0,0627$ \\
\hline
\end{tabular}


Tablica 3.6.5 (cd.)

\begin{tabular}{|c|c|c|c|c|}
\hline 1 & 2 & 3 & 4 & 5 \\
\hline \multirow{2}{*}{$P a(3,1,5)$} & $\hat{\theta}$ & $0,0018(p=0,01)$ & 0,0943 & 0,0388 \\
& $\hat{a}$ & $0,0504(p=0,19)$ & 0,1401 & 0,1205 \\
\hline \multirow{3}{*}{$P a(3,1,2)$} & $\hat{\theta}$ & $0,0025(p=0,01)$ & 0,2542 & 0,1929 \\
\cline { 2 - 5 } & $\hat{a}$ & $0,0391(p=0,18)$ & 0,1874 & 0,1769 \\
\hline
\end{tabular}

Źródło: opracowanie własne.

Tablica 3.6.6. Oszacowania błędów średniokwadratowych estymatorów parametrów wybranych rozkładów Pareto

\begin{tabular}{|c|c|c|c|c|}
\hline \multirow{2}{*}{ Rozkład } & \multirow{2}{*}{ Estymatory } & \multicolumn{3}{|c|}{ Metoda estymacji } \\
\cline { 3 - 5 } & $\hat{\theta}$ & $0,0002(p=0,01)$ & $m M W P$ & $z m M W P$ \\
\hline \multirow{3}{*}{$P a(3,2)$} & $\hat{a}$ & $0,0894(p=0,13)$ & 0,1113 & 0,0224 \\
& $\hat{\theta}$ & $0,0004(p=0,01)$ & 0,0631 & 0,0869 \\
\hline \multirow{2}{*}{$P a(3,1,5)$} & $\hat{a}$ & $0,0486(p=0,13)$ & 0,0921 & 0,0462 \\
& $\hat{\theta}$ & $0,0007(p=0,01)$ & 0,2006 & 0,1428 \\
\hline \multirow{2}{*}{$P a(3,1,2)$} & $\hat{a}$ & $0,0320(p=0,14)$ & 0,1007 & 0,0911 \\
\hline
\end{tabular}

Źródło: opracowanie własne.

Estymatory zmMWP charakteryzują się lepszymi własnościami niż estymatory $m M W P$, ale metodą kwantyli można uzyskać jeszcze lepsze oszacowania parametrów rozkładu Pareto. Podobnie jak w przypadku wcześniej analizowanych rozkładów, niepoprawny wybór rzędów kwantyli może doprowadzić jednak do estymatorów obciążonych o dużych błędach średniokwadratowych, np. dla rozkładu $P a(3,1,2)$ obciążenie estymatora parametru a może wynieść nawet 1,2419, a błąd średniokwadratowy 30,9691. 


\subsection{Zastosowanie procedur estymacji opartych na statystykach pozycyjnych w badaniach ekonomicznych}

W badaniach ekonomicznych zmienne losowe, z którymi utożsamiane są badane cechy statystyczne, charakteryzują się różnymi rozkładami. Są to zarówno rozkłady skokowe, jak i ciagłe, symetryczne i asymetryczne, rozkłady charakteryzujące się cienkimi lub grubymi ogonami, lub też posiadającymi skończony przedział wartości. W przypadku parametrycznego podejścia istotnym problemem jest szacowanie parametrów rozkładu rozważanej zmiennej, a w związku z tym wybór metody estymacji prowadzącej do estymatorów nieobciążonych i charakteryzujących się małymi błędami średniokwadratowymi.

Prezentowane $\mathrm{w}$ drugim rozdziale metody estymacji oparte na kwantylach z próby wraz z proponowanymi modyfikacjami pozwalają uzyskać estymatory o „dobrych” własnościach, o czym świadczą wyniki przeprowadzonych analiz omówione w tym rozdziale.

Rozważane metody mogą być wykorzystywane do estymacji parametrów rozkładu Cauchy'ego stosowanego do modelowania różnego rodzaju procesów na rynkach finansowych, parametrów rozkładu Frécheta, Gumbela i Weibulla używanych przy do modelowania wartości szkód pochodzących ze zdarzeń katastrofalnych.

W naukach społeczno-ekonomicznych, w szczególności w aktuariacie, w badaniach dotyczących dochodów ludności mamy do czynienia ze zmiennymi losowymi o rozkładzie Pareto i w tych przypadkach, jak wykazały analizy, parametry rozkładu można estymować metodami opartymi na statystykach pozycyjnych. Również w przypadku rozkładu log normalnego, który charakteryzuje rozkład dochodów gospodarstw domowych, można stosować metody oparte na kwantylach. Do innych rozkładów wykorzystywanych w analizach dochodów należą rozkład Daguma i Singha-Maddali. Ich parametry szacuje się zwykle numerycznie metodą największej wiarygodności, a stopień dopasowania sprawdza się, porównując kwantyle empiryczne $\mathrm{z}$ teoretycznymi. Metodę tę można zastapić kwantylową metodą najmniejszych kwadratów, która w swej konstrukcji zakłada minimalizację kwadratów różnic między wartościami kwantyli z próby i kwantyli rozkładu, albo medianowo-kwantylową metodą najmniejszych kwadratów.

W analizach ekonomicznych dotyczących czasu trwania zjawiska, np. w kontroli jakości badania trwałości urządzeń, mamy do czynienia z rozkładem logistycznym, którego parametry można szacować metodami opartymi na kwan- 
tylach z próby. Obok zmiennych losowych o rozkładzie logistycznym i normalnym w statystycznej kontroli jakości występują też zmienne o innych rozkładach, których parametry można oszacować metodami opartymi na statystykach pozycyjnych.

Empiryczne przykłady zastosowań rozważanych metod estymacji przedstawione zostaną w szóstym rozdziale monografii.

\subsection{Uwagi końcowe}

Badania, których wyniki zaprezentowano w tym rozdziale, dotyczyły własności estymatorów parametrów rozkładu zmiennej losowej, wykorzystujących statystyki pozycyjne wyznaczone na podstawie prób wylosowanych w sposób niezależny. Analitycznie i symulacyjnie wyznaczano obciążenia i błędy średniokwadratowe estymatorów parametrów wybranych klas rozkładów. Uzyskane wyniki porównano, formułując wnioski przydatne w praktycznych zastosowaniach.

Parametry rozkładów Cauchy'ego, logistycznego i Gumbela szacowano metodą kwantyli i modyfikacjami kwantylowej metody najmniejszych kwadratów. Okazało się, że proponowana kwantylowa metoda najmniejszych kwadratów z uciętą liczbą kwantyli (uKmnk) prowadzi do uzyskania estymatorów charakteryzujących się dużo mniejszymi obciążeniami i mniejszymi błędami średniokwadratowymi niż prezentowana $\mathrm{w}$ literaturze kwantylowa metoda najmniejszych kwadratów (Kmnk), jeżeli właściwie zostanie dobrana liczba pomijanych kwantyli. W przypadku rozkładu Cauchy'ego bardzo istotne jest pominięcie obydwu statystyk ekstremalnych, gdyż ich nieskończone wariancje w sposób istotny wpływają na wariancję estymatorów, a tym samym na ich błędy średniokwadratowe. Zarówno proponowana $u K m n k$, jak i metoda kwantyli wymagają dodatkowych informacji o rzędach kwantyli prowadzących do otrzymania optymalnych estymatorów. Informacje o tych rzędach można uzyskać dla każdego szacowania parametru rozkładu poprzez obliczenia analityczne lub analizy symulacyjne.

Druga autorska propozycja modyfikacji metody Kmnk, czyli medianowokwantylowa metoda najmniejszych kwadratów prowadzi do uzyskania estymatorów o nieznacznie gorszych własnościach $\mathrm{w}$ stosunku do estymatorów $u K m n k$, ale lepszych niż otrzymanych metodą Kmnk. Jej zaletą w praktycznych zastosowaniach jest to, że nie wymaga dodatkowych ustaleń dotyczących rzędów stosowanych kwantyli. 
Parametry rozkładu Pareto szacowane były metodą kwantyli oraz metodami momentów ważonych prawdopodobieństwami, w tym zmodyfikowaną metodą polegającą na zastosowaniu przy konstrukcji estymatorów dystrybuanty empirycznej level crossing. Otrzymane wyniki wskazują na lepsze własności estymatorów uzyskanych proponowaną metodą $\mathrm{w}$ porównaniu $\mathrm{z}$ metodą momentów ważonych prawdopodobieństwami wykorzystującą klasyczną dystrybuantę empiryczną. Inne wielkości rzędów kwantyli przy estymacji parametrów rozkładu Pareto metodą kwantyli, w stosunku do estymacji parametrów rozkładu Cauchy'ego, potwierdzają konieczność przeprowadzania wstępnych analiz w celu wyboru rzędów pozwalających uzyskać estymatory o małym obciążeniu i małym błędzie średniokwadratowym.

Rezultaty analiz własności estymatorów zaprezentowane są również w pracach D. Pekasiewicz [2013a, 2014], M. Małecka, D. Pekasiewicz [2013]. 



\section{PROCEDURY ESTYMACJI PARAMETRÓW POZYCYJNYCH ZMIENNEJ LOSOWEJ I ICH ZASTOSOWANIA}

\subsection{Uwagi wstępne}

Rozważania przedstawione w rozdziałach drugim i trzecim dotyczyły zastosowań statystyk pozycyjnych do konstrukcji metod opartych na statystykach pozycyjnych wykorzystywanych do estymacji parametrów rozkładów zmiennych losowych. Drugą równie ważną grupę zastosowań stanowią procedury estymacji punktowej i przedziałowej, parametrycznej i nieparametrycznej pozycyjnych parametrów populacji, takich jak kwantyle, w tym mediana.

Problematyka wykorzystania statystyk pozycyjnych w estymacji kwantyli i poszukiwania estymatorów o najlepszych własnościach rozważana jest m.in. w pracach F. E. Harrella, C. E. Davisa [1982], D. J. Olivie [2005], I. Takeuchi i in. [2006], R. Zielińskiego [1995, 1999, 2000, 2003, 2005a], R. Zielińskiego, W. Zielińskiego [2005].

W rozdziale tym przedstawiono wybrane estymatory kwantyli, w tym mediany, parametryczne i nieparametryczne przedziały ufności i ich własności. Prezentację metod estymacji kwantyli uzupełniono wynikami przeprowadzonych obliczeń medianowej obciążoności wybranych estymatorów, rezultatami analiz dotyczących dokładności oszacowań mediany, przy zastosowaniu estymacji przedziałowej, w tym bootstrapowej metody percentyli. Przeprowadzone analizy pozwoliły porównać rozważane metody estymacji dla wybranych klas rozkładów.

Miarą pozycyjną stosowaną $w$ badaniach ekonomicznych jest również dominanta. Wśród wielu metod estymacji dominanty prezentowanych w literaturze ważną rolę odgrywają procedury wykorzystujące statystyki pozycyjne (por. D. R. Bickel [2003], S. B. Hedges, P. Shah [2003], J. Wywiał [2000a], [2000b]) przedstawione $\mathrm{w}$ tym rozdziale.

Oprócz rozważań dotyczących wykorzystania statystyk pozycyjnych do konstrukcji estymatorów i przedziałów ufności dla wartości parametrów pozycyjnych zmiennej losowej zaprezentowano zastosowanie tych estymatorów w badaniach ekonomicznych do szacowania różnego rodzaju miar stosowanych 
w analizach dobrobytu, bogactwa i ubóstwa ludności, nierównomierności dochodów oraz $\mathrm{w}$ analizach dotyczących ryzyka związanego $\mathrm{z}$ inwestycjami finansowymi oraz w statystycznej kontroli jakości.

\subsection{Estymatory kwantyli}

Parametrem rozkładu zmiennej losowej znajdującym praktyczne zastosowanie jest kwantyl rozkładu. Wartość kwantyla, odpowiedniego rzędu, szacuje się na podstawie próby losowej, stosując metody estymacji punktowej lub przedziałowej oraz wartości statystyk pozycyjnych.

Niech $X$ będzie ciagłą zmienną losową określoną za pomocą dystrybuanty $F$ oraz niech $Q_{p}=F^{-1}(p)$ oznacza kwantyl rozkładu zmiennej $X$ rzędu $p$, gdzie $p \in(0,1)$.

Definicja 4.2.1. Estymatorem kwantyla $Q_{p}$ jest statystyka:

$$
\hat{Q}_{p}=F_{n}^{-1}(p)=\inf \left\{x: \quad F_{n}(x) \geq p\right\},
$$

gdzie $F_{n}(x)$ jest dystrybuantą empiryczną wyznaczoną na podstawie $n$-elementowej próby prostej $X_{1}, X_{2}, \ldots, X_{n}$.

W literaturze przedstawionych jest wiele nieparametrycznych estymatorów kwantyli. Ich postaci zależą m.in. od przyjętej definicji dystrybuanty empirycznej.

Niech

$$
F_{n}(x)=\frac{\operatorname{card}\left\{1 \leq j \leq n: x_{i} \leq x\right\}}{n} \quad \text { dla } x \in R
$$

będzie dystrybuantą empiryczną określoną na podstawie próby losowej $X_{1}, X_{2}, \ldots, X_{n}$.

Wykorzystując wzór (4.2.2), otrzymujemy estymator kwantyla $Q_{p}$ rzędu $p$ zdefiniowany następująco.

Definicja 4.2.2. Estymatorem kwantyla $Q_{p}$ rozkładu zmiennej losowej $X$ wyznaczonym na podstawie $n$-elementowej próby prostej $X_{1}, X_{2}, \ldots, X_{n}$ nazywamy statystykę: 


$$
\hat{Q}_{p}= \begin{cases}X_{n p}^{(n)}, & \text { gdy } n p \in N, \\ X_{[n p]+1}^{(n)}, & \text { gdy } n p \notin N .\end{cases}
$$

Do innych estymatorów kwantyla $Q_{p}$ należy zaliczyć estymator standardowy i estymator Huang-Brilla (por. R. Zieliński [2006]).

Definicja 4.2.3. Standardowym estymatorem kwantyla $Q_{p}$ wyznaczonym na podstawie $n$-elementowej próby prostej $X_{1}, X_{2}, \ldots, X_{n}$ nazywamy statystykę pozycyjną rangi $k(p)$ postaci:

$$
\hat{Q}_{p}^{\text {stand. }}=X_{(k(p))}^{(n)}
$$

gdzie

$$
k(p)= \begin{cases}n p, & \text { gdy } n p \in N \text { oraz } p<0,5, \\ n p+1, & \text { gdy } n p \in N \text { oraz } p>0,5, \\ \frac{n}{2}+I_{(0,0,5)}(u), & \text { gdy } n p \in N \text { oraz } p=0,5, \\ {[n p]+1,} & \text { gdy } n p \notin N,\end{cases}
$$

przy czym $u$ jest wartością zmiennej losowej o rozkładzie jednostajnym na przedziale $(0,1)$ oraz $I_{(0,0,5)}(u)$ jest indykatorem przyjmującym wartość 1 , gdy $u \in(0,0,5\rangle$ i $0 \mathrm{w}$ przeciwnym przypadku.

Zastosowanie dystrybuanty empirycznej level crossing (por. M. L. Huang, P. H. Brill, [1999]) o wzorze (2.6.3) prowadzi do estymatora Huang-Brilla zdefiniowanego w poniższy sposób.

Definicja 4.2.4. Statystykę pozycyjną, będącą funkcją $n$-elementowej próby prostej $X_{1}, X_{2}, \ldots, X_{n}$, o wzorze:

$$
\hat{Q}_{p}^{H B}=X_{([b]+2)}^{(n)},
$$

gdzie

$$
b=\sqrt{n(n-1)}\left(p-\frac{1}{2}\left[1-\frac{n-2}{\sqrt{n(n-1)}}\right]\right),
$$

nazywamy estymatorem Huang-Brilla kwantyla $Q_{p}$. 
Latwo zauważyć, że dla $p=0,5$ mamy $b=\left[\frac{n}{2}\right]-1$, czyli estymatorem kwantyla $Q_{0,5}$ jest statystyka pozycyjna $X_{\left(\left[\frac{n}{2}\right]+1\right.}^{(n)}$.

Ze względu na fakt, że nie zawsze istnieje wartość oczekiwana statystyk pozycyjnych wykorzystywanych w estymacji kwantyli, nie można badać nieobciążoności estymatorów $T$ zdefiniowanej w sposób klasyczny $\left(E(T)=Q_{p}\right)$, chyba że rozważania ograniczy się do klasy rozkładów posiadających wartość oczekiwaną kwantyli z próby. Takie podejście wiąże się jednak z wykluczeniem rozkładów istotnych z punktu widzenia zastosowań, np. rozkładów o grubych ogonach. Do badania, jak rozkład estymatora $T$ sytuuje się w stosunku do estymowanego parametru $\theta$, wykorzystuje się pojęcie medianowej nieobciążoności zdefiniowanej poniżej [por. R. Zieliński [2011, s. 34].

Definicja 4.2.5. Estymator $T$ jest medianowo-nieobciążonym estymatorem parametru $\theta$, gdy $M_{0,5}(T)=\theta$.

W tablicach 4.2.1 i 4.2.2 podane zostały obliczone na podstawie definicji 4.2.5 wartości (medianowych) obciążeń estymatorów $\hat{Q}_{p}, \hat{Q}_{p}^{\text {stand. }}, \hat{Q}_{p}^{H B}$ kwantyli rzędów 0,05 i 0,93 , czyli: $B\left(\hat{Q}_{p}\right)=M_{0,5}\left(\hat{Q}_{p}\right)-Q_{p}, B\left(\hat{Q}_{p}^{\text {stand. }}\right)=M_{0,5}\left(\hat{Q}_{p}^{\text {stand. }}\right)-Q_{p}$ oraz $B\left(\hat{Q}_{p}^{H B}\right)=M_{0,5}\left(\hat{Q}_{p}^{H B}\right)-Q_{p}$ dla liczebności prób równych $n=100$ oraz $n=150$. W nawiasach umieszczono względne medianowe obciążenia.

Dla $n p \in N$ i $p<0,5$ postać estymatora standardowego (4.2.4) jest taka sama jak estymatora określonego wzorem (4.2.3), natomiast dla $n p \in N$ i $p>0,5$ estymator Huang-Brilla przyjmuje identyczne wartości jak estymator (4.2.3). Dla $n p \notin N$ estymatory (4.2.3), standardowy i Huang-Brilla mają identyczne wartości.

Tablica 4.2.1. Wielkości obciążeń estymatorów kwantyli wybranych rzędów dla $n=100$

\begin{tabular}{|c|c|c|c|c|c|c|}
\hline \multirow{3}{*}{ Rozkład } & \multicolumn{3}{|c|}{ Estymatory kwantyla $Q_{0,05}$} & \multicolumn{3}{c|}{ Estymatory kwantyla $Q_{0,93}$} \\
\cline { 2 - 7 } & $B\left(\hat{Q}_{0,05}\right)$ & $B\left(\hat{Q}_{0,05}^{\text {stand. }}\right)$ & $B\left(\hat{Q}_{0,05}^{H B}\right)$ & $B\left(\hat{Q}_{0.93}\right)$ & $B\left(\hat{Q}_{0.93}^{\text {stand. }}\right)$ & $B\left(\hat{Q}_{0,93}^{H B}\right)$ \\
\hline 1 & 2 & 3 & 4 & 5 & 6 & 7 \\
\hline$N(0,1)$ & $-0,0344$ & $-0,0344$ & 0,0601 & $-0,0463$ & 0,0268 & $-0,0463$ \\
& $(2,09 \%)$ & $(2,09 \%)$ & $(3,65 \%)$ & $(3,14 \%)$ & $(1,82 \%)$ & $(3,14 \%)$ \\
\hline$N(8,3)$ & $-0,1031$ & $-0,1031$ & 0,1803 & $-0,1390$ & 0,0803 & $-0,1390$ \\
& $(3,36 \%)$ & $(3,36 \%)$ & $(5,88 \%)$ & $(1,12 \%)$ & $(0,65 \%)$ & $(1,12 \%)$ \\
\hline
\end{tabular}


Tablica 4.2.1 (cd.)

\begin{tabular}{|l|r|r|r|r|r|r|}
\hline 1 & \multicolumn{1}{|c|}{2} & \multicolumn{1}{c|}{3} & \multicolumn{1}{c|}{4} & \multicolumn{1}{c|}{5} & \multicolumn{1}{c|}{6} & \multicolumn{1}{c|}{} \\
\hline$L G(0,1)$ & $-0,0065$ & $-0,0065$ & 0,0120 & $-0,1980$ & 0,1188 & 0,1980 \\
& $(3,37 \%)$ & $(3,37 \%)$ & $(6,22 \%)$ & $(4,53 \%)$ & $(2,72 \%)$ & $(4,53 \%)$ \\
\hline$L G(1,0,5)$ & $-0,0204$ & $-0,0204$ & 0,0364 & $-0,1302$ & 0,0767 & $-0,1302$ \\
& $(1,04 \%)$ & $(1,04 \%)$ & $(1,86 \%)$ & $(2,29 \%)$ & $(1,35 \%)$ & $(2,29 \%)$ \\
\hline$C a(2,1)$ & $-0,4750$ & $-0,4750$ & 0,740 & $-0,3897$ & 0,2450 & $-0,3897$ \\
& $(11,01 \%)$ & $(11,01 \%)$ & $(17,17 \%)$ & $(6,02 \%)$ & $(3,78 \%)$ & $(6,02 \%)$ \\
\hline$C a(1,2)$ & $-0,9501$ & $-0,9501$ & 1,4809 & $-0,7795$ & 0,4999 & $-0,7795$ \\
& $(8,17 \%)$ & $(8,17 \%)$ & $(12,74 \%)$ & $(7,84 \%)$ & $(4,93 \%)$ & $(7,84 \%)$ \\
\hline$P a(3,1,5)$ & $-0,0075$ & $-0,0075$ & 0,01427 & $-1,0060$ & 0,6193 & $-1,0060$ \\
& $(0,24 \%)$ & $(0,24 \%)$ & $(0,46 \%)$ & $(5,70 \%)$ & $(3,51 \%)$ & $(5,70 \%)$ \\
\hline$P a(3,3)$ & $-0,0037$ & $-0,0037$ & 0,0070 & $-0,2103$ & 0,1265 & $-0,2103$ \\
& $(0,12 \%)$ & $(0,12 \%)$ & $(0,23 \%)$ & $(2,89 \%)$ & $(1,74 \%)$ & $(2,89 \%)$ \\
\hline$W(0,1,1)$ & $-0,0036$ & $-0,0036$ & 0,0069 & $-0,8796$ & 0,0517 & $-0,8796$ \\
& $(7,06 \%)$ & $(7,06 \%)$ & $(13,41 \%)$ & $(5,17 \%)$ & $(1,94 \%)$ & $(5,17 \%)$ \\
\hline$W(0,3,1)$ & $-0,0109$ & $-0,0109$ & 0,0206 & $-0,2639$ & 0,1551 & $-0,2639$ \\
& $(7,06 \%)$ & $(7,06 \%)$ & $(13,41 \%)$ & $(3,31 \%)$ & $(1,94 \%)$ & $(3,31 \%)$ \\
\hline
\end{tabular}

Źródło: opracowanie własne.

Tablica 4.2.2. Wielkości obciążeń estymatorów kwantyli wybranych rzędów dla $n=150$

\begin{tabular}{|l|c|c|}
\hline \multicolumn{1}{|c|}{ Rozkład } & $B\left(\hat{Q}_{0,05}\right)=B\left(\hat{Q}_{0,05}^{\text {stand. }}\right)=B\left(\hat{Q}_{0,05}^{H B}\right)$ & $B\left(\hat{Q}_{0.93}\right)=B\left(\hat{Q}_{0.93}^{\text {stand. }}\right)=B\left(\hat{Q}_{0,93}^{H B}\right)$ \\
\hline$N(0,1)$ & $-0,0098(0,59 \%)$ & $-0,0072(0,48 \%)$ \\
\hline$N(8,3)$ & $0,0293(0,95 \%)$ & $-0,0215(0,17 \%)$ \\
\hline$L G(0,1)$ & $0,0019(0,98 \%)$ & $0,0312(0,71 \%)$ \\
\hline$L G(1,0,5)$ & $0,0058(0,49 \%)$ & $-0,0203(0,36 \%)$ \\
\hline$C a(2,1)$ & $0,1277(2,96 \%)$ & $-0,0628(0,97 \%)$ \\
\hline$C a(1,2)$ & $0,2552(2,20 \%)$ & $-0,1257(1,26 \%)$ \\
\hline$P a(3,1,5)$ & $0,0022(0,07 \%)$ & $-0,1606(0,91 \%)$ \\
\hline$P a(3,3)$ & $0,0011(0,04 \%)$ & $-0,0332(0,46 \%)$ \\
\hline$W(0,1,1)$ & $0,0011(2,08 \%)$ & $-0,0137(0,52 \%)$ \\
\hline$W(0,3,1)$ & $0,0032(2,08 \%)$ & $-0,0411(0,52 \%)$ \\
\hline
\end{tabular}

Źródło: opracowanie własne.

W przypadku rozważanych rozkładów najmniejszymi obciążeniami charakteryzują się standardowe estymatory kwantyli. Wielkości obciążeń zależą od klasy rozkładu analizowanej zmiennej. 
Rozpatrywane estymatory kwantyli rzędu $p$ zostały zdefiniowane jako statystyki pozycyjne odpowiednio ustalonych rang. Drugą grupę estymatorów kwantyli $Q_{p}$ stanowią funkcje dwóch lub więcej statystyk pozycyjnych.

Estymatorem kwantyla rozkładu rzędu $p \in\left(\frac{1}{n+1}, \frac{n}{n+1}\right)$ jest liniowa kombinacje dwóch statystyk pozycyjnych rang $[(n+1) p]$ oraz $[(n+1) p]+1$ określona $\mathrm{w}$ definicji 4.2.6.

Definicja 4.2.6. Estymatorem kwantyla $Q_{p}$ rzędu $p$ rozkładu zmiennej losowej $X$, gdzie $p \in\left\langle\frac{1}{n+1}, \frac{n}{n+1}\right)$, jest statystyka określona wzorem:

$$
\hat{Q}_{p}^{L K}=(1-(n+1) p+[(n+1) p]) X_{([(n+1) p])}^{(n)}+((n+1) p-[(n+1) p]) X_{([n+1) p]+1)}^{(n)} .
$$

Estymatorami kwantyli rzędu $p$ będącymi kombinacjami liniowymi wszystkich statystyk pozycyjnych są estymatory Harrella-Davisa i Bersteina zdefiniowane poniżej (por. F. E. Harrell, C. E. Davis [1982], R. Zieliński [1999, 2005b]).

Definicja 4.2.7. Estymatorem Harrella-Davisa kwantyla $Q_{p}$ rozkładu zmiennej losowej $X$ określonym na podstawie próby prostej $X_{1}, X_{2}, \ldots, X_{n}$ nazywamy statystykę postaci:

$$
\hat{Q}_{p}^{H D}=\sum_{i=1}^{n} w_{p, i, n} X_{(i)}^{(n)},
$$

gdzie

$$
w_{p, i, n}=\frac{1}{B((n+1) p,(n+1)(1-p))} \int_{(i-1) / n}^{i / n} t^{(n+1) p-1}(1-t)^{(n+1)(1-p)-1} d t
$$

Definicja 4.2.8. Estymatorem Bersteina kwantyla $Q_{p}$ określonym na podstawie próby prostej $X_{1}, X_{2}, \ldots, X_{n}$ nazywamy statystykę określoną wzorem:

$$
\hat{Q}_{p}^{B r s}=\sum_{i=1}^{n}\left[\left(\begin{array}{c}
n-1 \\
i-1
\end{array}\right) p^{i-1}(1-p)^{n-i}\right] X_{(i)}^{(n)} .
$$


W celu zbadania obciążeń estymatora będącego liniową kombinacją dwóch statystyk pozycyjnych i estymatora Bersteina przeprowadzono analizę symulacyjną polegająca na powtórzeniu 20000 razy procedury estymacji kwantyli i wyznaczeniu $\hat{B}\left(\hat{Q}_{p}^{L K}\right)=\operatorname{Me}\left(\hat{Q}_{p}^{L K}\right)-Q_{p}$ oraz $\hat{B}\left(\hat{Q}_{p}^{B r s}\right)=\operatorname{Me}\left(\hat{Q}_{p}^{B r s}\right)-Q_{p}$. Otrzymane wyniki zawarte są w tablicy 4.2.3.

Tablica 4.2.3. Obciążenia estymatorów (4.2.8) i (4.2.11) dla wybranych kwantyli i $n=100$

\begin{tabular}{|l|c|c|c|c|}
\hline \multicolumn{1}{|c|}{ Rozkład } & $\hat{B}\left(\hat{Q}_{0,05}^{L K}\right)$ & $\hat{B}\left(\hat{Q}_{0,05}^{B r s}\right)$ & $\hat{B}\left(\hat{Q}_{0,93}^{L K}\right)$ & $\hat{B}\left(\hat{Q}_{0,93}^{B r s}\right)$ \\
\hline$N(0,1)$ & $-0,0309(1,88 \%)$ & $0,0175(1,07 \%)$ & $0,0203(1,37 \%)$ & $-0,0155(1,05 \%)$ \\
\hline$N(8,3)$ & $-0,0897(2,93 \%)$ & $0,0585(1,91 \%)$ & $0,0625(0,50 \%)$ & $-0,0440(0,35 \%)$ \\
\hline$L G(0,1)$ & $-0,0056(2,90 \%)$ & $0,0090(4,65 \%)$ & $0,0937(2,14 \%)$ & $-0,0380(0,87 \%)$ \\
\hline$L G(1,0,5)$ & $-0,0180(1,51 \%)$ & $0,0197(1,65 \%)$ & $0,0610(1,07 \%)$ & $-0,0099(0,17 \%)$ \\
\hline$C a(2,1)$ & $-0,4316(10,00 \%)$ & $-1,1866(27,51 \%)$ & $0,1920(2,97 \%)$ & $0,4877(7,53 \%)$ \\
\hline$C a(1,2)$ & $-0,9479(8,15 \%)$ & $-2,4945(21,45 \%)$ & $0,3833(3,85 \%)$ & $0,9984(10,04 \%)$ \\
\hline$P a(3,1,5)$ & $-0,0064(0,21 \%)$ & $0,0155(0,50 \%)$ & $0,5109(2,89 \%)$ & $0,7195(4,07 \%)$ \\
\hline$P a(3,3)$ & $-0,0031(0,10 \%)$ & $0,0076(0,25 \%)$ & $0,0998(1,37 \%)$ & $0,0546(0,75 \%)$ \\
\hline$W(0,1,1)$ & $-0,0032(6,14 \%)$ & $0,0071(13,94 \%)$ & $0,0440(1,66 \%)$ & $-0,0057(0,22 \%)$ \\
\hline$W(0,3,1)$ & $-0,0086(5,57 \%)$ & $0,0213(13,84 \%)$ & $0,1414(1,77 \%)$ & $-0,0193(0,24 \%)$ \\
\hline
\end{tabular}

Źródło: opracowanie własne.

Dla kwantyla rzędu 0,05 wszystkich rozważanych rozkładów, oprócz rozkładu normalnego, medianowe obciążenie estymatora (4.2.8) było mniejsze niż estymatora (4.2.11) oraz estymatorów z poprzedniej rozpatrywanej grupy. Dla kwantyla rzędu 0,93 rozkładów o cienkich ogonach estymator Bersteina charakteryzował się mniejszym obciążeniem niż estymator będący liniową kombinacją dwóch estymatorów.

Zarówno prezentowane, jak i inne postaci estymatorów kwantyli oraz ich własności przedstawione są we wspomnianych pracach R. Zielińskiego.

\section{Estymatory mediany}

Wśród kwantyli ważną rolę odgrywa mediana z próby. Stosuje się ją do szacowania wartości średniej populacji w przypadku, gdy istnieje podejrzenie o występowaniu obserwacji skrajnych sprawiających, że szacowanie jej przy użyciu średniej arytmetycznej obarczone będzie dużym błędem. 
W celu rozstrzygnięcia, czy do estymacji wartości średniej populacji o funkcji gęstości $f$ należy wykorzystać medianę z próby, czy też średnią arytmetyczną, może posłużyć współczynnik $e(F)$ (por. J. Lira, W. Wagner [2005]) określony wzorem:

$$
e(F)=\frac{D^{2}(\bar{X})}{D^{2}(M e)}=4 \sigma^{2} f^{2}(0),
$$

gdzie $\sigma^{2}$ jest wariancją zmiennej $X$.

Współczynnik ten stosuje się dla zmiennych losowych o rozkładach symetrycznych mających wariancję oraz dla dużych liczebności prób. Jeżeli $e(F)>1$, to mediana $z$ próby jest efektywniejszym estymatorem wartości średniej niż średnia arytmetyczna. Przykładem rozkładu, w którym należy wykorzystać medianę z próby jako estymator wartości średniej populacji, jest rozkład Laplace’a.

W przypadku rozkładów populacji, dla których nie istnieje wartość oczekiwana lub wariancja, czyli rozkładów charakteryzujących się grubymi ogonami, stosuje się medianę z próby jako estymator mediany rozkładu. Takimi rozkładami są m.in. rozkład Cauchy'ego oraz rozkłady Pareto dla $\alpha<1$.

Estymatorami mediany $M_{0,5}$ zmiennej losowej $X$ określonymi na podstawie próby prostej $X_{1}, X_{2}, \ldots, X_{n}$ są statystyki postaci:

$$
M e=\sum_{i=1}^{n} \lambda_{i} X_{(i)}^{(n)},
$$

gdzie $\lambda_{i} \geq 0$ oraz $\sum_{i=1}^{n} \lambda_{i}=1$, zaś $X_{(i)}^{(n)}$ są statystykami pozycyjnymi wyznaczonymi na podstawie próby losowej $X_{1}, X_{2}, \ldots, X_{n}$.

Mediana z próby określona wzorem (1.2.2) (estymator (4.2.8) dla $p=0,5$ ) jest medianowo-nieobciążona dla nieparzystej liczebności próby, natomiast dla parzystej liczby elementów próby estymator nie jest medianowo-nieobciążony. Analiza własności tego estymatora przedstawiona jest w pracy R. Zielińskiego [1995]. Z dowodu tam zaprezentowanego wynika, że dla każdej dodatniej liczby rzeczywistej $C$ istnieje taki rozkład $F$, iż różnica między wartością rzeczywistą a wartością jej estymatora jest większa od $C$, co zaś oznacza, że mediana z próby może być położona dowolnie daleko od szacowanego parametru. 
Z definicji 4.2.3 wyznacza się standardowy estymator mediany, który jest estymatorem medianowo-nieobciążonym. Jego postać określa definicja 4.2.9.

Definicja 4.2.9. Standardowym estymatorem mediany nazywamy statystykę pozycyjną z $n$-elementowej próby prostej $X_{1}, X_{2}, \ldots, X_{n}$ postaci:

$$
M e^{\text {stand. }}=X_{(k)}^{(n)}
$$

gdzie

$$
k= \begin{cases}\frac{n}{2}+I_{(0,0,5)}(u), & \text { gdy } n \text { jest liczbą parzystą, } \\ {\left[\frac{n}{2}\right]+1,} & \text { gdy } n \text { jest liczbą nieparzysta, }\end{cases}
$$

przy czym $u$ jest wartością zmiennej losowej $U$ o rozkładzie jednostajnym na przedziale $(0,1)$ oraz $I_{(0,0,5)}(u)$ jest indykatorem przyjmującym wartość 1 , gdy $u \in(0,0,5\rangle$ i $0 \mathrm{w}$ przeciwnym przypadku.

Z definicji 4.2.9 wynika, że jako estymator mediany przyjmuje się statystykę pozycyjną $X_{\left[\frac{n}{2}\right]_{+1}^{(n)}}$, gdy $n$ jest liczbą nieparzystą, natomiast gdy $n$ jest liczbą parzystą, estymatorem jest losowo wybrana jedna z dwóch statystyk $X_{\left(\frac{n}{2}\right)}^{(n)} \operatorname{lub} X_{\left(\frac{n}{2}+1\right)}^{(n)}$.

Innymi estymatorami mediany mogą być statystyki określone wzorami (4.2.9) i (4.2.11) dla $p=0,5$. Estymator Harrella-Davisa mediany ma postać:

$$
M e^{H D}=\sum_{i=1}^{n} w_{i, n} X_{(i)}^{(n)}
$$

gdzie $\quad w_{i, n}=\frac{1}{B((n+1) / 2,(n+1) / 2)} \int_{(i-1) / n}^{i / n} t^{(n-1) / 2}(1-t)^{(n-1) / 2} d t$, natomiast estymator Bersteina wyraża się wzorem:

$$
M e^{B r s}=0,5^{n-1} \sum_{i=1}^{n}\left(\begin{array}{c}
n-1 \\
i-1
\end{array}\right) X_{(i)}^{(n)} .
$$




\subsection{Klasyczne metody wyznaczania przedziałów ufności dla kwantyli}

Przy wyznaczaniu przedziału ufności dla kwantyla $Q_{p}$ rozkładu zmiennej losową $X$ zwykle stosuje się podejście nieparametryczne.

Nieparametryczna estymacja przedziałowa kwantyla $Q_{p}$ na podstawie $n$-elementowej próby prostej $X_{1}, X_{2}, \ldots, X_{n}$ związana jest z określeniem zmiennej losowej $K$, której wartości są równe liczbie elementów, spośród $n$ elementów, mniejszych od kwantyla $Q_{p}$. Zmienna losowa $K$ ma rozkład dwumianowy o funkcji prawdopodobieństwa postaci:

$$
P(K=k)=\left(\begin{array}{l}
n \\
k
\end{array}\right)(p)^{k}(1-p)^{n-k} \quad \text { dla } k=0,1,2, \ldots, n .
$$

Prawdopodobieństwo tego, że kwantyl rzędu $p$ znajduje się $\mathrm{w}$ przedziale wyznaczonym przez $r$-tą oraz $s$-tą statystykę pozycyjną, wynosi:

$$
P\left(X_{(r)}^{(n)} \leq Q_{p} \leq X_{(s)}^{(n)}\right)=\sum_{i=r}^{s-1}\left(\begin{array}{c}
n \\
i
\end{array}\right) p^{i}(1-p)^{n-i}, \quad 1 \leq r<s \leq n,
$$

gdzie $X_{(r)}^{(n)}, X_{(s)}^{(n)}$ są statystykami pozycyjnymi rangi, odpowiednio, $r$ i $s$.

Zatem przyjmując współczynnik ufności $1-\alpha$ na podstawie $n$-elementowej próby losowej, wyznaczamy rzędy kwantyli tak, aby spełniona była równość:

$$
\sum_{i=r}^{s-1}\left(\begin{array}{c}
n \\
i
\end{array}\right) p^{i}(1-p)^{n-i}=1-\alpha .
$$

Ponieważ zmienne losowe $F\left(X_{(i)}^{(n)}\right)$, dla $i=1,2, \ldots, n$, mają rozkład $U(0,1)$ równość (4.3.2) można zapisać następująco:

$$
P\left(U_{(r)}^{(n)} \leq p \leq U_{(s)}^{(n)}\right)=\sum_{i=r}^{s-1}\left(\begin{array}{c}
n \\
i
\end{array}\right) p^{i}(1-p)^{n-i},
$$

gdzie $U_{(r)}^{(n)}=F^{-1}\left(X_{(r)}^{(n)}\right)$ oraz $U_{(s)}^{(n)}=F^{-1}\left(X_{(s)}^{(n)}\right)$ są statystykami pozycyjnymi rozkładu $U(0,1)$.

Przy estymacji kwantyla rzędu $p$, na poziomie ufności $1-\alpha$, liczebność próby ma dolne ograniczenie wynikające z nierówności: 


$$
P\left(U_{(1)}^{(n)} \leq p \leq U_{(n)}^{(n)}\right)=\sum_{i=1}^{n-1}\left(\begin{array}{l}
n \\
i
\end{array}\right) p^{i}(1-p)^{n-i} \geq 1-\alpha,
$$

co oznacza, że musi ona spełniać nierówność:

$$
p^{n}+(1-p)^{n} \leq \alpha
$$

W tablicy 4.3.1 podane są minimalne liczebności prób dla wybranych współczynników ufności i wybranych rzędów kwantyli.

Tablica 4.3.1. Minimalne liczebności prób przy nieparametrycznej estymacji kwantyli

\begin{tabular}{|c|r|r|r|r|r|}
\hline \multirow{2}{*}{$p$} & \multicolumn{5}{|c|}{ Współczynnik ufności } \\
\cline { 2 - 6 } & 0,9 & 0,925 & 0,95 & 0,975 & 0,99 \\
\hline 0,50 & 5 & 5 & 6 & 6 & 8 \\
\hline 0,60 & 5 & 6 & 7 & 8 & 10 \\
\hline 0,70 & 7 & 8 & 9 & 11 & 13 \\
\hline 0,80 & 11 & 12 & 14 & 15 & 21 \\
\hline 0,90 & 22 & 25 & 29 & 23 & 44 \\
\hline 0,95 & 45 & 51 & 59 & 72 & 90 \\
\hline 0,99 & 230 & 258 & 299 & 368 & 459 \\
\hline
\end{tabular}

Źródło: obliczenia własne.

W wyniku poszukiwania przedziału spełniającego warunek $P\left(U_{(r)}^{(n)} \leq p \leq U_{(s)}^{(n)}\right)=1-\alpha$ nie otrzymujemy jednoznacznie określonego przedziału, gdyż pokrywa on szacowaną wartość $p$ w przybliżeniu, szczególnie dla małych liczebności prób, dlatego konieczna jest randomizacja (por. R. Zieliński, W. Zieliński [2005]). Spośród przedziałów ufności wybieramy dwa: $\left(U_{(r)}^{(n)}, U_{(s)}^{(n)}\right)$ oraz $\left(U_{\left(r^{\prime}\right)}^{(n)}, U_{\left(s^{\prime}\right)}^{(n)}\right)$ o najmniejszych długościach spełniające warunki:

$$
P\left(U_{(r)}^{(n)} \leq p \leq U_{(s)}^{(n)}\right)<1-\alpha \text { oraz } P\left(U_{\left(r^{\prime}\right)}^{(n)} \leq p \leq U_{\left(s^{\prime}\right)}^{(n)}\right)>1-\alpha,
$$

przy czym $r^{\prime}=r-1, s^{\prime}=s$ lub $r^{\prime}=r, s^{\prime}=s-1$, a następnie wyznaczamy wartości $R, S$ dla których przedział $\left(U_{(R)}^{(n)}, U_{(S)}^{(n)}\right)$ będzie przedziałem pokrywającym szacowaną wartość $p$ z ufnością równą dokładnie $1-\alpha$. Randomizacja związana jest zatem $\mathrm{z}$ wyznaczeniem $\lambda \mathrm{z}$ równania: 


$$
\lambda P\left(U_{(r)}^{(n)} \leq p \leq U_{(s)}^{(n)}\right)+(1-\lambda) P\left(U_{\left(r^{\prime}\right)}^{(n)} \leq p \leq U_{\left(s^{\prime}\right)}^{(n)}\right)=1-\alpha,
$$

a następnie wygenerowaniem liczby $\lambda_{0} \mathrm{z}$ rozkładu jednostajnego na przedziale $[0,1]$. Jeśli $\lambda_{0}<\lambda$, to wybieramy przedział ufności $\left(U_{(r)}^{(n)}, U_{(s)}^{(n)}\right)$, w przeciwnym przypadku przedział $\left(U_{\left(r^{\prime}\right)}^{(n)}, U_{\left(s^{\prime}\right)}^{(n)}\right)$.

W ten sposób otrzymujemy przedział ufności dla kwantyla $Q_{p}$ postaci $\left(X_{(R)}^{(n)}, X_{(S)}^{(n)}\right)$, gdzie $R=r, S=s$ lub $R=r^{\prime}, S=s^{\prime}$, a prawdopodobieństwo, że pokrywa on szacowany kwantyl rzędu $p$, jest równe $1-\alpha$.

Twierdzenie 1.4.18 dotyczące asymptotycznej zbieżności dystrybuanty kwantyla z próby $X_{p ; n}$ do dystrybuanty rozkładu $N\left(Q_{p}, \frac{1}{f\left(Q_{p}\right)} \sqrt{\frac{p(1-p)}{n}}\right)$, pozwala wyznaczyć przedział ufności dla kwantyla rozkładu $Q_{p}$ w następujący sposób:

$$
P\left(X_{p ; n}-u_{\alpha} \frac{\sqrt{p(1-p)}}{f\left(Q_{p}\right) \sqrt{n}} \leq Q_{p} \leq X_{p ; n}+u_{\alpha} \frac{\sqrt{p(1-p)}}{f\left(Q_{p}\right) \sqrt{n}}\right)=1-\alpha
$$

gdzie $\Phi\left(u_{\alpha}\right)=1-\frac{\alpha}{2}$ oraz $\Phi$ jest dystrybuantą rozkładu normalnego standaryzowanego, zaś $1-\alpha$ jest ustalonym poziomem ufności.

Wadą tej procedury konstrukcji przedziału ufności jest konieczność znajomości funkcji gęstości $f$. Zastąienie $f\left(Q_{p}\right)$ pewnym zgodnym estymatorem prowadzi do zmodyfikowanej procedury estymacji przedziałowej (por. R. Serfling [1991, s. 105-108]).

Niech $\left(k_{1 n}\right)_{n \in N}$ i $\left(k_{2 n}\right)_{n \in N}$ będą ciagami liczb całkowitych takimi, że $1 \leq k_{1 n}<k_{2 n} \leq n$ oraz

$$
\begin{aligned}
& \frac{k_{1 n}}{n}-p \sim-\frac{u_{\alpha} \sqrt{p(1-p)}}{\sqrt{n}}, \\
& \frac{k_{2 n}}{n}-p \sim \frac{u_{\alpha} \sqrt{p(1-p)}}{\sqrt{n}},
\end{aligned}
$$

gdy $n \rightarrow \infty$. Wówczas otrzymujemy: 


$$
P\left(X_{\left(k_{1 n}\right)}^{(n)} \leq Q_{p} \leq X_{\left(k_{2 n}\right)}^{(n)}\right) \approx 1-\alpha,
$$

gdzie $X_{\left(k_{1 n}\right)}^{(n)}, X_{\left(k_{2 n}\right)}^{(n)}$ są statystykami pozycyjnymi o rangach $k_{1 n}$ oraz $k_{2 n}$ wyznaczonymi na podstawie wylosowanej $n$-elementowej próby.

\section{Estymacja przedzialowa mediany}

Znajomość rozkładu rozważanej zmiennej losowej $X$ umożliwia konstrukcję parametrycznego przedziału ufności dla mediany.

Rozważmy problem przedziałowej estymacji mediany $M_{0,5}$ zmiennej losowej $X$, o dystrybuancie $F$ i funkcji gęstości symetrycznej względem mediany.

Niech $X_{1}, \ldots, X_{n}$ będzie $n$-elementową próbą prostą wylosowaną z populacji badanej ze względu na zmienną $X$ przy założeniu, że $n$ jest liczbą nieparzystą.

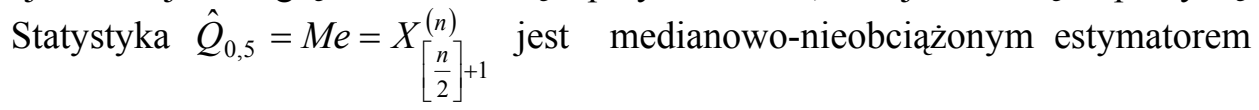
mediany i ma rozkład o dystrybuancie określonej wzorem (por. R. Zieliński [2010], [2011, s. 34-35]):

$$
F_{M e}(x)=B\left(F_{0}\left(x-M_{0,5}\right) ; \frac{n+1}{2}, \frac{n+1}{2}\right),
$$

gdzie $B(z ; a, b)$ oznacza dystrybuantę rozkładu beta z parametrami $a$ i $b$, zaś $F_{0}$ jest dystrybuantą rozkładu zmiennej $X-M_{0,5}$ symetrycznego względem zera. Zatem $F_{0}\left(x-M_{0,5}\right)=F(x)$, czyli kwantyl rozkładu mediany rzędu $p$ ma postać:

$$
x_{p}(M e)=M_{0,5}+F_{0}^{-1}\left(B^{-1}\left(p, \frac{n+1}{2}, \frac{n+1}{2}\right)\right) .
$$

Estymacja przedziałowa mediany związana jest $\mathrm{z}$ wyznaczeniem przedziału, który z ufnością $1-\alpha$ pokrywa szacowaną wartość mediany.

$\mathrm{Z}$ warunku:

$$
P\left(x_{\frac{\alpha}{2}}(M e) \leq M e \leq x_{1-\frac{\alpha}{2}}(M e)\right)=1-\alpha,
$$

gdzie $x_{\frac{\alpha}{2}}(M e), x_{1-\frac{\alpha}{2}}(M e)$ są kwantylami rozkładu mediany $M e$, odpowiednio, rzędu $\frac{\alpha}{2}$ i $1-\frac{\alpha}{2}$ oraz z postaci kwantyli otrzymujemy przedział ufności określony następująco: 


$$
P\left(M e-F_{0}^{-1}\left(B^{-1}\left(1-\frac{\alpha}{2} ; \frac{n+1}{2}, \frac{n+1}{2}\right)\right) \leq M_{0,5} \leq M e-F_{0}^{-1}\left(B^{-1}\left(\frac{\alpha}{2} ; \frac{n+1}{2}, \frac{n+1}{2}\right)\right)\right)=1-\alpha .
$$

W przypadku estymacji na podstawie próby o parzystej liczbie elementów estymator (1.2.2) nie jest medianowo-nieobciążony i należy wykorzystać standardowy bądź zrandomizowany estymator mediany, ewentualnie losowo odrzucić jeden element próby.

Konstrukcja przedziału ufności (4.3.16) jest możliwa, jeśli potrafimy wyznaczyć postać dystrybuanty $F_{0}(x)$ w oparciu o znaną dystrybuantę $F(x)$, co nie jest trudne dla rozkładów symetrycznych względem mediany, takich jak rozkład normalny, Cauchy'ego czy logistyczny.

Jeśli zmienna losowa $X$ ma rozkład normalny $N(\mu, \sigma)$, to dystrybuanta $F_{0}(x)$ jest dystrybuantą rozkładu normalnego $N(0, \sigma)$. Zatem zastosowanie wzoru (4.3.16) prowadzi do uzyskania przedziału ufności pokrywającego wartość mediany z ufnością $1-\alpha$ postaci:

$$
M e-\Phi^{-1}\left(B^{-1}\left(1-\frac{\alpha}{2}, \frac{n+1}{2}, \frac{n+1}{2}\right)\right) \sigma \leq M_{0,5} \leq M e-\Phi^{-1}\left(B^{-1}\left(\frac{\alpha}{2}, \frac{n+1}{2}, \frac{n+1}{2}\right)\right) \sigma,
$$

gdzie $M e$ jest medianą z $n$-elementowej próby losowej, natomiast $\Phi$ jest dystrybuantą rozkładu normalnego standaryzowanego.

Dla zmiennej losowej $X$ o rozkładzie Cauchy'ego $C a(m, \lambda)$, stosowanego do modelowania różnego rodzaju procesów na rynkach finansowych, zastosowanie wzoru (4.3.16) jest również możliwe. Funkcja $F_{0}(x)$ jest dystrybuantą rozkładu Cauchy'ego $C a(0, \lambda)$ i wyraża się wzorem $F_{0}(x)=\frac{1}{\pi} \operatorname{arctg}\left(\frac{x}{\lambda}\right)+\frac{1}{2}$. Zatem parametryczny przedział pokrywający medianę z ufnością $1-\alpha$ ma postać:

$$
M e-\lambda \operatorname{tg}\left(\pi\left(B^{-1}\left(1-\frac{\alpha}{2} ; \frac{n+1}{2}, \frac{n+1}{2}\right)-\frac{1}{2}\right)\right) \leq M_{0.5} \leq M e-\lambda \operatorname{tg}\left(\pi\left(B^{-1}\left(\frac{\alpha}{2} ; \frac{n+1}{2}, \frac{n+1}{2}\right)-\frac{1}{2}\right)\right) .
$$

Jeśli zmienna losowa $X$ ma rozkład logistyczny Logist $(\mu, s)$, to dystrybuantą zmiennej $X-M_{0,5}$ jest funkcja $F_{0}(x)=\frac{1}{1+e^{-\frac{x}{s}}}$, czyli przedział: 


$$
M e+s \ln \left(\frac{1}{B^{-1}\left(1-\frac{\alpha}{2} ; \frac{n+1}{2}, \frac{n+1}{2}\right)}-1\right) \leq M_{0,5} \leq M e+s \ln \left(\frac{1}{B^{-1}\left(\frac{\alpha}{2} ; \frac{n+1}{2}, \frac{n+1}{2}\right)}-1\right)
$$

z ufnością $1-\alpha$ pokrywa wartość szacowanej mediany $\mu$.

Podejście parametryczne nie zawsze jest możliwe do wykorzystania w zagadnieniach praktycznych. Brak znajomości postaci dystrybuanty $F_{0}(x)$ uniemożliwia konstrukcje przedziałów ufności. W tym przypadku alternatywą jest zastosowanie nieparametrycznych metod estymacji mediany.

Nieparametryczna estymacja mediany jest szczególnym przypadkiem nieparametrycznej metody estymacji kwantyli i polega na wyznaczeniu na podstawie $n$-elementowej próby prostej statystyk pozycyjnych $X_{(r)}^{(n)}$ i $X_{(s)}^{(n)}$ odpowiednio rang $r$ is, aby spełniona była równość:

$$
P\left(X_{(r)}^{(n)} \leq M_{0,5} \leq X_{(s)}^{(n)}\right)=\sum_{k=r}^{s-1} P(K=k)=\left(\frac{1}{2}\right)^{n} \sum_{k=r}^{s-1}\left(\begin{array}{l}
n \\
k
\end{array}\right) .
$$

Prawa strona wzoru określa wiarygodność oszacowania. Dobierając odpowiednio rangi $r$ i $s$ statystyk, otrzymujemy przedział ufności zawierający medianę $M_{0,5}$ nieznanego rozkładu populacji z wiarygodnością w przybliżeniu równą założonej $1-\alpha$.

Rzędy statystyk pozycyjnych służących do estymacji mediany, dla wybranych liczebności prób oraz wybranych wiarygodności oszacowań, przedstawione są m.in. w pracy A. Baszczyńskiej, D. Pekasiewicz [2010]. Podobnie jak w przypadku szacowania kwantyla rzędu $p$, różne statystyki pozycyjne $X_{(r)}^{(n)}$ i $X_{(s)}^{(n)}$ gwarantują w przybliżeniu taką samą wiarygodność oszacowania, przy czym wiarygodność ta jest zwykle w przybliżeniu równa współczynnikowi ufności $1-\alpha$. W takich sytuacjach dokonuje się randomizacji (por. (4.3.7), (4.3.8)).

Zastosowanie tej procedury estymacji jednak nie zawsze prowadzi do otrzymania przedziału ufności symetrycznego względem mediany z próby.

Do przedziałów ufności symetrycznych względem wartości stosowanego estymatora należą przedziały konstruowane w oparciu o twierdzenia graniczne. Są one stosunkowo łatwe w praktycznych zastosowaniach.

Jednym z przedziałów ufności dla mediany określonym dla dużych liczebności prób jest przedział postaci (por. D. A. Bloch, J. L Gastwirth [1968]; D. J. Olivie [2005]): 


$$
P\left(M e-t_{\alpha} s_{M e}<M_{0,5}<M e+t_{\alpha} s_{M e}\right)=1-\alpha,
$$

gdzie $M e$ jest medianą z próby określoną wzorem (1.2.2), zaś $s_{M e}$ jest obliczany ze wzoru:

$$
S_{M e}=0,5\left(X_{\left(k_{n}\right)}^{(n)}-X_{\left(l_{n}\right)}^{(n)}\right),
$$

gdzie

$$
l_{n}=\left\{\begin{array}{lll}
{[n / 2]-\sqrt{n / 4},} & \text { gdy } & \sqrt{n / 4} \in N, \\
{[n / 2]-[\sqrt{n / 4}]-1,} & \text { gdy } & \sqrt{n / 4} \notin N,
\end{array}\right.
$$

oraz

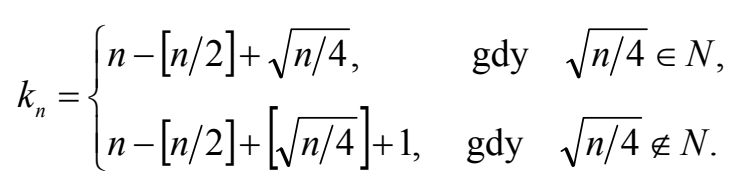

Wartość $t_{\alpha}$ odczytujemy z tablic wartości krytycznych rozkładu $t$-Studenta o $D f=k_{n}-l_{n}-1$ stopniach swobody. Ze wzorów (4.3.23) i (4.3.24) wynika, że $D f \approx[\sqrt{n}]$.

Dla bardzo dużych liczebności prób przedział ufności można zapisać w postaci:

$$
P\left(M e-u_{\alpha} s_{M e}<M_{0,5}<M e+u_{\alpha} s_{M e}\right)=1-\alpha,
$$

gdzie $\Phi\left(u_{\alpha}\right)=1-\frac{\alpha}{2}$, natomiast $\Phi$ jest dystrybuantą rozkładu normalnego standaryzowanego.

Należy zauważyć jednak, że ze wzoru (4.3.25) można korzystać wtedy, gdy rozkład $t$-Studenta jest zbieżny asymptotycznie do rozkładu normalnego, czyli gdy liczba stopni swobody jest większa niż 30, co implikuje liczebność próby co najmniej 900.

Przedstawione metody estymacji oparte na statystykach pozycyjnych dotyczą sytuacji, gdy próby losowane są w sposób niezależny. W literaturze przedmiotu można znaleźć również procedury estymacji wykorzystujące statystyki pozycyjne, przy bardziej złożonych schematach losowania próby (por. np. J. Allen i in. [2000], S. T. Gross [1980], Singh S. i in. [2001]. 


\subsection{Bayesowska estymacja kwantyli}

Metody estymacji bayesowskiej również można wykorzystać do szacowania kwantyli rozkładu, w tym mediany. Przy zastosowaniu liniowej funkcji straty estymatorem kwantyla rzędu $p$ zmiennej losowej jest kwantyl rozkładu a posteriori rzędu $p$ wyznaczony na podstawie próby losowej i danego rozkładu a prio$r i$ tego parametru.

Rozważmy problem bayesowskiej estymacji mediany zmiennej losowej $X$. Załóżmy najpierw, że $X \sim \operatorname{Exp}(\lambda)$ oraz $X_{1}, X_{2}, \ldots, X_{n}$ jest próbą prostą.

Związek między medianą $M_{0,5}=m$ i wartością oczekiwaną $\lambda$ postaci $m=\lambda \ln 2$ pozwala na przekształcenie funkcji gęstości do następującego wzoru:

$$
f(x, m)= \begin{cases}\frac{\ln 2}{m} \exp \left(-\frac{\ln 2}{m} x\right) & \text { dla } x \geq 0, \\ 0 & \text { dla } x<0 .\end{cases}
$$

Postać estymatora mediany zależy od rozkładu a priori mediany. Załóżmy najpierw, że rozkładem a priori jest rozkład jednostajny na przedziale $[a, b]$, gdzie $0<a<b$.

W tym przypadku łączna funkcja gęstości $f(\cdot \mid m)$ wyznaczona na podstawie próby losowej $X_{1}, X_{2}, \ldots, X_{n}$ jest postaci:

$$
f(\mathbf{x} \mid m)=\prod_{i=1}^{n} \frac{\ln 2}{m} \exp \left(-\frac{\ln 2}{m} x_{i}\right)=\left(\frac{\ln 2}{m}\right)^{n} \exp \left(-\frac{\ln 2}{m} \sum_{i=1}^{n} x_{i}\right)=\left(\frac{\ln 2}{m}\right)^{n} \exp \left(-\frac{\ln 2}{m} n \bar{x}\right)
$$

oraz

$$
\begin{gathered}
\int_{\Theta} f(\mathbf{x} \mid m) \cdot g(m) d m=\int_{a}^{b}\left(\frac{\ln 2}{m}\right)^{n} \exp \left(-\frac{\ln 2}{m} n \bar{x}\right) \cdot \frac{1}{b-a} d m=\frac{1}{b-a} \int_{a}^{b} \frac{(\ln 2)^{n}}{m^{n}} \exp \left(-\frac{\ln 2}{m} n \bar{x}\right) d m= \\
=\left\{\begin{array}{l}
t=\frac{\ln 2}{m} n \bar{x} \\
d m=-\frac{\ln 2 n \bar{x}}{t^{2}} d t \\
c=\frac{\ln 2}{a} n \bar{x}, \quad g=\frac{\ln 2}{b} n \bar{x}
\end{array}\right\}=\frac{1}{b-a} \int_{c}^{g} \frac{1}{(n \bar{x})^{n}} t^{n}\left(-\frac{\ln 2}{t^{2}} n \bar{x}\right) \exp (-t) d t=
\end{gathered}
$$




$$
=\frac{\ln 2}{b-a} \int_{g}^{c} \frac{1}{(n \bar{x})^{n-1}} t^{n-2} \exp (-t) d t=\frac{\ln 2}{b-a} \cdot \frac{\Gamma(n-1, g)-\Gamma(n-1, c)}{(n \bar{x})^{n-1}},
$$

gdzie $\Gamma(m, x)=\int_{x}^{\infty} t^{m-1} \exp (-t) d t$ jest niekompletną funkcją gamma.

Zatem funkcja gęstości rozkładu a posteriori parametru $m$ wyraża się wzorem:

$$
g(m \mid \mathbf{x})=\frac{f(\mathbf{x} \mid m) \cdot g(m)}{\int_{\Theta} f(\mathbf{x} \mid m) \cdot g(m) d m}=\frac{(n \bar{x} \ln 2)^{n-1} \exp \left(-\frac{\ln 2}{m} n \bar{x}\right)}{m^{n}\left(\Gamma\left(n-1, \frac{\ln 2}{b} n \bar{x}\right)-\Gamma\left(n-1, \frac{\ln 2}{a} n \bar{x}\right)\right)} .
$$

W wyniku zastosowania liniowej funkcji straty otrzymujemy równanie:

$$
\int_{0}^{d} \frac{(n \bar{x})^{n-1}(\ln 2)^{n-1} \exp \left(-\frac{\ln 2}{m} n \bar{x}\right)}{m^{n}\left(\Gamma\left(n-1, \frac{\ln 2}{a} n \bar{x}\right)-\Gamma\left(n-1, \frac{\ln 2}{b} n \bar{x}\right)\right)} d m=\frac{1}{2},
$$

a po przekształceniach:

$$
\frac{(n \bar{x})^{n-1}(\ln 2)^{n-1}}{\Gamma\left(n-1, \frac{\ln 2}{a} n \bar{x}\right)-\Gamma\left(n-1, \frac{\ln 2}{b} n \bar{x}\right)} \int_{0}^{d} m^{-n} \exp \left(-\frac{\ln 2}{m} n \bar{x}\right) d m=\frac{1}{2},
$$

czyli

$$
\Gamma\left(n-1, \frac{n \bar{x} \ln 2}{d}\right)=\frac{\Gamma\left(n-1, \frac{\ln 2}{a} n \bar{x}\right)-\Gamma\left(n-1, \frac{\ln 2}{b} n \bar{x}\right)}{2} .
$$

Korzystając z oprogramowania komputerowego, wyznaczamy numerycznie $d_{0}=\hat{m}$.

Rozważmy przypadek szacowania mediany w przypadku, gdy rozkład a priori mediany $m$ jest odwróconym rozkładem gamma o funkcji gęstości wyrażonej wzorem: 


$$
g(m)=\frac{(b)^{p} \exp \left(-\frac{b}{m}\right)}{m^{p+1} \Gamma(p)} \quad \text { dla } \quad m>0
$$

Ponieważ

$$
\begin{gathered}
\int_{0}^{\infty}\left(\frac{\ln 2}{m}\right)^{n} \exp \left(-\frac{\ln 2}{m} n \bar{x}\right) \cdot \frac{(b)^{p} \exp \left(-\frac{b}{m}\right)}{m^{p+1} \Gamma(p)} d m=\int_{0}^{\infty} \frac{b^{p} \ln ^{n} 2}{m^{p+n+1} n \bar{x} \Gamma(p)} \exp \left(-\frac{\ln 2}{m} n \bar{x}-\frac{b}{m}\right) d m= \\
=\left\{\begin{array}{l}
t=\frac{\ln 2}{m} n \bar{x}+\frac{b}{m} \\
d t=-\frac{\ln 2 \cdot n \bar{x}+b}{m^{2}} d m \\
d m=-\frac{\ln 2 \cdot n \bar{x}+b}{t^{2}} d t
\end{array}\right\}=-\int_{\infty}^{0} \frac{b^{p} \ln ^{n} 2}{(\ln 2 \cdot n \bar{x}+b)^{p+n+1} \Gamma(p)} t^{p+n+1} \exp (-t) \frac{\ln 2 \cdot n \bar{x}+b}{t^{2}} d t= \\
=\int_{0}^{\infty} \frac{b^{p} \ln ^{n} 2}{(\ln 2 \cdot n \bar{x}+b)^{p+n} \Gamma(p)} t^{p+n-1} \exp (-t) d t=\frac{\Gamma(p+n) b^{p} \ln ^{n} 2}{\Gamma(p)(\ln 2 \cdot n \bar{x}+b)^{p+n}}
\end{gathered}
$$

rozkład a posteriori parametru $m$ jest postaci:

$$
g(m \mid \mathbf{x})=\frac{f(\mathbf{x} \mid m) \cdot g(m)}{\int_{\Theta} f(\mathbf{x} \mid m) \cdot g(m) d m}=\frac{\left(\frac{\ln 2}{m}\right)^{n} \exp \left(-\frac{\ln 2}{m} n \bar{x}\right) \cdot \frac{b^{p} \exp \left(-\frac{b}{m}\right)}{m^{p+1} \Gamma(p)}}{\frac{b^{p} \Gamma(p+n) \ln ^{n} 2}{\Gamma(p)(\ln 2 \cdot n \bar{x}+b)^{p+n}}},
$$

czyli

$$
g(m \mid \mathbf{x})=\frac{(\ln 2 \cdot n \bar{x}+b)^{p+n} \exp \left(-\frac{\ln 2}{m} n \bar{x}-\frac{b}{m}\right)}{m^{p+n+1} \Gamma(p+n)} .
$$

Jest to gęstość odwróconego rozkładu gamma $I G(p+n, n \bar{x} \ln 2+b)$.

Wyznaczenie estymatora parametru $m$ przy liniowej funkcji straty związane jest z rozwiązaniem równania: 


$$
G_{I G\left(p_{0}, b_{0}\right)}(d \mid \mathbf{x})=\frac{1}{2}
$$

gdzie $G_{I G\left(p_{0}, b_{0}\right)}(d \mid \mathbf{x})$ jest dystrybuantą rozkładu a posteriori $g(m \mid \cdot)$ parametru $m$ oraz $p_{0}=p+n$ i $b_{0}=n \bar{x} \ln 2+b$.

Innym podejściem w estymacji mediany zmiennej losowej o rozkładzie wykładniczym jest wyznaczenie bayesowskiego estymatora parametru $\lambda$, przy znajomości jego rozkładu a priori, przy kwadratowej funkcji straty, a następnie estymacja mediany w oparciu o zależność $M_{0,5}=\lambda \ln 2$.

Estymacja bayesowska przy liniowej funkcji straty ma szczególne znaczenie w przypadku rozkładów, które nie posiadają wartości oczekiwanej, czyli analizowanych już rozkładów Cauchy'ego oraz Pareto.

Załóżmy, że zmienna losowa $X$ ma rozkład Cauchy'ego $\mathrm{Ca}(m, \lambda)$. Parametr $m$ jest medianą rozkładu Cauchy'ego.

Niech $X_{1}, X_{2}, \ldots, X_{n}$ będzie $n$-elementową próbą prostą. Łączna funkcja gęstości ma postać:

$$
f(\mathbf{x} \mid m)=\prod_{i=1}^{n} \frac{1}{\pi} \cdot \frac{\lambda}{\lambda^{2}+\left(x_{i}-m\right)^{2}}=\left(\frac{\lambda}{\pi}\right)^{n} \cdot \prod_{i=1}^{n} \frac{1}{\lambda^{2}+\left(x_{i}-m\right)^{2}} .
$$

Przy założeniu, że rozkładem a priori parametru $m$ jest rozkład jednostajny na przedziale $[a, b]$, otrzymujemy:

$$
\begin{gathered}
\int_{\Theta} f(\mathbf{x} \mid m) \cdot g(m) d m=\int_{a}^{b}\left(\frac{\lambda}{\pi}\right)^{n} \cdot \prod_{i=1}^{n} \frac{1}{\lambda^{2}+\left(x_{i}-m\right)^{2}} \cdot \frac{1}{b-a} d m= \\
=\left(\frac{\lambda}{\pi}\right)^{n} \frac{1}{b-a} \int_{a}^{b} \prod_{i=1}^{n} \frac{1}{\lambda^{2}+\left(x_{i}-m\right)^{2}} d m .
\end{gathered}
$$

Zatem funkcja gęstości rozkładu a posteriori wyraża się wzorem:

$$
g(m \mid \mathbf{x})=\frac{(b-a) \prod_{i=1}^{n} \frac{1}{\lambda^{2}+\left(x_{i}-m\right)^{2}}}{\int_{a}^{b} \prod_{i=1}^{n} \frac{1}{\lambda^{2}+\left(x_{i}-m\right)^{2}} d m}
$$


Zastosowanie liniowej funkcji straty sprawia, że estymatorem bayesowskim $d_{0}$ jest rozwiązanie równania:

$$
G(d \mid \mathbf{x})=\frac{1}{2}
$$

gdzie $G(d \mid \cdot)$ jest dystrybuantą rozkładu a posteriori parametru $m$ o gęstości $g(m \mid \cdot)$. Mathematica bądź inne pakiety komputerowe pozwalają, na podstawie wylosowanej próby, obliczyć wartość $d_{0}$ estymatora bayesowskiego.

W celu ilustracji bayesowskich metod estymacji mediany z liniową i kwadratową funkcją straty rozważano zmienną losową o rozkładzie wykładniczym $\operatorname{Exp}(\lambda)$ przy założeniu, że rozkładami a priori parametru $m$ są odwrócone rozkłady gamma $\mathrm{z}$ wybranymi parametrami. W przypadku zastosowania liniowej funkcji straty estymatorem mediany jest mediana rozkładu a posteriori $\left(M e^{L}\right)$, natomiast wykorzystanie funkcji kwadratowej sprawia, że wartość oczekiwana rozkładu a posteriori $\left(M e^{K}\right)$ stanowi oszacowanie mediany rozkładu. Przeprowadzone badanie symulacyjne miało na celu analizę własności tych estymatorów. Dla wygenerowanych populacji o rozkładzie wykładniczym bayesowskie procedury szacowania mediany, przy ustalonych liczebnościach prób, powtarzano 10000 razy. Oszacowane obciążenia i błędy średniokwadratowe estymatorów dla kilku wybranych parametrów odwróconego rozkładu gamma $I G(p, b)$ i wybranych liczebności prób przedstawione są w tablicy 4.4.1.

Tablica 4.4.1. Oszacowania obciążeń i błędów średniokwadratowych estymatorów mediany rozkładu wykładniczego, gdy rozkład a priori jest odwróconym rozkładem gamma

\begin{tabular}{|c|c|c|c|c|c|c|}
\hline \multicolumn{2}{|c|}{$\begin{array}{c}\text { Parametry rozkładu } \\
\text { a priori }\end{array}$} & \multirow[t]{2}{*}{$n$} & \multirow[t]{2}{*}{$\bar{M} e^{L}-M_{0,5}$} & \multirow[t]{2}{*}{$\operatorname{MSE}\left(M e^{L}\right)$} & \multirow[t]{2}{*}{$\bar{M} e^{K}-M_{0,5}$} & \multirow[t]{2}{*}{$\operatorname{MSE}\left(M e^{K}\right)$} \\
\hline$p$ & $b$ & & & & & \\
\hline 1 & 2 & 3 & 4 & 5 & 6 & 7 \\
\hline \multirow[t]{4}{*}{3} & \multirow[t]{4}{*}{3} & 10 & $-0,022$ & 0,084 & 0,043 & 0,096 \\
\hline & & 20 & $-0,011$ & 0,055 & 0,025 & 0,059 \\
\hline & & 30 & $-0,003$ & 0,040 & 0,022 & 0,043 \\
\hline & & 100 & $-0,002$ & 0,014 & 0,005 & 0,015 \\
\hline \multirow[t]{4}{*}{2} & \multirow[t]{4}{*}{3} & 10 & 0,151 & 0,090 & 0,207 & 0,136 \\
\hline & & 20 & 0,069 & 0,034 & 0,096 & 0,046 \\
\hline & & 30 & 0,049 & 0,021 & 0,067 & 0,026 \\
\hline & & 100 & 0,015 & 0,034 & 0,096 & 0,046 \\
\hline
\end{tabular}


Tablica 4.4.1 (cd.)

\begin{tabular}{|c|c|c|c|c|c|c|}
\hline 1 & 2 & 3 & 4 & 5 & 6 & 7 \\
\hline 0,5 & 2 & 10 & 0,090 & 1,118 & 0,342 & 1,496 \\
\cline { 3 - 7 } & & 20 & 0,043 & 0,054 & 0,164 & 0,628 \\
\cline { 3 - 7 } & & 30 & 0,051 & 0,409 & 0,131 & 0,570 \\
\cline { 3 - 7 } & & 100 & 0,000 & 0,120 & 0,022 & 0,123 \\
\hline
\end{tabular}

Źródło: obliczenia własne.

Wyniki analizy symulacyjnej wskazują, że przy estymacji mediany zmiennej losowej o rozkładzie wykładniczym przy założeniu, iż rozkładem a priori jest odwrócony rozkład gamma, lepsze wyniki uzyskano, stosując liniową funkcję straty. Mediana wyznaczonego rozkładu a posteriori charakteryzowała się mniejszym obciążeniem i błędem średniokwadratowym niż estymator otrzymany przy zastosowaniu kwadratowej funkcji straty.

\subsection{Bootstrapowe procedury estymacja kwantyli}

Metody bootstrapowe stosuje się do estymacji kwantyli rozkładu zmiennej losowej w przypadku, gdy brak jest informacji o klasie rozkładu tej zmiennej oraz dysponujemy małą próbą, co uniemożliwia wykorzystanie asymptotycznych własności estymatorów.

Niech $X$ będzie zmienną losową, o nieznanym rozkładzie $F$, z którą utożsamiamy badaną populację oraz niech $X_{1}, X_{2}, \ldots, X_{n}$ będzie próbą prostą wylosowaną $\mathrm{z}$ tej populacji. Ponadto niech $1-\alpha$ będzie ustalonym współczynnikiem wiarygodności.

Zastosowanie metody percentyli do estymacji kwantyla $Q_{p}$ rzędu $p$ sprowadza się do wygenerowania $N$ prób bootstrapowych i wyznaczenia na podstawie każdej z nich kwantyla z próby $X_{p, k}^{B}$ rzędu $p$, gdzie $k=1,2, \ldots, N$. Otrzymany $\mathrm{w}$ ten sposób ciąg uporządkowanych kwantyli $X_{p, 1}^{B}, \ldots, X_{p, N}^{B}$ pozwala aproksymować rozkład kwantyla z próby rzędu $p$. Wyznaczone kwantyle rzędu $\frac{\alpha}{2}$ oraz $1-\frac{\alpha}{2}$, czyli statystyki $X_{\frac{\alpha}{2} ; N}^{B}$ i $X_{1-\frac{\alpha}{2} ; N}^{B}$ służą do budowy przedziału ufności dla kwantyla $Q_{p}$, tzw. metodą percentyli (por. C. Domański, K. Pruska [2000, s. 262]): 


$$
P\left(X_{\frac{\alpha}{2} ; N}^{B}<Q_{p}<X_{1-\frac{\alpha}{2} ; N}^{B}\right) \approx 1-\alpha
$$

Liczba powtórzeń $N$ dobierana jest tak, aby $\frac{N \alpha}{2}$ było liczbą całkowita, wtedy kwantylem $X_{\frac{\alpha}{2} ; N}^{B}$ jest wartość statystyki pozycyjnej o randze $\frac{N \alpha}{2}$ w ciągu $X_{p, 1}^{B}, X_{p, 2}^{B}, \ldots, X_{p, N}^{B}$, natomiast kwantylem $X_{1-\frac{\alpha}{2} ; N}^{B}$ jest wartość o numerze $N-\frac{N \alpha}{2}$

Bootstrapowe szacowanie mediany $M_{0,5}$ metoda percentyli polega na wygenerowaniu $N$ prób bootstrapowych i wyznaczeniu na podstawie każdej z nich mediany. W ten sposób otrzymuje się ciąg uporządkowanych wartości median: $M e_{1}^{B}, M e_{2}^{B}, \ldots, M e_{N}^{B}$, określający rozkład empiryczny mediany. Na jego podstawie dla ustalonego współczynnika ufności $1-\alpha$ wyznacza się kwantyle z próby $M e_{\frac{\alpha}{2} ; N}^{B}, M e_{1-\frac{\alpha}{2} ; N}^{B}$ i buduje się przedział ufności dla mediany $M_{0,5}$ postaci:

$$
P\left(M e_{\frac{\alpha}{2} ; N}^{B}<M_{0,5}<M e_{1-\frac{\alpha}{2} ; N}^{B}\right) \approx 1-\alpha
$$

W celu porównania efektywności bootstrapowej metody szacowania mediany z metodami określonymi wzorami (4.3.20), (4.3.21) przeprowadzono badanie symulacyjne (por. A. Baszczyńska, D. Pekasiewicz [2010]). Rozważano populacje o rozkładach:

- jednomodalnych, wyraźnie asymetrycznych: wykładniczych i $\chi^{2}$ o małej liczbie stopni swobody;

- dwumodalnych, będących mieszaninami dwóch rozkładów normalnych o funkcji gęstości $f(x)=w f\left(x_{1}\right)+(1-w) f\left(x_{2}\right)$, gdzie $w \in(0,1)$.

$\mathrm{Z}$ wygenerowanych populacji losowano próby o różnych liczebnościach $n \geq 30$. Przy ustalonych współczynnikach ufności $1-\alpha \in\{0,9,0,95,0,99\}$ wyznaczano przedział ufności dla mediany trzema metodami:

- metodą I, wykorzystując wzór (4.3.20);

- metodą II, opierając się na wzorze (4.3.21);

- metodą III, bootstrapową metodą percentyli (wzór (4.5.2)). 
Każdą z procedur szacowania mediany powtarzano 20000 razy i na podstawie uzyskanych wyników wyznaczano błędy oszacowań $(d)$, jako połowy długości przedziałów ufności, oraz obliczano frakcje przypadków, w których otrzymane przedziały pokrywały szacowany parametr.

W tablicach 4.5.1 i 4.5.2 przedstawiono wyniki estymacji mediany dla wybranych rozkładów uzyskane w oparciu o 100-elementowe próby, przy ustalonym współczynniku ufności 0,95, zaś na rysunkach 4.5.1 i 4.5.2 zaprezentowano graficznie uzyskane wyniki dokładności oszacowań dla trzech rozważanych metod.

Dla pierwszej grupy eksperymentów przedziały ufności dla mediany miały najmniejszą długość w przypadku zastosowania bootstrapowej metody szacowania mediany. Metody I oraz II dały niemal identyczne wyniki, przy czym przy stosowaniu metody II prawdopodobieństwo tego, że przedział zawiera medianę, było mniejsze, czasem dużo mniejsze niż założona wielkość wiarygodności oszacowania. Metoda bootstrapowa (III) pozwoliła uzyskać najlepsze oszacowania mediany, tzn. z największą precyzją, przy wiarygodności oszacowania, w przybliżeniu równej ustalonemu współczynnikowi wiarygodności.

Tablica 4.5.1. Dokładności oszacowań i frakcje przypadków, w których uzyskane przedziały zawierały medianę rozkładu wykładniczego i $\chi^{2}$ dla 100-elementowej próby i współczynnika wiarygodności 0,95

\begin{tabular}{|c|c|c|c|c|c|c|c|c|}
\hline \multirow{2}{*}{$\begin{array}{c}\text { Rozkład } \\
X\end{array}$} & \multirow{2}{*}{$\begin{array}{c}\text { Parametr } \\
\text { rozkładu } \\
\lambda / k\end{array}$} & \multirow{2}{*}{$M_{0,5}$} & \multicolumn{2}{|c|}{ Metoda I } & \multicolumn{2}{|c|}{ Metoda II } & \multicolumn{2}{|c|}{ Metoda III } \\
\hline & & & $d_{1}$ & $p_{1}$ & $d_{2}$ & $p_{2}$ & $d_{3}$ & $p_{3}$ \\
\hline \multirow{7}{*}{ 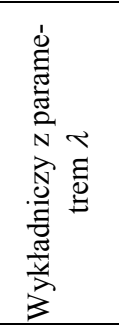 } & 0,5 & 0,347 & 0,104 & 0,951 & 0,103 & 0,920 & 0,098 & 0,962 \\
\hline & 1 & 0,693 & 0,203 & 0,953 & 0,201 & 0,924 & 0,194 & 0,949 \\
\hline & 2 & 1,386 & 0,398 & 0,955 & 0,391 & 0,923 & 0,391 & 0,951 \\
\hline & 3 & 2,079 & 0,605 & 0,956 & 0,601 & 0,920 & 0,588 & 0,955 \\
\hline & 4 & 2,773 & 0,807 & 0,953 & 0,806 & 0,917 & 0,787 & 0,937 \\
\hline & 5 & 3,466 & 1,035 & 0,959 & 1,027 & 0,928 & 0,973 & 0,945 \\
\hline & 6 & 4,159 & 1,243 & 0,954 & 1,239 & 0,921 & 1,147 & 0,952 \\
\hline \multirow{7}{*}{ 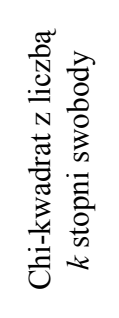 } & 1 & 0,456 & 0,226 & 0,957 & 0,219 & 0,919 & 0,208 & 0,955 \\
\hline & 3 & 2,390 & 0,554 & 0,953 & 0,552 & 0,923 & 0,515 & 0,957 \\
\hline & 4 & 3,324 & 0,644 & 0,955 & 0,648 & 0,919 & 0,621 & 0,956 \\
\hline & 5 & 4,374 & 0,742 & 0,956 & 0,741 & 0,926 & 0,722 & 0,952 \\
\hline & 6 & 5,387 & 0,832 & 0,955 & 0,836 & 0,927 & 0,856 & 0,947 \\
\hline & 7 & 6,317 & 0,900 & 0,956 & 0,900 & 0,930 & 0,900 & 0,956 \\
\hline & 8 & 7,356 & 0,969 & 0,956 & 0,968 & 0,931 & 0,942 & 0,941 \\
\hline
\end{tabular}

Źródło: obliczenia własne. 
Tablica 4.5.2. Dokładności oszacowań i frakcje przypadków, w których uzyskane przedziały zawierały medianę mieszaniny rozkładów normalnych dla 100-elementowej próby

\begin{tabular}{|c|c|c|c|c|c|c|c|c|}
\hline \multirow{2}{*}{ Rozkład $X$} & \multirow{2}{*}{$w$} & \multirow{2}{*}{$M_{0,5}$} & \multicolumn{2}{|c|}{ Metoda I } & \multicolumn{2}{|c|}{ Metoda II } & \multicolumn{2}{|c|}{ Metoda III } \\
\hline & & & $d_{1}$ & $p_{1}$ & $d_{2}$ & $p_{2}$ & $d_{3}$ & $p_{3}$ \\
\hline \multirow{9}{*}{ 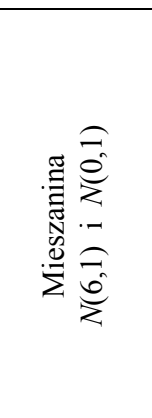 } & 0,9 & 5,4 & 0,229 & 0,955 & 0,258 & 0,944 & 0,221 & 0,950 \\
\hline & 0,8 & 4,8 & 0,209 & 0,956 & 0,234 & 0,948 & 0,200 & 0,957 \\
\hline & 0,7 & 4,2 & 0,192 & 0,956 & 0,215 & 0,948 & 0,184 & 0,945 \\
\hline & 0,6 & 3,6 & 0,182 & 0,958 & 0,203 & 0,952 & 0,174 & 0,946 \\
\hline & 0,5 & 3,0 & 0,179 & 0,957 & 0,200 & 0,951 & 0,171 & 0,952 \\
\hline & 0,4 & 2,4 & 0,182 & 0,955 & 0,206 & 0,946 & 0,175 & 0,945 \\
\hline & 0,3 & 1,8 & 0,193 & 0,951 & 0,217 & 0,945 & 0,185 & 0,945 \\
\hline & 0,2 & 1,2 & 0,209 & 0,954 & 0,234 & 0,948 & 0,202 & 0,955 \\
\hline & 0,1 & 0,6 & 0,231 & 0,954 & 0,259 & 0,946 & 0,222 & 0,949 \\
\hline \multirow{9}{*}{ 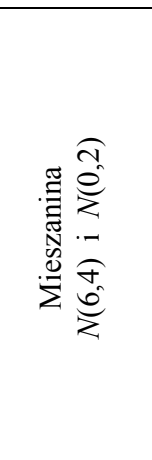 } & 0,9 & 5,4 & 0,910 & 0,953 & 1,025 & 0,948 & 0,883 & 0,949 \\
\hline & 0,8 & 4,8 & 0,816 & 0,955 & 0,918 & 0,943 & 0,786 & 0,952 \\
\hline & 0,7 & 4,2 & 0,725 & 0,956 & 0,813 & 0,946 & 0,697 & 0,963 \\
\hline & 0,6 & 3,6 & 0,638 & 0,956 & 0,715 & 0,949 & 0,611 & 0,941 \\
\hline & 0,5 & 3,0 & 0,565 & 0,956 & 0,634 & 0,948 & 0,542 & 0,947 \\
\hline & 0,4 & 2,4 & 0,505 & 0,958 & 0,563 & 0,951 & 0,485 & 0,941 \\
\hline & 0,3 & 1,8 & 0,465 & 0,953 & 0,521 & 0,950 & 0,445 & 0,953 \\
\hline & 0,2 & 1,2 & 0,452 & 0,955 & 0,511 & 0,942 & 0,436 & 0,954 \\
\hline & 0,1 & 0,6 & 0,468 & 0,955 & 0,524 & 0,949 & 0,452 & 0,954 \\
\hline
\end{tabular}

Źródło: obliczenia własne.

W drugiej grupie eksperymentów, dla populacji o rozkładach będących mieszaninami rozkładów normalnych, wszystkie uzyskane przedziały ufności spełniały w przybliżeniu założenie dotyczące wielkości współczynnika ufności. Metoda III okazała się również efektywniejsza w stosunku do pozostałych, tzn. dokładność oszacowań była większa $(d-$ mniejsze).

Dla innych współczynników wiarygodności uzyskano podobne wyniki w klasach badanych rozkładów. Również dla większych prób rezultaty były zbliżone.

W przypadku prób mniejszych niż 100-elementowe metoda II nie dała zadowalających rezultatów, ze względu na fakt, że wykorzystuje ona asymptotyczne własności rozkładu mediany i praktycznie, nie powinna być stosowana. Wyniki są dużo gorsze niż w przypadku wykorzystania I i III metody estymacji, gdyż rozpiętości przedziałów są znacznie większe. 


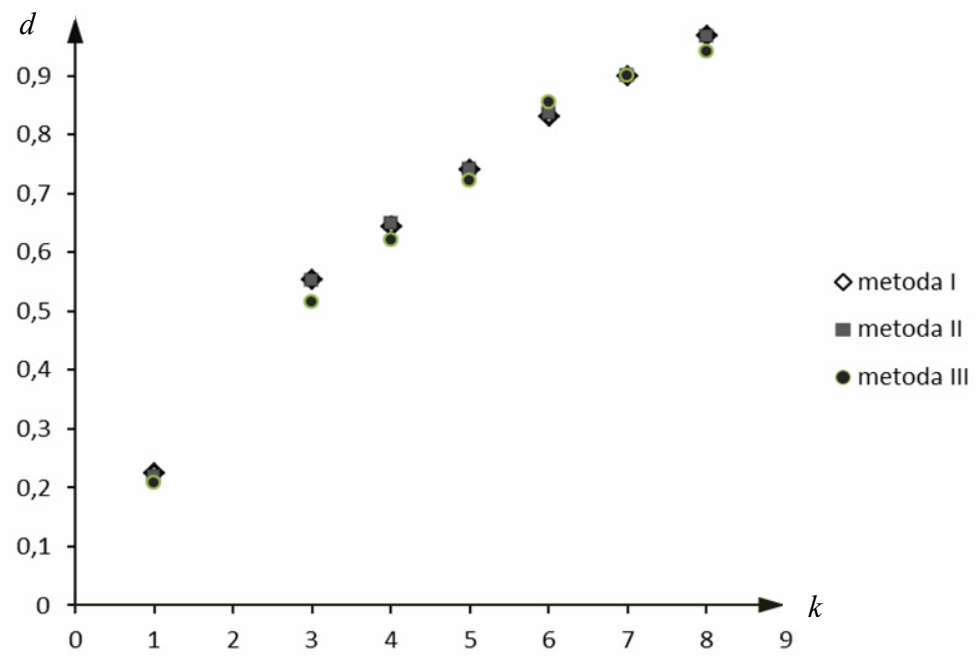

Rysunek 4.5.1. Dokładności oszacowań mediany rozkładu chi-kwadrat dla wybranych stopni swobody

Źródło: obliczenia własne

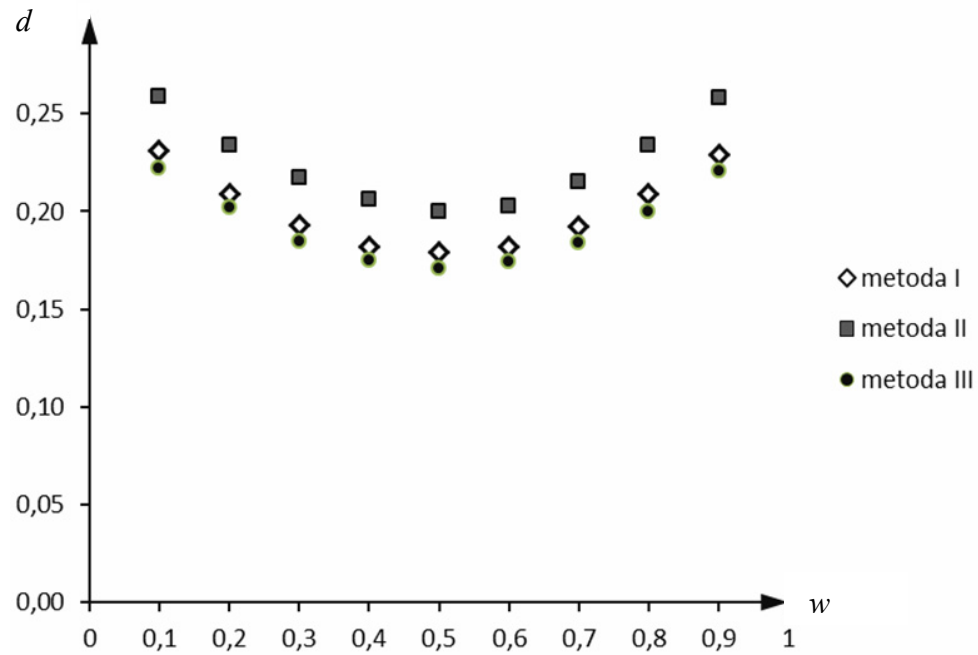

Rysunek 4.5.2. Dokładności oszacowań mieszaniny rozkładów $N(6,1)$ i $N(0,1)$ dla wybranych wag

Źródło: obliczenia własne

Zastosowanie metody bootstrapowej do szacowania obciążenia i wariancji mediany z próby wraz z wynikami badań symulacyjnych przedstawione jest w pracy K. Pruskiej [2007]. 
Metody bootstrapowe mogą być wykorzystywane do oszacowania innych parametrów zmiennej losowej w przypadku braku informacji o klasie jej rozkładu. Rezultaty analiz procedur estymacji przedziałowej wartości oczekiwanej prezentowane są w pracy A. Baszczyńskiej, D. Pekasiewicz [2008].

Procedury bootstrapowe można wykorzystać również do estymacji punktowej kwantyla $Q_{p}$ w oparciu o próbę prostą $X_{1}, X_{2}, \ldots, X_{n}$. W pracy E. Brodina [2006] przedstawiono estymację kwantyli rzędu $p$ przy użyciu L-estymatora optymalnego, czyli statystyki:

$$
L_{p}=\sum_{i=1}^{n} w_{i} X_{(i)}^{(n)}, \text { gdzie } \sum_{i=1}^{n} w_{i}=1,
$$

dla której błąd średniokwadratowy oszacowany metodą bootstrapową osiaga najmniejszą wartość.

Własności tego estymatora porównywano z własnościami kwantyla z próby:

$$
\hat{Q}_{p}=X_{[n p]+1}^{(n)}
$$

dla rozkładów: normalnego, log-normalnego, $t$-Studenta z czterema stopniami swobody i wykładniczego. Uzyskane wyniki wskazują na lepsze własności estymatora określonego wzorem (4.5.3).

Wariancję dowolnego estymatora kwantyla rozkładu można oszacować, korzystając ze wzoru:

$$
\hat{D}^{2}\left(\hat{Q}_{p}\right)=\frac{1}{N} \sum_{k=1}^{N}\left(\hat{Q}_{p, k}^{B}-\overline{\hat{Q}}_{p}^{B}\right)^{2}
$$

gdzie $N$ oznacza liczbę prób bootstrapowych, $\hat{Q}_{p, k}^{B}-$ kwantyl rzędu $p$ wyznaczony na podstawie $k$ - tej próby bootstrapowej, $k=1,2, \ldots, N$, oraz $\overline{\hat{Q}}_{p}^{B}=\frac{1}{N} \sum_{k=1}^{N} \hat{Q}_{p, k}^{B}$.

\subsection{Estymacja dominanty}

Dominanta, obok wartości oczekiwanej i mediany, jest parametrem położenia zmiennej losowej i odgrywa istotną rolę w przeprowadzanych analizach statystycznych.

Zaprezentowane metody estymacji dominanty wykorzystują statystyki pozycyjne i funkcje statystyk pozycyjnych. 
Niech $X_{1}, X_{2}, \ldots, X_{n}$ będzie $n$-elementową próbą, wylosowaną w sposób niezależny z populacji o rozkładzie ciagłym o dystrybuancie $F$.

Jednym z najstarszych estymatorów dominanty jest estymator Pearsona stosowany dla rozkładów umiarkowanie asymetrycznych postaci:

$$
D_{0}^{P}=3 M e-2 \bar{X}
$$

gdzie $M e$ i $\bar{X}$ są odpowiednio medianą i średnią arytmetyczną wyznaczoną na podstawie próby losowej.

Innym estymatorem dominanty wyznaczanym w oparciu o ciag statystyk pozycyjnych $X_{(1)}^{(n)}, X_{(2)}^{(n)}, \ldots, X_{(n)}^{(n)}$ jest estymator Grenandera wyrażony wzorem (por. U. Grenandner [1965]):

$$
D_{0}^{G}=\frac{\frac{1}{2} \sum_{i=1}^{n-k} \frac{\left(X_{(i+k)}^{(n)}+X_{(i)}^{(n)}\right)}{\left(X_{(i+k)}^{(n)}-X_{(i)}^{(n)}\right)^{p}}}{\sum_{i=1}^{n-k} \frac{1}{\left(X_{(i+k)}^{(n)}-X_{(i)}^{(n)}\right)^{p}}},
$$

gdzie $1<p<k$. Estymator ten jest zgodny, a jeśli $k>2 p$, to jego rozkład jest asymptotycznie normalny.

Kolejna metoda estymacji dominanty ciagłej zmiennej losowej wykorzystuje rozstęp z próby losowej. Estymator dominanty dla ciągłej zmiennej losowej o asymetrycznym rozkładzie zdefiniowany w oparciu o rozstęp z próby nazywany jest estymatorem half rang mode lub estymatorem Bickela (por. D. R. Bickel [2002]).

Procedura poszukiwania estymatora dominanty składa się z następujących kroków. Na podstawie wartości $x_{(1)}^{(n)}, x_{(2)}^{(n)}, \ldots, x_{(n)}^{(n)}$ wyznacza się wartość $r_{0}$ statystyki $R_{0}$ określonej wzorem:

$$
R_{0}=\frac{X_{(n)}^{(n)}-X_{(1)}^{(n)}}{2}
$$

a następnie określa się przedziały $\left[x_{(i)}^{(n)}, x_{(i)}^{(n)}+r_{0}\right]$, dla $i=1,2, \ldots, n$. Spośród $n$ otrzymanych przedziałów wybierany jest ten, który zawiera największą liczbę elementów próby. Przedział ten oznaczamy przez $I\left(r_{0}\right)$, a wartości należące do tego przedziału przez $x_{(1)}^{\left(n_{0}\right)}, x_{(2)}^{\left(n_{0}\right)}, \ldots, x_{\left(n_{0}\right)}^{\left(n_{0}\right)}$. 
W kolejnym kroku obliczamy rozstęp $r_{1}=\frac{x_{\left(n_{0}\right)}^{\left(n_{0}\right)}-x_{(1)}^{\left(n_{0}\right)}}{2}$ oraz powtarzamy procedurę, wybierając spośród przedziałów $\left[x_{(i)}^{\left(n_{0}\right)}, x_{(i)}^{\left(n_{0}\right)}+r_{1}\right]$, dla $i=1,2, \ldots, n_{0}$, przedział $I\left(r_{1}\right)$ zawierający największą liczbę elementów próby. Jeśli $s_{1}$ przedziałów $I_{1}\left(r_{1}\right), \ldots, I_{s_{1}}\left(r_{1}\right)$ zawiera taką samą liczbę elementów, to wybieramy przedział o najmniejszej rozpiętości.

Procedurę tę powtarzamy $k$-razy, aż do momentu, gdy otrzymany przedział będzie zawierał tylko dwa elementy $x_{1}^{h r m}=x_{(1)}^{(2)}$ oraz $x_{2}^{h r m}=x_{(2)}^{(2)}$.

Statystyka postaci:

$$
D_{0}^{h r m}=\frac{X_{1}^{h r m}+X_{2}^{h r m}}{2}
$$

jest asymptotycznie nieobciążonym estymatorem dominanty, a obliczona wartość $d_{0}^{h r m}=\frac{x_{1}^{h r m}+x_{2}^{h r m}}{2}$ jest oszacowaniem dominanty metodą half rang mode.

Estymatorem dominanty jest również estymator half sample (por. D. Bickel, R. Frühwirth [2006]). Aby oszacować dominantę za pomocą tego estymatora, liczebność próby $n$ musi być potęgą liczby 2, czyli powinna spełniać warunek: $n=2^{m}$ dla pewnego $m$. W tym przypadku uporządkowane wartości $n$-elementowej próby $x_{(1)}^{(n)}, x_{(2)}^{(n)}, \ldots, x_{(n)}^{(n)}$ dzielimy na dwie podpróby zawierające po $\frac{n}{2}$ elementów i wybieramy tę, dla której rozstęp jest mniejszy. Następnie podpróbę tę ponownie dzielimy na dwie, zawierające po $\frac{n}{4}$ elementów i znów wybieramy podpróbę o mniejszym rozstępie. Procedurę powtarzamy $k$ razy, aż do uzyskania przedziału zawierającego tylko dwa elementy $x_{1}^{h s}=x_{(1)}^{(2)}$ oraz $x_{2}^{h s}=x_{(2)}^{(2)}$.

Estymatorem dominanty jest statystyka:

$$
D_{0}^{h s}=\frac{X_{1}^{h s}+X_{2}^{h s}}{2},
$$

a jej wartość $d_{0}^{h s}=\frac{x_{1}^{h s}+x_{2}^{h s}}{2}$ stanowi oszacowanie mody. 
Kolejny estymator dominanty wyznaczany jest w oparciu o średnią arytmetyczną dla próby uciętej (por. J Wywiał [2000a]).

Niech $a_{1}=1$ oraz $b_{1}=n$.

Dla ciagu wartości próby losowej $x_{(1)}^{(n)}, x_{(2)}^{(n)}, \ldots, x_{(n)}^{(n)}$ obliczamy:

$$
\bar{x}\left(a_{1}, b_{1}\right)=\frac{1}{n} \sum_{i=1}^{n} x_{(i)}^{(n)} \quad \text { oraz } \quad C_{3}\left(a_{1}, b_{1}\right)=\frac{1}{n} \sum_{i=a_{t}}^{b_{t}}\left(x_{(i)}^{(n)}-\bar{x}\left(a_{1}, b_{1}\right)\right)^{3} .
$$

Gdy $C_{3}\left(a_{1}, b_{1}\right) \neq 0$, to próbę losową zmniejszamy, pomijając jeden element. Jeśli $C_{3}\left(a_{1}, b_{1}\right)>0$, to pomijamy $x_{(n)}^{(n)}$, czyli $a_{2}=a_{1}=1$, zaś $b_{2}=n-1$. Jeśli $C_{3}\left(a_{1}, b_{1}\right)<0$, to pomijamy element $x_{(1)}^{(n)}$, czyli $a_{2}=2$, zaś $b_{2}=b_{1}=n$.

W $k$-tym kroku $(k=2,3, .$.$) mamy n-k+1$ elementową próbę i obliczamy:

$$
\bar{x}\left(a_{k}, b_{k}\right)=\frac{1}{b_{k}-a_{k}+1} \sum_{i=a_{k}}^{b_{k}} x_{(i)}^{(n)}
$$

oraz

$$
C_{3}\left(a_{k}, b_{k}\right)=\frac{1}{b_{k}-a_{k}+1} \sum_{i=a_{k}}^{b_{k}}\left(x_{(i)}^{(n)}-\bar{x}\left(a_{k}, b_{k}\right)\right)^{3} .
$$

Jeśli $C_{3}\left(a_{k}, b_{k}\right)=0$ oraz $C_{3}\left(a_{k-1}, b_{k-1}\right) \neq 0$, to estymatorem dominanty jest tzw. quasi-dominanta $G_{k}^{(1)}$ na przedziale $\left[a_{k}, b_{k}\right]$ wyrażona wzorem:

$$
G_{k}^{(1)}=\bar{X}\left(a_{k}, b_{k}\right) .
$$

Jeśli $C_{3}\left(a_{k}, b_{k}\right) \neq 0$, to uporządkowaną próbę ucinamy i ponownie wyznaczamy średnią arytmetyczną dla próby uciętej.

Gdy $C_{3}\left(a_{k}, b_{k}\right)>0$, to $a_{k+1}=a_{k}$ oraz $b_{k+1}=b_{k}-1$ (próbę ucinamy lewostronnie), jeśli zaś $C_{3}\left(a_{k}, b_{k}\right)<0$, to $a_{k+1}=a_{k}+1$ oraz $b_{k+1}=b_{k}$ (próbę ucinamy prawostronnie).

Statystyka $G_{k}^{(1)}$ jest obciążonym estymatorem dominanty.

Metoda jackknife redukuje to obciążenie. Zatem estymator dominanty definiujemy w następujący sposób:

$$
D_{0}^{W 1}=\sum_{i=1}^{n}\left(G_{k}^{(1)}-\frac{(n-1)}{n} G_{k(i)}^{(1)}\right),
$$

gdzie $G_{k(i)}^{(1)}$ jest quasi-dominantą bez $i$-tej obserwacji. 
Estymatorem błędu średniokwadratowego jest statystyka:

$$
M \hat{S} E\left(D_{0}^{W 1}\right)=\frac{1}{n(n-1)} \sum_{i=1}^{n}\left(n G_{k}^{(1)}-(n-1) G_{k(i)}^{(1)}-D_{0}^{(W 1)}\right)^{2} .
$$

Estymator dominanty wykorzystujący średnią arytmetyczną z próby uciętej stosuje się, gdy rozkład badanej zmiennej jest w przybliżeniu symetryczny.

Dla rozkładów asymetrycznych, estymatora dominanty poszukuje się, wyznaczając medianę dla prób uciętych (por. J. Wywiał [2000b]).

Wyznaczanie wartości estymatora dominanty w oparciu o medianę z próby uciętej rozpoczynamy od obliczenia $\operatorname{Me}\left(a_{k}, b_{k}\right)$ wartości mediany $M_{0,5}\left(a_{k}, b_{k}\right)$ oraz średniej $\bar{x}\left(a_{k}, b_{k}\right)$ dla $k=1$ i uporządkowanej próby $x_{(1)}^{(n)}, x_{(2)}^{(n)}, \ldots, x_{(n)}^{(n)}$, a następnie porównania tych wartości.

Jeśli $M e\left(a_{k}, b_{k}\right)=\bar{x}\left(a_{k}, b_{k}\right)$, to estymatorem dominanty jest statystyka:

$$
G_{k}^{(2)}=\operatorname{Me}\left(a_{k}, b_{k}\right)
$$

gdzie $M e\left(a_{k}, b_{k}\right)$ oznacza medianę dla próby uciętej, czyli element próby uporządkowanej o numerze $\left[\frac{b_{k}-a_{k}+1}{2}\right]+1$.

Jeśli $M e\left(a_{k}, b_{k}\right) \neq \bar{x}\left(a_{k}, b_{k}\right)$, to zmniejszamy próbę.

Jeśli $\operatorname{Me}\left(a_{k}, b_{k}\right)<\bar{x}\left(a_{k}, b_{k}\right)$, to $a_{k+1}=a_{k}$ oraz $b_{k+1}=b_{k}-1$, czyli próbę ucinamy lewostronnie, jeśli zaś $M e\left(a_{k}, b_{k}\right)>\bar{x}\left(a_{k}, b_{k}\right)$, to $a_{k+1}=a_{k}+1$ oraz $b_{k+1}=b_{k}$, czyli próbę ucinamy prawostronnie.

Statystyka $G_{k}^{(2)}$ jest również obciążonym estymatorem dominanty i analogicznie jak dla estymatora $G_{k}^{(1)}$ metodą jackknife można zredukować obciążenie estymatora, określając estymator w następującej postaci:

$$
D_{0}^{W 2}=\sum_{i=1}^{n}\left(G_{k}^{(2)}-\frac{(n-1)}{n} G_{k(i)}^{(2)}\right)
$$

gdzie $G_{k(i)}^{(2)}$ jest quasi-dominantą bez $i$-tej obserwacji.

Estymatorem dominanty ciagłej zmiennej losowej może być również wartość maksimum lokalnego funkcji jądra (por. D. R. Bickel, R. Frühwirth [2006]):

$$
D_{0}^{K}=\max _{x} \hat{f}(x)
$$


gdzie

$$
\hat{f}(x)=\frac{1}{n h \sqrt{2 \pi}} \sum_{i=1}^{n} \exp \left[-\frac{1}{2}\left(\frac{x-x_{i}}{h}\right)^{2}\right],
$$

oraz $h=0,9 \min \left\{s_{x}, r\right\}, \quad s_{x}$ jest estymatorem odchylenia standardowego wyznaczonym na podstawie $n$-elementowej próby, zaś $r$ jest rozstępem.

Własności zarówno prezentowanych, jak i innych estymatorów mody przedstawione są m.in. w pracach D. R. Bickela [2002, 2006], D. R. Bickela, R. Fruhwirtha, [2006], S. Hedgesa, P. Shaha [2003]. A. Sokołowskiego [2013, s. 81-169] oraz J. Wywiała [2000a, b].

Wyznaczenie wartości wielu estymatorów dominanty umożliwia m.in. pakiet $R$. Przed przystąpieniem do szacowania dominanty należy pamiętać o sprawdzeniu, czy rozkład analizowanej populacji można uznać za jednomodalny. Do tego celu posłużyć może współczynnik modalności $B C$ (por. T. Knapp [2007], A. Baszczyńska, D. Pekasiewicz [2014]), test Hartigana (por. J. Hartigan, P. Hartigan [1985]) lub test Silvermana (por. B.W. Silvermann [1981]).

\subsection{Przyklady zastosowań estymatorów parametrów pozycyjnych}

\subsubsection{Szacowanie miar ubóstwa i bogactwa $w$ analizie dochodów ludności}

W badaniach dochodów ludności ważnym problemem jest identyfikacja i analiza ubóstwa. Rozstrzygnięcie, które $z$ gospodarstw domowych należy uznać za ubogie, związane jest z ustaleniem linii ubóstwa, zwanej również granicą lub progiem ubóstwa. Gospodarstwa domowe, osiagające dochód ekwiwalentny o wartości poniżej tej linii, uznaje się za ubogie. Granicę ubóstwa wykorzystuje się do określania innych miar typu wskaźnik zagrożenia ubóstwem, głębokość czy intensywność ubóstwa.

W praktyce w różny sposób wyznacza się linie ubóstwa. Na przykład w Stanach Zjednoczonych stosuje się metodę Orshansky, według której granica ubóstwa jest ilorazem kosztu minimum biologicznego i wskaźnika Engla, w Polsce za oficjalną linię ubóstwa przyjmuje się tzw. minimum socjalne ustalane przez ekspertów na podstawie podstawowego koszyka dóbr. W wielu krajach Europy wyznacza się relatywne linie ubóstwa. Jako linię ubóstwa traktuje się połowę dochodu przeciętnego lub połowę mediany rozkładu dochodów. Według 
definicji Eurostatu, granicę ubóstwa przyjmuje się na poziomie $60 \%$ mediany dochodów ekwiwalentnych w danym kraju. Jeszcze inne podejście do zdefiniowania progu ubóstwa wykorzystuje funkcje użyteczności dochodu. Określa się wtedy lejdejską linię ubóstwa i zmodyfikowaną lejdejską linię ubóstwa (por. S. Kot [2000, s. 193-194]).

Prezentowane $\mathrm{w}$ poprzednich podrozdziałach estymatory mediany moga być wykorzystane do szacowania relatywnych granic ubóstwa zdefiniowanych w oparciu o medianę.

Niech $X$ będzie zmienną losową określającą wielkość ekwiwalentnego dochodu gospodarstwa domowego w danej populacji. Przyjmując definicję Eurostatu, granicę ubóstwa $G_{u}$ wyraża wzór:

$$
G_{u}=0,6 M_{0,5},
$$

gdzie $M_{0,5}$ jest medianą rozkładu zmiennej $X$.

Granicę ubóstwa szacuje się punktowo:

$$
\hat{G}_{u}=0,6 M e,
$$

gdzie $M e$ jest estymatorem mediany wyznaczanym w oparciu o próbę losową.

Do punktowej estymacji mediany wykorzystać można nieparametryczne estymatory mediany $M_{0,5}$ określone m.in. wzorami (4.2.14), (4.2.16) i (4.2.17).

Przedziałowa estymacja granicy ubóstwa związana jest $\mathrm{z}$ wyznaczaniem przedziału ufności dla mediany ze wzorów (4.3.20), (4.3.21) i (4.3.25).

Informacja o klasie rozkładu dochodu ekwiwalentnego pozwala stosować metody parametryczne, konstruować przedział ufności (4.3.16) lub punktowo szacować granicę ubóstwa za pomocą dystrybuanty rozkładu dochodów z oszacowanymi na podstawie próby losowej parametrami. Parametry rozkładu dochodu ekwiwalentnego estymuje się, w zależności od klasy rozkładu, metodami największej wiarygodności, momentów lub metodami opartymi na statystykach pozycyjnych (por. rozdział 2).

Granica ubóstwa jest wykorzystywana do definiowania innych miar stosowanych w analizach ubóstwa, m.in. do wyznaczania wskaźnika zagrożenia ubóstwem, zwanego również stopą ubóstwa.

Wskaźnik zagrożenia ubóstwem definiuje się następująco:

$$
W_{z g . u b .}=F\left(0,6 M_{0,5}\right),
$$

gdzie $F$ jest dystrybuantą, zaś $M_{0,5}$ medianą rozkładu dochodów. 
Wskaźnik ten określa zasięg ubóstwa. Jeśli jest on równy 0 , oznacza to, że w populacji brak jest gospodarstw domowych ubogich, gdy zaś jest równy 1 , to wszystkie gospodarstwa domowe należy uznać za ubogie.

Nieparametrycznym estymatorem wskaźnika zagrożenia ubóstwem wyznaczonym na podstawie próby losowej $X_{1}, X_{2}, \ldots, X_{n}$ i klasycznej dystrybuanty empirycznej jest statystyka (por. W. Zieliński [2009, 2011]):

$$
\hat{W}_{z g . u b .}=\frac{\#\left\{X_{i} \leq 0,6 M e\right\}}{n},
$$

gdzie $M e$ jest wartością statystyki pozycyjnej rzędu $\left[\frac{n}{2}\right]+1$ wyznaczoną na podstawie $n$-elementowej próby $X_{1}, X_{2}, \ldots, X_{n}$.

Estymator wskaźnika ubóstwa określony wzorem (4.7.4) jest estymatorem praktycznie nieobciążonym, tzn. $E\left(\hat{W}_{z g . u b .}\right) \approx W_{z g . u b .} \quad$ o wariancji postaci $D^{2}\left(\hat{W}_{z g . u b .}\right) \approx \frac{1}{n} \hat{W}_{z g . u b .}\left(1-\hat{W}_{z g . u b .}\right)$.

Nieparametryczny przedział ufności dla wskaźnika zagrożenia ubóstwem oparty na statystyce $\zeta=\#\left\{X_{i} \leq 0,6 M e\right\}$ ma postać:

$$
P\left\{0,5 \cdot B^{-1}\left(\frac{\alpha}{2} ; \zeta,\left[\frac{n}{2}\right]-\zeta+2\right)<W_{z g . u b .}<0,5 \cdot B^{-1}\left(1-\frac{\alpha}{2} ; \zeta+1,\left[\frac{n}{2}\right]-\zeta+1\right)\right\}=1-\alpha,
$$

gdzie $B^{-1}(p ; a, b)$ jest kwantylem rzędu $p$ rozkładu beta z parametrami $(a, b)$.

Rozważania dotyczące własności tak skonstruowanego przedziału ufności przedstawione są w pracy W. Zielińskiego [2011].

Propozycję nieparametrycznego estymatora wskaźnika ubóstwa może stanowić statystyka określona wzorem:

$$
\hat{W}_{z g . u b .}=\frac{1}{2}-\frac{n-2 \zeta}{2 \sqrt{n(n-1)}} .
$$

Powstała ona w wyniku zastosowania dystrybuanty empirycznej typu level crossing (wzór (2.6.3)) do estymacji dystrybuanty teoretycznej $F$. 
Wskaźnik zagrożenia ubóstwem jest dość popularny, ale ma on swoje wady. Jest wrażliwy tylko na liczbę ubogich, a w obrębie grupy mogą znajdować się gospodarstwa o dochodach minimalnie niższych niż linia ubóstwa lub bardzo odległych od tej linii, dlatego w analizach ubóstwa wyznacza się wartości innych mierników. Należą do nich indeks luki dochodowej ubogich określający głębokość (natężenie) ubóstwa oraz indeks luki dochodowej oceniający intensywność ubóstwa.

Indeks luki dochodowej ubogich szacuje się z wzoru:

$$
\hat{I}_{d u}=\frac{1}{\zeta} \sum_{i=1}^{\zeta} \frac{\hat{G}_{u}-X_{i}}{\hat{G}_{u}}
$$

i mierzy dystans między dochodami ekwiwalentnymi ubogich gospodarstw domowych i granicą ubóstwa, a tym samym określa, jak bardzo ubogie są gospodarstwa domowe należące do grupy ubogich.

Indeks luki dochodowej (na osobę) dotyczy całej populacji gospodarstw domowych, nie tylko ubogich, przy czym dla gospodarstw nieubogich luka dochodowa wynosi zero, zatem:

$$
\hat{I}_{d}=\frac{1}{n} \sum_{i=1}^{n} \max \left\{\frac{\hat{G}_{u}-X_{i}}{\hat{G}_{u}}, 0\right\} .
$$

Obydwa indeksy łączy zależność: $I_{d}=I_{d u} \cdot W_{z g . u b}$.

Indeksem oceniającym dotkliwość ubóstwa jest indeks szacowany z wzoru:

$$
D U=\frac{1}{n} \sum_{i=1}^{n}\left(\max \left\{\frac{\hat{G}_{u}-X_{i}}{\hat{G}_{u}}, 0\right\}\right)^{2} .
$$

Obliczenie wszystkich wymienionych indeksów wymaga oszacowania metodą parametryczną bądź nieparametryczną granicy ubóstwa, a tym samym mediany rozkładu dochodów, przy wykorzystaniu statystyk pozycyjnych.

W analizach dochodów gospodarstw domowych oprócz grupy osób ubogich analizuje się również osoby bogate, o dochodach przekraczających pewną ustaloną wartość. Jedną z miar bogactwa jest wskaźnik bogactwa, określający odsetek ludzi w całej populacji osiagających dochody wyższe od ustalonej lub oszacowanej linii bogactwa $G_{b}$. Estymator wskaźnika bogactwa jest postaci: 


$$
\hat{W}_{\text {bogactwa }}=\frac{\#\left\{X_{i}>\hat{G}_{b}\right\}}{n} .
$$

Wartość granicy (linii) bogactwa ustalana jest w różny sposób, m.in. na poziomie dwóch lub trzech median rozkładu dochodów ekwiwalentnych (por. A. Peichl i in. [2008], Brzeziński [2014]), czyli

$$
\hat{G}_{b}=2 M e
$$

lub

$$
\hat{G}_{b}=3 M e .
$$

Podobnie jak w przypadku ubóstwa wyznacza się indeks luki dochodowej, tak w analizach bogactwa określa się indeks zamożności:

$$
\hat{I}^{o}=\frac{1}{n} \sum_{i=1}^{n} \max \left\{\frac{X_{i}-\hat{G}_{b}}{\hat{G}_{b}}, 0\right\} .
$$

Bardziej skomplikowane miary zamożności konstruuje się w oparciu o wzór ogólny $R\left(X, G_{b}\right)=\frac{1}{n} \sum_{i=1}^{n} f\left(\frac{X_{i}}{G_{b}}\right)$, gdzie $f: R^{+} \rightarrow[0,1]$ jest ciagłą, ściśle rosnąca funkcją i wklęsłą na przedziale $(0,+\infty)$ (por. A. Peichl i in. [2008]).

Jeśli

$$
f(x)= \begin{cases}\left(1-\frac{1}{x}\right)^{\alpha} & \text { dla } x>1, \\ 0 & \text { dla } x \leq 1,\end{cases}
$$

przy czym $\alpha \in(0,1)$ otrzymujemy indeks zamożności:

$$
R_{\alpha}\left(X, G_{b}\right)=\frac{1}{n} \sum_{i=1}^{n}\left(\max \left\{\frac{X_{i}-G_{b}}{X_{i}}, 0\right\}\right)^{\alpha},
$$

natomiast jeśli

$$
f(x)= \begin{cases}1-\frac{1}{x^{\beta}} & \text { dla } x>1 \\ 0 & \text { dla } x \leq 1\end{cases}
$$


oraz $\beta>0$ mamy:

$$
R_{\beta}\left(X, G_{b}\right)=\frac{1}{n} \sum_{i=1}^{n} \max \left\{1-\left(\frac{G_{b}}{X_{i}}\right)^{\beta}, 0\right\} .
$$

Obydwa indeksy wyznacza się na podstawie próby losowej, przy ustalonej lub oszacowanej granicy bogactwa.

Innym problemem $\mathrm{w}$ analizie dochodów jest badanie nierównomierności dochodów. Za jedną z lepszych miar nierównomierności uznaje się współczynnik Giniego.

Do estymatorów współczynnika Giniego $G$ należy m.in. estymator plug-in określony wzorem:

$$
\hat{G}=\frac{2}{n^{2} \bar{X}} \sum_{i=1}^{n}\left(i-\frac{1}{2}\right) X_{(i)}^{(n)}-1
$$

gdzie $X_{(i)}^{(n)}$ jest $i$-tą statystyką pozycyjną wyznaczoną na podstawie $n$-elementowej próby, natomiast $\bar{X}$ to średnia arytmetyczna dochodów.

Do punktowych miar koncentracji, które pokazują nie tylko przeciętną koncentrację dochodów, ale także poziom nierównomierności w każdym punkcie rozkładu, od najniższych do najwyższych grup dochodowych, należy miara koncentracji Zengi postaci (por. A. Jędrzejczak [2011, s. 19-20]):

$$
Z_{p}=\frac{Q_{p}-X_{p ; n}}{Q_{p}}
$$

gdzie $X_{p ; n}$ jest kwantylem dochodów rzędu $p$ uzyskanym na podstawie $n$-elementowej próby losowej, zaś $Q_{p}$ - kwantylem rozkładu dochodów.

Punkty $\left(p, Z_{p}\right)$ dla $p \in[0,1]$ zaznaczone na układzie współrzędnych tworzą krzywą koncentracji Zengi. Wykorzystując tę krzywą do analizy rozkładu dochodów, można ocenić, w których grupach dochodowych koncentruje się masa dochodów, a porównując kilka krzywych, można dokonać porównania poziomów koncentracji punktowej dla różnych zbiorowości lub tej samej zbiorowości w różnych okresach.

Na postawie krzywej Zengi określa się uśrednioną punktową miarę koncentracji (por. M. Zenga [1990]) postaci: 


$$
\xi=\int_{0}^{1} Z_{p} d p
$$

której nieparametrycznym estymatorem jest statystyka:

$$
\hat{\xi}=1-\frac{1}{n \bar{X}}\left(X_{(1)}^{(n)}+\sum_{j=1}^{n-1} X_{\left(r_{j}\right.}^{(n)}\right),
$$

gdzie $r_{j}=\left[\frac{\sum_{i=1}^{j} X_{(i)}^{(n)}}{\bar{X}}\right]$ dla $j=1, \ldots, n-1$ oraz $X_{(i)}^{(n)}$ jest $i$-tą statystyką pozycyjną

w $n$-elementowej próbie, zaś $\bar{X}$ jest średnią arytmetyczną dochodów.

\subsubsection{Estymacja miar ryzyka rynkowego}

Ryzyko jest podstawowym pojęciem nowoczesnych finansów, w szczególności analizy inwestycji. W teorii i praktyce funkcjonują dwa podejścia do ryzyka. Jedno z nich określa ryzyko jako możliwość poniesienia straty, a więc podkreśla negatywne jego skutki, czyli traktuje je jako zagrożenie. W drugim podejściu ryzyko to możliwość wystąpienia efektu działania niezgodnego z oczekiwaniami, ale w tym przypadku efekt może być gorszy lub lepszy niż oczekiwany, czyli ryzyko rozumiane jest $\mathrm{z}$ jednej strony jako zagrożenie, a $\mathrm{z}$ drugiej jako szansa (por. K. Jajuga, T. Jajuga [2001], s. 98-99).

$\mathrm{W}$ działalności inwestycyjnej występuje wiele rodzajów ryzyka powodującego skutki finansowe podmiotu, który jest na nie narażony. Jest to m.in. ryzyko rynkowe (kursu walutowego, stopy procentowej, cen akcji, cen towarów), kredytowe, operacyjne, płynności, prawne czy też wydarzeń. W ostatnich latach nastapił bardzo dynamiczny rozwój metod związanych z pomiarem ryzyka. Traktując ryzyko jako zmienną losową o określony ciagłym rozkładzie, można dokonać podziału miar ryzyka na trzy grupy (por. K. Jajuga [2007, s. 39-48]). Są to:

- miary zmienności,

- kwantyle rozkładu,

- wartości dystrybuanty rozkładu.

Do pierwszej grupy należą pozycyjne miary zmienności wykorzystujące pojęcia: rozstępu (połowa rozstępu), odchylenia ćwiartkowego, kwintylowego, decylowego czy percentylowego (por. podrozdział 1.2) oraz miara $\sigma$ zwana dolnym momentem cząstkowym, stosowana w negatywnej koncepcji ryzyka. 
Miara ta uwzględnia jedynie ujemne odchylenia zmiennej $X$ od wartości odniesienia, którą może być mediana lub midrange (obok klasycznej wartości oczekiwanej). Wyraża się ona wzorem:

$$
\sigma=\left[\sum_{X_{i}<M e}\left|X_{i}-M e\right|^{p}\right]^{\frac{1}{p}},
$$

lub

$$
\sigma=\left[\sum_{X_{i}<M_{r}}\left|X_{i}-M_{r}\right|^{p}\right]^{\frac{1}{p}},
$$

gdzie $M e, M_{r}$ są, odpowiednio, medianą i midrange, czyli statystykami wyznaczonymi na podstawie próby losowej $X_{1}, X_{2}, \ldots, X_{n}$ w oparciu o wzory (1.2.2), (1.2.6), zaś $p$ jest ustaloną liczbą dodatnią.

Z pojęcia kwantyla rozkładu wywodzi się popularna w ostatnich kilku latach miara ryzyka $\mathrm{VaR}$ - Value at Risk, nazywana wartością zagrożoną lub wartością narażoną na ryzyko. Miara $V a R$ definiowana jest jako strata wartości rynkowej instrumentu finansowego, portfela lub inwestycji taka, że prawdopodobieństwo jej osiagnięcia lub przekroczenia w pewnym przedziale czasowym jest równe zadanemu poziomowi tolerancji (por. K. Jajuga [2007, s. 99-104], C. Domański [2011, s. 142-152]).

Zatem wartością narażoną na ryzyko $V_{a} R_{p}$ dla zmiennej losowej $X$ określającej wielkość straty w portfelu nazywamy:

$$
\operatorname{VaR}_{p}=\inf _{x}\{x \in R: \quad P(X>x) \leq p\}
$$

gdzie $p \in(0,1)$ jest poziomem tolerancji.

Wartość zagrożona zależy od dwóch wielkości: poziomu tolerancji (im niższy poziom tolerancji $p$, tym wyższa wartość $V a R_{p}$ ) oraz od rozpatrywanego okresu (im dłuższy okres tym, wyższa wartość zagrożona).

Podstawowe metody szacowania $V a R$ wykorzystują kwantyl rozkładu strat estymowany na podstawie próby, przy ustalonym poziomie tolerancji.

Niech $X_{t}$ będzie zmienną losową oznaczającą stratę wartości instrumentów finansowych portfela w pewnym przedziale czasowym $(t, t+1)$, czyli

$$
X_{t}=W_{t+1}-W_{t},
$$


gdzie $W_{t}, W_{t+1}$ oznaczają wartość rynkową portfela lub cenę rozważanego instrumentu czy też wartość inwestycji, odpowiednio, w chwili $t$ oraz $t+1$.

Wartość zagrożoną ryzykiem na poziomie tolerancji $p$ zapisuje się w postaci:

$$
P\left(X_{t} \leq-\operatorname{VaR}_{p}\right)=p,
$$

czyli

$$
P\left(W_{t+1} \leq W_{t}-V a R_{p}\right)=p .
$$

Gdy rozkład zmiennej $X_{t}$ określony jest za pomocą znanej dystrybuanty $F$, to wartość narażoną na ryzyko wyznaczymy ze wzoru:

$$
\operatorname{VaR}_{p}=-F^{-1}(p) .
$$

Często analiza ryzyka prowadzona jest nie dla wartości instrumentu finansowego, lecz jego stopy zwrotu $\left(r_{t}\right)$ lub logarytmicznej stopy zwrotu $\left(R_{t}\right)$, definiowanych następująco:

$$
\begin{gathered}
r_{t}=\frac{W_{t+1}-W_{t}}{W_{t}}, \\
R_{t}=\ln \frac{W_{t+1}}{W_{t}}=\ln W_{t+1}-\ln W_{t} .
\end{gathered}
$$

Z definicji wartości zagrożonej otrzymujemy:

$$
P\left(\frac{W_{t+1}-W_{t}}{W_{t}}<\frac{-V a R_{p}}{W_{t}}\right)=P\left(r_{t}<\frac{-V a R_{p}}{W_{t}}\right)=p,
$$

stąd mamy:

$$
V a R_{p}=-r_{p} W_{t},
$$

gdzie $r_{p}=F_{r}^{-1}(p)$, czyli jest kwantylem rzędu $p$ rozkładu zmiennej losowej określającej stopę zwrotu $r_{t}$.

Zatem wartość narażona na ryzyko jest iloczynem wartości inwestycji $\mathrm{w}$ chwili $t$ i kwantyla rozkładu stopy zwrotu (wziętym ze znakiem minus). 
Ponieważ

$$
P\left(r_{t}<\frac{-V a R_{p}}{W_{t}}\right)=P\left(R_{t}<\ln \left(1-\frac{V a R_{p}}{W_{t}}\right)\right)=p,
$$

zatem wartość zagrożoną można zapisać:

$$
\operatorname{VaR}_{p}=\left(1-\exp R_{p}\right) W_{t},
$$

gdzie $R_{p}=F_{R}^{-1}(p)$ jest kwantylem rzędu $p$ logarytmicznej stopy zwrotu $R_{t}$.

W praktyce przyjmuje się najczęściej, że poziom tolerancji $p$ jest liczbą z przedziału $\langle 0,01,0,1\rangle$, tym samym poziom ufności $1-p \in\langle 0,9,0,99\rangle$. Każda $\mathrm{z}$ instytucji określa wartość $p$ na różnym poziomie, np. Citibank szacuje $V a R$ dla prawdopodobieństwa $p=0,055$, J.P. Morgan Bank of America $p=0,05$, Bazylejski Komitet Nadzoru Bankowego rekomenduje $p=0,01$ (por. A. GemzikSalwach [2004]).

Przy założeniu, że zmienna losowa $R_{t}$ ma rozkład normalny, wartość zagrożoną ryzykiem $R_{t}$ możemy estymować ze wzoru $\hat{V} a R_{p}=-\bar{R}_{t}+S_{R} u_{p}$, gdzie $\bar{R}_{t}, S_{R}$ są odpowiednio średnią arytmetyczną i odchyleniem standardowym obliczonym na podstawie próby losowej $R_{t, 1}, R_{t, 2}, \ldots, R_{t, n}$. Sytuacja taka rzadko jednak występuje. W analizach finansowych zwykle mamy do czynienia z rozkładami charakteryzującymi się leptokurtycznością, występowaniem grubych ogonów i skośnością, czyli znacznie różniących się od rozkładu normalnego, co uniemożliwia stosowanie tego podejścia.

W przypadku nieznanego rozkładu zmiennej $X_{t}$ określa się nieparametryczny estymator $\operatorname{VaR}_{p}$ za pomocą $i$-tej statystyki pozycyjnej (por. W. Zieliński [2008]):

$$
\hat{\operatorname{Va}} R_{p}^{(1)}=-X_{t,(i)}^{(n)},
$$

gdzie $\frac{i-1}{n}<p<\frac{i}{n}$.

Przedstawiona w podrozdziale 4.3 konstrukcja przedziału ufności dla kwantyla może być wykorzystana do szacowania wartości zagrożonej $V a R_{p}$. Gdy estymujemy np. kwantyl rzędu $p=0,01$ przy wiarygodności $1-\alpha=0,95$, szacujemy wartość ryzyka przekraczanego z prawdopodobieństwem 0,01 na pozio- 
mie ufności 0,95 . Dokonując odpowiedniej randomizacji, otrzymujemy przedział ufności dla wartości zagrożonej postaci:

$$
P\left(-X_{t,(s)}^{(n)} \leq \operatorname{VaR}_{p} \leq-X_{t,(r)}^{(n)}\right)=1-\alpha,
$$

gdzie $X_{t,(s)}^{(n)}, X_{t,(r)}^{(n)}$ są statystykami pozycyjnymi zmiennej $X_{t}$ wyznaczonymi na podstawie $n$-elementowej próby losowej.

Wykorzystanie różnych estymatorów kwantyli zmiennej $X_{t}$, prezentowanych w podrozdziale 4.2, prowadzi do różnych oszacowań $V a R$. Ze względu na dobre własności, na uwagę zasługuje nieparametryczny estymator standardowy (definicja 4.2.3). Jego zastosowanie pozwala zdefiniować wartość zagrożoną ryzykiem jako:

$$
\hat{\operatorname{Va}} R_{p}^{(2)}=-X_{k(p)}^{(n)},
$$

gdzie wielkość $k(p)$ określona jest wzorem (4.2.5).

Oszacowanie funkcji gęstości $f$ rozkładu zmiennej losowej $X_{t}$ metodą jądrową pozwala wyznaczyć przedział ufności dla $V a R_{p}$, w przypadku posiadania dużych liczebności prób, na podstawie wzoru (4.3.9):

$$
P\left(\hat{V} a R_{p}^{(2)}-\sqrt{\frac{p(1-p)}{n \hat{f}^{2}\left(-\hat{V} a R_{p}^{(2)}\right)}} u_{\alpha} \leq V a R_{p} \leq \hat{V} a R_{p}^{(2)}+\sqrt{\frac{p(1-p)}{n \hat{f}^{2}\left(-\hat{V} a R_{p}^{(2)}\right)}} u_{\alpha}\right)=1-\alpha,
$$

gdzie $\hat{f}$ jest estymatorem funkcji $f, 1-\alpha$ ustalonym współczynnikiem ufności, zaś $u_{\alpha}$ kwantylem standaryzowanego rozkładu normalnego rzędu $1-\frac{\alpha}{2}$.

Zastosowanie przy estymacji kwantyla rzędu $p$ estymatora Huang-Brilla (wzór (4.2.6)) prowadzi do następującego oszacowania wartości zagrożonej ryzykiem:

$$
\hat{V} a R_{p}^{(3)}=-\hat{Q}_{p}^{H B} .
$$


Z własności asymptotycznego rozkładu estymatora Huang-Brilla (por. Y. P. Chang i in. [2003]) otrzymujemy przedział:

$$
P\left(\hat{V} a R_{p}^{(3)}-\sqrt{\frac{p(1-p)}{n \hat{f}^{2}\left(-\hat{V} a R_{p}^{(3)}\right)}} u_{\alpha} \leq V a R_{p} \leq \hat{V} a R_{p}^{(3)}+\sqrt{\frac{p(1-p)}{n \hat{f}^{2}\left(-\hat{V} a R_{p}^{(3)}\right)}} u_{\alpha}\right)=1-\alpha .
$$

Badania własności estymatora kwantyla będącego funkcją dwóch statystyk pozycyjnych (wzór (4.2.8)) świadczą o lepszych jego własnościach w porównaniu z estymatorami Huang-Brilla i standardowym, dla kwantyli niskich rzędów rozkładów, tj. log-normalny, Cauchy'ego, Weibulla, Pareto (por. tablice 4.2.14.2.3). Stąd propozycja wykorzystania tego estymatora do estymacji wartości narażonej na ryzyko:

$$
\hat{\operatorname{Va}} R_{p}^{(4)}=(1-(n+1) p+[(n+1) p]) X_{([(n+1) p])}^{(n)}+((n+1) p-[(n+1) p]) X_{([n+1) p]+1)}^{(n)} .
$$

Powyższe estymatory Value at Risk można stosować dla szacowania VaR logarytmicznych stóp zwrotu $R_{t}$.

Medianowe obciążoności estymatorów kwantyli porównywane były w podrozdziale 4.2. Uzupełnieniem tych analiz jest porównanie estymatora $\mathrm{VaR}$ (4.7.32), często rozważanego w literaturze, $\mathrm{z}$ estymatorem:

$$
\hat{V} a R_{p}^{(5)}=-\hat{F}^{-1}(p),
$$

gdzie $\hat{F}$ jest dystrybuanta, której parametry oszacowano metodami przedstawionymi w rozdziale drugim.

Metodami estymacji wykorzystywanymi do szacowania parametrów rozkładu były proponowane, zmodyfikowane metody: kwantylowa metoda najmniejszych kwadratów z uciętą liczbą kwantyli i medianowo-kwantylowa metoda najmniejszych kwadratów. Rozważano estymację kwantyli rzędów: $p=0,05,0,01$ i 0,001 i wykorzystywano je do szacowania wartości narażonej na ryzyko. W tablicy 4.7.1 przedstawiono rezultaty badań dla rozkładu Cauchy’ego, który pojawia się w analizach finansowych jako rozkład logarytmicznych stóp zwrotu $z$ inwestycji. Parametry tego rozkładu zostały dobrane na podstawie analiz empirycznych. Liczbę pominiętych statystyk pozycyjnych w kwantylowej metodzie najmniejszych kwadratów z uciętą liczbą kwantyli ustalono na poziomie $98 \%$, 
czyli w przypadku próby 1000 -elementowej brano pod uwagę 20 środkowych statystyk pozycyjnych. Procedury estymacji powtórzono 20000 razy, badając różnice między wartościami oszacowanymi a rzeczywistymi. Średnie różnice (obciążenia estymatorów) oznaczono jako $B_{2}=\overline{\hat{V}} a R_{p}^{(2)}-V a R_{p}$ i $B_{5}=\overline{\hat{V}} a R_{p}^{(5)}-V a R_{p}$.

$\mathrm{Na}$ podstawie otrzymanych wyników należy stwierdzić, że oszacowania wartości narażonej na ryzyko w oparciu o dystrybuanty oszacowane metodami uKmnk i MKmnk były bliższe wartościom teoretycznym w stosunku do kwantyli wyznaczonych za pomocą estymatora standardowego. Szczególnie istotne różnice były dla kwantyli o małych rzędach, zatem jeśli istnieje możliwość oszacowania rozkładu zmiennej losowej, dla której wyznacza się $V a R$, należy skorzystać $\mathrm{z}$ estymatora (4.7.37).

Tablica 4.7.1. Średnie wartości estymatorów $V a R$ i ich obciążenia

\begin{tabular}{|c|c|c|c|c|c|c|c|c|}
\hline \multirow{2}{*}{$\begin{array}{c}\text { Parametry } \\
C a(m, \lambda)\end{array}$} & \multirow[b]{2}{*}{$p$} & \multirow[b]{2}{*}{$V a R_{p}$} & \multirow{2}{*}{$\overline{\hat{V}} a R_{p}^{(2)}$} & \multirow[b]{2}{*}{$B_{2}$} & \multicolumn{2}{|c|}{ Metoda $u K m n k$} & \multicolumn{2}{|c|}{ Metoda MKmnk } \\
\hline & & & & & $\overline{\overline{\hat{V}}} a R_{p}^{(5)}$ & $B_{5}$ & $\overline{\overline{\hat{V}}} a R_{p}^{(5)}$ & $B_{5}$ \\
\hline \multirow{3}{*}{$\begin{aligned} m & =0 \\
\lambda & =0,01\end{aligned}$} & & 0,0631 & 0,0646 & 0,0015 & 0,0633 & 0,0002 & 0,0632 & 0,0001 \\
\hline & 0,01 & 0,3182 & 0,3538 & 0,0356 & 0,3187 & 0,0005 & 0,3181 & 0,0001 \\
\hline & 0,001 & 3,1831 & 33,3907 & 30,2076 & 3,3188 & 0,0057 & 3,1820 & 0,0011 \\
\hline \multirow{3}{*}{$\begin{aligned} m & =0 \\
\lambda & =0,02\end{aligned}$} & 0,05 & 0,1263 & 0,1289 & 0,0026 & 0,1267 & 0,004 & 0,1269 & 0,0006 \\
\hline & 0,01 & 0,6364 & 0,7086 & 0,0722 & 0,6383 & 0,0019 & 0,6394 & 0,0030 \\
\hline & 0,001 & 6,3662 & 67,3287 & 60,9625 & 6,3690 & 0,0028 & 6,3966 & 0,0306 \\
\hline \multirow{3}{*}{$\begin{aligned} m & =0 \\
\lambda & =0,001\end{aligned}$} & 0,05 & 0,0063 & 0,0065 & 0,0002 & 0,0063 & 0,0000 & 0,0064 & 0,0001 \\
\hline & 0,01 & 0,0318 & 0,0354 & 0,0036 & 0,0318 & 0,0000 & 0,0339 & 0,0018 \\
\hline & 0,001 & 0,3183 & 3,5750 & 3,2567 & 0,3189 & 0,0005 & 0,3244 & 0,0061 \\
\hline
\end{tabular}

Źródło: Obliczenia własne.

W oparciu o $V a R$ wyznacza się inne miary ryzyka, m.in. DVaR - krańcowy $V a R$ określający wpływ zmian wag danego czynnika na ryzyko portfela, IncVaR - przyrostowy $V a R$ mierzący wpływ nowej pozycji na ryzyko portfela, czy też component $V a R$ - określający zmianę wartości narażonej na ryzyko dla portfela, jeśli usuniemy z niego jeden składnik, zwiększając tym samym proporcjonalnie wartość pozostałych aktywów (T. Bałamut [2002]).

W literaturze dotyczącej ryzyka zwraca się uwagę, że dobra miara ryzyka powinna być funkcją subaddytywną, monotoniczną, o dodatniej homogeniczności i niezmienności ze względu na translację, czyli powinna być tzw. miarą 
koherentną (por. C. Domański [2011, s. 152-155]). Wartość zagrożona Value at Risk nie spełnia warunku subaddytywności.

Do koherentnych miar ryzyka zalicza się Expected Shortfall $\left(E S_{p}\right)$ - miarę zwaną oczekiwanym niedoborem lub warunkową wartością zagrożoną. Jest to wartość oczekiwana (o ile istnieje) stóp zwrotu $R_{t}$ ponad poziom wartości zagrożonej i wyraża się wzorem (por. G. Trzpiot [2004a, 2004b]):

$$
E S_{p}\left(R_{t}\right)=-E\left(R_{t} \mid R_{t}<-\operatorname{VaR}_{p}\left(R_{t}\right)\right),
$$

gdzie $p$ jest poziomem tolerancji, czyli prawdopodobieństwem, z którym wartość $V a R_{p}$ nie może być przekroczona.

Innymi koherentnymi miarami wykorzystywanymi w analizach stóp zwrotu są:

$$
T C E_{p}\left(R_{t}\right)=-\inf \left\{E\left(\frac{R_{t}}{r} \mid \frac{R_{t}}{r}<-\operatorname{VaR}_{p}\left(R_{t}\right)\right)\right\}
$$

oraz

$$
W C E_{p}\left(R_{t}\right)=-\inf \left\{E\left(\frac{R_{t}}{r} \mid A\right): \quad P(A)>p\right\},
$$

gdzie $r$ jest stopą wolną od ryzyka.

Miara $T C E_{p}$ nosi nazwę dolnej warunkowej średniej, zaś $W C E_{p}$ - najgorszej warunkowej średniej $\left(T C E_{p} \leq W C E_{p}\right)$.

Miarą opartą na wartości zagrożonej i medianie rozkładu strat jest Median Shortfall $\left(M S_{p}\right)$ określona następująco (por. G. Trzpiot [2010, s. 146-147]):

$$
M S_{p}\left(R_{t}\right)=-M_{0,5}\left(R_{t} \mid R_{t}<-V a R_{p}\left(R_{t}\right)\right) .
$$

Szacuje się ją, wyznaczając medianę ze wszystkich stóp zwrotu przekraczających poziom wartości zagrożonej $V a R_{p}$.

Inną grupę miar ryzyka stanowią kwantylowe miary ryzyka standaryzowane wartością zagrożoną ryzykiem postaci: 


$$
m_{p}\left(R_{t}\right)=\frac{\operatorname{VaR}_{p}\left(R_{t}\right)+E S_{p}\left(R_{t}\right)}{\operatorname{VaR}_{p}\left(R_{t}\right)}
$$

oraz

$$
\tilde{m}_{p}\left(R_{t}\right)=\frac{\operatorname{VaR}_{p}\left(R_{t}\right)+M S_{p}\left(R_{t}\right)}{\operatorname{VaR}_{p}\left(R_{t}\right)} .
$$

Oszacowania wartości zagrożonej $V a R_{p}$ oraz wartości Expected Shortfall $\left(E S_{p}\right)$ i Median Shortfall $\left(M S_{p}\right)$ na określonym poziomie tolerancji prowadzą do otrzymania oszacowań odpowiednich standaryzowanych kwantylowych miar ryzyka.

Wszystkie wyszczególnione miary wykorzystują kwantyle odpowiednich rzędów $p$, które estymuje się rozważanymi metodami.

\subsubsection{Konstrukcja kart kontrolnych $\mathrm{z}$ wykorzystaniem estymatorów mediany}

Pierwsze zastosowania metod statystycznej kontroli jakości na szeroką skalę pojawiły się na początku XX w., a ich rozwój nastąpił w drugiej połowie XX w. Klasyczne metody analizy zmienności procesów, oceniających stabilność procesu i określających, kiedy proces wymaga regulacji, a kiedy należy zostawić go bez zmian, często odwołują się do założenia o normalności rozkładu badanej zmiennej i niezależności kolejnych pomiarów. Za skuteczne narzędzie zarządzania jakością uznaje się karty kontrolne, będące graficzną ilustracją pomiarów, zwykle zagregowanych $\mathrm{w}$ formie wartości średnich lub innych statystyk, procesu przemysłowego $\mathrm{w}$ czasie.

Do popularnych kart kontrolnych należą karta kontrolna $\bar{X}$ pozwalająca wykryć przesunięcie wartości średniej procesu, karta kontrolna $R$ i karta kontrolna $S$ służące do kontroli zróżnicowania procesu, czy też karta kontrolna $p$ związana z kontrolowaniem udziału wyrobów wadliwych w procesie produkcji.

Rzadziej stosowanymi w praktyce są ,odporne” karty kontrolne wykorzystujące medianę średnich próbkowych (por. J. R. Thomas i in., [2005, 79-84]).

Konstrukcja „odpornej” karty kontrolnej wartości średniej jest podobna do budowy karty kontrolnej $\bar{X}$. Na podstawie każdej z $k$ prób $n$-elementowych wyznacza się wartość średnią $\bar{X}_{i}, i=1,2, \ldots, k$, a następnie ze wzoru (1.2.2) 
medianę, która jest estymatorem średniej bardziej odpornym na zaburzenia rozkładu niż estymator będący średnią arytmetyczną średnich próbkowych. Linię centralną tej karty określa się równaniem:

$$
L C_{M e}= \begin{cases}\frac{1}{2}\left(\bar{X}_{\left(\frac{k}{2}\right)}^{(k)}+\bar{X}_{\left(\frac{k}{2}+1\right)}^{(k)}\right), & \text { gdy } k \text { jest parzyste } \\ \bar{X}_{\left(\frac{k+1}{2}\right)}^{(k)}, & \text { gdy } k \text { jest nieparzyste. }\end{cases}
$$

Górna i dolna linia kontrolna są postaci:

$$
\begin{aligned}
& D L K_{M e}=L C_{M e}-3 \frac{a(n) c(n) \widetilde{s}}{\sqrt{n}}, \\
& G L K_{M e}=L C_{M e}+3 \frac{a(n) c(n) \widetilde{s}}{\sqrt{n}},
\end{aligned}
$$

gdzie $\widetilde{s}$ jest medianą odchyleń standardowych $s_{i}$, dla $i=1, \ldots, k$, wyznaczanych na podstawie $n$-elementowych prób, zaś wielkości $a(n), c(n)$ odczytywane są wartościami stablicowanymi.

Dla wybranych liczebności prób zostały podane w tablicy 4.7.2.

Tablica 4.7.2. Współczynniki $a(n), c(n)$ dla wybranych liczebności prób

\begin{tabular}{|c|c|c|c|c|c|c|c|c|c|c|}
\hline$n$ & 3 & 4 & 5 & 6 & 7 & 8 & 9 & 10 & 15 & 20 \\
\hline$a(n)$ & 1,1284 & 1,0854 & 1,0638 & 1,0510 & 1,0423 & 1,0363 & 1,0317 & 1,0281 & 1,0180 & 1,0133 \\
\hline$c(n)$ & 1,0646 & 1,0374 & 1,0260 & 1,0201 & 1,0161 & 1,0136 & 1,0116 & 1,0103 & 1,0063 & 1,0046 \\
\hline
\end{tabular}

Źródło: J. R. Thompson, J. Koronacki, J. Nieckuła [2005].

„Odporną" kartą kontrolną odchylenia standardowego jest karta o granicach kontrolnych określonych równaniami:

$$
D L K_{\widetilde{s}}=\max \left(0, c(n) \widetilde{s}\left(1-3\left[\sqrt{a(n)^{2}-1}\right]\right)\right)
$$




$$
G L K_{\widetilde{s}}=c(n) \widetilde{s}\left(1+3\left[\sqrt{a(n)^{2}-1}\right]\right)
$$

gdzie $\widetilde{s}$ jest medianą odchyleń standardowych $s_{i}$, dla $i=1, \ldots, k$.

$\mathrm{W}$ przypadku zmiennych losowych o rozkładach normalnych lepszym estymatorem mediany jest estymator Bersteina. Estymator ten wykorzystano do wyznaczania linii kontrolnych (4.7.44) - (4.7.46), otrzymując:

$$
\begin{gathered}
L C_{M e}^{B r s}=0,5^{k-1} \sum_{i=1}^{k}\left(\begin{array}{c}
k-1 \\
i-1
\end{array}\right) \bar{X}_{(i)}^{(k)}, \\
D L K_{M e}^{B r s}=L C_{M e}^{B r s}-3 \frac{a(n) c(n) \widetilde{s}}{\sqrt{n}}, \\
G L K_{M e}^{B r s}=L C_{M e}^{B r s}+3 \frac{a(n) c(n) \widetilde{s}}{\sqrt{n}},
\end{gathered}
$$

gdzie $\tilde{s}$ jest estymatorem Bersteina odchyleń standardowych $s_{i}$, czyli $\widetilde{s}=0,5^{k-1} \sum_{i=1}^{k}\left(\begin{array}{c}k-1 \\ i-1\end{array}\right) s_{(i)}^{(k)}$.

W celu porównania możliwości kart kontrolnych wykrywających rozregulowanie procesu produkcyjnego zaprojektowano następujący eksperyment symulacyjny. W oparciu o próbę losową 100 wartości średnich arytmetycznych i odchyleń standardowych wyznaczanych na podstawie 6-elementowych prób wylosowanych z rozkładu $N(m, \sigma)$ wyznaczono linie kontrolne następujących kart:

- karty kontrolnej $\bar{X}$,

- „odpornej” karty kontrolnej wartości średniej (I) z liniami kontrolnymi (4.7.44)-(4.7.46),

- „odpornej” karty kontrolnej wartości średniej (II) z liniami kontrolnymi (4.7.49)- (4.7.51).

Następnie skonstruowane karty stosowano do wykrywania rozregulowania procesu, generując 70 prób 6-elementowych z rozkładu $N(m, \sigma)$ i 30 prób 6-elementowych z rozkładu $N\left(m_{1}, \sigma_{1}\right)$. Procedurę powtarzano 20000 razy, wyznaczając odsetek wartości przekraczających linię kontrolną górną lub dolna. Przykładowe wyniki zawiera tablica 4.7.3. 
Tablica 4.7.3. Odsetek wykrytych sygnałów rozregulowania procesu

\begin{tabular}{|l|l|c|c|c|}
\hline \multirow{2}{*}{$\begin{array}{c}\text { Parametry rozkładu } \\
N(m, \sigma)\end{array}$} & $\begin{array}{c}\text { Parametry rozkładu } \\
N\left(m_{1}, \sigma_{1}\right)\end{array}$ & $\overline{3}$ & $\begin{array}{c}\text { "odporna” } \\
\text { karta I }\end{array}$ & $\begin{array}{c}\text {,odporna” } \\
\text { karta II }\end{array}$ \\
\cline { 3 - 5 } & $m_{1}=4,85, \sigma_{1}=0,1$ & 74,816 & 75,206 & 75,256 \\
\hline$m=5, \sigma=0,1$ & $m_{1}=4,85, \sigma_{1}=0,08$ & 79,696 & 88,444 & 87,022 \\
\hline$m=5, \sigma=0,1$ & $m_{1}=4,90, \sigma_{1}=0,10$ & 31,153 & 32,204 & 32,365 \\
\hline$m=5, \sigma=0,1$ & $m_{1}=8,15, \sigma_{1}=0,10$ & 72,978 & 80,566 & 81,691 \\
\hline$m=8, \sigma=0,1$ & $m_{1}=8,15, \sigma_{1}=0,08$ & 81,166 & 85,123 & 84,557 \\
\hline$m=8, \sigma=0,1$ & $m_{1}=8,10, \sigma_{1}=0,08$ & 10,635 & 27,350 & 28,843 \\
\hline
\end{tabular}

Źródło: obliczenia własne.

Karty kontrolne oparte na „odpornych” estymatorach średniej i odchylenia standardowego wykrywają więcej sygnałów rozregulowania pochodzących z rzeczywiście zaburzonych rozkładów w porównaniu z popularną kartą $\bar{X}$. Zastosowanie estymatora Bersteina w „odpornej” karcie kontrolnej pozwoliło wykryć więcej zaburzeń procesu.

Przykłady innych kart kontrolnych wykorzystujące estymatory mediany i statystyki ekstremalne przedstawione zostaną w rozdziale piątym monografii.

\subsection{Uwagi końcowe}

Rozważania zawarte w niniejszym rozdziale poświęcono problematyce wykorzystania statystyk pozycyjnych do estymacji kwantyli i dominanty rozkładu zmiennej losowej. Zaprezentowane zostały wybrane parametryczne, jak i nieparametryczne metody estymacji punktowej i przedziałowej kwantyli wraz z wynikami badań własności wybranych estymatorów. Badania te przeprowadzono, stosując metody analityczne i symulacyjne.

Spośród prezentowanych metod na uwagę zasługują bootstrapowe metody estymacji kwantyli, które mogą być stosowane dla populacji o różnych rozkładach, w oparciu o próby o różnych liczebnościach. Na podstawie przeprowadzonych analiz porównawczych efektywności wybranych metod przedziałowej estymacji mediany można stwierdzić, iż w rozważanych przypadkach w wyniku zastosowania metody percentyli wyznaczone przedziały ufności charakteryzowały się większą dokładnością w stosunku do przedziałów uzyskanych innymi 
metodami, przy współczynniku ufności równym w przybliżeniu ustalonej wartości. Metody bootstrapowe, w szczególności bootstrapowa metoda percentyli, mogą być stosowane do estymacji innych parametrów, np. wartości oczekiwanej asymetrycznych zmiennych losowych, dla których zastosowanie twierdzeń granicznych związane jest z bardzo licznymi próbami (por. A. Baszczyńska, D. Pekasiewicz [2008]).

W rozdziale tym przedstawiono również przykłady zastosowań statystyk pozycyjnych do estymacji miar opartych na kwantylach używanych w badaniach społeczno-ekonomicznych na przykładzie miar ubóstwa i bogactwa ludności oraz miar ryzyka rynkowego, a także do tworzenia kart kontrolnych w statystycznej kontroli jakości. Do szacowania miar zdefiniowanych za pomocą mediany zaproponowano wykorzystanie estymatorów nieparametrycznych opartych na nieklasycznej dystrybuancie empirycznej. W przypadku szacowania wartości narażonej na ryzyko zaproponowano estymację parametrów rozkładu zmiennej losowej określającej wielkość straty kwantylową metodą najmniejszych kwadratów z uciętą liczbą kwantyli i medianowo-kwantylową metodą najmniejszych kwadratów, a następnie wykorzystanie otrzymanej dystrybuanty empirycznej do wyznaczenia kwantyla z próby odpowiedniego rzędu. Analizy symulacyjne przeprowadzone w celu oceny dokładności oszacowań kwantyli rozkładu Cauchy'ego wskazały na mniejsze obciążenie estymatorów parametrycznych, tj. estymatorów uzyskanych, przy znanej klasie rozkładu z parametrami oszacowanymi proponowanymi modyfikacjami kwantylowej metody najmniejszych kwadratów.

Empiryczne zastosowanie rozważanych metod zaprezentowane zostanie w szóstym rozdziale monografii. 


\section{STATYSTYKI POZYCYJNE W ANALIZACH ZDARZEŃ EKSTREMALNYCH}

\subsection{Uwagi wstępne}

Ze zdarzeniami ekstremalnymi, rzadko wystęującymi, mamy do czynienia w różnych dziedzinach życia. Załamania na rynkach finansowych, katastrofy, awarie systemów informatycznych, zasilania, anomalia pogodowe to przykłady zjawisk ekstremalnych, z których pojawieniem związane są ogromne koszty, dlatego istotne jest posiadanie informacji o postaciach rozkładów statystyk ekstremalnych. Pozwalają one określić prawdopodobieństwa wystąpienia szkód o ustalonych wartościach lub wielkości szkód, które mogą się pojawić ze z góry ustalonymi prawdopodobieństwami ich wystapienia.

$\mathrm{W}$ teorii analizy zjawisk ekstremalnych istotne jest szacowanie parametrów rozkładów statystyk ekstremalnych. Do metod, które mogą być wykorzystane, należą metody oparte na statystykach pozycyjnych przedstawione i analizowane $\mathrm{w}$ rozdziale drugim oraz trzecim.

Ważnym problemem jest również modelowanie tzw. ogonów rozkładu analizowanej zmiennej losowej. Rozważa się prawy i lewy ogon, przy czym prawym ogonem rozkładu zmiennej losowej jest rozkład tej zmiennej dla wartości przekraczających pewien ustalony kwantyl, natomiast lewym ogonem jest rozkład zmiennej losowej dla wartości mniejszych niż kwantyl ustalonego rzędu. Prawe ogony rozkładów wykorzystuje się do estymacji kwantyli wysokich rzędów stosowanych do określania miar wartości ekstremalnego zagrożenia ryzykiem.

W rozdziale tym przedstawione zostaną metody estymacji indeksu ekstremalnego i metody szacowania parametrów rozkładu statystyk ekstremalnych, $\mathrm{z}$ uwzględnieniem modyfikacji proponowanych $\mathrm{w}$ rozdziale drugim. Zaprezentowane wyniki przeprowadzonych analiz symulacyjnych dostarczają dodatkowych informacji o własnościach estymatorów wykorzystywanych w analizach zjawisk ekstremalnych m.in. do określania ryzyka ekstremalnego. 


\subsection{Estymacja parametrów uogólnionych rozkladów statystyk ekstremalnych}

Uogólnione rozkłady statystyk ekstremalnych wykorzystuje się do szacowania wielkości zjawisk ekonomicznych, społecznych i przyrodniczych pojawiających się z bardzo małym prawdopodobieństwem. Mimo że rzadko występuja, to związane są one zwykle z różnego rodzaju stratami, w tym finansowymi. Statystyki maksymalne rozważa się analizując straty finansowe wyrażone liczbami dodatnimi, natomiast statystyki minimalne, gdy rozważa się wielkości stóp zwrotu z inwestycji na rynku finansowym. Związek ujemnych stóp zwrotu ze stratami ponoszonymi przez inwestora sprawia, że w tych sytuacjach analizy mogą dotyczyć także statystyk maksymalnych.

Ważnym parametrem uogólnionego rozkładu maksimum (por. wzór (1.4.1)) jest parametr kształtu $\xi$, zwany indeksem ekstremalnym. Ten parametr rozkładu związany jest $\mathrm{z}$ wyglądem prawego ogona rozkładu analizowanej zmiennej losowej $X$. Jeśli $\xi>0$, to zmienna $X$ ma rozkład z tzw. grubym (ciężkim) prawym ogonem, gdy $\xi=0$, wówczas $X$ ma rozkład z cienkim (lekkim) ogonem, jeśli zaś $\xi<0$, to rozkład zmiennej charakteryzuje się krótkim prawym ogonem, czyli przyjmuje wartości z ograniczonego zbioru liczb rzeczywistych.

Estymację parametru $\xi$ oraz pozostałych parametrów uogólnionego rozkładu wartości maksymalnych lub minimalnych przeprowadza się różnymi metodami, w szczególności metodą największej wiarygodności, momentów, momentów ważonych prawdopodobieństwami, metodą kwantyli oraz zmodyfikowanymi kwantylowymi metodami najmniejszych kwadratów.

Jeśli rozkład analizowanej zmiennej losowej $X$ jest znany, to dystrybuanty graniczne statystyk ekstremalnych określonych na podstawie ciagu $X_{1}, X_{2}, \ldots, X_{n}$ można wyznaczyć, wykorzystując twierdzenia przedstawione w rozdziale pierwszym. Często jednak rozkład rozważanej zmiennej losowej jest nieznany. Dodatkowe informacje np. o grubości ogonów rozkładów lub wstępna analiza pozwalają stwierdzić, czy statystyki ekstremalne mają rozkłady typu Gumbela czy też innej postaci. Z rozkładami Gumbela i odwróconym Gumbela mamy do czynienia, m.in. gdy zmienne losowe mają rozkłady: normalny, gamma, lognormalny, logistyczny, Weibulla (por. tablica 1.4.3). Brak informacji o klasie rozkładu badanej zmiennej stwarza konieczność wylosowania dużej próby, podzielenia jej na $m$ bloków i w każdym z bloków wyznaczenia maksimum.

Oznaczmy przez $Z_{1}, Z_{2}, \ldots, Z_{k}$ próbę złożoną ze statystyk maksimum zmiennej losowej $X$, przy czym zmienna $Z_{i}=X_{(n) i}^{(n)}$ jest statystyką maksymalną wyznaczoną na podstawie $i$-tego $n$-elementowego bloku $X_{1, i}, X_{2, i}, \ldots, X_{n, i}$, 
$i=1,2, \ldots, k$. Gdy $Z_{i} \sim G l(\lambda, \delta)$ dla $i=1, \ldots, k$, to parametry rozkładu Gumbela można wyznaczyć metodą największej wiarygodności lub metodą momentów bądź metodami opartymi na kwantylach. Szacując parametry $\lambda, \delta$ metodą momentów $(m M)$, korzystamy z tego, że $E Z=\lambda+0,57772 \delta$ i $D^{2} Z=\frac{\pi^{2} \delta^{2}}{6}$, i tworzymy układ równań:

$$
\left\{\begin{array}{l}
\bar{z}=\lambda+0,57772 \delta, \\
s^{2}=\frac{\pi^{2} \delta^{2}}{6}
\end{array}\right.
$$

gdzie $\bar{z}$ i $s^{2}$ są odpowiednio średnią arytmetyczną i wariancją statystyki maksymalnej wyznaczonymi na podstawie $k$-elementowej próby wartości statystyk maksymalnych.

W wyniku rozwiązania tego układu otrzymujemy estymatory postaci:

$$
\begin{gathered}
\hat{\lambda}^{m M}=\bar{z}-0,57772 \frac{s \sqrt{6}}{\pi}, \\
\hat{\delta}^{m M}=\frac{s \sqrt{6}}{\pi} .
\end{gathered}
$$

Zastosowanie metody kwantyli związane jest z wykorzystaniem wzorów (2.2.16) i (2.2.17) dla zmiennej $Z$, kwantylowej metody najmniejszych kwadratów z uciętą liczbą kwantyli - wzorów (2.4.13) i (2.4.14), natomiast medianowokwantylowej metody najmniejszych kwadratów - wzorów (2.4.13), (2.4.14) i (2.4.17).

W tablicach 5.2.1-5.2.2 przedstawione są oszacowania parametrów rozkładu maksimum uzyskane w oparciu o 30-elementową próbę wartości maksymalnych wyznaczanych na podstawie 50 i 200-elementowych bloków. Parametry rozkładów dobierano tak, by wartości oczekiwane i wariancje analizowanych rozkładów były w przybliżeniu jednakowe. Dla pierwszych pięciu rozkładów są równe lub bliskie 1, w dwóch ostatnich równe lub bliskie wartości 2. Stosowano metodę kwantyli, kwantylową metodę najmniejszych kwadratów z uciętą liczbą kwantyli i medianowo-kwantylową metodę najmniejszych kwadratów.

Estymacja metodami kwantylowymi parametrów rozkładu Gumbela, będącego granicznym rozkładem statystyk maksymalnych rozważanych rozkładów, prowadziła do zbliżonych wartości estymatorów. 
Tablica 5.2.1. Oszacowania parametrów rozkładu Gumbela statystyki maksimum wyznaczanej w oparciu o 50-elementowe próby

\begin{tabular}{|l|c|c|c|c|c|c|}
\hline \multirow{2}{*}{$\begin{array}{c}\text { Rozkład } \\
\text { zmiennej } X\end{array}$} & \multicolumn{3}{|c|}{$\overline{\hat{\lambda}}$} & \multicolumn{3}{c|}{$\overline{\hat{\delta}}$} \\
\cline { 2 - 7 } & $m M$ & $u K m n k$ & $M K$ & $m M$ & $u K m n k$ & $M K$ \\
\hline$N(1,1)$ & 3,041 & 3,028 & 3,043 & 0,359 & 0,351 & 0,369 \\
\hline$L N(0,0,5)$ & 2,815 & 2,784 & 2,781 & 0,614 & 0,572 & 0,570 \\
\hline$G(1,1)$ & 3,936 & 3,887 & 3,892 & 0,976 & 0,936 & 0,959 \\
\hline$W(1,1)$ & 3,938 & 3,889 & 3,891 & 0,978 & 0,936 & 0,960 \\
\hline Logist $(1,1 / 3)$ & 2,301 & 2,285 & 2,289 & 0,329 & 0,315 & 0,342 \\
\hline$L N(2,2)$ & 6,086 & 6,059 & 6,081 & 0,717 & 0,701 & 0,742 \\
\hline$G(0,5,2)$ & 5,467 & 5,376 & 5,379 & 1,747 & 1,665 & 1,694 \\
\hline
\end{tabular}

Źródło: obliczenia własne.

Tablica 5.2.2. Oszacowania parametrów rozkładu Gumela statystyki maksimum wyznaczanej w oparciu o 200-elementowe próby

\begin{tabular}{|l|c|c|c|c|c|c|}
\hline \multirow{2}{*}{$\begin{array}{c}\text { Rozkład } \\
\text { zmiennej } X\end{array}$} & \multicolumn{3}{|c|}{$\overline{\hat{\lambda}}$} & \multicolumn{3}{c|}{$\overline{\hat{\delta}}$} \\
\cline { 2 - 7 } & $m M$ & $u K m n k$ & $M K$ & $m M$ & $u K m n k$ & $M K$ \\
\hline$N(1,1)$ & 3,569 & 3,556 & 3,563 & 0,308 & 0,301 & 0,316 \\
\hline$L N(0,0,5)$ & 3,643 & 3,610 & 3,609 & 0,672 & 0,627 & 0,629 \\
\hline$G(1,1)$ & 5,308 & 5,260 & 5,265 & 0,984 & 0,943 & 0,964 \\
\hline$W(1,1)$ & 5,313 & 5,265 & 5,275 & 0,980 & 0,939 & 0,965 \\
\hline Logist $(1,1 / 3)$ & 2,766 & 2,750 & 2,755 & 0,328 & 0,314 & 0,323 \\
\hline$L N(2,2)$ & 7,137 & 7,112 & 7,127 & 0,618 & 0,603 & 0,633 \\
\hline$G(0,5,2)$ & 7,916 & 7,824 & 7,833 & 1,804 & 1,723 & 1,762 \\
\hline
\end{tabular}

Źródło: obliczenia własne.

Rozkłady typu Frécheta i Weibulla charakteryzują graniczne rozkłady statystyk maksymalnych zmiennych losowych o grubych i krótkich ogonach (wzór (1.4.1) dla $\xi \neq 0)$ i wymagają zwykle numerycznego wyznaczenia wartości estymatorów. 


\subsection{Semiparametryczne metody szacowania indeksu ekstremalnego}

Parametr $\xi$ uogólnionego rozkładu statystyk maksymalnych, zwany indeksem ekstremalnym, jest parametrem kształtu i w przypadku rozkładów gruboogonowych za jego pomocą określa się grubość ogona. Zatem oszacowanie wielkości indeksu $\xi$ daje odpowiedź dotyczącą typu rozkładu zmiennej losowej $X$, a w konsekwencji rozkładu statystyki maksymalnej.

Wartość $\xi$, jako parametru uogólnionego rozkładu statystyki ekstremalnej, można szacować znanymi metodami estymacji, ale konieczne jest posiadanie próby złożonej z wartości statystyk ekstremalnych, co ma swoje wady. Po pierwsze musimy dysponować informacją o klasie uogólnionego rozkładu statystyk ekstremalnych (Gumbela, Frécheta, Weibulla), po drugie, biorąc pod uwagę jedną wartość ekstremalną z próby, pomijamy inne wartości występujące $\mathrm{w}$ danym okresie, które są również istotne w analizach zjawisk rzadkich.

Przy innych podejściach do estymacji $\xi$ wykorzystuje się statystyki pozycyjne wyznaczone na podstawie dużej $n$-elementowej próby $X_{1}, X_{2}, \ldots, X_{n}$ pochodzącej z populacji $X$ lub oszacowany tzw. ogon rozkładu zmiennej $X$, czyli część rozkładu odpowiadającą wartościom przekraczającym pewną ustaloną wielkość zwaną progiem.

Jednym z pierwszych estymatorów indeksu ekstremalnego $\xi$ wykorzystującym statystyki pozycyjne jest estymator Pickandsa (por. J. Pickands [1975], G. Matthys, J. Beirland [2003]).

Definicja 5.3.1. Estymatorem Pickandsa indeksu ekstremalnego $\xi$ nazywamy statystykę określoną na podstawie $n$-elementowej próby losowej $X_{1}, X_{2}, \ldots, X_{n}$ postaci:

$$
\hat{\xi}_{k, n}^{P}=(\ln 2)^{-1} \ln \left(\frac{X_{(n-k+1)}^{(n)}-X_{(n-2 k+1)}^{(n)}}{X_{(n-2 k+1)}^{(n)}-X_{(n-4 k+1)}^{(n)}}\right),
$$

gdzie $X_{(r)}^{(n)}$ są statystykami pozycyjnymi wyznaczonymi w oparciu o próbę losową $X_{1}, X_{2}, \ldots, X_{n}, 1 \leq k \leq \frac{n}{4}$ oraz $k=k(n) \rightarrow \infty$ i $k / n \rightarrow 0$.

Własności estymatora Pickandsa przedstawione są w pracy P. Embrechts $i$ in. [1997]. Jest to estymator zgodny, a odpowiednio unormowany ma graniczny rozkład normalny, którego postać określa twierdzenie 5.3.1. 
Twierdzenie 5.3.1. Jeżeli $\hat{\xi}_{k, n}^{P}$ jest estymatorem Pickandsa indeksu $\xi$ określonym na podstawie $n$-elementowej próby prostej $X_{1}, X_{2}, \ldots, X_{n}$, gdzie $n \rightarrow \infty$ oraz jeśli $k \rightarrow \infty$ i $k / n \rightarrow 0$, to

$$
\sqrt{k}\left(\hat{\xi}_{k, n}^{P}-\xi\right) \sim \operatorname{as} . N(0, v),
$$

gdzie $v=\frac{\xi \sqrt{2^{2 \xi+1}+1}}{2\left(2^{\xi}-1\right) \ln 2}$

Bardziej popularnym, choć stosowanym tylko do estymacji dodatnich indeksów ekstremalnych, jest estymator zaproponowany przez B. M. Hilla [1975], wykorzystujący $k$ największych statystyk pozycyjnych.

Definicja 5.3.2. Estymatorem Hilla indeksu $\xi$ nazywamy statystykę, określoną na podstawie $n$-elementowej próby prostej $X_{1}, X_{2}, \ldots, X_{n}$, wyrażoną wzorem:

$$
\hat{\xi}_{k, n}^{H}=k^{-1} \sum_{i=1}^{k} \ln X_{(n-i+1)}^{(n)}-\ln X_{(n-k)}^{(n)},
$$

gdzie $X_{(n-i+1)}^{(n)}$ są statystykami pozycyjnymi dla $i=1, \ldots, k+1$ oraz $1 \leq k<n$.

Jest to estymator zgodny, ale obciążony. Jego obciążenie wzrasta wraz ze wzrostem $k$. Asymptotyczną zbieżność unormowanego estymatora Hilla określa twierdzenie 5.3.2 (por. R. Davis, S. Resnick [1984]).

Twierdzenie 5.3.2. Niech $\hat{\xi}_{k, n}^{H}$ będzie estymatorem Hilla indeksu $\xi$, który jest funkcją $n$-elementowej próby prostej $X_{1}, X_{2}, \ldots, X_{n}$. Jeśli $\frac{k}{\ln \ln n} \rightarrow \infty$ oraz $k / n \rightarrow 0$, to

$$
\sqrt{k}\left(\hat{\xi}_{k, n}^{H}-\xi\right) \sim \operatorname{as} . N(0, \xi) .
$$

Dobre własności estymatora Hilla doprowadziły do jego uogólnienia na przypadek $\xi \in R$ i wprowadzenia tzw. uogólnionego estymatora Hilla (por. Z. Tsourti, J. Panaretos [2001]) oraz estymatora momentowego Dekkersa-Einmahla de Hanna (por. A. Dekkers i in. [1989]). 
Definicja 5.3.3. Uogólnionym estymatorem Hilla indeksu ekstremalnego $\xi$ nazywamy statystykę określoną na podstawie $n$-elementowej próby prostej $X_{1}, X_{2}, \ldots, X_{n}$ postaci:

$$
\hat{\xi}_{k, n}^{u H}=k^{-1} \sum_{i=1}^{k} \ln U_{(n-i+1)}-\ln U_{(n-k)},
$$

gdzie $U_{(n-i+1)}=X_{(n-i)}^{(n)}\left(\frac{1}{i} \sum_{j=1}^{n} \ln X_{(n-j+1)}^{(n)}-\ln X_{(n-i)}^{(n)}\right)$.

Definicja 5.3.4. Estymatorem momentowym indeksu ekstremalnego nazywamy statystykę określoną na podstawie $n$-elementowej próby prostej $X_{1}, X_{2}, \ldots, X_{n}$ wyrażoną wzorem:

$$
\hat{\xi}_{k, n}^{M}=M_{k}^{(1)}+1-\frac{1}{2}\left(1-\frac{\left(M_{k}^{(1)}\right)^{2}}{M_{k}^{(2)}}\right)^{-1},
$$

gdzie $M_{k}^{(l)}=\frac{1}{k} \sum_{i=1}^{k}\left(\ln X_{(n-i+1)}^{(n)}-\ln X_{(n-k)}^{(n)}\right)^{l}$ dla $l=1,2$.

Estymatorami będącymi modyfikacjami estymatora momentowego, posiadającymi mniejsze obciążenia, są estymator Penga i $W$-estymator (por. P. Peng [1998], Z. Tsourti, J. Panaretos [2001]).

Definicja 5.3.5. Estymatorem Penga indeksu $\xi$ nazywamy statystykę będącą funkcją $n$-elementowej próby $X_{1}, X_{2}, \ldots, X_{n}$ postaci:

$$
\hat{\xi}_{k, n}^{\text {Penga }}=\frac{M_{k}^{(2)}}{2 M_{k}^{(1)}}+1-\frac{1}{2}\left(1-\frac{\left(M_{k}^{(1)}\right)^{2}}{M_{k}^{(2)}}\right)^{-1},
$$

gdzie $M_{k}^{(l)}=\frac{1}{k} \sum_{i=1}^{k}\left(\ln X_{(n-i+1)}^{(n)}-\ln X_{(n-k)}^{(n)}\right)^{l}$ dla $l=1,2$.

Definicja 5.3.6. Estymatorem $W$ indeksu $\xi$ nazywamy statystykę będącą funkcją $n$-elementowej próby $X_{1}, X_{2}, \ldots, X_{n}$, wyrażoną wzorem:

$$
\hat{\xi}_{k, n}^{W}=1-\frac{1}{2}\left(1-\frac{\left(L_{k}^{(1)}\right)^{2}}{L_{k}^{(2)}}\right)^{-1},
$$


gdzie $L_{k}^{(l)}=\frac{1}{k} \sum_{i=1}^{k}\left(X_{(n-i+1)}^{(n)}-X_{(n-k)}^{(n)}\right)^{\prime}$ dla $l=1,2$.

Estymator Penga jest zgodny i asymptotycznie normalny, natomiast estymator $W$ jest zgodny dla $\xi<\frac{1}{2}$ i asymptotycznie normalny dla $\xi<\frac{1}{4}$.

Do innych estymatorów dodatniego indeksu ekstremalnego należy estymator jądrowy, który również wykorzystuje $k$ statystyk pozycyjnych (por. S. Csörgö i in. [1985]).

Definicja 5.3.7. Estymatorem jądrowym indeksu $\xi$ nazywamy statystykę będącą funkcją $n$-elementowej próby $X_{1}, X_{2}, \ldots, X_{n}$ postaci:

$$
\hat{\xi}_{k, n}^{j}=\frac{\sum_{i=1}^{k} K\left(\frac{i}{k}\right)\left(\ln X_{(n-i+1)}^{(n)}-\ln X_{(n-k)}^{(n)}\right)}{\sum_{i=1}^{k} K\left(\frac{i}{k}\right)},
$$

gdzie $K$ jest funkcją jądra (nieujemną, nierosnącą na przedziale $(0,+\infty)$ oraz spełniającą warunek $\left.\int_{0}^{+\infty} K(t) d t=1\right)$.

Estymator Hilla jest szczególnym przypadkiem estymatora jądrowego. Otrzymujemy go dla funkcji jądra $K(t)=I_{[0,1]}(t)$, gdzie $I$ jest indykatorem przyjmującym wartość 1 , gdy $t \in[0,1]$ oraz $0 \mathrm{w}$ przeciwnym przypadku.

Powyższe estymatory stanowią przykłady tzw. semiparametrycznych estymatorów stosowanych przy szacowaniu indeksu ekstremalnego. Aby je wykorzystać, należy dokonać wyboru wartości $k$. W praktyce wyznacza się wartości estymatora w zależności od $k$ i szuka obszarów stabilizowania się wartości.

Jako przykład rozważmy populację $X$ o rozkładzie Pareto $P a(2,1)$, czyli populację, dla której statystyka maksimum ma rozkład Frécheta o indeksie ekstremalnym $\xi=1$. Niech $X_{1}, X_{2}, \ldots, X_{1000}$ będzie próbą prostą wylosowaną z tej populacji. Szacowanie indeksu $\xi$ metodami Pickandsa, Hilla, momentów i Penga dla różnych wartości $k$ prowadzi do otrzymania wartości estymatorów przedstawionych na rysunkach 5.3.1-5.3.4.

Dla estymatorów: Hilla, momentowego i uogólnionego Penga określonych w oparciu o 1000 -elementową próbę oraz $1 \leq k \leq 250$, zauważyć można stabili- 
zację wartości estymatorów indeksu ekstremalnego, tzn. istnieje $k_{0}$ takie, że dla $k \geq k_{0}$ estymatory mają $\mathrm{w}$ przybliżeniu takie same wartości. Dla estymatora Pickandsa brak jest widocznej stabilizacji jego wartości, jest ona zauważalna dopiero przy bardzo dużych próbach, rzędu 10000.

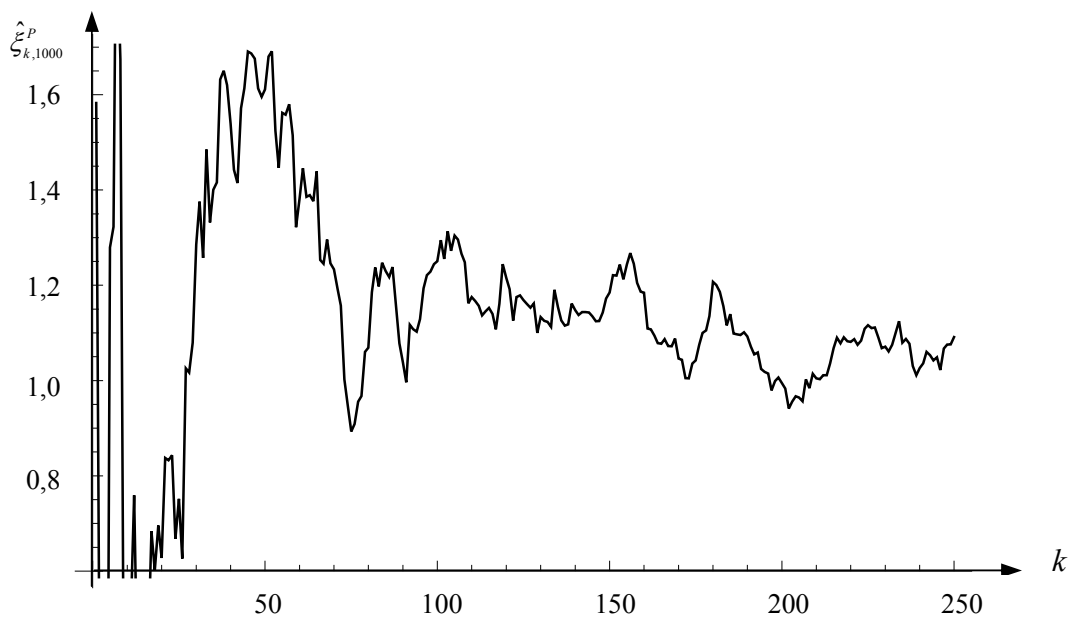

Rysunek 5.3.1. Wartości estymatora Pickandsa indeksu ekstremalnego $\xi$ populacji o rozkładzie $P a(2,1)$ dla różnych wartości $k$ Źródło: opracowanie własne

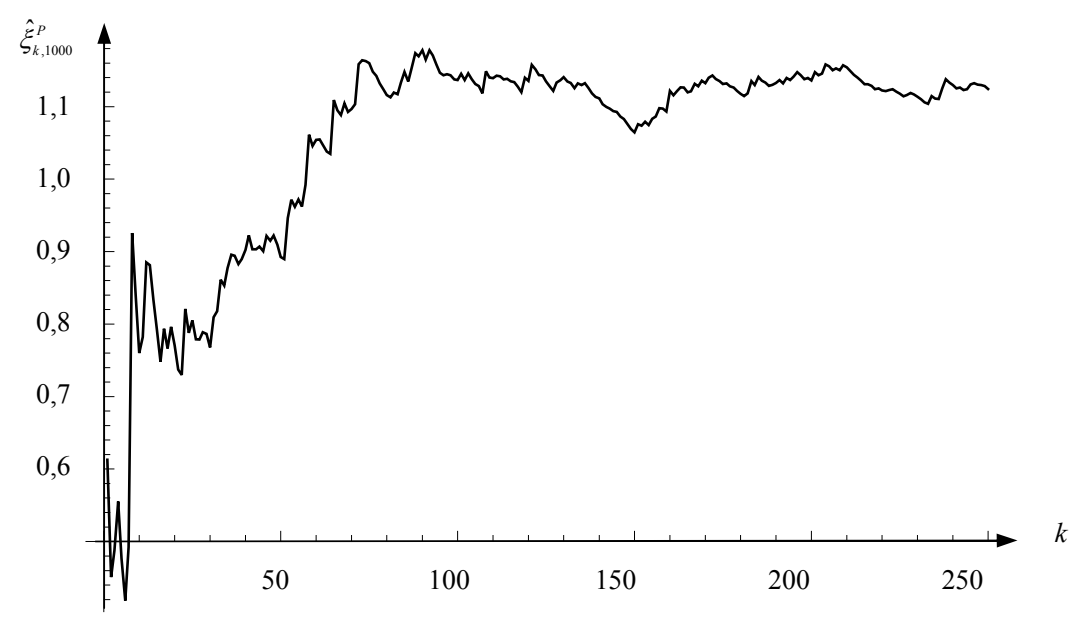

Rysunek 5.3.2. Wartości estymatora Hilla indeksu ekstremalnego $\xi$ populacji o rozkładzie $P a(2,1)$ dla różnych wartości $k$ Źródło: opracowanie własne 


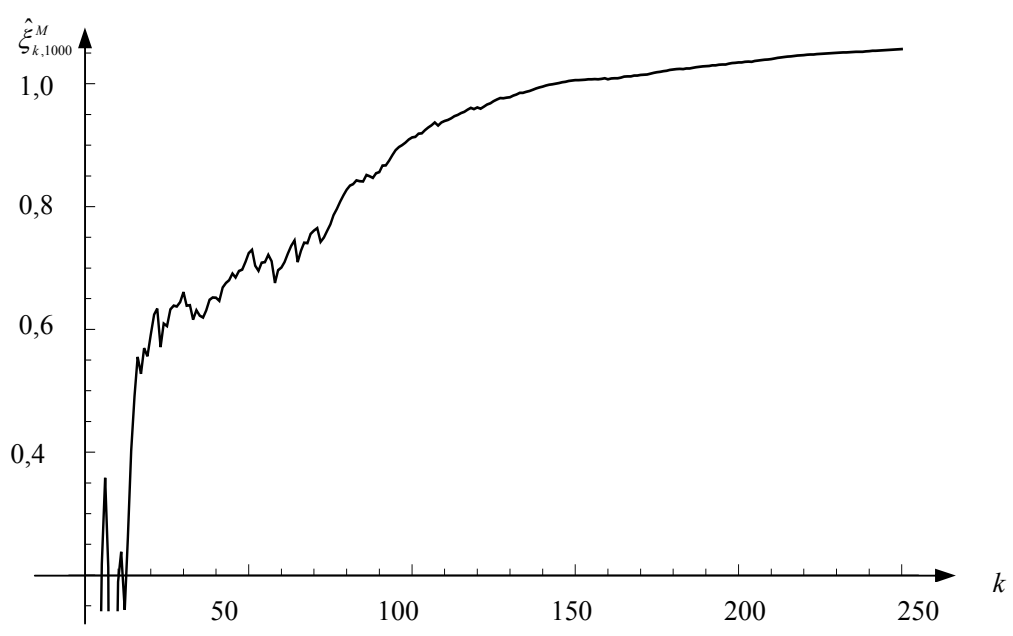

Rysunek 5.3.3. Wartości estymatora momentowego indeksu ekstremalnego $\xi$ populacji o rozkładzie $P a(2,1)$ dla różnych wartości $k$ Źródło: opracowanie własne

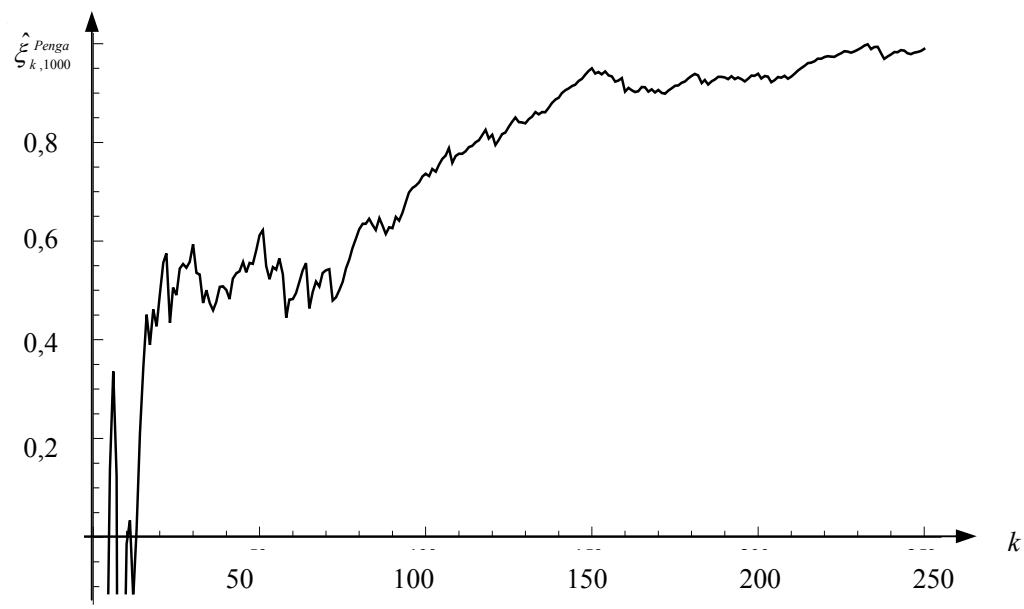

Rysunek 5.3.4. Wartości uogólnionego estymatora Penga indeksu ekstremalnego $\xi$ o rozkładzie $P a(2,1)$ dla różnych wartości $k$

Źródło: opracowanie własne

Własności asymptotycznej normalności estymatorów indeksu $\xi$ pozwalają dla dużych prób konstruować przedziały ufności. Wykorzystując asymptotyczną 
normalność estymatora Hilla (twierdzenie 5.3.2), określa się przedział ufności dla indeksu ekstremalnego postaci:

$$
P\left\{\frac{\sqrt{k} \hat{\xi}_{H}}{\sqrt{k}+u_{\alpha}} \leq \xi \leq \frac{\sqrt{k} \hat{\xi}_{H}}{\sqrt{k}-u_{\alpha}}\right\}=1-\alpha,
$$

gdzie $1-\alpha$ jest przyjętym poziomem wiarygodności, zaś $u_{\alpha}$ to kwantyl rzędu $1-\frac{\alpha}{2}$.

W badaniach ekonomicznych często mamy do czynienia ze zmiennymi losowymi charakteryzującymi się grubymi ogonami, czyli o indeksie ekstremalnym $\xi>0$.

Jeśli zmienna losowa $X$ ma rozkład o dystrybuancie $F$ o grubym ogonie, to jej dystrybuantę można zapisać w postaci:

$$
F(x)=1-x^{-\alpha} L(x)
$$

gdzie $L$ jest wolno zmieniającą się funkcją, tzn. $\lim _{x \rightarrow \infty} \frac{L(t x)}{L(x)}=1$ dla każdego skończonego $t$ oraz $\alpha>0$.

W związku z tym, w literaturze, obok pojęcia indeksu ekstremalnego, funkcjonuje dla rozkładów o grubych ogonach pojęcie indeksu ogona $\alpha$. Określa on zarówno grubość ogona, jak i rząd maksymalnego skończonego momentu rozkładu. Związek między indeksem ekstremalnym a indeksem ogona jest postaci: $\alpha=\frac{1}{\xi}$ dla $\alpha>0$. Im mniejsza jest wartość indeksu ogona, czyli większa wartość $\xi$, tym grubszy jest ogon rozkładu. Zależność między indeksami pozwala wykorzystać procedury charakterystyczne dla estymacji parametru $\xi$ przy szacowaniu indeksu ogona $\alpha$.

\subsection{Estymacja ogona rozkładu zmiennej losowej i jej zastosowanie}

W analizach zdarzeń ekstremalnych ważnym zagadnieniem jest asymptotyczne modelowanie ogonów rozkładu losowej $X$, czemu służą tzw. modele wartości ponadprogowych $(P O T)$. Są one użyteczne z punktu widzenia zarządzania 
ryzykiem, gdyż w oparciu o estymowane ogony dystrybuant szacuje się kwantyle wysokich rzędów i ekstremalne miary ryzyka.

Rozważmy aproksymację prawego ogona rozkładu. Definicje 5.4.1 i 5.4.2 określają pojęcia dystrybuanty rozkładu strat ponadprogowych oraz wartości oczekiwanej strat ponadprogowych (por. P. Embrechts i in. [1997, s.160-162]).

Definicja 5.4.1. Niech $X$ będzie zmienną losową o dystrybuancie $F$, natomiast $u$ ustaloną wartością. Dystrybuantę zmiennej losowej $Y=X-u$ postaci:

$$
F_{u}(y)=P(X-u<y \mid X>u),
$$

gdzie $0 \leq y<x_{0}-u$, zaś $x_{0} \leq \infty$ nazywamy dystrybuantą nadmiaru (excess distribution function) ponad próg $u$ lub dystrybuantą strat ponadprogowych (excess lossed distribution).

Powyższa dystrybuanta nazywana jest również dystrybuantą warunkowego rozkładu przekroczenia.

Najczęściej przyjmuje się $x_{0}=\infty$, dopuszczając tym samym wielkie straty.

$\mathrm{Z}$ własności prawdopodobieństwa wynika, że:

$$
F_{u}(y)=1-\frac{P(X>y+u)}{P(X>u)}=\frac{F(y+u)-F(u)}{1-F(u)} .
$$

Definicja 5.4.2. Dla zmiennej losowej $X$ i ustalonego progu wyrażenie:

$$
e(u)=E(X-u \mid X>u)
$$

nazywamy wartością oczekiwaną nadmiaru (mean excess function) lub wartością oczekiwaną strat ponadprogowych.

Dla zmiennych losowych o znanych rozkładach możemy ze wzorów (5.4.1) oraz (5.4.2) wyznaczać dystrybuantę i wartość oczekiwaną nadmiaru. Będą one zależne od ustalonego progu.

W zagadnieniach praktycznych zwykle rozkład zmiennej losowej $X$ jest nieznany.

Dla dużych liczebności prób $X_{1}, X_{2}, \ldots, X_{n}$, aby aproksymować dystrybuantę strat ponadprogowych, możemy skorzystać z przybliżenia: $(F(x))^{n} \approx F_{\xi, \mu, \sigma}^{M}$ i rozkładu statystyki maksimum: 


$$
(F(x))^{n} \approx\left\{\begin{array}{l}
\exp \left(-\left(1+\xi \frac{x-\mu}{\sigma}\right)^{-\frac{1}{\xi}}\right) \\
\exp \left(-\exp \left(-\frac{x-\mu}{\sigma}\right)\right)
\end{array} \quad \text { dla } \xi \neq 0\right.
$$

Logarytmując wzór (5.4.3) stronami, uzyskujemy:

$$
n \ln F(x) \approx \begin{cases}-\left(1+\xi \frac{x-\mu}{\sigma}\right)^{-\frac{1}{\xi}} & \text { dla } \xi \neq 0 \\ -\exp \left(-\frac{x-\mu}{\sigma}\right) & \text { dla } \xi=0\end{cases}
$$

a następnie, korzystając $\mathrm{z}$ równości $\ln F(x) \approx F(x)-1$ (por. E. Castillo $\mathrm{i}$ in. [2004, s. 264]) dla dużych wartości $x$, mamy:

$$
F(x) \approx \begin{cases}1-\frac{1}{n}\left(1+\xi \frac{x-\mu}{\sigma}\right)^{-\frac{1}{\xi}} & \text { dla } \quad \xi \neq 0 \\ 1-\frac{1}{n} \exp \left(-\frac{x-\mu}{\sigma}\right) & \text { dla } \xi=0\end{cases}
$$

Podstawiając (5.4.5) do wzoru na dystrybuantę strat ponadprogowych, otrzymujemy:

- gdy $\xi \neq 0$ :

$$
F_{u}(y)=1-\frac{1-F(y+u)}{1-F(u)}=1-\frac{\left(1+\xi \frac{y+u-\mu}{\sigma}\right)^{-\frac{1}{\xi}}}{\left(1+\xi \frac{u-\mu}{\sigma}\right)^{-\frac{1}{\xi}}}=1-\left(1+\frac{\xi y}{\sigma+\xi(u-\mu)}\right)^{-\frac{1}{\xi}},
$$

$-\operatorname{gdy} \xi=0$ : 


$$
F_{u}(y)=1-\frac{\exp \left(-\frac{y+u-\mu}{\sigma}\right)}{\exp \left(-\frac{u-\mu}{\sigma}\right)}=1-\exp \left(-\frac{y}{\sigma}\right)
$$

Dystrybuanta $F_{u}$ określona wzorem (5.4.6) lub (5.4.7) charakteryzuje asymptotyczny rozkład zmiennej losowej $Y=X-u$, gdzie $u$ jest ustalona, rzeczywistą wartością progową. Zatem rozkład zmiennej losowej $Y$ przybliża się uogólnionym rozkładem Pareto $G P D(\beta, \xi)$, przy czym $\beta=\sigma+\xi(u-\mu)$, gdy $\xi \neq 0$ (por. Aneks).

Dla wybranych parametrów funkcje gęstości rozkładu $G P D$ przedstawione są na rysunkach 5.4.1-5.4.2.

Jeśli $\xi>0$, to funkcje gęstości są nieujemne dla $x \in\langle 0,+\infty)$, natomiast w przypadku $\xi<0$ w przedziale $\left[0,-\frac{\beta}{\xi}\right]$.

Dla uogólnionego rozkładu Pareto wartość oczekiwana nadmiaru wyraża się wzorem:

$$
e(u)=\frac{\beta}{1-\xi}+\frac{\xi}{1-\xi} u,
$$

a jej estymatorem jest statystyka postaci:

$$
\hat{e}(u)=\frac{\sum_{i=1}^{n} \max \left\{\left(x_{i}-u\right), 0\right\}}{\sum_{i=1}^{n} I_{[u, \infty)}\left(x_{i}\right)} .
$$

Parametry przybliżonego rozkładu strat ponadprogowych, przy ustalonej wartości progu $u$, szacuje się na podstawie próby losowej $X_{1}, X_{2}, \ldots, X_{n}$, wybierając $n_{u}$ wartości $Y_{1}, \ldots, Y_{n_{u}}$, gdzie $Y_{i}=X_{(l+i-1)}^{(n)}-u$ oraz $l$ jest rangą pierwszej statystyki pozycyjnej przekraczającej próg $u$. W tym celu można wykorzystać metodę największej wiarygodności $(m N W)$, momentów $(m M)$ oraz metody przedstawione $w$ rozdziale drugim. Metoda największej wiarygodności znajduje zastosowanie w przypadku, gdy $\xi>-1$, gdyż dla $\xi \leq-1$ funkcja ilorazu wiarygodności nie ma maksimum (por. S. D. Grimshaw [1993]). 


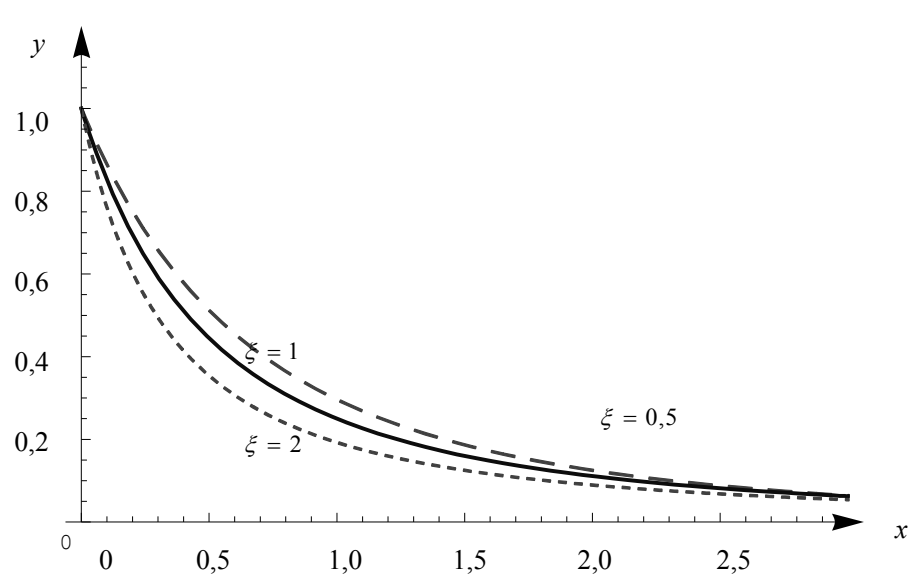

Rysunek 5.4.1. Funkcje gęstości uogólnionego rozkładu Pareto dla wybranych $\xi>0$ i $\beta=1$

Źródło: opracowanie własne

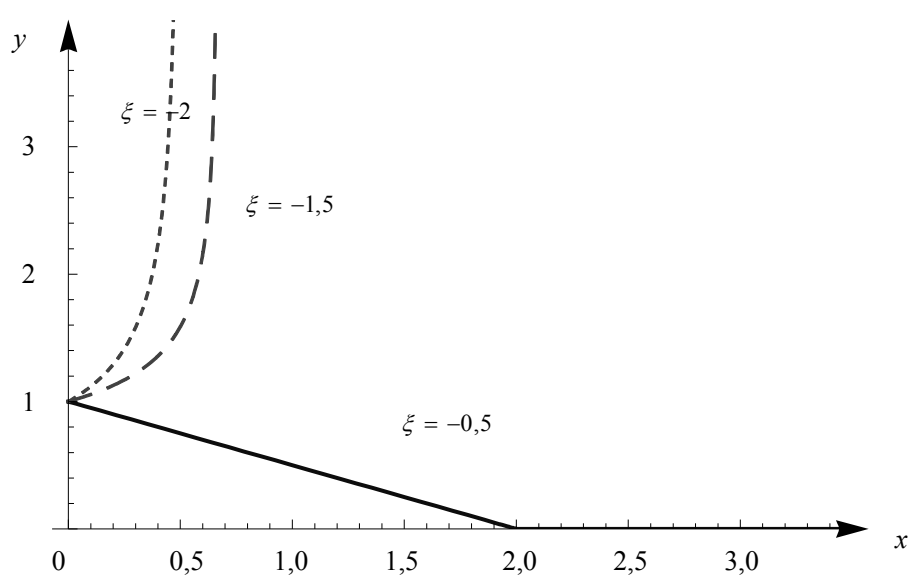

Rysunek 5.4.2. Funkcje gęstości uogólnionego rozkładu Pareto dla wybranych

$$
\xi<0 \text { i } \beta=1
$$

Źródło: opracowanie własne

W rozdziale trzecim przestawiono wyniki analiz własności estymatorów parametrów $\xi, \beta$ uogólnionego rozkładu Pareto dla $\xi>0$. Dla uzupełnienia tych badań rozważano zmienne losowe o rozkładach: $t$-Studenta, Pareto i log-gamma charakteryzujące się grubymi ogonami, dla których rozkład strat ponadprogowych jest rozkładem $\operatorname{GPD}(\beta, \xi)$ dla $\xi>0$. Z tego typu rozkładami mamy do 
czynienia w analizach finansowych. Wielkości parametrów tych rozkładów uzyskano na podstawie analizy danych rzeczywistych dotyczących rozkładu dziennych logarytmicznych stóp zwrotu indeksów giełdowych, natomiast wartość progową ustalono na poziomie kwantyla rzędu 0,90. Wielkości prób losowych musiały być na tyle duże, aby wartości przekraczające próg $u$ stanowiły duże próby, dlatego rozważano próby 1000 -elementowe. Powtórzenie procedur estymacji parametrów uogólnionego rozkładu Pareto dla dystrybuant empirycznych określonych wzorami:

$$
\begin{gathered}
F_{1, n}(y)=\frac{1}{n-1} \sum_{i=1}^{n}\left(I_{(-\infty, y)}\left(y_{(i)}^{(n)}\right)-1\right), \\
F_{2, n}(y)=\frac{1}{n} \sum_{i=1}^{n} I_{(-\infty, y)}\left(y_{(i)}^{(n)}\right), \\
F_{3, n}(y)= \begin{cases}0 & \text { dla } x<x_{(1)}^{(n)}, \\
\frac{1}{2}\left[1-\frac{n-2}{\sqrt{n(n-1)}}\right] & \text { dla } x_{(1)}^{(n)} \leq x<x_{(2)}^{(n)}, \\
\frac{1}{2}\left[1-\frac{n-2 i}{\sqrt{n(n-1)}}\right] & \text { dla } \quad x_{(i)}^{(n)} \leq x<x_{(i+1)}^{(n)}, i=2,3, \ldots, n-1, \\
1 & \text { dla } x \geq x_{(n)}^{(n)} .\end{cases}
\end{gathered}
$$

pozwoliło oszacować obciążenia i błędy średniokwadratowe estymatorów parametru $\xi$ oznaczonych odpowiednio $\hat{\xi}_{1}, \hat{\xi}_{2}, \hat{\xi}_{3}$, które zawarte są w tablicy 5.4.1.

Tablica 5.4.1. Oszacowane obciążenia i błędy średniokwadratowe estymatorów parametru $\xi$ otrzymane metodami momentów ważonych prawdopodobieństwami

\begin{tabular}{|l|c|c|c|c|c|c|}
\hline \multirow{2}{*}{ Typ rozkładu } & \multicolumn{3}{|c|}{ Obciążenia } & \multicolumn{3}{c|}{ Błędy średniokwadratowe } \\
\cline { 2 - 7 } & $\hat{\xi}_{1}-\xi$ & $\hat{\xi}_{2}-\xi$ & $\hat{\xi}_{3}-\xi$ & $\operatorname{MSE}\left(\hat{\xi}_{1}\right)$ & $\operatorname{MSE}\left(\hat{\xi}_{2}\right)$ & $\operatorname{MSE}\left(\hat{\xi}_{3}\right)$ \\
\hline$S(4)$ & $-0,109$ & $-0,092$ & $-0,084$ & 0,040 & 0,033 & 0,030 \\
\hline$S(2)$ & $-0,079$ & $-0,070$ & $-0,064$ & 0,032 & 0,029 & 0,027 \\
\hline$P a(1,4)$ & $-0,111$ & $-0,094$ & $-0,086$ & 0,041 & 0,033 & 0,030 \\
\hline$P a(1,2)$ & $-0,046$ & $-0,038$ & $-0,032$ & 0,023 & 0,021 & 0,019 \\
\hline$L G(2,0,2,0)$ & $-0,012$ & 0,003 & 0,011 & 0,015 & 0,014 & 0,014 \\
\hline$L G(2,0,6,0)$ & $-0,088$ & $-0,080$ & $-0,074$ & 0,066 & 0,052 & 0,056 \\
\hline
\end{tabular}

Źródło: obliczenia własne. 
W celu porównania uzyskanych estymatorów wyznaczano współczynniki określone wzorem:

$$
e f_{i j}=\frac{\operatorname{MSE}\left(\hat{\xi}_{i}\right)}{\operatorname{MSE}\left(\hat{\xi}_{j}\right)},
$$

gdzie $\operatorname{MSE}\left(\hat{\xi}_{i}\right)$ oznacza błąd średniokwadratowy estymatora parametru $\xi_{i}$, $i, j=1,2,3$ oraz $i \neq j$. Jeśli $e f_{i j}<1$, to estymator $\hat{\xi}_{i}$ posiada lepsze własności. Wartości współczynników dla rozważanych klas rozkładów przedstawione są w tablicy 5.4.2.

Tablica 5.4.2. Współczynniki efektywności metod estymacji parametru $\xi$

\begin{tabular}{|l|c|c|c|}
\hline \multirow{2}{*}{ Typ rozkładu } & \multicolumn{3}{|c|}{ Współczynniki efektywności } \\
\cline { 2 - 4 } & $e f_{21}$ & $e f_{32}$ & $e f_{31}$ \\
\hline$S(4)$ & 0,825 & 0,909 & 0,750 \\
\hline$S(2)$ & 0,906 & 0,931 & 0,844 \\
\hline$P a(1,4)$ & 0,805 & 0,909 & 0,732 \\
\hline$P a(1,2)$ & 0,913 & 0,905 & 0,826 \\
\hline$L G(2,0,2,0)$ & 0,933 & 1,000 & 0,933 \\
\hline$L G(2,0,6,0)$ & 0,788 & 1,077 & 0,848 \\
\hline
\end{tabular}

Źródło: obliczenia własne.

Na podstawie porównania współczynników efektywności można stwierdzić, że dla analizowanych rozkładów estymator $\hat{\xi}_{3}$ jest najefektywniejszy. Zatem również w przypadku szacowania indeksu $\xi$ dla granicznych rozkładów ogona rozważanych zmiennych losowych metoda momentów ważonych prawdopodobieństwami $\mathrm{z}$ proponowaną level crossing empirical distribution prowadzi do uzyskania estymatora o lepszych własnościach.

Istnienie momentów ważonych prawdopodobieństwami zależy od wartości parametru $\xi$, która nie jest znana. Konieczne jest zatem wstępne oszacowanie tego parametru np. przy użyciu jednego $z$ estymatorów semiparametrycznych albo skorzystanie z danych historycznych dotyczących jego wartości.

Rozważmy teraz problem szacowania dystrybuanty $F$ zmiennej losowej $X$ dla $x>u$ na podstawie $n$-elementowej próby prostej $X_{1}, \ldots, X_{n}$.

Ze wzoru (5.4.1) mamy:

$$
F_{u}(x-u)=\frac{F(x)-F(u)}{1-F(u)},
$$


czyli

$$
F(x)=[1-F(u)] F_{u}(x-u)+F(u)
$$

Korzystając z oszacowania:

$$
\hat{F}(u)=\frac{n-n_{u}}{n},
$$

gdzie $n_{u}$ jest liczbą przekroczeń ustalonego progu $u$ oraz postaci granicznego rozkładu dystrybuanty $F_{u}$, otrzymujemy oszacowanie ogona rozkładu $F$ wyrażone wzorem:

$$
\hat{F}(x)=1-\frac{n_{u}}{n}\left(1+\hat{\xi} \frac{x-u}{\hat{\beta}}\right)^{-\frac{1}{\hat{\xi}}} \quad \text { dla } x>u,
$$

gdzie $\hat{\xi}, \hat{\beta}$ są estymatorami, odpowiednio, parametrów $\xi, \beta$.

Dla $\hat{\xi}=0$ mamy:

$$
\hat{F}(x)=1-\frac{n_{u}}{n} \exp \left(-\frac{x-u}{\hat{\beta}}\right) .
$$

Wybór wartości progowej ma wpływ na otrzymywane wartości estymatorów. Zbyt duża wartość progowa $u$ powoduje, iż niewiele obserwacji przekroczy próg, co skutkuje dużą wariancją, natomiast zbyt mała jej wartość powoduje duże obciążenie estymatorów. Istotny jest więc wybór właściwej wartości $u$, stanowiącej kompromis między wielkością wariancji i obciążenia. Najczęściej przyjmuje się wartości ponadprogowe na poziomie kwantyla rzędu 0,95 lub 0,9.

Jednym ze sposobów ustalenia progu $u$ jest wykres mean excess plot. Tworzy się go, wyznaczając na podstawie próby prostej $X_{1}, \ldots, X_{n}$ graficznie zbiór następujących punktów (por. P. Embrechts i in. [1997, s. 296-297]):

$$
\left\{(u, \hat{e}(u)): \quad x_{(1)}^{(n)}<u<x_{(n)}^{(n)} \wedge \hat{e}(u)=\frac{\sum_{i=n_{0}}^{n}\left(x_{(i)}^{(n)}-u\right)}{n_{u}} \wedge n_{0}=\min \left\{i: x_{(i)}^{(n)}>u\right\}\right\},
$$


gdzie $x_{(1)}^{(n)}, \ldots, x_{(n)}^{(n)}$ jest ciagiem wartości statystyk pozycyjnych wyznaczonych na podstawie próby losowej. Miejsce, od którego punkty układają się wzdłuż prostej, uznaje się jako wartość progową $u$.

Odpowiednie oszacowanie ogona dystrybuanty $F$ (wzory (5.4.14), (5.4.15)) pozwala wyznaczyć kwantyle z próby wysokich rzędów, czyli kwantyle $X_{p ; n}$, gdzie $p>\sqrt[n]{0,5}$. Dla wybranych liczebności prób w tablicy 5.4.3. podane są minimalne rzędy, dla których uznaje się kwantyle za kwantyle wysokich rzędów.

Tablica 5.4.3. Minimalne rzędy kwantyli uznawanych za kwantyle wysokich rzędów

\begin{tabular}{|c|c|c|c|c|c|}
\hline$n$ & 100 & 200 & 500 & 1000 & 2000 \\
\hline$p$ & 0,99309 & 0,99654 & 0,99862 & 0,99931 & 0,99965 \\
\hline
\end{tabular}

Źródło: opracowanie własne.

Kwantyle z próby rzędu $p$ wyznaczone w oparciu o $\hat{F}$ mają postać:

$$
X_{p ; n}= \begin{cases}u+\frac{\hat{\beta}}{\hat{\xi}}\left(\left(\frac{n}{n_{u}}(1-p)\right)^{-\hat{\xi}}-1\right) & \text { dla } \xi \neq 0, \\ u-\hat{\beta} \ln \left(\frac{n}{n_{u}}(1-p)\right) & \text { dla } \xi=0 .\end{cases}
$$

Postaci innych estymatorów kwantyla wysokiego rzędu $p$ wyrażają się wzorami:

$$
\hat{Q}_{p}^{H 1}=X_{(n-k)}^{(n)}\left(\frac{k+1}{(n+1)(1-p)}\right)^{\hat{\xi}_{k, n}^{H}}
$$

gdzie $\hat{\xi}_{H}$ jest estymatorem Hilla indeksu ekstremalnego (por. A. Fils, A. Guillou [2004]) oraz

$$
\hat{Q}_{p}^{H 2}=X_{(n-k)}^{(n)}\left(-0,5+\sqrt{0,25+\frac{(1-p) n c(\hat{\xi})}{k}}\right)^{\hat{\xi}_{k, n}^{H}},
$$

gdzie $c(\hat{\xi}) \approx 1+\left(X_{(n-k)}^{(n)}\right)^{-\frac{1}{\xi}}+\left(X_{(n-k)}^{(n)}\right)^{-\frac{2}{\xi}}$ (por. N. M. Markovich, U. R. Krieger [2002]). 
$\mathrm{Z}$ analiz porównawczych własności estymatorów (5.4.17)-(5.4.19) przeprowadzonych dla zmiennych o rozkładach $t$-Studenta i Pareto, zawartych w N. Markovich [2007, s. 165-171], wynika, że estymator $\hat{Q}_{p}^{H 2}$ kwantyla wysokiego rzędu $p$ charakteryzuje się najmniejszym błędem średniokwadratowym.

Lewy ogon rozkładu zmiennej losowej $X$ modeluje się analogicznie jak prawy ogon rozkładu. Wartości poniżej pewnego progu aproksymuje się odwróconym, uogólnionym rozkładem Pareto (por. E. Castillo i in. [2004, s. 266-267]).

Przykładowo, dla zmiennej losowej o rozkładzie $t$-Studenta o 2 stopniach swobody, na podstawie 1000-elementowej próby oszacowano ogon jej dystrybuanty, wcześniej estymując parametry uogólnionego rozkładu Pareto dla trzech wybranych wartości progu $u$ - na poziomie kwantyli rzędu 0,$9 ; 0,95$ oraz 0,98 . Ze względu na lepsze własności estymatorów parametrów $G P D$ otrzymanych metodą momentów ważonych prawdopodobieństwami z dystrybuantą empiryczną level crossing właśnie tę metodę zastosowano, otrzymując następujące oszacowania ogonów rozkładu dla progów $u$ będących kwantylami rzędu, odpowiednio, 0,$9 ; 0,95$ oraz 0,98 . Dystrybuanty oznaczone $\hat{F}_{0,9}(x), \hat{F}_{0,95}(x), \hat{F}_{0,98}(x)$ są postaci:

$$
\begin{gathered}
\hat{F}_{0,9}(x)=1-0,1\left(1+0,565 \frac{x-1,886}{0,027}\right)^{-1,770} \quad \text { dla } x>1,886, \\
\hat{F}_{0,95}(x)=1-0,05\left(1+0,559 \frac{x-2,920}{0,036}\right)^{-1,789} \text { dla } x>2,92, \\
\hat{F}_{0,98}(x)=1-0,02\left(1+0,563 \frac{x-4,849}{0,062}\right)^{-1,776} \quad \text { dla } x>4,849 .
\end{gathered}
$$

\subsection{Bootstrapowa estymacja kwantyli wykorzystująca oszacowanie ogona rozkładu zmiennej losowej}

Spośród bootstrapowych metod estymacji parametrów zmiennej losowej najczęściej stosowane są nieparametryczne metody, niewykorzystujące żadnych informacji o klasie rozkładu analizowanej zmiennej tylko wyłącznie informacje pochodzące $\mathrm{z}$ próby. Ten sposób estymacji nie jest jednak efektywny w przypadku szacowania kwantyli wysokich rzędów oraz parametrów rozkładu statystyk ekstremalnych, ponieważ wylosowana próba bootstrapowa może nie zawierać 
obserwacji ekstremalnych, co nie pozwoli uzyskać dobrej aproksymacji ogona rozkładu. W tym przypadku stosuje się podejście semiparametryczne, wykorzystujące oszacowanie ogona rozkładu analizowanej zmiennej.

Semiparametryczną estymację bootstrapową charakteryzują podwójne symulacje bootstrapowe. Wartości próby bootstrapowej poniżej progu generuje się $\mathrm{z}$ empirycznego rozkładu, zaś wartości powyżej $u \mathrm{z}$ rozkładu uwzględniającego asymptotyczne własności rozkładu ogona (por. M. D. Pandey i in. [2003]). Zatem dystrybuantę rozkładu bootstrapowego można zapisać w następujący sposób:

$$
F_{B}(x \mid u)= \begin{cases}\left(1-F_{n}(u)\right) F_{P}(x)+F_{n}(u), & \text { gdy } x>u, \\ F_{n}(x), & \text { gdy } x \leq u,\end{cases}
$$

gdzie $F_{n}$ oznacza dystrybuantę rozkładu empirycznego, natomiast $F_{P}$ jest dystrybuantą uogólnionego rozkładu Pareto z oszacowanymi parametrami rozkładu uzyskanymi jedną $\mathrm{z}$ metod prezentowanych $\mathrm{w}$ rozdziale drugim.

Rozważmy problem estymacji kwantyla rzędu $p$, gdy $\xi \neq 0$, w oparciu o próbę losową $X_{1}, X_{2}, \ldots, X_{n}$ o dużej liczbie elementów. Ustalona wartość progowa $u$ dzieli próbę na dwie podpróby. Jedna z nich składa się ze statystyk pozycyjnych $X_{(1)}^{(n)}, X_{(2)}^{(n)}, \ldots, X_{(k)}^{(n)}$ takich, że $X_{(i)}^{(n)} \leq u$ dla $i=1,2, \ldots, k$, natomiast druga to statystyki $X_{(k+1)}^{(n)}, X_{(k+2)}^{(n)}, \ldots, X_{(n)}^{(n)}$.

$\mathrm{Z}$ pierwszej próby generujemy $k$ wartości $x_{1}^{B}, \ldots, x_{k}^{B}$ według rozkładu bootstrapowego:

$$
P\left(X^{B}=x_{(i)}^{(n)}\right)=\frac{1}{k} \quad \text { dla } i=1, \ldots, k .
$$

Pozostałych $n-k$ wartości generujemy z rozkładu o dystrybuancie wyrażonej wzorem:

$$
\hat{F}_{B}(x)=\left(1-\frac{k}{n}\right)\left(1-\left(1+\hat{\xi} \frac{x}{\hat{\beta}}\right)^{-\frac{1}{\hat{\xi}}}\right)+\frac{k}{n},
$$

czyli

$$
\hat{F}_{B}(x)=1-\left(1-\frac{k}{n}\right)\left(1+\hat{\xi} \frac{x}{\hat{\beta}}\right)^{-\frac{1}{\xi}}
$$


Otrzymujemy wartości postaci:

$$
x_{i}^{B}=\frac{\hat{\beta}}{\hat{\xi}}\left(\left(\frac{n-n p}{n-k}\right)^{-\hat{\xi}}-1\right) \quad \text { dla } i=n-k, \ldots, n,
$$

gdzie $p$ jest liczbą wygenerowaną z rozkładu jednostajnego $U(0,1)$.

Zastosowanie metod estymacji bootstrapowej związane jest z powtórzeniem $N$ razy procedury losowania próby bootstrapowej. Na podstawie każdej próby wyznacza się kwantyle rozważanego rzędu, otrzymując ciag kwantyli $X_{p ; n}^{B 1}, \ldots, X_{p ; n}^{B N}$, a następnie stosując bootstrapową metodę percentyli, wyznacza się kwantyle odpowiednich rzędów stanowiących krańce przedziału ufności przy ustalonym współczynniku ufności.

Metodą Monte Carlo analizowano dokładności (d) oszacowań kwantyli wybranych rozkładów uzyskanych nieparametryczną oraz semiparametryczną metodą bootstrapowa, powtarzając procedurę estymacji 1000 razy. Dokładnością oszacowania $d$ jest połowa długości przedziału ufności. Ponadto badano prawdopodobieństwo pokrycia rzeczywistego kwantyla dla wybranych rozkładów przez bootstrapowe przedziały ufności. Uzyskane wyniki oszacowań kwantyla rzędu 0,99 przedstawia tablica 5.5.1. Wartość progową $u$ ustalono na poziomie kwantyla rzędu 0,9 , a współczynnik ufności 0,95.

Tablica 5.5.1. Dokładności i wiarygodności oszacowań kwantyla rzędu 0,99 przy zastosowaniu nieparametrycznej i semiparametrycznej metody bootstrapowej

\begin{tabular}{|c|c|c|c|c|c|}
\hline \multirow{2}{*}{ Rozkład } & Rząd & \multicolumn{2}{|c|}{ Metoda nieparametryczna } & \multicolumn{2}{c|}{ Metoda semiparametryczna } \\
\cline { 3 - 6 } & $u$ & $d$ & ufność & $d$ & ufność \\
\hline \multirow{2}{*}{$S(4)$} & 0,90 & 2,302 & 0,928 & 2,033 & 0,943 \\
\cline { 2 - 6 } & 0,95 & 2,177 & 0,927 & 1,887 & 0,923 \\
\hline \multirow{2}{*}{$S(2)$} & 0,90 & 0,704 & 0,922 & 0,659 & 0,957 \\
\cline { 2 - 6 } & 0,95 & 0,710 & 0,939 & 0,617 & 0,942 \\
\hline \multirow{2}{*}{$C a(0,1)$} & 0,90 & 22,486 & 0,931 & 13,930 & 0,880 \\
\cline { 2 - 6 } & 0,95 & 23,267 & 0,933 & 14,890 & 0,891 \\
\hline \multirow{2}{*}{$P a(1,4)$} & 0,90 & 0,479 & 0,926 & 0,442 & 0,951 \\
\cline { 2 - 6 } & 0,95 & 0,486 & 0,913 & 0,412 & 0,927 \\
\hline \multirow{3}{*}{$P a(1,2)$} & 0,90 & 3,251 & 0,914 & 2,758 & 0,937 \\
\cline { 2 - 6 } & 0,95 & 3,173 & 0,937 & 2,559 & 0,927 \\
\hline \multirow{2}{*}{$L G(2,0,2,0)$} & 0,90 & 0,536 & 0,920 & 0,489 & 0,951 \\
\cline { 2 - 6 } & 0,95 & 0,538 & 0,925 & 0,460 & 0,939 \\
\hline$L G(2,0,6,0)$ & 0,90 & 23,890 & 0,917 & 19,151 & 0,919 \\
\cline { 2 - 6 } & 0,95 & 24,459 & 0,917 & 18,239 & 0,903 \\
\hline
\end{tabular}

Źródło: opracowanie własne. 
Dokładności oszacowań są większe ( $d$ - mniejsze), przy zastosowaniu semiparametrycznej metody bootstrapowej. Dla kwantyla rzędu 0,99 odsetek przedziałów zawierających szacowany kwantyl jest bliski ustalonej wiarygodności, czyli 0,95 . W przypadku zastosowania nieparametrycznej metody bootstrapowej odsetek ten jest zwykle nieznacznie niższy. Dokładności oszacowań wynikają z różnych wartości szacowanych oraz zależą od grubości ogona rozkładu. Dla rozkładów o grubszych ogonach, mniejszym indeksie $\xi$, uzyskuje się dokładniejsze oszacowania.

Semiparametryczna bootstrapowa metoda estymacji przedziałowej pozwala wyznaczyć przedziały ufności dla kwantyli rozważanych rozkładów z dokładnością większą niż nieparametryczna metoda estymacji.

Bootstrapową metodę estymacji można wykorzystać do szacowania wariancji estymatorów kwantyli wysokich rzędów. Mając próbę $X_{1}, X_{2}, \ldots, X_{n}$, wyznacza się kwantyl $X_{p ; n}$ rzędu $p$ z wzoru (5.4.17) przy oszacowanych parametrach $\xi, \beta$, a następnie generuje się $N$ prób bootstrapowych, wykorzystując wzory (5.5.2) i (5.5.3). Na podstawie każdej próby bootstrapowej wyznacza się $X_{p ; n, i}^{B}$ dla $i=1,2, \ldots, N$ i szacuje wariancję ze wzoru:

$$
D^{2}\left(X_{p ; n}\right)=\frac{1}{N} \sum_{i=1}^{N}\left(X_{p ; n}-X_{p ; n, i}^{B}\right)^{2} .
$$

\subsection{Zastosowanie statystyk ekstremalnych $\mathrm{w}$ wybranych procedurach estymacji}

\subsubsection{Szacowanie ryzyka ekstremalnego}

W rozdziale czwartym przedstawione zostały miary ryzyka tzw. zwykłego, wyznaczane w oparciu o kwantyl rozkładu straty lub kwantyl rozkładu logarytmicznej stopy zwrotu. Oprócz tego typu ryzyka wyróżnia się ryzyko ekstremalne związane ze zdarzeniami ekstremalnymi, mającymi charakter katastrof, dla których prawdopodobieństwo wystąpienia jest bardzo małe, ale straty są bardzo duże.

Zarządzanie ryzykiem ekstremalnym wymaga stosowania odrębnych miar wywodzących się z teorii wartości ekstremalnych. Przy wyznaczaniu miar ryzyka tego typu można wyróżnić podejście parametryczne i nieparametryczne. 
Znajomość rozkładu statystyki maksimum lub minimum pozwala, w oparciu o twierdzenia przedstawione w podrozdziale 1.4, wyznaczyć dystrybuantę rozkładu granicznego, którym jest rozkład Gumbela, Frécheta lub Weibulla (o ile istnieje), a następnie wartość dystrybuanty dla określonego prawdopodobieństwa wystąpienia zdarzenia ekstremalnego. Taka sytuacja rzadko się zdarza, ale znajomość chociażby klasy rozkładu umożliwia oszacowanie jego parametrów metodą największej wiarygodności, momentów lub metodami opartymi na kwantylach $\mathrm{z}$ próby przedstawionymi $\mathrm{w}$ rozdziale drugim i skorzystanie $z$ odpowiednich twierdzeń o rozkładzie odpowiedniej statystyki ekstremalnej.

Nieparametryczne podejście związane jest z szacowaniem parametrów rozkładu statystyki ekstremalnej na podstawie próby losowej składającej się $\mathrm{z}$ ciagu wartości statystyk maksymalnych lub minimalnych otrzymanych zwykle metodą blokową. W przypadku szacowania ekstremalnej straty $X_{t}=W_{t+1}-W_{t}$, gdzie $W_{t}, W_{t+1}$ oznaczają np. cenę rozważanego instrumentu czy też wartość inwestycji, odpowiednio, w chwili $t$ oraz $t+1$, estymuje się rozkład minimum za pomocą próby $Z_{i}^{m}=X_{(1) i}^{(n)}=\min \left\{X_{1, i}, X_{2, i}, \ldots, X_{n, i}\right\}$, dla $i=1, \ldots, k$, jeśli zaś rozważa się zmienne $Y_{t}=-X_{t}$, to na podstawie próby $Z_{i}^{M}=(-X)_{(n) i}^{(n)}=$ $=\max \left\{-X_{1, i},-X_{2, i}, \ldots,-X_{n, i}\right\}$, dla $i=1, \ldots k$, szacuje się rozkład maksimum.

Ekstremalna wartość narażona na ryzyko ma postać:

$$
\operatorname{VaR}_{p}^{m}=\left(F_{\mu, \sigma, \xi}^{m}\right)^{-1}(p)
$$

lub

$$
\operatorname{VaR}_{p}^{M}=\left(F_{\mu, \sigma, \xi}^{M}\right)^{-1}(1-p)
$$

gdzie $\left(F_{\mu, \sigma, \xi}^{m}\right)^{-1},\left(F_{\mu, \sigma, \xi}^{M}\right)^{-1}$ są funkcjami odwrotnymi do dystrybuant, odpowiednio, uogólnionego rozkładu minimum i uogólnionego rozkładu maksimum.

Ze względu na związek między statystykami ekstremalnymi i ich rozkładami (por. wzór (1.4.8)) dalsze rozważania dotyczyć będą maksimum z próby. Istotne jest tylko rozstrzygnięcie, czy uogólniony rozkład maksimum z próby jest typu Gumbela, czy też nie, co można zweryfikować testem zgodności lub testem dla indeksu ekstremalnego (por. C. Neves, M. I. Fraga Alves [2008]).Wtedy estymatory ekstremalnej wartości zagrożonej można zapisać wzorami:

$$
\hat{V} a R_{p}^{M}=\hat{\mu}+\hat{\sigma}\left(-1+(-\ln (1-p))^{-\hat{\xi}}\right) / \hat{\xi},
$$


lub

$$
\hat{V} a R_{p}^{M}=\hat{\mu}+\hat{\sigma} \ln (-\ln (1-p))
$$

w zależności od klasy rozkładu statystyki maksymalnej.

Dla rozkładów Frécheta i Weibulla charakteryzujących rozkłady statystyk maksymalnych strat utożsamianych ze zmiennymi losowymi o grubych i krótkich ogonach estymator określony jest wzorem (5.6.3), natomiast dla rozkładu maksimum typu Gumbela, odpowiadającego stratom, utożsamianym ze zmiennymi losowymi o rozkładach z cienkimi ogonami wzorem (5.6.4).

Wadą szacowania wartości narażonej na ryzyko w oparciu o kwantyle rozkładów statystyk ekstremalnych jest to, że uwzględnia ono tylko jedną wartość maksymalną bądź minimalną $\mathrm{w}$ jednym z $m$ rozważanych okresów, nie bierze pod uwagę faktu, że wartości takich może być kilka.

Kolejny sposób szacowania ekstremalnej wartości zagrożonej uwzględnia istnienie kilku wartości bardzo dużych, czy też bardzo małych, poprzez oszacowanie ogona rozkładu wielkości strat, czyli rozkładu zmiennej losowej o wartościach powyżej pewnego progu.

Dla zmiennych określających wielkość strat bądź wartość logarytmicznej stopy zwrotu można wykorzystać modele wartości ponadprogowych (POT) przedstawione w podrozdziale 5.4.

Wartość zagrożoną $\operatorname{VaR}_{p}^{P O T}$ dla zmiennej $X_{t}$ definiuje się jako kwantyl rzędu $1-p$ ogona rozkładu zmiennej $\left(-X_{t}\right)$, czyli

$$
\operatorname{VaR}_{p}^{P O T}=F^{-1}(1-p)
$$

gdzie $F$ jest dystrybuantą zmiennej $\left(-X_{t}\right)$ o wartościach przekraczających pewien ustalony próg. Oszacowaniem $F$ jest dystrybuanta $\hat{F}$ określona wzorem (5.4.14).

Estymator wartości zagrożonej wyznaczony w oparciu rozkład strat ponadprogowych ma postać:

$$
\hat{V} a R_{p}^{P O T}=u+\frac{\hat{\beta}}{\hat{\xi}}\left(\left(\frac{n}{n_{u}} p\right)^{-\hat{\xi}}-1\right) \quad \text { dla } \hat{\xi} \neq 0
$$

lub

$$
\hat{V} a R_{p}^{P O T}=u+\hat{\beta} \ln \left(\frac{n}{n_{u}} p\right) \quad \text { dla } \hat{\xi}=0,
$$


gdzie $u$ jest ustaloną wartością progową, $n_{u}$ to liczba elementów spośród $n$-elementowej próby przekraczających próg $u$, zaś $\hat{\beta}, \hat{\xi}$ są oszacowaniami parametrów uogólnionego rozkładu Pareto uzyskanymi np. metodą momentów ważonych prawdopodobieństwami $\mathrm{z}$ dystrybuantą empiryczną typu level crossing.

Próg $u$ ustala się zwykle na poziomie kwantyla rozkładu zmiennej $X$ rzędu nie mniejszego niż 0,9 , co w praktyce oznacza, że z próby 1000 -elementowej do szacowania wartości zagrożonej otrzymamy próbę składająca się $\mathrm{z}$ około 100 elementów przekraczających próg, czyli przy zastosowaniu tej metody niezbędne jest posiadanie bardzo dużych prób.

Analizę ryzyka ekstremalnego można przeprowadzać w ujęciu wielowymiarowym. Przykładem może być podmiot zaangażowany w transakcje na rynku walutowym w kilku walutach, który zainteresowany jest określeniem maksymalnych możliwych strat. Oszacowania maksymalnej straty można dokonać na podstawie oszacowanego rozkładu należącego do uogólnionych rozkładów wielowymiarowych statystyk ekstremalnych (por. wzór (1.4.29)).

W podejściu wielowymiarowym bada się zależność wystapienia wartości ekstremalnej jednej ze zmiennych ryzyka od wystapienia wartości ekstremalnej dla innych zmiennych ryzyka. Dla przypadku dwuwymiarowego $\left(X_{1}, X_{2}\right)$ zaproponowane zostały tzw. współczynniki zależności w ogonie, w szczególności współczynnik zależności w górnym ogonie (por. K. Jajuga [2007, s. 62-63]) określony wzorem:

$$
\lambda_{u}=\lim _{u \rightarrow 1} P\left(X_{2}>F_{2}^{-1}(u) \mid X_{1}>F_{1}^{-1}(u)\right.
$$

gdzie $F_{1}, F_{2}$ są dystrybuantami zmiennych losowych, odpowiednio, $X_{1}, X_{2}$.

Współczynnik ten określa graniczne prawdopodobieństwo, iż strata na jednej zmiennej ryzyka przekroczy pewną wysoką wartość (wysoki kwantyl), pod warunkiem że strata na drugiej zmiennej ryzyka przekroczy wysoką wartość (wysoki kwantyl).

Współczynnik zależności $\lambda_{u}$ jest liczbą z przedziału $[0,1]$. Im bliższy jest on 1, tym silniejsza jest zależność w ogonie, a silna zależność w tym samym kierunku oznacza większe ryzyko.

Funkcję połączenia wykorzystuje się do przedstawienia współczynnika zależności w górnym ogonie w następujący sposób: 


$$
\lambda_{u}=\lim _{u \rightarrow 1} \frac{1-2 u+C(u, u)}{1-u}
$$

co upraszcza analizę ryzyka ekstremalnego w przypadku dwuwymiarowym.

Istnieje wiele funkcji połączenia $C$, w szczególności połączenie gaussowskie i przedstawione w podrozdziale 1.4.

\subsubsection{Konstrukcja kart kontrolnych w oparciu o statystyki ekstremalne}

Kolejnym przykładem zastosowania statystyk ekstremalnych i ich funkcji jest statystyczna kontrola jakości. Statystyki maksimum i minimum wykorzystuje się do konstrukcji m.in. karty kontrolnej $R$ oraz karty $X_{\max }-X_{\min }$, $M e-R$ (por. G. Kończak, [2007, s. 70, 90-91]).

Kartę $R$ stosuje się, gdy proces produkcyjny charakteryzuje się dużą zmiennością, tzn. że parametry wyrobów mają szerszy niż dopuszczalny zakres. Własności rozstępu przedstawione w podrozdziale 1.2 mogą być wykorzystane przy tworzeniu kart kontrolnych.

Linia centralna karty kontrolnej $R$ określona jest na podstawie $k$ prób następującym równaniem:

$$
L C_{R}=\bar{R}=\frac{\sum_{i=1}^{k} R_{i}}{k},
$$

gdzie $R_{i}=X_{(n), i}^{(n)}-X_{(1), i}^{(n)}$, dla $i=1,2, \ldots, k$, jest rozstępem wyznaczanym na podstawie $n$-elementowych prób $X_{1, i}, X_{2, i}, \ldots X_{n, i}$.

Granice kontrolne dolna i górna określone są następująco:

$$
\begin{gathered}
D L K_{R}=\max \left(0, \bar{R}-3 \frac{d_{3}(n) \bar{R}}{d_{2}(n)}\right), \\
G L K_{R}=\bar{R}+3 \frac{d_{3}(n) \bar{R}}{d_{2}(n)},
\end{gathered}
$$

przy czym wartości współczynników dla wybranych liczebności prób zamieszczone są w tablicy 5.6.1. 
Tablica 5.6.1. Współczynniki $a_{2}(n), d_{2}(n), d_{3}(n)$ dla wybranych liczebności prób

\begin{tabular}{|c|c|c|c|c|c|c|c|c|c|c|}
\hline$n$ & 3 & 4 & 5 & 6 & 7 & 8 & 9 & 10 & 15 & 20 \\
\hline$a_{2}(n)$ & 1,023 & 0,729 & 0,577 & 0,483 & 0,419 & 0,373 & 0,337 & 0,308 & 0,223 & 0,180 \\
\hline$d_{2}(n)$ & 4,358 & 4,698 & 4,918 & 5,078 & 5,204 & 5,306 & 5,393 & 5,469 & 5,571 & 5,921 \\
\hline$d_{3}(n)$ & 0,000 & 0,000 & 0,000 & 0,000 & 0,076 & 0,136 & 0,184 & 0,223 & 0,347 & 0,415 \\
\hline
\end{tabular}

Źródło:www.zarz.agh.edu.pl/bsolins/karty_kontrolne.html.

Inną kartą kontrolną jest karta $X_{\max }-X_{\min }$ rejestrująca największą i najmniejszą wartość cechy w próbie, dla której centralna linia kontrolna określona jest poprzez wartość midrange średnich statystyk pozycyjnych (por. wzór (1.2.6)), czyli równaniem:

$$
L C_{m, M}=\frac{\bar{X}_{(n)}^{(n)}+\bar{X}_{(1)}^{(n)}}{2}=M_{r},
$$

gdzie $\quad \bar{X}_{(n)}^{(n)}=\frac{1}{k} \sum_{i=1}^{k} X_{(n) i}^{(n)}, \quad \bar{X}_{(1)}^{(n)}=\frac{1}{k} \sum_{i=1}^{k} X_{(1) i}^{(n)} \quad$ oraz $k$ jest liczbą $n$-elementowych prób, na podstawie których wyznaczane są wartości statystyk ekstremalnych $X_{(n) i}^{(n)}, X_{(1) i}^{(n)}$, dla $i=1, \ldots, k$.

Linie kontrolne dolna i górna określone są następująco:

$$
\begin{aligned}
& D L K_{m, M}=M_{r}-\frac{3 \bar{R}_{m, M}}{d_{2}(n) \sqrt{n}}, \\
& G L K_{m, M}=M_{r}+\frac{3 \bar{R}_{m, M}}{d_{2}(n) \sqrt{n}},
\end{aligned}
$$

gdzie $\bar{R}_{m, M}=\bar{X}_{(n)}^{(n)}-\bar{X}_{(1)}^{(n)}$, zaś $d_{2}(n)$ jest wartością odczytaną z tablic.

Obserwując położenia wartości maksymalnych i minimalnych, wnioskujemy o przebiegu procesu produkcyjnego. Jeśli punkty układają się równomiernie po obu stronach linii centralnej, pomiędzy linią górną i dolną, wnioskujemy o prawidłowym przebiegu produkcji. Jeżeli występują przekroczenia linii górnej, świadczy to o wzroście wartości badanej cechy, jeśli dolnej - o jej spadku, natomiast jednoczesne przekraczanie obu granic świadczy o wzroście rozrzutu.

Medianę i rozstęp wykorzystuje się również do kontroli procesu produkcyjnego poprzez kartę kontrolną $M e-R$, której linia centralna jest postaci: 


$$
L C_{M e-R}=\overline{M e}
$$

gdzie $\overline{M e}=\frac{1}{k} \sum_{i}^{k} M e_{i}, M e_{i}$ jest medianą wyznaczoną na podstawie $i$-tej próby.

Granice kontrolne dolna i górna określone są następująco:

$$
\begin{aligned}
& D L K_{M e-R}=\bar{M} e-a_{2}(n) \bar{R}, \\
& G L K_{M e-R}=\bar{M} e+a_{2}(n) \bar{R},
\end{aligned}
$$

gdzie $\bar{R}=\frac{\sum_{i=1}^{k} R_{i}}{k}$, zaś wartości $a_{2}(n)$ dla wybranych liczebności prób zawarte są w tablicy 5.6.1.

Znajomość rozkładu zmiennej losowej, z którą utożsamiana jest badana cecha, może być wykorzystana do modyfikacji rozważanych kart kontrolnych $R$ oraz $M e-R$, gdyż można oszacować charakterystyki funkcyjne rozstępu i mediany (twierdzenia $1.3 .8,1.3 .17$ ) i wykorzystać kwantyle odpowiednich rzędów do określenia granicy dolnej i górnej karty kontrolnej.

W monitorowaniu procesu nie tylko interesująca może być obserwacja poziomu przeciętnego badanej charakterystyki, czy też jej zróżnicowania, ale również ocena maksymalnej lub minimalnej jej wielkości. Do konstrukcji kart kontrolnych pozwalających wykryć przesunięcie wartości ekstremalnych procesu służą twierdzenia prezentowane w podrozdziale 1.4. G. Kończak [2013] rozważa zmienne losowe o rozkładach takich, że statystyka maksimum ma rozkład Gumbela (por. podrozdział 1.4). Oszacowanie parametrów rozkładu Gumbela dokonuje się na podstawie próby $k$-elementowej złożonej z wartości maksymalnych $X_{(n)}^{(n)}$ wyznaczanych na podstawie prób $n$-elementowych.

Linia centralna dla tej karty określona jest równaniem:

$$
L C_{E x V}=\hat{\lambda}+0,3665 \hat{\delta}
$$

gdzie $\hat{\lambda}, \hat{\delta}$ są wartościami estymatorów rozkładu Gumbela.

Linie kontrolne dolna i górna tworzą kwantyle rozkładu Gumbela odpowiednich rzędów, np. linię centralną - kwantyl rzędu 0,5, dolną - kwantyl rzędu 0,05 , natomiast górną - kwantyl rzędu 0,95. 
W przypadku analizy procesów, w których zmienna losowa charakteryzuje się rozkładami o grubych ogonach, przy konstrukcji kart kontrolnych należy wziąć pod uwagę medianę i kwantyle rozkładu Frécheta, będącego granicznym rozkładem maksimum (por. podrozdział 1.5 ). W tym przypadku linie karty kontrolnej określa się następująco:

$$
\begin{gathered}
L C_{E x V}=\hat{\lambda}+\frac{\hat{\delta}}{\hat{\gamma} \sqrt{0,693}}, \\
D L K_{E x V}=\hat{\lambda}+\hat{\delta}(-\ln p)^{-\frac{1}{\gamma}}, \\
G L K_{E x V}=\hat{\lambda}+\hat{\delta}(-\ln (1-p))^{-\frac{1}{\hat{\gamma}}},
\end{gathered}
$$

gdzie $\hat{\lambda}, \hat{\delta}$, i $\hat{\gamma}$ są oszacowanymi wartościami uogólnionego rozkładu maksimum z próby (por. tablica 1.4.1), zaś $p$ określa rząd kwantyla rozkładu Frécheta stanowiący dolną granicę karty.

\subsection{Uwagi końcowe}

W rozdziale szczególną uwagę poświęcono problemom estymacji indeksu ekstremalnego będącego parametrem kształtu rozkładu statystyki maksymalnej i jednocześnie parametrem uogólnionego rozkładu Pareto, który jest granicznym rozkładem wartości przekraczających pewien ustalony próg. Rozważano zarówno parametryczne, jak i semiparametryczne metody szacowania jego wartości, a wśród nich autorską propozycję - metodę momentów ważonych prawdopodobieństwami ze zmodyfikowaną dystrybuantą.

Ze względu na zastosowania kwantyli do wyznaczania ekstremalnej wartości narażonej rozważano metody estymacji kwantyli rozkładu zmiennej losowej wysokich rzędów. Na uwagę zasługuje semiparametryczna metoda bootstrapowa wykorzystująca oszacowanie rozkładu ogona zmiennej losowej. Jej zastosowanie prowadziło do otrzymania przedziałów ufności o mniejszej rozpiętości niż w przypadku zastosowania nieparametrycznej metody bootstrapowej, pokrywających szacowany kwantyl z prawdopodobieństwem równym ustalonemu współczynnikowi ufności.

Ponadto przedstawiono przykłady wykorzystywania statystyk ekstremalnych i ich funkcji do określania miar ryzyka ekstremalnego i tworzenia kart kontrolnych wraz ze wskazaniem możliwości ich modyfikacji w oparciu o wcześniej przeprowadzone analizy. 


\section{WYBRANE EMPIRYCZNE ZASTOSOWANIA STATYSTYK POZYCYJNYCH W BADANIACH EKONOMICZNYCH}

\subsection{Uwagi wstępne}

Statystyki pozycyjne są wykorzystywane do estymacji parametrów rozkładu zmiennych losowych, z którymi utożsamia się rozważane cechy ekonomiczne, społeczne czy też przyrodnicze, oraz do szacowania miar definiowanych w oparciu o kwantyle rozkładu tych zmiennych. Przykłady obydwu rodzajów zastosowań zaprezentowane zostaną w niniejszym rozdziale, z uwzględnieniem własnych propozycji przedstawionych w metodologicznej części pracy.

Do prezentacji przykładów empirycznych zastosowań statystyk pozycyjnych wybrano następujące obszary badań: analizy dochodów i wydatków ludności, analizy ryzyka na rynku finansowym i ubezpieczeniowym oraz tworzenie kart kontrolnych w statystycznej kontroli jakości.

Badanie poziomu i jakości życia ludności związane jest $\mathrm{z}$ analizą rozkładu ich dochodów, wydatków, badaniem nierównomierności dochodów i analizą miar ubóstwa oraz bogactwa. Na podstawie danych pochodzących z Badania Budżetów Gospodarstw Domowych z IV kwartału 2008 r. szacowano rozkłady dochodów oraz medianę rozkładu dochodów wykorzystywaną do określania różnego rodzaju miar stosowanych $\mathrm{w}$ badaniach ubóstwa i bogactwa gospodarstw domowych.

Rozwój statystycznych metod oceny ryzyka rynkowego, w szczególności metod bazujących na koncepcji pomiaru zagrożenia, sprawia, że w empirycznych przykładach nie można pominąć problemu estymacji tego typu miar. W oparciu o kwantyle odpowiednich rzędów definiuje się miary ryzyka rynkowego, takie jak: VaR - wartość narażoną na ryzyko i Expected Shortfall oraz modyfikacje $V a R$, typu $E a R$ - zysk narażony na ryzyko, $C F a R$ - przepływy pieniężne narażone na ryzyko, wykorzystywane w analizach ryzyka w przedsiębiorstwie.

Na podstawie danych rzeczywistych dotyczących stóp zwrotu indeksów giełdowych oraz akcji notowanych na giełdach papierów wartościowych szacowano miary wartości narażonej na ryzyko, zwykłe i ekstremalne. 
Zastosowanie bootstrapowej metody estymacji przedstawiono na przykładzie estymacji współczynnika bezpieczeństwa wykorzystywanego przy ustalaniu wysokości indywidualnych składek ubezpieczeniowych przez towarzystwa ubezpieczeniowe, na takim poziomie, aby prawdopodobieństwo poniesienia straty na danym portfelu w kolejnym okresie nie przekroczyło ustalonej wartości. Tego typu podejście sprawia, że współczynnik bezpieczeństwa jest kwantylem ustalonego rzędu rozkładu sumy roszczeń dla całego portfela.

Przedstawiono również zastosowanie statystyk pozycyjnych w konstrukcji odpornych kart kontrolnych.

Zaprezentowane praktyczne zastosowania statystyk pozycyjnych w przedstawionych procedurach estymacji uwzględniają autorskie propozycje metod rozważanych w poprzednich rozdziałach pracy.

\subsection{Zastosowanie statystyk pozycyjnych $w$ analizach dochodów i wydatków ludności}

W badaniach poziomu i jakości życia ludności mogą znaleźć zastosowanie metody estymacji oparte na statystykach pozycyjnych, w szczególności procedury estymacji proponowane $\mathrm{w}$ drugim rozdziale oraz estymatory parametrów pozycyjnych prezentowane w czwartym rozdziale monografii.

$\mathrm{W}$ analizach dochodów korzysta się z różnorodnych wariantów dochodu gospodarstwa domowego, m.in. rozważa się dochód brutto będący sumą wszystkich przychodów pieniężnych oraz dochód rozporządzalny, czyli dochód po odliczeniu podatku i powiększeniu o wszystkie dodatki. W Polsce w badaniach dochodów korzysta się z dochodu miesięcznego, w niektórych krajach analizuje się dochód roczny, który dla niektórych grup społeczno-zawodowych, np. gospodarstw rolnych, lepiej odzwierciedla strumień zasobów (por. S. Kot [2000, s. 105-106]).

Dochody utożsamiane są ze zmiennymi losowymi przyjmującymi wartości dodatnie, o jednomodalnym rozkładzie i dodatniej asymetrii. Empiryczne rozkłady dochodów aproksymuje się najczęściej rozkładem log-normalnym, Burra typu III, zwanym również Daguma, i Burra typu XII, nazywanym SinghaMaddali. Ograniczając rozważania do pewnych grup, otrzymujemy przybliżenia rozkładów empirycznych do innych rozkładów teoretycznych, np. rozkłady dochodów osób bogatych, czyli osób o dochodach ekwiwalentnych przekraczających ustaloną granicę bogactwa charakteryzują się rozkładem Pareto. Metody szacowania parametrów rozkładów dochodów wraz z przykładami zastosowań przedstawione są m.in. w pracy C. Domańskiego [2005, s. 16-48]. Do metod tych można dołączyć procedury oparte na kwantylach z próby przedstawione w rozdziałach drugim i trzecim. 
Rozważane metody momentów ważonych prawdopodobieństwami, w szczególności proponowana modyfikacja wykorzystująca dystrybuantę empiryczną level crossing, zastosowane zostaną do szacowania parametrów rozkładu zmiennej losowej określającej wysokość dochodów osób najbogatszych, tzn. o dochodach przekraczających granicę bogactwa zdefiniowaną jako trzy wartości mediany (por. podrozdział 4.7.1).

Analizę dochodów i wydatków w Polsce przeprowadzono na podstawie próby losowej pochodzącej z badania budżetów gospodarstw domowych, które odbyło się w IV kwartale 2008 r. W oparciu o dane dotyczące 9305 gospodarstw wyznaczono miesięczne dochody i wydatki ekwiwalentne. Stosowano stochastyczną skalę ekwiwalentności uwzględniającą liczbę osób w gospodarstwie domowym postaci:

$$
X=\frac{X_{m}}{m^{\varepsilon}},
$$

gdzie $X_{m}$ oznacza dochód gospodarstwa domowego składającego się z $m$ osób, zaś $\varepsilon$ jest ustaloną liczbą z przedziału $[0,1]$. W analogiczny sposób wyznaczano wydatki ekwiwalentne.

Z analiz przedstawionych w pracy S. Kota [2008, s. 75-77] dotyczących wydatków gospodarstw domowych w 2000 r. wynika, że przy wykorzystaniu potęgowej skali ekwiwalentności z wartością $\varepsilon=0,58139$ rozkłady zmiennych losowych opisujących wydatki $\mathrm{w} m$-osobowych gospodarstwach domowych były bardzo zbliżone do rozkładu wydatków w jednoosobowych gospodarstwach, stanowiących punkt odniesienia. Dlatego również w badaniach dotyczących roku 2008 wykorzystano $\varepsilon=0,58139$, analizując zarówno wydatki, jak i ściśle z nimi związane dochody gospodarstw domowych.

Na podstawie wartości dochodów ekwiwalentnych oszacowano granicę bogactwa, wykorzystując dwa estymatory mediany: standardowy i Bersteina.

Ze względu na bardzo dużą liczebność próby praktycznie nie ma różnic między wartościami rozważanych estymatorów (por. tablica 6.2.1).

Tablica 6.2.1. Wartości estymatorów mediany i granicy ubóstwa

\begin{tabular}{|l|l|c|}
\hline \multicolumn{1}{|c|}{ Estymator mediany } & $M e^{\text {stand. }}$ & $M e^{\text {Brs }}$ \\
\hline Wartość estymatora mediany (w zł.) & 1513,68 & 1513,44 \\
\hline Granica bogactwa (w zł.) & 4541,04 & 4540,32 \\
\hline
\end{tabular}

Źródło: obliczenia własne na podstawie danych GUS. 
Okazało się, że 245 gospodarstw domowych spośród 9305 charakteryzowało się dochodami ekwiwalentnymi wyższymi niż wartość granicy bogactwa. Histogramy rozkładów dochodów ekwiwalentnych $(X)$ i wydatków ekwiwalentnych $(Y)$ gospodarstw domowych osiagających dochody wyższe niż granica bogactwa otrzymane na podstawie tej próby przedstawiają rysunki 6.2.1 - 6.2.2.

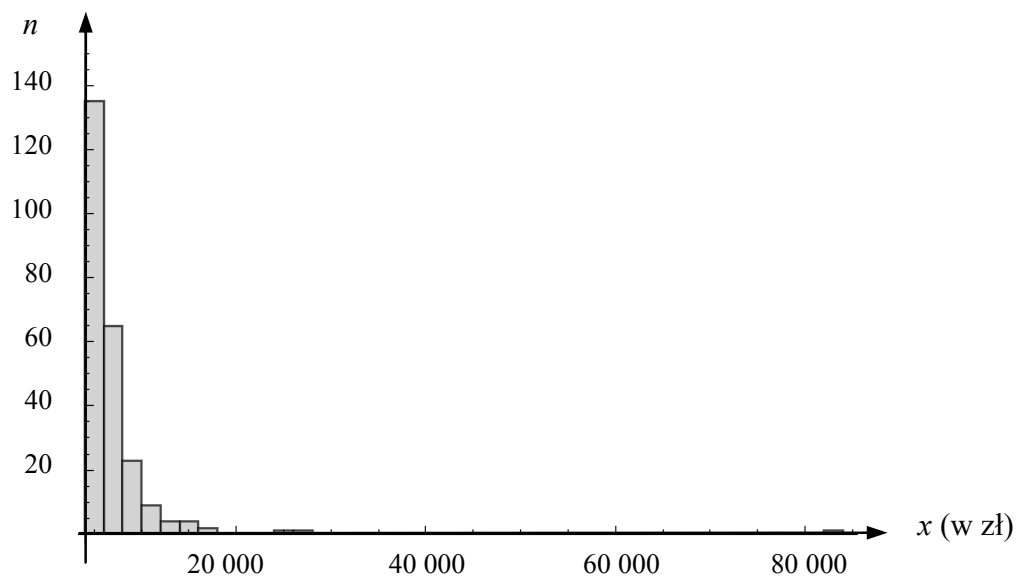

Rysunek 6.2.1. Histogram rozkładu dochodów ekwiwalentnych gospodarstw o dochodach wyższych niż linia bogactwa Źródło: opracowanie własne na podstawie danych GUS

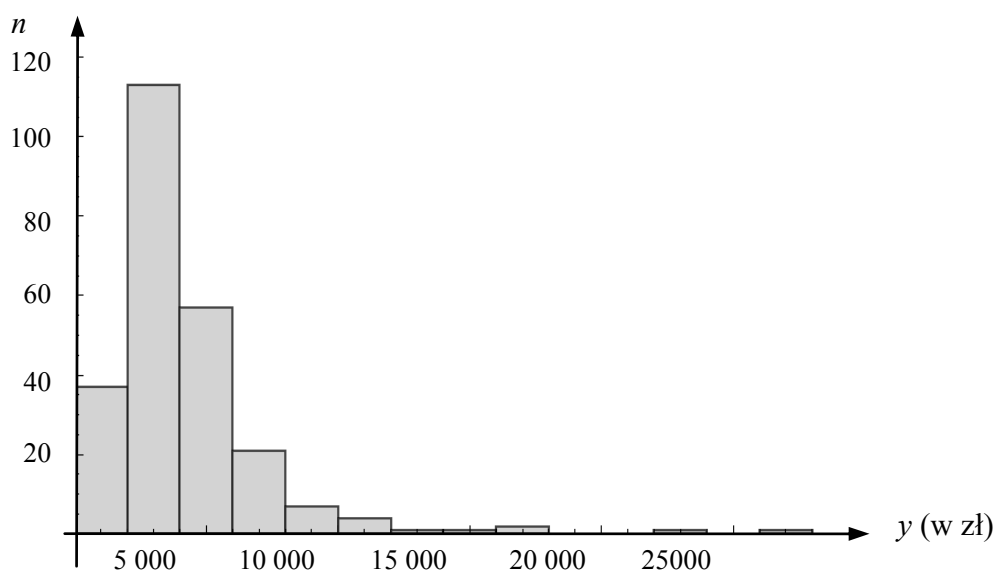

Rysunek 6.2.2. Histogram rozkładu wydatków ekwiwalentnych gospodarstw o dochodach wyższych niż linia bogactwa Źródło: opracowanie własne na podstawie danych GUS 
Rozkład dochodów ekwiwalentnych gospodarstw domowych okazał się rozkładem Pareto, w przeciwieństwie do rozkładu wydatków dla tej grupy gospodarstw. Parametry rozkładu Pareto opisującego rozkład zmiennej $X$ szacowano, stosując metodę momentów ważonych prawdopodobieństwami z klasyczną dystrybuantą empiryczną $(m M W P)$ oraz zmodyfikowaną metodę momentów ważonych prawdopodobieństwami z dystrybuantą empiryczną level crossing $(z m M W P)$.

W wyniku zastosowania metody $m M W P$ z klasyczną dystrybuantą empiryczną otrzymano następujące oszacowania parametrów $\theta$ i $a$ funkcji gęstości rozkładu Pareto (wzory (2.5.17), (2.5.18)):

$$
\hat{\theta}=4498,06 \text { zł., } \quad \hat{a}=2,8151 \mathrm{zl},
$$

natomiast $\mathrm{w}$ przypadku zmodyfikowanej metody $z m M W P$ (wzory (2.6.9), (2.6.10)):

$$
\hat{\theta}=4464,66 \mathrm{zl}, \quad \hat{a}=2,7776 \mathrm{zł} .
$$

Z przeprowadzonych analiz symulacyjnych, których przykładowe rezultaty dla wybranych rozkładów zaprezentowano w trzecim rozdziale pracy, wynika, że estymatory zmMWP charakteryzują się mniejszym błędem średniokwadratowym. Zasadne wydaje się zatem przyjęcie, iż rozkład dochodów ekwiwalentnych gospodarstw bogatych w Polsce charakteryzuje się rozkładem Pareto o dystrybuancie:

$$
F(x)=\left\{\begin{array}{lll}
0 & \text { dla } & x \leq 4464,66 \\
1-\left(\frac{4464,66}{x}\right)^{2,7776} & \text { dla } & x>4464,66
\end{array}\right.
$$

Dodatkowo z twierdzenia 1.4.9 wynika, że granicznym rozkładem standaryzowanej statystyki maksimum dochodów ekwiwalentnych osób bogatych jest rozkład Frécheta o dystrybuancie $H_{2, a}$. Oszacowany indeks ekstremalny $\hat{\xi}=\frac{1}{2,7776}=0,36$ może być wykorzystany do dalszych analiz związanych z estymacją ogona rozkładu dochodów osób bogatych.

Miesięczne wydatki ekwiwalentne gospodarstw domowych o dochodach przekraczających granicę bogactwa charakteryzuje rozkład jednomodalny, asymetryczny, dlatego szacowano najczęściej występującą wielkość wydatków 
w tej grupie. Ze względu na asymetrię rozkładu wykorzystano estymator dominanty określony wzorem (4.6.11), otrzymując wartość równą:

$$
\text { Do }=2934,959 \text { zl, }
$$

co oznacza, że najczęściej pojawiającymi się miesięcznymi wydatkami ekwiwalentnymi w grupie osób bogatych w IV kwartale 2008 r. w Polsce były wydatki na poziomie $2934,959 \mathrm{zł}$.

W badaniach dochodów ludności na podstawie mediany z próby szacuje się nie tylko miary bogactwa, ale również miary ubóstwa przedstawione w podrozdziale 4.7.1. Miary te zastosowane zostaną do analizy dochodów gospodarstw domowych ludności w Polsce w IV kwartale 2008 r, m.in. pod kątem natężenia i głębokości ubóstwa.

$\mathrm{Na}$ podstawie dochodów ekwiwalentnych oszacowano granicę ubóstwa za pomoca standardowego estymatora mediany i proponowanego estymatora Bersteina, otrzymując:

$$
\hat{G}_{u}^{s \operatorname{tand} .}=908,21 \mathrm{zł}, \quad \hat{G}_{u}^{B r s}=908,06 \mathrm{zł} .
$$

Wyznaczona linia ubóstwa pozwala oszacować wskaźnik zagrożenia ubóstwem. Za zagrożone ubóstwem uważa się osoby, których dochody są niższe niż ustalona granica ubóstwa. W IV kwartale 2008 r. okazało się, że poniżej linii ubóstwa znalazło się 1405 gospodarstw, spośród 9305 przebadanych, czyli otrzymano estymator wskaźnika zagrożenia ubóstwem (wzór (4.7.4)) o wartości:

$$
\hat{W}_{z g . u b .}=0,15099 \text {. }
$$

Jest to estymator nieobciążony o wariancji w przybliżeniu równej $0,14 \cdot 10^{-4}$.

Niemal identyczny wynik otrzymano, stosując proponowany estymator (4.7.6), tzn.

$$
\hat{W}_{z g . u b .}=0,15097 .
$$

Skonstruowany, w oparciu o wzór (4.7.5), przedział $(0,1444,0,1577)$ pokrywa wartość rozważanego wskaźnika zagrożenia ubóstwem z ufnością 0,95.

Wykorzystując oszacowania granicy ubóstwa, wyznaczano:

- indeks luki dochodowej ubogich,

- indeks luki dochodowej. 
Oszacowany indeks luki dochodowej ubogich w Polsce w badanym okresie wynosi:

$$
\hat{I}_{d u}=0,2358
$$

i określa przeciętne zubożenie w obrębie grupy gospodarstw biednych.

Indeks luki dochodowej:

$$
\hat{I}_{d}=0,0356
$$

informuje o stopniu przeciętnego zubożenia całej populacji gospodarstw domowych w Polsce w 2008 r.

Wartość indeksu $D U$ mierzącego dotkliwość ubóstwa wynosi 0,0142 .

Analiza zamożności społeczeństwa związana jest z obliczeniem wskaźnika bogactwa (wzór (4.7.10) i szacowaniem indeksu zamożności (wzór (4.7.13)). Dla gospodarstw domowych badanych w IV kwartale 2008 r. wynoszą one:

$$
\begin{gathered}
\hat{W}_{\text {bogactwa }}=0,0263, \\
\hat{I}^{o}=0,0141 .
\end{gathered}
$$

Mierniki ubóstwa i bogactwa można wykorzystać do analiz poziomu życia, jego zróżnicowania w regionach geograficznych czy w wyodrębnionych grupach społeczno-ekonomicznych.

W badaniach GUS wyróżnia się następujące grupy społeczno-ekonomiczne:

- gospodarstw pracowników,

- gospodarstw rolników,

- gospodarstw pracujaccych na własny rachunek,

- gospodarstw emerytów i rencistów,

- gospodarstw utrzymujących się z niezarobkowych źródeł.

$\mathrm{W}$ tablicy 6.2.2 przedstawiono indeksy charakteryzujące ubóstwo $\mathrm{w}$ poszczególnych grupach społeczno-ekonomicznych, natomiast $\mathrm{w}$ tablicy 6.2.3 mierniki zamożności. Otrzymane wyniki świadczą o zróżnicowaniu grup społeczno-ekonomicznych zarówno pod względem ubóstwa, jak i zamożności. Najbardziej dotkniętą ubóstwem okazała się grupa gospodarstw rolników charakteryzująca się najwyższym współczynnikiem zagrożenia ubóstwem i największą głębokością oznaczającą największy dystans między dochodami ekwiwalentnymi ubogich gospodarstw domowych i granicą ubóstwa. Odsetek gospodarstw 
o dochodach wyższych niż wyznaczona granica bogactwa okazał się największy w grupie gospodarstw pracujących na własny rachunek. Dla tej grupy również największy był indeks zamożności. Dość wysokie wskaźniki bogactwa charakteryzują również grupę gospodarstw rolników.

Tablica 6.2.2. Zróżnicowanie ubóstwa w poszczególnych grupach społeczno-ekonomicznych

\begin{tabular}{|l|c|c|c|c|c|}
\hline \multicolumn{1}{|c|}{ Grupy społeczno-ekonomiczne } & $n_{i}$ & $\hat{W}_{z g . u b .}$ & $\hat{I}_{d u}$ & $\hat{I}_{d}$ & $D U$ \\
\hline Gospodarstwa pracowników & 4656 & 0,1018 & 0,2053 & 0,0209 & 0,0074 \\
\hline Gospodarstwa rolników & 459 & 0,2658 & 0,4204 & 0,1117 & 0,0661 \\
\hline $\begin{array}{l}\text { Gospodarstwa pracujących na własny } \\
\text { rachunek }\end{array}$ & 632 & 0,0665 & 0,2745 & 0,0183 & 0,0097 \\
\hline Gospodarstwa emerytów i rencistów & 3233 & 0,1884 & 0,1936 & 0,0365 & 0,0113 \\
\hline $\begin{array}{l}\text { Gospodarstwa utrzymujących się z } \\
\text { niezarobkowych źródeł }\end{array}$ & 325 & 0,0281 & 0,3370 & 0,0095 & 0,0780 \\
\hline
\end{tabular}

Źródło: obliczenia własne.

Tablica 6.2.3. Zróżnicowanie zamożności w poszczególnych grupach społeczno-ekonomicznych

\begin{tabular}{|l|c|c|}
\hline \multicolumn{1}{|c|}{ Grupy społeczno-ekonomiczne } & $\hat{W}_{\text {bogactwa }}$ & $\hat{I}^{o}$ \\
\hline Gospodarstwa pracowników & 0,0305 & 0,0158 \\
\hline Gospodarstwa rolników & 0,0741 & 0,0410 \\
\hline Gospodarstwa pracujących na własny rachunek & 0,0807 & 0,0479 \\
\hline Gospodarstwa emerytów i rencistów & 0,0046 & 0,0025 \\
\hline Gospodarstwa utrzymujących się z niezarobkowych źródeł & 0,0092 & 0,0028 \\
\hline
\end{tabular}

Źródło: obliczenia własne.

\subsection{Zastosowanie kwantyli z próby do estymacji miar ryzyka na rynku finansowym}

Koncepcja $V a R$ jest znana od dawna, ale jej praktyczne znaczenie wzrosło dopiero w pierwszej połowie lat dziewięćdziesiątych ubiegłego stulecia. Badania i przykłady zastosowań wartości narażonej na ryzyko przedstawione są w wielu pracach, m.in. w artykułach takich autorów, jak: W. Dziubdziela i in. [2011], R. Gençay, F. Selçuk [2004], M. Gilli, E Këllezi [2006], I. A. Onour [2010], M. Stachura, B. Wodecka [2012]. 
Zaprezentowane w podrozdziale 4.7 miary ryzyka oparte na wartości zagrożonej wykorzystane zostały do analizy stóp zwrotu:

- indeksu WIG 20,

- indeksu DJIA,

- cen akcji Banku Handlowy.

Niech $R_{1}, R_{2}, \ldots$ będzie ciagiem zmiennych losowych określających logarytmiczne dzienne stopy zwrotu indeksu. Aby stosować przedstawione w poprzednich rozdziałach metody, należy poczynić założenia o niezależności zmiennych $R_{1}, R_{2}, \ldots$ oraz o ich identycznym rozkładzie.

Wartość zagrożoną szacowano, wykorzystując:

- kwantyl empirycznego rozkładu zmiennej losowej $R_{t}$;

- rozkład statystyki maksymalnej zmiennej $\left(-R_{t}\right)$, dzieląc obserwacje na miesięczne bloki;

- metodę progową z ustaloną wartością progu na poziomie kwantyla rzędu 0,9 .

Dzienne logarytmiczne stopy zwrotu indeksu WIG $20 \mathrm{w}$ ciągu kolejnych 1000 dni przedstawiono na rysunku 6.3.1.

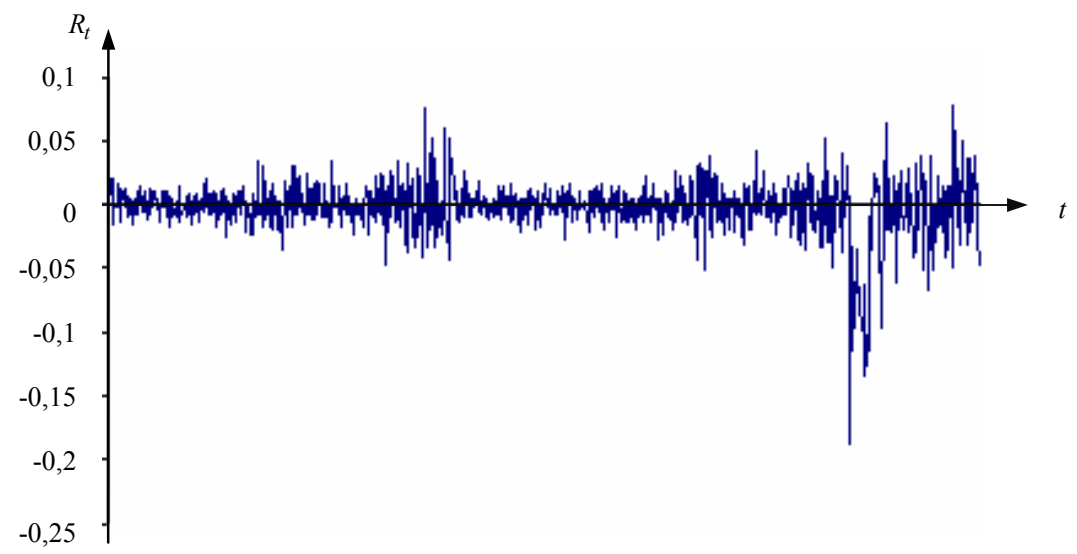

Rysunek 6.3.1. Dzienne logarytmiczne stopy zwrotu indeksu WIG 20

w okresie 28.04.2009 - 19.04.2013

Źródło: opracowanie własne

Z rozkładu empirycznego, dla dwóch wybranych poziomów tolerancji, otrzymano następujące oszacowania wartości narażonej na ryzyko:

$$
\hat{V} a R_{0,05}=0,0299, \quad \hat{V} a R_{0,01}=0,0981 .
$$

Oznacza to, iż prawdopodobieństwo sytuacji, w której wartość dziennej logarytmicznej stopy zwrotu będzie niższa niż $(-0,0299)$, jest równe 0,05 , nato- 
miast prawdopodobieństwo, że dzienna logarytmiczna stopa zwrotu będzie niższa niż $(-0,0981)$, wynosi 0,01 .

Kolejne metody dotyczyły oszacowania ekstremalnej wartości narażonej na ryzyko w oparciu o rozkład maksymalnych logarytmicznych stóp zwrotu oraz ogona rozkładu strat. Procedury te wymagają estymacji indeksu ekstremalnego $\xi$. Do tego celu wykorzystano estymator momentowy (wzór (5.3.6)). Na rysunku 6.3.2 przedstawiono zależność szacowanego indeksu ekstremalnego $\xi$ od ustalonej liczby $k$. Jak widać, w pobliżu $k=100$ wartość estymatora $\hat{\xi}$ się stabilizuje. Dla $k=100$ estymator ma wartość $\hat{\xi}=0,563$, dla $k=150$ wynosi $\hat{\xi}=0,569$, natomiast dla $k=200$ przyjmuje wartość $\hat{\xi}=0,586$. Dodatnia wartość $\hat{\xi}$ oznacza, że rozkład logarytmicznych stóp zwrotu indeksu WIG 20 charakteryzuje się grubym prawym ogonem.

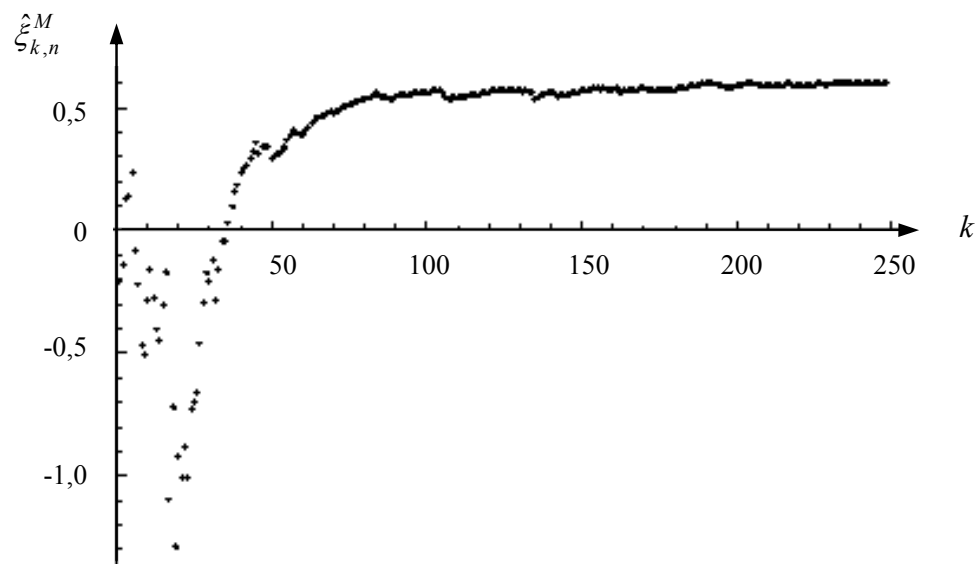

Rysunek 6.3.2. Wartości estymatora momentowego dla różnych wartości $k$ Źródło: opracowanie własne

W celu potwierdzenia decyzji o przynależności dystrybuanty rozkładu maksymalnych logarytmicznych stóp zwrotu indeksu WIG 20 do obszaru przyciagania dystrybuanty rozkładu Frécheta sformułowano hipotezę:

$$
H_{0}: F(z) \in \Omega_{H_{1, \lambda, \delta}}
$$

wobec hipotezy alternatywnej:

$$
H_{1}: F(z) \in \Omega_{H_{2, \lambda, \delta, \gamma}}
$$


i zastosowano Gt test (por. C. Neves i in. [2006]), którego statystyka postaci:

$$
G_{n}(k)=\sqrt{k / 4}\left(\frac{\frac{1}{k} \sum_{i=1}^{k}\left(X_{(n-i+1)}^{(n)}-X_{(n-k)}^{(n)}\right)^{2}}{\left(\frac{1}{k} \sum_{i=1}^{k} X_{(n-i+1)}^{(n)}-X_{(n-k)}^{(n)}\right)^{2}}-2\right)
$$

ma rozkład asymptotycznie normalny $N(0,1)$. Jeśli wartość statystyki testu spełnia nierówność: $G_{n}(k)>u_{1-\alpha}$, gdzie $\Phi\left(u_{1-\alpha}\right)=1-\alpha$, to na poziomie istotności $\alpha$ odrzuca się hipotezę zerową na korzyść alternatywnej.

Na podstawie obliczonej statystyki testu $G_{1000}(100)=3,946$ otrzymano decyzję o odrzuceniu hipotezy o rozkładzie Gumbela statystyki maksymalnej na korzyść alternatywnej, zgodnie z którą rozkład maksimum z próby jest rozkładem Frécheta, czyli rozkład zmiennej $X_{t}=-R_{t}$ charakteryzuje się grubym prawym ogonem.

Wyznaczenie wartości $V a R$ przy użyciu rozkładu statystyk ekstremalnych wymaga pogrupowania wartości w pewne bloki i wyznaczenia maksimów w każdym z bloków. Dzienne logarytmiczne stopy zwrotu WIG 20 podzielone zostały na miesiące i określono maksymalne miesięczne straty. Na podstawie otrzymanej próby oszacowano parametry rozkładu statystyki maksimum, stosując metodę największej wiarygodności. Uzyskano $\hat{\mu}=0,019, \hat{\sigma}=0,008$, $\hat{\xi}=0,509$. Zatem oszacowana dystrybuanta uogólnionego rozkładu maksimum wyraża się wzorem:

$$
\hat{F}_{\mu, \sigma, \xi}^{M}(x)=\exp \left(-\left(1+0,509 \frac{x-0,019}{0,008}\right)^{-1,965}\right),
$$

natomiast kwantyl rzędu $p$ :

$$
Z_{p}=0,019+\frac{0,008\left((-\ln p)^{-0,509}-1\right)}{0,509} .
$$

Ekstremalne wartości narażone na ryzyko, określone jako kwantyle rozkładu maksimum rzędów 0,95, 099 oraz 0,999 (por. wzór 5.6.2), wynoszą:

$$
\hat{V} a R_{0,05}=0,0746, \quad \hat{V} a R_{0,01}=0,1667, \quad \hat{V} a R_{0,001}=0,5320 .
$$


Inne podejście do szacowania maksymalnej wartości narażonej na ryzyko związane jest estymacją dystrybuanty ogona rozkładu zmiennej $X_{t}$. Ponieważ wartość oszacowanego indeksu ekstremalnego $\xi$ okazała się większa niż 0,5 , to rozkład zmiennej $Y_{t}=X_{t}-u$, gdzie $u$ jest ustalonym progiem, szacowano wykorzystując uogólniony rozkład Pareto o dystrybuancie określonej wzorem:

$$
F_{\beta, \xi}(y)=1-\left(1+\xi \frac{y}{\beta}\right)^{-\frac{1}{\xi}} .
$$

Parametry rozkładu strat ponad próg ustalony na poziomie kwantyla 0,9 i wynoszący 0,019 nie mogą być oszacowane ani poprzez zastosowanie metody największej wiarygodności (przy numerycznym wyznaczaniu wartości estymatorów parametru rozkładu za pomocą programu Mathematica 8 pojawia się informacja o braku zbieżności algorytmu), ani za pomocą metody momentów, gdyż dla uogólnionego rozkładu Pareto o wartości $\xi>0,5$ nie istnieje wariancja. Do oszacowania parametrów tego rozkładu zostały wykorzystane dwie metody momentów ważonych prawdopodobieństwami oraz kwantylowa metoda najmniejszych kwadratów. Metody te oznaczono następująco:

- metoda I: $m M W P$, w której prawdopodobieństwa określone zostały za pomocą dystrybuanty empirycznej $F_{n}(y)=\frac{1}{n-1} \sum_{i=1}^{n}\left(I_{(-\infty, y)}\left(y_{(i)}^{(n)}\right)-1\right)$,

- metoda II: $z m M W P$ z dystrybuantą empiryczną level crossing;

- metoda III: kwantylowa metoda najmniejszych kwadratów (Kmnk).

Otrzymane wyniki zawarte są w tablicy 6.3.1.

Tablica 6.3.1. Oszacowania parametrów uogólnionego rozkładu Pareto wybranymi metodami

\begin{tabular}{|c|c|c|c|}
\hline \multicolumn{1}{|c|}{ Parametr } & Metoda I & Metoda II & Metoda III \\
\hline$\beta$ & 0,015 & 0,014 & 0,024 \\
\hline$\xi$ & 0,437 & 0,453 & 0,121 \\
\hline
\end{tabular}

Źródło: opracowanie własne.

Poza metodą III wyniki oszacowań parametru $\beta$ są zbliżone. Wcześniejsze analizy własności metod wskazywały, że estymatory parametrów rozkładu zmiennej losowej otrzymane kwantylową metodą najmniejszych kwadratów mają większe obciążenia i błędy średniokwadratowe, zatem wyniki uzyskane metodą III należy uznać za najmniej wiarygodne. Dla parametru $\xi$ wartości estymatorów są nieco inne niż wstępnie oszacowanego semiparametrycznego 
estymatora momentowego, ale i w tym przypadku najbardziej różni się wartość estymatora otrzymanego metodą III.

Postaci oszacowanych dystrybuant ogona rozkładu strat mierzonych logarytmicznymi stopami zwrotu są następujące:

$$
\begin{aligned}
& \hat{F}_{1}(x)=1-0,1\left(1+0,437 \frac{x-0,019}{0,015}\right)^{-2,288} \quad \text { (metoda I), } \\
& \hat{F}_{2}(x)=1-0,1\left(1+0,453 \frac{x-0,019}{0,014}\right)^{-2,208} \quad \text { (metoda II), } \\
& \hat{F}_{3}(x)=1-0,1\left(1+0,121 \frac{x-0,019}{0,024}\right)^{-8,264} \quad \text { (metoda III). }
\end{aligned}
$$

Kwantyle z prób rzędu 0,999 przyjmują wartości: $\hat{Q}_{0,999}^{1}=0,241, \hat{Q}_{0,999}^{2}=0,237$, $\hat{Q}_{0,999}^{3}=0,167$ i stanowią oszacowania wartości narażonej na ryzyko na poziomie tolerancji 0,001. Otrzymane wartości kwantyli są niższe niż kwantyl rzędu 0,999 wyznaczony na podstawie dystrybuanty statystyki maksimum z próby.

Drugim analizowanym indeksem jest DJIA - jeden z najważniejszych indeksów akcji spółek notowanych na giełdzie papierów wartościowych w Nowym Jorku. Dzienne logarytmiczne stopy zwrotu tego indeksu przedstawione są na rysunku 6.3.3.

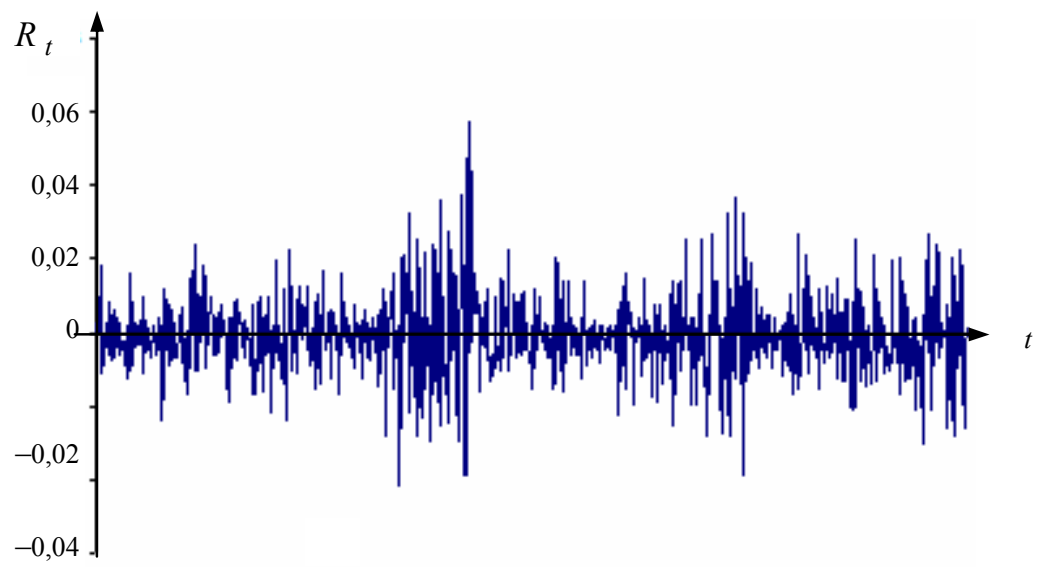

Rysunek 6.3.3. Dzienne logarytmiczne stopy zwrotu indeksu DJIA w okresie 29.04.2009-19.04.2013

Źródło: opracowanie własne 
Korzystając $\mathrm{z}$ dystrybuanty rozkładu empirycznego dziennych logarytmicznych stóp zwrotu indeksu DJIA, otrzymano, przy ustalonych poziomach tolerancji, następujące oszacowania wartości zagrożonej:

$$
\hat{V} a R_{0,05}=0,0164, \hat{V} a R_{0,01}=0,0281 .
$$

Oszacowanie parametru $\xi$ za pomocą estymatora momentowego w tym przypadku nie przyniosło pożądanych rezultatów. Jak widać na rysunku 6.3.4, nie można odczytać przybliżonej wielkości $k$, dla której wartości indeksu zaczynają się stabilizować.

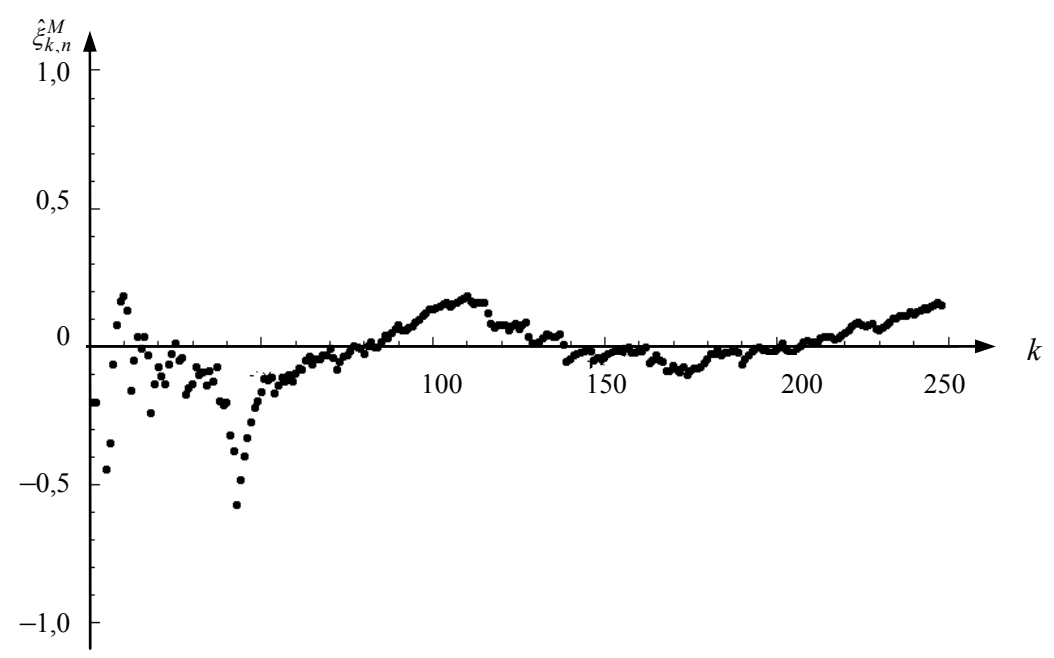

Rysunek 6.3.4. Wartości estymatora momentowego dla różnych wartości $k$ Źródło: opracowanie własne

W celu zbadania, czy dystrybuanta statystyki maksimum strat mierzonych wielkością logarytmicznej stopy zwrotu leży w obszarze przyciagania dystrybuanty rozkładu Gumbela, tym samym, czy wartość indeksu $\xi$ jest równa zero, sformułowano hipotezy analogiczne jak dla indeksu WIG 20. W tym przypadku zastosowano również test zgodności Gt, którego sprawdzianem jest statystyka wyrażona wzorem (6.3.1). Wartość statystyki wyniosła $G_{1000}(100)=0,050$, co oznacza brak podstaw do odrzucenia hipotezy zgodnie z którą statystyka maksimum ma rozkład Gumbela.

Rozkład wartości ponadprogowych, czyli zmiennej $Y_{t}=\left(-R_{t}\right)-u$, gdzie $u$ jest wartością progową ustaloną na poziomie kwantyla empirycznego rzędu 0,9 określa się za pomocą dystrybuanty postaci: 


$$
F_{\beta, \xi}(y)=1-\exp \left(-\frac{y}{\beta}\right) \text { dla } y \geq 0
$$

Zatem estymatorem parametru $\beta$ jest średnia arytmetyczna z próby, czyli $\hat{\beta}=0,0003$ oraz:

$$
\hat{F}(x)=1-0,1 \exp \left(-\frac{x-0,012}{0,0003}\right)
$$

Oszacowany kwantyl rzędu 0,999 przyjmuje wartość:

$$
\hat{Q}_{0,999}=0,012-0,003 \cdot \ln (0,01)=0,0258
$$

i określa wartość narażoną na ryzyko na poziomie tolerancji 0,001 .

Z analiz wynika, że wartości ryzyka dla polskiego indeksu WIG 20 są większe niż dla amerykańskiego indeksu DJIA. Otrzymane wyniki są zgodne $\mathrm{z}$ obserwacjami rynku finansowego związanego z inwestowaniem na giełdach. Można sądzić, że w analizowanym okresie bardziej ryzykowne były inwestycje na warszawskiej giełdzie niż na nowojorskiej.

Logarytmiczne stopy zwrotu akcji notowanych na GPW zwykle mają rozkłady charakteryzujące się grubymi ogonami. Jednym z rozkładów gruboogonowych jest rozkład Cauchy'ego ( $t$-Studenta o jednym stopniu swobody). Do badania zgodności rozkładu logarytmicznych stóp zwrotu indeksu WIG 20 zastosowano test Kołmogorowa, otrzymując decyzję o odrzuceniu hipotezy zerowej o zgodności z rozkładem Cauchy'ego. Dla indeksu DJIA nie ma podstaw do odrzucenia hipotezy o rozkładzie Gumbela statystyki maksimum (wynik testu Gt). Świadczy to również o braku zgodności rozkładu logarytmicznych stóp zwrotu DJIA z rozkładem Cauchy'ego. Analiza cen akcji Banku Handlowego w okresie 27.04.2009 r. - 19.04.2013 r. i weryfikacja hipotezy zerowej o zgodności rozkładu logarytmicznych stóp zwrotu cen akcji tego banku $(X)$ z rozkładem Cauchy'ego na poziomie istotności 0,05 dostarczyły informacji o braku podstaw do jej odrzucenia. Histogram otrzymany na podstawie 1000elementowej próby przedstawia rysunek 6.3.5.

Parametry rozkładu Cauchy'ego oszacowano proponowaną w drugim rozdziale medianowo-kwantylową metodą najmniejszych kwadratów, otrzymując:

$$
\hat{m}_{\text {MKmnk }}=0,0006, \quad \hat{\lambda}_{\text {MKmnk }}=0,0090 .
$$


Zatem oszacowana dystrybuanta zmiennej losowej $X$ ma postać:

$$
\hat{F}(x)=\frac{1}{2}+\frac{1}{\pi} \operatorname{arctg}\left(\frac{x-0,0006}{0,009}\right) .
$$

$\mathrm{Z}$ rezultatów badań przedstawionych $\mathrm{w}$ rozdziale czwartym wynika, że w tym przypadku należy skorzystać z oszacowania empirycznego rozkładu dystrybuanty. W wyniku jej wykorzystania otrzymujemy:

$$
\hat{V} a R_{0,05}=0,0562, \quad \hat{V} a R_{0,01}=0,2858 .
$$

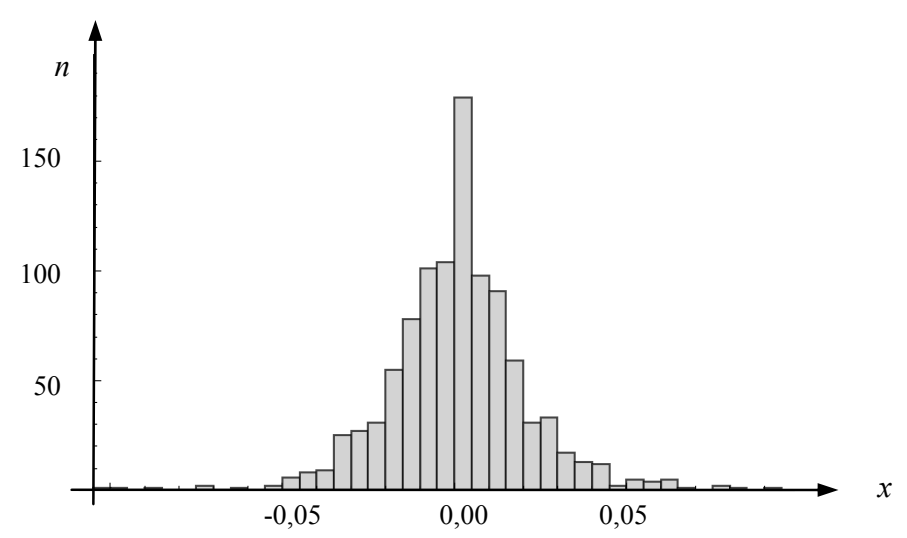

Rysunek 6.3.5. Histogram logarytmicznych stóp zwrotu akcji Bank Handlowy w okresie 27.04.2009-19.04.2013

Źródło: opracowanie własne

Rozkłady statystyki maksimum i minimum to odpowiednio rozkład Frécheta i odwrócony Frécheta (twierdzenie 1.4.8), a indeks ekstremalny $\xi=1$. Oszacowanie parametrów rozkładu wartości ekstremalnych w sposób analogiczny jak dla indeksu WIG 20 pozwala wyznaczyć miary ryzyka ekstremalnego.

\subsection{Zastosowanie metod estymacji opartych na statystykach pozycyjnych na rynku ubezpieczeniowym}

Przykładem wykorzystania kwantyli z próby na rynku ubezpieczeniowym jest estymacja współczynnika bezpieczeństwa stosowanego przy szacowaniu składek ubezpieczeniowych. W literaturze można znaleźć wiele zasad kalkulacji 
indywidualnych składek, w których pojawia się współczynnik bezpieczeństwa (por. W. Ronka-Chmielowiec [2002, s. 201-207]). Powinien on być określony na takim poziomie, aby zapewnić bezpieczeństwo zakładowi ubezpieczeń, a jednocześnie pozwolić na ustalenie ,atrakcyjnej” dla klientów wysokości składki ubezpieczeniowej (por. P. Kowalczyk i in. [2006]).W ubezpieczeniach majątkowych ryzyko ubezpieczeniowe mierzone jest dla całych portfeli, a składkę określa się na takim poziomie, aby prawdopodobieństwo poniesienia straty na danym portfelu w ciagu kolejnego okresu nie przekroczyło ustalonej z góry wartości. Oznacza to, że składka dla portfela ryzyka ustalana jest na poziomie pewnego kwantyla rozkładu łącznej sumy roszczeń w portfelu. W tym przypadku konieczna jest znajomość rozkładu łącznej sumy roszczeń $S$, która jest sumą niezależnych zmiennych losowych $X_{1}, X_{2}, \ldots, X_{N}$ oznaczających wartości kolejnych wypłat.

Wielkość składki $\Pi(S)$ dla całego portfela ustalana jest na takim poziomie, aby prawdopodobieństwo poniesienia straty na danym portfelu $\mathrm{w}$ kolejnym okresie nie przekroczyło ustalonej wartości $p \in(0,1)$, czyli $P(S>\Pi(S)) \leq p$.

Zatem

$$
F(\Pi(S)) \geq 1-p
$$

gdzie $F$ jest dystrybuantą zmiennej losowej $S$.

Rozkład zmiennej $S$ zależy zarówno od rozkładu zmiennej losowej $N$, jak i rozkładu zmiennych losowych $X_{i}$, gdzie $i=1,2, \ldots, N$, dlatego analityczne wyznaczenie dystrybuanty $F$ jest często trudne, a czasami niemożliwe. W tych przypadkach stosuje się metody aproksymacyjne (rozkładem normalnym lub przesuniętym rozkładem gamma) oraz symulacyjne.

Aproksymacja rozkładem normalnym możliwa jest dla dużych portfeli i niezbyt dużej asymetrii rozkładu, tzn. gdy współczynnik asymetrii $\gamma_{S}$ jest mniejszy niż 0,1 . Jeśli $0,1 \leq \gamma_{S}<1$, możliwa jest aproksymacja przesuniętym rozkładem gamma (por. Daykin i in. [1994]). Odmienne formuły aproksymacyjne prowadzą do różnych postaci składki łącznej sumy odszkodowań i różnych przybliżeń współczynników bezpieczeństwa, m.in. (por. K. Burnecki, J. Nowicka-Zagrajek [2006], W. Otto [2004, s. 158-168]):

- według formuly $W H 1$ (Wilsona-Hilferty'ego)

$$
Q_{W H 1}=\frac{2}{\gamma_{S}}\left(\left(1-\frac{\gamma_{S}^{2}}{36}+\frac{u_{p} \gamma_{S}}{6}\right)^{3}-1\right),
$$


- według formuły WH2 (Wilsona-Hilferty’ego)

$$
Q_{W H 2}=u_{p}+\frac{u_{p}^{2}-1}{6} \gamma_{S}+\frac{u_{p}^{3}-6 u_{p}}{108} \gamma_{S}^{2},
$$

- według formuły FC1 (Fishera-Cornisha)

$$
Q_{F C 1}=u_{p}+\frac{u_{p}^{2}-1}{6} \gamma_{S}
$$

- według formuły FC2 (Fishera-Cornisha)

$$
Q_{F C 2}=u_{p}+\frac{u_{p}^{2}-1}{6} \gamma_{S}+\frac{u_{p}^{3}-7 u_{p}}{144} \gamma_{S}^{2}
$$

Wadą ich jest brak możliwości stosowania, gdy współczynnik asymetrii jest większy niż 1 .

W tablicy 6.4.1 przedstawione zostały wartości współczynników bezpieczeństwa dla ustalonego $p=0,05$ oraz wybranych współczynników asymetrii.

\begin{tabular}{|c|c|c|c|c|c|}
\hline Formuła $\quad \gamma_{S}$ & 0,2 & 0,40 & 0,60 & 0,80 & 1,00 \\
\hline$W H 1$ & 1,69425 & 1,74413 & 1,78933 & 1,82961 & 1,86473 \\
\hline$W H 2$ & 1,69431 & 1,74460 & 1,79086 & 1,83311 & 1,87133 \\
\hline$F C 1$ & 1,69632 & 1,75264 & 1,80896 & 1,86528 & 1,92160 \\
\hline$F C 2$ & 1,69436 & 1,74479 & 1,79129 & 1,83386 & 1,87251 \\
\hline
\end{tabular}

Tablica 6.4.1. Współczynniki bezpieczeństwa dla $p=0,05$ i aproksymacji przesuniętym rozkładem gamma dla rozkładów sumy szkód o wybranych współczynnikach skośności

Źródło: obliczenia własne.

Stosując formuły określone wzorami (6.4.2)-(6.4.5), otrzymano zbliżone wartości narzutu bezpieczeństwa. Współczynnik wyznaczony w oparciu o formułę $F C 1$ nieznacznie odbiega wartością od pozostałych, przy czym im większa jest asymetria zmiennej $S$, tym większa jest ta różnica.

Na rysunkach 6.4.1 i 6.4.2 przedstawione są zależności wielkości narzutów bezpieczeństwa wyznaczonych w oparciu o formuly $W H 1$ i $F C 1$ od $p$, dla wybranych rozkładów sumy roszczeń. 
Okazuje się, że większy wpływ na wielkość narzutu bezpieczeństwa ma współczynnik asymetrii, gdy ustalane wartości $p$ są mniejsze. Dla dużych wartości $p$ (około 0,1$)$ nie zaobserwowano różnic między wartościami obliczonych współczynników bezpieczeństwa. Podobne rezultaty otrzymano dla współczynników bezpieczeństwa wyznaczonych w oparciu o formuły aproksymacyjne WH2 i $F C 2$.

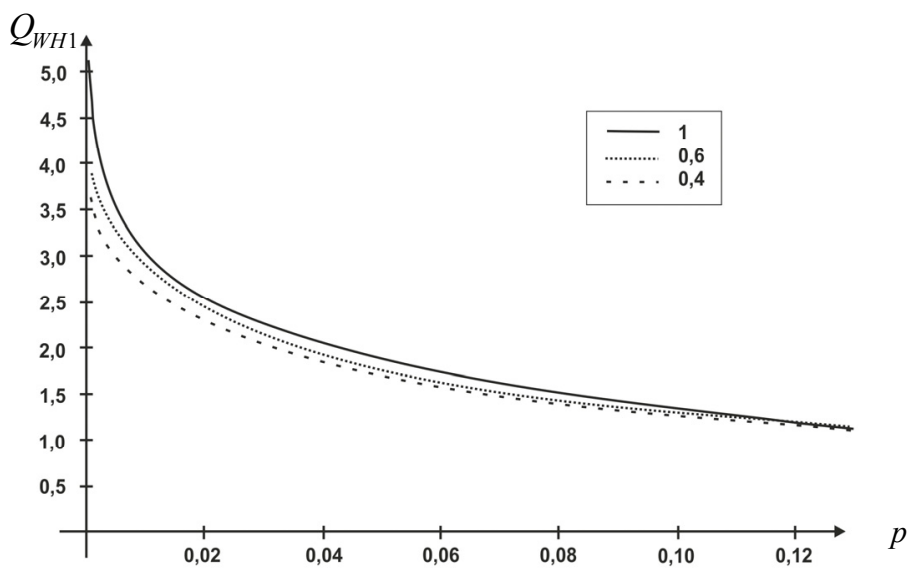

Rysunek 6.4.1. Zależność współczynników bezpieczeństwa wyznaczonych według formuły $W H 1$ od wartości $p$ dla wybranych rozkładów sumy roszczeń

Źródło: opracowanie własne

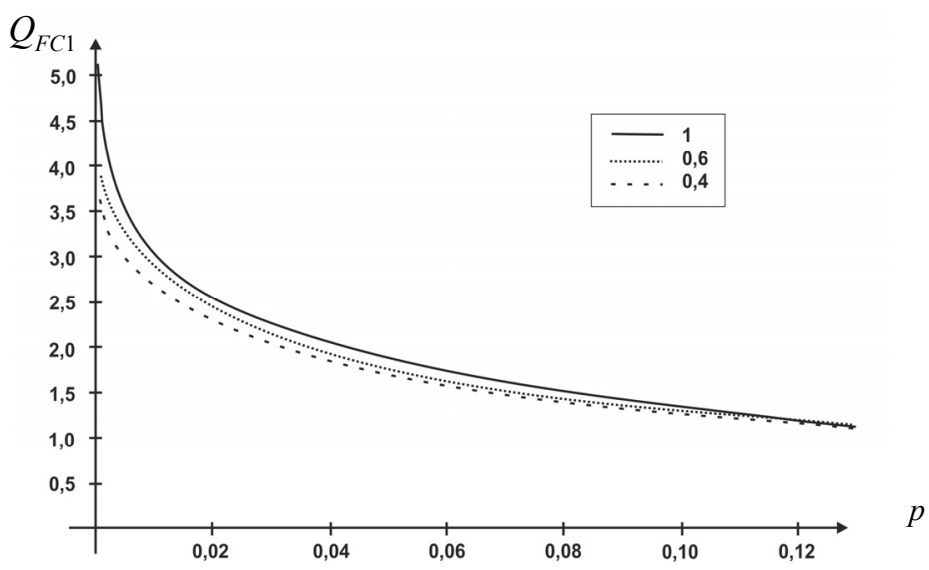

Rysunek 6.4.2. Zależność współczynników bezpieczeństwa wyznaczonych według formuły $F C 1$ od wartości $p$ dla wybranych rozkładów sumy roszczeń

Źródło: opracowanie własne 
Metodą, która nie wymaga założenia o wielkości współczynnika asymetrii, jest metoda oparta na bootstrapowej aproksymacji rozkładu sumy roszczeń (por. rozdział 2) i wyznaczeniu kwantyla odpowiedniego rzędu, który będzie wielkością współczynnika bezpieczeństwa dla całego portfela ubezpieczeń określonego typu.

W celu przeprowadzenia analizy porównawczej wyników uzyskanych przy zastosowaniu metody bootstrapowej i metod aproksymacji przesuniętym rozkładem gamma rozważano dwa przypadki. W obydwu wartości zmiennej losowej określającej liczbę wypłat generowano z rozkładu Poissona, natomiast wartości zmiennej określającej wielkość wypłat generowano z rozkładów gamma i logarytmiczno-normalnego. Wyboru rozkładów dokonano w oparciu o informacje dotyczące klas rozkładów charakterystycznych dla wypłat z tytułu ubezpieczeń komunikacyjnych OC. Parametry rozkładów wysokości wypłat dobrane zostały tak, aby ich wartości oczekiwane były równe 4 (tys. zł), a odchylenia standardowe 6 (tys. zł). Wartości tych parametrów ustalono na podstawie analizy rzeczywistych danych pewnego towarzystwa ubezpieczeniowego.

Na rysunku 6.4.3 przedstawiono otrzymany metodą bootstrapową rozkład wysokości sumy roszczeń dla 5000 polis, przy założeniu, że indywidualne wypłaty charakteryzuje rozkład gamma (próby bootstrapowe generowano 1000 razy).

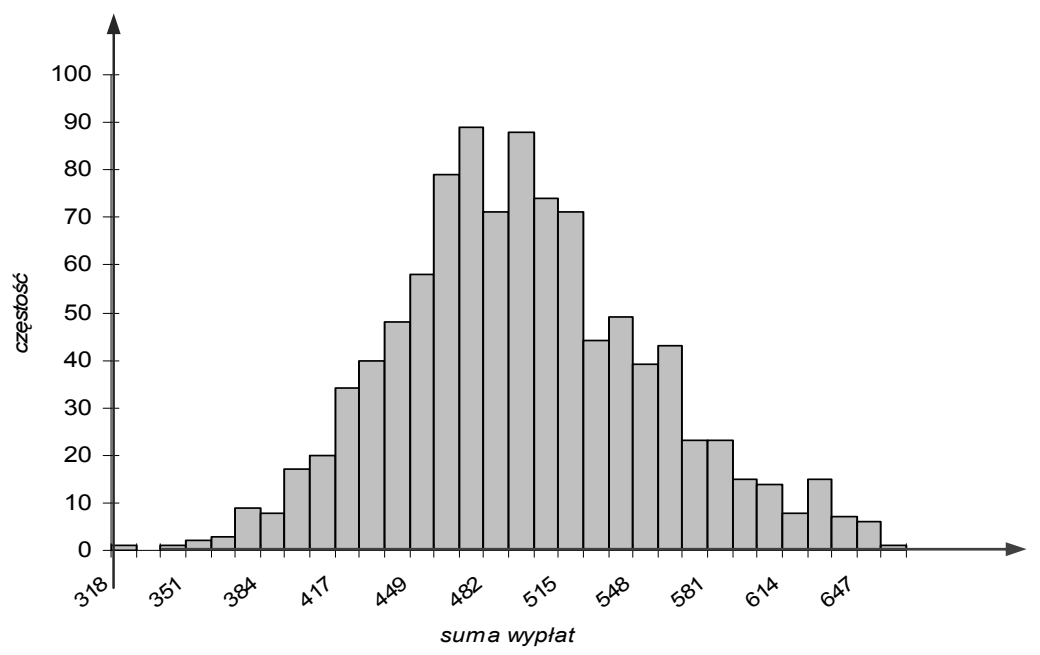

Rysunek 6.4.3. Rozkład sumy roszczeń, gdy indywidualne wielkości wypłat charakteryzuje rozkład gamma

Źródło: opracowanie własne 
Tablice 6.4.2-6.4.3 zawierają wartości $\Pi(S)$ wyznaczone metodą bootstrapową oraz w oparciu o aproksymacje przesuniętym rozkładem gamma dla wielkości szkód, odpowiednio, o rozkładzie gamma i logarytmiczno-normalnym.

Zastosowanie metody bootstrapowej do szacowania rozkładu sumy szkód i wyznaczenie kwantyla odpowiedniego rzędu spowodowało uzyskanie nieznacznie niższych składek w stosunku do wysokości składek ustalonych w oparciu o aproksymacje przesuniętym rozkładem gamma. Różnica ta stanowiła około 2,5-3\% wartości składki uzyskanej przy zastosowaniu przesuniętego rozkładu gamma.

Tablica 6.4.2. Wartości składki $\Pi(S)$ (w tys. zł) dla różnych metod aproksymacji dla rozkładu gamma wysokości szkód

\begin{tabular}{|l|c|c|c|c|c|}
\hline \multirow{2}{*}{$p$} & \multicolumn{5}{|c|}{ Metoda } \\
\cline { 2 - 6 } & $W H 1$ & $W H 2$ & $F C 1$ & $F C 2$ & bootstrap \\
\hline 0,1 & 576,7097 & 576,7117 & 576,8825 & 576,7253 & 562,14 \\
\hline 0,05 & 604,076 & 604,0814 & 604,2467 & 604,0855 & 591,23 \\
\hline 0,001 & 719,9422 & 719,9701 & 719,6361 & 719,8157 & 645,88 \\
\hline
\end{tabular}

Źródło: opracowanie własne.

Tablica 6.4.3. Wartości składki $\Pi(S)$ (w tys. zł) dla różnych metod aproksymacji dla logarytmiczno-normalnego rozkładu wysokości szkód

\begin{tabular}{|c|c|c|c|c|c|}
\hline \multirow{2}{*}{$p$} & \multicolumn{5}{|c|}{ Metoda } \\
\cline { 2 - 6 } & $W H 1$ & $W H 2$ & $F C 1$ & $F C 2$ & bootstrap \\
\hline 0,1 & 763,7368 & 763,7443 & 764,2281 & 763,7818 & 741,251 \\
\hline 0,05 & 803,0504 & 803,0729 & 803,5427 & 803,0833 & 772,293 \\
\hline 0,001 & 973,6970 & 973,8123 & 955,0467 & 973,3735 & 906,925 \\
\hline
\end{tabular}

Źródło: opracowanie własne.

Metoda bootstrapowa i kwantyle rozkładu pozwoliły określić wielkość składki dla całego portfela zawierającą narzut bezpieczeństwa.

Metodę tę można stosować w przypadku, gdy rozkład indywidualnych roszczeń jest nieznany, gdyż jest to metoda nieparametryczna, niewymagająca żadnych założeń o rozkładach zmiennych losowych. Nadaje się do wykorzystania również wówczas, gdy asymetria rozkładu sumy roszczeń jest większa niż 1 .

Oszacowana wartość oczekiwana sumy roszczeń i wariancja pozwalają wyznaczyć narzut bezpieczeństwa $Q$ dla całego portfela, a następnie narzut indy- 
widualny ze wzoru: $Q_{i n d}=\frac{Q}{\sqrt{n}}$, gdy wariancje poszczególnych zmiennych wchodzących w skład portfela są jednakowe lub ze wzoru: $Q_{i n d}^{(i)}=Q \frac{D\left(X_{i}\right)}{D(S)}$, gdy wariancje te są różne. Indywidualny współczynnik bezpieczeństwa pozwala określić składki indywidualne dla polis tak, aby prawdopodobieństwo poniesienia straty na całym portfelu nie przekroczyło ustalonej wartości.

W badaniach niekoniecznie trzeba korzystać z informacji o wartości sumy roszczeń w całym portfelu. Wartość tę można oszacować na podstawie próby losowej:

$$
S=N \cdot \bar{X}=N \frac{\sum_{i=1}^{n} X_{i}}{n},
$$

gdzie $N$ oznacza liczbę wszystkich polis, $\bar{X}$ średnią wysokość wypłat z $n$ wybranych polis.

$\mathrm{W}$ analizach wypłat $\mathrm{z}$ tytułu różnego rodzaju ubezpieczeń wykorzystuje się również rozkłady statystyk maksymalnych i wyznacza się ekstremalną wartość narażoną na ryzyko, przy ustalonym poziomie tolerancji.

\subsection{Wykorzystanie statystyk pozycyjnych w ocenie dzialalności przedsiębiorstw}

Statystyki pozycyjne i ich funkcje znajdują zastosowanie również przy ocenie działalności przedsiębiorstw zarówno $\mathrm{z}$ finansowego punktu widzenia, jak i jakości produkcji. Wykorzystywane karty kontrolne w statystycznej kontroli jakości oraz miary ryzyka $\mathrm{w}$ finansowej ocenie przedsiębiorstwa pozwalają podejmować właściwe decyzje podczas procesu produkcyjnego.

Statystyki ekstremalne, mediana i ich funkcje wykorzystywane są do konstrukcji kart kontrolnych stosowanych w statystycznej kontroli jakość. Karty kontrolne zaprezentowane $\mathrm{w}$ podrozdziałach 4.7.3 oraz 5.6.2 używane są do analizy procesu pod kątem jego rozregulowania. Na podstawie danych rzeczywistych dotyczących badania jakości elementów urządzenia gospodarstwa domowego produkowanego przez pewne przedsiębiorstwo przedstawione zostaną przykłady zastosowania kart kontrolnych wykorzystujących estymatory media- 
ny i rozstęp. Analizowano dwie cechy statystyczne, utożsamiane ze zmiennymi losowymi:

$X$ - długość pewnego detalu urządzenia gospodarstwa domowego mierzoną (w mm.),

$Y$ - bezwzględną różnicę długości przekątnych obudowy tego urządzenia ( $\mathrm{w} \mathrm{cm}$.).

Zmienna losowa $X$ ma w przybliżeniu rozkład normalny. Jej wartość nie powinna być mniejsza niż $55 \mathrm{~mm}$., a większa niż $56 \mathrm{~mm}$. Do analizy procesu produkcyjnego detalu wykorzystano „odporne” karty kontrolne.

W celu obserwacji długości produkowanego detalu skonstruowano, na podstawie próbek pochodzących z ustabilizowanego procesu, „odporną” kartę kontrolną wykorzystującą medianę średnich próbkowych. Dla każdej spośród 100 prób zawierającej po 9 elementów (po 3 pomiary pochodziły z każdej z trzech zmian) obliczono średnie arytmetyczne i odchylenia standardowe, a następnie utworzono kartę kontrolną, dla której linie wyznaczone w oparciu o wzory (4.7.44)-(4.7.46) były następujące:

$$
L C_{M e}=55,2128(\mathrm{~mm} .), \quad D L K_{M e}=55,1828(\mathrm{~mm} .), \quad G L K_{M e}=55,2427(\mathrm{~mm} .)
$$

Ze względu na mniejszą medianową obciążoność estymatora Bersteina $M e^{B r s}$ w stosunku do standardowego estymatora mediany dla rozkładów zbliżonych do rozkładu normalnego, do szacowania mediany wykorzystano proponowany estymator $M e^{B r s}$ i utworzono kartę kontrolną z liniami określonymi wzorami (4.7.49)-(4.7.51). W tym przypadku uzyskano:

$$
L C_{M e}^{B r s}=55,2134(\mathrm{~mm} .), \quad D L K_{M e}^{B r s}=55,1838(\mathrm{~mm} .), \quad G L K_{M e}^{B r s}=55,2431(\mathrm{~mm} .)
$$

Otrzymane linie kontrolne nieznacznie różniły się od linii kontrolnych karty wyznaczonej w oparciu o standardowy estymator mediany.

Tak skonstruowane karty kontrolne stosowano do badania rozregulowania procesu w kolejnych 40 dniach. Analiza procesu przy zastosowaniu obydwu kart kontrolnych dała identyczne wyniki, dwie wartości spośród 40 przekroczyły dolną linię kontrolną.

Badania jakości produkcji dotyczyły również pomiaru długości przekątnych obudowy urządzenia i analizy wartości bezwzględnej różnicy długości przekątnych $(Y)$. Jest to wielkość istotna z punktu widzenia montażu innych elementów urządzenia, zatem odchylenia od normy nie mogą być zbyt duże. W tym przypadku zmienna losowa $Y$ nie ma rozkładu normalnego ani zbliżonego do normalnego, charakteryzuje ją rozkład asymetryczny, którego histogram otrzymany na podstawie 600 obserwacji przedstawia rysunek 6.5.1. 
Do badania jakość produkcji obudowy zastosowana została karta kontrolna $X_{\max }-X_{\min }$ o granicach kontrolnych:

$$
L C_{m, M}=0,4991, \quad D L K_{m, M}=0,3857, \quad G L K_{m, M}=0,6125 .
$$

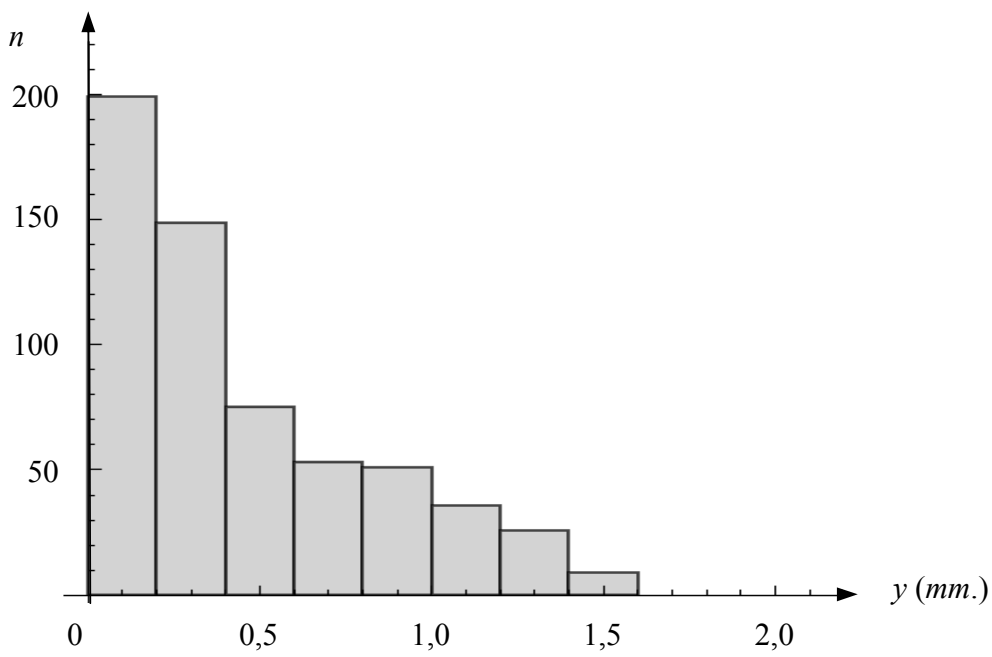

Rysunek 6.5.1. Histogram rozkładu zmiennej losowej $Y$ Źródło: opracowanie własne

Na podstawie 60 -elementowej próby złożonej z dziennych pomiarów, dokonywanych 10 razy, analizowano proces produkcyjny obudowy. Okazało się, że w 34 przypadkach przekroczona została górna linia kontrolna i w 20 dolna linia kontrolna, co świadczy o wzroście rozrzutu pomiarów, tym samym o wzroście różnic między długościami przekątnych produkowanej obudowy.

Ze względu na fakt, że działalności przedsiębiorstwa towarzyszą różnego rodzaju ryzyka, m.in. ryzyko rynkowe związane ze zmianami cen na rynkach, ryzyko biznesowe, pojawiające się na skutek istnienia konkurencji, odnoszące się także do jakości produktów i reputacji firmy, czy też ryzyko operacyjne, wynikające $\mathrm{z}$ błędów w funkcjonowaniu wewnętrznych systemów instytucji, istotnym problemem jest zarządzanie ryzykiem.

Źródłami informacji o ryzyku są: bilans, rachunek zysków i strat, rachunek przepływów pieniężnych. Pomiaru ryzyka można dokonać, stosując miary zmienności takie jak wariancja i odchylenie standardowe, miary wrażliwości, np. współczynnik beta, oraz miary zagrożenia, będące modyfikacjami VaR wartości narażonej na ryzyko. 
Do wykorzystywanych miar ryzyka należą (por. A. Kaszuba-Perz, P. Perz [2010]):

- zysk narażony na ryzyko: $E a R_{p}$ (earnings at risk),

- przepływy pieniężne narażone na ryzyko: $C_{F a R_{p}}$ (cash flow at risk).

Niech $E$ będzie zmienną losową określającą zysk netto przedsiębiorstwa w danym okresie. Zysk narażony na ryzyko $E a R_{p}$, przy założonym poziomie tolerancji $p$, określa wzór:

$$
P\left(E \leq E_{0}-E a R_{p}\right)=p,
$$

gdzie $E_{0}$ jest planowany zyskiem netto w danym okresie.

Określa on maksymalną wielkość, o którą może być mniejszy zysk netto przedsiębiorstwa w porównaniu z planowaną wielkością w danym okresie, przy czym prawdopodobieństwo, że zrealizowany zysk netto będzie niższy od planowanego zysku netto o więcej niż wartość $E a R_{p}$, jest równe zadanemu poziomowi tolerancji $p$.

Druga z miar $C F a R_{p}$ jest maksymalną wielkością, o którą może być mniejszy przepływ pieniężny w porównaniu z planowaną wielkością w danym okresie, przy czym prawdopodobieństwo, że przepływ pieniężny będzie niższy od planowanego o więcej niż jest równe zadanemu poziomowi tolerancji $p$.

$$
P\left(C F \leq C F_{0}-C F a R_{p}\right)=p,
$$

gdzie $C F$ jest zmienną losową określającą przepływ pieniężny w danym okresie, natomiast $C F_{0}$ jest planowanym przepływem pieniężnym w danym okresie.

Wartości obydwu miar ryzyka wyznacza się w sposób analogiczny jak $\operatorname{VaR}$, wykorzystując nieparametryczne bądź parametryczne estymatory kwantyli.

\subsection{Uwagi końcowe}

Zastosowanie metod opartych na statystykach pozycyjnych $\mathrm{w}$ badaniach dochodów gospodarstw domowych, badaniach finansowych i ubezpieczeniowych oraz statystycznej kontroli jakości stanowiło przedmiot przeprowadzonych analiz. Rozpatrując ich praktyczne wykorzystanie, zwrócono uwagę na 
zastosowanie kwantyli z próby i statystyk ekstremalnych. Rozważano parametryczne i nieparametryczne procedury estymacji $\mathrm{z}$ uwzględnieniem własnych propozycji prezentowanych $\mathrm{w}$ monografii.

Przedstawione empiryczne zastosowania statystyk pozycyjnych stanowią tylko przykłady ich różnorodnego wykorzystania. Nawet w obrębie rozważanych obszarów można wskazać inne ich zastosowanie, np. estymacja indeksu polaryzacji w badaniu polaryzacji ekonomicznej rozkładu dochodów oraz konstrukcja innych kart kontrolnych stosowanych w analizach procesu produkcyjnego pod kątem jego rozregulowania. We wszystkich tych badaniach ekonomicznych, w których wykorzystuje się miary określane na podstawie parametrów pozycyjnych oraz klasyczne metody nie mogą być stosowane, pomocne są procedury oparte na statystykach pozycyjnych.

Poza analizami ekonomicznymi statystyki pozycyjne dużą rolę odgrywają w badaniach przyrodniczych i meteorologicznych (por. m.in. A. Fiema, G. Kończak [2012], M. D. Pandey i in. [2001], N. Seckin i in. [2010]). Występowanie zdarzeń ekstremalnych: katastrof, awarii technicznych, anomalii pogodowych związanych z pojawiającymi się huraganami i trąbami powietrznymi, zbyt obfitymi opadami skutkującymi powodziami, czy też brakiem deszczu powodującym susze i wielkie pożary lasów, sprawia, że pojawiają się nietypowe sytuacje, generujące ogromne straty i wypłaty przez firmy ubezpieczające wysokich odszkodowań. Istotna jest więc obserwacja kwantyli określonych rzędów rozkładów zmiennych losowych i w przypadku alarmujących sytuacji zapobiegania katastrofom lub minimalizacji ich skutków. 


\section{ZAKOŃCZENIE}

Statystyki pozycyjne stosowane są w konstrukcjach wielu procedur wnioskowania statystycznego, dotyczących zarówno zjawisk typowych, jak i ekstremalnych, rzadko występujących.

W pracy wyróżniono kilka obszarów zastosowań statystyk pozycyjnych, m.in.:

- w konstrukcji estymatorów parametrów rozkładów populacji,

- w estymacji parametrów pozycyjnych - kwantyli, w tym mediany oraz dominanty,

- w estymacji parametrów rozkładów statystyk ekstremalnych, indeksu ogona oraz kwantyli wysokich rzędów.

W prezentowanych metodach wykorzystywane były statystyki pozycyjne będące funkcjami wylosowanych prób prostych (podejście klasyczne), statystyki pozycyjne będące funkcjami generowanych prób bootstrapowych (procedury bootstrapowe) oraz kwantyle rozkładów a posteriori (bayesowskie metody estymacji).

Głównym celem monografii było przedstawienie procedur estymacji parametrów populacji opartych na statystykach pozycyjnych wraz z autorskimi modyfikacjami, wynikami badań efektywności oraz przykładami ilustrującymi praktyczne zastosowanie rozważanych metod. Przeprowadzone analizy dostarczyły informacji o rozkładach statystyk pozycyjnych, własnościach estymatorów opartych na statystykach pozycyjnych oraz pozwoliły sformułować wnioski dotyczące ich wykorzystania przy szacowaniu parametrów populacji o wybranych rozkładach cienko i gruboogonowych.

Rozpatrywanymi w pracy metodami były: metoda kwantyli, kwantylowa metoda najmniejszych kwadratów, metoda momentów ważonych prawdopodobieństwami oraz proponowane ich modyfikacje. Zaletą większości metod estymacji wykorzystujących kwantyle z próby jest możliwość ich zastosowania do szacowania parametrów dowolnych rozkładów zmiennych losowych. Nie zawsze jednak otrzymane estymatory są nieobciążone oraz charakteryzują się małymi wariancjami, co dało się zauważyć m.in. w przypadku stosowania metody kwantyli oraz kwantylowej metody najmniejszych kwadratów. 
W celu polepszenia własności estymatorów zaproponowano dwie modyfikacje kwantylowej metody najmniejszych kwadratów: kwantylową metodą najmniejszych kwadratów z uciętą liczbą kwantyli oraz medianowo-kwantylową metodę najmniejszych kwadratów.

Kolejna propozycja modyfikacji dotyczyła metody momentów ważonych prawdopodobieństwami i polegała na zastosowaniu w estymacji momentów z próby wyznaczonych $\mathrm{w}$ oparciu o zmodyfikowaną dystrybuantę empiryczną level crossing.

W pracy rozważano nie tylko procedury estymacji funkcji gęstości zmiennych losowych, ale również metody szacowania parametrów pozycyjnych, w tym kwantyli. Przedstawiono różne postaci estymatorów kwantyli oraz ich własności. Informacje z literatury przedmiotu uzupełniono wynikami przeprowadzonych badań symulacyjnych, mających na celu porównanie wybranych estymatorów i sformułowanie wniosków. Analizowano nieparametryczne, semiparametryczne i parametryczne procedury przedziałowej estymacji kwantyli, w tym metody bootstrapowe, badając dokładności i wiarygodności uzyskanych oszacowań. Przedstawiono przykłady wykorzystywania kwantyli $\mathrm{z}$ próby do szacowania różnego rodzaju miar stosowanych w badaniach ekonomicznych, m.in. związanych $\mathrm{z}$ pomiarem ubóstwa i bogactwa gospodarstw domowych, pomiarem ryzyka finansowego czy też tworzeniem kart kontrolnych. Empiryczne zastosowania zilustrowano w szóstym rozdziale monografii.

Zaprezentowane rozważania dotyczyły również skrajnych statystyk pozycyjnych: maksimum i minimum, postaci ich rozkładów granicznych oraz metod szacowania parametrów tych rozkładów. W celu estymacji parametrów uogólnionych rozkładów statystyk ekstremalnych oraz parametrów uogólnionego rozkładu Pareto stosowanego do modelowania ogona rozkładu zmiennej losowej zaproponowano wykorzystanie metod estymacji opartych na kwantylach z próby, w szczególności zmodyfikowanej metody momentów ważonych prawdopodobieństwami.

$\mathrm{Na}$ podstawie przeprowadzonych rozważań, analitycznych obliczeń i badań Monte Carlo należy sformułować następujące wnioski.

1. Zastosowanie do szacowania parametrów rozkładu populacji metody kwantyli wymaga wyboru rang wykorzystywanych statystyk pozycyjnych. Dla poszczególnych klas rozkładów populacji można analitycznie bądź symulacyjnie określić wielkości rang umożliwiające otrzymanie estymatorów nieobciążonych lub asymptotycznie nieobciążonych i charakteryzujących się małymi błędami średniokwadratowymi.

2. Zastosowanie autorskich metod estymacji: kwantylowej metody najmniejszych kwadratów z uciętą liczbą kwantyli oraz medianowo-kwantylowej metody najmniejszych kwadratów, prowadzi do otrzymania estymatorów parametrów rozkładów populacji o mniejszych obciążeniach i mniejszych błędach 
średniokwadratowych niż estymatory uzyskane kwantylową metodą najmniejszych kwadratów.

3. Kwantylowa metoda najmniejszych kwadratów z uciętą liczbą kwantyli wymaga wcześniejszych ustaleń dotyczących liczby pomijanych kwantyli. Liczba ta zależy od klasy rozkładu, którego parametry się szacuje, można ją wyznaczyć korzystając z oprogramowania komputerowego.

4. Dobór rang stosowanych statystyk pozycyjnych w metodzie kwantyli i wybór liczby pomijanych kwantyli w kwantylowej metodzie najmniejszych kwadratów ma szczególne znaczenie w przypadku rozkładów o grubych ogonach.

5. Zmodyfikowana metoda momentów ważonych prawdopodobieństwami wykorzystująca dystrybuantę empiryczną level crossing pozwala uzyskać estymatory parametrów rozkładów charakteryzujące się mniejszymi obciążeniami i mniejszymi błędami średniokwadratowymi w porównaniu z estymatorami uzyskanymi metodą momentów ważonych prawdopodobieństwami z klasyczną dystrybuanta.

6. Metody bootstrapowe można wykorzystać do estymacji przedziałowej kwantyli rozkładu populacji. Zastosowanie bootstrapowej metody percentyli umożliwia uzyskanie przedziału ufności dla mediany pokrywającego wartość szacowanego parametru z prawdopodobieństwem równym ustalonemu współczynnikowi ufności, a dokładność oszacowania, przy zastosowaniu tej metody, jest większa w stosunku do dokładności oszacowań uzyskanych klasycznymi procedurami estymacji mediany.

7. Przy szacowaniu metodami bootstrapowymi kwantyli wysokich rzędów, stosowanych do konstrukcji miar ryzyka, próby bootstrapowe powinny być generowane w sposób gwarantujący pojawianie się elementów z ogona rozkładu analizowanej zmiennej, czyli stosowana powinna być semiparametryczna metoda bootstrapowa. Zastosowanie takiej procedury estymacji zwiększa precyzję oszacowania w porównaniu z bootstrapową nieparametryczną metodą.

8. Zmodyfikowane metody estymacji mogą być wykorzystane w badaniach ekonomicznych, m.in. w analizach rozkładów dochodów i wydatków, rozkładów strat lub stóp zwrotu na giełdach papierów wartościowych lub giełdach towarowych, a różne estymatory kwantyli, w tym mediany, pozwalają szacować miary ryzyka finansowego i miary ubóstwa oraz bogactwa, a także konstruować różnego rodzaju karty kontrolne badające stabilność procesu produkcyjnego.

9. W analizach ubezpieczeniowych metody bootstrapowe mogą być stosowane do określania współczynnika bezpieczeństwa ustalanego przez towarzystwo ubezpieczeniowe, służącego do wyznaczania stawki kolektywnej i indywidualnej dla ubezpieczeń majątkowych. Zaletą ich, w stosunku do innych procedur prezentowanych w literaturze, jest możliwość zastosowania w przypadku rozkładów wysokości świadczeń charakteryzujących się dużą asymetrią. 
10. Rozkłady skrajnych statystyk pozycyjnych, rozkłady ogonów analizowanych zmiennych losowych wykorzystuje się do szacowania ryzyka ekstremalnego $\mathrm{w}$ analizach finansowych, zatem istotne jest stosowanie metod charakteryzujących się możliwie dużą precyzją, w szczególności proponowanej metody momentów ważonych prawdopodobieństwami.

Analiza procedur estymacji parametrów umożliwiła zweryfikowanie hipotez badawczych sformułowanych we wstępie monografii.

Pozytywnie zweryfikowana została prawdziwość hipotezy pierwszej. W przypadku zastosowania metody kwantyli, dla każdej z analizowanych klas rozkładów określono wielkości rang statystyk pozycyjnych prowadzących do estymatorów praktycznie nieobciążonych i charakteryzujących się małym błędem średniokwadratowym.

Wyniki porównań metod estymacji parametrów wybranych rozkładów zawarte $\mathrm{w}$ rozdziale trzecim potwierdziły słuszność drugiej i trzeciej hipotez o większej efektywności proponowanych modyfikacji procedur estymacji w stosunku do kwantylowej metody najmniejszych kwadratów i momentów ważonych prawdopodobieństwami z klasyczną dystrybuantą empiryczną.

Rezultaty analiz symulacyjnych pozwoliły pozytywnie zweryfikować czwartą hipotezę badawczą. Uzyskane bootstrapową metodą percentyli dokładności oszacowań mediany populacji o różnych rozkładach asymetrycznych i mieszaninach rozkładów okazały się większe w stosunku do dokładności otrzymanych klasycznymi procedurami estymacji przedziałowej, przy prawdopodobieństwie pokrycia szacowanej wartości parametru w przybliżeniu równym ustalonemu współczynnikowi ufności.

Badania własności estymatorów przeprowadzane były metodami analitycznymi i symulacyjnymi w oparciu o programy samodzielnie przygotowane w środowisku Gauss oraz przy użyciu programu Mathematica. Konieczność zastosowania metod Monte Carlo związana była z bardzo skomplikowanymi estymatorami lub sposobem ich konstrukcji (np. medianowo-kwantylowa metoda najmniejszych kwadratów, metoda bootstrapowa).

Rozważano zastosowanie metod estymacji parametrów rozkładów, dla których klasyczne podejścia nie mogą być wykorzystane (brak momentów rozkładu, brak ekstremum lokalnego funkcji wiarygodności), bądź przy zastosowaniu twierdzeń granicznych wymagają bardzo dużych liczebności prób. Dlatego $\mathrm{w}$ analizach wykorzystano m.in. asymetryczne rozkłady populacji i rozkłady będące mieszaninami dwóch rozkładów ciągłych, rozkłady Pareto i Cauchy’ego. Dokonując wyboru rozkładów, kierowano się również ich praktycznymi zastosowaniami w badaniach ekonomicznych.

Prezentowane metody estymacji można wykorzystać do szacowania parametrów rozkładów populacji innych niż rozważane. Niezbędne jest analityczne wyprowadzenie wzorów na postaci estymatorów lub jeśli nie jest to możliwe, nume- 
ryczne wyznaczenie wartości spełniających pewne warunki charakterystyczne dla określonej metody. Niektóre $\mathrm{z}$ rozważanych metod (kwantyli, najmniejszych kwadratów z uciętą liczbą kwantyli) wymagają dodatkowych badań związanych $\mathrm{z}$ własnościami estymatorów, które przeprowadza się w sposób analogiczny jak dla rozważanych w pracy rozkładów.

Podsumowując rezultaty uzyskane na podstawie przeprowadzonych badań, należy podkreślić, że publikacja ma charakter metodologiczno-poznawczy. Poznawczy charakter pracy jest związany $\mathrm{z}$ uporządkowaniem wiedzy na temat statystyk pozycyjnych, ich własności i możliwości wykorzystania do określania estymatorów parametrów rozkładu zmiennych losowych oraz z oceną efektywności tych metod i ich praktycznym zastosowaniem w wybranych obszarach badań ekonomicznych. Rozważania metodologiczne doprowadziły do zaproponowania nowych procedur estymacji parametrów rozkładu zmiennych losowych opartych na statystykach pozycyjnych, zbadania własności estymatorów i sformułowania wniosków mogących stanowić wskazówki dla osób przeprowadzających różnego rodzaju badania statystyczne.

Do zagadnień związanych z zastosowaniem statystyk pozycyjnych w procedurach wnioskowania statystycznego wymagających dalszych badań należy zaliczyć m.in.:

- bootstrapowe nieparametryczne i semiparametryczne procedury estymacji,

- metody blokowe szacowania granicznych rozkładów statystyk ekstremalnych,

- wykorzystanie kwantyli z próby do konstrukcji testów statystycznych. 



\section{ORDER STATISTICS IN ESTIMATION PROCEDURES AND THEIR APPLICATIONS IN ECONOMIC RESEARCH}

\section{Summary}

Economic studies are becoming more and more complex, which makes statistical methods based on classic parameters and their estimators insufficient to carry out insightful analyses and formulate appropriate conclusions. Among others, missing ordinary or central moments of required orders of random variable distributions, which are identified in the considered populations, cause difficulties in application of classic statistical inference methods. In such cases procedures based on order statistics are useful.

Order statistics constitute a group of statistics that are computed on the basis of order samples. Basic statistics include sample quantiles, among others the median, and extreme statistics: the maximum and minimum from the sample and the sample mode. The sample median is used to estimate the average value when the population distribution is asymmetric or heavy-tailed. It is much more stable than the arithmetic mean, which is very sensitive to extreme values. Quantiles of the empirical distribution are used for measuring market, financial and operating risk. Measures based on order statistics are also used in analyses of income and analyses of extremely rare events, occurrence of which causes large financial losses. Estimation of the size of these losses is possible using extreme statistics, their distributions, including limiting distributions. They are also used in statistical quality control to create control charts for monitoring and regulation of production process.

The monograph presents order statistic-based methods of parameter estimation of population distribution, suggestions for modification of these methods and the results of the analyses of estimator properties. The research includes classic approach to estimation procedures as well as non-classic methods Bayesian and bootstrapping. Both parametric and nonparametric estimation methods are considered.

The monograph consists of six chapters. 
The first chapter section presents order statistics, their mathematical functions and basic theorems concerning their numerical and functional characteristics, including limiting distributions. This is supplemented with properties of order statistics, based of sequences of random variables sampled from chosen distributions.

The second and third chapters are dedicated to construction of estimation methods with the use of order statistics, including own propositions of estimators and their properties. Analysed methods are: the quantile method, the quantile least squares method, the pprobability weighted method of moments and their modifications, including the quantile least squares method with a truncated number of quantiles, median-quantile least squares method and the probability weighted method of moments using level crossing empirical distribution. The proposed methods allow for obtaining estimators with smaller bias and lower variance compared to the estimators obtained by the quantile least squares method and probability weighted method of moments with the classic distribution function. Properties of estimators for selected classes of distributions, among others: Cauchy, Pareto, logistic, Gumbel, have been studied analytically or by the Monte Carlo method with the use of procedures prepared in Gauss and Mathematica environments.

The next chapter of the monograph presents application of order statistics to estimation of the position parameters of random variable such as quantiles and mode. Attention was paid to their practical application in economic research, among others to determine the poverty and wealth or measures used in the analyses of income, measures of risk in financial analyses, insurance and construction of control charts in statistical quality control.

The fifth chapter section covers parametric and nonparametric estimation methods used in the analyses of extreme events. An important issue is the estimation of extreme index - a parameter specifying the shape of the distribution of extreme statistics. Its value depends on the family of the population distribution. The positive value indicates the heavy-tailed distribution, zero characterizes the thin-tailed distribution and the negative index is obtained when the distributions have short tails (limited range of values). The family of the distribution is necessary for detecting outliers and calculating occurrence probabilities of extreme events. Moreover this chapter section gives the examples of application of extreme statistics and their functions to determine the measures used in economic, including financial, analyses.

Empirical application of estimation methods based on order statistics are presented in the sixth chapter for above mentioned three example areas of economic research: analysis of income, wealth and poverty, statistical quality control and risk management, including both normal and extreme risk in the insurance and financial analyses. 
Empirical part presenting chosen estimation procedures uses the Central Statistical Office databases, data form control unit in the home appliances manufacturer, Polish and American stock indexes and data on damage payments from liability insurance contracts from the insurance company.

The presented monograph is mainly dedicated to methodological aspects of considered methods. The methodological studies resulted in propositions of order statistic-based estimation procedures of distribution parameters, gave estimator properties and allowed for conclusions, which may be useful for practitioners conducting statistical analyses, especially in the field of economic and sociological research. 



\section{ANEKS}

\section{CHARAKTERYSTYKI FUNKCYJNE I LICZBOWE WYBRANYCH ROZKLADÓW}

Rozklad Burra $\operatorname{Br}(a, c)$. Zmienna losowa $X$ ma rozkład Burra z parametrami $a, c>0$, jeśli jej funkcja gęstości i dystrybuanta są odpowiednio postaci:

$$
\begin{aligned}
& f(x)=\left\{\begin{array}{lll}
0 & \text { dla } & x \leq 0, \\
c a \frac{x^{c-1}}{\left(1+x^{c}\right)^{a+1}} & \text { dla } & x>0,
\end{array}\right. \\
& F(x)= \begin{cases}0 & \text { dla } x \leq 0, \\
1-\left(1+x^{c}\right)^{-a} & \text { dla } x>0,\end{cases}
\end{aligned}
$$

natomiast wartość oczekiwana: $E X=a B\left(\frac{1}{c}+1, a-\frac{1}{c}\right)$ dla $a c>1$ oraz wariancja $D^{2} X=a B\left(\frac{2}{c}+1, a-\frac{2}{c}\right)-a^{2} B^{2}\left(\frac{1}{c}+1, a-\frac{1}{c}\right)$ dla $a c>2$, gdzie $B(\cdot, \cdot)$ jest funkcją beta.

Rozklad beta $\beta(a, b)$. Zmienna losowa $X$ ma rozkład beta z parametrami $a, b>0$, jeśli jej funkcja gęstości jest postaci:

$$
f(x)=\left\{\begin{array}{lll}
\frac{x^{a-1}(1-x)^{b-1}}{B(a, b)} & \text { dla } & 0<x<1, \\
0 & \text { dla } & \text { pozostałych }
\end{array}\right.
$$

gdzie $B(\cdot, \cdot)$ jest funkcją beta. 
Dystrybuanta tej zmiennej wyraża się wzorem:

$$
F(x)= \begin{cases}0 & \text { dla } x \leq 0, \\ I(x, a, b) & \text { dla } 0<x<1, \\ 1 & \text { dla } x \geq 1,\end{cases}
$$

gdzie $I$ jest niekompletną funkcją beta.

Wartość oczekiwana i wariancja są postaci:

$$
E X=\frac{a}{a+b}, D^{2} X=\frac{a b}{(a+b)^{2}(1+a+b)} .
$$

Rozklad Cauchy'ego $\mathrm{Ca}(m, \lambda)$. Zmienna losowa $X$ ma rozkład Cauchy'ego z parametrami $m \in R$ i $\lambda>0$, jeśli jej funkcja gęstości jest postaci:

$$
f(x)=\frac{\lambda}{\pi\left(\lambda^{2}+(x-m)^{2}\right)} \quad \text { dla } x \in R,
$$

natomiast dystrybuanta:

$$
F(x)=\frac{1}{2}+\frac{1}{\pi} \operatorname{arctg}\left(\frac{x-m}{\lambda}\right) \text { dla } x \in R .
$$

Zmienna losowa o rozkładzie $C a(m, \lambda)$ nie ma wartości oczekiwanej i wariancji.

Rozklad chi-kwadrat $\chi^{2}(k)$. Zmienna losowa $X$ ma rozkład chi-kwadrat $\mathrm{z} k$ stopniami swobody $(k>0)$, jeśli jej funkcja gęstości jest postaci:

$$
f(x)= \begin{cases}0 & \text { dla } x \leq 0, \\ \frac{2^{-\frac{k}{2}} \exp \left(-\frac{x}{2}\right) x^{\frac{k}{2}-1}}{\Gamma\left(\frac{k}{2}\right)} & \text { dla } x>0,\end{cases}
$$

natomiast dystrybuanta:

$$
F(x)= \begin{cases}0 & \text { dla } x \leq 0, \\ \frac{\gamma\left(\frac{k}{2}, \frac{x}{2}\right)}{\Gamma\left(\frac{k}{2}\right)} & \text { dla } x>0,\end{cases}
$$


gdzie $\gamma$ jest (górną) niekompletną funkcją gamma, zaś $\Gamma($.$) to funkcja gamma.$

Wartość oczekiwana i wariancja są postaci: $E X=k, D^{2} X=2 k$.

Rozkład Frécheta $\operatorname{Fr}(\lambda, \delta, \gamma)$. Zmienna losowa $X$ ma rozkład Frécheta z parametrami $\lambda, \delta \in R, \gamma>0$, jeśli jej funkcja gęstości wyraża się wzorem:

$$
f(x)= \begin{cases}0 & \text { dla } x \leq \lambda, \\ \frac{\gamma}{\delta}\left(\frac{x-\lambda}{\delta}\right)^{-\gamma-1} \exp \left(-\left(\frac{x-\lambda}{\delta}\right)^{-\gamma}\right) & \text { dla } x>\lambda,\end{cases}
$$

a dystrybuanta jest postaci:

$$
F(x)= \begin{cases}0 & \text { dla } x \leq \lambda, \\ \exp \left(-\left(\frac{x-\lambda}{\delta}\right)^{-\gamma}\right) & \text { dla } x>\lambda .\end{cases}
$$

Wartość oczekiwana i wariancja określone są następująco: $E X=\lambda+\delta \Gamma\left(1-\frac{1}{\gamma}\right) \quad$ dla $\quad \gamma>1 \quad$ oraz $D^{2} X=\delta^{2}\left[\Gamma\left(1-\frac{2}{\gamma}\right)-\Gamma^{2}\left(1-\frac{1}{\gamma}\right)\right]$ dla $\gamma>2$, gdzie $\Gamma(\cdot)$ jest funkcją gamma.

Rozkład gamma $G(p, \lambda)$. Zmienna losowa $X$ ma rozkład gamma z parametrami $p, \lambda>0$, jeśli jej funkcja gęstości jest postaci:

$$
f(x)=\left\{\begin{array}{lll}
0 & \text { dla } & x \leq 0, \\
\frac{1}{\lambda^{p} \Gamma(p)} x^{p-1} \exp \left(-\frac{x}{\lambda}\right) & \text { dla } & x>0,
\end{array}\right.
$$

gdzie $\Gamma($.$) jest funkcją gamma.$

Dystrybuanta tej zmiennej wyraża się wzorem:

$$
F(x)= \begin{cases}0 & \text { dla } x \leq 0, \\ \frac{\gamma\left(p, \frac{x}{\lambda}\right)}{\Gamma(p)} & \text { dla } x>0,\end{cases}
$$

gdzie $\gamma$ jest (górną) niekompletną funkcją gamma. 
Wartość oczekiwana i wariancja są odpowiednio równe: $E X=p \lambda$, $D^{2} X=p \lambda^{2}$.

Rozklad Gumbela $G l(\lambda, \delta)$. Zmienna losowa $X$ ma rozkład Gumbela z parametrami $\lambda, \gamma \in R$, jeśli jej funkcja gęstości jest postaci:

$$
f(x)=\frac{1}{\delta} \exp \left(-\frac{x-\lambda}{\delta}-\exp \left(-\frac{x-\lambda}{\delta}\right)\right) \text { dla } x \in R .
$$

natomiast dystrybuanta:

$$
F(x)=\exp \left(-\exp \left(-\frac{x-\lambda}{\delta}\right)\right), \quad \text { dla } x \in R
$$

Wartość oczekiwana i wariancja są postaci: $E X=\lambda+0,57772 \delta$, $D^{2} X=\frac{\pi^{2} \delta^{2}}{6}$.

Rozklad jednostajny $U(a, b)$. Zmienna losowa $X$ ma rozkład jednostajny na przedziale $[a, b]$, jeśli jej funkcja gęstości ma postać:

$$
f(x)= \begin{cases}\frac{1}{b-a} & \text { dla } x \in[a, b], \\ 0 & \text { dla } x \notin[a, b] .\end{cases}
$$

Dystrybuanta tej zmiennej wyraża się wzorem:

$$
F(x)=\left\{\begin{array}{lll}
0 & \text { dla } & x \leq a, \\
\frac{x-a}{b-a} & \text { dla } & \mathrm{a}<x \leq b, \\
1 & \text { dla } & x>b .
\end{array}\right.
$$

Wartość oczekiwana i wariancja są postaci: $E X=\frac{a+b}{2}, D^{2} X=\frac{(b-a)^{2}}{12}$.

Rozkład log-gamma $L G(p, \lambda, \mu)$. Zmienna losowa $X$ ma rozkład loggamma z parametrami $p, \lambda>0, \mu \in R$, jeśli jej funkcja gęstości jest postaci: 


$$
f(x)=\left\{\begin{array}{lc}
0 & \text { dla } \quad x<\mu, \\
\frac{1}{\lambda^{p} \Gamma(p)}(1+x-\mu)^{-\frac{1+\lambda}{\lambda}} \ln (1+x-\mu)^{p-1} & \text { dla } \quad x \geq \mu,
\end{array}\right.
$$

Dystrybuanta wyraża się wzorem:

$$
F(x)= \begin{cases}0 & \text { dla } x<\mu, \\ \frac{\gamma\left(p, \frac{\ln (1+x-\mu)}{\lambda}\right)}{\Gamma(p)} & \text { dla } x \geq \mu,\end{cases}
$$

gdzie $\gamma(\cdot, \cdot)$ jest (górną) niekompletną funkcją gamma, zaś $\Gamma($.$) jest funkcją$ gamma.

Wartość oczekiwana i wariancja wyrażają się wzorami: $E X=-1+(1-\lambda)^{-p}+\mu$ dla $\lambda<1, D^{2} X=(1-2 \lambda)^{-p}-(1-\lambda)^{-2 p}$ dla $\lambda<0,5$.

Rozkład logistyczny $\operatorname{Logist}(\mu, s)$. Zmienna losowa $X$ ma rozkład logistyczny z parametrami $\mu \in R, s>0$, jeśli jej funkcja gęstości ma postać:

$$
f(x)=\frac{\exp \left(-\frac{x-\mu}{s}\right)}{s\left(1+\exp \left(-\frac{x-\mu}{s}\right)\right)^{2}} \quad \text { dla } x \in R .
$$

Dystrybuanta tej zmiennej wyraża się wzorem:

$$
F(x)=\left(1+\exp \left(-\frac{x-\mu}{s}\right)\right)^{-1} \text { dla } x \in R,
$$

a wartość oczekiwana i wariancja: $E X=\mu, D^{2} X=\frac{\pi^{2} s^{2}}{3}$.

Rozkład log-normalny $L N(\mu, \sigma)$. Zmienna losowa $X$ ma rozkład lognormalny (logarytmiczno-normalny) z parametrami $\mu \geq 0$ i $\sigma>0$, jeśli jej funkcja gęstości ma postać:

$$
f(x)=\frac{1}{x \sigma \sqrt{2 \pi}} \exp \left(-\frac{(\ln x-\mu)^{2}}{2 \sigma^{2}}\right) \quad \text { dla } x \in R .
$$


Dystrybuanta tej zmiennej wyraża się wzorem:

$$
F(x)=\frac{1}{2}+\frac{1}{2} \operatorname{erf}\left(\frac{\ln x-\mu}{\sigma \sqrt{2}}\right) \text { dla } x \in R .
$$

Wartość oczekiwana zmiennej losowej o rozkładzie $L N(\mu, \sigma)$ wynosi $E X=e^{\mu}$, zaś wariancja $D^{2} X=\left(\exp \left(\sigma^{2}\right)-1\right) \exp \left(2 \mu+\sigma^{2}\right)$.

Rozkład normalny $N(\mu, \sigma)$. Zmienna losowa $X$ ma rozkład normalny z parametrami $\mu \in R$ i $\sigma>0$, jeśli jej funkcja gęstości i dystrybuanta są postaci:

$$
\begin{gathered}
f(x)=\frac{1}{\sqrt{2 \pi} \sigma} \exp \left(-\frac{(x-\mu)^{2}}{2 \sigma^{2}}\right) \quad \text { dla } x \in R . \\
F(x)=\frac{1}{\sqrt{2 \pi} \sigma} \int_{-\infty}^{x} \exp \left(-\frac{(t-\mu)^{2}}{2 \sigma^{2}}\right) d t \quad \text { dla } x \in R .
\end{gathered}
$$

Wartości oczekiwana zmiennej o rozkładzie $N(\mu, \sigma)$ wynosi $\mu$, a odchylenie standardowe $\sigma$.

Rozklad odwrócony Frécheta $\operatorname{IFr}(\lambda, \delta, \gamma)$. Zmienna losowa $X$ ma odwrócony rozkład Frécheta z parametrami $\lambda, \delta \in R, \gamma>0$, jeśli funkcja gęstości ma postać:

$$
f(x)= \begin{cases}-\frac{\gamma}{\delta}\left(\frac{x-\lambda}{\delta}\right)^{-\gamma-1} \exp \left(-\left(\frac{x-\lambda}{\delta}\right)^{-\gamma}\right) & \text { dla } x<\lambda, \\ 0 & \text { dla } x \geq \lambda .\end{cases}
$$

Dystrybuanta tej zmiennej wyraża się wzorem:

$$
F(x)= \begin{cases}1-\exp \left(-\left(-\frac{x-\lambda}{\delta}\right)^{-\gamma}\right) & \text { dla } x<\lambda, \\ 1 & \text { dla } x \geq \lambda .\end{cases}
$$

Wartość oczekiwana wynosi $E X=\lambda-\delta \Gamma\left(1-\frac{1}{\gamma}\right)$ dla $\gamma>1$, zaś wariancja $D^{2} X=\delta^{2}\left[\Gamma\left(1-\frac{2}{\gamma}\right)-\Gamma^{2}\left(1-\frac{1}{\gamma}\right)\right]$ dla $\gamma>2$, gdzie $\Gamma$ jest funkcją gamma. 
Rozklad odwrócony gamma $I G(p, b)$. Zmienna losowa $X$ ma odwrócony rozkład gamma z parametrami $p, b>0$, jeśli:

$$
g(x)= \begin{cases}0 & \text { dla } \quad x \leq 0, \\ \frac{b^{p} \exp \left(-\frac{b}{x}\right)}{x^{p+1} \Gamma(p)} & \text { dla } x>0,\end{cases}
$$

gdzie $\Gamma(\cdot)$ jest funkcją gamma.

Dystrybuanta tej zmiennej wyraża się wzorem:

$$
F(x)= \begin{cases}0 & \text { dla } x \leq 0, \\ \frac{\gamma\left(p, \frac{\lambda}{x}\right)}{\Gamma(p)} & \text { dla } x>0,\end{cases}
$$

gdzie $\gamma(\cdot, \cdot)$ jest (górną) niekompletną funkcją gamma.

Wartość oczekiwana wynosi $E X=\frac{a}{p-1}$ dla $p>1$, zaś wariancja $D^{2} X=\frac{a^{2}}{(p-1)^{2}(p-1)}$ dla $p>2$.

Rozkład odwrócony Gumbela $\operatorname{IGl}(\lambda, \delta)$. Zmienna losowa $X$ ma odwrócony rozkład Gumbela z parametrami $\lambda, \delta \in R$, jeśli:

$$
f(x)=\frac{1}{\delta} \exp \left(-\exp \left(\frac{x-\lambda}{\delta}\right)+\frac{x-\lambda}{\delta}\right) \text { dla } x \in R .
$$

Dystrybuanta tej zmiennej wyraża się wzorem:

$$
F(x)=1-\exp \left(-\exp \left(\frac{x-\lambda}{\delta}\right)\right), \text { dla } x \in R
$$

Wartość oczekiwana i wariancja są postaci: $E X=\lambda-0,57772 \delta$, $D^{2} X=\frac{\pi^{2} \delta^{2}}{6}$. 
Rozklad odwrócony Weibulla $I W(\lambda, \delta, \gamma)$. Zmienna losowa $X$ ma odwrócony rozkład Weibulla z parametrami $\lambda, \delta \in R, \gamma>0$, jeśli jej funkcja gęstości ma postać:

$$
f(x)= \begin{cases}\frac{\gamma}{\delta}\left(-\frac{x-\lambda}{\delta}\right)^{\gamma-1} \exp \left(-\left(-\frac{x-\lambda}{\delta}\right)^{\gamma}\right) & \text { dla } x \leq \lambda, \\ 0 & \text { dla } x>\lambda\end{cases}
$$

a dystrybuanta:

$$
F(x)= \begin{cases}\exp \left(-\left(-\frac{x-\lambda}{\delta}\right)^{\gamma}\right) & \text { dla } x \leq \lambda, \\ 1 & \text { dla } x>\lambda\end{cases}
$$

natomiast wartość oczekiwana i wariancja wyrażają się wzorami: $E X=\lambda-\delta \Gamma\left(1+\frac{1}{\gamma}\right), \quad D^{2} X=\delta^{2}\left[\Gamma\left(1+\frac{2}{\gamma}\right)-\Gamma^{2}\left(1+\frac{1}{\gamma}\right)\right]$, gdzie $\Gamma$ jest funkcja gamma.

Rozklad Pareto $\mathrm{Pa}(\theta, a)$. Zmienna losowa $X$ ma rozkład Pareto z parametrami $\theta, \alpha>0$, jeśli jej funkcja gęstości jest postaci:

$$
f(x)=\left\{\begin{array}{lll}
0 & \text { dla } & x<\theta, \\
\frac{a \theta^{a}}{x^{a+1}} & \text { dla } & x \geq \theta .
\end{array}\right.
$$

Dystrybuanta tej zmiennej wyraża się wzorem:

$$
F(x)=\left\{\begin{array}{lll}
0 & \text { dla } & x \leq \theta, \\
1-\left(\frac{\theta}{x}\right)^{a} & \text { dla } & x>\theta .
\end{array}\right.
$$

Wartość oczekiwana wynosi $E X=\frac{a \theta}{a-1}$ dla $\alpha>1$, natomiast wariancja wyraża się wzorem $D^{2} X=\frac{\theta^{2} a}{(a-1)^{2}(a-2)}$ dla $\alpha>2$. 
Rozkład potęgowy $P o(\lambda)$. Zmienna losowa $X$ ma rozkład potęgowy z parametrem $\lambda>0$, jeśli jej funkcja gęstości jest postaci:

$$
f(x)=\left\{\begin{array}{lll}
\lambda x^{\lambda-1} & \text { dla } & 0 \leq x \leq 1, \\
0 & \text { dla } & x<0 \vee x>1 .
\end{array}\right.
$$

Dystrybuanta tej zmiennej wyraża się wzorem:

$$
F(x)=\left\{\begin{array}{lll}
0 & \text { dla } & x \leq 0 \\
x^{\lambda} & \text { dla } & 0<x \leq 1 \\
1 & \text { dla } & x>1
\end{array}\right.
$$

Wartość oczekiwana i wariancja są równe: $\quad E X=\frac{\lambda}{\lambda+1}$, $D^{2} X=\frac{\lambda}{(\lambda+1)^{2}(\lambda+2)}$.

Rozklad $t$-Studenta $S(k)$. Zmienna losowa $X$ ma rozkład $t$-Studenta o $k$ stopniach swobody $(k>0)$, jeśli jej funkcja gęstości jest postaci:

$$
f(x)=\frac{\left(\frac{k}{x^{2}+k}\right)^{\frac{1+k}{2}}}{\sqrt{k} B\left(\frac{k}{2}, \frac{1}{2}\right)} \quad \text { dla } x \in R
$$

gdzie $B$ jest funkcją beta.

Dystrybuanta tej zmiennej wyraża się wzorem:

$$
F(x)=\frac{1}{2}+x \frac{{ }_{2} F_{1}\left(\frac{1}{2}, \frac{k+1}{2} ; \frac{3}{2},-\frac{x^{2}}{k}\right)}{\sqrt{k} B\left(\frac{k}{2}, \frac{1}{2}\right)} \quad \text { dla } x \in R,
$$

gdzie ${ }_{2} F_{1}$ jest funkcją hipergeometryczną.

Wartość oczekiwana i wariancja są postaci: $E X=0$, dla $k>1$, $D^{2} X=\frac{k}{k-2}$ dla $k>2$. 
Rozklad uogólniony Pareto $G P D(\beta, \xi)$. Zmienna losowa $X$ ma uogólniony rozkład Pareto z parametrami gdzie $\xi \in R$ i $\beta>0$, jeśli jej funkcja gęstości wyraża się wzorem:

$$
f(x)= \begin{cases}\frac{1}{\beta}\left(1+\xi \frac{x}{\beta}\right)^{-\frac{1}{\xi}-1} \quad \text { dla } \quad \xi \neq 0, \quad \xi x>-\beta, x>0, \\ \frac{1}{\beta} \exp \left(-\frac{x}{\beta}\right) \quad \text { dla } \quad \xi=0, \quad x \geq 0,\end{cases}
$$

a dystrybuanta jest postaci:

$$
F(x)= \begin{cases}1-\left(1+\xi \frac{x}{\beta}\right)^{-\frac{1}{\xi}} & \text { dla } \quad \xi \neq 0, \quad \xi x>-\beta \wedge x>0, \\ 1-\exp \left(-\frac{x}{\beta}\right) & \text { dla } \quad \xi=0, \quad x \geq 0 .\end{cases}
$$

Wartość oczekiwana i wariancja wyrażają się wzorami: $E X=\frac{\beta}{1-\xi}$ dla $\xi<1, \quad D^{2} X=\frac{\beta^{2}}{(1-\xi)^{2}(1-2 \xi)}$ dla $\xi<0,5$.

Rozklad Weibulla $W(\lambda, \delta, \gamma)$. Zmienna losowa $X$ ma rozkład Weibulla z parametrami $\lambda, \delta \in R, \gamma>0$, jeśli:

$$
f(x)= \begin{cases}0 & \text { dla } x \leq \lambda . \\ \frac{\gamma}{\delta}\left(\frac{x-\lambda}{\delta}\right)^{-\gamma-1} \exp \left(-\left(\frac{x-\lambda}{\delta}\right)^{-\gamma}\right) & \text { dla } x>\lambda,\end{cases}
$$

Dystrybuanta tej zmiennej wyraża się wzorem:

$$
F(x)= \begin{cases}0 & \text { dla } \quad x<\lambda, \\ 1-\exp \left(-\left(\frac{x-\lambda}{\delta}\right)^{\gamma}\right) & \text { dla } x \geq \lambda .\end{cases}
$$


Wartość oczekiwana i wariancja są postaci: $E X=\lambda+\delta \Gamma\left(1+\frac{1}{\gamma}\right)$, $D^{2} X=\delta^{2}\left[\Gamma\left(1+\frac{2}{\gamma}\right)-\Gamma^{2}\left(1+\frac{1}{\gamma}\right)\right]$, gdzie $\Gamma(\cdot)$ jest funkcją gamma.

Rozkład $W(0, \delta, \gamma)$ nazywany jest rozkładem dwuparametrowym Weibulla.

Rozkład wykładniczy $\operatorname{Exp}(\lambda)$. Zmienna losowa $X$ ma rozkład wykładniczy z parametrem $\lambda>0$, jeśli jej funkcja gęstości wyraża się wzorem:

$$
f(x)=\left\{\begin{array}{lll}
0 & \text { dla } & x<0, \\
\frac{1}{\lambda} \exp \left(-\frac{x}{\lambda}\right) & \text { dla } & x \geq 0,
\end{array}\right.
$$

a dystrybuanta jest postaci:

$$
F(x)=\left\{\begin{array}{lr}
0 & \text { dla } \quad x \leq 0 \\
1-\exp \left(-\frac{x}{\lambda}\right) & \text { dla } \quad x>0
\end{array}\right.
$$

Wartość oczekiwana i wariancja wynoszą: $E X=\lambda, D^{2} X=\lambda^{2}$. 



\section{WYBRANE OZNACZENIA}

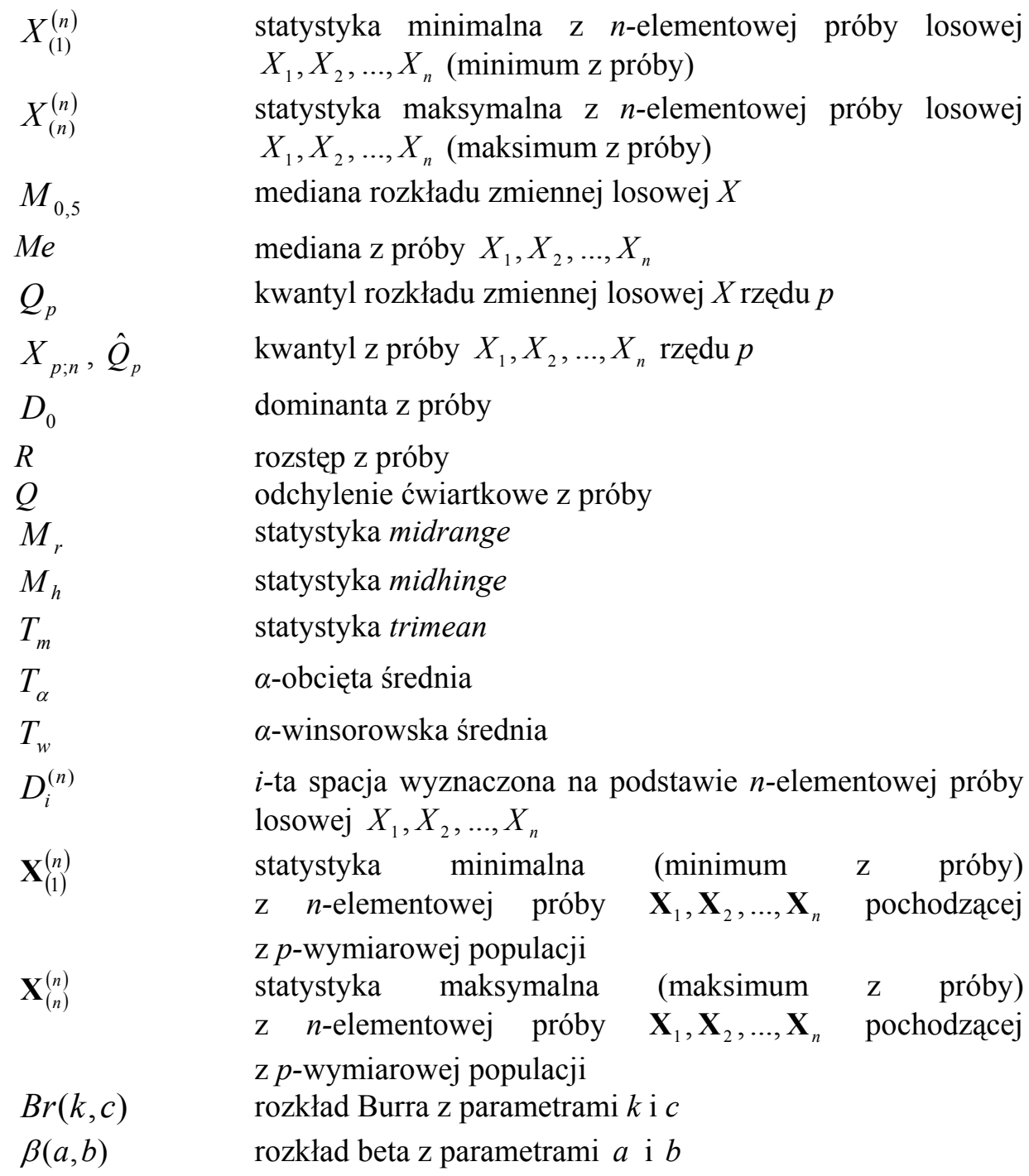




$\begin{array}{ll}C a(m, \lambda) & \text { rozkład Cauchy'ego z parametrami } m \text { i } \lambda \\ F r(\lambda, \delta, \gamma) & \text { rozkład Frécheta z parametrami } \lambda, \delta, \gamma \\ I F r(\lambda, \delta, \gamma) & \text { rozkład odwrócony Frécheta z parametrami } \lambda, \delta, \gamma \\ G(p, \lambda) & \text { rozkład gamma z parametrami } p \text { i } \lambda \\ I G(p, b) & \text { rozkład odwrócony gamma z parametrami } p \text { i } b \\ G l(\lambda, \delta) & \text { rozkład Gumbela z parametrami } \lambda \text { i } \delta \\ I G l(\lambda, \delta) & \text { rozkład odwrócony Gumbela z parametrami } \lambda \text { i } \delta \\ L o g i s t(\mu, s) & \text { rozkład logistyczny z parametrami } \mu \text { i } s \\ L G(p, \lambda, \mu) & \text { rozkład log-gamma z parametrami } p, \lambda \text { i } \mu \\ L N(\mu, \sigma) & \text { rozkład log-normalny (logarytmiczno-normalny) z parame- } \\ N(\mu, \sigma) & \text { trami } \mu \text { i } \sigma \\ P a(\theta, \alpha) & \text { rozkład normalny z parametrami } \mu \text { i } \sigma \\ P o(\lambda) & \text { rozkład Pareto z parametrami } \theta \text { i } \alpha \\ U(a, b) & \text { rozkład potęgowy z parametrem } \lambda \\ S(k) & \text { rozkład jednostajny na przedziale }[a, b] \\ W(\delta, \gamma) & \text { rozkład } t \text {-Studenta z } k \text { stopniami swobody } \\ W(\lambda, \delta, \gamma) & \text { rozkład Weibulla (dwuparametrowy) z parametrami } \delta \text { i } \gamma \\ I W(\lambda, \delta, \gamma) & \text { rozkład Weibulla z parametrami } \lambda, \delta \text { i } \gamma \\ E x p(\lambda) & \text { rozkład odwrócony Weibulla z parametrami } \lambda, \delta \text { i } \gamma \\ G P D(\beta ; \xi) & \text { rozkład wykładniczy z parametrem } \lambda \\ G E V D_{M}(\mu, \sigma, \xi), & \text { uogólniony rozkład Pareto z parametrami } \beta \text { i } \xi \\ G E V D_{M} & \text { dystrybuan rozkład statystyki maksimum } \\ G E V D_{m}(\mu, \sigma, \xi), & \text { uogólniony rozkład statystyki minimum } \\ G E V D_{m} & \text { styki maksimum } \\ F_{\beta, \xi}(y) & \text { dystrybuanta uogólnionego rozkładu Pareto z parametrami } \\ F_{\mu, \sigma, \xi}(x) & \text { dystrybuanta uogólnionego rozkładu statystyki maksimum } \\ F_{\mu, \sigma, \xi}^{m}(x) & \text { dystrybuanta uogólnionego rozkładu statystyki minimum } \\ H_{1, \lambda, \delta}(x) & \text { dystrybuanta rozkładu Gumbela statystyki maksimum } \\ H_{2, \lambda, \delta, \gamma}(x) & \text { dystrybuanta rozkładu Frécheta statystyki maksimum } \\ H_{3, \lambda, \delta, \gamma}(x) & \text { dystrybuanta rozkładu Weibulla statystyki maksimum } \\ H_{1,0}(x) & \end{array}$




\begin{tabular}{|c|c|}
\hline$H_{2, \gamma}(x)$ & $\begin{array}{l}\text { dystrybuanta standaryzowanego rozkładu Frécheta statysty- } \\
\text { ki maksimum }\end{array}$ \\
\hline$H_{3, \gamma}(x)$ & $\begin{array}{l}\text { dystrybuanta standaryzowanego rozkładu Weibulla staty- } \\
\text { styki maksimum }\end{array}$ \\
\hline$L_{1, \lambda, \delta}(x)$ & dystrybuanta rozkładu Gumbela statystyki minimum \\
\hline$L_{2, \lambda, \delta, \gamma}(x)$ & dystrybuanta rozkładu Frécheta statystyki minimum \\
\hline$L_{3, \lambda, \delta, \gamma}(x)$ & dystrybuanta rozkładu Weibulla statystyki minimum \\
\hline$L_{1, \gamma}(x)$ & $\begin{array}{l}\text { dystrybuanta standaryzowanego rozkładu Gumbela staty- } \\
\text { styki minimum }\end{array}$ \\
\hline$L_{2, \gamma}(x)$ & $\begin{array}{l}\text { dystrybuanta standaryzowanego rozkładu Frécheta statysty- } \\
\text { ki minimum }\end{array}$ \\
\hline$L_{3,0}(x)$ & $\begin{array}{l}\text { dystrybuanta standaryzowanego rozkładu Weibulla staty- } \\
\text { styki minimum }\end{array}$ \\
\hline$g_{k ; n}(x)$ & funkcja gęstości $k$-tej statystyki pozycyjnej $X_{(k)}^{(n)}$ \\
\hline$F_{k ; n}(x)$ & dystrybuanta $k$-tej statystyki pozycyjnej $X_{(k)}^{(n)}$ \\
\hline$F_{n}(x)$ & dystrybuanta empiryczna zmiennej losowej $X$ \\
\hline$B(x ; a, b)$ & dystrybuanta rozkładu beta $\beta(a, b)$ \\
\hline$\hat{\theta}$ & estymator parametru $\theta$ \\
\hline$E(\hat{\theta})-\theta$ & obciążenie estymatora parametru $\theta$ \\
\hline $\operatorname{MSE}(\hat{\theta})$ & błąd średniokwadratowy estymatora parametru $\theta$ \\
\hline$\hat{\theta}^{m M}$ & estymator parametru $\theta$ otrzymany metodą momentów \\
\hline$\hat{\theta}^{m K}$ & estymator parametru $\theta$ otrzymany metodą kwantyli \\
\hline$\hat{\theta}^{K m n k}$ & $\begin{array}{l}\text { estymator parametru } \theta \text { otrzymany kwantylową metoda } \\
\text { najmniejszych kwadratów }\end{array}$ \\
\hline$\hat{\theta}^{u K m n k}, \hat{\theta}_{k=r}^{u K m n k}$ & $\begin{array}{l}\text { estymator parametru } \theta \text { otrzymany kwantylową metoda } \\
\text { najmniejszych kwadratów z uciętą liczbą } r \text { kwantyli }\end{array}$ \\
\hline$\hat{\theta}^{M K}$ & $\begin{array}{l}\text { estymator parametru } \theta \text { otrzymany medianowo-kwantylowa } \\
\text { metodą najmniejszych kwadratów }\end{array}$ \\
\hline$\hat{\theta}^{m M W P}$ & $\begin{array}{l}\text { estymator parametru } \theta \text { otrzymany metodą momentów wa- } \\
\text { żonych prawdopodobieństwami }\end{array}$ \\
\hline$\hat{\theta}^{z m M W P}$ & $\begin{array}{l}\text { estymator parametru } \theta \text { otrzymany zmodyfikowaną metoda } \\
\text { momentów ważonych prawdopodobieństwami }\end{array}$ \\
\hline$\hat{\theta}_{j}^{B}$ & bootstrapowy estymator parametru $\theta$ \\
\hline$M_{1, j, 0}, M_{1,0, k}$ & $\begin{array}{l}\text { momenty rozkładu zmiennej losowej } X \text { ważone prawdopo- } \\
\text { dobieństwami }\end{array}$ \\
\hline
\end{tabular}




$\begin{array}{ll}m_{1, j, 0}, m_{1,0, k} & \text { momenty z próby losowej } X_{1}, X_{2}, \ldots, X_{n} \text { ważone prawdo- } \\ L(\theta, d) & \text { podobieństwami } \\ V a R_{p} & \text { funkcja straty } \\ E S_{p} & \text { wartość narażona na ryzyko, Value at Risk } \\ M S_{p} & \text { warunkowa wartość zagrożona, oczekiwany niedobór, } \\ T C E_{p} & \text { miara ryzyka Median Shortfall } \\ W C E_{p} & \text { miara ryzyka - dolna warunkowa średnia } \\ \gamma_{S} & \text { miara ryzyka - najgorsza warunkowa średnia } \\ G_{u b .} & \text { współczynnik asymetrii } \\ W_{z g . u b .} & \text { granica ubóstwa } \\ G & \text { współczynnik zagrożenia ubóstwem } \\ Z & \text { współczynnik Giniego } \\ L C & \text { miara koncentracji Zengi } \\ D L K & \text { linia centralna karty kontrolnej } \\ G L K & \text { dolna linia kontrolna katy kontrolnej } \\ & \text { górna linia kontrolna karty kontrolnej }\end{array}$




\section{LITERATURA}

Aitchison J., Brown J. A. C. [1975], The Lognormal Distribution, Cambridge University Press, Cambridge.

Allen J., Singh H. P., Singh S., Smarandache F. [2000], A General Class of Estimators of Population Median Using Two Auxiliary Variables in Double Sampling, http://arxiv.org/ftp/math/ papers/0203/0203001.pdf, 9.01.2012.

Anscombe F. J. [1961], Bayesian Statistics, „The American Statistics”, 15, 21-24.

Bałamut T. [2002], Metody estymacji Value at Risk, „Materiały i Studia”, 147, Narodowy Bank Polski, Warszawa.

Bartoszewicz J. [1996], Wyklady ze statystyki matematycznej, Państwowe Wydawnictwo Naukowe, Warszawa.

Baszczyńska A., Pekasiewicz D. [2008], Bootstrap Confidence Intervals for Population Mean in the Case of Asymmetric Distributions of Random Variables, „Acta Universitatis Lodziensis. Folia Oeconomica", 216, 9-20.

Baszczyńska A., Pekasiewicz D. [2010], Selected Methods of Interval Estimation of the Median. The Annals of Accuracy of Estimation, „Acta Universitatis Lodziensis. Folia Oeconomica”, 235, 21-30.

Baszczyńska A., Pekasiewicz D. [2014], Statistical Inference About Modality of Random Variable, (w:) Proceedings of the $32^{\text {nd }}$ International Conference Mathematical Methods in Economics, 19-24.

Beirlant J., Goegebeur Y.,Segers J., Teugels J. [2004], Statistics of Extremes. Theory and Applications, John Wiley \& Sons, Hoboken.

Berger J. O. [1985], Statistical Decision Theory and Bayesian Analysis, Springer-Verlang, New York.

Bickel D. R. [2002], Robust Estimators of the Mode and Skewness of Continuous Data, „Computational Statistics and Data Analysis", 39, 151-163.

Bickel D. R. [2006], Robust and Efficient Estimation of the Mode of Continuous Data; The Mode as a Variable Measure of Central Tendency, http://interstat.statjournals.net/YEAR/2001/abstracts/ 0111001.pdf, 5.06.2012.

Bickel D. R., Fruhwirth R. [2006], On a Fast, Robust Estimator of the Mode: Comparisons to Other Robust Estimators with Applications, „Computational Statistics and Data Analysis”, $50,3500-3530$.

Bloch D. A. Gastwirth J. L. [1968], On a Sample Estimate of Reciprocal of the Density Function, „Annals of Mathematical Statistics”, 39, 1083-1085.

Brodin E. [2006], On Quantile Estimation by Bootstrap, „Computational Statistics and Data Analysis", 50 (6), 1398-1406.

Brzeziński M. [2014], Statistical Inference for Richness Measures, „Applied Economics”, 46 (14), 1599-1608. 
Burnecki K., Nowicka-Zagrajek J. [2006], Składka kwantylowa w modelu ryzyka kolektywnego a dane szkodowe z obcięciem dolnym, (w:) Ostasiewicz W. (red.), Statystyka aktuarialna stan i perspektywy rozwoju z Polsce, „Prace Naukowe Akademii Ekonomicznej we Wrocławiu, 1108, 306-317.

Carlin B. P., Louis T. A. [2000], Bayes and Empirical Bayes Methods for Data Analysis, Chapman $\&$ Hall/CRC, Boca Raton.

Castillo E., Hadi A. S., Balakrishnan N., Sarabia J. M. [2004], Extreme Value and Related Models with Application in Engineering and Science, Wiley Interscience, A. John Wiley \& Sons, New York.

Chang Y. P., Huang M. C., Wu Y. F. [2003], Nonparametric Estimation for Risk in Value-at-Risk Estimator, „Communication in Statistics”, 32 (4), 1041-1064.

Csörgö S., Deheuvels P., Mason D. [1985], Kernel Estimates of the Tail Index of a Distribution, „The Annals of Statistics”, 1050-1077.

Czekała M. [2001], Statystyki pozycyjne w modelowaniu ekonometrycznym. Wybrane problemy, Wydawnictwo Akademii Ekonomicznej im. O. Langego, Wrocław.

David H. A., Nagaraja H. N. [2003], Order Statistics, Wiley \& Son, New York.

Davis R. A., Resnick S. T. [1984], Tail Estimates Motivated by Extreme Value Theory, „The Annals of Statistics", 17, 1467-1487.

Davison A. C., Hinkley D. V. [1997], Bootstrap Methods and their Application, Cambridge University Press, Cambridge.

Daykin C. D., Pentikäinen T., Pesonen E. [1994], Practical Risk Theory for Actuaries, Chapman $\&$ Hall, London.

Dekkers, A. L. M., Einmahl, J. H. J., de Haan, L. [1989], A Moment Estimator for the Index of an Extreme-Value Distribution, „The Annals of Statistics”, 17, 1833-1855.

Desu M. M. [1971], A Characterization of the Exponential Distribution by Order Statistics, „Annals of Mathematical Statistics", 42, 837-838.

DiCiccio T., Efron B. [1996], Bootstrap Confidence Intervals, „Statistical Science”, 11 (3), 189-228.

Dimaki C. Xekalaki E. [1993], Characterizations of the Pareto Distribution Based on Order Statistics, „Lecture Notes in Mathematics”, 1546, 1-16.

Domański C. [1986], Teoretyczne podstawy testów nieparametrycznych $i$ ich zastosowanie w naukach ekonomiczno-społecznych, Wydawnictwo Uniwersytetu Łódzkiego, Łódź.

Domański C. [2011], Nieklasyczne metody oceny efektywności i ryzyka, Polskie Wydawnictwo Ekonomiczne, Warszawa.

Domański C., Pruska K. [2000], Nieklasyczne metody statystyczne, Polskie Wydawnictwo Ekonomiczne, Warszawa.

Domański C. [2005], Analiza rozkładów płac i dochodów w Polsce w przekroju terytorialnym, Wydawnictwo Uniwersytetu Łódzkiego, Łódź.

Domański C., Pruska K., Wagner W. [1998], Wnioskowanie statystyczne przy nieklasycznych założeniach, Wydawnictwo Uniwersytetu Łódzkiego, Łódź.

Dziubdziela W., Stachura M., Wodecka B. [2011], Extreme Value Index of Left and Right Tails for Financial Time Series, „Acta Universitatis Lodziensis. Folia Oeconomica”, 255, 227-238.

Dziubdziela W. [2012], Matematyczne modele ryzyka systemowego po kryzysie finansowym w latach 2007-2008, (w:) Zieliński Z. E. (red.), Rola informatyki w naukach ekonomicznych i spolecznych. Innowacje i implikacje interdyscyplinarne, Wydawnictwo Wyższej Szkoły Handlowej, Kielce, 72-79.

Efron B. [1979], Bootstrap Methods: Another Look at the Jackknife, „The Annals of Statistics”, 7, 1-21.

Efron B., Tibshirani R. J. [1993], An Introduction to the Bootstrap, Chapman \& Hall, New York. 
Embrechts P., Klüppelberg C., Mikosch T. [1997], Modelling Extremal Events for Insurance and Finance, Springer-Verlag, New York.

Fiema A., Kończak G. [2012], Wykorzystanie rozkładów wartości ekstremalnych $w$ analizie zagrożeń meteorologicznych, (w:) Zieliński Z. E. (red.), Rola informatyki w naukach ekonomicznych i społecznych. Innowacje i implikacje interdyscyplinarne, Wydawnictwo Wyższej Szkoły Handlowej, Kielce, 80-89.

Fils A., Guillou A., [2004], A New Extreme Quantile Estimator for Heavy-Tailed Distributions, C. R. Acd. Sci., Paris, 493-498.

Fisz M. [1967], Rachunek prawdopodobieństwa i statystyka matematyczna, Państwowe Wydawnictwo Naukowe, Warszawa.

Freimer M., Kollia G., Mudholkar G., Lin C. [1988], A Study of the Generalized Tukey Lambda Family, „Communications in Statistics, „Theory and Methods”, 17 (10), 3547-3567.

Furrer R., Naveau P. [2007], Probability Weighted Moments Properties for Small Samples, „Statistics \& Probability Letters", 190-195.

Gemzik-Salwach A. [2004], Zastosowanie metody Value at Risk $w$ kalkulacji wyniku odsetkowego banku, „Finansowy Kwartalnik Internetowy”, www.e-finanse.com/artykuly/34.pdf, 10.12.2012.

Gençay R., Selçuk F. [2004], Extreme Value and Value at Risk: Relative Performance in Emerging Markets, „International Journal of Forecasting”, 20, 287-303.

Gilchrist W. G. [2000], Statistical Modelling with Quantile Functions, Chapman \& Hall/CRT, Boca Raton.

Gilli M., Këllezi E. [2006], An Application of Extreme Value Theory for Measuring Financial Risk, „Computational Economics”, 27 (1), 1-23.

Grenander U. [1965], Some Direct Estimates of the Mode, „Annals of Mathematical Statistics”, 36, 131-138.

Greenwood J. A., Landwehr J. M., Matalas N. C., Wallis J. R. [1979], Probability Weighted Moments: Definition and Relation to Parameter of Several Distributions Expressible in Inverse Form, „Walter Resources Research”, 15, 1049-1054.

Grimshaw S. D. [1993], Computing Maximum Likelihood Estimates for the Generalized Pareto Distribution, „Technometrics”, 35, 185-191.

Gross S. T. [1980], Median Estimation in Sample Survey, www.amstat.org/sections/srms/ Proceedings/papers/1980 037.pdf, 12.04.2012.

Gumbel E. J. [2004], Statistics of Extremes, Dover Publications, Mineola, New York.

Harrell F. E., Davis C. E. [1982], A New Distribution - Free Quantile Estimator, „Biometrika”, 69, 635-640.

Hartigan J., Hartigan P. [1985], The Dip Test of Unimodality, „The Annals of Statistics”,13 (1), $70-84$.

Hedges S. B. , Shah P. [2003], Comparison of Mode Estimation Methods and Application in Molecular Clock Analysis, „BMC Bioinformatics”, 1-11.

Hill B. M. [1975], A Simple General Approach to Inference about the Tail of a Distribution, „The Annals of Statistics", 3 (5), 1163-1174.

Hosking J. R. M., Wallis J. R., Wood E. F. [1985], Estimation of the Generalized Extreme-Value Distribution by the Method of Probability - Weighted Moments, „Technometrics”, 27, 251-261.

Hosking J. R. M., Wallis J. R. [1987], Parameter and Quantile Estimation for the Generalized Pareto Distribution, „Technometrics”, 29, 339-349.

Huang M. L., Brill P. H. [1999], A Level Crossing Quantile Estimation Method, „Statistics \& Probability Letters", 45, 111-119.

Jajuga K. [2007], Zarzqdzanie ryzykiem, Wydawnictwo Naukowe PWN, Warszawa.

Jajuga, K., Jajuga, T. [2001]. Inwestycje: instrumenty finansowe, ryzyko finansowe, inżynieria finansowa, Wydawnictwo Naukowe PWN, Warszawa. 
Jajuga K., Papla D. [2005], Extreme Value Analysis and Copulas, (w:) Čižek P., Hărdle W., Weron R. (red.), Statistical Tools for Finance and Insurance, Spinger, Berlin.

Jędrzejczak A. [2011], Metody analizy rozkładów dochodów i ich koncentracji, Wydawnictwo Uniwersytetu Łódzkiego, Łódź.

Kaszuba-Perz A., Perz P. [2010], Rola zarzadzania ryzykiem w przedsiębiorstwie w obliczu wzrostu zewnętrznych czynników ryzyka, „Finansowy Kwartalnik Internetowy e-Finanse”, 6 (2), 53-63, www.e-finanse.com/artykuly_eng/144.pdf, 22.11.2012.

Kleiber Ch., Kotz S. [2003], Statistical Size Distributions in Economics and Actuarial Sciences, Wiley Series in Probability and Statistics, Wiley \& Sons, New York.

Knapp T. [2007], Bimodality Revisited, „Journal of Modern Applied Statistical Methods”, 6, 8-19.

Kończak G. [2007], Metody statystyczne w sterowaniu jakościa produkcji, Wydawnictwo Akademii Ekonomicznej im. K. Adamieckiego, Katowice.

Kończak G. [2013], On the Use of the Extreme Value Distribution in Monitoring Production Processes, „Acta Universitatis Lodziensis. Folia Oeconomica”, 286, 307-315.

Korzonek R. [2009], Uwagi o granicznych rozkładach ekstremalnych statystyk pozycyjnych, „Didactics of Mathematics”, 89-98.

Kot S. M. [2000], Ekonometryczne modele dobrobytu, Wydawnictwo Naukowe PWN, Warszawa.

Kot S. M. [2008], Polaryzacja ekonomiczna. Teoria i zastosowanie, Wydawnictwo Naukowe PWN, Warszawa.

Kotz S., Balakrishnan N., Read C. B., Vidakowic B. [2006], Encyklopedia of Statistic Sciences, Wiley \& Sons, New York.

Kotz S., Nadarajah S.[2000], Extreme Value Distributions. Theory and Applications, Imperial College Press, London.

Kowalczyk P., Poprawska E., Ronka-Chmielowiec W. [2006], Metody aktuarialne, Wydawnictwo Naukowe PWN, Warszawa.

Krzyśko M. [1996], Statystyka matematyczna, Wydawnictwo Uniwersytetu A. Mickiewicza, Poznań.

Lakhany A., Mausser H. [2000], Estimating the Parameters of the Generalized Lambda Distribution, „Algo Research Quarterly”, 3, 47-58.

Landwehr J. M., Matalas N. C., Wallis J. R. [1979], Probability Weighted Moments Compared with Some Traditional Techniques in Estimating Gumbel Parameters and Quantiles, „Water Resources Research", 15 (5), 1055-1064.

Lira J., Wagner W. [1997], Asymptotic Efficiency of Arithmetic Mean and Median, (w:) Proceedings of $16^{\text {th }}$ International Conference on Multivariate Statistical Analysis, Absolwent, Łódź, $165-172$.

Małecka M., Pekasiewicz D. [2013], Modification of Probability Weighted Method of Moments and its Application to Estimation of Financial Return Distribution Tail, „Statistics in Transition", new series, 14, 495-506.

Markovich N. [2007], Nonparametric Analysis of Univariate Heavy-Tailed Data, John Wiley \& Sons, New York.

Markovich N. M., Krieger U. R. [2002], The Estimation of Heavy-Tailed Probability Density Functions, their Mixtures and Quantiles, „Computer Networks”, 40 (3), 459-474.

Matthys G., Beirlant J. [2003], Estimating the Extreme Value Index and High Quantiles with Exponential Regression Models, „Statistics Sinica”, 13, 853-880.

Neves C., Picek J., Fraga Alves M. I. [2006], The Contribution of the Maximum to the Sum of Excesses for Testing Max-Domains of Attraction, „Journal of Statistical Planning and Inference" 136, 1281-1301.

Neves C., Fraga Alves M. I. [2008], Testing Extreme Value Conditions - an Overview and Recent Approaches, „REVSTAT - Statistical Journal” 6, 83-100. 
Olivie D. J. [2005], A Simple Confidence Interval for the Median, http: http://lagrange.math.siu.edu/ Olive/ppmedci.pdf, 15.03.2012.

Onour I. A. [2010], Extreme Risk and Fat-Tails Distribution. Model: Empirical Analysis, „Journal of Money, Investment and Banking”, 13, 27-34.

Osiewalski J. [1991], Bayesowska estymacja i predykcja dla jednorównaniowych modeli ekonometrycznych, Wydawnictwo Akademii Ekonomicznej, Kraków.

Otto W. [2004], Ubezpieczenia majatkowe, cz.1: Teoria ryzyka, Wydawnictwo NaukowoTechniczne, Warszawa.

Öztürk A., Dale R. [1985], Least Squares Estimation of the Parameters of the Generalized Lambda Distribution, „Technometrics”, 27, 81-84.

Pandey M. D., Van Gelder P. H. A .J. M., Vrijling J. K. [2001], The Estimation of Extreme Quantiles of Wind Velocity Using L-Moments in the Peaks-over-Threshold Approach, ,Structural Safety", 23, 179-192.

Pandey M. D., Van Gelder P. H .A .J. M., Vrijling J. K. [2003], Bootstrap Simulations for Evaluating the Uncertainty Associated with Peaks-over-Threshold Estimates of Extreme Wind Velocity, Environmetrics", 14, 27-43.

Peichl A., Schaefer T., Scheicher Ch. [2008], Measuring Richness and Poverty: A Micro Data Application to Europe and Germany, IZA Discussion Paper, 3790, http://ftp.iza.org/dp3790.pdf, 26.11.2012.

Pekasiewicz D. [2012], Zastosowanie metod symulacyjnych do badania własności estymatorów otrzymanych metoda kwantyli, (w:) Zieliński Z. E., Rola informatyki w naukach ekonomicznych $i$ spolecznych. Innowacje i implikacje interdyscyplinarne, Wydawnictwo Wyższej Szkoły Handlowej, Kielce, 236-244.

Pekasiewicz D. [2013a], Wybrane metody estymacji parametrów uogólnionego rozkładu Pareto, (w:) Zieliński Z. E., Rola informatyki w naukach ekonomicznych i społecznych. Innowacje i implikacje interdyscyplinarne, Wydawnictwo Wyższej Szkoły Handlowej, Kielce, 143-151.

Pekasiewicz D. [2013b], Wyznaczanie współczynnika bezpieczeństwa w oparciu o kwantyl rozkładu sumy roszczeń $w$ portfelu ubezpieczeń komunikacyjnych, (w:) Jajuga K., RonkaChmielwiec W. (red.), Inwestycje finansowe i ubezpieczenia - tendencje światowe a rynek polski, „Prace Naukowe Uniwersytetu Wrocławskiego”, 241-252.

Pekasiewicz D. [2014], Application of Quantile Methods to Cauchy Distribution Parameters Estimation, „Statistics in Transition New Series”, 15 (1), 133-144.

Peng L. [1998] Asymptotically Unbiased Estimators for the Extreme Value Index, „Statistics and Probability Letters", 38, 107-115.

Pickands J. [1975], Statistical Inference Using Extreme Order Statistics, „The Annals of Statistics", 3 (1), 119-131.

Pruska K. [2007], Estimation of Bias and Variance of Sample Median by Jackknife and Bootstrap Methods, „Acta Universitatis Lodziensis. Folia Oeconomica”, 206, 67-79.

Rasmussen P. F. [2001], Generalized Probability Weighted Moments: Application to the Generalized Pareto Distribution. „Water Resources Research”, 37 (6), 1745-1751.

Rasool M. T, Arshad M., Ahmad M. I. [2002], Estimation of Generalized Logistic Distribution by Probability Weight Moments, „Pakistan Journal of Applied Sciences”, 2 (4), 485-487.

Resnik S. I. [1997], Heavy Tail Modelling and Teletraffic Data, „The Annals of Statistics”, 25 (5), 1805-1869.

Ronka-Chmielowiec W. [2002], Ubezpieczenia. Rynek i ryzyko, Polskie Wydawnictwo Ekonomiczne, Warszawa.

Seckin N., Yurtal R., Haktanir T., Dogan A. [2010], Comparison of Probability Weighted Moments and Maximum Likelihood Methods Used in Flood Frequency Analysis for Ceyhan River Basin, „The Arabian Journal for Science and Engineering”, 35, 49-69. 
Serfling R. J. [1991], Twierdzenia graniczne statystyki matematycznej, Państwowe Wydawnictwo Naukowe, Warszawa.

Silverman B. W. [1981], Using Kernel Density Estimates to Investigate Multimodality Density, „Journal of the Royal Statistical Society”, Series B (Methodological), 43 (1), 97-99.

Singh S., Joarder A. H., Tracy D. S. [2001], Median Estimation Using Double Sampling, „Australian \& New Zealand Journal of Statistics", 43, 33-46.

Singh S. K., Singh U., Kumar D. [2011], Bayesian Estimation of the Exponential Gamma Parameter and Reliability Function Under Asymmetric Loss Function, „REVSTAT - Statistical Journal", 9 (3), 247-260.

Sokołowski A. [2013], Bezpośrednie estymatory modalnej, Wydawnictwo Uniwersytetu Ekonomicznego, Kraków.

Stachura M., Wodecka B. [2012], Zastosowanie estymatora k-to-rekordowego do szacowania wartości narażonej na ryzyko, (w:) Jajuga K., Ronka-Chmielowiec W., Inwestycje finansowe i ubezpieczenia - tendencje światowe a rynek polski, Wydawnictwo Uniwersytetu Ekonomicznego, Wrocław, 289-297.

Szreder M. [1989], Wykorzystanie kwantyli do szacowania parametrów informacyjnych rozkładów a priori dla potrzeb estymacji bayesowskiej, „Przegląd Statystyczny”, 36, 141-150.

Szreder M. [1994], Informacje a priori w klasycznej i bayesowskiej estymacji modeli regresji, Wydawnictwo Uniwersytetu Gdańskiego, Gdańsk.

Takeuchi I., Le Q. V., Sears T.D., Smola A. J. [2006], Nonparametric Quantile Estimation, „Journal of Machine Learning Research”, 7, 1231-1264.

Thompson J. R., Koronacki J., Nieckuła J. [2005], Techniki zarzqdzania jakościq od Shewhardta do metody ,Six Sigma”, Akademicka Oficyna Wydawnicza „Exit”, Warszawa.

Trzpiot G. [2004a], O wybranych własnościach miar ryzyka, Badania operacyjne i decyzje 3-4, Katowice, 91-98.

Trzpiot G. [2004b], Kwantylowe miary ryzyka, „Prace Naukowe Akademii Ekonomicznej we Wrocławiu" 1022, Taksonomia, 11, 420-430.

Trzpiot G. [2010], Wielowymiarowe metody statystyczne w analizie ryzyka inwestycyjnego, Polskie Wydawnictwo Ekonomiczne, Warszawa.

Trzpiot G., Majewska J. [2010], Estimation of Value at Risk: Extreme Value and Robust Approaches, „Operation Research and Decision”, 1, 131-143.

Tsourti Z., Panaretos J. [2001], Extreme Value Index Estimators and Smoothing Alternatives: Review and Simulation Comparison, http://mpra.ub.uni-muenchen.de/ 6384/1/MPRA_paper_6384.pdf, 8.01.2013.

Wilcox R. R. [2001], Fundamentals of Modern Statistical Methods, Springer, New York.

Wywiał J. [2000a], Estimation of Mode on the Basis of Truncated Sample, „Acta Universitatis Lodziensis. Folia Oeconomica", 152, 73-81.

Wywiał J. [2000b], Estimation of Distribution Function Mode on the Basis of Sample Moment or Sample Median, (w:) Badania operacyjne i decyzje, Oficyna Wydawnicza Politechniki Wrocławskiej, Wrocław, 89-98.

Wywiał J. [2004], Wprowadzenie do wnioskowania statystycznego, Wydawnictwo Akademii Ekonomicznej, Katowice.

Zellner A. [1971], An Introduction to Bayesian Inference in Econometrics, J. Wiley \& Sons, New York.

Zellner A. [1986], Bayesian Estimation and Prediction Using Asymmetric Loss Functions, „Journal of the American Statistical Association", 81, 446-451.

Zenga M. [1990], Concentration Curves and Concentration Index Derived from them (w:) Incoe and Wealth Distribution, Inequality and Property, Springer-Verlang, Berlin, 94-110. 
Zhang J. [2007], Likelihood Moment Estimation for the Generalized Pareto Distribution, „Australian \& New Zealand Journal of Statistics", 49 (1), 69-77.

Zieliński R. [1995], Estimating Median and Other Quantiles in Nonparametric Models, „Applicationes Mathematicae", 363-370.

Zieliński R. [1999], Best Equivalent Nonparametric Estimator of Quantile, „Probability \& Statistic Letter", 45, 79-84.

Zieliński R. [2000], A Median - Unbiased Estimator of the Characteristic Exponent of a Symmetric Stable Distribution, „Statistics”, 39 (1), 67-71.

Zieliński R. [2001], PCM-Optimal Nonparametric Quantile Estimator, „Statistics”, 35 (4), 453-462.

Zieliński R. [2003], Constructing Median - Unbiased Estimators in One - Parameter Families of Distributions, „Applicationes Mathematicae”, 30 (3), 251-255.

Zieliński R. [2005a], Estimating Quantiles with Linex Loss Function. Applications to VaR Estimation, „Applicationes Mathematicae”, 32 (4), 367-373.

Zieliński R. [2005b], L-Statistic as Nonparametric Quantile Estimation, IMPAN, www.impan.pl/Preprints/p657.pdf, 10.09.1012.

Zieliński R. [2006], Small-Sample Quantile Estimators in a Large Nonparametric Model, „Communications in Statistics Theory and Methods", 35, 1223-1241.

Zieliński R. [2010], O średniej i medianie, „Matematyka Stosowana”, 11, 5-14.

Zieliński R. [2011], Statystyka matematyczna stosowana. Elementy, Wydawnictwo Centrum Studiów Zaawansowanych Politechniki Łódzkiej, Warszawa.

Zieliński W. [2008], Przykład zastosowania dokładnego nieparametrycznego przedziału ufności dla VaR, „Metody Ilościowe w Badaniach Ekonomicznych”, 9, 239-244.

Zieliński W. [2009], A Nonparametric Confidence Interval for at-Risk-of-Poverty-Rate, „Statistics in Transition", 10 (3), 437-444.

Zieliński W. [2011], Robustness of the Confidence Interval for at-Risk-of-Poverty-Rate, „Statistics in Transition", 12 (1), 115-126.

Zieliński R, Zieliński W. [2005], Best Exact Nonparametric Confidence Intervals for Quantiles, „Statistics”, 34, 353-355. 



\section{OD REDAKCJI}

Dr Dorota Pekasiewicz jest adiunktem w Katedrze Metod Statystycznych Uniwersytetu Łódzkiego. Ukończyła studia matematyczne, a w 2000 r. uzyskała stopień doktora nauk ekonomicznych.

Zainteresowania naukowe dr D. Pekasiewicz koncentrują się wokół nieklasycznych metod wnioskowania statystycznego. Rezultatem badań związanych z sekwencyjną estymacją i weryfikacją hipotez statystycznych była rozprawa doktorska pt. Zastosowanie metod sekwencyjnych w statystyce matych obszarów, napisana pod kierunkiem dr hab. Krystyny Pruskiej, prof. nadzw. UŁ. Inny obszar badań naukowych stanowią metody estymacji i testy statystyczne wykorzystujące statystyki pozycyjne. Jest autorką ponad 40 artykułów i współautorką monografii Testy statystyczne w procesie podejmowania decyzji. W latach 1997-1999 dr D. Pekasiewicz brała udział w realizacji projektu badawczego KBN Zastosowanie metod klasycznych i symulacyjnych $w$ statystyce matych obszarów, natomiast w okresie 2011-2014 była jednym z głównych wykonawców projektu NCN pt. Metodologia testów statystycznych. Analiza procedur testowych z punktu widzenia jakości decyzji. Wyniki swoich badań prezentowała na krajowych i międzynarodowych konferencjach naukowych.

Od wielu lat dr D. Pekasiewicz prowadziła i prowadzi zajęcia na Wydziale Ekonomiczno-Socjologicznym i Wydziale Zarządzania UŁ, m.in. z matematyki, analizy matematycznej, rachunku prawdopodobieństwa, statystyki matematycznej, metody reprezentacyjnej, zastosowań pakietów statystycznych na rynku finansowym oraz zastosowań pakietów statystycznych w procesach ekonomicznych. Jest współautorką podręcznika skierowanego głównie dla studentów kierunków ekonomicznych pt. Analiza matematyczna dla ekonomicznych kierunków studiów. Jest promotorem 59 prac dyplomowych. W 2012 r. została wyróżniona Złotą Odznakę UŁ, natomiast w 2013 r. Srebrnym Medalem za Długoletnią Służbę.

Rozprawa habilitacyjna Statystyki pozycyjne w procedurach estymacji i ich zastosowania $w$ badaniach ekonomicznych stanowi podsumowanie kilkuletnich badań autorki nad wykorzystaniem statystyk pozycyjnych do konstrukcji estymatorów parametrów rozkładów zmiennych losowych. 